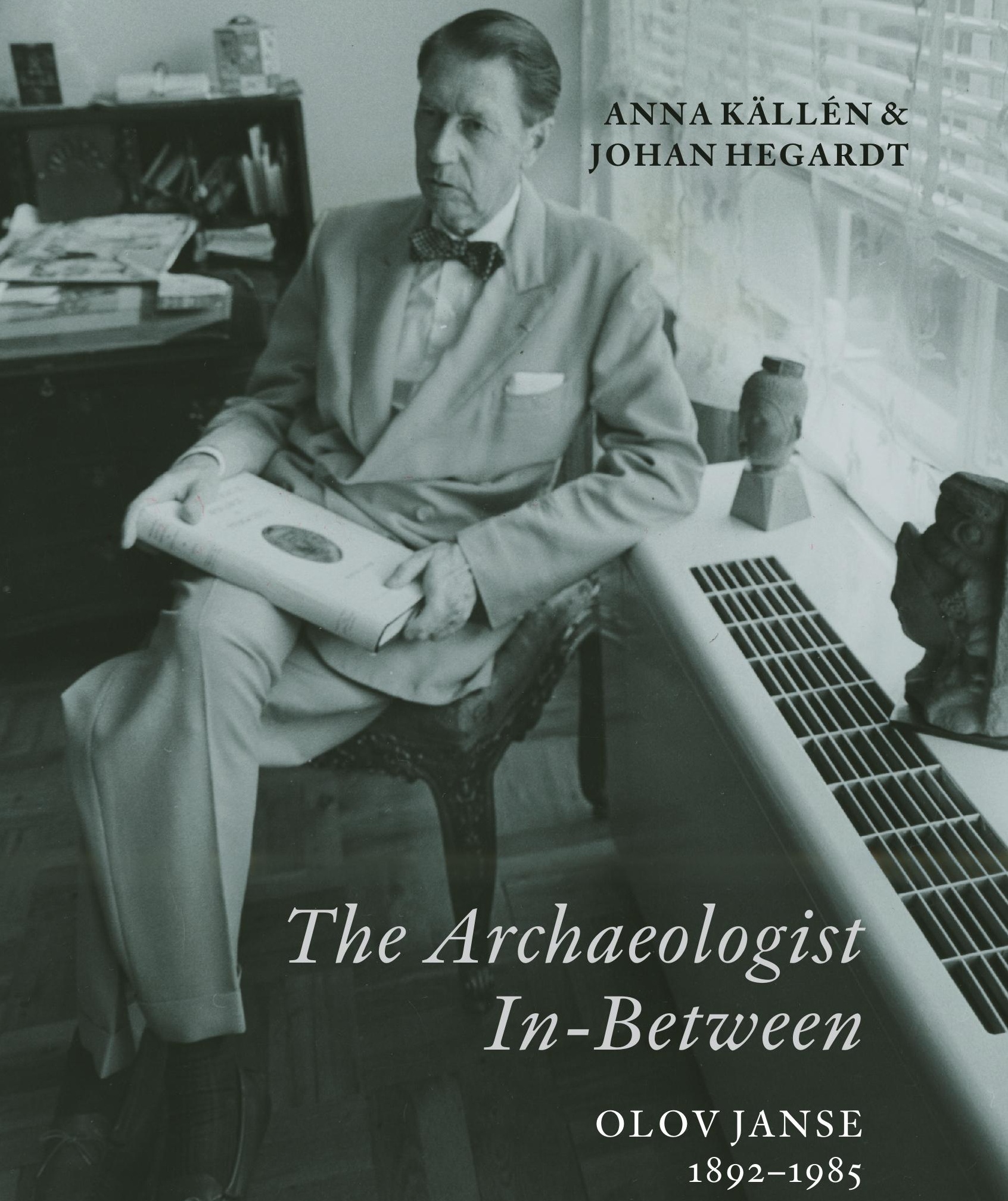


THE ARCHAEOLOGIST IN-BETWEEN 


\section{THE ARCHAEOLOGIST IN-BETWEEN OLOV JANSE 1892-1985}

ANNA KÄLLÉN \& JOHAN HEGARDT

Makadam 
MAKADAM PUBLISHERS

GÖTEBORG • STOCKHOLM

WWW.MAKADAMBOK.SE

Published with the support of

Stiftelsen Riksbankens Jubileumsfond

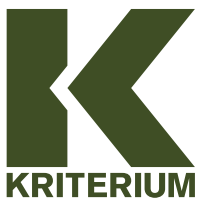

This book is published within Kriterium, a consortium for peer review of Swedish academic literature. The manuscript has been reviewed by a minimum of two external, independent experts, and Kriterium has subsequently approved the book for publication. Kriterium is an initiative of Swedish universities, and aims to support and strengthen the position of academic books in relation to other forms of academic publishing. All books published within Kriterium are available as open access through the website www.kriterium.se.

IS SN: 2002-2131 Kriterium (Online)

https://doi.org/10.22188/kriterium.19

The Archaeologist In-Between. Olov Janse 1892-1985

(C) Anna Källén, Johan Hegardt and Makadam Publishers 2021

Cover photograph: Courtesy of Olov and Renée Janse papers, National Anthropological Archives, Smithsonian Institution

(C) for illustrations, see p. 491

IS B N 978-91-7061-805-5 (pdf) 
ACKNOWLEDGEMENTS 7

INTRODUCTION 11

$\begin{array}{ll}\text { I. FOUNDATIONS } & 27\end{array}$

OTTO AND THE CANDY FACTORY 28

TRAVEL WRITING 43

ARCHAEOLOGICAL FOUNDATIONS 53

BETWEEN FRANCE AND SWEDEN (1919-1929) 68

RONNY 123

II. EXPEDITIONS 131

THE THREE EXPEDITIONS REVISITED 132

$\begin{array}{ll}\text { PRELUDE } & 136\end{array}$

EUPHORIA: INDOCHINA, OCTOBER 1934MAY $1935 \quad 140$

INTERLUDE: MAY 1935-OCTOBER $1936 \quad 180$

CRISIS: INDOCHINA, OCTOBER 1936-

DECEMBER 1937

INTERLUDE: DECEMBER 1937-NOVEMBER 1938231

REFOCUS: INDOCHINA AND THE PHILIPPINES,

NOVEMBER 1938-AUGUST $1940 \quad 248$

POSTLUDE 298 
III. EXPERTISE

305

PRIVILEGED EXILE

306

OSS AND THE DEPARTMENT OF STATE

316

DARLING, DEAREST: LETTERS FROM

UNESCO 1946-1947

343

RENÉE 367

COCKTAILS AND PUBLIC DIPLOMACY 380

CONCLUSION: THE ARCHAEOLOGIST IN-BETWEEN

425

POSTLUDE: MEMORABILIA

444

REFERENCES

465

ARCHIVES

484

PICTURE SOURCES

491

INDEX

494 


\section{ACKNOWLEDGEMENTS}

Every book takes its author on a journey to unexpected places. The writing of The Archaeologist In-Between started out in research fields already familiar to us - in the history of archaeology in Sweden and French Indochina - but soon urged us to move out to unfamiliar academic territories and uncharted spaces in-between. Much like Olov Janse, who relied on generous individual and institutional support across borders to fulfil his work, we could not have done it without backing, assistance, and contributions from a great number of institutions and individuals along the way.

During the main period of research and writing (2012-2019), we were affiliated with the Swedish History Museum, the Department of Archaeology and Classical Studies at Stockholm University, the Research School of Cultural History at Stockholm University, the Department of Culture and Aesthetics at Stockholm University, and the Department of Culture and Education at Södertörn University. We much appreciate the administrative support from these institutions, and are grateful for the intellectual input from seminars and everyday discussions with colleagues and students there.

In addition to our home institutions, we have benefited from the services and support of a number of archives and research institutions. In Sweden we would like to mention in particular the Regional State Archives in Vadstena, the Norrköping City Archive, the Swedish National Archives, the Swedish Television Archives, and the Museum of Far Eastern Antiquities in Stockholm; in France the Musée d'archéologie nationale et domaine national de Saint-Germain-en-Laye, the Musée 
Cernuschi, the Musée Guimet, the Musée de Quai Branly, the Collège de France, the École française d'Extrême-Orient, and the UNE SCO Archives in Paris; in Vietnam the National History Museum, the Vietnam Institute of Archaeology, and the École française d'Extrême-Orient in Hanoi, the Museum of Vietnamese History in Ho Chi Minh City, and the Thanh Hoa Culture Office; in Singapore the National Museum of Singapore; and in the USA the Smithsonian Institution's National Anthropological Archives and the Freer Sackler Gallery in Washington, DC, and the Harvard Peabody Museum and the Harvard-Yenching Institute in Cambridge, Massachusetts.

In and around these institutions there are some individuals who have contributed crucial support and direct input to the writing process. It was the encouragement and generous gifts of Magnus Fiskesjö, Patrik Nordström, and the late Wilhelm G. Solheim II that first sparked our interest in Olov Janse, and for that we are eternally grateful. At the very end of the writing process Adam Hjorthén, Anna Karlström, Ian Lilley, Christine Lorre, Inga Sanner, Nathan Schlanger, Daniel Strand, and one anonymous peer reviewer have read and commented on drafts of the text. Their critique and suggestions for improvement have been of the utmost importance, and we are much obliged to them for their time and effort, and for lending their knowledge and brilliant minds to the benefit of our work. Then, of course, the book would not be a book without the meticulous works and efforts of Alan Crozier (to whom we are grateful not only for copy-editing but also for help to identify the elusive Professor Valot!), and our excellent editor, Tove Marling Kallrén at Makadam, who pulled it all together.

We moreover wish to acknowledge the vital support and contributions at different stages of the research process from Susan S. Alpert, Kent Andersson, Anders Andrén, Tatiana Antontchik, Birgit Arrhenius, Elisabeth Arwill Nordbladh, Françoise Aujogue, Pierre Baptiste, Nathalie Baills-Barré, Ingrid Berg, Sally Brockwell, Robin Carlaw, Louise Cort, Do Quoc Trong, Elin Engström, Victoria Fareld, Anne Fort, Cheryl Fox, Michèle Galdemar, Lia Genovese, Ian Glover, Guillaume Goujon, Bo Gräslund, Claire Guttinger, Jenni Hjohlman, David Hogge, Ho Quang Son, Marjorie Delabarre, Mikael Jakobsson, Rolf Jonsson, Kanji Tawara, Patricia Kervick, Alice Lemaire, Jonas Thungren Lindbärg, Luan an Trong, Cynthia Mackey, Wilbert Mahoney, Göran Malmquist, PierreYves Manguin, Ingela Matsson, Robert Mauss, Katherine Meyers, Adam Minakowski, Eva Myrdal, Nguyen Kim Dzung, Nguyen Tien Dong, 
Nguyen Van An, Elisabeth Niklasson, Daisy Njoku, Hanna Nydahl, Victor Paz, Kathryn Phillips, Gina Rappaport, Örjan Romefors, John Rosa, David Sager, Eric Van Slander, Matthew Spriggs, Lindsay Strogatz, Sun Il, Fredrik Svanberg, Birgitta Svensson, Jackie Taffinder, Paul M. Taylor, Adèle Torrance, Tim Winter, and Karin Åström Iko.

We have been very fortunate to enjoy the steadfast and generous support of Olov Janse's family and friends, and wish to extend our sincere thanks to Carl Otto and Helga Janse, Per Janse, Christina Janse Petersson and Jan-Erik Petersson, Per Arne Falk and Gunilla Friberg, Agneta Lundström, Elisabeth Nerman, and the late Anders Nerman for letting us use their family archives, and allowing us to get closer to the personal lives of Olov and Renée Janse.

No research can be done without funding. The Olov Janse project was funded by a three-year research grant from Riksbankens Jubileumsfond The Swedish Foundation for Humanities and Social Sciences, which has also funded the production of this book. We are also grateful to Stiftelsen Olle Engkvist Byggmästare, Birgit och Gad Rausings stiftelse för humanistisk forskning, Helge Ax:son Johnsons stiftelse, and Åke Wibergs stiftelse for additional grants that enabled the completion of the book.

Last but not least, we wish to extend our heartfelt thanks to the family, without which the research and writing process would be neither realizable nor enjoyable. To Torun Hegardt, Birgitta Gustafsson, Staffan Lagerwall, and Per Arne and Marianne Källén for support and opportunities to have extra writing time. And to Hugo, Hedvig and Otto - who have (hopefully) enjoyed a little and (certainly) endured much.

Stockholm, May 2021

Anna Källén \& Johan Hegardt 



\section{INTRODUCTION}

On a rainy morning in February 1935, Olov Janse travelled by train from Hanoi towards Yunnan-fu ${ }^{1}$ with his wife Ronny. Excited and elated, they had just arrived for the first time in Indochina and were ready to start excavating. But a typhoon with heavy rains held them up, and they passed the time with a three-day journey on the modern railway connecting the French colony with China. French officials had arranged so they could travel in style in the railway company's saloon car, without having to leave the train and resort to the simple - "very Chinese" - accommodation offered at the night stops along the way. Through the train window they saw the endless plains around Hanoi giving way to a chaotic, wild alpine landscape, where the train snaked along steep mountain sides. At the stations were women from native tribes in colourful clothing with big umbrellas, who turned away and refused to look into the eye of their camera. But why? They are afraid, Janse thought to himself, because their irrational primitive minds are slaves to superstition. When the train passed through the unremarkable gate that marked the border with China, he felt a rush of excitement and emotion. At last, he had made it to the Far East and a childhood dream had come true. ${ }^{2}$ From the stop-over in Yunnan-fu he wrote to his friend Ture Nerman, an influential political journalist in Sweden:

1. Now Kunming.

2. Janse 1959:69-72. 
The town is almost completely untouched by Western culture. The people there are still living in complete medieval times. At the flea market in Yunnan-fu I bought an iron fire starter, of exactly the same type as those that were used in Sweden in the Viking Age. In Yunnan-fu they are still in use. ${ }^{3}$

The Indochina expedition was just one of Olov Janse's many international endeavours. During his lifetime, he would travel several times around the world, and witness some of the most important events in twentieth-century world history. He moved from a late nineteenth-century industrial town in central Sweden, through early twentieth-century Scandinavian archaeology, to museums, research and higher education in France and Sweden, to colonial excavations in Southeast Asia, finally ending up in the intelligence service and Cold War public diplomacy for the US Department of State. Throughout his life, he adopted a set of modern technologies to bridge and overcome distance - passenger liners, railways, and postal services - in combination with narratives and visual techniques that conveyed knowledge of distant places and upheld notions of cultural distance. In his letter from Yunnan-fu, he used temporal metaphors to create a sense of cultural and developmental distance by describing contemporary lifestyle and mundane objects as ancient, forming a conceptual package which stabilized notions of distance and essential difference between people, at the same time as it offered a privileged in-between position for himself as a storytelling scholar.

By concentrating on the life and work of Olov Janse, this book investigates the sprawling trajectories of the archaeological profession in the twentieth century. Rather than considering archaeologists to be moored in specific fields or trenches, this book argues that archaeologists have also in fact occupied positions of the in-between, and that such transient positions have had important effects on the organization of archaeological knowledge. Janse's constant movement between contexts has urged us to pay attention to and maintain a sharp focus on the communicative aspects of archaeology. A core argument of the book, therefore, is that narration - telling stories about the relations between ancient and recent

3. Letter from O. Janse to T. Nerman, 28 February 1935. Arbetarrörelsens arkiv och bibliotek. Ture Nerman. 3.1.7. In the Swedish original: "Staden är nästan fullständigt oberörd av västerländsk kultur. Människorna där lever ännu i full medeltid. På loppmarknaden i Yunnan-fu köpte jag ett eldstål av järn, alldeles av samma typ som de vilka var i bruk i Sverige på vikingatiden. I Yunnan-fu används de fortfarande.” 
times, in academic publications, in official administration and to broader audiences through popular media - should be just as important to consider as methodology, if we are to understand the historical developments of archaeological knowledge.

Historiographically, Olov Janse has been more or less unknown in all the contexts he worked in. This can be seen as a consequence of the tendency to compartmentalize in historical research. Compartmentalization has resulted in distinct research fields, which, in turn, have contributed to the formation of historical discourses where former institutions and historical contexts often stand out as self-sufficient islands, developed and driven almost entirely by their own inner logic. Here we have, for example, the history of Scandinavian archaeology, the history of French national museums, the history of archaeology in French Indochina, the history of US intelligence services, and the history of UNESCO. Olov Janse was present at all these contexts and made considerable contributions to them, but not enough to be recognized as a historical character of major impact in any one of these "islands" alone.

As such, Olov Janse can best be described as an archaeologist in-between. He made a trade of moving in and controlling the spaces between nation states and language spheres: the Scandinavian, Francophone, and the Anglophone. He also moved in-between institutions and fields of expertise: archaeological research and education, museums, the intelligence service, and national and international political administration, often with tasks relating to soft or public diplomacy - all of which have established their own historiographical traditions. "Scholars routinely tell stories to each other and to themselves about how their discipline or specialism emerged, how it evolved over time and how they fit into this account," says Duncan Bell. He calls these stories discipline-defining mythologies: "Myths, on this anthropological reading, are highly simplified narratives ascribing fixed and coherent meanings to selected events, people and places." ${ }_{4}$ Olov Janse has so far only had a minor role, if any, to play in such stories of one institution, one field of expertise, or one nation. ${ }^{5}$ If noticed at all, he is mostly referred to as a Swedish archaeologist who worked in French Indochina.

4. Bell 2009:5.

5.E.g. Daniel 1981; Murray \& Evans 2008; Lorre 2015b; Hegardt 2015a; Johansson 2012; Clémentin-Ojha \& Manguin 2001; Smith 2005; Valderrama 1995; Logevall 2012. See also Kaeser 2002. 
In our study we have chosen to focus on the itineraries - Olov Janse's movements between nation states, institutions and fields of expertise. Discipline-defining mythologies and established historiographies will be referred to along the way and used for purposes of contextualization, but it is the itinerary that matters the most here. The purpose is not so much to draw attention to Olov Janse as a person and to judge whether the effects of his archaeological pursuits were essentially good or bad. Rather, we want to see what a focus on movement, translation, and connection can offer to fields of historiography that have traditionally been based on ideals of boundedness and essential stability. We want, in other words, to focus on routes rather than roots, with the purpose of creating new vantage points for the study of familiar institutions such as Swedish archaeology, the Cernuschi Museum, UNE SCO, and the Harvard-Yenching Institute. The idea and ambition of the shift from roots to routes is not new. It has in fact defined much of the developments in critical cultural theory over the past couple of decades. ${ }^{6}$ In this case, however, the emphasis on routes has also grown during the research process as a response to the actual movements of Olov Janse and the texts and materials he left behind, so it was derived from the constitution of the empirical material just as much as it was informed by a critical theoretical ambition. With the lens focused on Janse's itineraries, an unusual image of archaeology has emerged. In a sort of kaleidoscopic vision it contains transience, translation, negotiation and paradox. And it features archaeology in as differing frameworks as internationalism, colonialism, exile, the intelligence service, and public diplomacy.

Our analytical and narrative approach is microhistorical. The microhistorical approach means in this case that Olov Janse's biography, and empirical details within it, are used as prisms through which his contemporary world is represented in our text. With Janse as prism, our text will shed light on each of the contexts where he was active from a particular perspective, which is offered by his position and movements in and around that context. The end result is a form of situated cultural history, ${ }^{7}$ which allows for a perhaps less complete but more complex (sometimes paradoxical) view than traditional historical narratives can accommodate. Furthermore, the use of Janse as a prism emphasizes the connectedness between these contexts, which have often been overlooked - for instance between

6.E.g. Clifford 1997; Trinh 2011. See also Källén 2019.

7. Haraway 1988; Burke 1992. 
French and Swedish museums; between archaeological narratives and US public diplomacy; or between UNESCO and pre-war colonialism. In short, this book has been written as one specifically situated, empirically driven, concrete example of an archaeologist on the move between nation states, institutions and fields of expertise in the twentieth century. It puts emphasis on archaeological knowledge production from transient positions, and maintains that narration is just as important, and intimately intertwined with, methodology in the formation of archaeological knowledge. It intends to be relevant beyond the concrete example of Olov Janse, and seeks to open up for a perspective where it is possible to pick up and analyse hitherto elusive histories of archaeology. With this perspective comes also an appeal to unlearn the privilege of roots in the history of archaeology, to challenge the traditional focus on bounded political and administrative units in the history of archaeological thought, by taking more interest in the effects of transient in-between positions on the organization of archaeological knowledge.

\section{Itineraries}

Olov Janse has had extraordinary potential to succeed in his expeditions to distant lands. A sharp eye for the location of untouched archaeological grounds across the world, an amazing ease in speaking foreign languages, $[\ldots]$ an unusually pleasing personal appearance, and an ability to put up, calmly and patiently, with even the most difficult situation and find resourceful ways out of it, [as well as] a rich interest in various forms of culture and people of different races. ${ }^{8}$

Olov Robert Thure Janse - known to his family and friends as Olle ${ }^{9}-$ was born in 1892 in Norrköping, Sweden. His father ran a successful

8. By Birger Nerman, childhood friend and colleague of Olov Janse. In the Swedish original: "Olov Janse har haft sällsynta förutsättningar att lyckas med sina expeditioner till dessa färran länder. Ett vaket öga för var obearbetade arkeologiska marker funnes att tillgå i världen, en fantastisk lätthet att tala främmande språk, [...] ett ovanligt sympatiskt personligt framträdande, en förmåga att med lugn och tålamod finna sig i även svåra situationer och finna rådiga vägar därur, ett mångsidigt intresse för skilda kulturformer och människor av olika raser." (Janse 1959: preface).

9. In Swedish Olle is pronounced ['ul:s], and Janse ['jan:se]. 


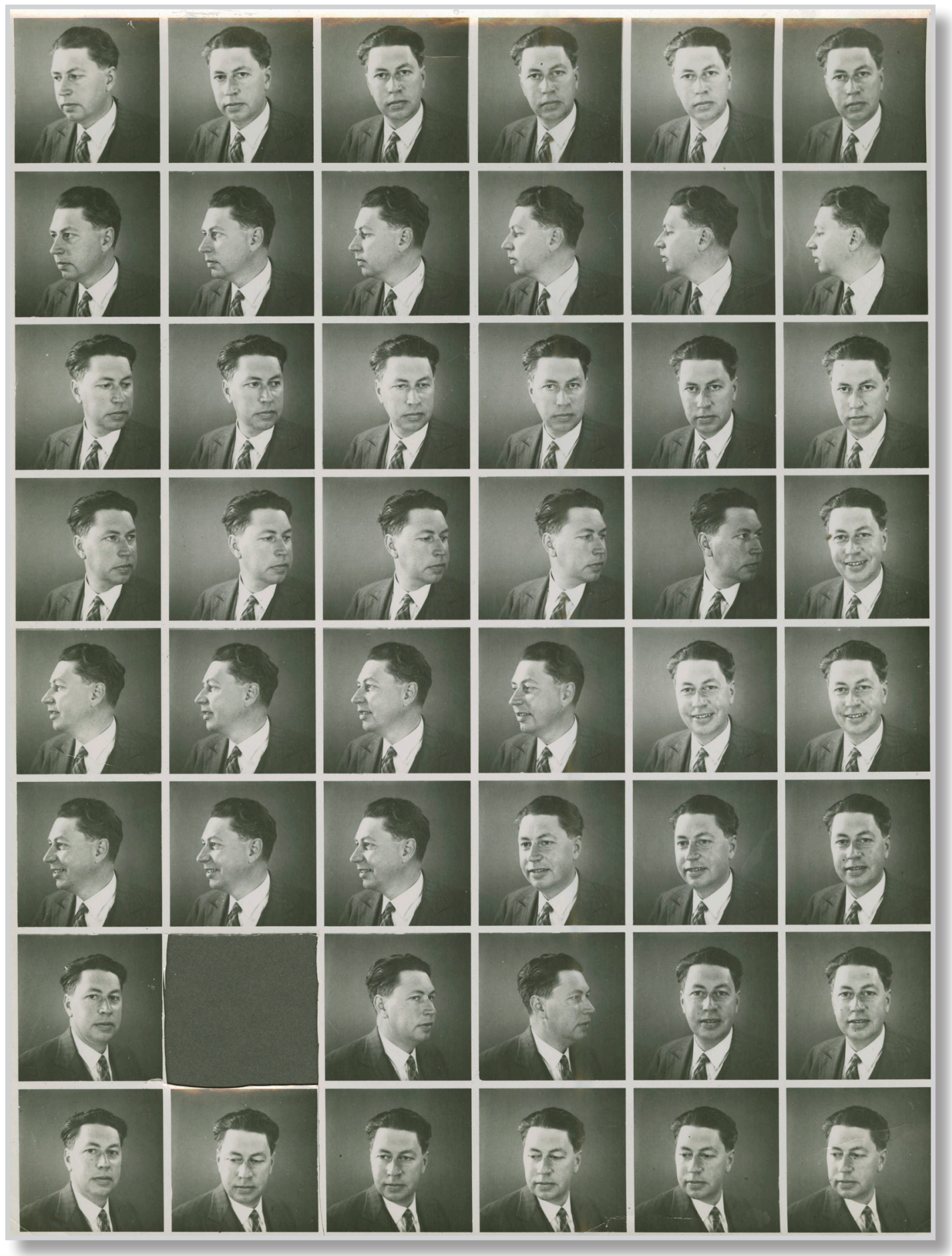

Fig. 1. Olov Janse. 
candy factory, and the family belonged to the town's wealthy industrial bourgeoisie. He was also very fond of his uncle Otto Janse, who was a renowned art historian and archaeologist. And already as a young boy Olle became friends with his neighbours Ture, Birger and Einar Nerman, who introduced him to the art of writing and inspired him to study archaeology. So at the age of twenty, he left Norrköping and enrolled to study archaeology at Uppsala University.

At about the same time he began to travel, first to Iceland and later to France, and wrote travel reports for his local newspaper. The meeting with France had a profound impact on him, and soon he began referring to himself as a Francophile. The First World War forced him to stay in Sweden during his mid-twenties, but as soon as the peace treaty was signed he was on his way to Paris again. There he met Henri Hubert, historian and sociologist, who became his mentor and friend, and introduced him to museum work at the Musée des antiquités nationales (now Musée d'archéologie nationale) in Saint-Germain-en-Laye, and to university teaching at the Sorbonne and the École du Louvre. For several years he shared his time between France and Sweden. He returned to Sweden in the summers to work at Historiska museet, the Swedish History Museum in Stockholm, and to complete his doctoral thesis at Uppsala University. ${ }^{10}$

In his mid-thirties he lost much of his professional support in Paris when Henri Hubert suddenly died. A couple of years later he met and married Ronny Sokolsky. Ronny was eleven years younger than Olov, came from Krasnodar in Russia and worked at the Swedish-Russian Trade Commission in Stockholm. They travelled between Paris and Stockholm, and made trips across the European continent. Together, and with support from official museums and private artefact collectors in Paris, they began to plan for an archaeological expedition to French Indochina. In October 1934, they set off from Marseille on the SS d'Artagnan bound for Saigon.

On the first expedition they spent six months in Indochina. They worked with support from the research institute École française d'ExtrêmeOrient (EFEO) in Hanoi. With EFEO as a professional base, they visited famous archaeological sites such as Angkor, and made ethnographic observations of native people in the mountains. Assisted by secretary Nguyen Xuan Dong (Vietnamese: Nguyên Xuân Dông) they pursued ar-

10. Janse 1922. 
chaeological excavations of brick tombs from the Han period (206 B CAD 220), and began investigations at the prehistoric Dong Son site.

They returned to Paris in May 1935 with a substantial collection of excavated artefacts that was immediately put on display at the Cernuschi Museum. They stayed in Europe for a year and a half, before they departed for a second expedition in October 1936, which lasted fifteen months until January 1938. Their work continued at mostly the same sites as the first expedition, and most of the excavated collections were shipped to the Guimet Museum in Paris. They had nurtured plans to return to Europe and settle in Sweden after the expedition, with Olov as new director of the Museum of Far Eastern Antiquities in Stockholm. But the plans failed, and with the political situation in Europe becoming more and more acute they decided to travel to the USA.

They found respite in Buffalo, New York State, where Janse worked at the Buffalo Science Museum on a Rockefeller grant. Meanwhile they got in touch with Serge Elisséeff, an old friend from the years in Paris, who was now the Director of the Harvard-Yenching Institute in Cambridge, Massachusetts. Together they began to make plans for a third expedition to Indochina, now under the auspices the Harvard-Yenching Institute, and in cooperation with the EFEO in Hanoi.

They set off from San Francisco in November 1938. Upon arrival in Indochina they continued to excavate and pursue ethnographic documentation in much the same manner as their previous expeditions, but before long the Sino-Japanese War affected the situation in Indochina so badly that it was virtually impossible to continue the work. To make the most out of the expedition they travelled to the Philippines where they ended up staying nine months, from November 1939 to August 1940. Janse excavated about a hundred tombs from the Ming period at the private estate of Hacienda Calatagan, but also ended up in controversy with the influential American archaeologist H. Otley Beyer. When they eventually had to leave the Philippines due to the escalation of the war across Asia, they brought a substantial collection of excavated artefacts from Indochina and the Philippines back to the Harvard-Yenching Institute.

Back at Harvard they worked with the excavated collections and the excavation reports, and in May 1941 the collections were put on display at the Fogg Art Museum. At the same time Janse was appointed Lecturer in Far Eastern Archaeology at Harvard University. A year and a half later, at the end of 1942 , Janse was recommended to join OSS - the Office 
of Strategic Services ${ }^{11}$ - in Washington, DC. There he was appointed to a position with the Morale Operations for OSS in Indochina, while Ronny worked as an OS S biographical analyst. When OSS was dissolved in 1945 , they both moved to the US Department of State where Olov became deputy chief of the South-East Asia section of the Research and Analysis Branch. Olov Janse was then fifty-three years old.

When the war came to an end, so did their appointments with the State Department. In April 1946 Ronny obtained a new position at the Library of Congress. Olov joined the Secretariat of UNE SCO - The United Nations Educational Scientific and Cultural Organization, that was about to take shape. In November 1946 he travelled alone to Paris, where he spent eight months, working as Head of Section for Philosophy and the Humanities in the UNESCO Secretariat. If they had both initially seen UNESCO as an opportunity to return to Europe for good, the harsh reality of post-war Paris, and the difficulties haunting the new organization, soon made him long to go back to the United States, and to Ronny who stayed in Washington and the Library of Congress.

He returned to USA in July 1947, and the first volume of his extensive report Archaeological Research in Indo-China was published later the same year. They became US citizens in September 1948, and at the same time Ronny changed her first name to Renée. He was once again contracted by the State Department and in 1947-1955 was a Senior Research Analyst for the Foreign Service Institute. Meanwhile he continued to work on the excavation reports from Indochina and the Philippines, and had the second volume published in 1951, and the third in 1958. He also wrote his archaeological memoirs in Swedish - Ljusmannens gåta: arkeologiska upplevelser $i$ Sydöstasien - which was published in 1959.

At the end of the 1950 s Olov and Renée were actively involved in the high social and diplomatic life of Washington, DC. In 1958 he returned to Southeast Asia and stayed five months in Saigon, as a Visiting Professor under the auspices of the US Smith-Mundt Act for public diplomacy. In his lectures he focused on the role of archaeology and heritage in the postcolonial nation-building process, but maintained his strong beliefs in a Western origin of Vietnamese civilization. He was still a Francophile, but expressed commitment to the postcolonial future of South Vietnam - against communism, which was in accordance with his own personal political orientation as well as US policy. Back in the United States he

11. The United States' wartime intelligence agency, predecessor of the CIA. 
initiated a return of a substantial collection of his own excavated artefacts from Harvard to the History Museum in Saigon. Political developments in Vietnam were now a priority in US foreign policy, and Janse spoke about Vietnam on Voice of America, and organized an exhibition with public diplomacy ambitions: "The Art and Archaeology of Viet-Nam", which opened at the Smithsonian Institution in 1960.

With this, Olov Janse's professional life ended on a high. He was awarded prizes and awards for his work, such as the Knight of the French Legion of Honour, and Knight of the Swedish Royal Order of the Polar Star. He and Renée lived a comfortable life in Washington, DC, posing photograph after photograph, as a perfect couple with perfect smiles. At the same time, Olov wrote sad letters to his Swedish friends and Renée wrote dark poetry, speaking of unbearable loss, anxiety, and weariness with life. Olov died in March 1985, at the age of ninety-two. Renée survived her husband by fifteen years, lived to the age of ninety-seven and died in Washington, DC, in the year 2000.

\section{The Olov Janse Research Project}

We began our research into Olov Janse's life and work in 2005, only five years after Renée died. With our common interest in critical theory, and our combined expertise - in the history of museums and early Scandinavian archaeology, and the colonial history of archaeology and archaeological heritage in Southeast Asia - we found Olov Janse to be an irresistibly intriguing character. Despite his early professional achievements at the Swedish History Museum and his active presence at a number of crucial moments of twentieth-century world politics, he was curiously unknown in the history of Swedish archaeology. It was mainly archaeologists in Vietnam who knew about him, but there too he was a rather hazy character. In fact, attending her first international conference in Malaysia in 1998, Källén was approached by Bill Solheim - Olov Janse's younger colleague and friend who has described him as "one of the best 'dirt archaeologists' to excavate in Southeast Asia during the thirties" ${ }^{12}$ - who urged her to take an interest in Janse because his work had not received the attention it deserved. ${ }^{13}$

12. Solheim 1969:4.

13. Bill Solheim passed away in July 2014 , at the age of eighty-nine, only days after this was written. Hence he never came to see the results of the research that he once sparked. 
In 2005 , we received a grant for preliminary research, ${ }^{14}$ and went to Vietnam to search for traces of Janse and his work there. In collaboration with the Vietnam Institute of Archaeology in Hanoi we visited some of the sites he and Ronny had excavated. In a village near one of the sites, we had an unforgettable meeting with two old men who had childhood memories of the excavations. We studied the collections of their excavated materials in the National History Museum in Hanoi and searched (in vain) all available archives for material related to him and his work. Back home in Sweden we met with his relatives and were given access to the original films he made on his travels and fieldwork. ${ }^{15}$ More than anything, this preliminary study convinced us that much more research ought to be done on Olov Janse's life and work, and that it promised unique insights into the workings of archaeology outside and between political and institutional units that have often been taken for granted in the history of archaeology.

Other work and projects then got in the way, so it was not until 2012 that we picked up the threads again, now supported by a three-year research grant from Riksbankens Jubileumsfond. Over the years 2012-2015 we visited places, conducted interviews, searched archives, and studied museum collections associated with Olov Janse in Europe, the United States, and Southeast Asia. We began with all the published material, academic and popular, and the most obvious archives and museums where we knew we would find traces of Janse. From there we moved onwards and outwards in circles with the ambition to find as much as possible of what Olov, Ronny and Renée had left behind.

Olov Janse's published works represent the most obvious, official rendering of his professional life and archaeological legacy. Among these are a large number of scholarly articles, from the early days in Scandinavian archaeology to his more senior years in the United States, his substantive three-volume report from the Indochina expeditions, a few pieces (one anonymous) from his intelligence service work, and a range of newspaper articles about his work and travels. There is also Ljusmannens gåta, his travel memoirs from Indochina published in Swedish in 1959. Written in a light, often humorous style, it contains not only accounts of the Indochina years but also some information about his earlier work in France. We have used this, as we have the rest of his own published materials, not

14. Thanks to the Åke Wiberg Foundation.

15. The films are now kept in the Swedish Television Archives in Stockholm. 
so much as sources of plain facts, but as examples of how he wanted his work and his career to be known and remembered.

To complement this official image and contextualize the published works, we have consulted more than twenty archives in Europe, the United States, and Vietnam. ${ }^{16}$ Our main archive resource has been Olov and Renée Janse's personal archive in the Smithsonian Institution's $\mathrm{Na}$ tional Anthropological Archives in Maryland, referred to as NAA in the text. It contains mostly personal documents that remained in their home in Washington, DC, when Renée died. At the time of our study (2012-2013) it consisted of four open cardboard boxes filled with photo albums, letters, professional documents and newspaper clippings (fig. 2), and one oversize box with large portraits and diplomas. ${ }^{17}$ It had not yet been processed at the time, which was perfect for us who, like most archaeologists, take particular interest in the materiality of things. The contents of the boxes came straight out of Renée Janse's home, so the touch, smell, order, layering, and juxtaposition of the things in the boxes - in other words, their materiality - offered those extra pieces of evasive information about Olov and Renée Janse as corporeal persons that plain documents cannot give. The acquisition files show that it was Renée's wish to have their documents kept in the Smithsonian Institution archives, ${ }^{18}$ so we know that she was aware that what she left there would become official after her death. The fortunate fact that the contents of these boxes had not yet been reorganized in the standard impersonal format of the official archive thus also gave us the opportunity to trace Renée's conscious editing of the archive after Olov's death, which to some extent has decided what should be included in and excluded from the official version of his life and career. ${ }^{19}$

On a visit to members of Olov Janse's family in Sweden in 2005 , we were informed that they had in their possession sixteen original films shot on travels and fieldwork from 1934 onwards. Renée had given them the films when they visited her in Washington after Olov had passed away, and they kept the stack of original tin containers stored in a paper bag at the back of their study. After consulting the Swedish Television archives

16. A full list of archives will be found at the end of the book.

17. A smaller box with personal photographs and family-related material was given to Per Janse, the son of Olov's cousin in Sweden, in the partition of the estate after Renée's death. Per Janse has generously allowed us to use that material for our research.

18. NAA: Janse 2001-29. We discuss this in more detail in the chapter "Memorabilia". 19. See a discussion about the editing wife in Engström 2015. 
we suggested, for preservation and safety reasons, that the films should be donated to be restored and kept in the archive..$^{20}$ The archive accepted the donation, and in turn made DVD copies for the family's private use, and for our research. For us, the films have offered invaluable research material to complement the archives, particularly for the Indochina years.

As a further complement to archives and films, we have conducted interviews with a number of people who knew or interacted with Olov, Ronny and Renée. Most have been relatives and children of their friends in Sweden, but we have also interviewed people in Vietnam who visited their excavation sites. These personal memories have also rendered important insights into Olov's, Ronny's and Renée's looks and personalities.

As archaeologists, we maintain that it is of great importance to have knowledge not only of Olov, Ronny and Renée Janse's texts, images, and

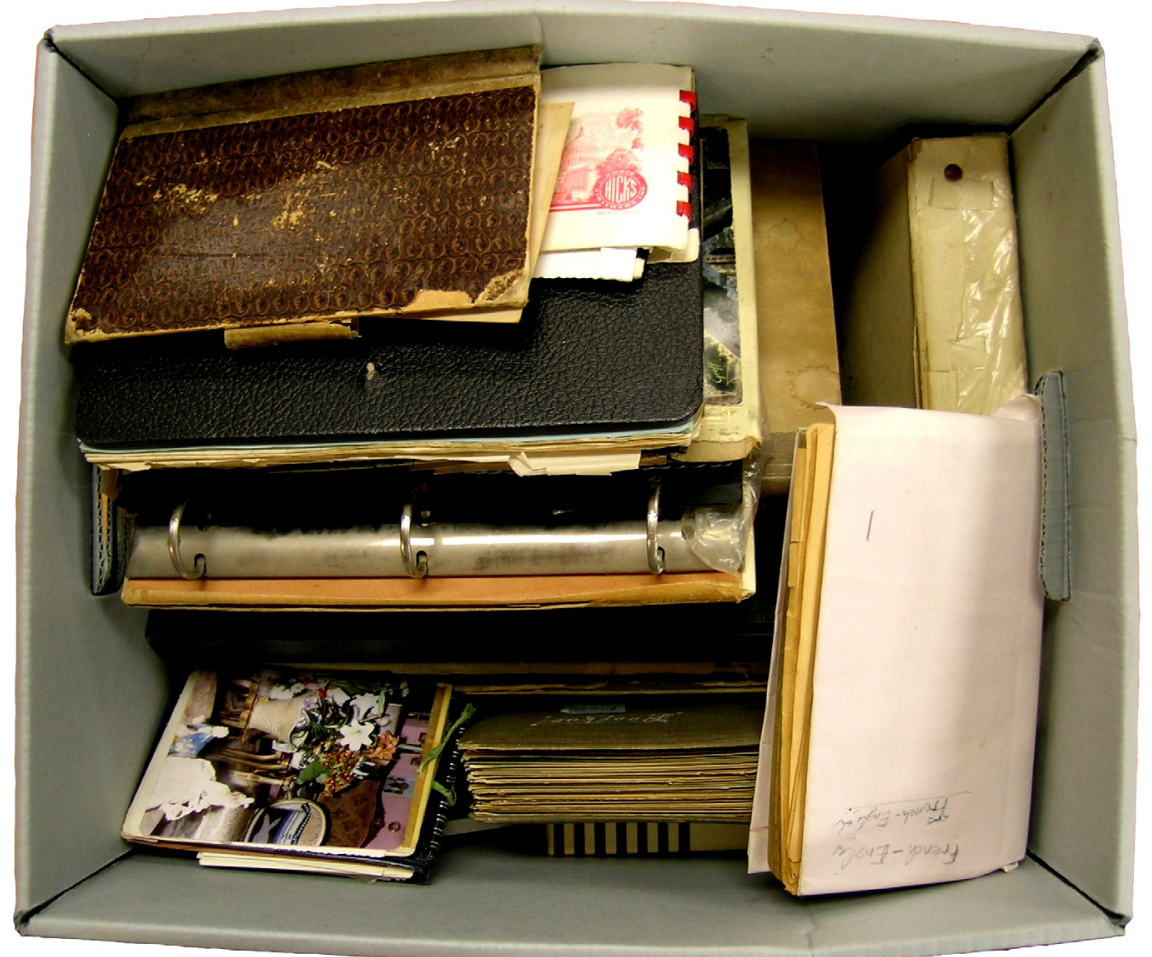

Fig. 2. The contents of one of the boxes in the unprocessed Janse archive.

20. Two DVD copies: Olov Janses filmer 40-05/2112-004-016. Olov Janses filmer, 40-05/2112-017-020. The second copy contains the OSS film. Swedish Television Archive. (c) SVT Arkiv. 
personal appearances, but also of the actual physical sites where they worked and moved. For that reason we have explored excavation sites and museums where they worked in France, Sweden, the United States, and Vietnam. We have visited addresses where they lived and hotels where they stayed, have walked their daily promenades, and paused in their hotel bars. This sharing of physical space has added significantly to our deeper understanding of Olov, Ronny and Renée Janse and the conditions surrounding their archaeological work.

Last but not least, we have taken interest in the artefacts, archaeological objects and fragments connected with Olov and Ronny Janse's work. A crucial part of Olov Janse's archaeological legacy resides in the artefacts that he and Ronny excavated or bought, worked with, packed, unpacked, categorized, displayed, donated, and exchanged. ${ }^{21}$ Today they can be found in a great number of museums across the world, and in private collections, many of which have been beyond our research scope. Unlike the texts he wrote, which are forever frozen in their exact accounts, these artefacts and fragments continue to live semi-independent lives. In most cases they retain (if you look for it) a connection with Janse's name, but they are just as much used and known primarily for other reasons. The control over these things was also, as we will argue throughout this book, one of the main assets of an archaeologist working in-between nations and heritage institutions, and therefore the artefacts have been a crucial research material for this project.

\section{The Book}

The book is divided into three parts, reflecting three more or less distinct phases of Olov Janse's life and career.

The first, which we have called Foundations, deals with the formative years of his childhood, adolescence, and archaeological education in Sweden. It begins at the peak of the belle époque when Thure Janse's candy factory is at an all-time high, and ends after the First World War. In the first chapter - "Otto and the Candy Factory" - we meet Olle Janse as a child and a young man in Norrköping, and look closer into his family background. In the second chapter - "Travel Writing" - we focus on his early friendship with Ture, Birger, and Einar Nerman, and see how it inspires him to a form of creative writing that would become a crucial

21. Hegardt \& Källén 2014. 
asset in his later archaeological career. In the next chapter - "Swedish Archaeological Foundations" - we move to Uppsala and his student years, when he becomes an academic archaeologist and is introduced to a typical Scandinavian form of archaeological thought and method pursued by his tutor Oscar Almgren and his famous colleague Oscar Montelius. In the next - "Between France and Sweden" - we follow Janse as he moves through Europe, writes his doctoral thesis and builds a career as a cosmopolitan archaeologist. In Sweden we linger on a celebrated gold exhibition at the Swedish History Museum, and in France on his work at the Musée des antiquités nationales, his friendship with Henri Hubert and Marcel Mauss, and the Durkheimian comparative sociology that they advocated. The final chapter of part I - "Ronny" - is about his meeting and marriage with Ronny Sokolsky. We write some of her previous history, and discuss the decisive impact their relationship had on the rest of his life and career.

The second part of the book - Expeditions - is the longest one, and it represents the centre of gravity in Janse's professional life and career. Here we describe and discuss the three expeditions to French Indochina and the Philippines, with preparations and interludes, and situate them in relation to the acute circumstances and dramatic events that happened during these years, in world politics as well as in Olov's and Ronny's personal lives.

The third part is called Expertise, and begins with the final years of the Second World War and ends at the peak of the Cold War. It begins in 1941, when Olov and Ronny has left Asia, are unable to return to Europe, and settles in the United States. The first chapter of this part - "Privileged Exile" - focuses on their situation in exile as a Janus-faced experience, which on one hand brought a sense of unbearable sorrow and loss, and on the other gave an opportunity to begin a successful new career. The second chapter - "OSS and the US Department of State" - deals with their work for the US Intelligence Services, during and after the war. In the third - "Darling, Dearest" - we zoom in on Janse's work in the Secretariat of a newborn UNE SCO in Paris, with help from eighty-one letters that he wrote to Ronny, remaining in the United States to work for the Library of Congress. The fourth chapter - "Renée" - is devoted to Ronny, her important yet often invisible contribution to Olov's career, and her dramatic transformation from Ronny the brunette to the platinum blond Renée S. Janse. The final chapter of the third part - "Cocktails and Public Diplomacy" - deals with the last long phase of Olov Janse's career. He and 
Renée frequents cocktail parties with the political and diplomatic elite in Washington, D C, and he makes a final journey to Southeast Asia within the US Smith-Mundt programme for public diplomacy.

In the Conclusion we weave together the most important strands of the previous parts with the aim to identify conditions for and consequences of twentieth-century archaeology in-between not only nation states, but language zones and institutional cultures. What structures, networks, and resources enabled such movements, and what structures were again created by an archaeologist in-between? Can we better understand the international or global frameworks for archaeology and heritage management of today, by looking at the individual histories of archaeologists in-between, and by studying the structures, related actors and technologies that enabled their movements and supported their transient positions? Are the legacies of an archaeologist in-between (in terms of academic text, popular culture, or museum collections) in any way different from the legacies of an archaeologist who remained within the boundaries of one nation state and one or very few institutions? These questions will be addressed and discussed in the Conclusion. At the very end of the book is a postlude - "Memorabilia" - where we find memories of Olov, Ronny and Renée Janse connected with things and people - some in rather unexpected places - around the world today. 


\section{FOUNDATIONS}




\section{OTTO AND THE CANDY FACTORY}

Let's start by question no 1, which many times has been fired at me: "Mr Janse, where in the world did you get that queer idea to go in for archaeology?" Thank you, this is a good question. [...] To some extent my interest in art and archaeology is a family tradition as it often is in Europe, where I happened to be born and raised. [...] It was first thanks to an uncle of mine, who was head of the Swedish archaeological service and secretary of the Royal Academy, that I became acquainted with archaeology, and even fascinated by the mysteries of the past, which he tried to unwrap for me..$^{22}$

In one of his last public performances, Olov Janse summarized his career for a curious audience at the American Association in Saigon. His archaeological life began, he said, when his uncle Otto inspired him to think about the mysteries of the past. Otto Theodor Janse (1867-1957) was the youngest brother of Olov's father Thure. He established from early on a warm and close relationship with his nephew that lasted until Otto died, only two years before the lecture in Saigon.

The two brothers Otto and Thure were born and raised in a large family, with their parents Johanna (born Johansdotter) and Erik Johan Janse, four more brothers (Carl, Gustaf, Erik, and Johan), and two sisters

22. Olov Janse's handwritten notes for a lecture at the American Association in Saigon, Vietnam, on 14 January 1959 [the notes are incorrectly dated to 1958]. ATA: Enskilda arkiv 59. Olov Janse. Arbetspapper vol. 2. 
(Theresia (married Karlholm), and Emma). ${ }^{23}$ The family lived in Valdemarsvik, a small town on the southeastern coast of Sweden, where they owned and ran Hotell Janse. At the time, Valdemarsvik was an important trading port linking sea and rail transports, and was known for its animated social life with heavy drinking and more than occasional fist fights. Hotel Janse was right in the centre of action, on Storgatan near the harbour and the railway station. It was a three-storey hotel and social gathering point for the local community, with dinner dances, coffee receptions, and public performances. ${ }^{24}$ The hotel also contained a restaurant (Swe: schweizeri) run by Erik Janse, and the family seems to have been in a comfortable situation in Valdemarsvik, both socially and financially.

The youngest son of the family, Otto Theodor, enrolled to study history at Uppsala University, which was one of the oldest and most prestigious universities in Europe, and earned a Bachelor degree (Swe: fil. kand.)

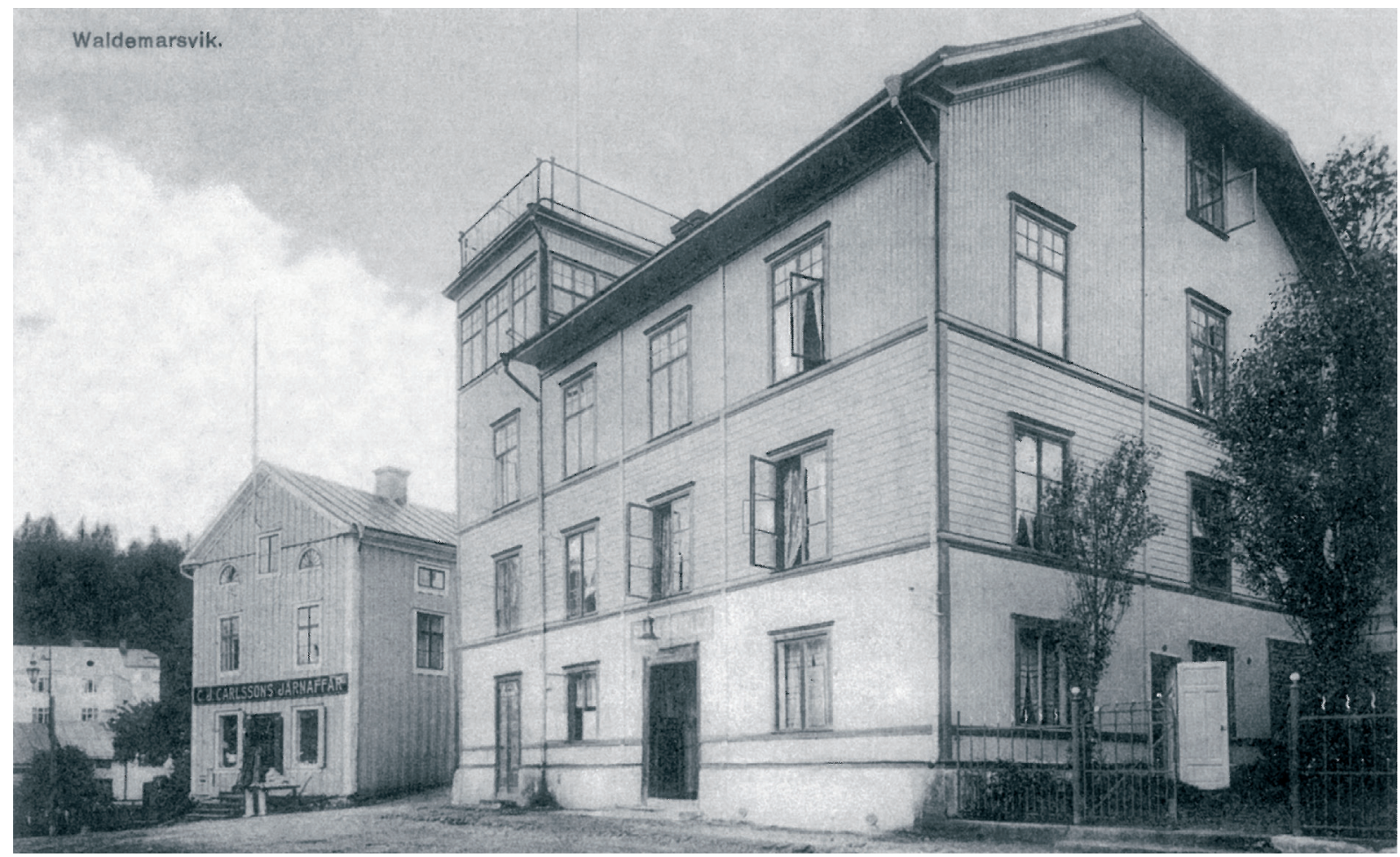

Fig. 3. Hotell Janse in Valdemarsvik c. 1911.

23. Johan and Emma died as infants.

24. Malmberg \& Malmberg 1943. 
in $1893 .{ }^{25}$ After a brief sojourn in Lund, which resulted in a Licentiate degree (Swe: fil. lic.) in 1900, he moved to Stockholm and became curator $^{26}$ at the Swedish History Museum in $1896 .{ }^{27}$ Eleven years later, he was put in charge of the museum's medieval collections. There were only a few members of staff and all had rather voluminous responsibilities. Otto Janse's was not only to manage the medieval collections in the Swedish History Museum, but also to supervise the management of monuments and antiquities from medieval times across the entire country. Among these, the architecture and remains of older medieval churches were considered of primary interest, and it was a priority that suited Otto Janse well. He was passionate about the remains of medieval churches, which had been largely neglected because they were from a period of Catholic dominance (AD 1050-1527) and hence associated with the obscure (in nationalist terms) temporal space between the nation's prehistory (pre1050), and its Protestant national history (post-1527). Thanks to Otto Janse's attention and persistence, the Swedish History Museum saw a considerable increase in the collection and display of medieval church objects in the first decades of the twentieth century. ${ }^{28}$ Otto Janse has been described as a humble and very likeable person, devoted to the study of artefacts and historical material. Although he was not an archaeologist but a historian by training, and although he had no doctoral degree, he became an authority in Swedish (particularly medieval) archaeology. He was awarded an honorary doctorate by Lund University in 1918, and was Acting Director of the National Heritage Board (Swe: Tillförordnad Riksantikvarie) between 1918 and 1923. He remained in charge of the medieval department of the Swedish History Museum until he retired in 1933.

Otto was married to Karin Maria Lundborg (1870-1928). They had a son named Per (1903-1971) and a daughter named Ann-Mari (19051998). In 1928 Karin Maria died suddenly during a journey to Italy. Otto,

25. The biographical information on Otto Janse is drawn from Thordeman 1958 , 1973-1975.

26. His exact title was first "extraordinary amanuensis" (Swe: eo amanuens), later amanuensis.

27. The Swedish History Museum (Swe: Historiska museet) opened in 1866 as a department on the ground floor of the National Museum on Blasieholmen. It remained a part of the National Museum until 1939, when it became an independent institution and moved to its current premises on Narvavägen.

28. Interview with Andreas Lindblom by Lars Lagerqvist, 1973. Transferred to CD 14 December 2008. ATA. 
who was 61 years old, lived alone for two years, before he married again, this time to Baroness Märta Sofia Eckhoff Leijonhufvud (1878-1970), who was the widow of Otto's older colleague Emil Eckhoff (1846-1923). They had met over the work of completing and publishing Eckhoff's unfinished study of the medieval town wall of Visby. After Janse's formal retirement from the Swedish History Museum he continued to work with Märta on Visby stadsmur, which was published jointly, hence partly posthumously, by Emil Eckhoff and Otto Janse in 1936. ${ }^{29}$ Although it was not his study to begin with, Visby stadsmur is the work that is most commonly associated with Otto Janse's academic oeuvre.

But let us go back again, to the early years in Valdemarsvik. When Otto left the hotelier family trade for Uppsala and an academic career in medieval history, Thure, ${ }^{30}$ the second youngest son of Johanna and Erik Johan Janse, chose instead to continue the family's tradition in the food industry. He became a pastry baker and left Valdemarsvik in his early twenties. After a brief sojourn in Söderköping he moved fifty kilometres northwest, to the bustling industrial town of Norrköping.

Young and handsome with an auburn moustache, ${ }^{31}$ Thure Janse arrived in Norrköping in 1888 and established his own bakery shop at the corner of Trädgårdsgatan and Drottninggatan..$^{22}$ In the census of 1890 , a Hilma Wilhelmina Svensson was listed in his household as an unmarried assistant (Swe: biträde).

Hilma was born in 1859 in a

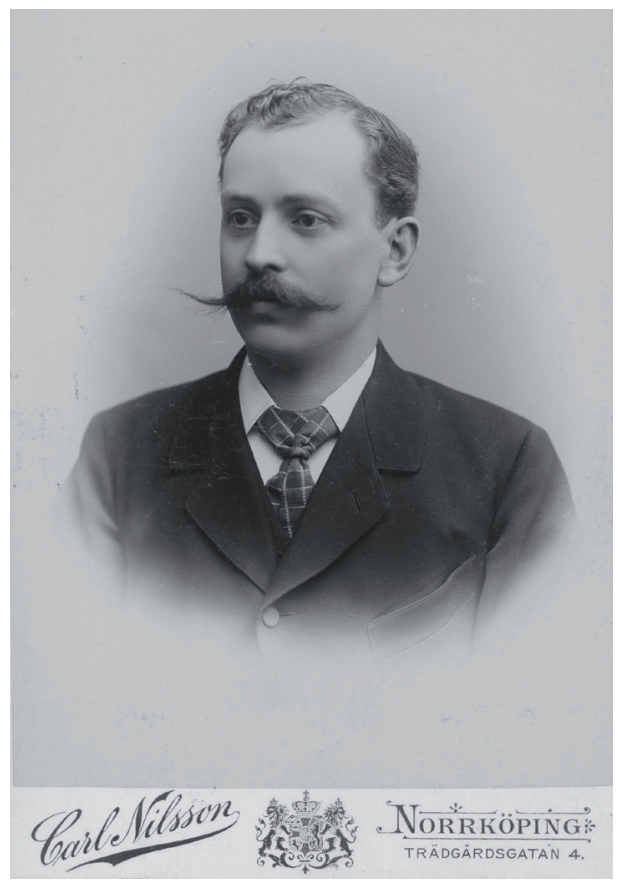

Fig. 4. Thure Janse, around 1890.

29. Eckhoff \& Janse 1936; Thordeman 1973-1975.

30. Thure Johan Janse (1864-1939).

31. Nerman 1948:93.

32. Thure Janse's first bakery shop was called Häggströms konditori, and later changed its name to Milles (Christina Janse Petersson, interview 30 September 2014). 
cottage at Marmorbrottet in the parish of Ljung, some fifty kilometres west of Norrköping. She was the youngest of three children to Anders Peter Svensson (born 1826) and Brita Katarina Persdotter (born 1831). She had a six-year-older sister, Anna Sofia, and a four-year-older brother named Axel Herman. ${ }^{33}$ Almost the entire parish of Ljung belonged to an estate with the same name, ${ }^{34}$ which had been owned since 1730 by the noble family of von Fersen. Axel von Fersen (1755-1810), famous marshal (Swe: Riksmarskalk) and Swedish Minister to France, who was Marie Antoinette's special friend and mastermind of the French royal family's failed escape from Paris in 1791, was the owner of Ljung until he died in 1810. The estate was very successful in the late eighteenth and early nineteenth century, and its property expanded to eventually cover almost the entire parish. The Ljung estate stretched along the river Motala Ström, which was one of the most important routes for transport and communication in central Sweden. The manor house was connected to the parish church by an impressive avenue, and the estate had its own sawmill, ironworks, brickworks, and marble quarry. The von Fersen family was also successful elsewhere. In the early nineteenth century they owned a number of castles and estates and were one of the wealthiest families in Sweden. Both Hilma's parents were natives of Ljung and lived their entire lives in the workers' community within the estate. They were born and raised while the estate flourished, and when Hilma was born in 1859 they lived at the marble quarry - Marmorbrottet - where her father Anders Peter Svensson worked as an assistant worker (Swe: dräng). But changes had been on the way since 1839, when Fabian von Fersen died and all the family's fortunes and estates, including Ljung, were inherited by his daughter Louise. Louise was married to the chamberlain Carl August Gyldenstolpe, and the couple spent most of their time abroad, particularly in France, Italy, and Germany, where they squandered the family fortunes in casinos and on an extravagant lifestyle. ${ }^{35}$ Meanwhile, the estates in Sweden were mismanaged and financially drained. Ljung was eventually bankrupt and sold in 1867 to the German family von Mecklenburg, who used the estate to grow sugar beets and built a sugar factory. The sugar project, however, was not a success and the factory was closed only a few years later.

33. Parish records (Swe: Husförhörslängder, födelse och dopböcker) at Landsarkivet, Vadstena.

34. Swe: Ljungs slott or Ljungs säteri. Länsstyrelsen Östergötland 2002.

35. Trolle 1944. 
The situation was difficult for the many people who, like the Svensson family, lived their lives within the estate and depended on the economic universe that it had been for over a century. In 1869, when Hilma was ten years old and two years after Louise Gyldenstolpe had bankrupted the estate and sold it to von Mecklenburg, the Svensson family moved from Marmorbrottet and built a new cottage a stone's throw away, at Fridensberg just beside the important Göta Kanal, where Hilma's father Anders found work as a canal assistant. The family got by, but on small means. When Hilma was nineteen, her unmarried older sister had a baby girl who was named Anna Alfrida. She got married a month later to a local worker, but the marriage failed and Anna Sofia soon moved back home to her parents with her little girl. For several years Hilma lived at Fridensberg with her sister and niece. Meanwhile, the economic situation on the former estate grew more acute and many young people decided to move to America. Over a hundred people from Ljung emigrated in 1869 and many more around $1880.3^{6}$ Hilma's brother Axel Herman was one of them. He left the family home in Fridensberg and set off to North America in 1881. One year later the twenty-three-year-old Hilma also left Ljung, but she stayed in Sweden and moved only a hundred kilometres north to the town of Örebro. Seven years later, she moved again and found a job as an assistant in Thure Janse's bakery in Norrköping.

Somehow, the thirty-one-year-old assistant and the twenty-six-yearold pastry baker found each other in the bakery, and before long she was pregnant. They married on 4 January $1891,{ }^{37}$ and less than three months later, on 23 March, she gave birth to their first child: Nils Harald Thure. Both baby and bakery business were healthy and growing, and at the end of the year, Hilma was pregnant again. But happiness did not last long for the young family. In April, eighteen days after his first birthday, Nils contracted pneumonia and died. Hilma was then five months pregnant, and before the end of the summer, on 3 August 1892, she gave birth to their second son: Olov Robert Thure. ${ }^{38}$

Olov Robert Thure, known as Olle to his family and friends, grew up in the urban centre of Norrköping as the second, but only surviving

36. https://runelarsson.blogspot.se "måndag 25 mars 2013", accessed 2 December 2017.

37. In the official wedding registry, their occupations are listed as Pastry Baker (Swe: Sockerbagare) and Pastry Baker Assistant (Swe: Sockerbagarbiträde).

38. The photo in fig. 5 has been donated by Christina Janse Petersson to the City Archive in Norrköping. 
Fig. 5. Olle with his mother Hilma Wilhelmina Janse.

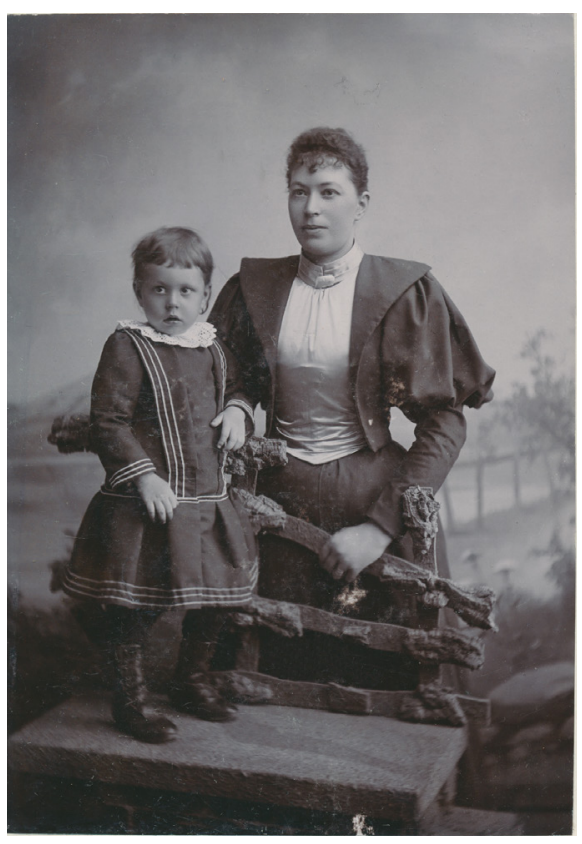

child of Hilma and Thure Janse. Hilma was described as a frail and quiet person, anguished perhaps by what must have been the unbearable loss of her first son, when she had just begun to feel the movements of the new baby inside. In Olle's first years, the family moved house several times within the same area in the centre of Norrköping. ${ }^{39}$ When he was six years old they moved to a groundfloor apartment at Repslagaregatan 31. In the apartment on the first floor was the family of a bookshop owner, Janne Nerman with his wife Ida and their three sons Ture, Birger, and Einar. The Nerman brothers would later become famous names in Swedish culture, arts, and politics, with their own biographies and archives. The oldest, Ture Nerman, describes vividly in his memoirs how it rocked the world of his family when "handsome Janse" and his "quiet and frail wife" moved in with their son Olle, and the backyard, which had been their playground with ramshackle buildings and kitchen gardens, was turned into a building site for Janse's first candy factory..$^{\circ}$ Olle, for his part, later describes in a letter, with warmth and affection, the first time they met. "On a spring day 1899 , on the stairs to Repslagaregatan 31, [...] Ture entertained me with music and play". ${ }^{41}$

The Janse family stayed almost a decade at Repslagaregatan and became close friends with their Nerman neighbours. Olle spent much of his childhood years with the three brothers, while his father was successfully expanding his confectionery business to an industrial scale. It was a prosperous time for the family. For Hilma, it had been quite a journey in

39. In 1890 they lived at Generalsgatan 6, Kv Vattnet, Hedvigs församling; in 1894 at Hospitalsgatan 21, Kv Svärdet, Hedvigs församling; and in 1897 at Hospitalsgatan 23, Kv Svärdet, Hedvigs församling.

40. Nerman 1948:93.

41. Letter from O. Janse to T. Nerman, 4 August 1952. Arbetarrörelsens arkiv och bibliotek. Ture Nerman 3.1.46. 
less than a decade - from the tough economic situation with a divorced sister and an emigrant brother at the cottage in Ljung, via marriage, two pregnancies, and the loss of one child, to a prosperous bourgeois life as a successful industrialist's wife.

Norrköping is one of Sweden's oldest and largest towns. It was founded in 1384 and its location - where the river Motala Ström meets the Baltic Sea bay Bråviken - made it an ideal place for markets and industrial projects. Its industries flourished at the end of the nineteenth century, and the population increased to around 40,000. There were considerable differences in income and social standing between industry directors and factory workers. In 1894, as many as a quarter of all the deceased in Norrköping died from tuberculosis, indicating the unhealthy environment and lack of medical care for the working classes. ${ }^{42}$ But the Janse family belonged to the wealthy industrial bourgeoisie. They lived in the most attractive ground-floor apartment of their building, and could afford to put their son Olle in a private primary school.43

The years around the turn of the twentieth century were particularly prosperous times for the candy and confectionery businesses. And Thure Janse seems to have been a shrewd businessman, knowing how to ride the wave of industrial modernity. An advertisement in the Norrköping directory from 1899 says that Thure Janse's candy factory at Repslagaregatan is "recommended", "new built", "up to date", and has "vacuum cooking". ${ }^{44}$ It was not the largest factory in town, but by far the most efficient. ${ }^{5}$ By 1905 his accumulated profits from the past decade allowed him to build a larger factory with his own horses in a stable block, and its very own automobile garage as an extra embellishment.

At the opening of the new factory, the Janse family moved two blocks south, to Handtverkaregatan 51, where they lived in a grand apartment in a new-built art nouveau style building next to the factory (see fig. 8). A

42. Nerman 1948:39-40.

43. Swe: Enskild skola: Elisabeth Lundgrens förberedande skola för gossar och flickor. Pupil lists including Janse's name (1899) are found in Norrköping City Archive.

44. Norrköpings adresskalender 1899, p. 111: "Thure Janses Karamellfabrik", Repslagaregatan 31, "rekommenderas", "Nybygd", "Tidsenlig", "Vacuumkokning".

45. In the year 1900, Janse's factory at Repslagaregatan had eight employees and produced candy worth 115,000 Swedish crowns. This can be compared with the largest factory, Svensk Marmelad A.B., which had 116 employees and produced candy worth 557,000 Swedish crowns. Janse's factory was the third largest factory of a total of seven in Norrköping (Ringborg 1923:348). 
Fig. 6. Letter-

head of Thure

Janse's new

candy factory

at Handtver-

karegatan 51, featuring the factory building with stables in the back and the living quarters in the building facing the street.

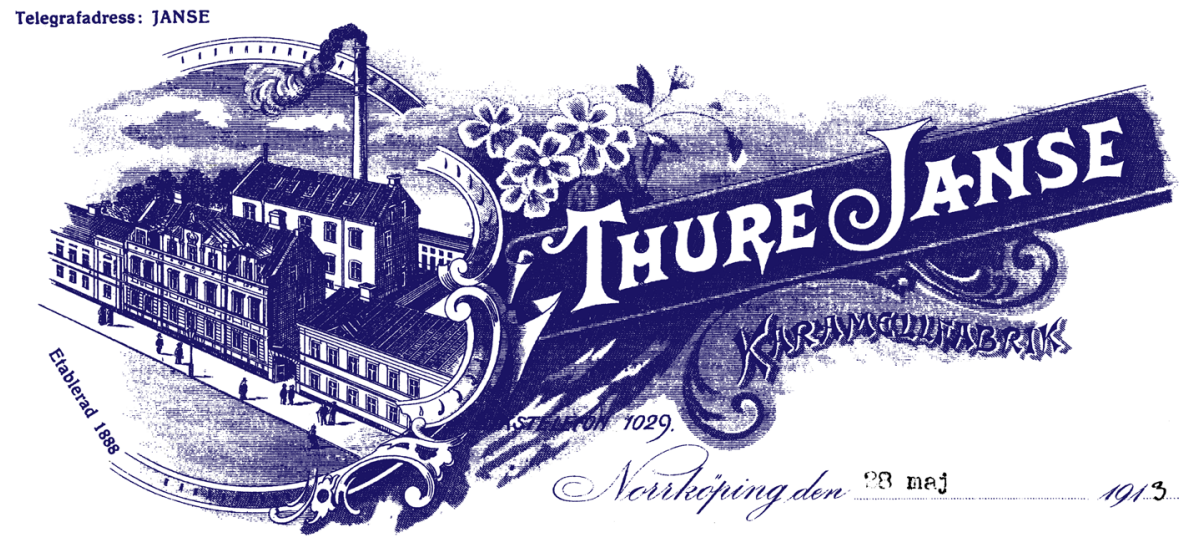

cook and several maids assisted Hilma in the household, and the building had a number of rental apartments and rooms. Among the tenants were candymaster Karl Oskar Svensson with his wife Anna Sofia and their two children, and several more workers at the factory. There were also the families of a police superintendent, a pharmacist, an organist, and a ship broker. ${ }^{46}$ In the yard behind the residence were the new factory buildings. In figure 7 , Thure Janse is seen posing proudly in front of his factory, in a smart-looking cap and starch-ironed white apron, surrounded by members of his staff. This was Olov Janse's world in the first twenty years of his life. When he later looked back at his childhood - which was "played like a film for him" when as a 56-year-old US citizen he read a copy of Ture Nerman's memoirs - he saw a home that was both warm and secure. He recalled fond memories of when the birch logs were lit in the fireplace on winter mornings just before Christmas: "It was cold and dark outside, but at home it was warm and light." 47

After graduation from private primary school at the age of nine, Olle enrolled for the rest of his mandatory education at Norrköpings Högre Allmänna Läroverk. ${ }^{8}$ He started there in August 1902 and received his el-

46. "Kv. Kannan 4 och 5a": Hedvig församlingsbok 1916-21. Landsarkivet, Vadstena.

47. "[V]år barndom på Repslagaregatan rullas upp för mig, som på en film. Den där björkvedsbrasan har jag ofta tänkt på, särskilt när den tändes på vintermorgnarna strax före jul. Ute var det kallt och mörkt men hemma var det varmt och ljust." Letter from O. Janse to T. Nerman, 26 December 1948. Arbetarrörelsens arkiv och bibliotek. Ture Nerman 3.1.46. See also Nerman 1948.

48. Now a public high school named DeGeer-gymnasiet. 


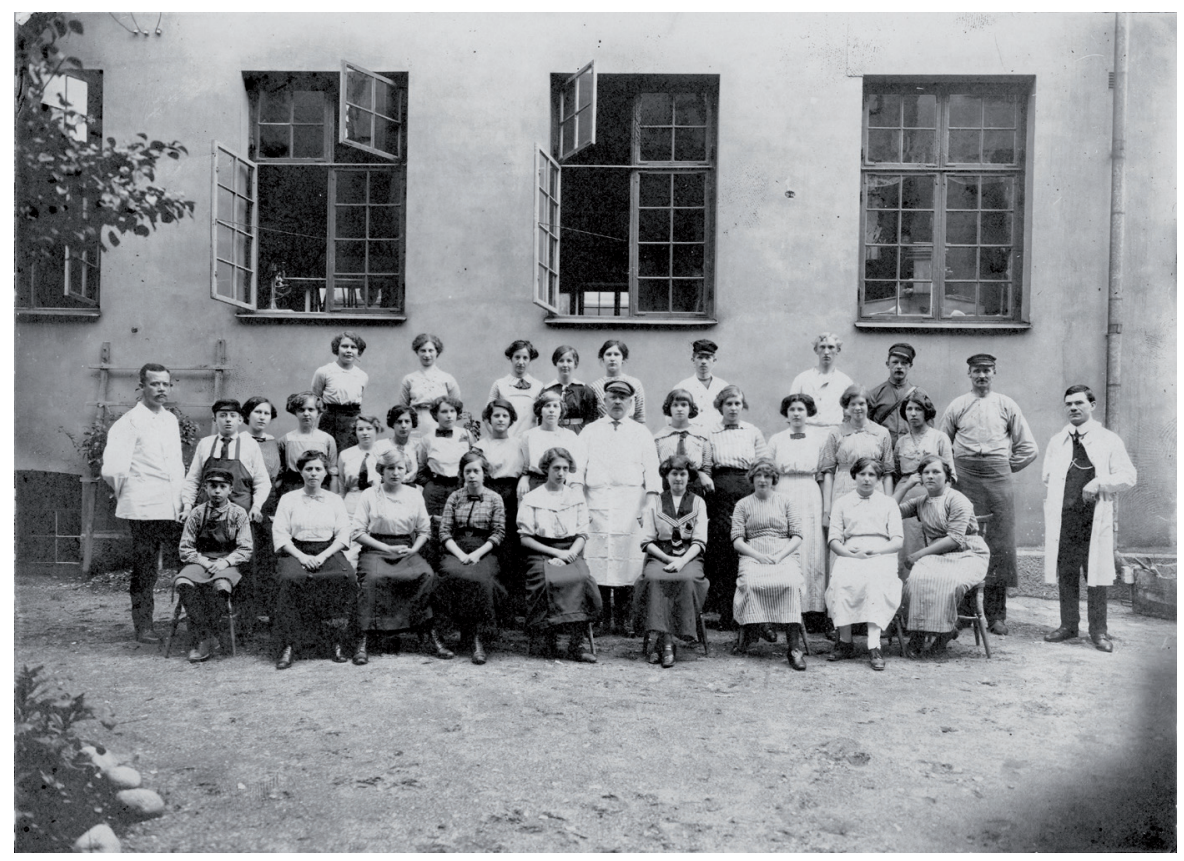

Fig. 7. Janse's candy factory staff outside the factory building, around 1910.

Fig. 8. The art nouveau style

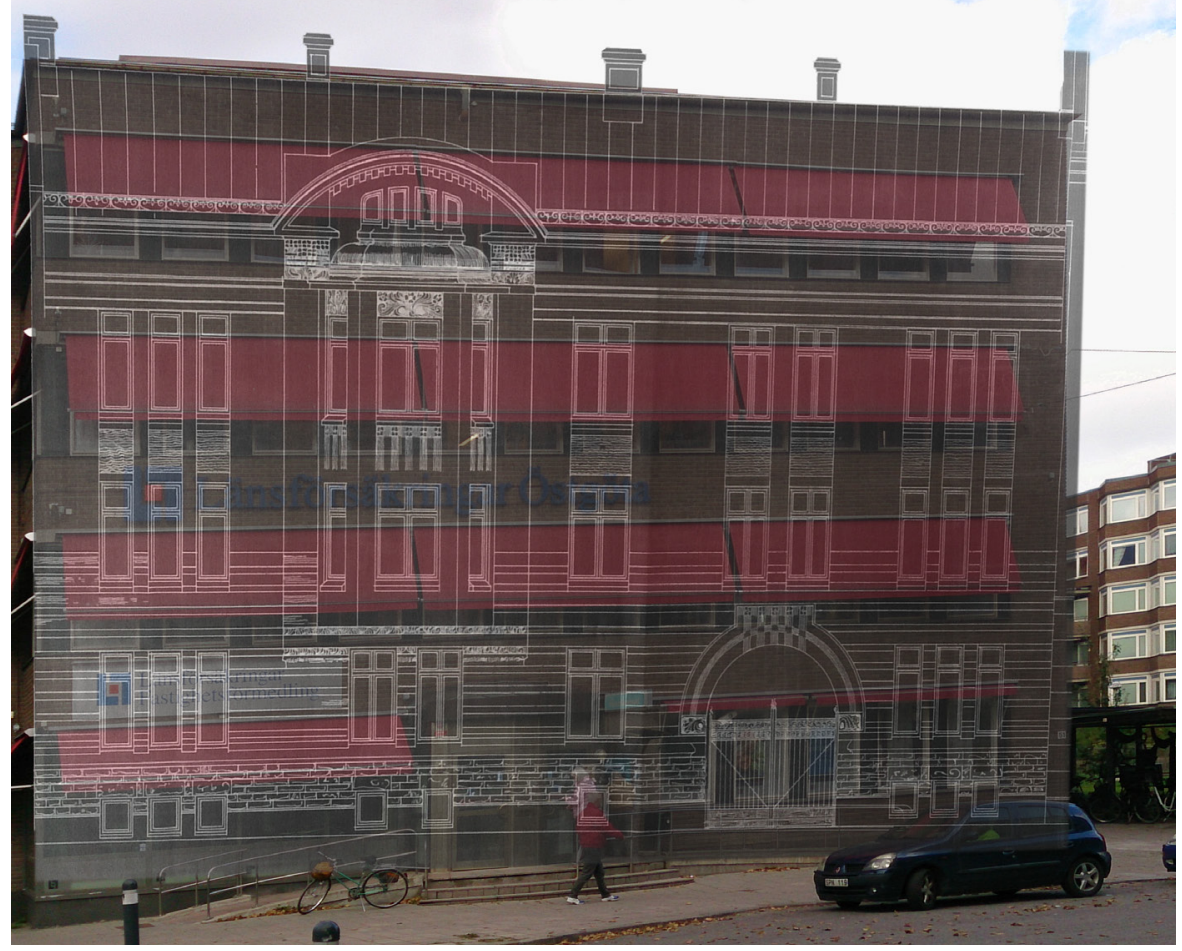
living quarters of Janse's candy factory at Handtverkaregatan 51 (demolished in 1971) in an overlay montage with the present building on the same site. 
Fig. 9. Hilma Wilhelmina Janse in the apartment on the first floor of Handtverkaregatan 51.



ementary education certificate (Swe: Realexamen) at the end of the spring semester 1908. In August the same year he enrolled for the equivalent of high school, also at Norrköpings Högre Allmänna Läroverk. He chose the Latin programme, which was the humanities choice, and when he graduated (Swe: Studentexamen) four years later his grades were average rather than exceptional. Of the seven possible grades he did not get either of the two highest (berömlig and med utmärkt beröm godkänd) nor the two lowest (underkänd and icke fullt godkänd). He got only the three middle grades: godkänd, icke utan beröm godkänd, and med beröm godkänd. His best subjects were The Swedish Essay, The German Exam, Christianity, Swedish, German, English, French, and History. The weakest were Latin, Translation from Latin, Mathematics, Physics, and Drawing. ${ }^{49}$ During the high school years he was exempted from Physical Education (Swe: gymnastik) and Singing.

There were several optional extracurricular clubs and student organizations at the school, and he was active in two: Fosterländska förbundet

49. A copy of the high school graduation grades (Swe: Studentexamen) is found in the archive of Norrköpings Högre Allmänna Läroverk at Landsarkivet, Vadstena. 
(1908-1911) and Helnykterhetsföreningen Njord (1910-1912)..$^{\circ}$ The first (not to be confused with the right-wing political organization with the same name) was a student club to promote culture and literature, and the second was an organization for non-drinkers promoting teetotalism. Olle Janse's engagement in these two organizations was likely an expression of his admiration for Ture Nerman, who was a leading member of Fosterländska förbundet in his high school years, and remained throughout his whole life a passionate advocate of a teetotal lifestyle.

Meanwhile, the candy factory continued to grow, and the business peaked in September 1913, when Olle had just graduated from high school and left to study at the university in Uppsala. Encouraged by the business success, Thure Janse submitted an application to the city council planning office for an extension of his factory building. The plans were approved, but the extension was never built. ${ }^{51}$ The reason for the cancelled plans was probably the outbreak of the First World War a year later. The war meant dramatic changes for the confectionery business, which depended on expensive ingredients like sugar and global trade goods like vanilla and cocoa. Moreover, the war left the people of Norrköping starving. Grand avenues were turned into potato fields, and hunger and desperation sparked an historical event known as "the bread riot" (Swe: Brödupproret) in May 1917. Bakeries were plundered and the situation in the city was out of control. Candy was not a priority in such difficult times.

Adding to the already critical situation, the Janse family suffered a terrible blow when Hilma Wilhelmina died unexpectedly on 9 August 1917 , five days after Olov's $25^{\text {th }}$ birthday. She had been feeling unwell for some time and died of endocarditis, fifty-eight years old. ${ }^{52}$ According to the family, Thure suffered from depression in the years that followed, 53 and a guess is that it was owing to Hilma's unexpected death, the war that destroyed Europe, and the critical situation of his business. Between 1916 and 1920, the number of people living in Janse's property at Handtverkaregatan 51 was successively reduced from 34 to 15 people..$^{54}$

50. School yearbooks containing class lists with subjects and extracurricular clubs are found in the archive of Norrköpings Högre Allmänna Läroverk at Landsarkivet, Vadstena.

51. The application is found in Norrköping City Archive.

52. In the parish records (Swe: Död- och begravningsboken, Hedvig församling, Norrköping) the registered cause of death is "cardiac inflammation" (Swe: hjärtinflammation). Landsarkivet, Vadstena.

53. Interview with Christina Janse Petersson, 30 September 2014.

54. "Kv. Kannan 4 och 5a": Hedvig församlingsbok 1916-21. Landsarkivet, Vadstena. 
Tenants left, and the factory workforce diminished year by year. In less than five years, Thure Janse's once so prosperous and secure world had collapsed, and he never seems to have regained his strength.

However, he got married again, less than a year after Hilma's death, to Signe Karolina Andersson (1877-1958).55 Signe was the widow of Thure Ludvig Andersson, a travelling merchant who had died from pneumonia only fifteen months after the birth of their only son Bengt Ludvig (born 1910)..$^{56}$ Rumours say that they met at the local swimming pool where Signe worked as a cashier. Once married, she and Bengt moved in with Thure at Handtverkaregatan. Olov was still registered at the same address, but spent most of his time in Uppsala and moved out officially on 9 January 1919. One year later Thure Janse sold what was left of the candy factory - for almost nothing, it is said in the family ${ }^{57}$ - to AB Chokladfabriken Fyrisi in Uppsala, ${ }^{58}$ and was left without a business. He stayed a few years in the apartment at Handtverkaregatan with Signe and Bengt, and then moved to another address in Norrköping where they lived until Thure died, on 12 December 1939. He had grown weaker and weaker with the years, and the outbreak of the Second World War was the final straw. Olle wrote in a letter to Ture Nerman that "Dad enjoyed life in his healthy days, but the world's destruction, hatred and lies weighed his spirit down, and his strength failed him." 59

But let us return to the days when Hilma was still alive and the candy factory was prospering. For it was in the happy days before it all collapsed, when the Janse family had just moved and settled in their new exclusive apartment at Handtverkaregatan 51, that Olle began to take an interest in archaeology. In 1906, when he was about to turn fourteen, his uncle Otto was in Norrköping to arrange a display of historic art and artefacts for the town's big industrial exhibition.

55. Thure Janse and Signe Andersson married on 20 July 1918.

56. Bengt Ludvig Thuresson was born on 9 November 1910. His family name was changed to Janse when he was seven years old and his mother married and changed her name to Signe Janse. His daughter Christina Janse Petersson has donated family photographs and documents of Thure Janse's family to Norrköping City Archive.

57. Interview with Christina Janse Petersson, 30 September 2014.

58. According to the tax register: Uppbördsboken för 1920, kv. Kannan 4 och 5 a.

59. Letter from O. Janse to T. Nerman, 27 June 1940. Arbetarrörelsens arkiv och bibliotek. Ture Nerman 3.1.24. In the Swedish original: "I sina friska dagar gladde sig Pappa åt livet men världens förstörelse, hat och lögn nedstämde så hans sinne att krafterna ej längre stod bi." 
Norrköping was then, around the turn of the twentieth century, an important industrial centre built on the power supplied by the river Motala Ström, and the easy transport routes the river offered to and from the town. It had an intellectual bourgeoisie elite and many famous Swedes of the time were natives of Norrköping. Industrialism and education (Swe: bildning) went hand in hand for the bourgeoisie at the time, and it was therefore only logical that Otto Janse arranged a display of historic art and artefacts as part of the industrial exhibition.

The area around Norrköping is fertile and rich, and abounds of traces of historic and prehistoric settlements. The famous Bronze Age rock art at Himmelstalund and other prehistoric landmarks were well known among the city's bourgeoisie and intellectual elite, and the historic art and artefact display was a crucial part of the industrial exhibition. Otto Janse was in charge of the display, and when he came to collect suitable pieces to show (mainly objects from medieval churches, in keeping with his own interests), he borrowed a horse and cart from his brother's new candy factory and invited his young nephew to come along with him. ${ }^{60}$ Fifty-three years later Olov Janse remembered, in Saigon:

[...] as I was on summer vacation from school, I was of course very thrilled to get this opportunity to see a little bit of the world around me. ${ }^{61}$

The collection tour with Otto sparked an interest in ancient things in the young teenage boy. He went to see the exhibition (as did his friend Birger Nerman, who also became a prominent Swedish archaeologist and later Director of the Swedish History Museum), which propagated for better care and more attention to the ancient art on display. A few years later (in 1908, 1910 and 1912) Otto Janse excavated a fourteenth-century fort near Norrköping, ${ }^{62}$ and it is likely that Olov visited and to some extent participated in the excavations. The Nerman brothers (with whom we will get acquainted in more detail in the next chapter) had also taken an early interest in archaeology, and it was probably their influence more

60. Janse 1959:14.

61. Olov Janse's handwritten notes for a lecture at the American Association in Saigon, Vietnam, on 14 January 1959 [the notes are incorrectly dated to 1958]. ATA: Enskilda arkiv 59. Olov Janse. Arbetspapper vol. 2.

62. Thordeman 1973-1975. 
than Otto's that eventually steered Olov into archaeology as a career path. But Otto Janse's invitation to join him on that collection tour around Norrköping in 1906 was surely the very first step in Olov Janse's lifelong career in archaeology.

So, Olov Janse grew up in the home of a well-born family in Norrköping's wealthy industrial bourgeoisie. There was a sense of quietness and frailty surrounding his mother and a lingering sorrow after the death of his older brother Nils. But the home was secure and embracing - a warm and bright retreat that offered shelter from the cold and darkness outside. His father provided a financial and social security that young Olle must have taken for granted in the years before the First World War. It seems as if an obvious career path would have been to follow in the entrepreneurial footsteps of his father and grandfather, and establish his own successful business. But industrialism and bildning went hand in hand in the prospering town of Norrköping, so Olov Janse chose to follow in the footsteps of his uncle Otto and the Nerman brothers, and began to study archaeology. Nonetheless, there is a certain sense of entrepreneurship in his later movements, which is arguably an interest and skill inherited from his father, and which was pivotal for the success of the archaeology in-between nations and institutions that he later pursued. From these early days, standing with one foot in each territory (be it social, professional, or national) and moving between these units would become Olov Janse's main asset, as well as his main weakness. 


\section{TRAVEL WRITING}

A few years later it so happened that a schoolmate of mine and a good neighbour, discovered at their family countryplace a dwellingsite from the stoneage, about 4000 years old. I became very curious and got permission to attend the excavations which the Royal Academy then had decided to carry out. I now learned a great deal about the mysterious past and from now on I became seriously concerned about devoting at least some of my time to the exploration of the infinite and intricate inner space of the human mind, as revealed by old potsherds and many other curious items, brought to light after thousands and thousands of years of oblivion. ${ }^{63}$

If uncle Otto was his very first archaeological inspiration, it was his friendship with the Nerman brothers that introduced Olle to the world of words and writing. Their father Janne Nerman had a bookshop and their mother Ida was, just like Hilma Janse, a former shop assistant who had married her employer. Janne and Ida Nerman lived with their three sons in an apartment in the same building as the Janse family on Repslagaregatan 31, and the two families spent much time together. The two youngest sons, Birger (1888-1971) and Einar (1888-1983), were non-identical twins and four years older than Olle. Their older brother Ture (1886-1969)

63. Olov Janse's handwritten notes for a lecture at the American Association in Saigon, Vietnam, on 14 January 1959. ATA: Enskilda arkiv 59. Olov Janse. Arbetspapper vol. 2 [the notes are incorrectly dated 1958]. 
became something of an idol and inspiration for Olle. ${ }^{64}$ In his memoirs Allt var ungt, Ture Nerman describes his early friendship with Olle Janse:

[Olle] played theatre with us, sometimes at his place downstairs, and at Torsskär where we were neighbours for a couple of summers. We read poetry together, and perhaps my endeavours inspired Olle to write some pieces $[\ldots]^{65}$

Ture Nerman was one, if not the most, important source of inspiration for Olle Janse's early writing. He was a man of words, radical and creative. He even introduced his own reformed spelling system, in which the words were spelled as they sound, often with a more frequent use of the letters $\ddot{a}, \ddot{a}$, and $\ddot{o}$. Some of Janse's early writing and letters, in particular his correspondence with the Nerman brothers, are written in this reformed spelling.

Ture Nerman later pursued a successful career as a radical political journalist, editor, poet, and author, and ended his professional life as a Member of Parliament for the Social Democratic Party (1946-1953). He is now most widely known in Sweden for his fierce critique of Nazism and what he saw as a submissive Swedish politics during the Second World War. For that he famously served a three-month prison sentence for breaking with official neutrality, by publishing critical texts in his own journal Trots Allt!.

But before his journalistic career took off, back in the summer of 1905 when the thirteen-year-old Olle Janse enjoyed a safe and prosperous life next to the candy factory in Norrköping, Ture Nerman was a frustrated twenty-year-old student in Uppsala. He had taken a course in archaeology (Swe: fornkunskap) for his BA degree, and during the summer break he found and began to excavate a Stone Age site on a hillside at Säter near Norrköping. The excavations soon caught the interest of his professor Oscar Almgren who took part in the excavations the following year, and

64. He remained friends for life with Ture and Birger (who became professor of archaeology and ended his career as director of the Swedish History Museum (1938-1954)). He did not, however, have as close a relationship with Einar Nerman, who became a famous artist and graphic designer, widely known in Sweden for his classic matchbox design Solstickan.

65. "Han [Olle] och vi spelade teater ihop, ibland hos honom i våningen under vår, också på Torsskär där vi ett par somrar var grannar. Vi läste vers ihop, kanske inspirerade mina försök Olle till några dikter [...]" (Nerman 1948:93). 
obtained funding from Vitterhetsakademien, The Royal Swedish Academy of Letters, History and Antiquities, to further the investigations. ${ }^{66}$ Ture, however, soon lost interest in archaeology and concentrated on his career as a political journalist. But the excavations at Säter had a lasting impact on his younger brother Birger and his friend Olle, who both decided to study archaeology under Oscar Almgren in Uppsala. Birger left Norrköping for Uppsala in 1907, and only a couple of years later he reopened his brother's investigation at Säter and excavated there in the summers of 1913 and $1914 .{ }^{67}$ Olle, who had just begun his studies in Uppsala, joined the excavation team and reported on the results in the local newspaper. ${ }^{68}$ Hence it seems to have been a double influence from his uncle Otto and his friends Ture and Birger Nerman that sparked and stimulated Olov Janse's childhood interest in archaeology.

His relationship with the intellectual and creative Nerman brothers laid yet another important brick in the foundation of his archaeological career. Their early theatre and poetry sessions were followed by adolescent efforts in journalistic and academic writing. While Olle was still in school in Norrköping, the six years older Ture found a political passion that he expressed with poetic precision, and he travelled across Europe, the United States, and Russia, on funding that he acquired from writing travel reports for Swedish newspapers. Birger developed academic ambitions as an archaeologist in Uppsala, and Einar enjoyed his life as an art student in belle-époque Paris. Influenced by all three Nerman brothers, Olov Janse found his very own intellectual identity, in the fertile space where archaeology meets travel writing.

After he had left Norrköping to study in Uppsala, Ture Nerman became editor of the Social Democratic newspaper Nya Samhället in Sundsvall.69 Inspired by his friend, Olle Janse wrote poems and short reviews for his local newspaper in Norrköping. In January 1911 he published his very first text - a romantic poem under the pseudonym Fremissin:

66. Nerman 1948:291-292; Olov Janse's handwritten notes for a lecture at the American Association in Saigon, Vietnam, on 14 January 1959. ATA: Enskilda arkiv 59. Olov Janse.

67. Nerman 1927.

68. Janse 1913a; 1959:14.

69. Letter from O. Janse to T. Nerman. 19 September 1912. Arbetarrörelsens arkiv och bibliotek. Ture Nerman. 3.1.7. 


\section{Den tredje passageraren}

(Fritt efter Heine)

En natt på tu man hand vi sutto

i deligensens mörksta vrå.

Vi flörtade försvarligt

och hade roligt båda två.

Men tänk, när morgon åter grydde

hon bar, som jag, förundrans air,

ty mellan oss satt amor

en liten osedd resenär. ${ }^{70}$

In her seminal work Imperial Eyes: Travel Writing and Transculturation, Mary-Louise Pratt analyses the phenomenon of travel writing in the light of European imperialism, from the eighteenth century until today. Pratt sees travel writing as a crucial component of colonial culture, spellbinding the audiences at home to a certain view of the imperial projects. Travel books, says Pratt,

[...] gave European reading publics a sense of ownership, entitlement and familiarity with respect to the distant parts of the world that were being explored, invaded, invested in, and colonized. ${ }^{71}$

This genre of political prose, often presented in the form of adventure tales, was widespread and very popular in the nineteenth and early twentieth century. It created "a sense of curiosity, excitement, adventure, and even moral fervor about European expansionism". ${ }^{2}$ For a young bourgeois boy in Norrköping around the turn of the century, adventure tales were an exciting and inspirational source of information about far-away lands. They presented children like Olov Janse with an imperial order of the world, and offered them a dominant position in it. In this sense, ac-

70. Östergötlands Dagblad, 17 January 1911: "Den tredje passageraren.” Our translation: "The third passenger /(free after Heine) // One night the two of us sat/in the darkest corner of the coach./We were flirting a little/both having a good time//But imagine, when the morning broke/she carried, like me, an air of surprise/because between us sat Amor/a small unseen traveller. //Fremissin."

71. Pratt 2008:3.

72. Pratt 2008:3. 
cording to Pratt, travel writing is a way to dominate the world by writing and reading about it.

The poem Den tredje passageraren, which was the very first piece that Janse published, reveals a romantic sentiment attached to travelling. The sense of romance and thrill connected with travelling is characteristic of Janse's earliest writings. His early correspondence with Ture Nerman shows that dreams about a better world and erotic yearning for unattainable young women were common points of reference in their friendship. Alone in Norrköping, longing for more excitement, he writes in a letter to Birger Nerman who had left home to study in Uppsala:

Norrköping is immensely boring. The only thing interrupting the monotony is an old mutt standing outside barking itself hoarse. He has been here about a month ranting and howling again and again and again and again, so now that has also become monotonous. $^{73}$

The sense of longing (away from Norrköping, or for a romantic meeting) implies a distance, which Janse would later carry with him to his more mature travel writing. A deeper understanding of the figure of distance that is inherent in the fusion of travel writing and archaeology, which would become an important part of Olov Janse's professional profile, is offered by a critical view on the narrative format Mary-Louise Pratt calls "the monarch-of-all-I-survey genre". ${ }^{74}$ Peaking in Victorian England with the writings of British explorers searching for the source of the Nile, this is a common style for travel writing to this day. Travel writing in this genre is centred on discoveries (for example of the source of the Nile), and the appropriation of the discovered object by the successful explorer and his patria (in this case Britain). The more complex circumstances of native presence are always left out of such writing. Discoveries and appropriations like these are of great importance in archaeological travel writing. A famous example is Henri Mouhot's "discovery" (and the subsequent French appropriation) of Angkor Wat, where the actual native

73. Letter from O. Janse to B. Nerman, n.d., (around 1908-1910). Riksarkivet. Kartong 9. Korrespondens Brev Osorterade. In Swedish: "Norrköping är ofantligt trist. Det enda som avbryter enformigheten är en gammal hundracka som står här utanför på gatan och skäller sig hes. Han har stått här ungefär en månad och skällt och tjuter ideligen ideligen så nu börjar det också bli enformigt."

74. Pratt 2008:197. 
presence, knowledge and use of the ruins has simply been ignored or twisted to induce images of primitive ignorance. ${ }^{75}$

In her analysis of the discovery rhetoric in the monarch-of-all-I-survey genre, Pratt identifies three narrative strategies: (i) an aestheticization of the landscape, (ii) a search for density of meaning in the passage, and (iii) a prediction of mastery in the relation between seer and the seen. These strategies contribute to a certain rhetoric of presence in the monarch-of-allI-survey genre..$^{76}$

Olov Janse's first report from a journey abroad, was in the form of a series of newspaper articles with the title Iceland: Impressions from a journey. ${ }^{77} \mathrm{He}$ was twenty years old and had just left Norrköping to study in Uppsala. He travelled to Bergen in Norway by train, and from Bergen to Iceland by steamship via the Faroe Islands, along with his travel companion Birger Nerman (referred to as Dr N). The young student Olov Janse was not the Victorian scientist exploring colonial territories who was the original model for Pratt's monarch-of-all-I-survey. Nor had Sweden any colonial ambitions for Iceland (or Norway, which he passed on the way). But if we view his travel report in terms of Pratt's three rhetorical strategies, we find the first (an aestheticization of the landscape) reflected already in the first two paragraphs of the first article:

The first rays of the morning sun find their ways through the misty wagon windows. Awake but still sleepy the passengers get up, one after the other. They wipe the condensation off the windows and look out in awe. [...] Just after Kongsvinger, the typical Norwegian landscape begins to reveal itself. Nature has here created a coherent chain of the most delightful sceneries. $[\ldots]$ The high forest-covered mountains rising towards the sky, on both sides of the sea, make a magnificent frame to the beautiful painting. ${ }^{78}$

75.E.g. Cooper 2001:17.

76. Pratt 2008:200-201.

77. Swe: "Island - intryck från en resa" (Janse 1913b-f).

78. Janse 1913b. In the Swedish original: "Morgonsolen kastar sina första strålar genom de dimmiga kupéfönstren. Nyvakna och sömniga börja passagerarna att resa på sig, den ena efter den andra. Man torkar bort imman och kastar en spörjande blick genom fönstret [...] Redan när man passerat Kongsvinger börjar det för Norge så typiska landskapet att visa sig. Här har naturen bildat en sammanhängande kedja av de mest 
And a little later, we find the second strategy (a search for density of meaning in the passage):

Bergenbanan is probably one of the most outstanding and awe-inspiring railways on earth, having been built high up in the mountains. It is a masterpiece of engineering. A journey on this railway is a memory for life. ${ }^{79}$

In order to fully understand Bergen and its inhabitants, you need to imagine the town without the grand railway, which has taken us there. The only major connection with the outer world before the construction of the railway, that is 1907 , was the sea. With its history of isolation behind the mountains, the town has taken on an old-fashioned character. ${ }^{80}$

When I see the massive cascading waves wrestling the boat, I come to think of past times, when the Norsemen thousands of years ago steered their open longships over the sea, not knowing if they would find land, or if the sea stretched all the way to the ultimate cold and darkness of Niflheim. ${ }^{81}$

The account of Janse's passage by train through Norway and by boat via the Faroe Islands creates a sense of meaning and purpose by repeating a figure of tension between the eternal landscapes and primitive cultures that he sees around him, and the modern train and steamship vehicles moving through that landscape towards his final destination. Once dis-

förtjusande naturscenerier. [...] De skogklädda höga bärjen [sic], som resa sig mot skyn, på båda sidor om havet, bilda en präktig ram till den vackra tavlan."

79. Janse 1913b. In the Swedish original: "Bergenbanan är förmodligen en av de egendomligaste och mest storslagna järnvägar på jorden, byggd som den är högt uppe på fjällen. Den är en ingenjörskonstens mästerverk. En resa med denna bana blir ett minne för livet."

80. Janse 1913b. In Swedish: "För att rätt förstå Bergen och bergenborna måste man tänka sig staden utan den grandiosa järnväg, som fört oss dit. Dess enda större förbindelse med yttervärlden var före banans tillkomst, d v s 1907, havet. Isolerat som det varit genom de höga fjällen, har staden fått en gammaldags prägel.”

81.Janse 1913b. In the Swedish original: "Då jag ser de väldiga störtsjöarna, som båten brottas med, kommer jag att tänka på gångna tider, då nordborna för tusen år sedan på sina öppna drakar styrde ut över havet utan att veta om de skulle finna land, eller om havet sträckte sig ut i köldens och mörkrets Niflheim." 
embarked in Iceland, Janse put Pratt's third rhetorical strategy (a prediction of mastery in the relation between the seer and the seen) into play:

After almost six days on the sea, we had finally reached "Ultissima Thule", and my long-nurtured dream was about to come true: to see this enchanted land of songs and sagas with my very own eyes. $^{82}$

As we all know, Reykjavik is the largest town in Iceland, with approximately 15,000 inhabitants. [...] The streets were full of life and the many foreigners gave the town a rather continental character. German tourists were strolling, dressed à la mode, searching with obvious interest the shop windows for suitable souvenirs. $[\ldots]$ Everywhere one could hear the sound of small ponies' hooves hitting the paving stones. And as I was walking along I heard mirabile dictu - the sound of an approaching automobile, and I could certainly smell it as well. I turned around and saw to my surprise a modern "stink-panter" - Iceland's only automobile and the pride and joy of Reykjavik. ${ }^{83}$

In Janse's travel report, the Icelandic houses have a "boring" appearance and the Reykjavik cathedral looks "in our sense" more like a half derelict country church. The people are slow, stupid and parsimonious. And they are ugly too; the women's faces remind him of raw potato. ${ }^{84}$

On our way back [we] saw a peculiar cottage. On the exterior it was built entirely of peat. The chimneys were two herring barrels with knocked-out bottoms. To me, the cottage seemed more like a

82.Janse 1913d. In the Swedish original: "Efter nära sex dagars sjöresa hade vi äntligen kommit hit upp till 'Ultissima Tule', och nu skulle en länge närd önskan gå i uppfyllelse, att med egna ögon få se detta sagans och sångens förlovade land.”

83. Janse 1913e. In the Swedish original: "Reykjavik är som bekant Islands största stad med cirka 15000 invånare. [...] På gatorna var det nu liv och rörelse och de många utlänningarna satte en viss kontinental prägel på staden. Överallt spatserade de tyska turisterna alamodiskt klädda och betraktade med synbart intresse butiksfönstren för att se, om de kunde finna några lämpliga souvenirer. [...] Överallt hördes ljudet av de små ponnyernas hovar då de slogo mot gatstenarna. Bäst som jag gick och spatserade hörde jag - mirabile dictu - ljudet av att en automobil var i annalkande, också tydligt kändes ju lukten. Jag vände mig om och såg till min överraskning en modärn [sic] stinkstånka - Islands enda automobil och Reykjaviks stolthet."

84. Janse 1913d, 1913e. 
museum object than a place to live. Inside it was smoky and dark. An old lady, who looked as if she had witnessed the saga times, was frying meat on a couple of rocks. On the floor, which was of raw clay, sheep, cats, and rats walked unabashedly. We tried to contact the old lady, but it was not possible, because "she knew no language" as she put it herself. ${ }^{85}$

It is clear that Janse, twenty years old at the time, had a talent for writing travel tales. His descriptions are at once witty and condescending, true to the ideal of his time. The rhetoric is clear and sharp, fitting with great precision the strategies in Pratt's monarch-of-all-I-see genre of travel writing. He had no direct colonial ambitions, but mimicking its rhetorical turns allowed him, the twenty-year-old Uppsala student, to pose as a monarch-of-all-he-saw. It offered him a sense of control over the landscape he travelled through, and a secure lofty position in relation to the travelees, ${ }^{86}$ the people he met and wrote about. Communicating his experiences to the readers of Östergötlands Dagblad, he allowed them to share his sense of control and lofty position vis-à-vis the Icelandic people. This, in turn, gave the travel writer power and position in his home community. Having returned from Iceland, Janse wrote later the same year a review of Albert Engström's book At Häcklefjäll, itself a travel description from Iceland, in which he used his own travel experiences. ${ }^{87}$ Since Engström was one of Sweden's most famous artists and writers at the time, the review strengthened Janse's position as a travel writer.

Already here, as a young student, we see how Janse makes canny use of metaphors of time and distance that are common in ethnographic and archaeological travel writing. By physical and metaphorical movement, the travel writer takes control over distance. The archaeological (and ethnographic, by metaphorical association) travel writer moves through

85.Janse 1913b. In the Swedish original: "På återvägen fick Gräslund och jag syn på en egendomlig stuga. Den var utvändigt helt och hållet byggd av torv. Skorstenarna bestodo av två silltunnor, vars bottnar voro utslagna. Mig syntes stugan lämpligare som museiföremål än som boningshus. Invändigt var det rökigt och mörkt. En gumma, som såg ut som om hon varit med under sagoåldern, höll på att steka kött på ett par stenar. På golvet, som var av tilltrampad lera, promenerade ogenerat får, kattor och råttor. Vi försökte komma i kontakt med gumman med det gick inte alls, ty hon 'kunde inget språk', som hon själv sade."

86. Pratt 2008:225.

87. Socialdemokraten, 25 November 1913, "Litteratur". 
time and space and can thus claim a double control over distance. Mobility is therefore key to the archaeological travel writer, as is translation. By moving between distant units (in time and/or space), and translating between them, the archaeological travel writer gains prestige and position.

Looking back at his archaeological career in Saigon in 1959, Olov Janse said that the Säter excavations had inspired him to devote his life to "the exploration of the infinite and intricate inner space of the human mind, as revealed by old potsherds and many other curious items, brought to light after thousands and thousands of years of oblivion" ${ }^{88}$ He recycles here a package of metaphors that arranges signs of time and distance, the human body and mind, of culture and development in a particular order, which is common to much archaeological writing in the nineteenth and twentieth centuries. But with a sharp emphasis on distance, Olov Janse found a distinct identity that allowed him to stand out from most of his fellow Swedish archaeologists. He found a rhetoric and a tone, already in his first texts, that he would retain for the rest of his career. Distance remained a privileged sign in all of his work, and by travelling and translating between units he built a successful career on the capacity to bridge and master it. ${ }^{89}$

88. ATA: Enskilda arkiv 59. Olov Janse. Arbetspapper vol. 2.

89. On the importance of distance, see Stewart 1993. In the Conclusion we take a more detailed look at Stewart and the importance of distance in antiquarian and collecting enterprises. 


\title{
ARCHAEOLOGICAL FOUNDATIONS
}

\author{
B. B. Birger!
}

Vore Dig tacksam om Du ville skicka mej ett kort o säja när föreläsningarne (i nord. språk) börjar. Jag förmodar att tiden är bestämd nu.

Järtliga hälsningar

Olle $^{9 \circ}$

Tall, slender and well dressed, with a serious look and precocious diction, Olle Janse left Norrköping shortly after his twentieth birthday and moved two hundred kilometres northeast to Uppsala, where he enrolled at the University for a course in Scandinavian languages.

With 27,000 inhabitants Uppsala was a much smaller town, only half the size of Norrköping. ${ }^{91}$ In contrast to Norrköping's bustling industrial life celebrating modern innovation and capital growth, Uppsala offered a sense of roots and tradition with a ritualized academic lifestyle revolving around the University. It was the oldest of the Nordic universities, founded in the fifteenth century as a development of an important eccle-

90. Letter from O. Janse to B. Nerman, 26 August 1912. Riksarkivet. Kartong 10. Korrespondens X. Written in Ture Nerman's radical spelling style. Sweden reformed its spelling style in 1906 by turning dt into $t$ or tt, hv into $v$ and so forth. Nerman hade a more radical idea and used a phonetic spelling style, used here by Janse. In our translation: "Best Brother Birger! // Would be grateful to you if you could send me a [post]card and say when the lectures (in Scand. Lang) begin. I assume that the time has been set now.// Cordially// Olle."

91. Norrköping had 47,000 inhabitants listed in the 1912 census. 
Fig. 10. Olov Janse with the Uppsala student cap.

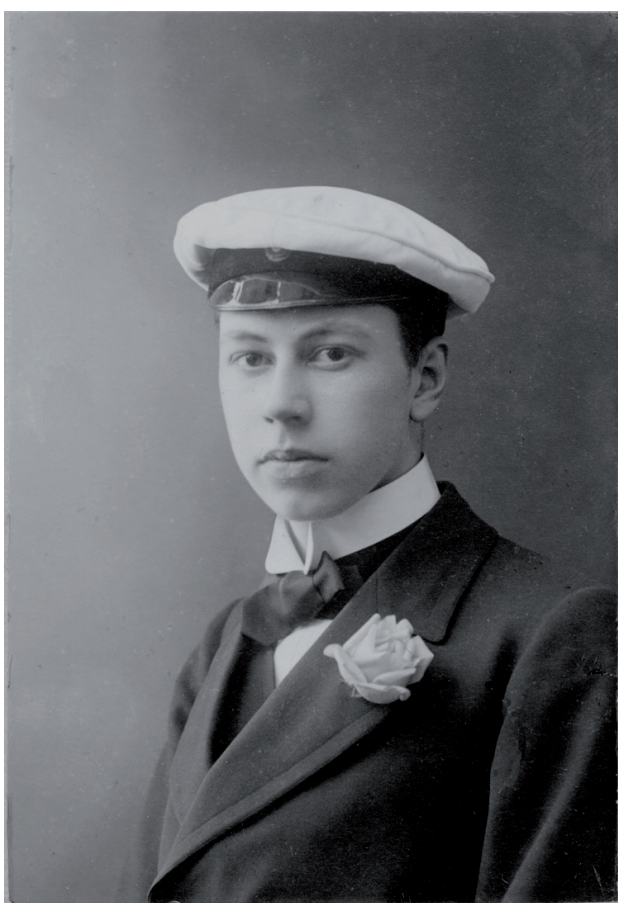

siastical centre. Theology, philosophy and law dominated the curriculum over the first couple of centuries, but since the seventeenth century Uppsala University had also fostered science megastars like Olof Rudbeck, Anders Celsius, and Carl Linnaeus. It remained an exclusive male milieu for centuries, until Betty Pettersson enrolled as the first female student in 1872 and Ellen Fries was promoted as the first female Doctor of Philosophy in 1883. When Olov Janse arrived in 1912, Uppsala University was one of Sweden's principal universities, on a par with Lund in the south. There were important university colleges in both Gothenburg and Stockholm, but Lund and Uppsala were older and more prestigious, and proudly maintained their own distinctive academic traditions and rituals. Women were allowed, but it was essentially a male social environment reserved for the privileged bourgeoisie and upper classes.

When Janse arrived in Uppsala and enrolled at the University in August 1912, Birger Nerman had already been there five years. Only a year later he defended his doctoral thesis, which combined philology with history and archaeology in a study of Swedish pagan literature. ${ }^{92}$ In Uppsala, students were organized in "nations" - nationer - which were mandatory student corporations with regional names dating back to medieval times. Like Birger Nerman and his brother Ture before him, Olle Janse joined Östgöta nation, one of the largest and oldest, dating back to 1646 , with a name alluding to the region around Norrköping. Birger seemed to thrive in student life with all its rituals and traditions, and acted as the nation's librarian. Ture, in contrast, had never warmed to academia and left Uppsala in 1908:

92. Nerman 1913 
His time at University was marked by loneliness, erotic longing, sublime life cult, poet dreams, student playwriting, and aimless reading. But it also sparked a more pronounced interest in politics, mainly in a socialist and pacifist direction in the wake of the bloody Russo-Japanese war and the Russian revolution of 1905 . [...] Eventually, in 1908, he managed to scrape together a bachelor's degree in Scandinavian languages, archaeology and political science. Just a few weeks after graduation, he was charged and later fined for having distributed flyers with pacifist messages by Tolstoy. With that, he left the academic world where he never felt at home. ${ }^{93}$

Ture Nerman did, however, leave a mark as an early member of the Social Democratic student club Laboremus, founded in 1901 with the intention "to form an association for labourers of body and mind, with the purpose to safeguard common political and social interests through supportive collaboration based on the premises of social democracy". ${ }^{44}$ Ture was active in Laboremus until he left Uppsala in 1908, and Birger became its chair in 1914-15. Following in the footsteps of his older friends, Olov Janse also became a member of Laboremus, and acted as its librarian for a year, between 1915 and $1916 .{ }^{95}$

Janse is otherwise a rather hazy character in the University's student records. Unlike Birger Nerman, who completed his bachelor's and doctoral degrees in seven years, while at the same time being widely active in the social life of the nation and Laboremus, Janse appears to have

93. Vahlquist, n.d. In the Swedish original: "Efter avlagd mogenhetsexamen skrev Nerman 1903 in sig vid Uppsala universitet. Tiden där präglades av ensamhet, erotisk längtan, högstämd livskult, poetdrömmar, en del spexförfattande och planlös läsning. Här väcktes också ett mer uttalat intresse för politik i främst socialistisk och pacifistisk riktning, inte minst i kölvattnet efter det blodiga rysk-japanska kriget och 1905 års ryska revolution. [...] Så småningom, 1908, lyckades han samla sig till en kandidatexamen i nordiska språk, fornkunskap (arkeologi) och statskunskap. Bara några veckor efter examen blev han åtalad och sedermera dömd till böter för att ha spridit flygblad med pacifistiska budskap av Tolstoj. Med det gjorde han sorti från den akademiska värld där han aldrig känt sig hemma."

94. "Föreningen L avser att utgöra en sammanslutning av tanke- och kroppsarbetare i syfte att genom solidariskt samarbete på socialdemokratisk grundval tillvarataga gemensamma politiska och sociala intressen [...]." Uppsala universitets katalog, 92, V.T. 1915 , p. 168.

95. Uppsala universitets katalog, 92, V.T. 1915, p. 168; 92-93, V.T. 1916, p. 169. 
Fig. 11. Map of Uppsala in 1920, with Janse's accommodation marked with an $X$.

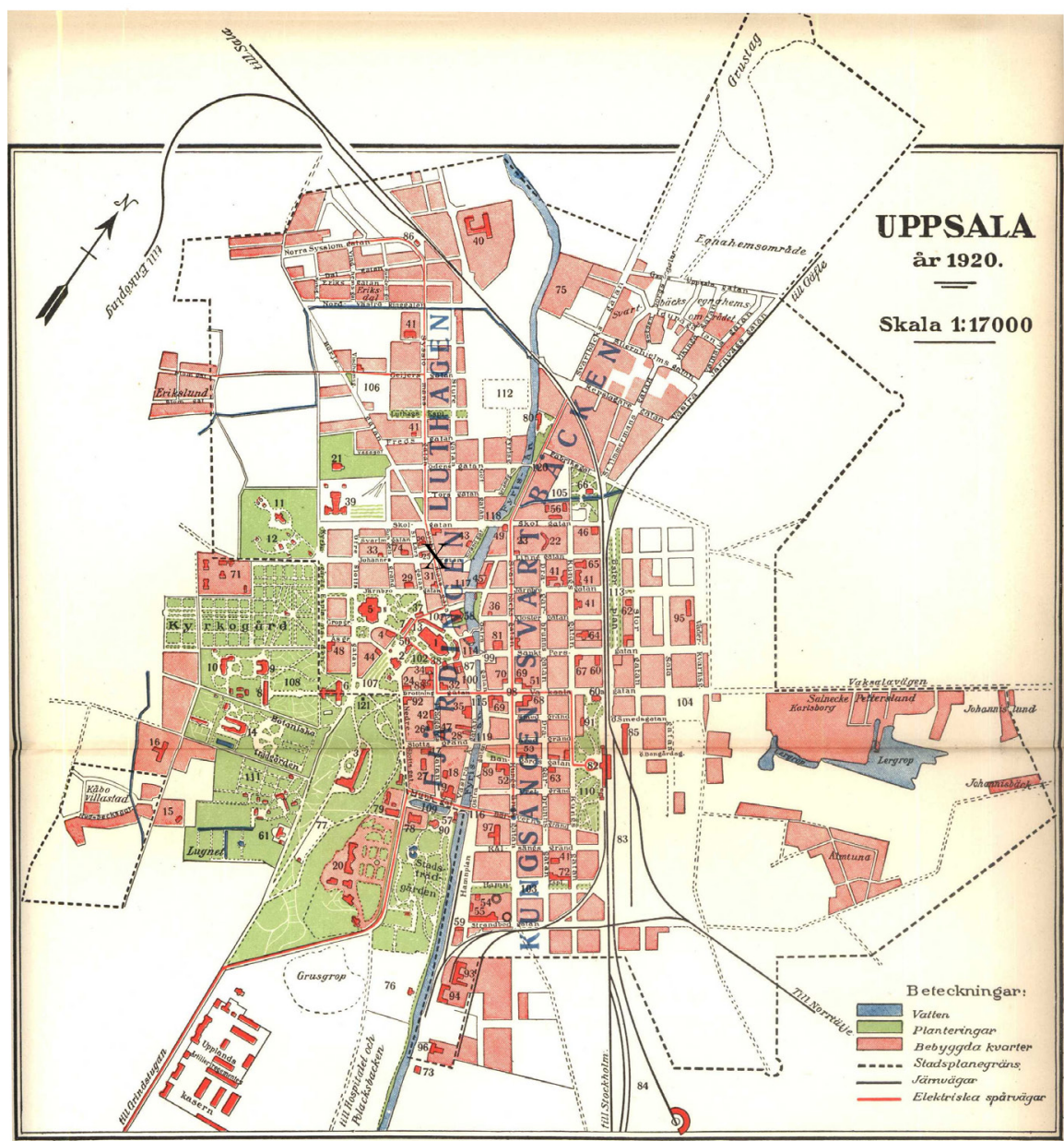

been more of a searching, restless character - similar to Ture Nerman, but without the exceptional talent for writing that made Nerman turn to journalism, and the burning political ambitions that drew him to revolutionary communism. The flirtation with the radical left in Janse's earliest writings are most likely owing to his idolizing of Ture Nerman, and he never seems to have shared Ture's true passion for politics.

As a student, Janse appears to have kept a distance to the student life of the nations, and was - unlike most of his fellow students who lived in accommodation provided by the nations - housed in private accommodation. First at Stora Torget 1, and after that at Torsgatan 6. From the autumn of 1913 he lived at St Johannesgatan $9 \mathrm{~B}$, near the University centre (fig. 11). He even had a telephone, with number 2152. Not many 
students had a telephone number to their accommodation, so it stands as a sign of Janse's social identity and financial position vis-à-vis his fellow students. ${ }^{96}$ Like both Nerman brothers before him, he took classes in Scandinavian languages and archaeology, and earned his bachelor's degree after four years, in the autumn semester 1916 with a supplementary test in spring $1917 .{ }^{97}$

\section{Archaeology at Uppsala University}

When Janse enrolled in 1912, archaeology was not yet an independent subject at Uppsala University. Its equivalent - fornforskning - was taught by Docent ${ }^{98}$ Oscar Almgren $(1869-1945)$ as a subfield within Scandinavian languages. ${ }^{99}$ In 1913 , however, the two subjects were separated with the establishment of a new professorial chair, and Oscar Almgren was installed as Professor of Scandinavian and Comparative Archaeology (Swe: Nordisk och jämförande fornkunskap). Through this manoeuvre, Uppsala became the first Swedish university with a professorial chair in archaeology, followed by Lund University in 1919.

In Sweden and Scandinavia more broadly, archaeology already had a long history and was well known as an important field of knowledge, but its practical dimensions connected it with museums and antiquarian authorities rather than universities. Sweden is known to have the world's oldest national heritage legislation - Kongl: Mayst:tz Placat och Påbudh, Om Gamble Monumenter och Antiquiteter - dating back to 1666 in the era of the Swedish Empire (Swe: stormaktstiden). Concurrently with the passing of the new law in 1666, a new government office was instigated - Antikvitetskollegium - which laid the foundation for an exceptionally strong administrative apparatus for national inventory, collection and protection of monuments and ancient artefacts that worked for over a century. To-

96. Uppsala universitets katalog, 40-41, H.T. 1913, p. 96.

97. Uppsala universitets katalog, 85-86, H.T. 1916 , p. 157 ; 88, V.T. 1917 , p. 158 . The supplementary test (Swe: efterprövning) was included in the Swedish degree system until 1969 , and means a later addition to the degree in the form of an extra subject, or a raised grade on one of the existing subjects.

98. A title that was awarded for an excellent doctoral thesis, and was a crucial step on the way to becoming a full professor. The title remains today, but with a different connotation.

99. Research in Scandinavian languages was then largely based on early Norse texts, hence the connection. 
wards the end of the eighteenth century, a recently formed Royal Academy of Letters, History and Antiquities - Vitterhetsakademien - took over most of Antikvitetskollegium's functions, including the management of a national collection of ancient artefacts. Again, this structural layout for knowledge and management of antiquities remained in practice for well over a century.

Yet if the administrative structures with Vitterhetsakademien as a hub remained more or less intact from the eighteenth to the early twentieth century, the collections of antiquities were radically reformed and reorganized in the nineteenth century. The reform was according to a new paradigm informing the knowledge of the past and changing the organization of artefact collections: from a horizontal, taxonomic, cabinet-of-curiosity structure, to a vertical, chronological, and teleological structure formed around the three periods Stone, Bronze, and Iron Age.

The reforms of the organization of collections and knowledge about the prehistoric past were set off in Sweden in 1837 by the nomination of the thirty-one-year-old Docent Bror Emil Hildebrand (1806-1884), as new Director of National Antiquities (Swe: Riksantikvarie). Hildebrand had studied at Lund University, where he abandoned his first plans to become a priest in favour of historical studies, and became Docent in Numismatics in 1830 . Hildebrand was trained to work taxonomically, i.e. with a horizontal and flexible structure for the organization of artefacts. While he was working with a collection of antiquities owned by the University (which later formed the foundation for the Historical Museum at Lund University), he went to be tutored by the Danish antiquarian Christian Jürgensen Thomsen (1788-1865) in Copenhagen. Thomsen was truly avant-garde, and had set about organizing the Danish national collections of antiquities according to a chronological system with three periods: the Stone, Bronze, and Iron Age. Thomsen had studied in Paris and was inspired by the contemporary developments in geology and other disciplines that had reformed scientific knowledge from horizontal taxonomy to a vertical, teleological chronology (which has been described and analysed for instance by Michel Foucault in The Order of Things). ${ }^{100}$ Over the following decades, Thomsen's three-age system revolutionized the knowledge of prehistory all over the Western world and their colonized territories. Once adopted, it led to radical rearrangements of historical museum collections, which had previously been organized

100. Foucault 1970. 
taxonomically and according to the principles of curiosity cabinets, and were now rearranged in teleological series: from the earliest origins of the nation, via the Stone, Bronze, and Iron Age, to modern times and the ever forward-moving telos represented by industrial society. Hence Thomsen's chronological alternative set a global standard for archaeology and history museums that is still at work today. ${ }^{101}$

Bror Emil Hildebrand became Thomsen's devout student and friend, and brought his ideas to Stockholm when he was appointed Director of National Antiquities at Vitterhetsakademien. With great fervour, Hildebrand set about reforming the Swedish collections of antiquities according to the new three-age system, and in the mid 1840 s he began referring to the collections as The State's Museum of History - Statens Historiska Museum. When the Parliament voted for the construction of a new national museum in 1845 , Hildebrand was quick to respond with a memorandum describing his plans for the organization of the State's Museum of History within the new national museum. ${ }^{102}$ And at the opening of the new Nationalmuseum in 1866 (in the same building as today), the History Museum filled the entire ground floor. The displays were designed and organized entirely according to Thomsen's new system, as an unbroken sequence from the Stone Age, through the Bronze Age, to the Iron Age. Medieval and early historical times were added at the end, completing the illustration of societal development - from the nation's origin in the earliest Stone Age, to modern Sweden as telos. ${ }^{103}$

Bror Emil Hildebrand's forceful early introduction of Thomsen's new system to the Swedish organization and display of national antiquities paved the way for an exceptionally strong early development of archaeological thought and method in Sweden. Bror Emil Hildebrand's son Hans Hildebrand (1842-1913) and his childhood friend Oscar Montelius (1843-1921) were tutored by Bror Emil in the new style of archaeology, and continued the reformation work that he had begun. The Hildebrand family were also friends with the wealthy silk-industrialist Almgren family, whose son Oscar became the first Professor of Archaeology in Uppsala in 1913. Olov Janse's connection to this older generation of archaeologists through his uncle Otto, and his own fraternal relations with the Nerman brothers, are worth remembering in this context. Fraternity

101. Trigger 1989:73-86.

102. Hildebrand 1845 .

103. Hegardt 2015:209-228. 
and family liaisons were of crucial importance for the early developments of archaeology in Sweden. ${ }^{104}$

As young men in their early twenties, Oscar Montelius and Hans Hildebrand were tutored by Bror Emil Hildebrand in the collections of the new Nationalmuseum in Stockholm. He taught them Thomsen's new methodology with direct, practical references to the artefact collections. The three-age system was (and is) based on a relative chronology, creating developmental series of artefacts that represented cultural evolution in the grand narrative of how the nation was formed, from origin to telos. Methodologically, a relative chronology depends on the principle of "closed finds": groups of artefacts which were associated in an original depositional context. Such groups of closed finds had apparently been deposited together, and must consequently have been in use at the same moment of prehistory. By comparing and combining many such closed finds, Thomsen was able to establish how artefact forms and materials had developed in Denmark - from the Stone Age to the Iron Age. ${ }^{105}$

Oscar Montelius and Hans Hildebrand later, in the 1870s, developed a refined method for artefact analysis out of Thomsen's serial approach. They called it typology. ${ }^{106}$ By also taking finds outside of Scandinavia into account, they got a broader base for comparative analysis. The methodological foundation was still the combination of closed finds, but the broader search base enabled a finer tuning of the result. Montelius in particular was a keen traveller, and was often abroad studying collections in central Europe and the Mediterranean. By noting and comparing variations in form and decoration of certain kinds of artefacts, such as brooches (Swe: fibulor), across the European continent, he was able to develop a scheme for cultural development and relations between different parts of Europe. Many of the finds on the European continent also contained artefacts, particularly coins, that could be dated in exact chronological time. Montelius and Hildebrand (the latter was more focused on the Swedish finds) eventually worked out a typology with six main Bronze Age periods, four Neolithic (late Stone Age) periods, and ten Iron Age periods.

Montelius explained the fact that similar forms of artefacts were found in geographically distant locations by the principle of diffusion. The logic

104. Baudou 2012:24.

105. Gräslund 1974; Trigger 1989:74-79; Jensen 1992.

106. Trigger 1989:156-161. 
behind the principle of cultural diffusion was that forms and decorations from a culturally advanced centre (such as the Mediterranean during the Bronze Age) would automatically diffuse to less developed areas (such as Scandinavia during the same time), like a drop of ink in a glass of water. ${ }^{107}$ When a more dominant cultural form diffused into a more recessive one, it would first leave a trace in the form of a slight tint, and if the diffusion continued the dominant form would gradually take over. This logic was derived partly from natural science (with observations of, for instance, ink in water), and partly from the colonial ideology that dominated European scholarship in the nineteenth and early twentieth centuries, where it served as a convenient hierarchical understanding of culture that justified colonial intervention as a benevolent enterprise. As such, the idea of cultural diffusion was also akin to Charles Darwin's theory of natural selection, ${ }^{108}$ and both Montelius and Hildebrand published texts where they explained why they were Darwinists. ${ }^{109}$ There is no clear, direct reference in Montelius's work that links the typological method with Darwin's development theories. But Nils Åberg (a fellow student with Janse at Uppsala and also a native of Norrköping, who was one of the strongest promoters of typology in Swedish archaeology after Montelius's death) made direct links between typology and Darwinism, with reference to both Montelius and Hildebrand, in an entry on "Typologie" for a German encyclopaedia of prehistory published in 1929. ${ }^{110}$

The question of direct links between Darwin's theories and the typological method has been debated, ${ }^{111}$ often in arguments that tend to treat archaeological research methodology as something separate from archaeological narration and popular communication. Oscar Montelius is an interesting character in such a discussion, because he was exceptionally influential both in the development of the typological research method and as a public narrator of grand histories of the Swedish nation, with clear political ambitions. We maintain that archaeology always contains both research method and narration, and that it would be fruitless to try to separate one from the other in the same subject, such as Oscar Montelius. Hence it should be safe to say that nineteenth-century Scandina-

107. Trigger 1989:158-160.

108. See discussion on diffusionism as something different from, yet not incompatible with evolutionary theory in Conklin 2013:42n 58 .

109. Hildebrand 1873; Montelius 1899. See also Gräslund 1974:207-216.

110. Åberg 1929; Gräslund 1974:207; Baudou 2002.

111.E.g. Trigger 1989; Gräslund 1974. 
vian archaeology flirted with Darwinism in the sense that it was inspired by a view of culture similar to that represented by the theory of natural selection. That was, however, a view that was not restricted to Darwin's theories nor to the development of typology; it could be found in human and natural science all over nineteenth-century Europe, and was moreover connected with colonial ideology. ${ }^{112}$

Oscar Montelius and Hans Hildebrand worked in Stockholm and were two generations older than Olov Janse, so they never played any direct tutoring roles in his education. But the academic and social context of which Janse became part in Uppsala was very much influenced by their methods and perspectives. Oscar Almgren, the new professor and Janse's tutor, was family friends with Hildebrand (and Montelius, by proxy), and worked with them at the History Museum in Stockholm. Just like Montelius, Almgren had started his career at the museum in Stockholm and travelled the European continent to visit over a hundred museums for his doctoral thesis, which was based on Montelius's typological methods. ${ }^{113}$ Almgren was also a keen fieldwork archaeologist, and it was his excavations of Kung Björns hög, a Bronze Age burial mound near Uppsala in 1902, that sparked the Swedish Crown Prince, later King Gustaf V I Adolf's life-long passion for archaeology. ${ }^{114}$

Hence the archaeology that Janse was taught by Oscar Almgren in Uppsala had a strong emphasis on artefacts, and the archaeological analyses relied on practical management of artefacts through excavations and museum work. Even before Janse commenced his studies, he was initiated into archaeological excavation practice through the Nerman brothers' work at the Säter settlement site. Through his uncle Otto, who had a strong position at the History Museum in Stockholm, he obtained an entrance ticket to the museum world and a link to the older generation of archaeologists at the museum (although Otto Janse was also considerably younger than Hildebrand and Montelius). Throughout his active career in archaeology, Olov Janse maintained the strong connection with excavation work and the work with museum collections that he was introduced to as a young man.

In excavations, the Scandinavian archaeologists worked with a stratigraphic method. Stratigraphy, which was originally invented in geology

112. Fabian 1983; Clifford 1988; Källén 2015.

113. Almgren 1897.

114. Almgren 1905; Isaksson 1972; Whitling 2014. 
and means the documentation and analysis of layers, was used by early field archaeologists such as Almgren as a key method to establish relative chronology, and has since become a standard archaeological excavation method. By excavating in trenches with straight walls, the vertical section of the soil could be observed and documented. The stratigraphic drawing was used as an analytical illustration of the passage of time at an archaeological site - from the oldest lowest stratum to the most recent topsoil. Artefacts found in the different strata were analysed typologically, using Montelius's scheme of prehistoric periods, to produce a relative dating for the different phases of the site. Hence stratigraphy was of key importance to understand and establish the exact contexts of the finds, which in turn was crucial to allow for comparative analysis. The comparative analysis required methods that could establish exact dates, and similarities in form and function among the artefacts. Olov Janse had theoretical and practical training in these artefact-oriented methods in Uppsala, and we shall see in later chapters how he pursued them in his work in excavations and museums, from Sweden and France to Indochina and the United States. ${ }^{115}$

If Oscar Almgren and the Uppsala milieu provided the theoretical and practical foundation for Janse's later work, Oscar Montelius was his intellectual lodestar. Oscar Montelius was an extraordinary character in Swedish public life in the late 1800 s and at the turn of the century. Like pop stars or influencers of our time, he had crowds queuing outside the History Museum for his public lectures. And in active support of the work of his feminist and social philanthropist wife Agda, he was an early advocate for women's voting rights. He was such a national celebrity that a special stamp was issued to mark the centennial of his birth (fig. 12).

In a photo album kept in Olov Janse's personal archive, there are a couple of clippings from a magazine with photographs of Montelius, the Swedish archaeologist Knut Stjärna, and the Norwegian archaeologist Haakon Shetelig walking around the menhirs of Carnac in France in

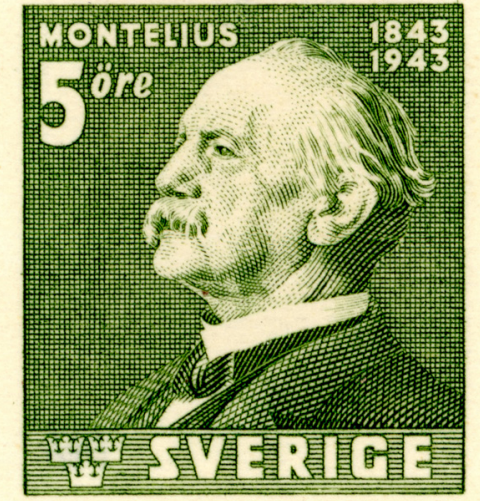

Fig. 12. Oscar Montelius stamp, 1943 .

115. E.g. stratigraphic drawings of the Dong Son site in Janse 1958:21, 22, 28, 29. 
Fig. 13. Illustration of Montelius's method, in Janse's lecture notes from 1958.
1906. ${ }^{116}$ Janse was fourteen years old at the time. It was the same year as Otto Janse produced his exhibition in Norrköping and invited his young nephew to come along on the research tour. In Janse's first academic publication on his own thirteen years later - an article in a festschrift for Oscar Almgren - the references to Montelius are prominent. ${ }^{117}$

Olov Janse wrote two pieces that are particularly revealing of his admiration for Oscar Montelius. One is a lecture in French on "Montelius méthode" that he gave on his lecture tour in Saigon $1958-59,{ }^{118}$ where he describes how Montelius managed to date ancient artefacts in Scandinavia with his typological method. Janse illustrates the broad comparative element of the typological method with a series of boxes, representing different geographical regions (Scandinavia, Italy, Greece...). In each box there are four letters, representing artefact types, which connect the boxes and thereby enable comparison and exact dating between and across geographical regions.

In the same lecture Janse describes and illustrates the stratigraphic method. Although the lecture was given half a century after he learnt these methods from Oscar Almgren in Uppsala, when his time as an excavating archaeologist was long over, they were still fundamental for his

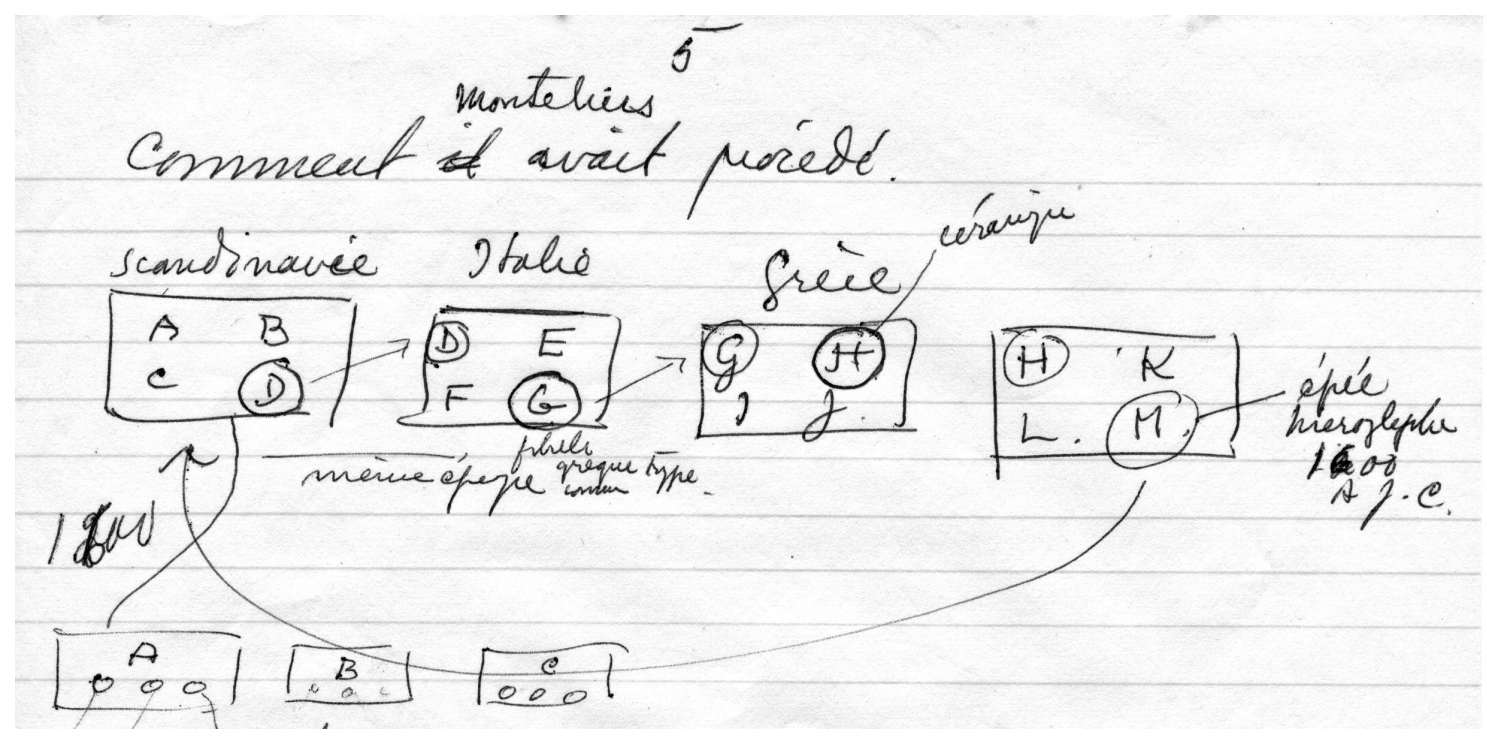

116. NAA: Janse 2002-29.

117. Janse 1919a.

118. "Montelius méthode" ATA: Olov Janse. Enskilda arkiv 59. 
approach to and understanding of the past and he still connected them to the format of Montelius's archaeology.

The other text is an article for the Swedish newspaper Dagens $N y$ heter on the occasion of Montelius's $75^{\text {th }}$ birthday in September 1918. ${ }^{119}$ Olov Janse was then twenty-six years old, had graduated from Uppsala and begun his new cosmopolitan life with one foot in Paris and one in Stockholm. In this text it is clear that his admiration for Montelius went beyond his groundbreaking methodology. The "magnificent" typological method is indeed mentioned and described as "the principle of natural selection applied to the products of human labour", since "Montelius and Hildebrand discovered that such products abide by the same rules of evolution as living species, so that one form generates the next" ${ }^{120}$ But the focus of the text is on Montelius's international importance and scholarly recognition. Janse puts emphasis on publications about Italian and Greek prehistory in French and German, and writes that outside of Sweden he was known as "L'éminent Suédois" - The Distinguished Swede. Among Swedish archaeologists of his time, Montelius was indeed one of a kind. When his colleagues studied mostly Swedish materials and published in Swedish or German, Oscar Montelius had a much wider vision, enjoying broader comparative studies with the Mediterranean or even China, ${ }^{121}$ and communicated with ease in French as well as German and English. He had star quality, and was a major source of inspiration for an aspiring cosmopolitan archaeologist like Olov Janse.

\section{End of the Uppsala years}

Only two years into his studies in Uppsala, Olov Janse was on the move. He travelled to Paris for the first time in 1914, and appears thereafter to have been absent from Uppsala from time to time. From this period there are also long gaps in his otherwise regular correspondence with Birger and Ture Nerman. He attended courses and graduated eventually in 1917, but did not share Birger Nerman's enthusiasm and devotion for Swedish university life. After graduation in 1917, which coincided with

119. Dagens Nyheter, 8 September 1918: "Oscar Montelius 75 år”.

120. Ibid. In the Swedish original: "Den typologiska metoden är utvecklingsläran tillämpad på det mänskliga arbetets produkter. Montelius och Hildebrand upptäckte nämligen att dessa produkter äro underkastade samma utvecklingens lagar som de levande arterna, så att den ena typen ger upphov till den andra."

121. Chen \& Fiskesjö 2014. 


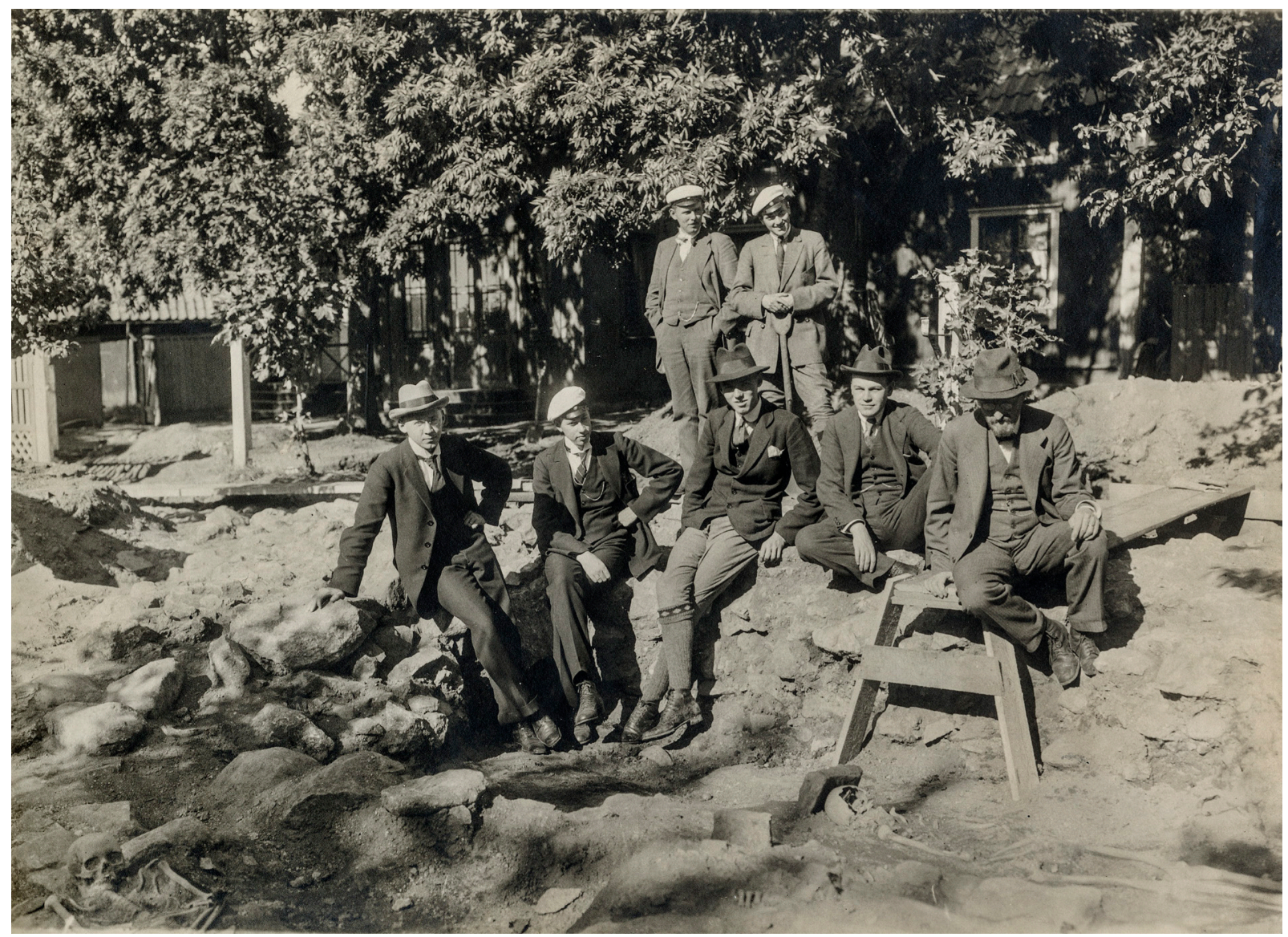

Fig. 14. Excavation at Sigtuna, summer 1915. A new historical museum will be built on the spot. Parts of a wall and skeletons are uncovered. Standing from left to right: Eskil Olson and Bengt Tordeman. Seated from left to right Nils Palmgren, Olov Janse, Carl Mörner, Evald Uggla and Oscar Almgren. Photo by Olof Palme (1884-1918), historian and uncle to the later Prime Minister Olof Palme (1927-1986).

the death of his mother, he disappeared immediately from Uppsala and did not return until autumn 1920 , when he earned a licenciate degree. ${ }^{122}$ His home address was then registered as Heimdalsgatan 3 in Stockholm, so he was no longer taking part in Uppsala's student life. ${ }^{123}$ In the spring semester 1922 he registered once again at Östgöta Nation, but only to be

122. The Licenciate degree (Swe: fil. lic.) was then a degree half-way between BA (fil. kand.) and $\mathrm{PhD}(f i l . d r)$.

123. Uppsala universitets katalog, 40, H.T. 1920, p. 99; 85-87, H.T. 1920, p. 167. 
promoted to Doctor of Philosophy on 31 May 1922. ${ }^{124}$ With that, Olov Janse left Uppsala for good and turned his full attention to Stockholm and Paris.

Even though Olov Janse did not thrive in student life in Uppsala, the years at university provided a number of important pieces to the archaeological foundation that characterized the rest of his life and career. It gave him the methodological training based on stratigraphy and typology, and the diffusionist comparative analysis that he would rely on for the rest of his working life. Both Oscar Almgren and Oscar Montelius showed the way with their study trips to museums on the European continent, although Montelius with his bold comparative analyses spanning over vast continents became the star that shone clearest. Janse also built professional networks that he maintained later on in his career, for example with Arthur Nordén (1891-1965) and Nils Åberg (1888-1957), who were also from Norrköping and studied archaeology in Uppsala. In the next chapter we will look further into the building of professional networks, and Olov Janse's years as a graduate student on the move between Sweden and France.

124. Uppsala universitets katalog, 87, H.T. 1922, p. 170. 


\section{BETWEEN FRANCE AND SWEDEN (1919-1929)}

Olov Janse made his first journey to Paris in June 1914, after two years of studies in Uppsala. He may have been inspired by Ture Nerman's journalistic travels across Europe, Russia, and the United States, or by Einar Nerman, who had spent three years in Paris studying under Henri Matisse. But unlike Ture, who quickly returned to home base after each journey, and Einar, who also returned and settled in Sweden after his study sojourn, Olov Janse fell in love with Paris. With exceptional social abilities and a linguistic talent he soon became fluent in French. Translation came easier for him than for most others, and he soon turned his social competence and language skills into professional assets. In letters to Ture and Birger Nerman, he expresses his love for France and clear political sentiments: "Vive la France! A bas l'Allemagne!!"125

While his fellow students spent the summer of 1914 excavating and vacationing in Sweden, Olov Janse set off to more distant lands. He travelled via Cologne to France where he stayed with a Professor Valot and his family in Liesle and Boulogne-sur-Mer, from June to September. ${ }^{126}$ It was

125. Letter from O. Janse to B. Nerman, 7 September 1914. Riksarkivet. Kartong I. Korrespondens Brev I 1897-1922.

126. This was likely the family of Jules Valot (1851-1926), Professor at the University of Liesle, with the son Stephen Valot (1879-1950), who became a journalist at L'Oeuvre, author, and Secretary-General of the International Federation of Journalists. Letters and 
his first visit to France, and it was love at first sight. Letters and postcards to his friends in Sweden abound with positive sentiments: "I am still splendidly content here in 'the delightful land'." ${ }^{127}$ But the war broke out when he had just arrived in July, and as he was preparing to leave France to return to Uppsala at the end of September, he wrote to Birger Nerman that he feared he might not be able to reach Sweden and would be forced to turn back to France: "It is like (pardon the word) Hell to travel now." ${ }_{128}$

He did, however, return safely to Sweden, where he spent the war years completing his graduate studies in Uppsala. In the summers of 1915-16 he travelled to the island of Gotland in the Baltic Sea and assisted Birger Nerman in his excavations of an Iron Age burial site at Trullhalsar. ${ }^{129}$ In the summer of 1917 , just after he had completed his bachelor's degree at Uppsala, he joined Birger Nerman in another excavation, this time of six grave mounds from the late Iron Age at Kummelby near Norrköping, ${ }^{130}$ and the following year he pursued his own excavations at an Iron Age burial site with sixteen mounds at Åby in Kvillinge, not far from Norrköping. ${ }^{131}$ Both excavations were supported and funded by Vitterhetsakademien - the Royal Swedish Academy of Letters, History and Antiquities. Apart from excavations and studies in Uppsala he wrote and published a couple of reviews and short texts in the local and national newspapers, ${ }^{132}$ waiting for the war to end.

The war was initially like a distant theatre play for the young archaeologist - "God how they fight. [...] A war is undoubtedly exciting" 133 - but

postcards from O. Janse to B. Nerman, 16 June 1914; 21 June 1914; 7 September 1914. Riksarkivet. Kartong I. Korrespondens Brev I 1897-1922.

127. Letter from O. Janse to B. Nerman, 10 August 1914. Riksarkivet. Kartong I. Korrespondens Brev I 1897-1922. In Swedish: "Trivs fortfarande överdådigt här i 'det juvliga landet'."

128. Postcard from O. Janse to B. Nerman, 25 September 1914. Riksarkivet. Kartong I. Korrespondens Brev I 1897-1922. In the Swedish original: "Bäste Broder! // Står i begrepp att fara till England f.v.b. mot Nårge-Uppsala män fruktar få vända tillbaka till Frankrike. Det är ett (förlåt ordet) Hälsike att resa nu. // I all hast. // Din vän Olle.”

129. Letter from O. Janse to B. Nerman, 14 May 1918. Riksarkivet. Kartong nr 1. Korrespondens Brev I 1897-1922.

130. Norrköpings Tidningar, September 1917. "Kummelby forntidskummel genomforskade".

131. Norrköpings Tidningar, 19 June 1918. "Forngravar vid Åby undersökta."

132. E.g. Janse 1918.

133. Letter from O. Janse to B. Nerman, 7 September 1914. Riksarkivet. Kartong I. Korrespondens Brev I 1897-1922. In Swedish: "Gud så dom slåss. [...] Ett krig är onek- 
by the time it was over in November 1918, the remaining impression was of horror and meaningless destruction. Huge numbers of individual lives had been wrecked, and political and cultural institutions across Europe has been left in ruins. Ture Nerman wrote a famous poem about the destruction of the war - Den vackraste visan om kärleken:

\author{
Den vackraste visan om kärleken \\ kom aldrig på pränt. \\ Den blev kvar i en dröm på Montmartre \\ hos en fattig parisstudent. \\ Den skulle ha lyst över länderna \\ och bringat en vår på knä, \\ och en värld skulle tryckt till sitt hjärta \\ en ny, en ny Musset. \\ Han skulle ha vandrat längs kajerna \\ med en blåögd liten Lucile \\ och diktat violer och kyssar \\ nu en natt i april. \\ Men den vackraste visan om kärleken \\ kom aldrig på pränt. \\ Den begrovs i en massgrav i Flandern \\ med en fattig parisstudent. ${ }^{134}$
}

The poem reflects a romantic image of Paris and its student life that was maintained by Olov's friend and role model Ture Nerman, and how that image of Paris as the place for innocent romantic adventure and pleasurable intellectual creativity was irreversibly shattered by the war. Meanwhile in Norrköping, the war put an end to the privileged security and prosperity that characterized Olov's childhood and adolescence, with the candy factory facing ruin and Hilma Janse's unexpected death

\footnotetext{
ligen spännande.”

134. Ture Nerman 1916 (first published in the poetry collection Fruntimmer 1918, and set to music by Lille Bror Söderlundh 1939). In our translation: "The most beautiful song of love / was never put in print. / It remained in a dream at Montmartre / with a poor Paris student. // It would have lit up the lands / and brought a spring to its knees, / and a world would have taken to heart / a new, a new Musset. // He would have wandered along the quays / with a blue-eyed little Lucile / and written violets and kisses / now on a night in April. // But the most beautiful song about love / was never put in print. / It was buried in a mass grave in Flanders / with a poor Paris student."
} 
in August 1917. The war also meant the end of the habitual travelling that had been part of prominent Swedish archaeologists' research profiles since the nineteenth century. In the previous chapter we described how Oscar Montelius and Oscar Almgren both travelled widely and visited hundreds of museums and artefact collections across Europe for their research. Their travels enabled the development of the important typological method, and also contributed to pan-European ideas dominating nineteenth-century archaeology. ${ }^{135}$ These ideas, and the lifestyle of the travelling nineteenth-century archaeologists were fundamental inspirations for Olov Janse, who also had the resources to develop a cosmopolitan travelling lifestyle with his father's wealth, the networks offered by his uncle Otto and the Nerman brothers, and of course his own linguistic and social talents. But the war put a definitive end to the travelling habits of the nineteenth century, with its restrictions of movement and several years of closed borders, and with the introduction of passports that emphasized the importance of border control. If the nineteenth century had been a time of unrestricted movement (for the privileged classes), the twentieth century would be characterized by a focus on the nation state with citizenship, passports, and border controls. ${ }^{136}$ In Sweden, the dissolution of the union with Norway in 1905 , combined with awakening Scandinavianist political sentiments, contributed to an inward focus on the Swedish nation. ${ }^{137}$ This brought an intensified concentration on the nation in archaeological research, which meant that the broader panEuropean and diffusionist perspectives that had prevailed in the nineteenth century fell out of fashion in Swedish archaeology. ${ }^{138}$

When Janse was finally able to travel to France again, he did not waste any time. He was on the move already in August 1919, seven weeks after

135. As an example, Oscar Almgren visited over 100 museums and other archaeological collections in Europe and Russia when writing his theses. Svenskt Biografiskt Lexikon, Band 1 (1918), p. 435 .

136. Torpey 2000:111-115. See also letter from O. Janse to B. Nerman, 5 December 1916; 11 December 1916. Riksarkivet. Kartong I. Korrespondens Brev I 1897-1922.

137. The dissolution of the union with Norway had, for example an impact on Nordiska museet (The Nordic Museum) in Stockholm. From having been a museum covering all the Nordic countries, it now focused on Swedish folk culture in a very nationalistic sense. Oscar Montelius played a significant part in this change of direction (Hillerström 2010).

138. Most Swedish archaeologists active in the years after the First World War (including Birger Nerman) tuned into the national focus, and many restricted their international outlook to communication with Germany. A few, including Ture Arne and Nils Åberg (Nordström 2015:137), shared Janse's interest in broader European perspectives. 
the peace treaty had been signed in Versailles. But it was in many ways a new world that he travelled through. While he kept and maintained the internationalist, cosmopolitan ideals of the nineteenth and early twentieth century, the world around him had changed, with an intensified focus on national identity and the security and integrity of the nation state.

He left Scandinavia on SS Jupiter, travelling from Bergen in Norway to Newcastle in the United Kingdom in August 1918. In Bergen he stopped to meet with the Norwegian archaeologists Brøgger and Shetelig, only to find that they were away on excavations. ${ }^{139}$ Haakon Shetelig (1877-1955) has been described as "the European among Norwegian archaeologists", and he was a Francophile just like Janse. After the First World War he even deleted the $\mathrm{c}$ in his original family name (Schetelig) to avoid any associations with Germany. ${ }^{10}$ It remains obscure how they first met, but somehow Shetelig pointed Janse to the École pratique des hautes études (EPHE) at the Sorbonne, where the renowned sociologist Henri Hubert was lecturing on Celtic and Germanic archaeology and history of religion. ${ }^{141}$ Upon arrival in Paris, Olov Janse enrolled at the EPHE in accordance with Shetelig's advice and soon got in contact with Henri Hubert. Their acquaintance and subsequent friendship meant the beginning of a new phase in Janse's life and career.

Henri Hubert (1872-1927) was twenty years senior to Janse, and one of the most devoted members of the academic circle around the legendary Émile Durkheim (1858-1917) and his journal L'Année Sociologique. ${ }^{142}$ In the late nineteenth century Émile Durkheim had launched a new sociological

139. Letter from O. Janse to B. Nerman, ["D/S Jupiter, Nordsjön”], 13 August 1919. Riksarkivet. Kartong 1. Korrespondens Brev I 1897-1922.

140.https://nbl.snl.no/Haakon_Shetelig, accessed 18 September 2016. See also Slomann 1955 .

141. Janse 1959:15.

142. For details on the underpinnings of Henri Hubert's professional contributions, see the volumes Henri Hubert et la sociologie des religions edited by Jean-François Bert (2015) and La Mémoire et le Temps edited by Laurent Olivier (2018). Janse is only mentioned a couple of times in passing, and in the latter volume referred to as "Olaf Jansé". See also Dussaud 1927 and Seligman 1927 for biographical details. We are most grateful to Christine Lorre at the Musée d'Archéologie nationale (MAN), for providing us with valuable information about Henri Hubert and the MAN during the research process. 
paradigm that became foundational for modern social science. It consisted of a view of society as a sui generis reality - something which is unique to itself and forms a whole that is greater than the parts it contains. Society could not, according to Durkheim, be reduced to psychological or biological explanations. It needed to be studied socio-logically. Hence he developed a new methodology for the study of human societies based on "social facts", elements of collective life (such as kinship, religion, political organization, or currency) that exerted external constraints on the individual. Émile Durkheim, who had a distinct political profile, was actively pro-Dreyfus and a founding member of the French Human Rights League, was immensely influential in French academic life around the turn of the century. He surrounded himself with a group of followers, an équipe of younger scholars whose works he published alongside his own in his journal L'Année Sociologique.

In this équipe, in the inner circle closest to Durkheim, was Henri Hubert. Hubert's proximity to Durkheim was very much due to his close relationship with Durkheim's nephew and closest disciple Marcel Mauss. They were in many ways each other's opposites. If Mauss had an outgoing air of self-evident importance, Hubert was more timid in character, as if he was always longing to retreat to his study. And while Mauss spent most of his senior career finishing the works of others (mainly colleagues lost to the First World War), Hubert started and maintained many projects at once, but left most uncompleted. ${ }^{143}$ Yet they were joined by their passion for Durkheimian sociology, and they had known each other since they were fellow students at the prestigious École Normale Supérieure, and later at the École pratique des hautes études at the Sorbonne. Hubert had originally been a student of Semitic languages and the history of religion of the Near East, but in his later career focused his research on comparative archaeology and the history of religion in Europe and Asia. His historical interests made him unique in Durkheim's équipe, where all other members focused on the study of contemporary societies. ${ }^{144}$

In 1898, in the same year as Durkheim founded L'Année Sociologique, Hubert was appointed lecturer in sciences religieuses at the École pratique des hautes études in Paris, and in the same year he was attached as unpaid curator to the Musée des antiquités nationales. Four years later, in 1902, he was nominated to represent France at the first international congress

143. Olivier 2018:119-122.

144. Strenski 1987:354. 
for the study of the Far East in Hanoi in French Indochina, ${ }^{145}$ a congress that celebrated the recent foundation of the colonial research institute École française d'Extrême-Orient (EFEO, which would three decades later be hosting Janse's work in Indochina), and took the opportunity to make a journey around the world. His experiences from this world tour and the Hanoi congress fed his interest in comparative cultural studies. ${ }^{146}$

Several aspects of Henri Hubert's persona and academic oeuvre are worth mentioning in relation to Olov Janse. Like most members of Durkheim's équipe, Hubert was politically motivated and saw the French republican society as the highest form of civilization. ${ }^{147}$ He was, just like Janse, a privileged cosmopolitan, and he opposed the anti-Jewish nationalistic sentiments that were growing in Germany and in parts of French politics and science. ${ }^{148}$ Like Marcel Mauss and the other Durkheimians, he understood the value of broad language skills to enable comparative cultural analysis. And just like Mauss, who worked with ethnographic museum collections, Hubert had a taste for material objects. ${ }^{149}$ Both Mauss and Hubert worked in museums and based their analyses on artefacts from "primitive" societies. They organized them in analytical series and used their language skills to make comparative studies of the cultural contexts they belonged to. Hubert, however, stood out from the rest of the Durkheimian équipe with his focus on prehistoric societies, and hence on ancient artefacts. His works have thus been mentioned as noteworthy for merging Durkheimian sociology with prehistoric studies. ${ }^{150}$ What he ended up with was an artefact-oriented, broad and bold comparative cultural analysis akin to the works of Janse's academic lodestar Oscar Montelius. ${ }^{151}$

145. EFEO 1903.

146. Lorre 2015 a.

147. Strenski 1987:356.

148. Strenski 1987; see also how these sentiments affected his approach to archaeological interpretation in the chapter "Des Celtes aux Germains" in Olivier 2018.

149. Hubert \& Besnard 1979:207; Mauss 1966:3.

150. Strenski 1987:354; Lorre 2015b:152; Olivier 2018.

151. There were other important nineteenth-century scholars for the development of comparative culture-historical studies in both Sweden and France. In Sweden, Sven Nilsson should be mentioned (e.g. Hegardt 1997), and in France, Gabriel de Mortillet had since the mid nineteenth century shown the way in comparative analysis of "primitive" cultures in the past and present (e.g. Olivier 2018:133). It should be pointed out that Janse's interest in diffusionism as a model of explanation was not, however, a main strand in Henri Hubert's oeuvre (Lewuillon 2018:155). Other French archaeologists who 
In a short autobiographical text, ${ }^{152}$ Hubert describes how he was attracted to the ethnographic side of archaeology, and how he worked with the comparative collections displayed in the Salle de Mars at the Musée des antiquités nationales - "where the diversity of archaeological relics corresponds exactly with the diversity of peoples" - to "create a microcosm" on display. ${ }^{153}$ The way Hubert made use of the archaeological and ethnographic objects as illustrations, or reminiscences of his comparative cultural theories, and hence made the Salle de Mars into an intellectual laboratory on public display, bore striking resemblance to the way Oscar Montelius had worked with the displays of the History Museum in Stockholm to make his theories of typology and cultural development available for public consumption. ${ }^{154}$ However, with his bold ethnographic comparisons, Hubert widened the scope of possible comparative analysis much further, when he ascribed primacy to the similarities of things regardless of whether their contexts of origin were separated by thousands of miles or thousands of years, and thus more or less ignored the detailed temporal contexts that were absolute key for Montelius's analyses and displays.

Hubert's analytical approach to historic and prehistoric societies was fully in line with the Durkheimian perspective of comparative cultural analysis that flourished around L'Année Sociologique. However, the First World War left the intellectual milieu around the Année severely injured. The radical intellectual principles at the heart of the Année were battered, as were the members of Durkheim's équipe. Hubert served in the infantry, where many of his peers were killed. Durkheim also died, from a stroke, during the war. When the war came to an end, his devout disciples Mauss and Hubert decided to join efforts and take over what was left of the Année. And it was here, in the period of shock and restoration immediately after the First World War, that Janse first met Hubert. ${ }^{155}$

Inspired by the advice from Haakon Shetelig, Janse attended Hubert's lectures in Celtic and Germanic archaeology and history of religion at

have worked more clearly with the concept of cultural diffusion were Paul Rivet, to whom we will return later in this chapter, and Marcel Mauss's student André Leroi-Gourhan (1911-1986), e.g. Stiegler 1998:48-49.

152. Written at the time of war mobilization in 1915 as an intellectual testimony meant for his young son and friends (Hubert \& Besnard 1979).

153. Hubert \& Besnard 1979:206-207; our translation.

154. See Part I for more details on Montelius and the National Museum in Stockholm, also Baudou 2012.

155. Correspondence from Janse to Hubert is found in the archive of MAN. 
the École pratique des hautes études (E PHE) in the years following the war. Hubert had lost his friends and his mentor in the war. Janse had just lost his mother, and the relationship with his father had taken a blow when he remarried soon after her death. Hubert, who has been described as a very gentle and honest scholar with vast knowledge, lively intellect, and fragile health, ${ }^{156}$ took the young Janse under his wings and they eventually developed a strong intellectual and personal relationship that would have a decisive impact on the rest of Janse's life and career.

In the autumn of 1919 Janse was back in Paris, relieved. In a letter to Birger Nerman he writes about his thoughts for the future:

\begin{abstract}
When I have defended my doctoral thesis God knows what I shall do. Most of all I would like to return to the homeland of my soul, where I hope to find something to do. Review Scand. archaeol. lit. in d'Anthropologie e.g. [...], correspondent for [Social-Demokraten], library assistant at the Scand. Library, assistant curator at some museum $[\ldots]$. At least I would like to try to get the opportunity to stay here a couple of years. ${ }^{157}$
\end{abstract}

He stayed in Paris the whole winter and spring. He attended Hubert's lectures at the EPHE, spent time with the visiting Swedish archaeologist Nils Åberg, and did studies in preparation for his doctoral thesis. In an article published in the Swedish newspaper Social-Demokraten, he writes in glowing terms about the student life in le quartier latin. He writes that the universities at the Sorbonne and the Collège de France offer interesting lectures (almost for free $)^{158}$ and through the student association, students can have good food and wine (again, almost for free) and discounts on

156. Dussaud 1927 .

157. Letter from O. Janse to B. Nerman, 1 December 1919. Riksarkivet. Kartong 1. Korrespondens Brev I 1897-1922. In the Swedish original: "Sedan jag disputerat vete Gud vad jag ska ta mej till. Hälst skulle jag vilja återvända till min själs fädernesland, där jag hoppas alltid kunna hitt på något. Recensera skand. arkeol. litt. i d'Anthropologie t.ex. (om Akad. skulle bevilja något anslag för saken), korrespondent för Soc-D., biblioteksamanuens på Skand. biblioteket, amanuens på ngt museum eller dylikt leker mej i hågen. Åtminstone skulle jag vilja försöka skaffa mej möjlighet att stanna här några år.”

158. The lectures at the Collège de France were in fact entirely free. 
books, clothes, and theatre tickets. Student life, however, was marked by the war and Janse writes, reminiscent of Ture Nerman's poem: "the five years of war struggles and nameless sufferings have indeed put a damper on the joy. When they gathered again after the peace, many of their friends had not returned from Yser, Champagne, Verdun ...". But despite the sorrows of the war, he concludes, a sojourn in le quartier latin is an excellent opportunity for Swedish students to get to learn, understand, and love the French language and French culture. ${ }^{159} \mathrm{He}$ did not return to Sweden until May 1920.

Then he stayed in Sweden for about a year. This time he settled in Stockholm (an hour by train from Uppsala, and three hours from Norrköping), first at Bellmansgatan 8 in Södermalm, and later at Heimdalsgatan 3 in Vasastan. While in Stockholm he wrote regularly to Henri Hubert in Paris. The first letter was sent immediately upon

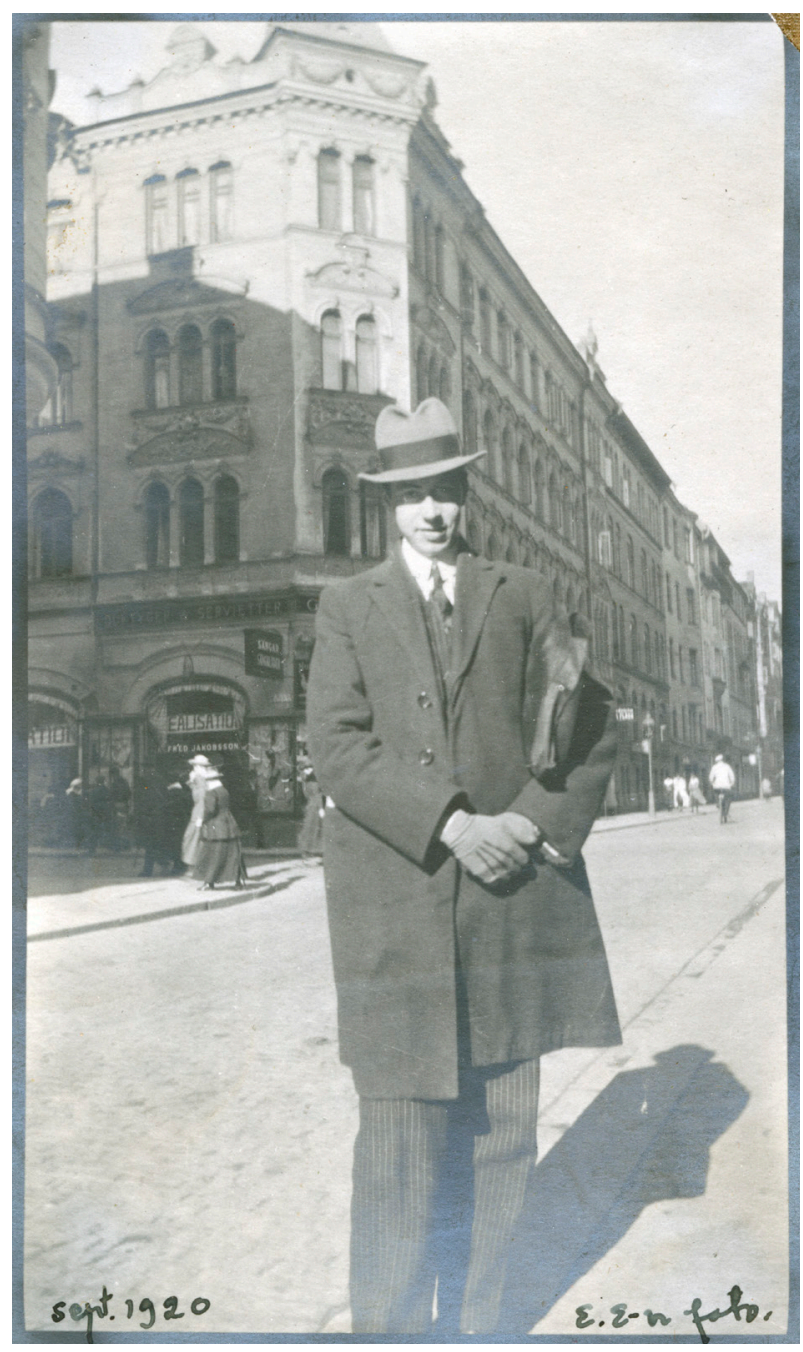
arrival on 27 May to express his gratitude for the generosity and kindness he had been shown in Paris, and to ensure Hubert that he would receive the information they had talked about as soon as possible. ${ }^{160}$ In October he wrote from Heimdalsgatan 3, with apologies for his long silence. He had been held up by

Fig. 15. Olov Janse in Stockholm, September 1920.

159. Social-Demokraten, 15 July 1920: (Olov Janse), "Bland Parisstudenter: Några intryck från le quartier latin."

160. Letter from O. Janse to H. Hubert, 27 May 1920. IMEC-Fonds Mauss-Correspondance Janse-Hubert. Transcription Professor Rafael Faraco Benthien - December 2009 . 
personal affairs and with work for his degree, and it was only now that he had found time for his chères études - his beloved studies. In November he wrote again, only to say that he would not return to Paris until the following year. ${ }^{161}$ Evidently, he was torn between the steady, inward research work that was needed in order to complete his doctoral thesis in Uppsala, and the more exciting cosmopolitan life and museum work with Hubert in Paris. With support from Henri Hubert he published an article in the French journal Revue archéologique summarizing the findings of his thesis. ${ }^{162}$ The article, which relied heavily on Montelius's typology and argued that the stylized male figure on golden bracteates from the Migration Period found in Scandinavia was Attila, leader of the Huns (and not Odin, as had been argued by Scandinavian scholars). Its publication was noticed in the Scandinavian press and received positive reviews in Swedish and Norwegian newspapers. ${ }^{163}$

He returned to France late in the spring 1921, and made an immediate escape to the countryside to rest after a bowel infection he had come down with ("on the way through Germany - of course"). ${ }^{164}$ Back in Paris in early June, he stayed at Rue de Prague near Place de la Bastille, and took up the connection with Henri Hubert at the Musée des antiquités nationales. Maintaining his role as facilitator and communicator between France and Sweden, he made plans with Nils Åberg to make and send replicas (moulages) of artefacts from the Musée des antiquités nationales to a museum in Uppsala, ${ }^{165}$ and communicated with the Director of the Musée des antiquités nationales, Salomon Reinach, about photographs (clichés) of bracteates he had made for his article in the Revue Archéologique. ${ }^{166} \mathrm{But}$ most of his time was devoted to completing his doctoral thesis: Le travail de l'or en Suède à l'époque mérovingienne: Études précédées d'un mémoire sur les solidi romains et byzantins trouvés en Suède, which he printed in France and published with Paul Pigelot $\&$ fils, because it was cheaper than in Swe-

161. Letters from O. Janse to H. Hubert 4 October 1920; 24 November 1920. Ibid.

162. Janse 1921.

163. Social-Demokraten, 4 May 1922: "En tilltalande teori av en svensk arkeolog"; Tidens Tegn, 8 May 1922: "Sigurd Favnesbane eller Attila? En ny hypotese om de gamle brakteater."

164. Letter from O. Janse to Nils Åberg, 3 June 1921. ATA: Nils Åbergs arkiv.

165. Ibid.

166. Letter from O. Janse to Solomon Reinach, 28 July 1921. Archive of MAN: General Correspondence/Janse. 
den. ${ }^{167}$ He defended it in Uppsala on 15 May 1922 with Birger Nerman as the Faculty Opponent. The thesis itself was a study of golden bracteates and similar pieces of jewellery from Scandinavia (mostly found on Öland and Gotland) in the Migration Period (Swe: folkvandringstid, AD 400-600), 259 pages long and written in French. Bracteates are coin-like pendants that appear to mimic Roman coins depicting the face, torso or full figure of a human, often assumed to be male, with text elements and other associated motifs. If previous studies had focused on the Norse characteristics of the bracteates (arguing they were depictions of Odin with his two ravens Hugin and Munin), Janse looked for broader comparative references and argued that the figure was Attila and the birds were falcons, according to the culture of the ancient Huns. ${ }^{168}$ Salomon Reinach, Director of the Musée des antiquités nationales, wrote in a short review that the composition of the book left much to be desired and therefore that it had been printed with unnecessary luxury, but that it nonetheless contained some very useful statistics and was overall a testament to a work of high quality. ${ }^{169}$ In Sweden, the thesis was well received with positive reviews in the newspapers, of which several were written by Janse's friends (for example Birger Nerman and Arthur Nordén). ${ }^{170}$

Janse's doctoral thesis is not, however, particularly well known among Swedish archaeologists of later generations. There are probably several reasons. One is Janse's choice to write in French (Swedish archaeology would have Swedish and German as working languages over the following decades), and another is the fact that Janse was about to leave Sweden for good, and therefore is not very well known in Swedish archaeology. But perhaps most importantly, the trend in Swedish archaeology was about to turn away from the broad comparative and international perspectives that had been advocated by Oscar Montelius and adopted by Olov Janse, towards an inward-focused and German-inspired perspective that would form a dominant discourse for decades to come. ${ }^{171}$

167. Letter from O. Janse to N. Åberg, 3 June 1921.

168. Janse 1922.

169. Reinach 1922.

170.E.g. Dagens Nyheter, 5 May 1922: (Sven Jansson), "Våra brakteater minnespenningar till Attilas ära"; Norrköpings Tidningar, 9 June 1922: (Arthur Nordén), "Ännu en Norrköpingsarkeolog"; Stockholms Dagblad, 19 March 1923: (Birger Nerman), "Ett arbete om Sveriges 'guldålder"'.

171. Works by prominent archaeologists such as Sune Lindkvist (1887-1976) and Birger Nerman are examples of the Scandinavian/German turn, a shift that would not 
The defence of his thesis, and the subsequent promotion to Doctor of Philosophy on 31 May 1922, also in some sense marked the end of Olov Janse's adolescence. Oscar Montelius had died in December the previous year, and Ture Nerman got married, to Nora Hedblom, in January 1922. ${ }^{172}$ Both Norrköping and Uppsala now belonged to his past. His future lay in Stockholm and - so he hoped - in Paris. In August he would be thirty years old.

Henri Hubert, who wanted to expand his comparative collections and nurtured a particular interest in Scandinavian cultural history, was keen to pursue exchanges of artefacts, or artefact replicas, between the Musée des antiquités nationales and the History Museum in Stockholm. Somewhat curiously, Hubert proposed an exchange involving Palaeolithic artefacts from the famous Piette collection, ${ }^{173}$ which was not allowed to leave the museum in Saint-Germain. Olov Janse acted as mediator, conveying Hubert's proposal to have original artefacts from the Piette collection sent to Stockholm in exchange for replicas of artefacts from the Swedish collection, to the Director of the History Museum in Stockholm. The proposal, which was made in June 1922, was accepted "with pleasure" by the Director - who also happened to be Olov's uncle Otto. Awaiting a formal decision by the Royal Swedish Academy of Letters, History and Antiquities (Vitterhetsakademien), Olov Janse wrote to Hubert that when he later returned to Paris he was hoping to bring to the Musée des antiquités nationales:

end until the 1950 s when Swedish archaeologists after the Second World War turned to the English language and to British archaeology as the main source of inspiration. Cf. Åkerlund 2010 .

172. Olov Janse wrote and sent Birger Nerman a poem on the occasion of Ture's wedding. In the Swedish original: “[...] Överraskande nyhet om Tures giftermål. Ett mariage coup de foudre? Framför till brudparet mina järligaste lyckönskningar men visa dem ej denna vanvördiga bröllopsvers (åtminstone ej för bruden). 'Bortgift Blev Bäddens Bärsärk, // Butnings Bötors Blide Betalare, // Brottslige Borgares Blodige Bane. // Bikte sig Birgers Bråttome Broder, //(Beständigt i Brynja och Brånad). // Blek Bleve Bruden!"” Letter from O. Janse to B. Nerman, 5 January 1922. Riksarkivet. Kartong 1. Korrespondens Brev I 1897-1922.

173. The Piette collection is a unique private collection, which was once incorporated into the Musée d'Archéologie nationale under the pretext that it must never be dispersed or removed from the museum. 
[...] casts, galvanized replicas, replicas in bronze and iron (the latter made by an art foundry in Stockholm), some cardboard reproductions of picture stones or rune stones, as well as some originals (pottery samples, axes, swords, etc.). Should you be interested, I could also perhaps bring a certain number of archaeological publications from the Academy of Letters, History and Antiquities ("Gravfältet vid Vendel", "Birka", "Kung Björns hög", "Die ältere Eisenzeit Gotlands", the "Fornvännen", etc., etc.). Here in Stockholm we would be very pleased to have, if possible, apart from objects from the Palaeolithic period, some pieces from other periods that would be of interest for comparative studies. I will send later a list of objects wanted by the Sthlm Museum. As for exchanges with the Museums in Copenhagen, Christiania [Oslo] and Bergen, I plan to have that arranged by the end of this month. ${ }^{174}$

After a brief excavation sojourn on Gotland and a visit to Norrköping in June and July, Olov Janse returned to Paris (without artefacts or publications, as far as we can see) at the end of the summer 1922. Once settled in Paris, he immediately began working with Henri Hubert at the Musée des antiquités nationales. The museum, the official French name of which was Musée des antiquités nationales à Saint-Germain-en-Laye, was founded in a grand château in Saint Germain, 13 kilometres west of Paris, by Napoleon III in 1862, and has ever since housed the official French archaeological collections. ${ }^{175}$

174. Letter from O. Janse to H. Hubert, 10 June 1922. Archive of MAN, Fonds Hubert/Correspondance dossiers/Dossier Janse. In the French original: “[...] des moulages, des galvanos, des copies en bronze et en fer (ces dernières faites par une fonderie d'art de Stockholm), quelques reproductions sur carton de pierres imagées ou runiques, ainsi que quelques authentiques (des spécimens de poterie, des haches, des épées, etc.). Si vous le croyez intéressant, je pourrais aussi peut-être apporter un certain nombre de publications archéologiques de l'Académie des Belles-lettres, etc. ('Gravfältet vid Vendel', 'Birka', 'Kung Björns hög', 'Die ältere Eisenzeit Gotlands', le 'Fornvännen', etc., etc.). Ici à Sthlm on serait très heureux d'avoir, si possible, outre des objets de l'époque paléolitique, quelques pièces d'autres époques et offrant un intérêt pour les études comparatives. Je vous transmetterai plus tard une liste des objets désirés par le Musée de Sthlm. Quant aux échanges avec les Musées de Copenhagen, de Christiania et de Bergen, je pense pouvoir arranger cette question à la fin de ce mois-ci."

175. Lorre 2015b. See also Lundbeck-Culot 1997 for a discussion of the museum's foundational relations to Scandinavia, through Napoleon III's relations with the Danish 
Janse worked mainly with the museum's comparative collections in the Salle de Mars. His presence was informal at first, but the affiliation was formalized as a one-year employment by the Ministre de l'Instruction Publique et des Beaux-Arts on 13 January $1923 .{ }^{176} \mathrm{~A}$ letter written by Henri Hubert to the Director of the Museum, Salomon Reinach, in December 1922, offers insights into why they wanted to have Janse attached to the museum. Henri Hubert begins his letter with a description of how his colleague at the Louvre, Monsieur Guiffrey, had managed to get a Dutchman to work as a temporary foreign attaché (attaché libre temporaire étranger) with a classification of Dutch drawings in the collections of the Louvre, by writing to the Minister. He continues:

[...] I propose that you do the same; I not only propose, but I demand that you do this for me. To hand we have Janse, who managed to annoy you last year with your proofs [?], but who, nonetheless, gave us a really interesting article, with a fine discovery. He is a serious boy, with all possible qualifications. He came to complete his education with me. I can think of no better than to begin again to sort out the Piette collection together with him. He has now worked with me three weeks, three days a week; it is a real pleasure to work with a boy of this kind; his meticulousness and sense of order is particularly valuable considering the diabolical mess that I have to sort out. On the one hand, I would like to be able to keep him, by offering some kind of honorary benefits in return for his services according to my instruction; together with him I may be able to sort out the nightmare of the Piette collection, and that would be no small thing. On the other hand I would like to not always be stuck to his heels; if we had him as foreign attaché on a temporary mission, he would be a key, he would have a certain responsibility, I would not be obligated to guide him, I could from time to time let him work alone; at the moment all the help he gives me should be reason for embarrassment. But think also of the moral effect of making a young Scandinavian with good connections, good reputation, who has been temporarily affiliated with the museum in Stockholm, who

king Frederik VII.

176. Letter from O. Janse to H. Hubert, 2 February 1927. Archive of MAN: Fonds Hubert/Correspondance non classé. 


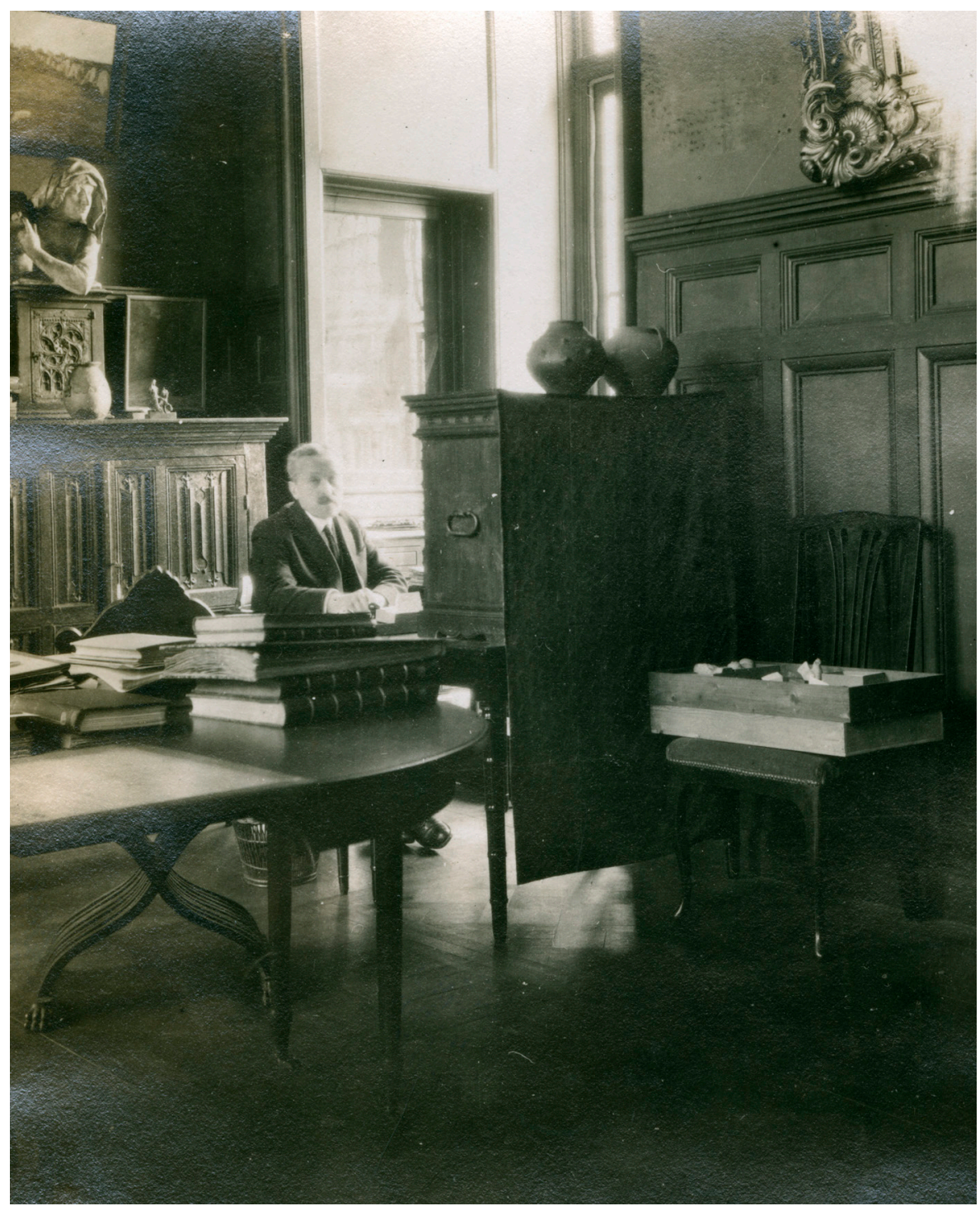

Fig. 16. Henri Hubert in his office at the Musée des antiquités nationales. Photo by Johannes Bøe.

may one day become curator there, come to do a period of work with us. I believe that would have a very good effect. Consider also that I am in great need of help; I have been able to start breathing only after I was offered Meunier, the brave soldier, as secretary; that has given me four arms; my affairs look a little better since I remitted Pépin to do the numbering; I don't dare say that they would be entirely fine if I had an attaché, because we have a horrible past, but they start to get close to being fine. 
Would you like it if I took, with your approval, the necessary actions towards the administration? We could perhaps give Janse the mission to classify our Scandinavian collections. Last but not least there is a precedent in Guiffrey's Dutchman, and Guiffrey is certainly not in as much need of help as I am. ${ }^{177}$

The letter contains several important pieces of information that could not be found in official accounts. One is that Henri Hubert found himself in desperate need of help at the Musée des antiquités nationales; understaffed, with a difficult financial situation, and with "a diabolical mess" to sort out in "the nightmare of the Piette collection". ${ }^{178}$ Another is that Janse had a reputation of being well connected and well regarded, and

177. Letter from H. Hubert to Salomon Reinach, 14 December 1922. Archive of MAN/ Correspondance/Hubert_à_Reinach. In the French original: “Je vous propose d'en faire autant; non seulement je vous le propose, mais je vous le demande pour moi. Nous avons sous la main Janse, qui a pu vous agacer l'année dernière avec vos épreuves, mais qui, tout de même, vous a fait un article bien intéressant, avec une jolie découverte. C'est un garçon sérieux, avec tous les titres possibles. Il vient compléter son éducation auprès de moi. Je n'ai rien trouvé de mieux que de me remettre avec lui au triage de la collection Piette. Voilà trois semaines qu'il travaille avec moi trois jours par semaine; c'est un véritable plaisir de travailler avec un garçon de cette espèce; ses qualités de minutie et d'ordre sont mises en valeur par l'infernal désordre que j'ai à débrouiller. D'une part, je voudrais pouvoir le retenir, lui imposer une espèce d'obligation en échange de l'instruction que je lui donne, en lui donnant une espèce d'avantage honorifique; avec lui j'arriverai peut-être à sortir de ce cauchemar de la collection Piette et ce ne serait pas peu de chose. D'autre part, je voudrais pouvoir ne pas être toujours attaché à ses talons; si nous l'avions comme attaché étranger en mission temporaire, il aurait une clef, il aurait une certaine responsabilité, je ne serai pas obligé de le conduire, je pourrais de temps à autre le laisser travailler seul; en ce moment l'aide qu'il me donne a une contre partie de gêne. Mais songez aussi à l'effet moral du fait qu'un jeune scandinave bien apparenté, bien vu, qui a été attaché temporaire au musée de Stockholm, qui y sera quelque jour conservateur adjoint, vienne faire un stage chez nous. Je crois que cela ferait un très bon effet. Songez aussi que j'ai bien besoin d'aide; j'ai commencé à respirer quand on m'a donné ce brave gendarme de Meunier comme secrétaire; cela m'a fait quatre bras; mes affaires vont un peu mieux depuis que j'ai remis Pépin au numérotage; je n'ose pas dire qu'elles iraient tout à fait bien si j'avais un attaché, car nous avons un arriéré effrayant, mais elles commenceraient à s'approcher du bien. Voulez-vous que je fasse, avec votre approbation, les démarches nécessaires à l'administration? Nous pourrions faire donner à Janse la mission de classer nos collections scandinaves. Enfin il y a le précédent du Hollandais de Guiffrey, qui n'a certes pas autant besoin d'aide que moi".

178. Cf. Reinach's description of Hubert as someone who "Took on too much at the same time and moved from one set to the next before having finished the first work 
that Hubert thought that he did his museum work meticulously with an outstanding sense of order. Hubert was interested in developing the typological method and must have seen Janse's training from Scandinavian archaeology (hence the reference to "meticulousness and sense of order") as a real asset. ${ }^{179} \mathrm{~A}$ third important piece of information is that Janse had somehow managed to annoy Reinach, the Director, in connection with the article that he published in Revue archéologique earlier the same year. ${ }^{180}$ Salomon Reinach was the official Director of the museum, but he was not present in the everyday museum work nearly as much as Henri Hubert. As a member of the Académie des Inscriptions et Belles Lettres and editor of Revue archéologique he had duties elsewhere. Moreover he suffered from poor health, which also affected his presence at the museum. But he was a man of power and influence, at the museum and in French academic life. Reinach overcame, it seems, his initial irritation vis-à-vis Janse, and they had a good professional relationship for several years until they ended up in severe controversy, which forever ended the good spirit between them. We shall return to that controversy shortly.

Janse's formal affiliation with the Musée des antiquités nationales in January $1923^{181}$ was noticed widely in the Swedish press, with Janse being described as the first foreign person ever to be officially attached to a French museum. ${ }^{182}$ This marks the beginning of a period of great intensity in his life and career. His first, temporary, one-year position at the museum was renewed several times. ${ }^{183}$ Between 1923 and 1927 he was constantly on the move between France and Sweden, and appears to have been standing more and more securely with one foot in Stockholm and one in Paris.

(Fre: Entreprit trop à la fois et passât d'une série à l'autre avant d'avoir ermine le premier travail)" (Salomon Reinach 1927, quoted in Olivier 2018:13.

179. Laurent Olivier has written about Hubert's development of a "technotypological method" as avantgarde, but without any reference to Scandinavian inspirations or connections (2018:142-144).

180. Letter from O. Janse to S. Reinach, 5 June 1921. Archive of MAN.

181. Document addressed to Salmon Reinach from Le Directeur des Musées Nationaux et de l'École du Louvre, 17 January 1923. Archive of MAN.

182.E.g. notices in Svenska Dagbladet, Dagens Nyheter, and Stockholms Dagblad, 22 February 1922 .

183. Letter from Salomon Reinach to the Ministry of Foreign Affairs, 1924 (n.d.). Archive of MAN. 
In Paris, his relationship with Henri Hubert deepened through their work together at the museum. Janse's official assignment was to organize a collection of Scandinavian artefacts that were the very first to have entered the inventory of the museum, as a gift from the Danish King Frederik VII to Napoleon III in the 1860 s. ${ }^{184} \mathrm{He}$ organized the artefacts according to Montelian typology, which was also in line with Hubert's preferences, and filled the gaps in the typological series with cast replicas (moulages) made by conservators at the History Museum in Stockholm. ${ }^{185}$ In an article in the Swedish newspaper Aftonbladet from the summer 1923, it is reported that, to date, Janse had commissioned between four and five hundred casts to complete the Scandinavian collections in the Salle de Mars:

Together, the originals and cast replicas will render a complete view of prehistoric Sweden, which obviously is a great asset for all students and researchers who visit the museum to acquire knowledge about our prehistory. ${ }^{186}$

In focus for Janse's work with Hubert at the Musée des antiquités nationales were the Scandinavian parts of the museum's comparative collections on display in the Salle de Mars. However, Janse's knowledge of Scandinavian languages and culture, and not least the prospect of having an in-house mediator to facilitate exchanges and communication with Scandinavian museums and Academies, undoubtedly contributed to Hubert's eagerness to have him attached to the museum. Indeed, the Swedish press reports of Janse's affiliation in spring 1923 also emphasized his role as mediator between academics and institutions in France and Scandinavia. ${ }^{187}$

An important part of the communication between museums at this time was the exchange of artefacts, or cast replicas of artefacts, to complete

184. Janse 1959:16-17. See also Lundbeck-Culot 1997.

185. According to Aftonbladet, 1 August 1923: "Svensk forskning i S:t Germain", it was the museum's conservators E. Sörling and Mr Schultz, who were assigned to make the cast replicas.

186. Aftonbladet, 1 August 1923: "Svensk forskning i S:t Germain". In the Swedish original: "Tillsammans komma originalen och avgjutningarna att lämna en fullständig bild av det forntida Sverige, vilket givetvis är till stor fördel för alla studerande och vetenskapsmän, som besöka museet i syfte att inhämta kunskap om vår förhistoria.”

187. E.g. notices in Svenska Dagbladet, Dagens Nyheter, and Stockholms Dagblad, 22 February 1922. NAA: Janse 2001-29. 
typological series. ${ }^{188}$ Having one's own collection of complete typological series from different cultural contexts served the purposes of comparative analyses, so archaeologists with an interest in broad international comparative studies, like Hubert and Janse, had a particular interest in this form of exchange. During the four years that they worked together at the museum in Saint Germain, they pursued a number of artefact exchanges with the History Museum in Stockholm. In April 1923 a decision was made by the Swedish government (Swe: K. M:t) to have a number of artefacts in the collections of the Swedish History Museum released from state ownership to be sent to the Musée des antiquités nationales. In return for the artefacts, which belonged to the older collections of the museum and therefore lacked inventory numbers as well as details of their provenance, the Musée des antiquités nationales would send a number of objects, books, and leaflets of archaeological interest, says a newspaper article. ${ }^{189}$ The article does not mention any names, but Janse and Hubert were no doubt the motors of the exchange project, which complemented the parallel exchanges of cast replicas.

And their exchange ambitions stretched further, beyond the FrenchSwedish connection. Janse discussed (but never pursued, as far as we know) exchanges with museums in Norway and Denmark, and when Birger Nerman moved to Estonia in 1923 to become professor in Dorpat (now Tartu), they immediately started to plan for artefact exchanges, which were realized later the same year. ${ }^{190}$

Over the following years, the shipments of artefacts from Paris to Stockholm continued. In April 1924 came a Roman terra sigillata bowl along with a collection of ostraca found at the famous site of Lésoux, ${ }^{191}$ and in July 1925 came a collection of Scandinavian-style Viking Age weapons that had emerged from the dredging of a tributary of the Seine. The weapons were donated to the Swedish History Museum by a French industrialist and amateur archaeologist named Henry Koechlin, and

188. See Proust $2017 \mathrm{a}$ and $2017 \mathrm{~b}$ for a discussion of the importance of replicas in French archaeology, and the practice of manufacturing moulages at the Musée d'antiquités nationales.

189.Dagens Nyheter, 2 August 1923: "Utbyte av föremål mellan Statens historiska museum och franskt museum".

190. Letter from O. Janse to B. Nerman, 6 November 1923. Riksarkivet. Kartong 1. Korrespondens Brev II 1923-1934.

191. Svenska Dagbladet, 20 March 1924: "Årets fornfynd i Statens historiska museum." 
Fig. 17. The Piette Collection at the Musée d'archéologie nationale in SaintGermain-enLaye.

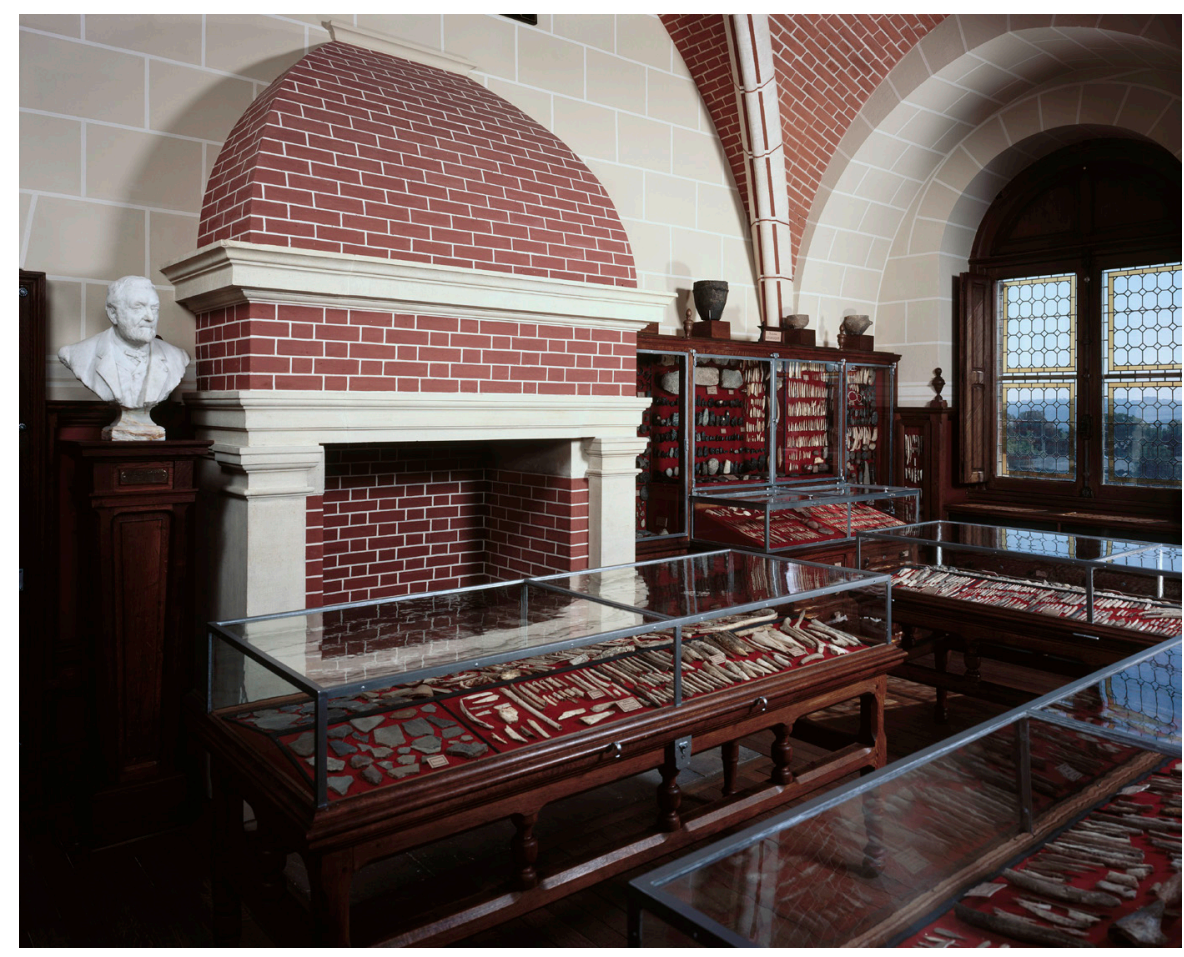

brought to Stockholm by Olov Janse. ${ }^{192}$ At the same time, in the summer of 1926 , there also came a number of objects from ongoing excavations of a Palaeolithic site at La Quina in Charente. The excavations were led by the French archaeologist and palaeontologist Léon Henri-Martin, and Janse had already visited the site in $1923 .{ }^{193}$ The objects that came to Sweden in 1926 were, however, brought to the museum in Stockholm by Janse's colleague Ture Arne, who had participated in the excavations together with the Swedish botanist John af Klercker. ${ }^{194}$

The most important was, however, Hubert's and Janse's last and final transfer of objects from Paris to Stockholm, which was executed by Janse in September 1927. A collection of Palaeolithic objects from the famous Piette collection, which Henri Hubert had described as "a nightmare" in his letter to Reinach, and which he had mentioned in his very first

192. Nya Dagl. Allehanda, 20 July 1925: "Nordiska vikingars vapen uppmuddrade ur Seinen, nu i svenska statens ägo.”

193. Letter from H. Hubert to Léon Henri-Martin, 6 August 1923. Archive of MAN, Fonds Hubert/Correspondance non classé.

194. Nya Dagl. Allehanda, 20 July 1925. 
exchange proposal to the Swedish Academy in 1922, were now sent to the museum in Sweden. ${ }^{195}$ The Piette collection was, and is, however, a very special part of the collections of the Musée des antiquités nationales (now Musée d'archéologie nationale). It consists of the entire private collection of the famous palaeontologist and archaeologist Édouard Piette (1827-1906), and was donated to the museum in 1904 under the strict condition that it would always be kept intact and never dispersed. ${ }^{196} \mathrm{Judg}-$ ing from Janse's letter from June 1922 (above), it was a priority for the Swedish museum to obtain Palaeolithic objects. This is not surprising considering the prominence of France and French sites in Palaeolithic archaeology, and the fact that the land that is now Sweden was covered by ice during much of the Palaeolithic period, hence Palaeolithic artefacts found in Sweden are sparse. However, it remains obscure why Henri Hubert agreed to exchange original objects and not replicas, and how he managed to sidestep the important conditions of Piette's testament, to have objects from that particular collection sent to Stockholm. ${ }^{197}$

While Janse strengthened his relation to Henri Hubert and built a more solid foundation for his presence in Paris, the situation in Stockholm was more fragile. After Montelius's death in 1921, the triangular relation of power and authority between the Swedish History Museum, the National Board of Antiquities, and Vitterhetsakademien (the Royal Swedish Academy of Letters, History and Antiquities) was destabilized. Bernhard Salin had been appointed Director of the National Board of Antiquities after Montelius retired in 1913, but resigned only two years later, unable to fulfil his obligations. Otto Janse stepped in as Acting Director of the National Board of Antiquities and Secretary of Vitterhetsakademien from 1918 to 1923 , at the same time as he was the curator in charge of the medieval collections at the History Museum.

Having his uncle at these key positions ought to have helped to open important doors for Olov Janse in the early years of his career, and to stabilize his position in Sweden. We have seen, for example, how he pur-

195.Dagens Nyheter, 28 September 1927: (Sven Jansson), “Då kubisterna ännu härjade med ensamrätt: Vacker föremålssamling från fransk stenålder."

196. Schwab 2008.

197. At an inventory in the Musée d'archéologie nationale around 2010 , it was discovered that the above-mentioned objects from the Piette collection had been removed (on the initiative of Henri Hubert and Olov Janse) and were located in Stockholm. The objects have since then been returned and have been back in the Piette collection since October 2012. 


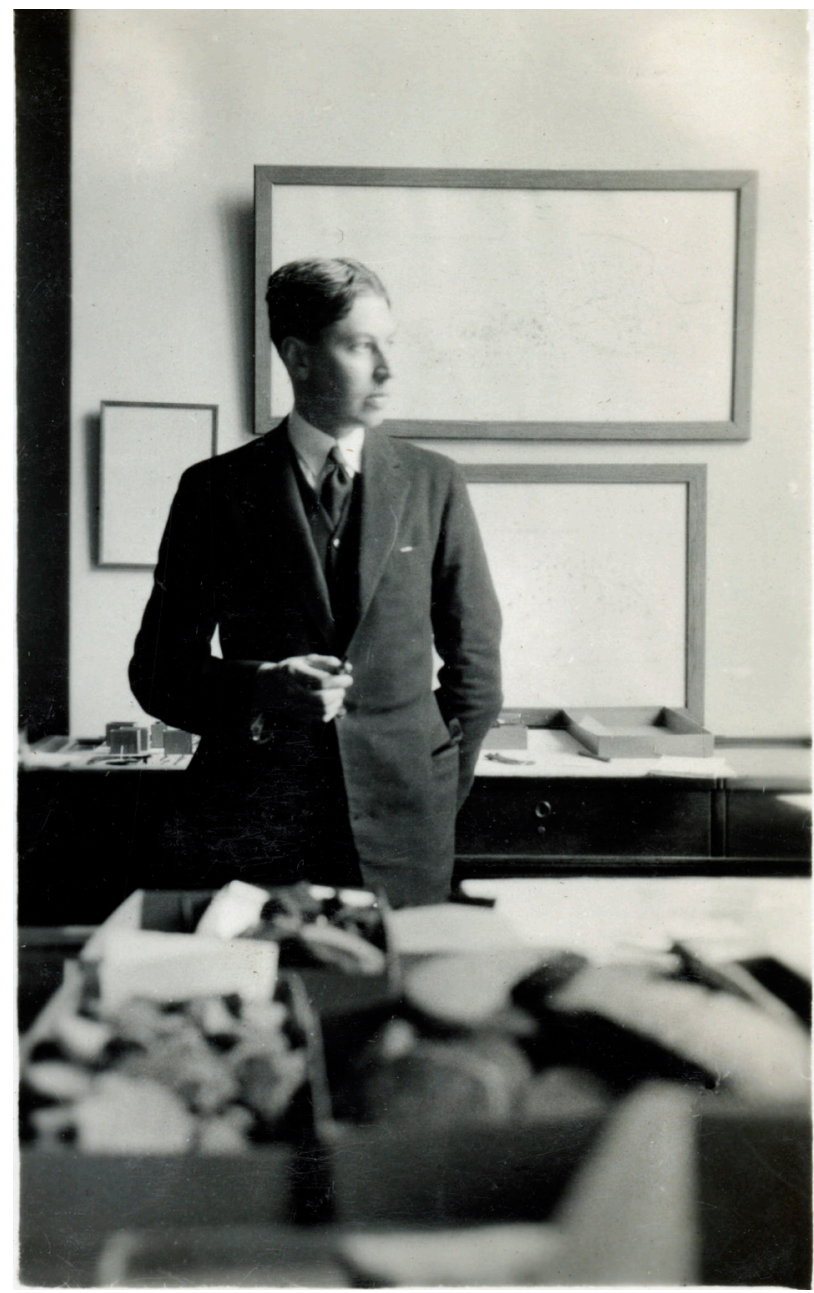

sued excavations under the auspices of Vitterhetsakademien during his summer breaks. In 1923, however, Otto Janse was replaced by the charismatic and dynamic Sigurd Curman (1879-1966), who became Director of the History Museum and Director of the National Board of Antiquities (Swe: Riksantikvarie) and would make dramatic changes in both institutions over the following years. This meant that Olov Janse had lost some of his secure base in Sweden during the summer breaks, and he spent the summer of 1923 travelling around France, visiting excavation sites like La Quina. Birger Nerman, who had recently taken up his position in Estonia, came to visit and they discussed artefact exchanges between Dorpat and the Musée des antiquités nationales.

Over the following years, Janse established a good relationship with Sigurd Curman, although it was never close or cordial as with Henri Hubert. In the summer of

Fig. 18. Olov Janse in the Swedish History Museum 1926, with the new cardboard boxes in the foreground. 1924 he returned to Sweden for summer employment (Swe: sommartjänstgöring) at the History Museum, and excavated an Iron Age burial site on Gotland. ${ }^{198}$ When he returned to Stockholm the following summer he was put to work at the museum. In July 1925 he writes to Henri Hubert that he is busy organizing the osteological collections of the History Museum, which "have until now been deposited without order in the basement". He mentions that the comparative collections had been summarily classified, apart from the Chinese objects, which would be

198. Janse 1924a. 
personally handled by Johan Gunnar Andersson. ${ }^{199}$ Sigurd Curman had serious plans for the museum, which was still located on the ground floor of Nationalmuseum at Blasieholmen, where it had been founded and built in $1866 .{ }^{200}$ When Curman took over as director, there was chaos behind the scenes. The storerooms were bursting at the seams and there was no efficient system for storage of the artefacts and materials that were not on display. To sort out the mess, Curman almost doubled the number of employees, from 20 to 36 over his first five years on the post. In addition to these, a number of people (Axel Bagge, Birger Nerman, Hanna Rydh, Nils Åberg, and Olov Janse, to mention a few) worked on temporary assignments funded by Vitterhetsakademien. ${ }^{201}$

Olov Janse was employed on such a temporary assignment in the summer of 1925 , together with a colleague two years his junior, Axel Bagge (1894-1953). Their task was to come up with a new system to organize the storage. After only a brief overview, they were able to confirm that there was no existing comprehensive system; the collection had been registered according to several different systems, and artefacts and materials were stored randomly all over the storerooms. Bagge and Janse suggested that the objects should instead be placed in cardboard boxes, which would in turn be placed in accessible wooden drawers. The objects should be ordered according to the accession numbers they were given as they entered the collection, and two card indexes should be set up; one for objects, and one for topography. With this system, the objects could be stored in a fixed place, and new objects could be added without any need for reorganization. To find a certain object, one could find clear directions to its storage place in the card indexes. With the new system, anyone would have access to the objects in the collection and it was no longer dependent on the museum staff's personal knowledge of the storeroom. Their ideas were realized, and by 1926 chaos had been turned into order in the stores of the Swedish History Museum. ${ }^{202}$

199. Letter from O. Janse to H. Hubert, 26 July 1925. Archive of MAN: General correspondence/Janse.

200. The Swedish History Museum was separated from Nationalmuseum (which then became devoted entirely to historic art and design) and moved to its present location on Narvavägen in 1939.

201. Nordström 2015:58.

202. Nordström 2015:61. Still today Janse's and Bagge's wooden drawers containing cardboard boxes can be seen in the stores at the Swedish History Museum. See more in the chapter "Memorabilia". 
Encouraged by Henri Hubert, Janse spent quite a lot of time in Sweden between 1925 and 1926. A letter to Salomon Reinach in August 1923 shows that Hubert saw Janse's work at the Stockholm museum as beneficial for Janse's own career and thereby in the long run also for the Musée des antiquités nationales. ${ }^{203}$ In addition to his work with Bagge in the museum stores, Janse pursued contract excavations in the summer of 1925, at the site of Rekane between Eskilstuna and Kvicksund, under the auspices of the History Museum. ${ }^{204}$

But there were changes on the way in Swedish archaeology. In Uppsala, Oscar Almgren had become weaker and was steadily losing his sight, until he was entirely blind and had to retire from his position in $1925 .{ }^{205}$ He was succeeded in 1927 by Sune Lindqvist (1887-1976), who held the professorial chair until 1952. Sune Lindqvist had started his career at the Swedish History Museum in 1910, and when Sigurd Curman, as a part of his great reformation project, set about modernizing the displays in 1926-1928, he appointed Lindqvist to manage the work. ${ }^{206}$ Sune Lindqvist belonged to a new generation of Swedish archaeologists who were not so keen on the typological method with its broad comparative analyses that had been advocated by Montelius and Almgren. Instead, he was focused on writing the prehistory of the Swedish nation state, from a more limited and German-related perspective. This focus suited the dominant nation-focused politics in Swedish society at large at the time, and it fitted well with Sigurd Curman's ambition to be aligned with the political formation of a new, modern Swedish nation based on the concept of folkhemmet. ${ }^{207}$ During the 1930 s and ' 40 s this new generation, with Lindqvist in the forefront, would come to dominate the research milieu in the archaeology department at Uppsala University and the Swedish History Museum, with a patriotic focus on the prehistory of the Swedish nation..$^{208}$

In addition to the new nation-bound and Germany-related focus, which was quite contrary to Olov Janse's Francophile cosmopolitan movements and broad comparative analyses (remember his claim that

203. Letter from H. Hubert to S. Reinach, 6 August 1923. Archive of MAN. Correspondance/Hubert à Reinach.

204. Sörmlandsposten, 12 August 1925: "Gravfältet i Rekarne undersökes idag"; Sörmlandsposten, 24 August 1925: "Vikingagravarna i Rekarne nu undersökta."

205. Nerman 1945.

206. Nordström 2015:61.

207. Bergström \& Edman 2005.

208. Nordström 2015:60. See also Berggren 1999; Werbart 2000. 
the figure depicted on the bracteates was Attila, not Odin), was the fact that Sune Lindqvist did not like Janse at all. Already in 1924, Janse had written from Paris to Birger Nerman to ask if he could investigate why he had never got any response to an article proposal that he had submitted a long time ago for the journal Fornvännen, and suggested it may be owing to the fact that Lindqvist's works had not been referenced. ${ }^{209}$ And, indeed, Lindqvist's aversion to Janse is confirmed by a letter to Sigurd Curman in 1932, where he furiously attacks Janse for being incompetent and not referring to Lindqvist's own publications. ${ }^{210}$ Ergo, despite his international qualifications, his language skills, and his reputation as a person with an excellent sense of order and a meticulous attitude to museum work, his antipathetic relations with Lindqvist made it increasingly difficult for Janse to find a secure position in Swedish archaeology.

Moreover, the aversion was mutual. In Paris, where he spent most of his time between 1923 and 1927, Janse took a clear stance against the nationalistic Germany-oriented tendencies advocated by Sune Lindqvist among others. Like Henri Hubert he maintained a view in which French republican society rested on a historical foundation of many races which had together formed the nation (rather than the German conception of the nation as based on one pure race) represented the highest form of civilization. ${ }^{211}$ He surrounded himself with Scandinavian archaeologists who, like himself, had an internationalist and cosmopolitan rather than a nationalistic approach. In his closest network were Ture Arne (1879-1965), Nils Åberg (1888-1957), ${ }^{212}$ Johannes Bøe (1891-1971), Haakon Shetelig

209. Letter from O. Janse to B. Nerman, 14 December 1924. Riksarkivet. Kartong 1. Korrespondens Brev II 1923-1934. See also letter dated 6 June 1928.

210. Letter from Sune Lindqvist to Sigurd Curman, 26 July 1932. Gustavianums arkiv. Korrespondens med svenskar F8 D:10.

211. See for instance an interview with Janse in Dagens Nyheter, 3 September 1926: "Svensk arkeolog lär fransmän vår fornkunskap". See also Saada 2002; Conklin 2013: chapter 2.

212. See Baudou 2002 for a discussion of the relations between Nils Åberg, Sune Lindqvist, Oscar Montelius, and Gustaf Kossinna. Kossinna (who is often associated with laying the foundation for the use of archaeology by Nazist ideologists) was strongly influenced by Montelius when he developed his "settlement archaeology", but they were in disagreement as to where the origins of the cultures of Germany and Sweden were to be found. Åberg, who was perhaps the Swedish archaeologist who most strongly promoted Montelius's typological method after his death (e.g. Åberg 1929), and who also pursued international artefact studies much like Janse, was also closely associated with Kossinna. This demonstrates that it was not the question of clear-cut categories of nationalistic 


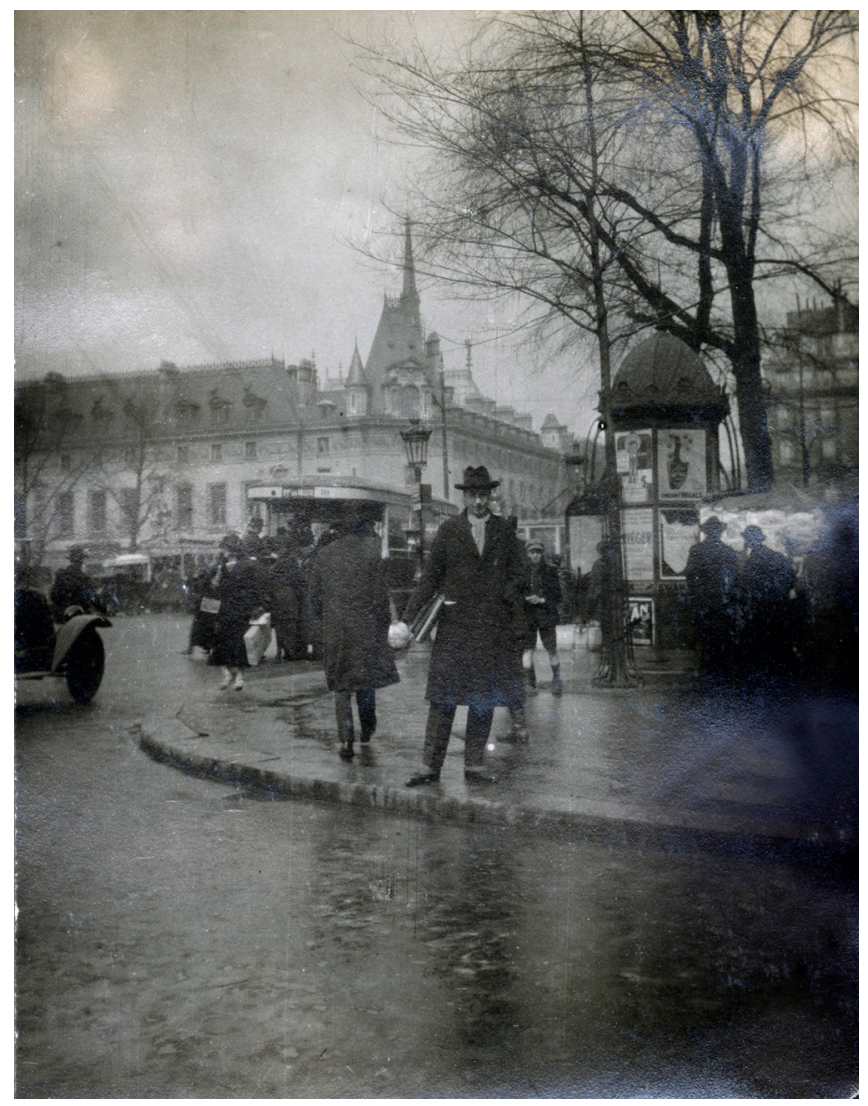

(1877-1955), Hanna Rydh (1891-1964), and Bror Schnittger (1882-1942). He encouraged them to plan visits to Paris, and facilitated connections with museums and academic institutions for exchanges and lectures. ${ }^{213}$ Johannes Bøe spent five months with Janse at the Musée des antiquités nationales in 1923-1924. With Birger Nerman, Hanna Rydh, and Bror Schnittger he even made plans for a French-Scandinavian archaeological society, ${ }^{214}$ but the plans were never realized. In this context, however, his relation with Birger Nerman became more complicated. If Nerman had at first been keen on the French connections, at this point he began to shift focus and became more interested in the nationalistic Germany-in-

Fig. 19. Olov Janse in Paris 1925. Photographer: Johannes Bøe.

spired approach advocated by Sune Lindqvist. In a letter from January 1924, Janse warns him about getting too close to the German archaeologist Gustaf Kossinna: ${ }^{215}$

archaeologists who were sympathetic to Germany (and later Nazism) vs internationalist archaeologists who were anti-Germany (and later Nazism) in Sweden in the 1920 s and '3os, but a more complex mix of personal relations, methodological preferences, and political sentiments (e.g. Werbart 2000).

213. These persons are mentioned frequently in correspondence with B. Nerman, found in Riksarkivet (Kartong 1. Korrespondens Brev II 1923-1934) and in correspondence with H. Hubert. Archive of MAN: General correspondence/Janse.

214. E.g. letter from O. Janse to B. Nerman, 14 January 1924. Riksarkivet. Kartong 1. Korrespondens Brev II 1923-1934.

215. Kossinna died in 1931, but his work was foundational for Nazi ideology (e.g. Arnold 2006:11, Baudou 2002). 
P.S. In the article about Germanic emigration when you talk about Kossinna, avoid saying "have the honour of, is rewarded with", etc. To be correct to him will suffice! Anything above that can only do harm. He has acted towards his colleagues both in France and in Germany in a way that is incompatible with good manners and normal tact. Even before the war he resorted to the most grotesque vulgarities against France. All (undeserved) politeness vis-à-vis K., could be read as some kind of sympathy for Kossinna's political excesses. Be therefore on your guard, because you may harm yourself. ${ }^{216}$

Birger Nerman would later, during the 1930 s and '40s, become more and more aligned with Sune Lindqvist's nation-bound focus on prehistory. ${ }^{217}$ Their differences of opinion on this matter, however, seemed not to have had any major damaging effects on the life-long friendship between Nerman and Janse.

From his position with one foot in Sweden and one in Paris, Janse worked as a promoter - for French scholars and institutions in Sweden, and for Swedish scholars and institutions in France. Henri Hubert became a foreign corresponding member of Vitterhetsakademien in 1922, and in 1927 Janse was involved in organizing a lecture tour for Léon HenriMartin in Stockholm, with the Crown Prince and Princess attending the first lecture on 12 May. ${ }^{218}$ In France, he made démarches to have Birger Nerman elected as member of the Société Préhistorique française in 1926, and introduced Nerman to both Hubert and Reinach when he came to visit Paris. He reviewed his friends' works in French journals, beginning with a review of Birger Nerman's work in Revue des Études anciennes in

216. Letter from O. Janse to B. Nerman, 14 January 1924. Riksarkivet. Kartong 1. Korrespondens Brev II 1923-1934. In the Swedish original: "P.S. Undvik i artikeln om Germanska utvandringar att på tal om Kossinna säga 'har äran av, tillkommer förtjänsten' 1. dyl. Det räcker att vara correct mot honom! Vad därutöver är, är av ondo. Han har uppträtt mot sina collegor både i Frankrike o. Tyskland på ett sätt som är oförenligt med god hyfs o. vanlig takt. Mot Frankrike har han även före kriget farit ut i de mest groteska klumpigheter. All (oförtjänt) artighet mot K., kan bli uppfattad som något slags sympatiyttring för Kossinnas politiska förlöpningar[?]. Var därför på din vakt, ty du kan skada dig själv."

217. Nordström $2015: 60$.

218. Letter from O. Janse to B. Nerman, 27 April 1927. Riksarkivet. Kartong 1. Korrespondens Brev II 1923-1934. 


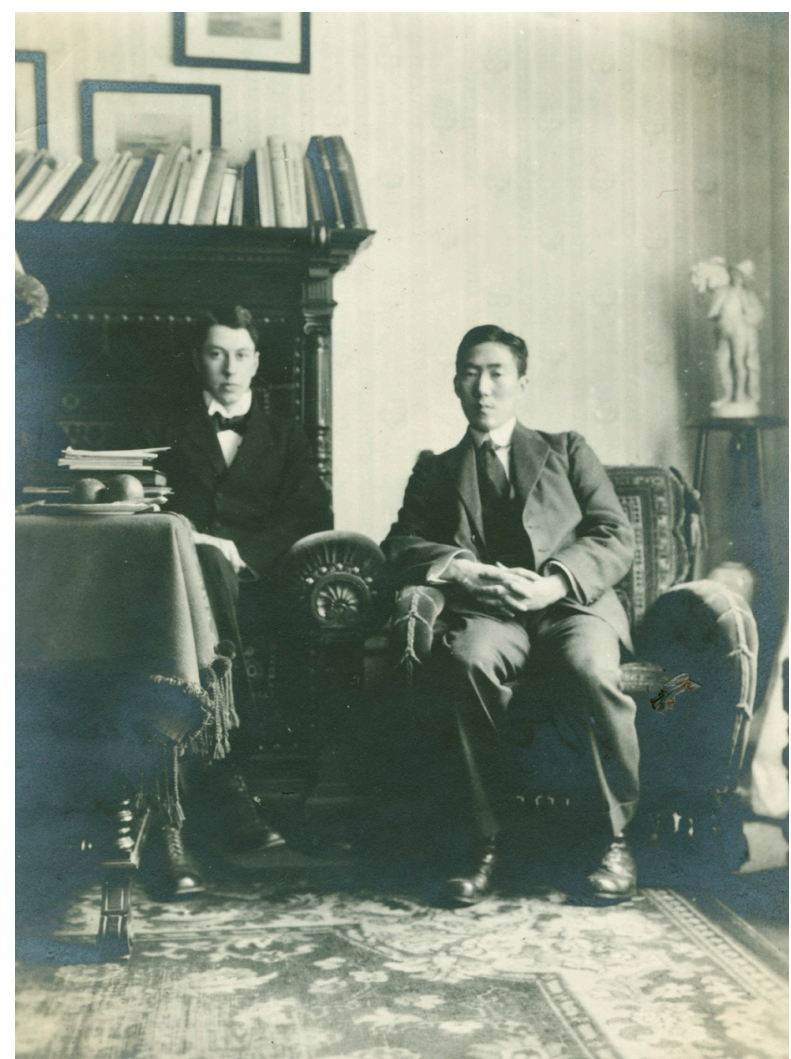

$1924,{ }^{219}$ and continuing through the early 1930s. When the Japanese archaeologist Sueji Umehara visited Paris in December 1926, he spent time with Janse at the Musée des antiquités nationales. Janse encouraged him to travel to Sweden, and made sure he was well looked after by Birger Nerman. ${ }^{220}$ Both Nerman and Janse eventually became good friends with Umehara, who made several visits to Stockholm.

In Paris, Janse also made a name for himself as a facilitator and guide for visiting Swedes from a much wider circle than his closest associates. In December 1926 he accompanied Sigurd Curman to the Musée des antiquités nationales, where he met Henri Hubert and studied museum technology. He even arranged accommodation for Curman's daughter Brita when she visit-

Fig. 20. Olov Janse and Sueji Umehara in Paris 1926.

ed Paris in 1926. He was also active at the Scandinavian Institute at the Sorbonne, where he met and entertained acclaimed invited lecturers such as Andreas Lindblom and Marika Stiernstedt, and was keen to be noticed by members of the press. ${ }^{221} \mathrm{~A}$ Swedish newspaper article with the headline "Between Montmartre and Montparnasse" features Janse's work and endeavours in Paris. ${ }^{222}$ The 1920 s are known as les années folles - the crazy years in the entertainment quarters of Montmartre, and intellectual life was thriving in the cafés of Montparnasse. Janse's personal letters to Ture and Birger Nerman abound with allusions to theatres, cabarets, and more

219. Janse 1924b.

220. Letters from O. Janse to B. Nerman, 31 December 1926; 15 February 1927. Riksarkivet. Kartong 1. Korrespondens Brev II 1923-1934.

221.E.g. Stockholms Dagblad, 22 March 1927, Kjell Strömberg: "Mellan Montmartre och Montparnasse."

222. Ibid. 
or less unattainable women in and around the Parisian nightlife. ${ }^{223}$ In another newspaper article, the author Widar concludes: "A better, more knowledgeable, and more sympathetic cicerone one could not wish for." ${ }^{224}$

His time in Paris gave him great joy and intellectual inspiration, but his life was also rather lonely. In March 1926 he writes to Birger Nerman that he has just acquired a radio, which is "great company". ${ }^{25}$ And in yet another newspaper article he is described as a "Swedish-French museum man". ${ }^{26}$ His identity was now that hyphen, literally in the space between Sweden and France.

Along with the work that they did together in the collections of the Musée des antiquités nationales, Hubert soon began to involve Janse in his university teaching. In early January 1923, even before his museum affiliation was formalized, Hubert had offered Janse to give a series of lectures in Nordic and comparative history of religion for the EPHE at the Sorbonne. ${ }^{227}$ It took some time, however, before these plans were realized, and Janse's first lecture at the Sorbonne on 6 December 1924 was instead in a series of public lectures organized by the Institut d'Études Scandinaves and hosted by the founder of the Institute, Professor Paul Verrier.

The subject of Janse's first lecture was Scandinavian Bronze Age rock carvings, and it was given on Saturday at 5 p.m. in Amphithéâtre Descartes, one of the large lecture halls at the university. According to Swedish press reports and Janse's own letters to Birger Nerman, it was a great success. $^{228}$ In the audience, with over 200 people, were the Swedish minister Albert Ehrensvärd, a number of notable members of French academ-

223.E.g. letters from O. Janse to T. Nerman, 20 December 1925; 19 January 1926; 27 March 1926. Arbetarrörelsens arkiv och bibliotek. Ture Nerman 3.1.7. and to B. Nerman, 7 January 1926. Riksarkivet. Kartong 2. Korrespondens Brev II 1923-1934.

224. Dagens Nyheter, 22 January 1926: "En svensk vetenskapsman i Paris." In Swedish: "Bättre, sakkunnigare och trevligare ciceron kan man inte önska sig."

225. Letter from O. Janse to B. Nerman, 12 March 1926. Riksarkivet. Kartong 1. Korrespondens Brev II 1923-1934.

226. Norrköpings Tidningar, 23 January 1926: "Norrköpingsbo vik. fransk professor: D:r Olof Janse som svensk-fransk museiman."

227. Letter from O. Janse to B. Nerman. 6 January 1923. Riksarkivet. Kartong 1. Korrespondens Brev II 1923-1934.

228. Aftonbladet, 15 December 1924: (Harald Wägner), "Dr O. Janse föreläser i Paris: Intressanta föredrag om hällristningar i Skandinavien."; Letters from O. Janse to B. 
Fig. 21.

Flyer for

Olov Janse's

first public

lecture at the

Sorbonne in

1924.

\section{UNIVERSITÉ DE PARIS}

INSTITUT D'ÉTUDES SCANDINAVES

CONFÉRENCES PUBLIQUES

Ce que nous apprennent

les gravures sur rochers des pays scandinaves

(Avec projections)

par M. OLAV JANSE

Docteur ès lettres, attaché au musée de Saint-Germain

Les 6 et 13 Décembre 1924, à 17 heures

à la SORBONNE, Amphithéâtre Descartes

ia, and representatives from the Scandinavian embassies in Paris. In his introduction, the host Paul Verrier had emphasized the importance of political and cultural contacts between France and Scandinavia through history. In the lecture, which was illustrated by "excellent diapositives", Janse referred to the research of his old teacher Oscar Almgren, and drew attention to similarities between the Scandinavian rock carvings and prehistoric finds in other parts of the world. The icing on an already delicious cake was Janse's flawless French, which was noted by a professor of French literature in the audience. ${ }^{229}$ The lecture was followed by second one, on the same subject and in the same venue, on the following Saturday.

Soon thereafter, in early 1925 , Janse was invited to step in for Henri Hubert and lecture in his undergraduate courses on Germanic prehistory, at both the EPHE and the École du Louvre. If the EPHE was a university institution with a broader scope, the École du Louvre had been dedicated to studies in Archaeology in the early years after its foundation in 1882, and from there expanded to include Art History, Anthropology and

Nerman, 9 December 1924; 14 December 1924. Riksarkivet. Kartong 1. Korrespondens Brev II 1923-1934.

229. Aftonbladet, 15 December 1924. 
Epigraphy. Janse stepped in for Hubert at both the EPHE and the École $\mathrm{du}$ Louvre during the spring semester 1925. After the summer break he wrote gratefully, almost in awe, from Stockholm to accept an offer to continue Hubert's courses:

My dear Master,

I am, how could one not be, flattered by your gracious offer to continue the course on the Germanics at the École du Louvre. How could I thank you enough for the kindness that you show me? ${ }^{230}$

His position in Paris was formalized in the late autumn (after a long time in the museum stores in Stockholm), when it was clear that Hubert had to take a long leave of absence owing to poor health. He was appointed Assistant Professor at the École du Louvre for the academic year 1925-1926, and gave his first lecture on 11 December 1925. In the first semester he lectured on the Germanic civilization in the pre-Roman Iron Age, based on research publications from Scandinavia and Germany, and artefacts in museum collections at the Musée des antiquités nationales, and at museums in Germany and Scandinavia. Like Henri Hubert before him, he emphasized the Celtic influence on Germanic culture. ${ }^{231}$ In the second semester he lectured on the Iron Age in the Gaul region, based on artefacts in the collections of the Musée des antiquités nationales. The course followed upon, as a sort of paraphrase and complement, a course on the Bronze Age of the Gaul region previously given by Henri Hubert. ${ }^{232}$ Janse spent most of his time in Sweden during the years 1925-26, and did not return to Paris until late October 1926, a little more than a month before he began teaching at the École du Louvre. In Paris, he stayed in a room in L'Île de la Cité, at 9 Quai aux Fleurs. He continuously filled in for Hubert, at the Musée des antiquités nationales and in his courses and public lectures at the École du Louvre and at the EPHE. In the spring of

230. Letter from O. Janse to H. Hubert, 24 August 1925. Archive of MAN: General correspondence/Janse. In French: "Mon cher Maître,// Je suis, on ne peut plus, flatté de la gracieuse offre que vous me faites de continuer votre cours sur les Germains à l'Ecole du Louvre. Comment vous remercier de la bienveillance que vous me temoignez?"

231. Cf. Olivier 2018, where there is no mention of Janse in relation to Hubert's research and writings on les Germains.

232. Extrait du Journal officiel de la république française, 1926: "Rapport sur L'administration et la conservation des musées nationaux et sur l'enseignement de l'école du Louvre pendant l'année 1926". NAA: Janse 2001-29. 
1927, Hubert was back to do some of his teaching. But Salomon Reinach was largely absent owing to poor health, ${ }^{233}$ and Hubert was left with the duties of the museum. Hence Janse continued to lecture in lieu of Hubert at the École du Louvre, ${ }^{234}$ and delivered ten lectures on the Germanics at the Institut d'études Scandinaves, from 7 March to 15 May. ${ }^{235}$ In late April he wrote to Birger Nerman, evidently content, that the lectures were very well paid, with 500 francs per lecture, and attracted audiences of up to 150 people. ${ }^{236}$ In another letter to Birger Nerman, Janse wrote that he had been asked to maintain Hubert's professorship during 1928 as well, and that Hubert had moreover asked if he would be interested to participate with a section on Germanic History of Religion, for a large comprehensive publication on the History of Religion, of which Hubert was the editor. He appeared very keen to accept both offers. ${ }^{237}$ Then, suddenly, the unthinkable happened. On 26 May 1927, Janse received a telegram saying that Henri Hubert had died in his home in Chatou. ${ }^{238}$ Three days later he wrote to Birger Nerman:

\section{Paris Saturday}

Mon cher ami,

Have this morning followed Henri Hubert to the grave. [...] Was invited to déjeuner at Hubert's a short while ago. He seemed then to be in particularly good spirits and relatively good health. He was at the museum on [Tues]day and worked there until around five o'clock. When he arrived at his home in Chatou he felt tired and went to bed not feeling any worry. On Wednesday morning, however, the situation had got worse. He lost consciousness

233. Letter from O. Janse to B. Nerman, 20 April 1927. Riksarkivet. Kartong 1. Korrespondens Brev II 1923-1934.

234. Letter from O. Janse to H. Hubert, 9 April 1927. Archive of MAN, Fonds Hubert/ Dossier personnel.

235. Letter from O. Janse to H. Hubert, 2 February 1927. Archive of MAN, Fonds Hubert/Correspondance non classé.

236. Letter from O. Janse to B. Nerman, 27 April 1927. Riksarkivet. Kartong 1. Korrespondens Brev II 1923-1934.

237. Letter from O. Janse to B. Nerman, 15 February 1927. Riksarkivet. Kartong 1. Korrespondens Brev II 1923-1934.

238. Letter from O. Janse to B. Nerman, 26 May 1927. Riksarkivet. Kartong 1. Korrespondens Brev II 1923-1934. 
during the course of the day and death occurred in the afternoon on the same day. It is a hard blow for his young sons and for his many friends and disciples. The funeral was very moving. I am struggling to take it in that Hubert is no longer among the living.

Yours truly

Olle ${ }^{239}$

All of a sudden, Janse found himself in a new, much more fragile position in Paris. Already on the day before Hubert died, Janse wrote to Birger Nerman that he would probably decline the offer to keep the position at the École du Louvre for the academic year 1927-28, considering how little he was paid and the fact that he would never be able to get a permanent position there. ${ }^{240}$ Two weeks later, when Hubert was gone, he wrote, again to Birger Nerman, that he was not sure if he would return to Paris in the autumn. ${ }^{241}$ The situation at the Musée des antiquités nationales was insecure. Salomon Reinach suffered from diabetes and insomnia, and had been largely absent in the months before Hubert's death. ${ }^{242}$ The archaeologist Raymond Lantier (1886-1980) had been appointed conservateur adjoint (Hubert's previous position) in 1926, and stepped in to take over more of the responsibility for the running of the museum after Hubert's death and in Reinach's absence. Letters indicate that Lantier and Janse

239. Letter from O. Janse to B. Nerman, n.d. around 29 May 1927. Riksarkivet. Kartong 1. Korrespondens Brev II 1923-1934. In the Swedish original: "Paris lördag / Mon cher ami, / Har idag på morgonen följt Henri Hubert till graven. [...] Var bjuden på déjeuner hos Hubert för kort sedan. Han föreföll då vid ovanligt gott humör och relativt god hälsa. Han var på museet i [tis]dags och arbetade där till bortåt fem-tiden. När han kom hem till Chatou kände han sig trött och gick till sängs men anade ingen oro. På onsdags morgon hade tillståndet emellertid förvärrats. Han förlorade medvetandet under dagens lopp och på eftermiddagen samma dag inträffade döden. Det är ett hårt slag för hans små söner och för alla hans många vänner och lärljungar [sic]. Jordfästningen var mycket gripande. Jag har svårt att fatta att Hubert icke mera är bland de levande. / Din tillgivne / Olle."

240. Letter from O. Janse to B. Nerman, 25 May 1927. Riksarkivet. Kartong 1. Korrespondens Brev II 1923-1934.

241. Letter from O. Janse to B. Nerman, 10 June 1927. Riksarkivet. Kartong 1. Korrespondens Brev II 1923-1934.

242. Letter from O. Janse to B. Nerman, 20 April 1927. Riksarkivet. Kartong 1. Korrespondens Brev II 1923-1934. 
were on good terms, and that Lantier supported Janse's continued presence at the museum. ${ }^{243}$ But the situation at the museum remained fragile.

Then there were the publications. At the time of his death, Henri Hubert had been working on two major publications: one that was almost complete on prehistoric and historic Celtic civilization - Les Celtes, and one on the Germanic - Les Germains, that was in a more fragmentary state. Marcel Mauss took on the task of finishing the book on the Celts, which was published in $1932 .{ }^{244}$ And shortly after Hubert's death, Olov Janse, supported by Mauss, set out to complete the research on Les Germains and edit it for publication. Janse knew this part of Hubert's work better than anyone else. It was based largely on the courses Janse had taught alongside Hubert at the École de Louvre, and in letters from Sweden he instructed Mauss on where exactly in Hubert's office he could find notes and research material on a given subject. ${ }^{245}$ So Mauss needed Janse to sort out the work of their mutual friend. But although he fully encouraged Janse's efforts to complete Hubert's oeuvre, it is clear that Mauss's practical support for Janse was not as strong as the support he had enjoyed while Hubert was alive.

Marcel Mauss, however, exerted a major influence on Janse's own work, as it was about to take a turn towards Asia. Together with Paul Rivet, who had a background in physical anthropology, Mauss organized the first university training in "ethnology" (Fre: ethnologie) in France, at the Sorbonne in 1925. Rivet and Mauss were both active socialists, and the new ethnology (which was more akin to social anthropology as we know it today than to folklore studies, which is more commonly associated with ethnology today) took a clear stance for cultural pluralism, against the growing anti-Jewish racist tendencies in parts of French society expressed for example in the Dreyfus affair. ${ }^{246}$ Their political orientation was shared by Olov Janse and characterized overall the academic and museum-oriented community he was part of in Paris. Over the late 1920 s and 1930s, Mauss and Rivet also reformed the Musée de l'Homme - the Museum of Man - and thus put a decisive mark on the development of academic studies of Man in France in the direction of Durkheimian

243. Letters from O. Janse to R. Lantier, 27 September 1933; 5 October 1933. Archive of MAN: General correspondence/Janse.

244. Hubert 1932.

245. Letter from O. Janse to M. Mauss, 5 October 1932. Fonds Marcel Mauss au Collège de France: mauss-janse-०o8.pdf

246. Conklin 2013:3. 
sociology, with on-site fieldwork and studies of ethnographic artefacts. ${ }^{247}$

In the years that followed after Hubert's death, Janse's relationship with Salomon Reinach went from friendly to ice-cold, when they ended up on opposite sides of the debate about Glozel. What has become known as The Glozel Affair ${ }^{24}$ was sparked in March 1924, when Émile Fradin, a seventeen-year-old son of a local farmer, uncovered an underground chamber made of bricks and tiles that contained bone and ceramics, after one of his cows had got stuck in a field in Glozel near Vichy in central France. The news about the unusual find first attracted local attention, and enticed Antonin Morlet, a physician and amateur archaeologist from Vichy, to come to Glozel to excavate. He found clay tablets with what appeared to be the script of an unknown language, and engraved figures reminiscent of Palaeolithic cave art. Had they been authentic prehistoric finds, they would have challenged much of what was known about prehistory in Western Europe. In 1925, Dr Morlet published a report with Émile Fradin as co-author, saying that the finds were Neolithic. The report was readily dismissed by academic archaeologists in Paris, but Morlet responded by inviting a number of leading archaeologists to Glozel to excavate in 1926 . Among them were Salomon Reinach and the esteemed archaeologist Henri (Abbé) Breuil, who both returned from the excavation site impressed and apparently convinced of its authenticity. Reinach immediately wrote a statement to the Académie des Inscriptions et Belles-Lettres verifying the authenticity of the finds. Abbé Breuil, on the other hand, withdrew his initial judgement in 1927, blaming his misjudgement on bad weather and poor light at the time of his visit to Glozel, and from that moment on maintained that everything but the stoneware pottery was fake. He was soon joined by the renowned prehistorian Vayson de Pradenne, and two distinct positions emerged - one of "Glozelians" claiming authenticity and the other of "anti-Glozelians" claiming it was all fake and fraud. New finds appeared over the years that followed, and the Glozel affair ballooned to become one of the most famous cases of alleged fraud in the history of archaeology. In 1928, René Dussaud, renowned epigrapher and Curator at the Louvre, accused the young farmer Émile Fradin of being guilty of fraud in an interview in the morning newspaper Le Matin. Fradin, who was offered free legal repre-

247. Ibid.

248. Reinach 1928; Biaggi 1994; Gerard 2005; Craddock 2009:119-125; "Emile Fradin”, Obituary in The Telegraph, 4 March 2010. 
sentation by the Glozelians, responded by filing a lawsuit and had both Dussaud and Le Matin convicted for defamation. The site at Glozel has been excavated and investigated many times since 1924 , but the question of whether or not the finds were authentic to a prehistoric or historic period, or deliberately fabricated in modern times, remains unresolved. ${ }^{249}$

From his position at the Musée des antiquités nationales and the École du Louvre, Janse was located at the centre of events concerning the Glozel affair. The first time Glozel is mentioned by Janse is in a letter to Birger Nerman in November $1926.5^{\circ} \mathrm{He}$ had just arrived from Stockholm to begin teaching at the École du Louvre. Hubert was still alive, Reinach had just returned from three days of excavations at Glozel, convinced of its authenticity, and Abbé Breuil had not yet taken a clear stance for the fraud side. In the letter Janse writes that he had just had tea at Hubert's house, where they had discussed the developments at Glozel. Hubert had resisted making any definite judgement before he had had the chance to talk to Abbé Breuil, but thought, nonetheless, that Reinach had given the finds too early a date and suggested that they might be Eneolithic (i.e. between the Neolithic and the Bronze Age).251 Janse, at this point, had no opinion at all.

It took until the summer 1927 before he focused on Glozel again. Hubert was dead, and the debate between Glozelians and anti-Glozelians was getting heated. In a letter to Birger Nerman he writes, on 10 June, that he might be going to Glozel on a mission for the Swedish newspaper Stockholms Dagblad. ${ }^{252}$ And indeed, before he left France for his usual summer employment in Sweden, he went to visit Glozel together with the Swedish botanist John af Klercker (1866-1929), the military commander and epigrapher Émile Ésperandieu (1857-1939), Professor Auguste Audollent (1864-1943) from Clermont-Ferrand, the editor and ethnologist Émile Nourry (1870-1935), and his "critical-minded" wife Camille Nourry-Saintyves. ${ }^{253}$ The group arrived in Glozel on 21 June, and the pur-

249. Biaggi 1994; Gerard 2005; Craddock 2009: 119-125; "Emile Fradin", Obituary in The Telegraph, 4 March 2010.

250. Letter from O. Janse to B. Nerman, 1 November 1926. Riksarkivet. Kartong 1. Korrespondens Brev II 1923-1934.

251. Ibid.

252. Letter from O. Janse to B. Nerman, 10 June 1927. Riksarkivet. Kartong 1. Korrespondens Brev II 1923-1934.

253. Sydsvenska Dagbladet, 23 October 1927: (John af Klercker), "Som vetenskaplig Sherlock Holmes i Glozel." 
pose of their visit was to oversee the excavation of a hitherto unexcavated grave that had recently been discovered. ${ }^{254}$ On behalf of the surveillance group, Olov Janse was given the task of registering all the finds as they were taken out of the trench, but was, according to af Klercker, constantly distracted by the local school teacher Miss Picandet, who disturbed him with her "witty and gracious conversation". In a letter to Birger Nerman, Janse also describes Vichy, as "a nice town with many beautiful and gracious women". ${ }^{255}$ Having witnessed the excavation, the surveillance group expressed doubts concerning the control and integrity of the site, but could not point to any clear evidence of a fraud. John af Klercker, however, brought some soil samples back to Sweden for analysis. ${ }^{256}$

The Glozel affair caught a lot of attention in the Swedish press in the autumn of 1927. In several articles from early September, Janse is interviewed and referenced, expressing doubts about the authenticity of the finds. ${ }^{257}$ In October, after Abbé Breuil had turned and taken a clear stance for the fraud side, Janse's and other Swedish archaeologists' opinions were suddenly quite clear in favour of the anti-Glozelian side. ${ }^{258}$ After November 1927, when the famous interview with René Dussaud had been published in Le Matin, all the question marks from September had been replaced with exclamation marks, in articles with acerbic headlines like:

254. The excavation is described in detail in a long newspaper article written by John af Klercker: Sydsvenska Dagbladet, 23 October 1927: (John af Klercker), "Som vetenskaplig Sherlock Holmes i Glozel”. See also Sydsvenska Dagbladet, 17 October 1927: (John af Klercker), "Med två svenska forskare i Glozel, där sommaren omstridda fornfynd gjorts"; Dagens Nyheter, 30 October 1927: (Olov Janse) "Farsteatern i Glozel".

255. Letter from O. Janse to B. Nerman, 20 June 1927. Riksarkivet. Kartong 1. Korrespondens Brev II 1923-1934.

256. Sydsvenska Dagbladet, 23 October 1927: (John af Klercker), "Som vetenskaplig Sherlock Holmes i Glozel."

257. Svenska Morgonbladet, 2 September 1927: "Jättefalsarium eller epokgörande fynd? Vichyfynden vålla oerhört skarp strid."; Nya Dagl. Allehanda, 2 September 1927: "Falsarium eller vetenskapliga fynd?"; Stockholmstidningen, 3 September 1927: "Urtidsskrift eller jättefalsarium? Bondpojken och läkaren väcka med sitt franska stenåldersarkiv en vetenskapens hetsigaste fejder."; Svenska Dagbladet, 3 September 1927: "Fransk kultur den äldsta i världen? Fransk skrift från 3000 år f.Kr. - eller renässanstid?”.

258. Svenska Dagbladet, 7 October 1927: "Glozelproblemet. Spänningen ökas varje dag. Kontrollkommitténs medlemmar ha delade åsikter. Fyra för, två mot. Salomon Reinach illa ute på annat håll.”; Stockholmstidningen, 13 October 1927: "Glozelfynden: en förfalskning under trance? Dr af Klerckers jordanalyser klara i dag eller i morgon. 'En otrolig bluff."'; Dagens Nyheter, 30 October 1927: "Farsteatern i Glozel.”; Letter from O. Janse to B. Nerman, 2 November 1927. Riksarkivet. Kartong 2. Korrespondens Brev II 1923-1934. 
“'Glozel's gnome' offers good finds to his Masters", and "Glozel is humbug!" 259 Olov Janse was quoted or interviewed in most of these articles.

Three decades later, Janse described the Glozel affair in elaborate detail in his memoirs Ljusmannens gåta. ${ }^{200}$ Even if the finds had no connection to his research interests or his archaeological expertise, which was of much later periods (the Iron Age, rather than the Stone Age), he clearly thought of Glozel as an important event for his career. We can see two main reasons for that. One is that Glozel became an international media event. We have seen how Janse was drawn to the limelight, how he was always keen to have good relations with the press, and how he learnt to use newspapers to have his activities and achievements noticed across borders. When news about Glozel surfaced in the Swedish press, he could act as the perfect translator between the French scene of academic archaeology and the Swedish readers. Hence the Glozel affair became a great opportunity for him to boost his career by increasing his visibility in the Swedish press. ${ }^{261}$ The second reason why Glozel became so important for Janse was that it led to a serious conflict between him and Salomon Reinach. Reinach remained a staunch supporter of the Glozelian side and advocated the authenticity of the finds for the rest of his life. He even wrote a small book on Glozel published in 1928, where he describes the ancient "Glozelians" in a vivid narrative, as a people who were "not yet farmers or weavers" but sedentary pottery makers, whose underground dwellings were now being uncovered. ${ }^{262}$ From Janse's point of view, at least from 1928 onwards, Reinach was clearly wrong. Most of the academic archaeological experts were also on the anti-Glozelian side, and depicted Reinach as a sad and slightly stupid figure who had been fooled by a physician and a peasant boy. "He has completely lost his head", says Janse in a letter to Birger Nerman:

259. Svenska Dagbladet, 6 November 1927: "Nytt dokument i striden om Glozelfynden. Arkeologen Dussauds broschyr utkommen. Åberopar bl.a. en svensk arkeolog som betvivlar fyndens äkthet.”; Dagens Nyheter, 24 November 1927: “Glozels tomte' ger goda fynd åt sina herrar. Skarpt uttalande av franska arkeologen René Dussaud 'Allt är falskt: föremål, inskrifter och teorier."; Dagens Nyheter, 7 December 1927: "Sentida ben i 'forntida' Glozelgravar. Organiska beståndsdelar betänkligt väl bevarade. Märkligt resultat av portugisisk arkeologs analys."; Aftonbladet, 6 March 1928: "Glozel är humbug! Intervju med svensk arkeolog i Paris."

260. Janse 1959:24-30.

261. He declined, however, an offer made by Sigurd Curman to write about Glozel in the Swedish journal Fornvännen. Letter from O. Janse to S. Curman, 14 March 1928. ATA: Sigurd Curmans arkiv, vol. 108.

262. Reinach 1928:44. 
Not long ago, he said at a reception at his home that he wanted to call all anti-Glozelians a short word of three letters. This word is very vulgar and can barely be written. It begins with a $\mathrm{c}$ and ends with an $n$ [i.e. cunt, Fre: con, our remark]. Several members of L'Institut have written to R. and protested against his harsh personal outburst. ${ }^{263}$

Hence Janse's involvement on the anti-Glozelian side made it increasingly difficult to work at the Musée des antiquités nationales when he returned to Paris in January 1928, after a long stay in Stockholm. ${ }^{264}$

The spring of 1927 , which ended with the death of Henri Hubert and the surveillance trip to Glozel, had taken its toll on Janse. He arrived in Sweden exhausted around midsummer, after a journey via Brussels, Cologne, Berlin (where he fainted from exhaustion), Hannover, and Skanör in southern Sweden where he made a stop and stayed in John af Klercker's house. After a few weeks of rest in his family's summer house at Skagshamn near Valdemarsvik, he set off to Stockholm where he stayed with Ida Nerman (mother of Ture, Birger and Einar) at Sibyllegatan 6 in Östermalm. When he was not engaging in the Glozel debate he spent the autumn working for the Swedish History Museum, where he received the shipment with objects from the Piette collection in September, ${ }^{265}$ and endured the cold winds and rains of October and November in various inspections and minor excavations in Östergötland (in Klockrike, Skärkind, Häradshammar, Hannäs, and Gryt). Between his assignments, he spent all his free time on the completion of Henri Hubert's book on the Germanics. In a letter to Marcel Mauss in August he describes how the work is proceeding, and says that he has discussed "his future natural-

263. Letter from O. Janse to B. Nerman, 18 January 1928. Riksarkivet. Kartong 1. Korrespondens Brev II 1923-1934. In the Swedish original: "R. har alldeles tappat huvudet. För inte länge sedan, sade han vid en mottagning i hans hem att han ville kalla alla antiglozelianer med ett litet kort ord med tre bokstäver. Detta ord är mycket vulgärt och kan knappast skrivas. Det börjar med c och slutar med n. Flera medlemmar av l'Institut ha skrivit till R. och protesterat mot hans hätska, personliga utfall.”

264 . Letters from O. Janse to B. Nerman, 16 January 1928, 18 January 1928 , n.d. written on paper from Abda Hotel. Riksarkivet. Kartong 1. Korrespondens Brev II 1923-1934.

265. Dagens Nyheter, 28 September 1927: (Sven Jansson), "Då kubisterna ännu härjade med ensamrätt. Vacker föremålssamling från fransk stenålder. Nya förvärv. Åter en värdefull sändning till Historiska museet."; Norrköpings Tidningar, 29 September 1927: "Fornsaker från Frankrike till svenskt museum. En ny sändning till historiska [sic] museet. D:r. Janse sänder 12,000-åriga synålar och en statyett.” 
ization" with Monsieur Mondon at the French legation in Stockholm. ${ }^{266}$ Evidently, he was still hoping for a future in Paris.

Back in Paris in January 1928 he stayed in the guesthouse Abda Hotel, on 12 rue Juliette-Lamber near Place de Wagram. He was now 35 years old, and kept moving from room to room, back and forth between France and Sweden. Despite the increasingly tense situation with Reinach, he continued to do some work at the Musée des antiquités nationales. He collaborated with the new curator Raymond Lantier to complete the display in the Scandinavian part of the comparative collections. Lantier showed a vivid interest in Scandinavia and endorsed Janse's presence at the museum. In a letter to Birger Nerman, Janse writes that "once he becomes Director of the Musée des antiquités nationales he will surely continue on the same path as Hubert. He is even thinking about learning Swedish." ${ }^{267}$ So there were glimpses of hope in Paris, despite the conflict with Reinach.

In Sweden, however, Janse's mobility was becoming a problem. Although his presence in France was in many ways regarded as an asset - a well-informed translator of the happenings in the Glozel affair; a facilitator of contacts between Swedish and French academics and institutions; a motor for artefact exchanges; and a door-opening guide for Swedish academics and their relatives visiting Paris - his movements were at the same time considered uncomfortable and unfit for the Swedish system. The previous interest in broad international contacts and collaborations cooled down during the 1920s, and became more or less ice-cold in the 1930 s, with a political rhetoric that encouraged an inward-focusing and border-controlling nation. And as mentioned earlier, if Swedish archaeology showed any interest in, or derived any inspiration from, any country outside Scandinavia, it was Germany. In the spring of 1928 , when the Glozel debate peaked and dominated French archaeology, Swedish archaeology was dominated by a scandal of more personal character: Sigurd Curman, Director of the National Board of Antiquities and the Swedish History Museum, left his wife and children to marry his secretary. Janse writes to Birger Nerman, on 23 June:

266. Letter from O. Janse to M. Mauss, 19 August 1927. Fonds Marcel Mauss au Collège de France: mauss-janse--001a.pdf

267. Letter from O. Janse to B. Nerman, 11 March 1928. Riksarkivet. Kartong 1. Korrespondens Brev II 1923-1934. In the Swedish original: "När han en gång blir chef för Saint-Germainmuseet kommer han säkerligen att fortfölja traditionerna från Hubert's tid. Han funder [sic] t.o.m. på att lära sig svenska." 
The news about Curman's sentimental adventures is nigh-on unbelievable. It is particularly distressing for Mrs C. and the children, especially the small girls. [...] It must be a strange atmosphere at the museum now? ${ }^{268}$

With Curman occupied with his private family issues, Sune Lindqvist became more dominant and Janse's position in Stockholm looked increasingly fragile. At this point, early in the summer of 1928 , he was counting on his naturalization to be completed in a few months, and was not sure if he could come home [sic] for the summer. He wrote to Birger Nerman that it all depended on his financial situation. ${ }^{269}$ Two weeks later, his uncle Otto stepped in and arranged a late summer employment at the History Museum in Stockholm. ${ }^{20}$ The summer in Paris was unbearable "so hot so I can just barely lift the pen", he wrote to Birger Nerman - and on 25 July he travelled to Sweden via Trier, Cologne, Hamburg, Kiel, and Lübeck. ${ }^{271}$ As usual, he made stops to study museum collections on the way. Now, as in the summer before, he found it particularly important to study collections in Germany for his work with Hubert's book on the Germanics.

During the autumn 1928, Janse sat quietly in Stockholm. He worked on Hubert's book, but the work proceeded much slower than he had hoped and wanted. He was still waiting for his naturalization to be completed, and his contract with the EPHE looked insecure. But at least Raymond Lantier had promised him a future at the Musée des antiquités nationales. ${ }^{272}$

Most of his energy this autumn, however, was devoted to an upcoming gold exhibition at the History Museum in Stockholm. The temporary exhibition, which was on display for a month in January-February 1929,

268. Letter from O. Janse to B. Nerman, 23 June 1928. Riksarkivet. Kartong 1. Korrespondens Brev II 1923-1934. In the Swedish original: "Nyheten om Curmans sentimentala äventyr är hart när otrolig. Det är särskilt synd om fru C. och barnen i synnerhet om de små flickorna. [...] Det bör vara en egendomlig stämning på museet nu?"

269. Ibid.

270. Letter from O. Janse to B. Nerman, 9 July 1928. Riksarkivet. Kartong 1. Korrespondens Brev II 1923-1934.

271. Letter from O. Janse to B. Nerman, 18 July 1928. Riksarkivet. Kartong 1. Korrespondens Brev II 1923-1934.

272. Letter from O. Janse to M. Mauss, 20 December 1928. Fonds Marcel Mauss au Collège de France: mauss-janse-०002.pdf. 
Fig. 22. Invitation card for the gold exhibition at the Swedish History Museum, 1929.

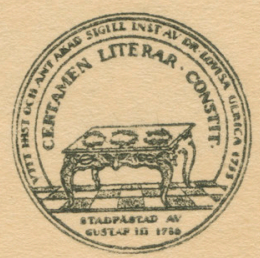

\title{
STATENS HISTORISKA MUSEUM
}

\author{
inbjuder Eder bärmed \\ att tisdagen den 15 januari $1929 \mathrm{kl} .12-2 \mathrm{e} . \mathrm{m}$. \\ laga $i$ betraklande en tillfällig \\ utställning as \\ SVENSKA GULDFYND \\ FRAN TIDEN 100-600 E. KR. \\ Utotällningen pågair c:a en mainad \\ Museet bailles öppel \\ Söndagar 1-3 (fritt), onsdagar ocb lördagar 12-2 (frill), \\ örriga dagar 12-2 (inträde 50 öre), maindagar stängt \\ Detta kort medgiver frilt tillträde \\ vid elt besök $i$ museet under utotäliningotiden \\ Gäller för 2 personer
}

RIKSANTIKVARIEN 
featured gold artefacts from the Roman Iron Age and Migration Period (100-600 AD) in the museum's collections. It opened on 15 January 1929 , and was a great success. Janse was the curator responsible for the selection of objects. He also wrote an exhibition catalogue, where he used the expertise gained through the work with his doctoral thesis to give the visitors contexts and more information about the objects on display. ${ }^{273}$ Press reports talk of an outstanding, beautiful and interesting display, where the pièce de résistance was a massive neck ring weighing seven kilograms. They lament the limitations of the premises of the History Museum, with its displays restricted to the ground floor of the National Museum, allowing only a small alcove of space and a month's time for the gold exhibition. Janse, however, gets nothing but praise for his knowledgeable introduction to the exhibition: "A moment's study of the gold exhibition guided by Dr Janse's descriptions opens up for various culture-historical perspectives", one reviewer writes. ${ }^{274}$ In addition to the catalogue, Janse wrote a long newspaper article for Social-Demokraten with a background and introduction to the objects on display, ${ }^{275}$ and another

273. Janse 1928.

274. Svenska Morgonbladet, 15 January 1929: "Prima guld från hedenhös. En enastående utställning på Historiska museet". In Swedish: "En stunds studium av guldutställningen med ledning av dr. Janses beskrivning öppnar åtskilliga kulturhistoriska perspektiv"; see also Nya Dagl. Allehanda, 14 January 1929: “2.000-åriga guldsmycken ur svensk jord exponeras i Historiska museet. En utsökt vacker och högintressant exposition. Förtrollade halsringar och andra underbara ting"; Aftonbladet, 14 January 1929: "Gammalt guld från fem sekel. Intressant utställning på Historiska museet”; Svenska Dagbladet, 15 January 1929: “'Betalningsringar', filigransmycken o. gamla guldmynt. Från Folkvandringstidens Sverige. Intressant utställning på Historiska museet"; Social-Demokraten, 15 January 1929: "Svenska guldfynd från vår tidräknings början. En intressant utställning på Nationalmuseum under en månad"; Stockholms Dagblad, 16 January 1929: "Dvärgasmiden och drakguld. Historiska museet utställer praktfynd från tiden 100-600 e. Kr.”; Dagens Nyheter, 20 January 1929: "Gotiska ordnar och järnåldersportmonnäer"; Aftonbladet, 11 February 1929: "Fin lampkrok"; Nya Dagl. Allehanda, 11 February 1929: "Svenskt fornguld"; Sydsvenska Dagbladet, 12 February 1929: "Svenska guldskatter på ståtlig parad. Historiska museet visar fram rikedomar, som funnits i Sveriges jord"; Svenska Dagbladet, 12 February 1929: "Kragar av guld"; Nya Dagl. Allehanda, 14 February 1929: "Utställningen av svenskt fornguld."

275. Social-Demokraten, 9 February 1929: (Olov Janse), "Svenskt guldsmide hade en storhetstid för 1500 år sedan. Fynden av ädelmetall ha ibland fått göra tjänst som 'trilleband' och lampkrokar." 


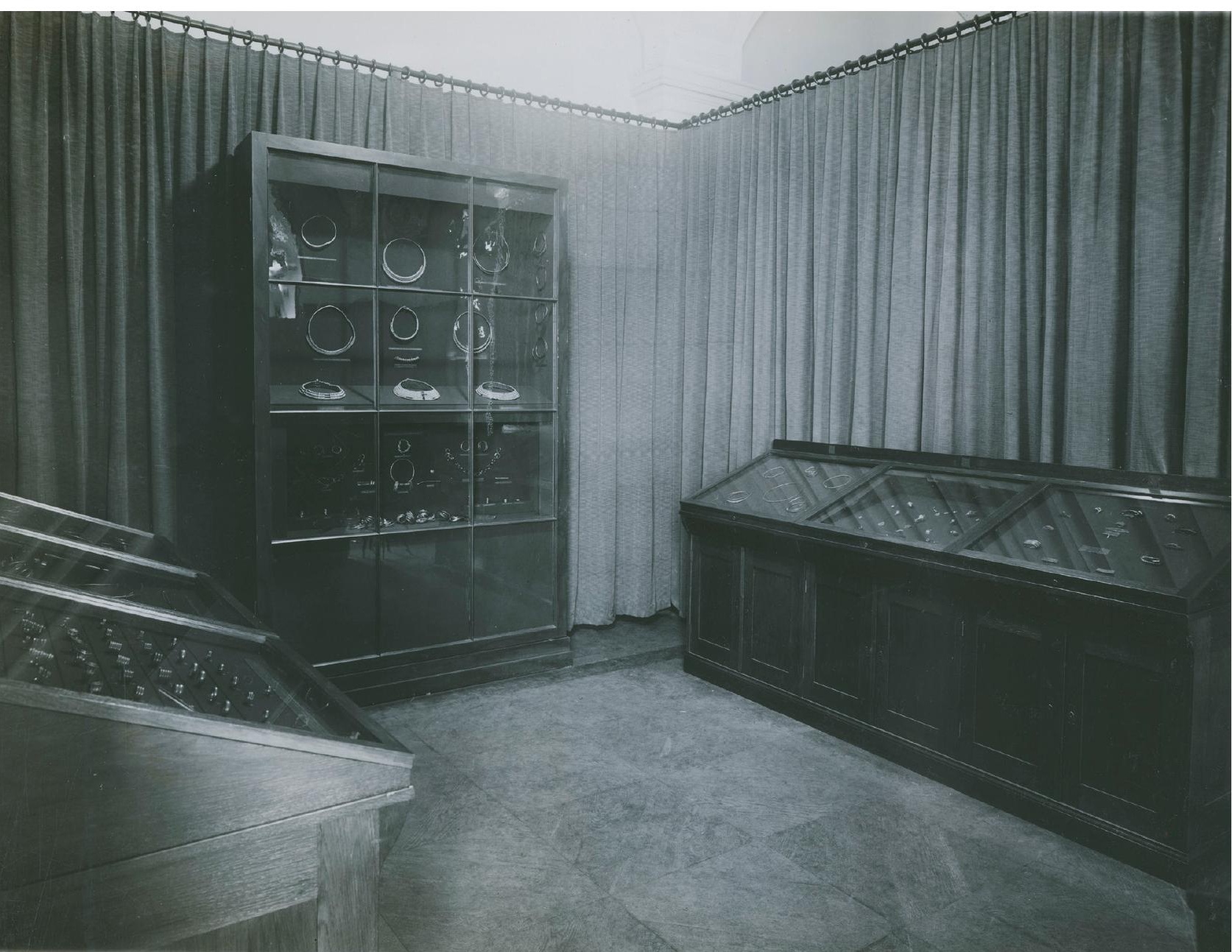

Fig. 23. Olov Janse's gold exhibition at the Swedish History Museum, 1929. article for the French Le Figaro. ${ }^{276}$ The exhibition was also noticed in both German and British press. ${ }^{277}$

The successful gold exhibition is a great example of Janse's situation at the end of the 1920 s. Stimulating in its unpredictability, with bursts of acclaim and short periods of success - and at the same time volatile, draining (financially, physically, and mentally) and frustrating because of its unpredictability. For several years to come he would continue to travel between Sweden and France, and he waited yet another year, in vain, for

276. Le Figaro - supplement artistique, 28 February 1929: (Olov Janse), “l'Orfèvrerie ancienne en Suède", pp 326-328.

277. Prager Presse, 24 January 1929: "Antike Guldfunde in Schweden. 2000jährige Goldschmuck-Gegenstände und Goldmünzen."; The Illustrated London News, 16 March 1929: Notice with photographs, p. 449; International Studio: (Naboth Hedin), "Pre-Viking Age of Gold in Sweden.", June 1929, Vol. XCIII, No. 385, pp 27-29. 
his naturalization to become French citizen. ${ }^{278}$ For as long as he was a Swedish citizen, he could not proceed to a permanent position as lecturer or museum curator in France.

There was, however, another possible way forward. New plans, marked by a new interest in Asia, began to take shape in the last years of the 1920s. Henri Hubert had taken much inspiration from his world tour and sojourn in Hanoi in 1902, and he may well have conveyed some of that enthusiasm to Janse when they worked together in the Salle de Mars. ${ }^{279}$ Janse's friendship with Sueji Umehara, as well as the plans to create a separate museum for the Swedish geologist, archaeologist, palaeontologist and art collector Johan Gunnar Andersson's magnificent collections of East Asian art that germinated in Stockholm around 1926, might further have sparked Janse's interest. Marcel Mauss and his ethnology must also have been an important influence.

For Janse, however, the interest in Asia was initially only of a long-distance character. Rather than considering travelling to East Asia himself, he saw prospects of studying how elements of Asian culture had influenced European culture by diffusion. ${ }^{280}$ In the months after his successful gold exhibition at the History Museum, he received a research grant Letterstedtska stipendiet - for a seven-month study of eastern influences on the early Iron Age Hallstatt culture of Central Europe. ${ }^{281}$ But the interest in Asia would eventually grow stronger, and in hindsight this moment stands out as the beginning of an entirely new phase in Olov Janse's life and career.

There was also an important change in Janse's social life around this point in time. He met and married Ronny Sokolsky, whom we will get to

278. He eventually withdrew his application for naturalization in 1930. The process up to the withdrawal can be followed in his letters to Marcel Mauss. Fonds Marcel Mauss au Collège de France: mauss-janse-0016.pdf

279. Janse 1959:17-18.

280.E.g. Svenska Dagbladet, 27 September 1927: "Stockholm har nu blivit Kinaforskningens centrum. Japansk lärd är imponerad. Tror sin kunna konstatera ett kultursamband redan i stenåldern mellan Skandinavien och Kina. Vackra gåvor till Nationalmuseum", on the occasion of Sueji Umehara's visit to Stockholm.

281. The grant was of 5000 Swedish kronor. Dagens Nyheter, 10 December 1929: "Forntrust i Hallstadt. D:r O. Janse stipendiereser sju månader nästa år." 
know better in the next chapter. The fact that he was no longer alone also affected his new, or rather, their new interest in Asia. Further enabling the turn towards Asia were a number of influential new friends: Johan Gunnar Andersson, René Grousset, David David-Weill, and C. T. Loo.

The Swedish museum director Johan Gunnar Andersson (1874-1960) was one of Janse's most important professional relations in the years after Henri Hubert's death. Andersson, who was originally a geologist working for China's National Geological Survey, had developed his knowledge and skills in Chinese archaeology through on-site experiences and artefact collection. ${ }^{282} \mathrm{He}$ was an outstanding entrepreneur, creating a museum (with one of the world's finest collections of Chinese art and archaeological artefacts), an academic position as Professor of Chinese archaeology, a national reputation as a leading China expert (with the nickname Kina-Gunnar as testimony to his popularity), and an international reputation as one of the founding fathers of Chinese archaeology and as partly responsible for the discovery of the Peking Man. The correspondence in Andersson's professional archive around the time that he became acquainted with Janse demonstrates his extraordinary skills at fundraising and building support structures for his museum activities within the highest strata of Swedish society. He made particularly canny use of his close relation to the Swedish Crown Prince (later King Gustaf VI Adolf), who was himself a keen amateur archaeologist and art collector, ${ }^{283}$ to attract wealthy industrialists and other potential supporters to fundraising events. ${ }^{284}$

In 1929, when Johan Gunnar Andersson was busy organizing his new museum, the Museum of Far Eastern Antiquities in Stockholm, he took some time off to go on a lecture and study trip to Paris, London, and Berlin. Back in Stockholm he wrote to his friend and fellow collector of Chinese antiquities, Orvar Karlbeck:

[In Berlin] was a major exhibition of Chinese art [...] which was quite beautifully arranged, yet without being sensational. [...] In London there were no outstanding new things either [...]. More remarkable was what I saw in Paris, which is now bustling with

282. Cf. Fiskesjö \& Chen 2004 and Johansson 2012 for two slightly differing perspectives on Andersson's archaeological and collecting pursuits.

283. Isaksson 1972; Whitling 2014.

284. Östasiatiska samlingarnas arkiv. Korrespondens 1928-1934. 
new impressions and wonderful treasures on the Chinese antiquities market. ${ }^{285}$

More spectacular than anything else that he had seen in the bustling French capital was the Pagoda - a six-storey Chinese-style building in the centre of Paris, which was the showroom of C. T. Loo, famous dealer in Chinese art and antiquities. An awestruck Andersson reported back to Karlbeck that the Pagoda was, "a true temple of beauty", where Loo had his "Chinese treasures exposed in a way that had no equivalence on earth". ${ }^{286}$

Andersson had thus identified Paris as the current and future hot-spot of the Chinese antiquities market, but his French was not as good as his excellent English, and he lacked both networks and competence to establish the connections with Paris that he desired. Olov Janse's presence and good connections in Paris were well known among Swedish archaeologists at the time, and shortly after his return Andersson wrote to ask Janse to investigate some bronze artefacts from Indochina in the comparative collections at the Musée des antiquités nationales. ${ }^{287}$ In the same letter he also asked if Janse, "with as much discretion as possible", could track down a French private collector named Monsieur Malortigue (who had lived in Yunnan-fu and was said to have over thirty small bronze objects in his possession), and "in a nice way" persuade him to sell his bronzes to the Museum of Far Eastern Antiquities. ${ }^{28}$ Janse took on both tasks, completed the museum investigations successfully, but never, despite considerable efforts, managed to find Monsieur Malortigue. He had, however, proven useful to Andersson.

This was two years after Henri Hubert's death, and Janse had lost much of his professional support in Paris. He still did some teaching and

285. In the Swedish original: "Jag utreste i början av Februari på en föreläsnings och studieresa till Paris, London och Berlin. På det sistnämnda stället pågick just den stora utställningen av kinesisk konst [...] som var mycket vackert ordnad, utan att dock vara sensationell. [...] I London var heller icke någonting märkligt nytt [...]. Desto märkvärdigare var det som jag såg i Paris, som nu sjuder av nya intryck och underbara rikedomar på den kinesiska antikvitetsmarknadens område." Östasiatiska samlingarnas arkiv. Korrespondens $1929 \mathrm{E} 1 \mathrm{~A}: 3,0255^{-0256 .}$

286. Östasiatiska samlingarnas arkiv. Korrespondens 1929 E1A:3, $0255^{-0256 . ~}$

287. Letter from J. G. Andersson to O. Janse. Östasiatiska samlingarnas arkiv. Korrespondens $1929 \mathrm{E} 1 \mathrm{~A}: 3,0237$.

288. Ibid. 
some work for the Musée des antiquités nationales (not least the task of editing Hubert's Les Germains). But he was struggling to make ends meet, and his future was uncertain. ${ }^{289}$ Andersson's invitation to focus on Asia came as a welcome detour, and it did not take long before Janse started working at the Museum of Far Eastern Antiquities in Stockholm. He was put in charge of editing the three first volumes of the museum's new Bulletin of Far Eastern Antiquities, helped Andersson with connections in Paris, and did some study trips on his behalf. During this time, Andersson developed and nurtured relations with important French art collectors such as David David-Weill and C. T. Loo. We know that they later became close friends with Janse, and guess that it was here that they first met and became acquainted.

Janse was profoundly impressed by Andersson's ways and manners as a museum director and artefact collector. The relationship with the influential Swedish Crown Prince, which would remain cordial through Janse's later career, was also established while he was working for Andersson. It was here, through Andersson's movements in the slippery borderlands between official (which ought to be legal) and private (not always legal) collections of Asian antiquities ${ }^{290}$ that the social sphere of influential private collectors and the rules and realities of the antiquities market entered Olov Janse's professional realm. For reasons that we shall return to in the following chapters, Janse's relation to Andersson was broken completely after 1938. But it was while working for Andersson at the Museum of Far Eastern Antiquities that he learnt many of the crucial skills and manners of an archaeological expedition leader and artefact collector, and also came to understand the value of rich and influential patrons.

An immensely influential actor in the art museums of Paris from the 1920 s to his death in 1952 was the philanthropist banker and passionate art collector David David-Weill (1871-1952). ${ }^{291}$ He was born in San Fran-

289.E.g. letters from O. Janse to M. Mauss, 3 March 1932; 17 June 1932. Fonds Marcel Mauss au Collège de France: mauss-janse--005.pdf; mauss-janse-००06.pdf

290. Andersson used private addresses in Sweden to pass customs in China. To be able to get the delivery through Swedish customs he wrote the authorities and explained the deal. Östasiatiska samlingarnas arkiv. Korrespondens 1932 E1A: 7, 0740, which shows O. Janse's part in the deal.

291. Feliciano 1997: chapter 7. 
cisco, into the enormously wealthy family of the Lazard Frères bank. His father Alexandre Weill, a French entrepreneur who had founded Lazard Frères with his brothers, moved his family back to France in 1884 so that his son would get a French education. David, who later changed his family name to David-Weill, retained a close connection with the United States, but lived for the rest of his life in France where he worked as the head of the Paris branch of Lazard Frères.

His passion for art started at an early age. When he was still a child and the Weill family was moving back to France from the United States, they did a typical grand tour of Europe before settling in Paris. Young David visited museums and was deeply influenced by what he saw on the trip. A few years after the family had settled in Paris he, then a teenager, began to collect art in the form of miniatures and enamels. ${ }^{292}$ In 1897 he married Flora Raphaël, who also had a great interest in art, and his father built a house for them in wealthy Neuilly on the outskirts of Paris. They moved to Neuilly in 1904 and began to fill their new house with fine art. They gradually expanded their collection, from European eighteenthand nineteenth-century art works, outwards in time and space to include large parts of the world, from early historical to contemporary art:

Enamels from Limoges and porcelain from Japan were displayed alongside Egyptian antiquities and Islamic ceramics and metal-work. There were prints by Degas, Manet, Renoir, Toulouse-Lautrec, Gauguin, Bonnard, and Vuillard, who was a friend of the family. There were sculptures by Sarrazin, Houdon, Caffieri, and Carpeaux, as well as Dancers and Horses by Degas and female figurines by Maillol. In the garden was Rodin's The Age of Bronze. ${ }^{293}$

David-Weill's first donation to the Louvre was in 1912. This marked the beginning of a long and intense relationship with the museums of Paris. Unlike other private collectors, David David-Weill made donations during his lifetime. His profound interest in art seems to have overshadowed the desire to own it, and he is known to have donated objects from his own collections to a museum if curators pointed out the importance of the object for the museum's collection. Moreover, he occasionally

292. Feliciano 1997:86-87.

293. Ibid.:87. 
contributed financially to the activities of museums and their staff. ${ }^{294}$ This symbiotic relationship between the private collector and the official museum institutions not only gave David-Weill much credit and position as a leading philanthropist, but it also gave him access to leading experts and important events related to the national collections.

In 1931, David David-Weill became president of the Board of Directors of the French National Museums. His collections had grown so large that he decided to employ Marcelle Minet (who had already worked with his collection for several years along with Georges-Henri Rivière, the prominent museologist who later became one of the founders of ICOM) as a full-time curator. Janse made the acquaintance of David-Weill around this time, but it is not entirely clear how it happened. We know, however, that David-Weill's interest in Asian art was growing at this time, and he was close to René Grousset at the Cernuschi Museum, whom we shall return to in a moment. We know also that David-Weill was in contact with Johan Gunnar Andersson around the same time, when Janse worked at the Museum of Far Eastern Antiquities. Through his work for Andersson, and later with his and Ronny's growing interest in Indochina, Janse became more closely involved in the Parisian web of influential museum curators, directors, and private collectors of Asian art, where David-Weill was one of the main actors.

Another important collector and patron was Gabriel Cognacq (18801951). In 1928 Gabriel Cognacq inherited the legendary Paris department store la Samaritaine from his uncle by adoption, Ernest Cognacq. Like David David-Weill, Ernest Cognacq and his wife Louise Cognacq-Jaÿ had used the wealth from their successful business for social philanthropy and art-collecting (their collection was donated to the city of Paris after their death and became the Cognacq-Jay museum). At the death of his uncle, Gabriel Cognacq also took over the presidency of their Cognacq-Jay foundation; a foundation for social solidarity promoting health, social service and education. But Gabriel Cognacq had a particular interest in art, and in the first years after taking over the business from his uncle he made several donations to the museums of Paris, for instance to purchase the studio of the sculptor Antoine Bourdelle and turn it into a museum (now the Musée Bourdelle). It was also around this time that he became acquainted with Janse.

The world-famous dealer in Chinese art and antiquities, Chang-Tsin

294. Feliciano 1997:88-89. 
Loo (1880-1957 $)^{295}$ was not a direct financial contributor to Janse's work in Asia, but their friendship and professional collaboration offered important support in other ways. C.T. Loo had a remarkable life and career. Born as Lu Huan Wen in a village in the Zhejiang province in China, he lost both his parents at a young age and began to work for the rich and influential Zhang family in and around Shanghai. He soon advanced to become assistant to the family's brilliant son Zhang Jinjiang, who suffered from a muscular disease and needed constant assistance. When Zhang Jinjiang was appointed Third Secretary at the Chinese Embassy in Paris, Lu Huan Wen was chosen to go with him. He arrived in Paris twenty-two years old, at the peak of the belle époque. Zhang Jinjiang had business interests and let Lu Huan Wen manage a shop for Chinese merchandise. Lu Huan Wen knew no French and had no business experience. But he was ambitious and attentive to the surrounding world, and it was not long before he exchanged his silk robe and hair plait for a three-piece suit and a dandy haircut. Managing the "Curio Zhang" shop he learnt the basics of Parisian business life and exports of goods from China. His exotic dandy appearance was attracting attention in the social life of Paris, but his flirts always remained secret, for it was unthinkable for a French woman to get openly involved with a young Chinese man. So when he met the love of his life, she chose to deny their relationship officially, but arranged for him to marry her daughter Marie-Rose. Marie-Rose hesitantly agreed to the marriage, they had four daughters, and remained for the rest of their lives in an unofficial threesome relationship with her mother.

After a few years managing Curio Zhang, Lu Huan Wen realized that the only things selling really well in the shop were antiquities. They cost almost nothing to buy in China, hence the gross profit was potentially great. In 1908 he opened his own gallery in Paris called Lai Yuan, and changed his name to Lu Qin Zhai, which was later adjusted to ChangTsin Loo and abbreviated to C.T. Loo. In 1915 he opened a branch gallery on Fifth Avenue in New York, and another one in London's Manchester Square after the First World War. Loo soon got a reputation as an discerning dealer in fine Chinese art and antiquities, and his network included the richest and most influential art collectors of the Western world. But his methods of purchase and export from China were questioned, and he has been accused of pillaging his own patrimonial heritage. He

295. All the biographical information about C.T. Loo is taken from Géraldine Lenain's biography Monsieur Loo (2013). 


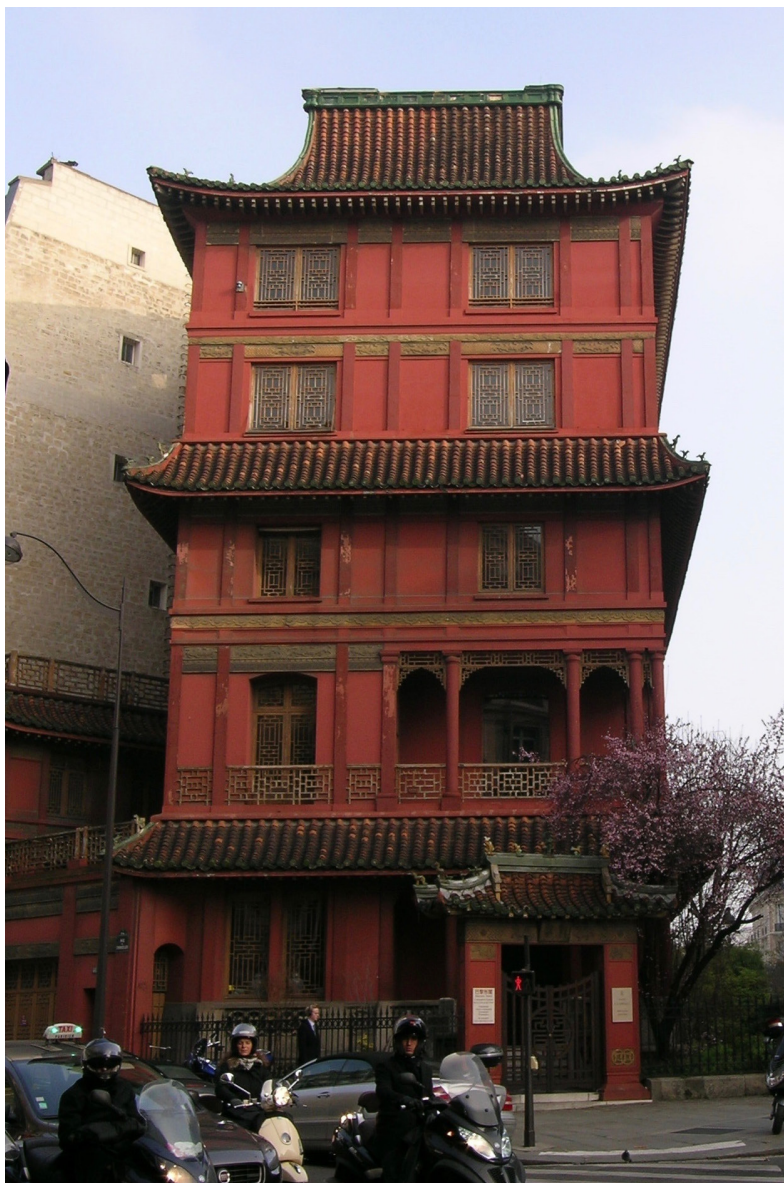

was chased by Chinese authorities, but always claimed that his business had been legal and rightful, often by arguing that there were no laws to prevent his actions at the time.

In 1928, C.T. Loo was awarded the French Legion of Honour, and the same year he opened his magnificent Pagoda - a five-storey gallery and showroom in a mandarin-style building designed by the French architect Fernand Bloch on Rue de Courcelles. The international market for exclusive Chinese art and antiquities, which C.T. Loo had been involved in creating, was at an all-time high around 1930. Johan Gunnar Andersson had just opened his new museum in Stockholm, and was awestruck by his visit to the Pagoda. David David-Weill was tuning in to Asian art as well, and Indochina was featured as the Pearl of the French Colonial Empire in national colonial propaganda. The newly-weds Olov and Ronny Janse

Fig. 24. The Pagoda on Rue de Courcelles in April 2014. mingled with influential curators and wealthy collectors of Asian art at Loo's Pagoda events, which attracted his extensive social and professional networks in the upper Parisian bourgeoisie. C.T. Loo was known for his amiability and loyalty to his friends, and his social functions at the Pagoda were legendary. During these years, Ronny Janse and Marie-Rose Loo developed a close friendship which lasted the rest of their lives.

Most important of all of Janse's new friends was, however, the French historian, orientalist and museum director René Grousset (1885-1952). A historian by training, Grousset published in 1922 Histoire de l'Asie, a three-volume opus which rendered him a position as a leading French orientalist. Over the following thirty years he wrote a great number of ambitious, comprehensive works on the history, art, and philosophy of Asia - from the Near East to India, Indonesia, Indochina, China, and 
the Mongolian steppes. He relied almost entirely on studies of written sources and artefacts, and only visited Asia twice, on one trip to Syria and Iran in 1929-1930, and one to Japan, with a stopover in Indochina, in 1949. Hence René Grousset is best described as a celebrated armchair orientalist and culture-historian, who, "with a scholar's precision and a poet's imagination" made the history of Asia alive for public consumption and school curricula. ${ }^{296}$ An exceptionally active academic, Grousset was not only writing influential books on Asia but also worked as a museum director. He was appointed curator (conservateur adjoint) at the French musées nationaux in 1925, and later became Director (conservateur en chef) of the Cernuschi and Guimet Museums, ${ }^{297}$ which are the two main museums and research institutions for Asian art in Paris. Paul Demiéville writes in his obituary that he was a remarkably social person, who enjoyed "the spectacles of Parisian life" and was ever present and active at salons, dinners and committees of all sorts. But, adds Demiéville, he never forgot about his professional obligations, and it was the combination of his devoted professionalism and social skills, with the ability to connect his museums with benevolent collaborators, that made the Cernuschi and Guimet Museums into model institutions for instructive display and centres of vital research. ${ }^{298}$

When Olov Janse, sometime around 1930, began to turn his career away from European comparative archaeology towards Asia and Indochina, René Grousset became an invaluable supporter of his project. Like Grousset, Janse was a person of great social skills, who thrived on the spectacles of Parisian life. They shared an interest in bold comparative history writing, and they both relied on artefacts in museum collections for their analyses. Grousset was just seven years older, but had pursued a splendid early career so he was professionally more senior. The amiable René Grousset was influential and well connected among museum col-

296. Auboyer 1955:3. In French: "Avec une précision de savant et une imagination de poète $[\ldots] . "$ "

297. The Cernuschi Museum belongs administratively to the City of Paris, and is located in the former residence of the Italian banker and art collector Henri Cernuschi at 7 Ave Vélasquez, adjacent to Parc Monceau. René Grousset was the Director of the Cernuschi Museum from 1933 to his death in 1952. The Guimet Museum is the French national museum of Asian art located at Place d'Iéna. René Grousset was affiliated with the Guimet Museum from 1925 (first as Curator, later Director) from 1925 to his death in 1952 .

298. Demiéville 1954:414. 
lectors and academics of Asian art and archaeology in Paris, and he was keen to support Janse's career turn towards Asia. For Janse, this offered a vital support similar to what he had once received from Henri Hubert for his comparative European studies, and Grousset's backing allowed him to continue his in-between archaeological pursuits, but now with the focus set on Asia. Through Janse, Grousset gained access to direct experience of archaeology in Asia that he could not reach from his armchair. They eventually developed a close friendship that would last until Grousset's death in 1952.

On an academic level, Grousset connected Janse with knowledgeable and influential Asia scholars like Paul Pelliot and Sylvain Lévy, and anthropologists like Paul Rivet. Although they were not close to Janse, they were part of the same milieu in Paris and shared the same networks. Paul Rivet, in particular, shared Janse's interest in comparative cultural analysis with diffusionist models of explanation, but had South America as his area of expertise. ${ }^{299}$ In the coming years, Rivet would be passionately engaged in intellectual resistance to fascism and Nazism, and at the time Janse was planning his expedition, Rivet worked together with Marcel Mauss and Georges-Henri Rivière (who will appear later on in our story) in the establishment of the Musée d'ethnographie de Trocadéro (MET) which opened its doors to the public in 1932..$^{300}$ Marcel Mauss, who also endorsed Janse's turn towards Asia and came in with support along the way, was particularly interested in the possibility of using Janse as an ethnographic envoyé, as he did with his doctoral students and other young anthropologists that were going to be associated with the MET. ${ }^{301}$ Even though Paul Rivet, Sylvain Lévy, and Paul Pelliot were not immediately involved in Janse's work, they were important actors in the milieu that encouraged and supported Janse's planning for his expedition.

But the practical scale of Janse's new turn to Asia also required considerable financial support. Through his position at the Guimet and Cernuschi Museums, René Grousset were connected with patrons and collectors like David David-Weill and Gabriel Cognacq. They all joined forces and created a web of funding and institutional support for an archaeological expedition to Indochina, allowing Olov and Ronny Janse to embark in Marseille in October 1934, on the S S d'Artagnan bound for Saigon.

299. Rival 2010:140; Conklin 2013:65.

300. Conklin 2013: chapter 3.

301. Conklin 2013:3. 


\section{RONNY}

They must have met some time in 1929. He a tall, dark and brown-eyed thirty-seven-year-old cosmopolitan archaeologist, with one foot in Paris and one in Stockholm. She a petite brown-haired and brown-eyed twenty-six-year-old corresponding secretary at the Swedish-Russian Trade Commission in Stockholm. ${ }^{302}$ They got married in Stockholm's City Hall on 23 November $1930 .{ }^{303}$ In her loose-fit crêpe-de-Chine dress surrounded by his family and friends, she looks a little anxious on the wedding photo beside her new husband, looking just as tense in his tail tuxedo with arms crossed over his chest.

She was born in Grodno in Poland (now Belarus) on 27 October 1903, as the first child of Semen Seymour Sokolsky and Mathilde Sokolovskaya. Her first name was Ronny, but they called her Ronichka or Ronja. Two years after Ronny was born, the family was extended with the twin brothers Alexandre and Semen Jr, and another ten years later with a sister,

302. This chapter on Ronny, and a later chapter on Renée, has been based mainly on a compilation and interpretation of fragmentary data found on documents, in letters, and on the back of photographs in Olov and Renée Janse's personal archive (NAA: Janse 2001-29; Per Janse archive). Thanks to a grant from Birgit and Gad Rausing's Foundation for Humanistic Research in 2014, we were able to pursue further investigations into Ronny's earlier history and family, and have help to translate archive information. At this point we made several attempts to find and contact relatives in Russia, and access information at the Russian Embassy in Stockholm and Russian-Swedish Trade Commission in Stockholm, but without success.

303. Stockholms stadsarkiv, Janse: Lysnings- och vigselbok Hedvig Eleonora, 6/11 1930; Lysningsbevis 238; Vigselprotokoll 1199. 
Liubov (later married Dobray). The family, which we believe were Orthodox Christian and Ronny later described as bourgeois, moved around in Eastern Europe during her childhood years, and she attended grammar school in "various places". They eventually settled in the city of Ekaterinodar in southern Russia, not far from the Black Sea, where Ronny went to high school and spent her teenage years.

These were turbulent times in Russia, and the Civil War broke out in 1912 when Ronny was fourteen years old. Ekaterinodar, which had been an important trade centre for southern Russia since the late 1880 s, was taken over several times by opposing parties, and was eventually given the more communist-sounding name Krasnodar, following the October Revolution 1920. The Sokolsky family, however, seem to have been doing rather well, at least initially, and all four children got a higher education. Alexandre studied to become an industrial engineer, Semen an aviation engineer, and Liubov studied medicine and became a physician. At the

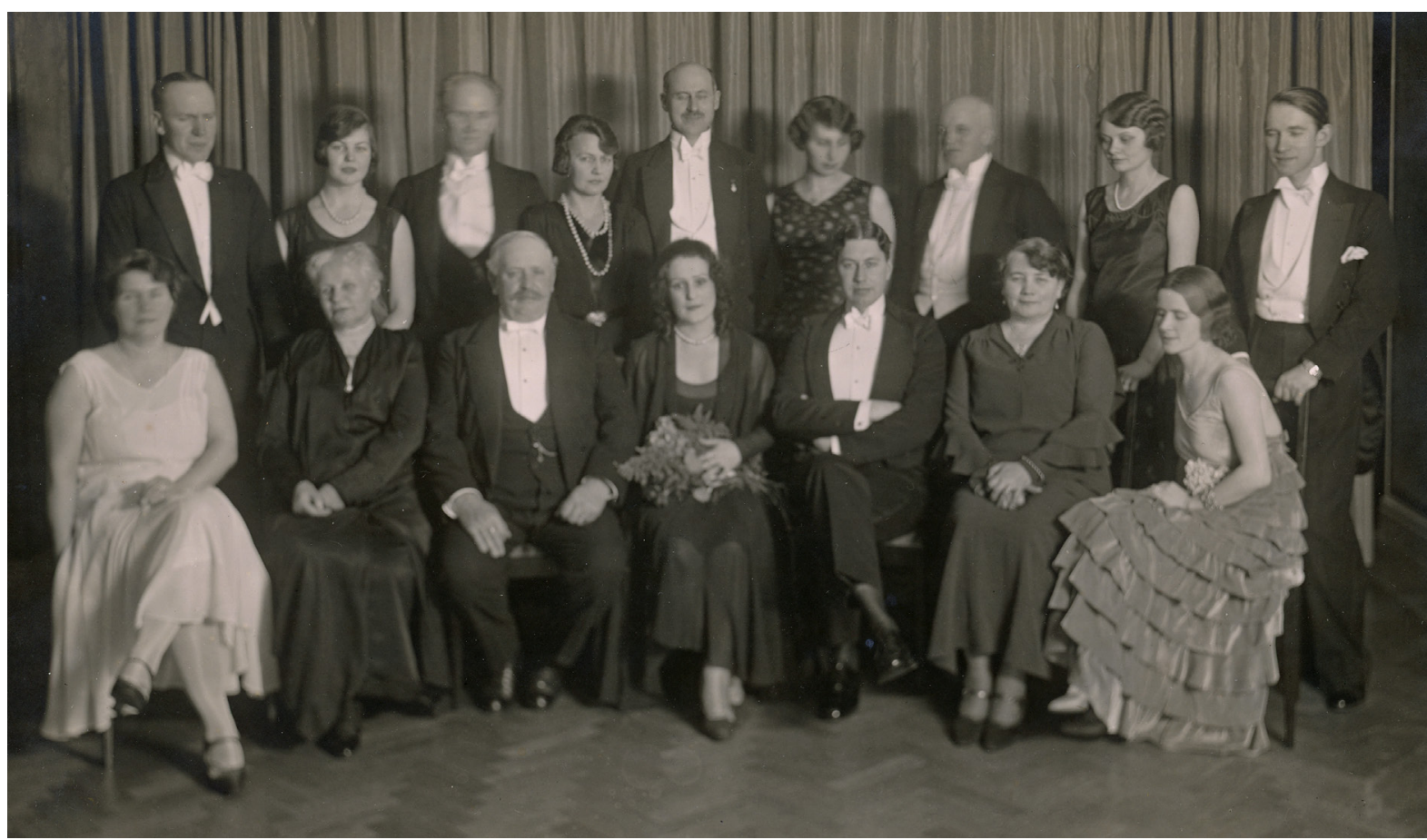

Fig. 25. Wedding photograph 23 November 1930. Top from the left: Birger Nerman, Ann-Mari Janse, Ture Nerman, Nora Nerman, Per Janse, unidentified female, Otto Janse, unidentified female, Einar Nerman. Bottom from the left: Unidentified female, Ida Nerman, Thure Janse, Ronny Janse, Olov Janse, Signe Janse, Kajsa Nerman. 


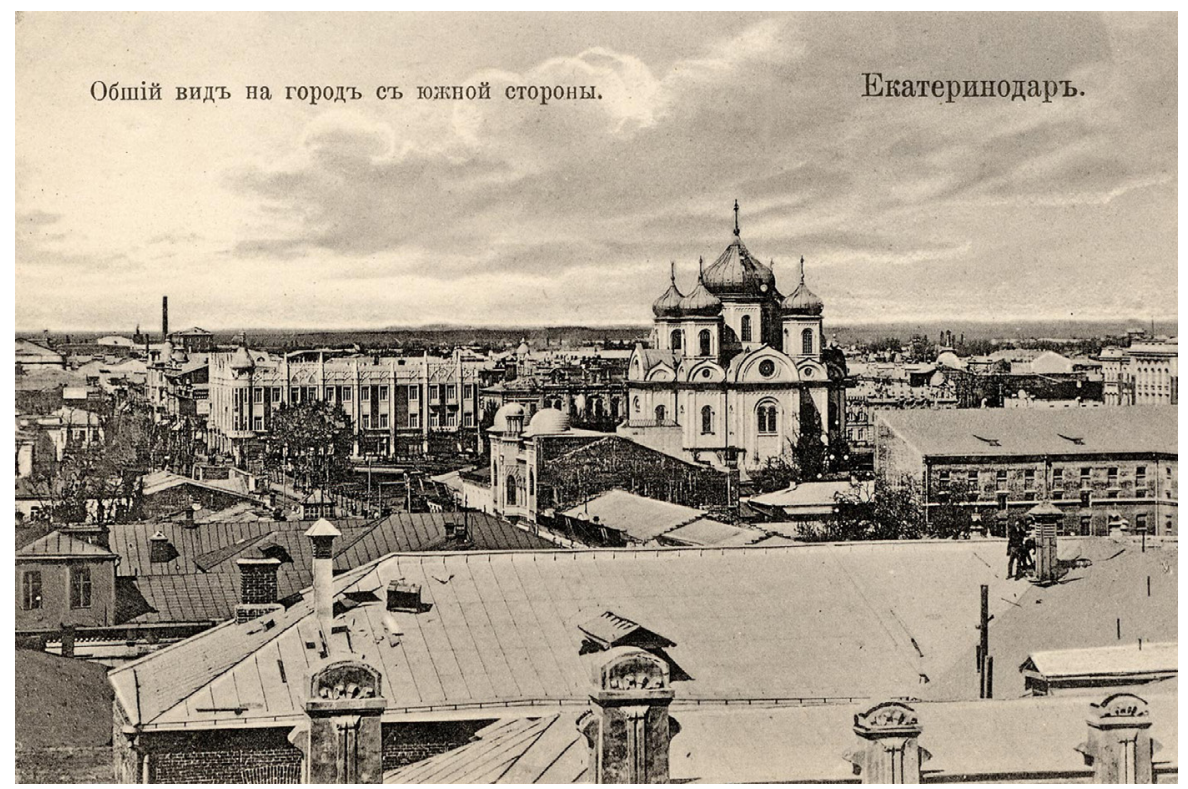

Fig. 26. Ekaterinodar in the early 20 th century seen from the south.

time of the revolution, when she was seventeen years old, Ronny began working as parliamentary reporter for the Department of Foreign Trade in Ekaterinodar. In parallel with her employment she enrolled at the Faculty of Social Science, where she studied a year and a half before her student's status was changed to auditor, and her student privileges were withdrawn on account of her bourgeois background.

She was then twenty years old and left Krasnodar for Moscow, where she assumed the same position, as parliamentary reporter at the Department of Foreign Trade. After only a couple of years in Moscow, she received a posting at the Swedish-Russian Trade Commission in Stockholm and left Russia for good. She travelled through Finland and was twenty-two years old when she arrived in Stockholm in 1925. There she began working for the Commission as a corresponding secretary. We do not know why she decided to go to Stockholm, and apart from the fact that she travelled quite extensively during the years she was based in Stockholm (to Germany and Czechoslovakia in 1926-27, and to Denmark, Holland, England, and France in 1929) it is unclear exactly what kind of work she did for the Trade Commission. We know very little about Ronny Sokolsky's family history and professional life before she married and became Mrs Janse.

But we know that both their lives were changed dramatically with their marriage. Both had been independent professional individuals, not 
Fig. 27.

Ronny

Sokolsky in 1929. 
afraid to travel and settle in new places. For her, the marriage meant that she resigned from her employment and cut the formal ties with her native country. Meanwhile, her family were struggling in Krasnodar. Josef Stalin had taken over as leader of the Soviet Union after Lenin's death in 1924 , and the situation for the bourgeoisie was severe. We will see in the following chapter how it grew more and more acute during the first half of the 1930s, how Ronny eventually lost touch with her family, and was left to assume that most of them had been executed around 1935 .

In the painful relation to the Soviet Union, she found an unexpected connection with Ture Nerman's wife Nora. Nora (born Hedblom) was a daughter of a wealthy industrialist from Hudiksvall who had married a naturalized Trotskyist diplomat, Grigorij Alexandrov in 1910. They had two daughters: Tanja and Mimi, and had divorced just before she met and married Ture Nerman in 1921. Alexandrov later remarried, had another daughter, and took all three girls with him when he emigrated back to the Soviet Union in 1928, two years before Ronny and Olov got married. He was arrested for treason in 1937 and executed a year later. The daughters remained in the Soviet Union, and the separation was a major trauma for Nora. In his earlier years Ture Nerman had been a keen communist, singing the praises of Lenin and the October Revolution, and was one of the founders of the Swedish Communist Party. On a well-known press photo he is seen walking next to Vladimir Lenin on his visit to Stockholm in 1917. But his marriage to Nora and the developments in the Soviet Union after 1924 gave him reason to take a strong stance against Stalinism, and in 1939 he instead joined the Social Democratic Party.

As a couple, Ronny and Olov also formed a warm and close relationship with Birger and Barbro Nerman, who married in 1932. A letter from Olov to Birger ends with: "P.P.S.S. Ronny kisses Barbro and Birger heartily, because a greeting is not enough for her Caucasian temperament." Letters from Ronny to Barbro have been kept in Birger Nerman's archive, and here we get a glimpse of Ronny's characteristic, intensive, lively, and enthusiastic tone, with a Russian accent, and with underscores and exclamation marks in abundance:

How are You, dear Barbro? It will be wonderful to hear about You soon. Do You still smile so sweet and warmly? How are things with little Birger? We shall be glad to hear that You have not abandoned us and forgotten. I have a feeling, that it is years that we have nothing heard from You, dear friends. 
How ar [sic] Ture's! Hope well. If you visit them in the country, then send our heartfelt greetings - the red front! [illegible]! Hitler!

What fun stories from Arne's \& their excavations?

Will You not soon come to Paris, it would be so great to see You, dear little sweeties! ${ }^{304}$

In letters from this period we see that married life seems to have done them both good. The tone is warm, loving and cheerful. Olov's letters have suddenly a more mature character and he seems overall more content. They lived in a third-floor flat at Polhemsgatan 18 in Kungsholmen in Stockholm (fig. 28). In the summers they passed the time with "boat trips, swimming, walks, log burning, and garden work" at the Janse family's summer house in Skagshamn near Valdemarsvik, and visited Ture and Nora Nerman in their summer house on Blidö in the Stockholm archipelago.

Most of the autumns, winters, and springs they spent in Paris, where Olov worked as before, and they had a rich and active social life among the academic and art-collecting bourgeoisie. Ronny writes to Barbro Nerman that "Olle was so heartily and warmly greeted here in French circles and so sought-after, that I can say that my heart was overfilled with proudness [...]". They stayed first in a "nice flat" on Rue Saint-Honoré in the city centre, with "a good maid who cooks good food". A little later they moved to a flat on Rue des Sablons, with a terrace where they planted flowers. Beside her "conjugal duties" Ronny attended courses in the history of French art and literature at the Sorbonne and the École du Louvre. In February 1933 she writes that she is very pleased with her courses, but has "not yet lost her desire to work and earn". It is clear that Ronny was a professional woman with many skills, who enjoyed working and being busy. The life of an idle bourgeois wife was not something she desired. ${ }^{05}$

Olov lectured as before at the Sorbonne and the École du Louvre.

304. Letter from O. Janse to B. Nerman, n.d., possibly 1932. Riksarkivet. Kartong 2. Korrespondens Brev II 1923-1934; Letter from O. Janse to B. Nerman, 11 July 1932. Riksarkivet. Kartong 2. Korrespondens Brev II 1923-1934; Letter from Ronny to Barbro Nerman, 18 February 1933. Riksarkivet. Kartong 2. Korrespondens Brev II 1923-1934; Letter from O. Janse to B. Nerman, 22 January 1934. Riksarkivet. Kartong 2. Korrespondens Brev II 1923-1934.

305. Ibid. 


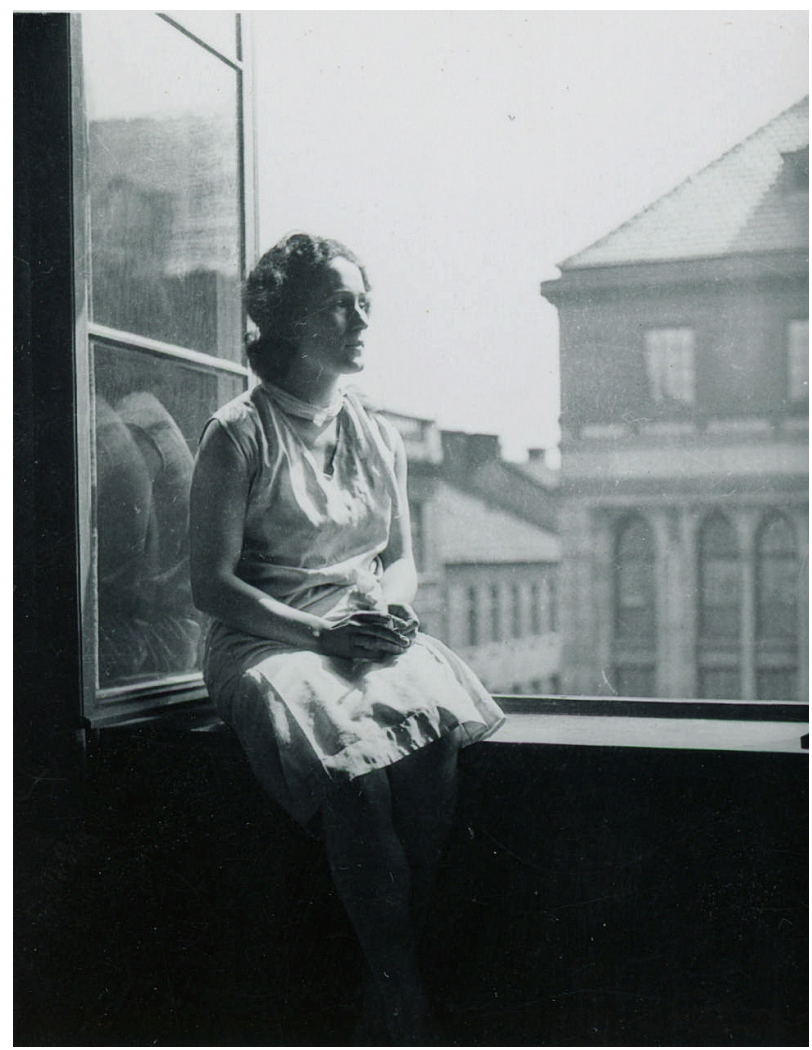

Fig. 28. Ronny smoking a cigarette in the window at Polhemsgatan 18, 1929.

Together they planned and carried out an excavation in Villambis, at the estate of the Swedish Count Wrangel, in the autumn of 1933. And they planned for their upcoming expedition to Indochina. They visited the Exposition Coloniale in Vincennes in 1931, and formed the necessary support network of institutions and wealthy patrons. Ronny played a crucial role, creating and stabilizing relations with the female parts of the social networks, which are often officially invisible in the historical archive material, but were of utmost importance in reality. It was, for example, Ronny's close affinity with Marie-Rose Loo that formed the strongest bond in what would be a long-lasting and important friendship between C.T. Loo and Olov Janse. ${ }^{306}$ In July 1933, Olov added a P.S. to Birger, in a letter from Ronny to Barbro Nerman:

306. Throughout the following chapters we will return to the Ronny's pivotal importance for many of the professional pursuits that were carried out in Olov Janse's name. We will also return to the friendship between Marie-Rose and C.T. Loo, and Ronny and Olov Janse in the chapters "Darling, Dearest" and "Renée". 
An acquaintance of ours Mr Jacques Orcel visits Stockholm at the end of this month and brings our best greetings. It would be really great if Birger would show him the museum and assist him with advice. Mr Orcel is a prominent art collector and patron.

With this starts the next phase in Ronny and Olov Janse's lives and careers: the Indochina expeditions. 
II. EXPEDITIONS 


\section{THE THREE EXPEDITIONS REVISITED}

The main purpose of our campaign was to study the Chinese civilization in Indo-China, especially under the Han dynasty, and its possible connections with the West. Three different expeditions were devoted to this work. ${ }^{307}$

The expeditions to Indochina (1934-1940) form a centre of gravity in Olov Janse's life and career, and have been formative for most of his professional legacy. In the history of archaeology Janse is mostly known as a Swedish archaeologist who worked in Indochina; his main scientific oeuvre is the three-volume report Archaeological Research in Indo-China; and when he wrote his memoirs for a Swedish audience he formed it around a travel account from the Indochina years. The three expeditions 1934-1940 were at once a crescendo and the end of his earlier cosmopolitan career in Europe, and they defined his later internationalist career in the United States. But what do we in fact know about these important years in his archaeological life? Official accounts - the three report volumes, ${ }^{308}$ his memoirs, ${ }^{309}$ and articles in journals and newspapers - are all crafted on the same theme: that the aim was to study the westward relations of the southern extension of the Chinese Han empire (206 BC-AD 220 ), and that the expeditions discovered groundbreaking facts about this

307. Janse 1947: v.

308. Janse $1947 ; 1951 ; 1958$.

309. Janse 1959 . 
and other prehistoric cultures such as Dong Son ${ }^{310}$ and Sa Huynh..$^{31}$ But a more detailed study of a wider range of archive material, viewed against a backdrop of political circumstances, offers a more complex understanding of the three expeditions.

In world politics, the mid and late 1930 s was a time of increasing political tension, decreasing resources, and the eventual outbreak of the Second World War. In their personal lives, Olov and Ronny Janse first experienced a period of great success followed by a deep crisis, which in turn led to a professional and personal reorientation towards a new life in the United States. Published reports and articles from the expeditions have, like almost all archaeological text of that era, omitted such concrete details to create an illusion of a freestanding archaeological enterprise driven merely by prehistoric facts and scientific ideals. But judging from the much richer accounts found in letters and other archive materials, ${ }^{312}$ it was circumstances other than prehistory and science - from world politics to the most intimate personal sphere - that were the most decisive in the formation of their three expeditions. Viewed with such an embedded vision, the three expeditions to Indochina stand out as quite different from one another, and each has its own distinctive mood.

The first expedition, which lasted nearly eight months from October 1934 to May 1935, is surrounded by an aura of exhilaration and success. In terms of world politics, this was the swansong of Imperial France. The expedition was conceived in the slipstream of the immensely successful 1931 Exposition Coloniale in Vincennes, and Olov and Ronny enjoyed the positive energy of the last push of the French colonial project. The expedition was their first major project together as a married couple, and it turned out to be a great professional success. On a personal level it was not only a magnificent adventure but a professional investment, which they hoped would give Olov a secure position as director of the Museum of Far Eastern Antiquities in Stockholm and allow them to settle in Sweden for good. Hence the whole expedition and the following seventeen-month interlude in France and Sweden passed in a mood of euphoria.

The second expedition, lasting fourteen months from October 1936

310. In Vietnamese: Đông-so'n.

311. In Vietnamese: Sa-huỳnh.

312. Personal material concerning the Indochina years are found mainly in the Smithsonian Institution's National Anthropological Archives, Östasiatiska samlingarna, Riksarkivet, Arbetarrörelsens arkiv, the Marcel Mauss archive, and the archives of the Harvard-Yenching Institute and the Peabody Museum. 
to December 1937, was a major turning point in their lives and careers, and the mood here is crisis. The first six months passed in much the same fashion as the previous expedition, although their letters home had lost some of the earlier euphoric tone. These were times of anxiety, with the economic depression in Europe, the recent outbreak of the Spanish Civil War, and a political and financial crisis in France. But Olov and Ronny Janse maintained their Indochina work as before, under the auspices of French authorities. The first major blow came in April 1937, when they received a letter from Paris with the news that Janse was not even being considered in the search for a new director of the museum in Stockholm. This coincided with a new crisis in the French economy, which meant that the funding they had been granted to cover the expedition expenses suddenly lost much of its value. Moreover, the economic crisis led to a political decision not to employ any foreign citizens on French state funding. All their plans for the future had failed, they had lost most of the support that had only recently looked so secure, and they were freefalling. But they managed to get an invitation to the United States from the Buffalo Science Museum, and left Saigon on a ship bound for Honolulu and the United States. From the year-long stay in Buffalo they corresponded with a friend from Paris, the Russian-born Japanologist Serge Elisséeff who had recently been appointed director of the Harvard-Yenching Institute in Cambridge, Massachusetts. They persuaded him and the Institute's Board of Trustees to sponsor a third expedition, and to fund the subsequent work of publishing the results from all three expeditions.

So when they departed again from the United States and travelled back to Saigon, it was on a mission from the Harvard-Yenching Institute. The mood of this twenty-month-long third expedition is refocus. All their efforts from now on were refocused on creating a new life for themselves, with new professional opportunities, in the United States. The volatile political situation in Asia and Europe forced them to reorientate and refocus their plans several times. After one year of excavations that largely repeated their previous work, the increasing threat from the Sino-Japanese War forced them to leave Indochina. They decided to travel to the Philippines, which had a US-supported Commonwealth Government, and there excavated a number of sites from the Song and Ming periods. The excavated finds were shipped from Manila to the Harvard-Yenching Institute, to be added to the finds that had already been shipped from Hanoi. The Second World War had now broken out in Europe and the political situation in Southeast Asia made it increasingly difficult to 
pursue their work. Hence they ended their third and final expedition and returned to Harvard in Cambridge, Massachusetts, where the cases full of finds from Indochina and the Philippines waited to be unpacked. 


\section{PRELUDE}

The preparations for the first expedition took several years. ${ }^{313}$ In his memoirs Janse describes how his interest in Indochina was first sparked in Paris, when Henri Hubert was still alive and Johan Gunnar Andersson came to visit the Musée des antiquités nationales in Saint Germain. ${ }^{314}$ Andersson had taken an interest in some bronzes from Indochina in the comparative collections and contracted Janse to write a paper comparing them with some specimens in his Stockholm collection. ${ }^{315} \mathrm{~A}$ few years later, when Henri Hubert was dead and Janse had fallen out with Salomon Reinach over the Glozel affair, he renewed his interest in Asia and approached René Grousset, director of the Cernuschi Museum. In his memoirs Janse says that he was driven by a life-long fascination with China when he decided to pursue his plans for an archaeological expedition to Indochina. China would normally have "offered the richest harvests and should have best furthered the scientific purpose of an expedition" and hence it was, he says, the political circumstances of the 1930s, when foreigners were no longer welcome to pursue archaeological missions in China, that made him focus on Indochina - "little China" - instead. ${ }^{316}$ But is this the full story? On closer inspection there seem to have been at least three other

313. Janse 1959; Östergötlands Dagblad, 1 September 1934: "Prof. Olov Janse till Indo-Kina."

314. Janse 1959:18.

315. Janse 1931. He would later regard these artefacts as representing the Dong Son culture, e.g. Janse 1959:18.

316. Janse 1959:18-20. 
factors involved in his move towards Indochina, which are not mentioned in any official accounts.

One is Janse's long association with France, his familiarity with French official institutions and his fluency in the French language. At the immensely successful Exposition Coloniale in Vincennes 1931, Indochina was described as the Pearl of the French Colonial Empire (a paraphrase of India as the Jewel of the Crown in the British Empire), and a full-scale replica of Angkor Wat was the star turn of the exhibition. The exhibition was staged at a time of colonial anxiety, with the explicit aim of turning the public opinion in favour of the French colonial project. It was a tremendous success, and was followed by a wave of procolonial sentiment in metropolitan France. ${ }^{317}$ Olov and Ronny Janse visited the Exposition Coloniale, ${ }^{318}$ and they began to plan for their expeditions around this time, characterized by procolonial fervour. Moreover, working in Indochina was literally the same as working in France when it came to official language and bureaucratic structure. It was in every sense more practically accessible to him than China, where he lacked all such skills.

A second important factor is Ronny. When Olov was first contracted by Johan Gunnar Andersson to do the comparative study of bronze artefacts, Ronny had not yet entered his life. A few years and a wedding later, her presence as a constant assistant - and his obligation to support her meant that he could, and needed to, pursue larger and more independent professional projects.

A third factor, related to the second, is the prospect of Johan Gunnar Andersson's retirement. With a less favourable situation at the Musée des antiquités nationales after Hubert's death, ${ }^{319}$ he and Ronny were looking for opportunities to settle in Sweden. With the prospect of achieving valuable knowledge and experiences from "little China", Andersson's upcoming retirement seemed like an effective opportunity to seize a secure position in Stockholm. All these circumstances (along with Janse's childhood fascination with China and the impossible situation with Reinach, which is also mentioned in his memoirs as a crucial factor) must have contributed to the decision to approach René Grousset and start planning for an expedition to Indochina.

René Grousset had recently been appointed director of the Cernuschi

317. Norindr 1996; Morton 2000; Källén 2015: chapter 5.

318.E.g. NAA: Janse 2001-29.

319. Janse 1959:21-30. 
Museum, which is the Paris city museum of Asian art, located at Parc Monceau. Founded on the private collections of Italian banker Henri Cernuschi, the museum housed collections of fine art rather than archaeological material. But Grousset, himself an armchair historian, came in with strong support for Janse's expedition plans. Janse was elected to the museum's advisory board ${ }^{320}$ where he argued, along with Grousset, for the need to include excavated archaeological artefacts in the collections. Grousset suggested that the Cernuschi Museum would be formally responsible for Janse's expedition and offered a first contribution of funding. Janse, in turn, promised to return to Paris with a unique set of original artefacts to enrich the museum's collections..$^{321}$

As a second step, Grousset informed George Cœedès, Director of the French research institute École française d'Extrême-Orient (EFEO) in Hanoi, about their plans. The archaeology at EFEO had so far focused either on the art and epigraphy of monumental architecture, or on scientific investigations of prehistoric sites akin to geology and craniology..$^{32}$ Coedès saw an opportunity to have some known archaeological sites systematically investigated by an archaeologist with methodological training from Scandinavia, and hence fully endorsed Janse's plans. ${ }^{323}$ The influential art collector and patron David David-Weill, who was at the

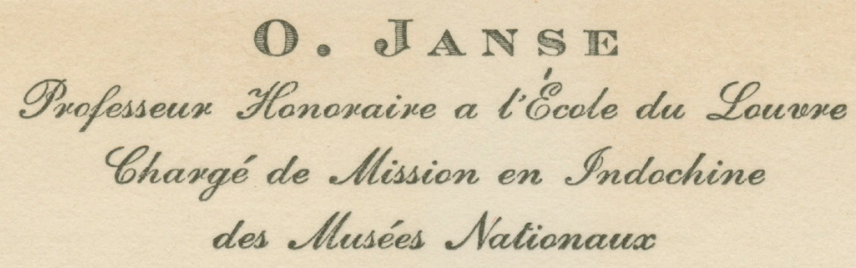

Fig. 29 .

Olov Janse's

business

card.

$$
\text { 22. Rue Washington Paxis - VIII }{ }^{B}
$$

320. The decision to elect Janse to the Scientific Committee of the Cernuschi Museum was made on 30 April 1933. NAA: Janse 2001-29.

321. Janse 1959:21-22. For a more detailed analysis of the relations between Janse and his patrons, see "Conclusion".

322. Clémentin-Ojha \& Manguin 2001; Källén 2015.

323. Janse 1959:23. See also Dias 1991 for a more general discussion of French and Scandinavian archaeology in the early twentieth century. 
time President of the Council of the National Museums in Paris, also contributed with funding and support for the project. Georges-Henri Rivière at MET, the ethnographic museum at Trocadéro, offered support and got a promise of ethnographic collections in return. Further scholarly support was secured from renowned scholars like Paul Pelliot, Georges Salles, and Joseph Hackin, and smaller contributions of funding came from the wealthy art collectors Gabriel Cognacq and Jacques Orcel in Paris, and the Musée du Cinquantenaire in Brussels, Belgium. Janse also reached an agreement with Gerhard Lindblom, Director of the Ethnographic Museum in Stockholm (Swe: Statens etnografiska museum). While in Indochina, he would acquire ethnographic objects and produce ethnographic documentation that he sent back to Lindblom and the Ethnographic Museum in Stockholm. ${ }^{324}$ The formal sponsors of the expedition were the French Department of National Education, the Museums of Paris, the French Government of Indochina, and the École française d'Extrême-Orient. ${ }^{325}$

324. Letters from O. Janse to G. Lindblom (1934-1952, 33 in all) are kept in the archive of the Ethnographic Museum in Stockhom (Statens museer för världskultur). Inkl skrivelser. Huvudserie 1934 (E1:7); 1935 (E1:8); 1936 (E1:9); 1937 (E1:10); 1938 (E1:11); 1945 (E1:19); 1946 (E1:20); 1947 (E1:21); 1948 (E1:22); 1952 (E1:27).

325. The "Ordre de Mission" was signed by Henri Verne, director of the French National Museums, 24 September 1934. NAA: Janse 2001-29; Janse 1947: vi-x; 1959:23, $31-32$. 


\section{EUPHORIA}

INDOCHINA, OCTOBER 1934-MAY 1935

Having secured the necessary support and funding, Olov and Ronny embarked on the S S d'Artagnan in Marseille bound for Saigon, on 14 October $1934 \cdot{ }^{326}$ Once on board, they began to record the journey with their new film camera. On the films they are seen posing and laughing by the gunwale. ${ }^{327}$ Giggling and flirtatious, they seem relaxed and exhilarated. Relaxed, perhaps, to have left all the stressful preparations behind, and exhilarated about the adventure they had just embarked on.

The first journey from Marseille to Saigon was itself an important event. Unlike their subsequent journeys to and from Asia, it is featured in detail in letters, and in Janse's memoirs. The d'Artagnan sailed from Marseille, via the Suez Canal to Djibouti (then in French Somaliland), Kandy (then in British Ceylon) and Singapore, before reaching Saigon. Descriptions of the journey in Janse's memoirs and letters repeat the narrative format of popular travel writing that he acquired as a young man writing travel reports for his hometown newspaper. ${ }^{328}$ Sticking to the

326. Janse 1959:32.

327. This, and the following references to their films, are taken from the film shot during the second expedition, which had initially a very similar mood to the first and followed the same itinerary. The films shot during the first expedition were left in Paris during the first interlude, and were not recovered (owing to the war) until Janse was back in Paris going through their stored belongings in 1946-47 (see the chapter "Darling, Dearest"). These films from the first expedition are not among the ones now stored at the Swedish Televison Archives (see the chapter "Memorabilia"), and we have no knowledge of their present whereabouts.

328. See the chapter "Travel Writing". 
format of Mary-Louise Pratt's monarch-of-all-I-survey genre, ${ }^{329}$ he works with rhetorical figures that induce distance. This, in turn, gains position for himself as narrator and expedition leader:

Like the rest of the Compagnie des Messageries Maritimes' large luxury ships, the d'Artagnan had chefs with a reputation of being at the top of French cuisine. Each meal except breakfast was served with wine à discrétion, i.e. ad libitum. The very large, beautifully decorated menu offered a generous selection of the finest French culinary compositions. ${ }^{30}$

As a city, Port Said is uninteresting and lacks any picturesque element. The poverty, which prevails in the streets and alleys, makes a distressing impression, especially when one suddenly stands face to face with deprivation after the perhaps unnecessarily luxurious life on board. Swarms of cripples, itinerant hawkers and beggars, covered in rags, followed us everywhere. Some children slept in the gutters, with flies buzzing over the pus that ran down their cheeks from their trachoma-infected eyes. [...] Depressed by the sad views we hurried back aboard. ${ }^{331}$

[T] he d'Artagnan made another stopover in Djibouti. At the harbour, located a short distance from the city itself, were a long line of cab-like, wobbly carts, drawn by old skinny nags who could barely stand on their stiff legs. The carts could have served as museum pieces. However, they were the only available means of transport to get into town unless you wanted to make use of your

329. Pratt 2008:200.

330. Janse 1959:34. In the Swedish original: "I likhet med de övriga av Compagnie des Messageries Maritimes' stora lyxbåtar hade 'd'Artagnan' kockar med rykte om sid att stå på höjden av fransk kokkonst. Till varje mål utom frukosten serverades vin à discrétion, d.v.s. i obegränsad mängd. De jättestora, vackert dekorerade matsedlarna bjöd på ett stort urval av de bästa franska kulinariska kompositioner."

331. Janse 1959:35. In the Swedish original: "Port Said är ointressant, som stad betraktat, och saknar varje pittoreskt inslag. Fattigdomen, som råder på gator och i gränder, gör ett beklämmande intryck, särskilt när man plötsligt står ansikte mot ansikte med nöden efter det kanske onödigt luxuösa livet ombord. Svärmar av krymplingar, kringvandrande gatuförsäljare och tiggare, höljda i trasor, förföljde oss överallt. Några barn sov i rännstenarna, med flugor surrande över varet, som rann nedför kinderna från deras trakomsjuka ögon. [...] Deprimerade av den sorgliga synen skyndade vi oss åter ombord.” 
own feet. And you wouldn't, in the heat. We took courage and stepped into one of these "cabs", while the charioteer, black as the night, shouted jubilantly and cracked his whip with joy at having a couple of passengers. ${ }^{332}$

The monarch-of-all-I-survey genre of travel writing builds characteristically on (i) an aestheticization of the landscape, (ii) a search for density of meaning in the passage, and (iii) a prediction of mastery in the relation between seer and the seen. ${ }^{333}$ In Janse's accounts, the d'Artagnan represents France; the opulent and luxurious, functional, and up to date. From a secure position inside the vessel (metaphorically: inside France), he comments on the landscapes and cultures he passes along the way. A "red-hot, desolate sandy plain, stretching as far as the eye could see" 334 amplifies the feeling of slowness and boredom in their passage through the Suez Canal and across the "equally disconsolate, infernally hot Red Sea". ${ }^{335}$ Unlike the aestheticized landscapes in Pratt's monarch-of-all-Isurvey, these sceneries are neither beautiful nor interesting. As contrasts to the beautiful and alluring landscapes closer to the destination, they rather work to enhance the length of the passage, hence emphasizing the distance covered. With ample use of contrasting adjectives and prepositions, life on board is juxtaposed with sites and sceneries along the way. In the quotations above, Janse uses words such as large, luxury, at the top, beautifully decorated, generous, and finest to describe life on board the ship. The passages describing their visits to Port Said and Djibouti are instead filled with diminishing and demeaning adjectives, such as uninteresting, distressing, infected, depressed, skinny, barely, and only. Contrasting health with illness, the beautiful with the plain or ugly, and opulence with need,

332. Janse 1959:35-36. In the Swedish original: "Vid utloppet gjorde 'd'Artagnan' ytterligare ett uppehåll i Djibouti. Vid hamnen, belägen ett stycke från själva staden, stod en lång rad vingliga, droskliknande kärror, förspända med gamla magra hästkrakar, som nätt och jämnt kunde stå på de stela benen. Kärrorna kunde ha tjänat som museipjäser. De var emellertid de enda fortskaffningsmedel som stod till buds för att komma in i staden, om man inte ville begagna apostlahästarna. Och det ville man inte i värmen. Vi tog mod till oss och klev in i en av dessa 'droskor', medan den nattsvarte körsvennen jublande hojtade och smällde med piskan i glädjen över att ha fått ett par passagerare.”

333. Pratt 2008:200.

334.Janse 1959:35. In the Swedish original: "denna glödheta, ödsliga sandslätt, som sträckte sig så långt ögat nådde”.

335. Janse 1959:35. In the Swedish original: "det likaledes tröstlösa, infernaliskt heta Röda havet". 
Janse assumes a superior position for himself, his French peers, and his Swedish readers, vis-à-vis the peoples and cultures of Port Said and Djibouti.

Because Janse is an archaeologist and the quotations are from his memoirs (with the subtitle Archaeological experiences in Southeast Asia), it is particularly interesting to see how he makes use of words that imply temporal distance. The cart that took them from the harbour to Djibouti city is one example. The cart is described at length, with an abundance of details designating primitivity: squeaking and wobbling with loose wheels, no springs, a missing roof, and so on. Writing about it as cablike, and using ironic quotation marks around "cabs", Janse marks the distance from the modern cab and thereby emphasizes its identity as something inferior, or a pre-form to the modern norm. The relegation of the Djibouti carts to the past is ultimately confirmed by saying that they could have served as museum pieces. On the same stop-over, Janse also purchased a bundle of long spears (primarily to get rid of an annoying man at the market) ${ }^{336}$ that he sent to the Ethnographic Museum in Stockholm. The people they encountered in Djibouti are metaphorically relegated to the past by their association with the material museum pieces. Their dark skin colour is repeatedly emphasized and they are described in terms that mark a distance to modern culture. As such they stand out in Janse's text as a dark, blunt, and ignorant backdrop to the light civilized presence of the visitors from the French passenger ship. This can be compared with the slightly less demeaning tone in a letter to his friends in Sweden, from the same visit to French Somaliland:

We travelled into the desert to an oasis, and in one place we got to see a real Negro village. The Somali Negroes are generally wellgrown, and appear to be agreeable. ${ }^{337}$

336. Janse 1959:36. In the Swedish original: "En annan höll i ena handen ett knippe långa spjut [...] för att slutligen bli av med honom, köpte jag lansarna, vilka skickades till Etnografiska museet i Stockholm."

337. Letter from O. Janse to T. Nerman, 19 October 1934. Arbetarrörelsens arkiv och bibliotek. Ture Nerman 3.1.7. In the Swedish original: "Vi reste in över öknen till en oas och fick på ett ställe se en verklig negerby. Somalinegrerna är i regel välväxta och verkar vara hyggliga." 
In his memoirs we see how Janse once again ${ }^{33^{8}}$ operates as an archaeological (cum-ethnographic) travel writer who cunningly moves through time and space, claiming a double control over distance. As a narrator he gains prestige and position by moving between distant units (in time and/or space), and acting as an expert by offering translations between them.

After crossing the Indian Ocean they arrived in Ceylon (now Sri Lanka) where they stopped one day to visit Colombo and the historical town of Kandy. The memoir descriptions of Ceylon also work to create a sense of contrast and distance to the modern European way of life. But unlike the Africans they encountered earlier, the Buddhist locals are not portrayed as blunt and ignorant, they appear rather as sluggish yet philosophically dignified:

Here in Ceylon all pious people seemed to have resigned, accepted their lot. By suppressing natural desires and passions and forsaking even the simplest amenities they have reached a state of peace of mind. They ignore, in other words the telephone and telegraph, plumbing, military service, taxes and the eight-hour working day. $[\ldots] \mathrm{We}$, on the other hand, hurried on as usual. ${ }^{339}$

The arrival of the d'Artagnan in Saigon, the southern port of French Indochina (now Ho Chi Minh City in Vietnam), is also featured in detail on film and in the memoirs. As they travelled slowly upstream the shallow river, surrounded by marshy shores and an uninhabitable, depressing landscape, ${ }^{34}$ someone spotted the spires of the French cathedral in Saigon and shouted: les Voilà! - there they are! This marks an important point of transition in Janse's text, from the slow and depressing passage, to the exciting entry into the civilization awaiting them at the destination. And as soon as the ship had berthed at the quay, they were welcomed by representatives from the local French government:

338. See also the chapter "Travel Writing".

339. Janse 1959:38, in the Swedish original: "Här på Ceylon tycktes alla fromma människor ha resignerat, funnit sig i sin lott. Genom att undertrycka naturliga önskningar och lidelser och försaka även de enklaste bekvämligheter har de uppnått ett tillstånd av själsfrid. De struntar med andra ord i telefon och telegraf, rörläggning, värnplikt, skatter och åtta timmars arbetsdag. [...] Själva var vi däremot jäktade som vanligt."

340. Janse 1959:38, in the Swedish original: "sumpiga stränderna", "obeboeligt, tröstlöst landskap". 
The customs inspection was nice and easy. When we had come down the gangplank together, mademoiselle [Naudin, Director of the Musée Blanchard de la Brosse] took us to a car with driver and said: "This is a car, which the Governor has placed at your disposal during your stay here." With light hearts we took off to the Hotel Continental, where rooms had been reserved for us. The hotel seemed typically French, with good beds, good food and excellent wines. ${ }^{341}$

The passage describing their arrival and the French hotel where they checked in, has a cheerful tone and is filled with positive adjectives such as nice, easy, light, good, and excellent. Altogether, these text passages featuring an opulent life on board the SS d'Artagnan, a miserable situation in Port Said and Djibouti, a carefree, sluggish yet dignified Buddhist life in Ceylon, and a well-organized outpost of French civilization in "little China", are designed rhetorically to create a sense of meaning in his passage from Europe to Indochina. At the same time, the memoirs effectively imbue readers (who are likely to have trusted its contents as facts about different lands and cultures) with a strong, stereotyped, hierarchized vision of the world, with Janse himself and his French associates posing as the only representatives of modernity and civilization and hence the rightful masters of the world.

The land they had arrived in - then French Indochina, now Vietnam - had a long and complex history. After the rule of several independent states, most famously under the Hùng kings, it was dominated for long periods by Chinese empires beginning with the Han (206 BC-220 AD). The rule of native kingdoms and dynasties (such as the Lý, Lê, Tràn, Nguyen, and Champa) followed over the next 1500 years, interrupted by waves of Chinese domination and disturbed by various interests and interventions from foreign powers, until France, after years of fighting with the native rulers, made it a protectorate under the name Indochine française in $1887 .{ }^{342}$ The first protectorate included the regions Tonkin,

341. Janse 1959:39, in the Swedish original: "Tullvisitationen var trevligt okonstlad. När vi tillsammans hade kommit nedför landgången, förde mademoiselle [Naudin, chef för Musée Blanchard de la Brosse] oss fram till en bil med chaufför och sade: 'Detta är en bil, som guvernören har ställt till ert förfogande under er vistelse här'. Med lätt hjärta begav vi oss till hotel Continental, där rum hade beställts för oss. Hotellet verkade typiskt franskt, med bra bäddar, god mat och utmärkta viner."

342. Cooper 2001. 
Annam, and Cochinchine (which together are the equivalent of today's Vietnam) and Cambodge (which is now Cambodia). ${ }^{343}$ The final region, les Laos (now Laos) was added six years later, in $1893 .{ }^{344}$ Indochina eventually became something of a favourite colony in the French empire, with considerable economic importance as a source of rubber, metals, rice, tea, coffee, pepper, and coal.

But the establishment of Indochina as a French colony in the last decades of the nineteenth century was not only a matter of physical establishment of a conquered territory. It meant also the establishment of an imaginary space, or trope, in Imperial France. In the words of Panivong Norindr, Indochina became for the French "a space of cultural production". ${ }^{345}$ And as part of this process, an image of Indochina was created in the European imagination and was moreover reflected in the growth of a literary body of colonial fiction in metropolitan France. This fiction mimicked scientific tales of discovery and research, creating and maintaining ideas of a cultural and developmental distance between the modern French colon and the Indochinese Other, much like the images conveyed by Janse's traveller's tales.

When Indochina was formally attached as a protectorate to the French republic in 1887 , the previous hyphenated name Indo-Chine (marking that the colony had been perceived as a hybrid space empty of an identity of its own between the civilizations of India and China) was changed to Indochine française, to mark its newborn identity as a full member of the French Empire and French civilization..$^{346}$ And around the turn of century, the colonial policy went through a reformulation from the previous focus on conquest, pacification, and assimilation to a much softer policy of association, with an increased emphasis on French beneficial contribution and mise en valeur. Education, science, and technology now became even more important. They were at the heart of this reformed and "ethical" colonial approach based on a trinity of values and principles - generosity, benevolence, and protection - that embodied the French nation's renewed vision of its role as colonizer. ${ }^{347}$ These changes occurred after Paul Doumer, a rising star in French politics (and later President of the

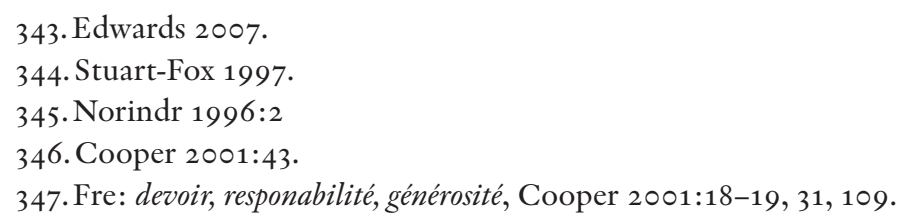


Republic) was appointed Governor General of Indo-Chine in 1897. Paul Doumer, who had degrees in mathematics and law, was a strong advocate for the beneficial potentials of science and research. As a result, one of his many important and influential contributions to the French colonial administration in Indochina was the foundation of several scientific institutes. Among them were the Service Géologique and a permanent Mission Archéologique, which later became the École française d'ExtrêmeOrient (EFEO). ${ }^{348}$ So Paul Doumer established EFEO in 1899 as part of the benevolent and generous French programme of mise en valeur from the turn of the century onwards. ${ }^{349}$ However, if the idea of losing the hyphen was to create a new image of Indochina as something more than a passive mix between the cultures of India and China, the primary goal of the EFEO was to study precisely the "confluence of races and civilizations" that had been essential to its previous (and evidently lingering) image. 350 Olov Janse's ambition to study the southern extension of the Han empire in Indochina was thus a perfect fit with the aims of EFEO.

After a few days of wining, dining, official meetings (with the Governor General René Robin amongst others) and sightseeing in Saigon, Olov and Ronny Janse found themselves unable to pursue their planned journey to Hanoi because of a typhoon further north. So they decided to take the opportunity to visit to the Cambodian capital Phnom Penh and the famous archaeological ruins of Angkor, with a car provided by the governor. Along the way they purchased items for the Ethnographic Museum in Stockholm, among which were a sword ("of the same type as those depicted on the famous friezes of Angkor") and a crossbow with quiver. ${ }^{351}$ In Phnom Penh they met the French Director of the library, Suzanne Karpelès, who assisted them with their ethnographic collecting by assigning one of her native employees as assistant on their purchase tours, and by presenting them with a "beautiful collection representing Cambodian Buddhism". ${ }^{352}$ At Angkor they visited the famous ruins and met the Director of the French archaeological mission, Henri Parmentier. Parmentier did not appear overly enthusiastic about Janse's plans to

348. Clémentin-Ojha and Manguin 2001:16-19.

349. Cooper 2001:30.

350. Auguste Barth in Clémentin-Ojha and Manguin 2001:22.

351. Svenska Dagbladet, 27 December 1934: "Olof Janse sänder hem fin samling. En första rapport från Indokina. Franska staten synnerligen hjälpsam.”

352. Ibid. In the Swedish original: "M:lle Karpelès överlämnade dessutom som gåva en vacker samling, som belyser buddhismen i Kambodja." 
excavate Han period brick tombs, and warned him that as far as he knew most had already been emptied of their contents. Janse took this as a sign that he had "unknowingly entered hunting grounds that were regarded as reserved for others than [him] self", 353 and did not approach Parmentier again. In his memoirs (published as late as 1959, when Indochina had become the independent states of Cambodia, Laos and Vietnam), we can see how Janse had fully adopted the colonial propaganda of French heroic rescues of Angkor and other heritage objects from native oblivion, destruction and decay:

French scientists still pursue persistently and patiently the work of liberating these ruins from the firm grip of the jungle, restoring them and trying to interpret their religious meaning and artistic, historical and archaeological significance. ${ }^{354}$

Back in Saigon they packed and left almost immediately for Hanoi, travelling north along the coast by train and bus. In his memoirs Janse dwells on a stop-over in Nha-trang, known as the land of the Cham people. The ancient Champa kingdom, which was at its height in the ninth century $\mathrm{AD}$, made its fortune from trade. Its culture had both Hindu and Muslim elements and is known archaeologically for its interesting art and religious architecture. But Janse describes the present-day Cham in terms of French colonial discourse, supplemented by a typical Swedish interest in race as defined by blood, particularly the purity of blood:

There are not many full-blooded Cham left. Some small groups in southern Viet Nam have however, thanks to the intervention of French authorities, been saved from destruction and are now regarded as ethnographic curios. Centuries of suffering and humiliation have left a sad mark on these human relics. They have now sunk into extreme poverty and as a result become taciturn in depressed indifference. [...] But the fact that Cham blood still

353.Janse 1959:48. In the Swedish original: "ovetande givit mig in på jaktmarker, som ansågs reserverade för andra än mig själv".

354. Janse 1959:52, in the Swedish original: "Franska vetenskapsmän ägnar alltjämt ett ihärdigt och tålamodsprövande arbete åt att söka lösgöra dessa ruiner från djungelns fasta grepp, restaurera dem och försöka tolka deras religiösa innebörd och konstnärliga, historiska och arkeologiska betydelse." 
flows in the veins of many Vietnamese, especially among fishermen, is evident from their appearance. 355

The passage is characteristic of Janse's ethnographic accounts, in his memoirs and newspaper travel reports. His ethnographic project consisted of short visits to various primitive tribes, whose customs and traditions he often describes in a paternalistic, supposedly humoristic, tone as being naïve and ignorant. Their physical appearance is described with reference to skin colour and the relative purity or blending of their blood. The things they used are presented as collectible artefacts, sometimes compared with prehistoric artefacts in Scandinavia. ${ }^{36}$

This is interesting in relation to the developments of the academic subject of ethnology and the Musée de l'Homme in France, led by Paul Rivet and Marcel Mauss. With its active political commitment to human pluralism and anti-racism and with its foundation in Durkheimian sociology, it has often been conceptualized as an entirely "good" or benign form of knowledge contrasted with the earlier, more problematic, physical anthropology developed by Paul Broca and his disciples. Olov Janse's descriptions of native people offer a more complex picture, which has also been suggested by the works of Emmanuelle Saada and Alice Conklin, who argue that the deep-seated interest in "primitive society" led this school of ethnology to conclusions that created illusions of a natural hierarchy between primitive and modern ways of life. 357

Combined with his abundant usage of adjectives signifying high and low, prosperous and miserable, Janse's ethnographic accounts contribute to a characteristic image where native people in Southeast Asia are metaphorically, or even literally, back-projected to a remote past. The fact that Janse was a qualified archaeologist, an expert on the past, added credibility and extra spice to his ethnographic project. As an example, Swedish reviews of Janse's memoirs say that the "opportunity to experi-

355.Janse 1959:55, in the Swedish original: "Det finns inte många fullblodiga cham kvar. Några små grupper i södra Viet-Nam har emellertid, tack vare de franska myndigheternas ingripande, räddats från förintelse och betraktas numera som etnografiska kuriosa. Århundraden av lidanden och förnedring har satt sin sorgliga stämpel på dessa människoreliker. De har nu sjunkit ned i yttersta armod och till följd därav blivit tillknäppta i deprimerad liknöjdhet. [...] Att emellertid chamblod alltjämt rinner i ådrorna hos många vietnameser, särskilt bland fiskarbefolkningen, framgår av deras utseende."

356. See for example the quote from Yunnan-fu in "Introduction".

357. Saada 2002; Conklin 2013. 
ence prehistory in a sort of double exposure" was considered one of the most important qualities of the book:

The excavations and finds are direct reminders of the past, and the author's escapades in the present surroundings are not only reflections of the present in general, but, at least for a Westerner, stand out as pure and utter prehistory. ${ }^{358}$

The critical anthropologist Johannes Fabian has famously called it a denial of coevalness, this effect of ethnographic thought and writing. ${ }^{359}$ In Janse's writing we see how the temporal dimension of his archaeological expertise is married to his ethnographic project, so they become two different ways to reach the same image of the peoples of Indochina: as belonging to the past. As an effect of the denial of coevalness, all people of Indochina - past and present - could be regarded through an analytical filter of temporal distance. At a distance they pose as evidence of French competence, generosity, and benevolence, and ultimately as a justification of the French colonial presence.

After a three-day train journey to Yunnan-fu across the border to China, waiting for the typhoon rains to give in, they eventually arrived and settled in Hanoi three weeks after they had disembarked from the d'Artagnan in Saigon. Having rested for a few days and been introduced to their colleagues at the research institute École française d'Extrême-Orient, they set out to the nearby Bac Ninh province and started their first excavations in early November 1934 .

At the time of their arrival in 1934, French Indochina consisted of five regions (see map in fig. 42). Apart from les Laos and Cambodge, which

358. Review of Ljusmannens gåta: Wilhelm Holmqvist, 1959, "Exotisk forntid", Vi no. 49. In the Swedish original: "Kanske är det även detta, som utgör styrkan och tjusningen i hans framställning, nämligen att man får uppleva forntiden i ett slags dubbelexponering. Grävningarna och fynden erinrar direkt om [forntiden], och författarens upplevelser i den nutida miljön återspeglar inte bara [nuet] så där i största allmänhet, utan framstår åtminstone för en västerlänning som rena, rama förhistorien." See also reviews by Arthur Nordén, Norrköpings Tidningar/Östergötlands Dagblad, 23 November 1959; by Torgny Säve-Söderberg, Dagens Nyheter, 17 December 1959; by Hanna Rydh, Svenska Dagbladet, 10 February 1960. Archaeologists were interested in the relationship between East and West. Public reviewers focused on the double exposure of primitive culture.

359. This is a common characteristic of early ethnographic writing, which has been discussed and critiqued at length by Johannes Fabian (1983) and James Clifford (1988) among others. 


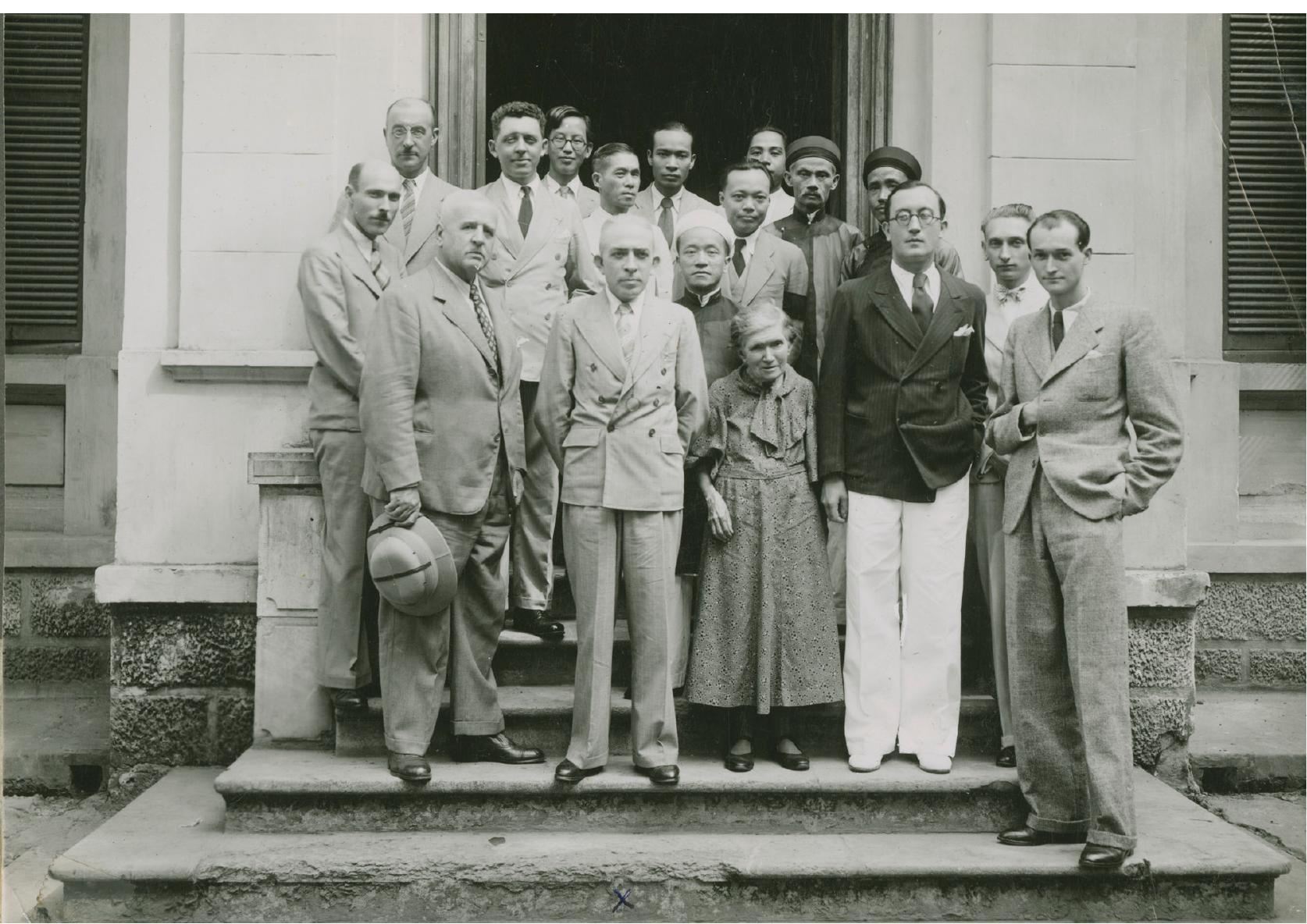

Fig. 30. The Ecole française d'Extrême-Orient in Hanoi 1939. Janse has written the names on the back of the photograph, but with one exception named only the French members. From left to right: Louis Bezacier, René Mercier, Victor Goloubew, Jean-Yves Claeys, George Coedès (director of E FEO), Madeleine Colani, Pierre Dupont, Jean Mannikus, and Paul Léry. Behind and between George Coedès and Madeleine Colani is the secretary Thô. Photo by Olov Janse.

later formed the postcolonial states of Laos and Cambodia, there was Cochinchine (in the south, with Saigon as the main city), Annam (along the central coast), and Tonkin (in the north, with Hanoi as the main city), which have together become Vietnam, as we know it today. Apart from a couple of visits to Cambodge and Cochinchine, Olov and Ronny Janse did most of their work in the northern part of Annam (in a province called Thanh Hoa), and some in Tonkin, mostly in the Bac Ninh province, where they were now about to start their first excavations. They were working 
Fig. 31. Nguyen Xuan Dong. Photo by Olov Janse.

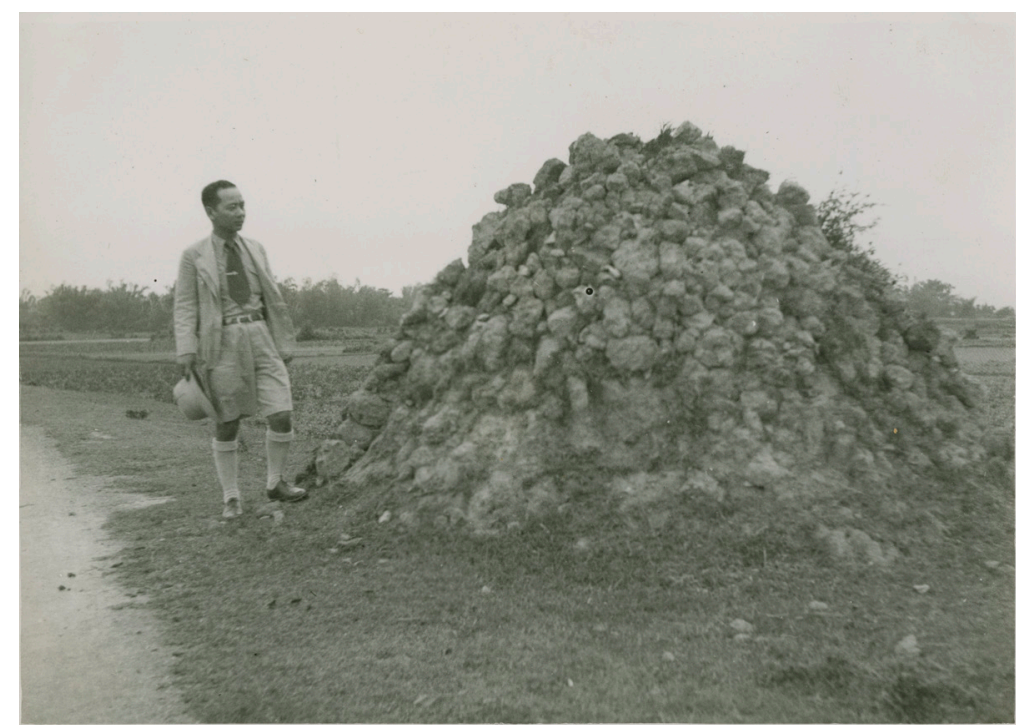

for and in collaboration with the EFEO and its director George Cœdès. At least initially, Cœdès indicated the sites to excavate, and they were assigned a native member of staff to act as secretary, draughtsman, and interpreter. ${ }^{360}$ The first person to get this assignment was Mr Chung, who did not get on with Janse (his, in Janse's opinion, outrageous behaviour is described at length in Janse's memoirs) ${ }^{361}$ and he was soon replaced with Nguyen Xuan Dong, ${ }^{362}$ mostly called Dong (fig. 31), who remained with the project as secretary and draughtsman through the first two expeditions.

\section{$\operatorname{Lim}$}

The first site they set out to excavate was Lim, twenty kilometres from Hanoi in the province of Bac Ninh. It was previously known to EFEO for a large Han-period brick tomb, and George Codès suggested this as their first excavation site. When they arrived at Lim they saw a corner of the brick construction, which had been exposed by recent roadworks. Janse instructed Dong to supervise their team of local workers to clear

360. See Cherry 2004 and Clémentin-Ojha \& Manguin 2001:35 for a reminder of the importance of the native members of the EFEO.

361. Janse 1959:78-82.

362. Also incorrectly referred to in some of Janse's texts as Nguyen Van Dong. 
the brick structure from the rest of its covering mound, while he set off to survey the surrounding area.

Once the brick construction had been cleared they could see that the vaults, just as Henri Parmentier had warned him when they met at Angkor, had been opened and emptied. Some coins inside suggested that it had been done in the nineteenth century. For Janse - who was looking for untouched grave inventories with outstanding artefacts to fit museum displays in Paris - this was nothing but a failure. The rather magnificent brick construction with one central tunnel-formed vault and two perpendicular ones sticking out on each side is mentioned only in passing in his memoirs, ${ }^{363}$ and the finds inside are only touched upon in a couple of footnotes in his excavation report.

He had more luck with his surveys of the surrounding area, where he managed to locate another site with Han period finds by talking to local farmers. The excavations there uncovered two smaller brick tombs with collapsed roofs, but with their grave inventories intact. Some of the bricks were decorated on the sides, and once refitted they appeared to depict the famous Chinese legend of Shên I, yet with distinct non-Chinese elements in it. Altogether the finds seemed to indicate that the people who built these graves had a culture that was not quite Chinese and not entirely native, but a hybrid form incorporating elements of both..$^{364}$

Notwithstanding the rather meagre results, particularly at the large spectacular tomb, the excavations attracted a lot of attention, not only from people in the nearby villages, but also from visitors to the local market, and French officials in Hanoi. On 9 December, only a month after the excavations had begun at Lim, the Society of Friends of the EFEO organized an excursion to the sites (fig. 32).

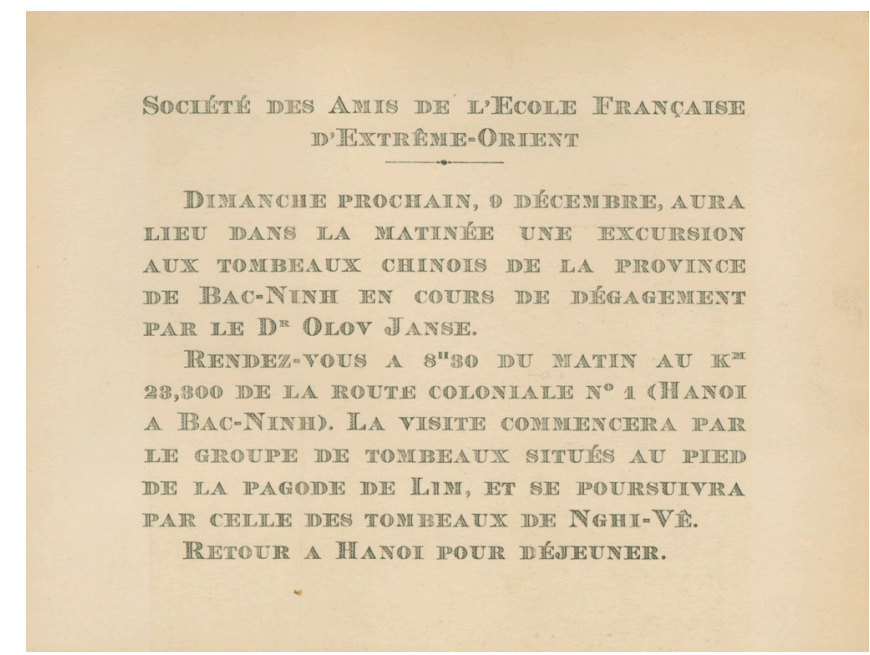

363. Janse 1959:81.

364. Janse 1951:47-51; 1959:86. 
Nghi-vê

While they were working at Lim, and Janse felt that his presence was not always called for (he appears to have been present mostly for the excavations of the parts of the tombs where he expected to find artefacts of interest, that is, at the bottom of the chambers), he decided to take the opportunity to extend his working area to a nearby site in the village Nghi-vê, which was known to the EFEO from a previous excavation by Henri Parmentier. ${ }^{365}$ To his great disappointment Janse found that the tomb which had been excavated and restored by Parmentier was gone, having been transformed into building material for houses nearby. But once again, a local farmer came to his rescue and pointed to a mound not far away where he had found traces of another Han brick tomb. The farmer was rewarded with a coin, and a promise to be employed as a worker in the upcoming excavations. ${ }^{366}$ When Janse later returned to excavate the site with Dong and the local team, they found an intact tunnel-shaped brick tomb, with a unique detail in the form of a band of bricks with a geometric pattern running horizontally along the walls. ${ }^{67}$

Even more interesting was a second tomb, indicated by another farmer while they were excavating the first. The tomb Nghi-vê no. 2 is described in Janse's report as "one of the largest subterranean brick buildings ever discovered in Indo-China", ${ }^{68}$ with a high vault built with geometrically decorated bricks (figs. 33, 34a, 34b). The floor was tiled, also with bricks, and was elevated at one end of the chamber. This grave too had been opened and partly emptied, but the remaining grave goods included elaborate ceramics, beads, iron nails, an incense burner, a mirror and a house model (fig. 35). ${ }^{369}$ Near the tomb they found roof tiles, indicating that there had once been a mourning house on top of the grave mound. ${ }^{370} \mathrm{It}$ is said in the reports and later newspaper interviews that all the bricks from Nghi-vê no. 2 were transported to Hanoi, to have the tomb recon-

365. Parmentier 1918.

366. Janse 1959:87-88.

367. Janse 1935a; 1935-36; 1947:9.

368. Janse 1947:v; see also Bulletin de l'École française d'Extrême-Orient, Tome 34, 1934, p. 750 , pl XIX-XX.

369. Janse 1935a; 1935-36; 1947:16, 18, 26, 40, pl 126; 1951:12, 18, 79, 96, 120, 161, $173,191$.

370. Janse 1935-36; 1947: 5, pl 160; 1951: 237. 

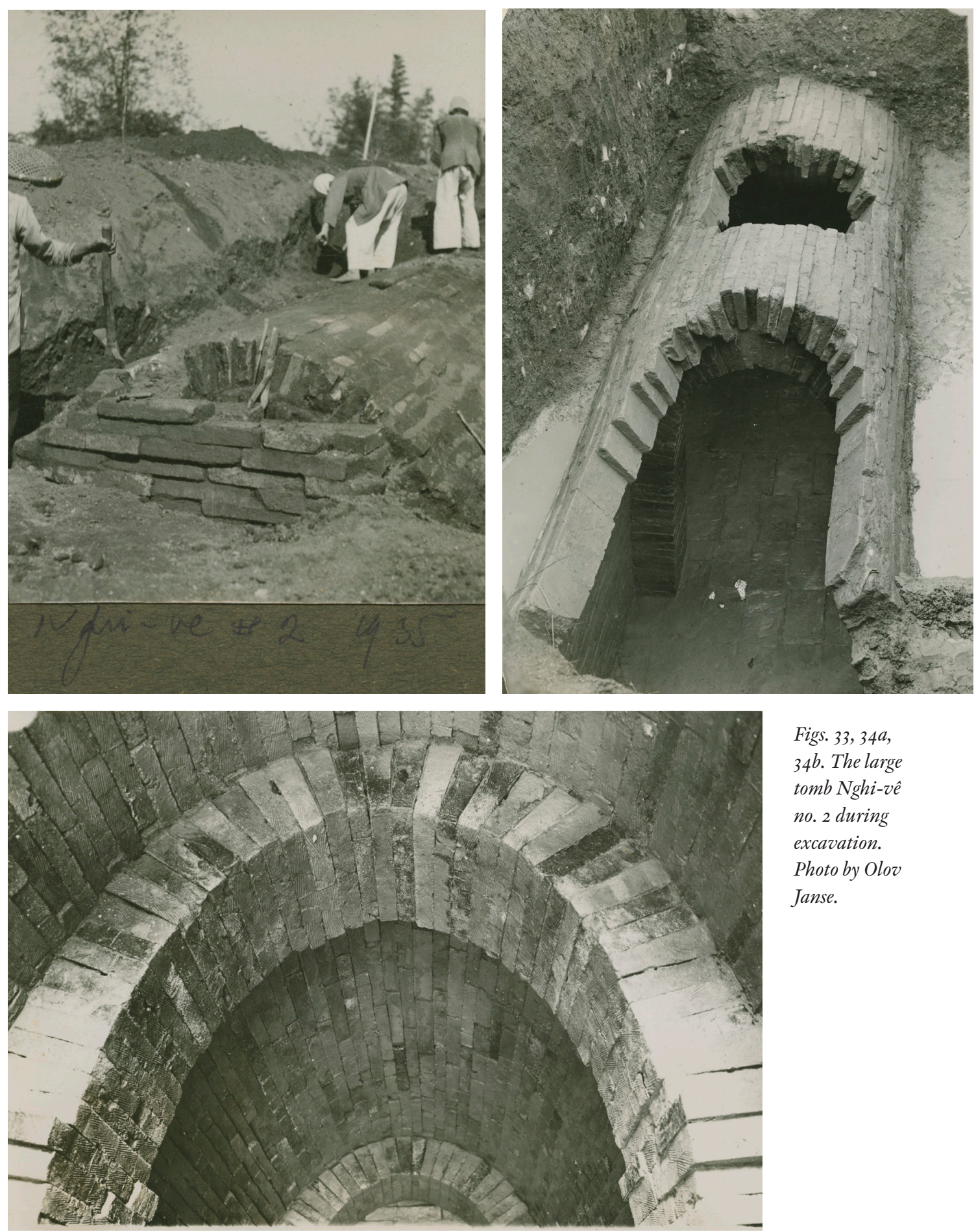

Figs. 33, 34a, 34b. The large tomb Nghi-vê no. 2 during excavation. Photo by Olov Janse. 
Fig. 35. House model found in the tomb Nghi-vêno. 2, after reconstruction.

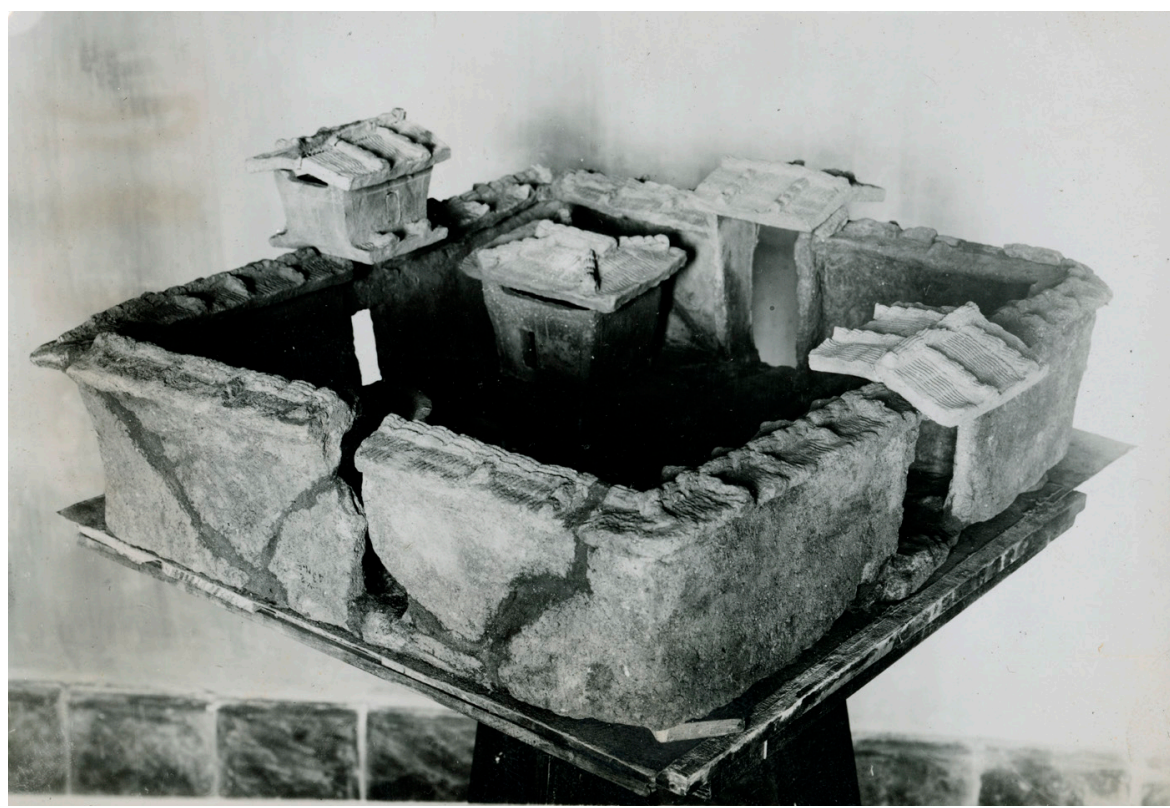

structed in the garden of the Louis Finot Museum. ${ }^{371}$ It appears, however, that the plans were ever realized.

The excavations were reported in the Indochina press; in the French newspaper France-l'Indochine and the largest paper in Vietnamese language: Trung-Bac Tan-Van (News of Annam and Tonkin). The Vietnamese paper was particularly enthusiastic, publishing three successive articles on the excavations at Lim and Nghi-vê. ${ }^{372}$ Janse's expedition was also noticed in Swedish press, but there the articles concerned the arrival of a collection of ethnographica sent to the Ethnographic Museum in Stockholm. ${ }^{373}$

\section{Dong Son}

As 1934 came to an end, Olov and Ronny Janse left Tonkin with Dong and moved south to Annam and the Thanh Hoa province. On the bank

371.Beaux-Arts: Le Journal des Arts, 5 July 1935: "Au Musée Cernuschi renové: Les découvertes archéologique de M. O. Jansé".

372. Trung-Bac Tan-Van, 12 December 1934, 14 December 1934, 20 December 1934.

373. Svenska Dagbladet, 27 December 1934: "Olof Janse sänder hem fin samling. En första rapport från Indokina. Franska staten synnerligen hjälpsam”; Östergötlands Dagblad, 29 December 1934: "Etnografika från prof. Janse". 
of the Song Ma river, near the village Dong Son, was a large and interesting site, which had been officially known to the EFEO since 1924. Construction works for roads and canals had revealed large amounts of ancient artefacts, and in 1924 the EFEO officially instructed a French customs official named Louis Pajot to make inquiries among the local population about finds of ancient things. Pajot, a former circus artist who had ended up in Indochina via a sailor's assignment, took on the project and set about surveying the area and collecting artefacts for the EFEO and Musée Louis Finot in Hanoi. And the villagers, who received a small reward for every artefact they handed to Pajot, soon began to initiate their own excavations. Over the following decade, villagers and French amateurs were digging for treasures at the site, and Louis Pajot himself pursued undocumented excavations. Some of the artefacts, including bronze weapons and the spectacular bronze kettledrums that have become known as "Dong Son Drums", were collected at the Musée Louis Finot in Hanoi, while others were sold and spread among private collectors. ${ }^{374}$ The news about the intriguing site with magnificent bronzes travelled as far as Stockholm, where Olov Janse was working at the Museum of Far Eastern Antiquities and was encouraged by Johan Gunnar Andersson to write an article, suggesting that the finds at Dong Son represented a distinct prehistoric bronze industry spread over Indochina, South China, and Indonesia. ${ }^{375}$

So Janse was already well acquainted with the findings at Dong Son before he arrived at the site, ten years after Pajot and the local communities had started their excavations. At the EFEO, George Codès welcomed the initiative to have the Dong Son site investigated with professional archaeological methods and proper documentation, and encouraged Janse to contact Louis Pajot at his home in the town of Thanh Hoa. They travelled to Thanh Hoa, where they checked in at a French hotel owned by the local personality Madame Renaud, and went to pay Louis Pajot a visit. Initially reluctant, Pajot eventually came round to help Janse with his investigations, and they would become good friends. Janse also got in touch with a local farmer named Soang, who had been a key

374. The only published piece from this first phase of Dong Son's life as an archaeological site is an article by the EFEO member Victor Goloubew (1929).

375. Janse 1931. See also Solheim 1989; Heger 1902; and Franz Heger's presentation "Sur d'anciens tambours de métal du sud-est de l'Asie" at the Hanoi Conference 2002 (with Henri Hubert attending and commenting) in EFEO 1903, pp 89-91. 
Fig. 36.

Madame

Renaud's

hotel in

Thanh Hoa.

The man

standing by

the car might

be Olov

Janse.

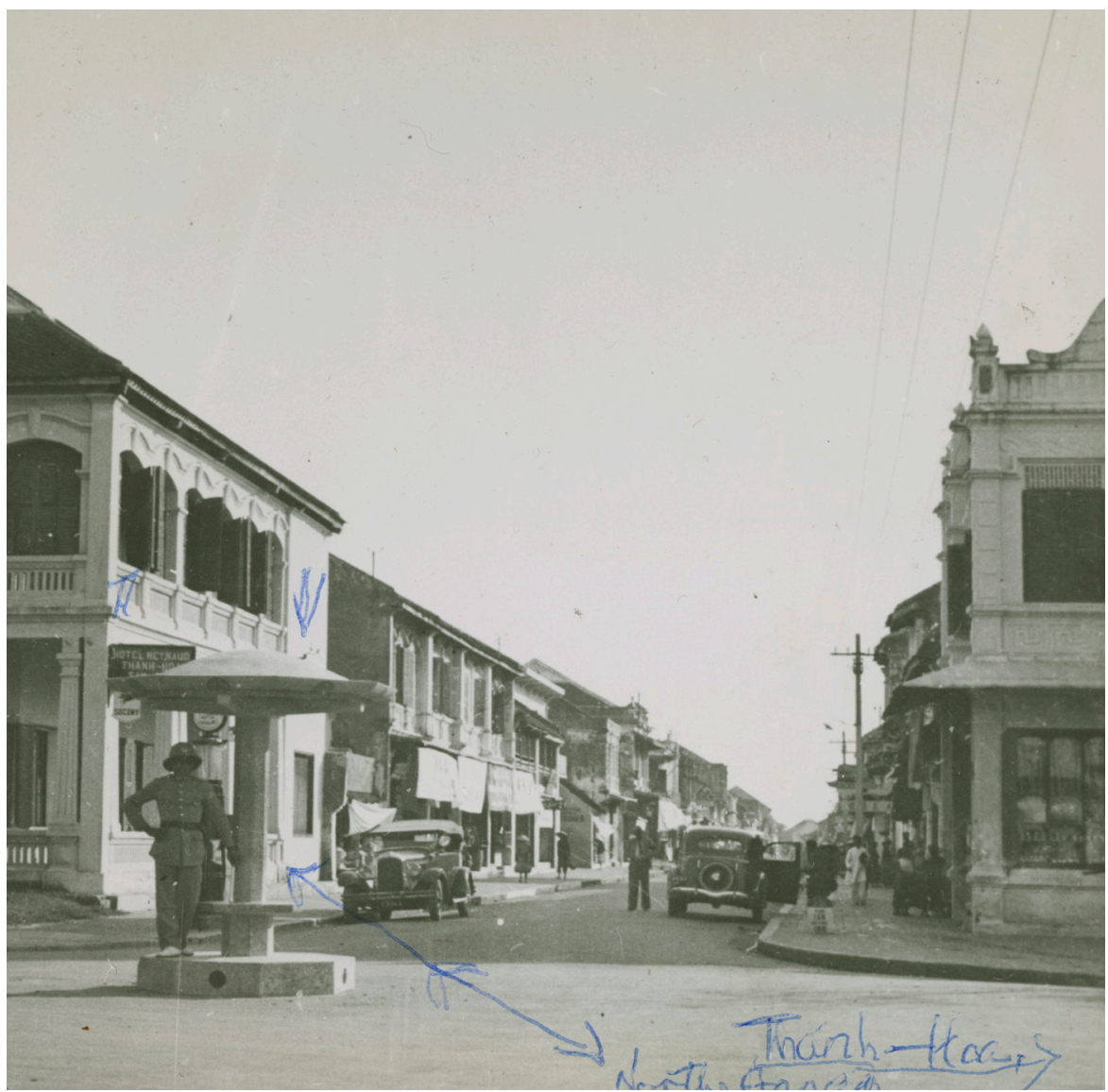

collaborator with Pajot during his investigations, and made him foreman as he formed a local excavation team.

Olov Janse is often described as a particularly likeable person, and there was clearly something with his ways and manners that inspired confidence in the people he met. The ability to create positive relations with French and Annamite officials as well as local farmers seems to have been a crucial asset in all the work he did in Indochina. In an interesting chapter of his memoirs, ${ }^{376}$ he describes at length the problems he faced with a local dragon named Long (which means "dragon" in Vietnamese) who resided at a tomb site in the Hoà-chung village. Janse describes the strategies he employed to overcome the problems and eventually reach a form of coexistence with Long. The chapter is riddled with the usual ar-

376. The chapter "Draken och jag", Janse 1959:165-179. 
rogant, supposedly witty, descriptions of the villagers' "superstitious" and "archaic" belief in the presence of a dragon, or more precisely a dragon vein, in the mound of a brick tomb Janse had set out to excavate. But behind the veneer of paternalistic disdain, the chapter contains interesting and important information about the villagers' engagement in the protection of the mound, and the logic by which they explained its value as a community heritage site. It also contains interesting information about Olov Janse's negotiation skills, and how much effort he invested to win the villagers' confidence and find a way to excavate the mound in co-existence with Long, hence with the consent of the community. It took considerable effort, listening, and thinking to understand the logic behind the villagers' sentiments and actions to preserve the mound. And once he had figured out some of the logic, he worked with it. He engaged local shamans and presented food offerings, while he continuously argued that the Chinese people who had once built the tomb must have been aware of the dragon's vein and would have been careful not to dig too deep and disturb it. Hence by the same logic, his team would not disturb the dragon if they stopped the excavations at the floor of the tomb. The villagers were content with that idea, and Janse was eventually given permission to excavate down to the brick floor, which was exactly what he wanted in the first place.

They began their investigations at Dong Son on 3 January 1935. The places where artefacts had been found by locals and amateur diggers indicated that the settlement area stretched along the Song Ma river, in a narrow strip of flat land between the riverbank and a steep hill behind it. While Dong and the foreman Soang tried to locate the places previously excavated so they could avoid them (as with the Han tombs, it was untouched ground with undisturbed intact contexts that they were after), Janse investigated the stratigraphic sequence in the eroded riverbank. With his Scandinavian training in archaeology, he used stratigraphy - the analytical documentation of the thickness, contents, and internal relation of soil layers - as a key analytical method. By means of stratigraphy, he sought to determine the dates for the beginning and end of the settlement, and to organize the remains into separate datable phases. The stratigraphic sequence of Dong Son was quite simple, with one major cultural layer about 60 centimetres thick, containing "primitive" stone tools as well as "datable" metal artefacts. Below this main cultural layer was a layer of sterile clay, and above it a layer with gravel and scattered artefacts of more recent date. This was before the invention of radiocarbon dating (which 
is now the common, more precise method to date a stratigraphic layer), so dating was done by identification of artefacts (often metal or coins) with forms or inscriptions known from written sources or previous archaeological investigations to have been in circulation during a particular period of time. ${ }^{377}$ The main cultural layer at Dong Son contained artefacts that could be dated between the second century BC and the first century AD. This seemed to indicate that the main settlement had appeared and flourished during a couple of centuries until it was abandoned, sometime in the first century AD. ${ }^{378}$ In his memoirs, Janse writes:

We had already solved one of the archaeological problems. It was evident that the population of these lands in the years before the birth of Christ had lived at the Stone Age level with fishing and primitive cultivation as their main economy, but that the contact with the higher Chinese culture then suddenly made the inhabitants acquainted with the use of bronze and iron tools, and a considerably more developed cultivation than their own. ${ }^{379}$

Let us stop here for a moment and take a closer look at this quotation. Residing between the lines here is an important presupposition for the story Janse tells about Dong Son, and more generally in all his archaeological narration. Without saying it explicitly, he presupposes that human culture can, and must, be categorized as either "primitive" (low) or "civilization" (high), and that there is a universal teleological force of cultural development from low to high. The "archaeological problem" that he refers to initially is the fact that stone tools (essentially "primitive", or "Stone Age level", according to his definition) are found with metal objects (to him representing "civilization") in one and the same layer. If, however, we removed the implicit either-or presupposition from the argument, the problem would cease to exist, and a more straightforward

377. For a more elaborate discussion of stratigraphy and typological dating, see the chapter "Archaeological Foundations".

378. Janse 1958:19-21.

379. Janse 1959:107. In the Swedish original: "Vi hade redan löst ett av de arkeologiska problemen. Det var tydligt att befolkningen i denna trakt under tiden närmast före Kristi födelse hade levt på stenåldersstadiet och idkat fiske och primitivt åkerbruk som huvudnäringar, men att beröringen med den högre, kinesiska kulturen då plötsligt kom invånarna att lära känna bruket av brons- och järnverktyg och en i stort sett betydligt mer utvecklad odling än deras egen.” 
explanation of the contents of the cultural layer would be that the people at the Dong Son site in the first century BC had a culture that included things made of both stone and metal. And this is also what later, post-independence archaeological interpretations of Dong Son have said..$^{30}$ But Janse's archaeological gaze, which presupposed a definition of culture as either primitive (associated with stone) or civilized (associated with metal), enticed him to create an explanatory narrative of a primitive native culture meeting a civilized Chinese culture, and thereby developing into a "higher" form that included metallurgy. Hence the narrative of a primitive native culture developing to a more advanced form under influence of a foreign civilization is essentially dependent on a historically contingent presupposition informed by early twentieth-century colonial archaeological discourse, ${ }^{381}$ rather than the archaeological material actually found at Dong Son.

Satisfied with the results from the stratigraphic analysis, and informed by the surveys undertaken by Dong and Soang, Janse was now ready to start excavating. Because there were no visible structures on the ground (as with the Han tombs, which were given away by their covering mounds), they were guided by more subtle information to find the places to dig. One part of the area was covered by grass and left untilled, and the farmers explained that it was placed under an ancient taboo. Janse took the taboo as an indication that it contained ancient graves, and decided to open a trench of seven by fourteen metres. In the trench, which is called fouille 3 or loc. 3 in the reports, they first encountered three small brick tombs from the Tang period (AD 618-906). Beside and below the Tang tombs were two graves from the main settlement phase (which Janse refers to in the records as "Indonesian tombs"). The two graves, which had no visible built structure surrounding them, contained an array of grave goods including ceramics (which, according to the master narrative of culture as being either primitive or civilized, are described in the reports as either native or Chinese), coins, spearheads, spindle whorls, one fishhook, a stone pillar, stone discs, axes, bronze situlae, bronze vases, miniature bronzes, and so on. Particularly noteworthy are the finds of miniature bronzes, such as small kettledrums, which were never found

380.E.g. Solheim 1989; Hà Văn Tàn 1991; Han Xiaorong 1998; Cherry 2004:11; Long 2011. See also Malleret 1959.

381. Trigger 1984 . 
in any of the brick tombs..$^{32}$ But the most spectacular find was of two large bronze kettledrums found in situ, one in each grave. ${ }^{383}$ The bronze kettledrums have now, in our time, become famous signature artefacts of "the Dong Son culture", and iconic pieces representing Southeast Asia in museum collections and the antiquities trade around the world. ${ }^{384}$ Janse's were the first in situ finds of such bronze drums in a documented archaeological excavation..$^{85}$

As they moved on, they were not quite so lucky. The first two "Indonesian tombs" would prove to be the only intact elaborate graves found during this and the following two excavation seasons at Dong Son. They opened three smaller trenches near loc. 3: loc. 4 , loc. 6 and loc. $\sigma^{b i s}$, and one at the other end of the settlement area: loc. $5 .{ }^{386}$ In loc. 6 and $\sigma^{b i s}$ they found a similar array of artefacts, yet not as rich and elaborate as in loc. 3 , arranged in groups that appeared to represent graves. To be on the safe side they called them "groups" in the documentation. Because they had no superstructure and the soil conditions had made all bone disappear, it was difficult to identify them with precision as graves. In loc. 6 they also found and excavated one tomb from the Sung period (AD 960-1279), and in loc. 5 a Han period brick tomb (in the report referred to as Tomb 1). ${ }^{887} \mathrm{~A}$ further three Han period tombs (Tombs $A-C$ ) were found and excavated in the surrounding fields. ${ }^{388}$

During the first excavation season at Dong Son they also found, near the eroding riverbank, an area with vertical, partly decomposed wooden poles. It appeared to be the remains of stilt houses, preserved by the moist conditions near the river. They made a note of the location, and planned to return to excavate there in the following season..$^{389}$

The local newspapers, particularly the Annamite Trung-Bac Tan-Van,

382.Janse 1947:xxxviii; 1958:35, 46, plates 12-14, 16-17, 37, 42 .

383. Janse 1958:21-23, 34-41, plates 8-12. In fig. 40 are two smaller specimens on display at the National History Museum in Hanoi.

384.E.g. Sprennemann 2015.

385. Janse 1959:109.

386. Janse 1958:15.

387.Janse 1958:23-27; 1951:131-133.

388. Janse 1951:134-136.

389. Janse 1958:28-32; 1959:112. Although the report deals with the pile dwelling during the second excavation campaign, letters (e.g. letter from Olov Janse to Birger Nerman, 15 January 1935. Riksarkivet. Korrespondens, brev III 1935-41) and the memoirs indicate that this work began already during the first season. 
continued to report on the excavations, and published three articles on their work at Dong Son. ${ }^{390}$ The finds from the first excavation season at Dong Son were shipped to Paris, where many of them still remain in the collections of the Cernuschi Museum. ${ }^{391}$ Some were later returned to the Musée Louis Finot (now the National History Museum in Hanoi), 392 and some items were offered as a gift to the Swedish Crown Prince and are now incorporated in the collections of the Museum of Far Eastern Antiquities in Stockholm.

\section{Quang-xu'o'ng}

When the excavations at Dong Son had been halted, they also left their base camp at Madame Renaud's hotel in Thanh Hoa, and moved to her smaller establishment in the seaside resort of Sam Son. In the area around Sam Son they pursued further (unreported) excavations of tombs from the Sung and Tang periods. ${ }^{393}$ They would later return to this region, called Quang-xu'o'ng, in the second season. They also excavated number of Sung period graves at the Có-dinh site in the region of Nông-công. The introduction to Janse's report says that one of the graves at Có-dinh contained a wooden coffin, ${ }^{394}$ but apart from that brief note, there is no report published of these excavations.

\section{Lach-truong}

In February it was nearing the end of the excavation season. The cold, damp winter climate gave way to hot and humid spring days, and occasional rains came as omens of the heavy monsoon rains soon to arrive. And here, at the very end of the first euphoric expedition, Olov Janse discovered his most important site and made the find that was going to become an icon of his and Ronny's archaeological endeavours in Indochina. Following a common format of dramatic discovery stories, his

390. Trung-Bac Tan-Van 17 January 1935, 19 January 1935, 24 February 1935.

391. See further details in the chapter "Memorabilia".

392. Visiting Vietnam in November 2005 we received a list of objects from Janse's excavations that are stored with the museum in Hanoi. The list is in Vietnamese and includes 182 entries.

393. Janse 1951:179 (map); 1959:123-134.

394. Janse 1947:v. 
memoirs describe how he stumbled upon it, purely by accident. ${ }^{395}$ With their base camp in Madame Renaud's Sam Son hotel, Olov and Ronny made survey trips along the coast. On one of these trips their driver lost his way, and they stopped to ask for the way at a crossroads in the district of Hâu-Lôc. While the driver went to talk to some people nearby, Olov and Ronny went out to stretch their legs.

I nearly swooned when I saw, quite close to the corner of the house, a large grave mound of an almost rectangular shape, about 15 metres long. I realized immediately that the mound covered a larger grave from the Han period. It also struck me that this grand mound might not be an isolated find and that there could be others in the neighbourhood. ${ }^{396}$

He was right, of course. The grave mound was part of a large necropolis, referred to in the reports as Lach-Tru'o'ng, or simply Lach-truong. ${ }^{397}$ The location of the tombs was given away by the covering elliptic mounds, ten to thirty metres long, rising about a metre above the surrounding plains. Before the first season came to an end, they had excavated twelve Han period brick tombs at Lach-truong (in the reports referred to as tombs 1-12)..$^{39}$ Two of these: tomb 3 and tomb 4 , were found intact and contained rather spectacular grave inventories. ${ }^{399}$ The layout of the tomb structures and the artefacts found inside are presented in great detail in the reports, ${ }^{400}$ and in addition we have included here a couple of Janse's original photos from the excavations of tombs 2 and 4 , and Dong's original plan drawing from tomb 4 (figs. 37-39).

In his memoirs, Janse dwells on the contexts of the Lach-truong graves, and describes their inventories beyond their usual function as potential museum pieces. He explains the form and layout of tomb 3 and

395. Janse 1959:135-136.

396. Janse 1959:136. In the Swedish original: "Jag nästan baxnade när jag alldeles intill husknuten fick se en stor gravhög med en nästan rektangulär omkrets, ca 15 meter lång. Jag förstod genast att denna kulle täckte en större grav från Han-dynastins tid. Det slog mig också att denna präktiga gravhög kanske inte var en isolerad företeelse och att det kunde finnas andra i grannskapet."

397. Janse 1951:3-5.

398. Janse 1947: plates 3-32.

399. Janse 1947: plates 7-16; 1951: plates 30-31.

400. Janse 1947: plates 3-32; 1951:3-91, plates 30-31. 

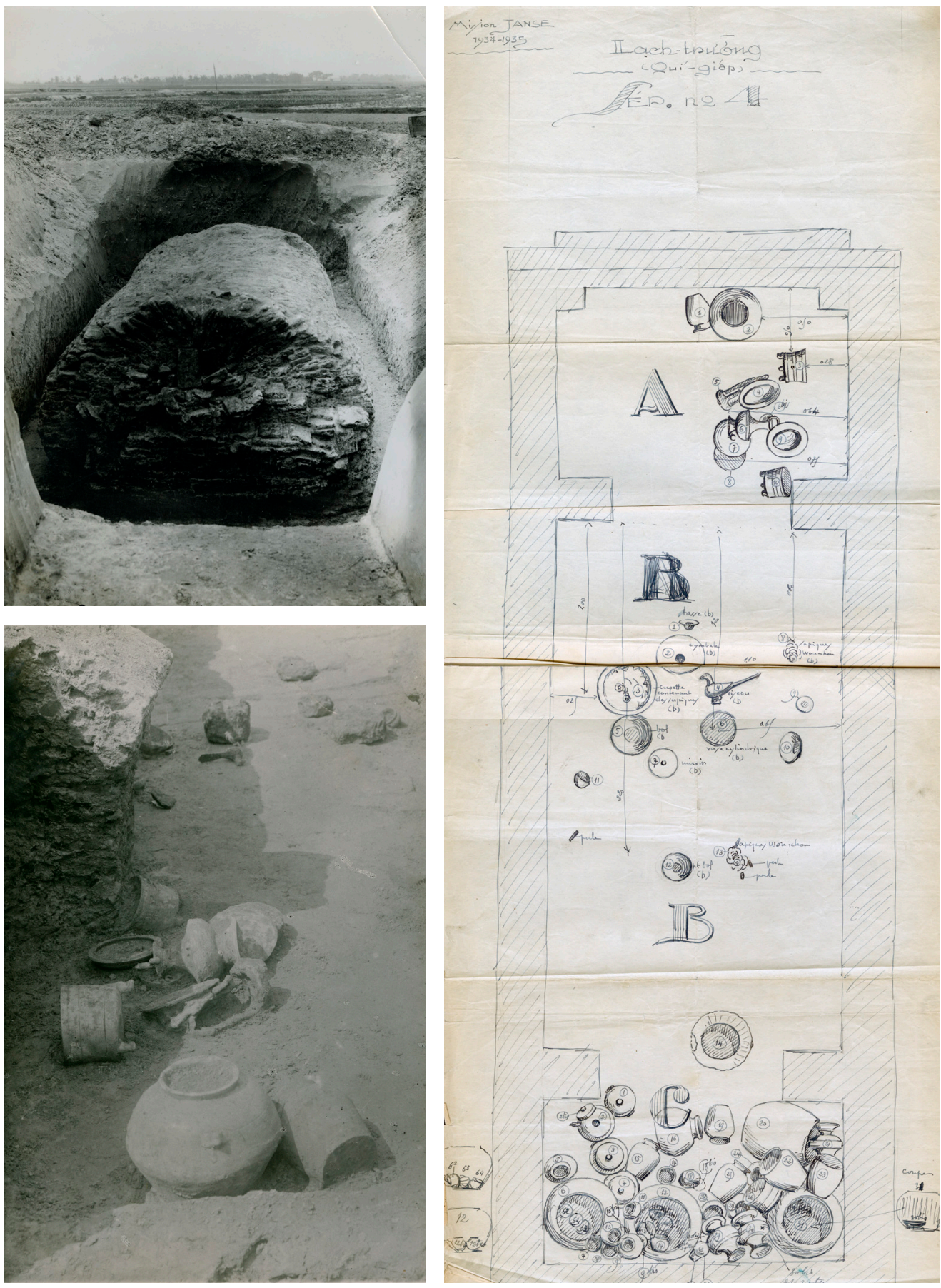

Figs. 37-39. Excavations at Lach-truong in 1935. The brick structure of tomb 2 revealed (Fig. 37), and below the grave inventories of tomb 4 during excavation, photographed from the north end of the tomb (Fig. 38). The original plan drawing of tomb 4 (Fig. 39). 
its contents in accordance with scholarship on Han Chinese culture, by describing it as a separate spiritual universe:

The orientation of the tomb and the placement of the gifts were intended to induce a beneficial interaction between the two polarized cosmic principles of Yin and Yang. [...] In the case of tomb no. 3, the objects impregnated with the negative Yin principle, particularly the ceramics, were placed in the southern part, which is the direction that represents the positive Yang principle. In the northern part of the tomb, the direction which represents the Yin principle, the objects were impregnated with the Yang principle, in particular the metal objects. To have the desired effect of the invigorating currents, the deceased and his spirits must be placed at the focal point between these two groups. ${ }^{401}$

Because the graves were created and organized as separate spiritual universes with such clear references to Han Chinese culture, Janse and his team were intrigued to find that some of the grave inventories were not so easily attributed to the Chinese sphere. In particular it was the set of Yang-impregnated metal objects that fell out of the expected frame. While the ceramics appeared to be of Chinese make, the bronze objects suggested a different origin.

Two of the bronze objects in tomb 3 were particularly interesting in this respect: a smaller figurine with horns sitting on a pedestal on a tray holding what looks like an enormous phallus in his hands, ${ }^{402}$ and a larger, more elaborate figurine in the form of a kneeling man holding a tray, with three branches, or candle holders, growing out of his back like wings (fig. 40). ${ }^{403}$ Neither of the two objects looked particularly Chinese, and in his

401. Janse 1959:139. In the Swedish original: "Gravens orientering och bigåvornas placering avsåg att framkalla och befordra en välgörande växelverkan mellan de två polariserade, kosmiska principerna: Yin och Yang. [...] I fråga om graven $\mathrm{nr} 3$ var de med Yin eller den negativa principen impregnerade föremålen, särskilt keramiken, placerade i den del, som låg i söder, det väderstreck som motsvarar den positiva eller Yang-principen. I den del, som låg i norr, det väderstreck som motsvarar Yin-principen, fanns de med Yang-principen impregnerade föremålen, i synnerhet metallföremålen. För att de livgivande strömningarna skulle få önskad verkan, måste den avlidne och hans andar befinna sig i brännpunkten mellan dessa grupper."

402. Janse 1947: plate 14 (3); 1951:30, 57-58, fig. 43

403. Janse 1947: plates $8-10,15 ; 1951: 32-57$, plate 1 . Janse refers to this object as a "lampadary", and in Swedish as ljusmannen, i.e. the "light-man" or "candle-man". We will 


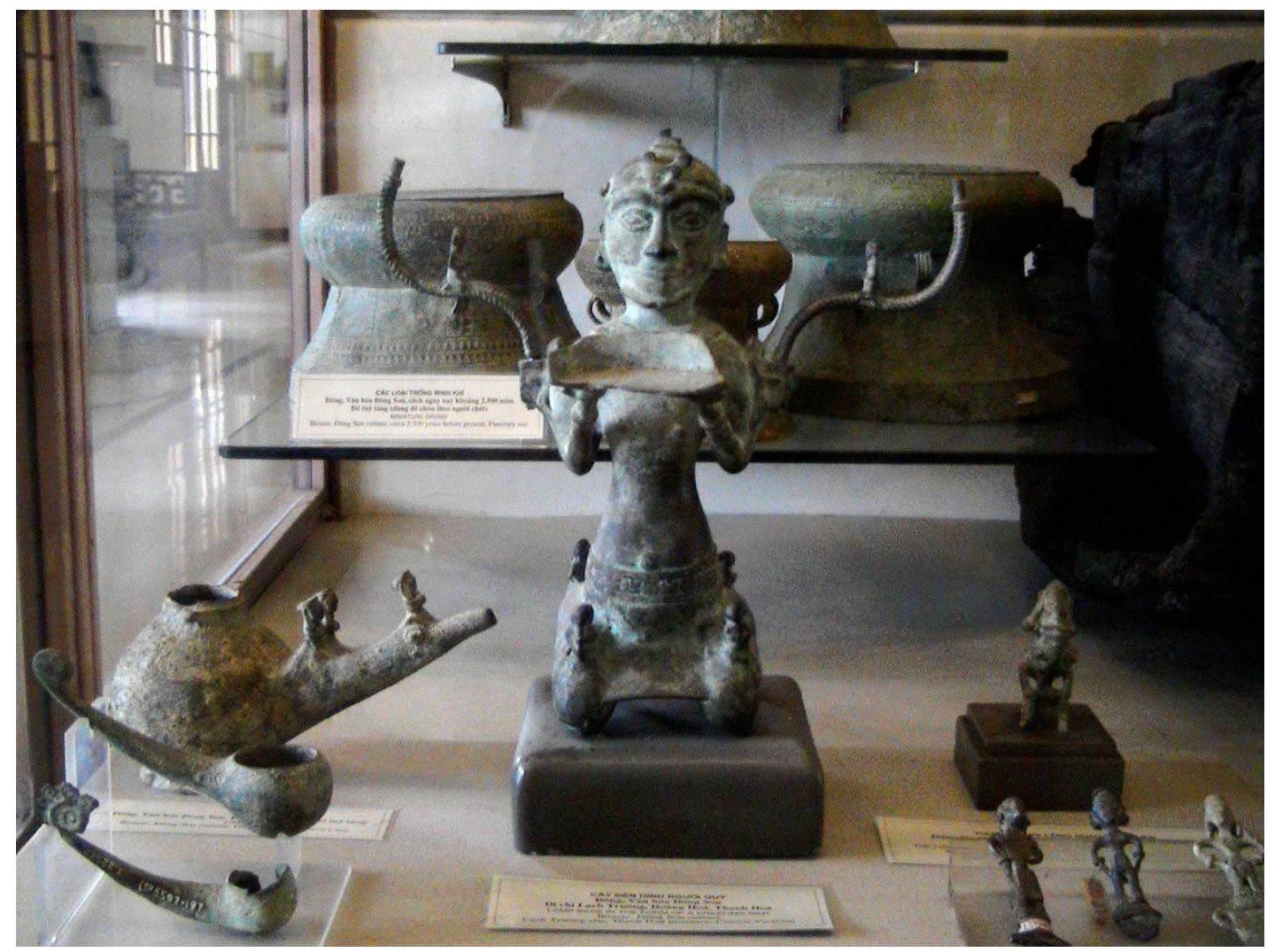

Fig. 40. The kneeling figurine found at Lach-truong, tomb 3. Around 25 centimetres in height it is here seen on display at the National History Museum in Hanoi, surrounded by other signature bronze artefacts from Janse's excavations. To the left a bronze lamp with anthropomorphic figures on the spout found at Dong Son, and to the front right three anthropomorphic dagger handles, of which one was found at Dong Son. In the background three mediumsize Dong Son kettledrums.

attempts to explain their origin Janse resorted to a rather eclectic, at times best described as wild, comparative analysis. He compares the hair of the kneeling figurine with Indian Buddhas and Hellenistic Gandara art, while his diadem is compared with Dionysos; his beard is ascribed to a contemporary fashion style among mountain tribes in western Pakistan, and his earlobes are again compared with Buddha; the difference in size between the kneeling figurine and the smaller figures surrounding him is explained by a principle in Classical Art, while the three branches or candle holders are compared with a Chinese candelabrum in Toronto,

refer to it throughout this book as "the kneeling figurine". 
and ancient Greek depictions of Dionysos. ${ }^{404}$ The smaller man with the tray and phallus is declared in a much simpler argument to be a depiction of Dionysos's steady companion: "Now there cannot be even the tiniest doubt that we had found a representation of an Indo-Hellenistic Pan." ${ }^{405}$

You can tell from the lengthy text in the report and memoirs ${ }^{406}$ that this kind of comparative analysis is what Janse enjoys the most. He reaches the conclusion that the two bronzes are indeed depictions of Pan and Dionysos, and that they represent a local cult based on elements which had spread from the Mediterranean via the Near East and India, and had reached this area by the important trading port of Oc Eo in Cochinchina further south. ${ }^{407}$

With twenty-five pages of report text and five plates, the kneeling figurine gets an outstanding amount of analytical attention compared with all the other objects found in Janse's excavations. Through this association, the kneeling figurine also ends up reshaping the contexts it was previously part of, becoming the prime object at the centre. The importance of the kneeling figurine - in Swedish: Ljusmannen - as an icon for Janse's archaeological endeavours in Indochina, means in other words that Lach-truong is now known as the place where the kneeling figurine was found, and tomb 3 in particular is described as "the tomb of the kneeling person". ${ }^{408}$ And much because of the kneeling figurine, Lach-truong is devoted an entire chapter in Janse's memoirs - the memoirs that were also given the title Ljusmannens gåta: The Mystery of the Kneeling Man. ${ }^{409}$

On the last day of February, when the first season of excavations in Thanh Hoa was coming to an end, Janse wrote a letter to Ture and Nora Nerman in Stockholm. He said that they were now working with simultaneous excavations on several sites, and he was in fact so busy - with four excava-

404. Janse 1959:140-144.

405. Janse 1959:145.

406. Janse 1959:139-148.

407. To our knowledge, no later literature has picked up these strands from Janse's analysis, and the explanation for the presence of the kneeling figurine and the smaller figurine with the tray in the Han tombs in Lach-truong remains an open question.

408. Janse 1951:28.

409. Janse 1959. 


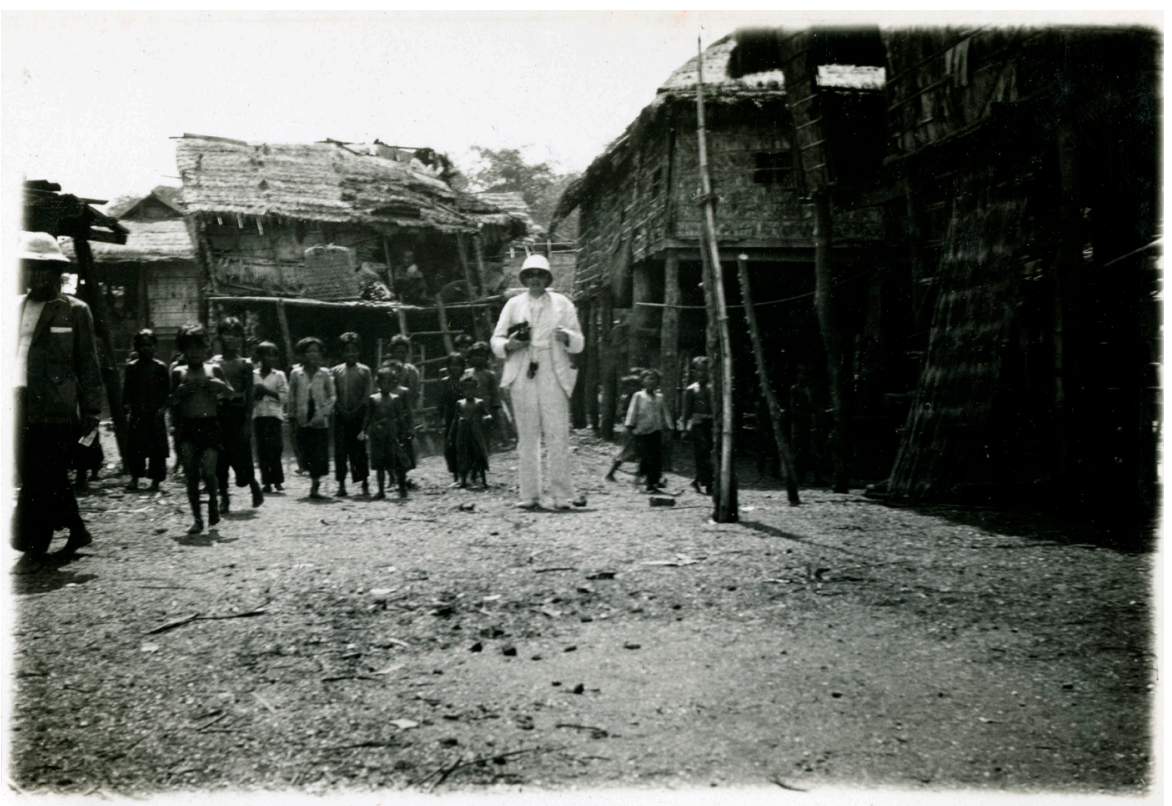

Fig. 41. Olov Janse with children in a village near Samrong Sen, March 1935

tion sites to supervise - that he found it difficult to find the time to write letters. On a normal day he was out in the field from early morning to late at night, and only because it was now raining had he found the time to write. Despite the apparently stressful situation, the tone of his letter is at once exhilarated and content:

We have had a wonderful time here, and have seen a tremendous amount. A whole new world is opening up for us. [...] I have now succeeded in sorting out the development of Chinese tomb structures, from the Han to the Song period, i.e. a timespan covering most of the first millennium AD. - I am very pleased with the results gained so far. ${ }^{40}$

A couple of weeks later, on 11 March, they halted the excavations in Lachtruong and returned to Hanoi and the basement of the Musée Louis

410. Letter from O. Janse to T. Nerman, 28 February 1935. In the Swedish original: "Vi har haft en underbar tid här och sett ofantligt mycket. En helt ny värld öppnar sig för oss. [...] Det har nu lyckats mig att klara upp utvecklingen av de kinesiska gravbyggnadernas utveckling från Han-dynastiens dagar till Song d.v.s. en tidsrymd, som i stort motsvarar 1sta årtusendet efter Kr. -Jag är mycket nöjd med de hittills vunna resultaten.” Arbetarrörelsens arkiv och bibliotek. Ture Nerman 3.1.7. 
Finot (now the National History Museum in Hanoi) to sort out and pack the last pieces of their findings for transport to Paris. As soon as they had finished packing, and Olov had given a lecture about their findings at the museum, ${ }^{411}$ they left Hanoi and travelled south. They were not going to leave Indochina until early April, so they took the opportunity to reconnect with their friend since the last visit, Suzanne Karpelès in Phnom Penh. With her help (and some sources say, ${ }^{412}$ in the presence of the Cambodian Princess Vukanthor), they set out to excavate some test trenches at a prehistoric settlement site called Samrong Sen near Tonle Sap - the Great Lake.

The excursion and quick test-pit dig at Samrong Sen is a curious detour in an excavation season otherwise focused on later periods and more spectacular findings with the potential to become outstanding museum pieces or fill typological blanks in archaeological study collections. In their personal archive there are a few photographs marked Samrong Sen, and one of them features a heap of soil, indicating that the test-pit excavation actually took place. ${ }^{413}$ But there is no excavation report, and apart from a short chapter in Janse's memoirs focusing mostly on the boat journey to Tonle Sap, ${ }^{414}$ there is no published information that indicates why they made this detour.

However, back at the hotel Le Royal in Phnom Penh, Janse wrote a letter that offers a clue. In the letter, addressed to Marcel Mauss in Paris, he reported that the excavations in Annam had borne much fruit, and asked to see Mauss upon his return to Paris to have his advice on some issues from the excavations. He reported further that they had just arrived in Phnom Penh after a survey at Samrong Sen, where he had not forgotten Mauss's recommendation "to search in the garbage", and had collected some interesting ethnographic objects. ${ }^{415}$ Always keen to please his mentors and patrons, Janse made a number of curious detours over the years in Indochina, which were not quite compatible with the official aims of the expeditions. Often they resulted in no concrete results other than a few objects sent to a museum in Europe, or a brief remark in his

411. The lecture is reported in an article in L'Avenir du Tonkin, 19 March 1935: "Anciennes sépultures du Tonkin et du Nord-Annam: Conférence de M. O. Janse."

412. E.g. Janse 1959:200-207.

413. NAA: Janse 2001-29.

414. Janse 1959:200-207.

415. Letter from O. Janse to M. Mauss, 20 March 1935. Fonds Marcel Mauss au Collège de France: mauss-janse-०023.pdf. 
memoirs. In almost every case these detours can, as here with help from the letter to Marcel Mauss, be connected with an expressed wish, or a piece of advice from one of his mentors or patrons..$^{416}$

From the letter to Marcel Mauss we also know that by now, Olov and Ronny were suffering from the heat and felt very tired. They would have preferred to go straight back to Paris, but had to travel back from Saigon via China, Japan and the United States, because there were no tickets left for the boats bound for Marseille. ${ }^{417}$

In the official accounts, however, the tone is quite different. Back in Saigon waiting for the boat to take them to France via Japan and the United States, Janse took the opportunity to give interviews about the results from his successful expedition. For the journalists, he talked about the upcoming visit to Japan as a planned lecture tour, adding to the impression of himself as an internationally sought-after expert. In the newspaper articles Janse is described as un jeune savant - a young distinguished scholar, toujours modeste et toujours souriant - always modest and always smiling, ${ }^{418}$ who responds to the journalist's questions fort aimablement et d'une voix souple assez inattendue pour un Nordique - ever so friendly, and with a soft voice very rare for a Nordic person. ${ }^{419}$ In all interviews Janse is keen to acknowledge his colleagues and collaborators from the E FEO; Nguyen Xuan Dong is mentioned as an "excellent Annamite collaborator" responsible for the high-quality plan drawings (see fig. 39), Jean-Yves Claeys for shooting some of the films, and Jean Mannikus for taking some of the photographs. ${ }^{420}$ In fact, the whole society and administration in Indochina is repeatedly acknowledged for the extraordinary generosity and support they have extended to him and Ronny since their arrival in Saigon:

Allow me to tell you one more time how pleased we are, Mrs Janse and I, with our sojourn in French Indochina. We are stunned by everything we have seen in this enchanting country, which we

416. See more about Janse's relations with mentors and patrons in the Conclusion.

417. Letter from O. Janse to M. Mauss, 20 March 1935. Fonds Marcel Mauss au Collège de France: mauss-janse-0023.pdf.

418. Huynh Cong-Can in Le Populaire de l'Indochine, 3 April 1935: "La conférence du Dr. Janse sur les récentes fouilles archéologiques dans le Tonkin et le Nord-Annam."

419. La Depêche, 2 April 1935: "Un quart d'heure avec M. Jansse: Délégué des Musées de Paris."

420. L'Avenir du Tonkin, 22 March 1935: "Un entretien avec le Dr O. Janse." 
are deeply fond of. Everywhere we have been able to observe the day-by-day progress of the Union, of science and French civilization. When we now leave the soil of Indochina, we take with us unforgettable memories and a longing for more. ${ }^{421}$

Generosity and gentle manners are recurring themes in descriptions of Janse's first Indochina expedition. In the same spirit, and as a sort of grande finale of their first expedition, he gave an acclaimed public lecture with the title Les dernières fouilles archéologiques au Tonkin et au Nord-Annam - "The recent archaeological excavations in Tonkin and Nord-Annam", hosted by the Société des Études Indochinoises at the Salle Philharmonique in Saigon, on the evening of Tuesday 2 April. The lecture was a great success, and the newspapers abounded with positive reviews. L'Impartial wrote that although a lecture on the latest excavations in Tonkin normally would interest only the initiated few, Dr Janse filled the lecture hall as if he had been a movie star or a sports hero. ${ }^{422}$ L'Opinion wrote in the same spirit that the event gathered a numerous and elegant crowd, and to say that the lecturer made a great success would be a banal cliché, which would fail to convey how he completely captured his audience's attention. ${ }^{423}$ The lecture ended with projections of films and photographs, from the excavations and of native tribes. The visual projections in par-

421. L'Avenir du Tonkin, 22 March 1935: “Un entretien avec le Dr O. Janse." In the French original: "Permettez-moi de vous dire encore une fois combien nous sommes heureux Mme Janse et moi de notre séjour en Indochine française. Nous sommes émerveillés de tout ce que nous avons vu dans ce pays enchanteur que nous aimons profondément. Partout nous avons pu constater le progrès qu'apportent chaque jour à l'Union, la science et la civilisation française. Lorsque nous quitterons le sol indochinois, nous emporterons avec nous des souvenirs inoubliables et une nostalgie de plus."

422. L'Impartial, 3 April 1935: "La belle conference du Dr O. Janse sur les fouilles archéologiques au Tonkin". In the French original: "Une conférence sur les dernières fouilles archéologiques au Tonkin et au Nord Annam est, sans conteste, réservés à certain un nombre d'initiés. Mais hier le Dr O. Janse fit tout simplement salle comble, comme une vedette de l'écran ou du sport."

423.L'Opinion, 3 April 1935: "Conférence du Dr. O. Janse à la Philharmonique". In the French original: "La personnalité du Dr O. Janse, accolée à celles, morales, de l'Ecole Française d'E.O. et de la Société des Etudes Indochinoises, avaient naturellement attiré une assistance nombreuse et élégante dans la vaste et coquette salle de la Philharmonique. [...] Dire que le conférencier a obtenu un gros succès, c'est utiliser un cliché banal et ce n'est pas souligner assez exactement l'attention que lui prêta un auditoire litérairement captive." 
ticular were reportedly much appreciated by the audience and were commented on in every one of the articles. ${ }^{424}$

When it came to the results from his first excavation season, it is noteworthy that in the lecture in Saigon, and the newspapers reviewing it, it was the excavations at Dong Son that caught the most attention. Unlike his later excavation reports, and media coverage in Europe and the United States, which are all more focused on the Han brick tombs, and spectacular finds such as the kneeling figurine from Lach-truong, here it was the new interpretation of Dong Son that stood out as the most important result. This is also the first time that Janse officially talks about a "Dongsonian civilization", with links to the native tribes of Indochina:

The principal aim of my archaeological researches here, have been to study the little known civilization that Mr Codès and Mr Goloubew have called Indonesian, and which has also been referred to as Dongsonian, after an ancient settlement near the village of Dong Son in the Thanh Hoa province. [...] It is intriguing to observe that some of the scenes reproduced on one of these [bronze] drums could be compared with ceremonies that are still to this day practised by the Muong tribes in Thanh Hoa and Hoa-binh. There are no doubt parallels to be drawn between the Dongsonian civilization two thousand years ago, and the Muong tribes of our days. ${ }^{425}$

424. E.g. La Presse Indochinoise Saigon, 3 April 1935: "Une intéressante conference de H. O. Jause [sic]."; Le Populaire de l'Indochine, 3 April 1935, Huynh Cong-Can: "La conférence du Dr. Janse sur les récentes fouilles archéologiques dans le Tonkin et le Nord-Annam."; L'Opinion, 3 April 1935: "Conférence du Dr. O. Janse à la Philharmonique"; L'Impartial, 3 April 1935: "La belle conference du Dr O. Janse sur les fouilles archéologiques au Tonkin".

425. Olov Janse, quoted in an interview by Huynh Cong-Can, in Le Populaire de l'Indochine, 3 April 1935: "La conférence du Dr. Janse sur les récentes fouilles archéologiques dans le Tonkin et le Nord-Annam". In the French original: "Le but principal de mes recherches archéoliques [sic] ici étatit d'étudier la civililogisation [sic] si peu connue que MM. Cœè̀s et Goloubew ont dénommée d'indonésienne et que l'on a aussi voulu dénommer de Dongsonienne, d'après une station ancienne qui se trouve près du village de Dong-son dans le Thanh Hoa. [...] Il est curieux de constater que quelques scenes reproduites sur un de ces tambours peuvent être compares à des ceremonies que pratiquent encore de nos jours les Muongs de Thanh Hoa et de Hoa-binh. Il est indiscutable qu'il $\mathrm{y}$ a un rapprochement à faire entre la civilisation Dongsonienne, deux fois millenaire et celle des Muongs de nos jours." 
This focus on links between prehistoric finds and present native culture is accompanied by a concern for the placement of the findings. In an interview in La Depêche, Janse says that all the finds from his excavations will be gathered at the Cernuschi Museum in Paris shortly after their return to France. The reporter asks:

This may be a stupid question, but isn't there in Indochina a sense of having been robbed of the results of your important research? ${ }^{226}$

Janse responds:

You can be calm, all the pieces will not stay in France. The exhibition [at the Cernuschi Museum] is organized under the auspices of the Société des Amis de l'EFEO so the colony's archaeological interests will be completely safeguarded. You could say that all objects which the [Musée Louis Finot] does not already have an equivalent of will be immediately returned to Hanoi. Only the duplicates will remain in France and put in safe custody by the City of Paris. We must not forget that [the City of Paris] has with generous support significantly contributed to the success of my mission. ${ }^{427}$

They were now ready to leave Indochina, and only two days after the lecture, on 4 April, they embarked on the MS Félix Roussel bound for Japan. The letters they wrote indicate that they were tired, but content. In hindsight we know that already here, at the end of the first and shortest expedition, the most important sites had been excavated and their most spectacular finds had been made. During the following two expeditions

426.La Depêche, 2 April 1935: "Un quart d'heure avec M. Jansse [sic]: Délégué des Musées de Paris". In the French original: "Mais, fîmes-nous assez étonné, l'Indochine ne se trouvera elle pas ainsi frustrée du bénéfice de vos importantes recherches?"

427. La Depêche, 2 April 1935: "Un quart d'heure avec M. Jansse: Délégué des Musées de Paris". In the French original: "Tranquillisez vous, toutes les pieces ne resteront pas en France. Cette exposition sera faite sous l'égide de la Société des Amis de l'Ecole Française d'Extrême Orient et les intérêts archéologiques de la Colonie seront scrupuleusement sauvegardés. Vous pouvez dire que tous les objets dont le Musée de l'Ecole Française ne possède pas d'équivalent seront renvoyés ensuite à Hanoi. Seuls les doubles resteront en France confiés aux bons soins de la Ville de Paris. Il ne faut pas oublier qu'elle a largement contribué au success de ma mission en y subvenant d'appréciable manière." 
they would, with few exceptions, return to the same sites and repeat what they had done in the first.

Janse had already found a temporal focal point for his research in Indochina, around the year AD 40. According to Chinese chronicles, the Thanh Hoa province had then been incorporated in the Chinese Han Empire for 150 years (since $111 \mathrm{BC}$ ), and was known by the Chinese name Chiu-chen. In the year AD 40 a woman named Trung-Trac, who was the daughter of a native chief from a nearby province, started a revolt against the Han colonizers. She was joined by the native chiefs of the surrounding provinces, and eventually forced the colonizers to leave. The rebellion was, however, repressed shortly thereafter with extreme brutality by the Han, in an invasion led by general Ma Yüan in the year AD 43. According to Chinese records from the time, thousands of people were killed in Ma Yüan's offensive, hundreds of families were deported to China, and the natives who managed to escape became refugees in the mountains or islands far away. ${ }^{428}$ In his first report (published 1947) Janse uses this historical event as a focal point to explain the cultural context of the findings he made, in the Han brick tombs and the Dong Son settlement site. He says that his findings indicate that Dong Son was a native centre of great importance long before the Han colonized the area in $111 \mathrm{BC}$. And moreover, that Dong Son existed as a commercial and strategic hub through the first period of Han rule and was destroyed in Ma Yüan's invasion in 43 AD because of its strategic importance. When the native population was killed or fled, the Dong Son area was taken over by the conquerors, who left traces in the form of Han brick tombs. Not all the brick tombs they had excavated, however, could be attributed to the time after the invasion in 43 AD. Those of earlier date, Janse suggested, should rather be linked to a wave of political refugees to Chiu-chen on the southern margins of the empire after the dramatic downfall of emperor Wang Mang (AD 9-23).429

The political background he sketches to contextualize his findings is an intriguingly complex image of the Han "colonization" of this area. Although restricted by the one-sided information found in Chinese chronicles (propped up with a few shaky references to philology and

428. Janse 1947:xv-xxiv.

429. Janse 1947:xv-xxi, 58-59. 
blood groups), ${ }^{43}$ it is possible to discern a number of different social situations, including native rule and rebellion, and Chinese exile and invasion. Moreover, all seem to fit with Janse's excavation findings, if we trust his interpretations. In archaeology today, it would have been common to use the archaeological material for further analysis of these complex social situations. But Janse stops there and leaves it as a flat backdrop, only mentioned in his scientific reports, where he declares: "Our excavations have on some points corroborated evidence supplied by the ancient, written documents." ${ }^{331}$ In his lectures and popular texts he resorts instead to the more marketable format of cultural diffusion, where a complex colonial culture is gradually taking over a simple native one, with Han times described very much as a paraphrase of the official image of the present French colonization.

Janse's archaeological narratives in newspaper articles and his memoirs are, as we noticed earlier, organized around a categorization of culture as either primitive or civilized. Such an essential and evolution-bound view of culture is characteristic of French (and European more generally) colonial discourse of the early twentieth century. Hence in Janse's interpretations of the so-called native, or "Indonesian" finds from Dong Son, the analogies for comparison are taken from other supposedly "primitive" cultures found in prehistoric Europe or among living tribes in colonized lands. His analyses of the contemporary Han tombs on the other hand, are never compared with "primitive" cultures, but are instead discussed in similar eclectic comparisons with other "civilizations" (albeit only prehistoric, no contemporary) in Asia and Europe.

The assumed development stage (Stone Age level, or primitive) guides the search for analogies, rather than context or contents. Hence he uses examples from living groups under the denomination Moï (which were named after the Vietnamese word for "savage" 432 ) and the Muong (sometimes more generally referred to as "mountain tribes"), or "primitive tribes" in Burma, randomly mixed with prehistoric examples such as Scandinavian bog bodies, megaliths, and Stone Age single graves, to fill in the blanks and create spectacular images of the Don Son people that were not actually supported by the things they found at the site.

430. Janse 1947:xl.

431. Janse 1951: v.

432. Jennings 2011:16. 
The latter find [which consisted of parts of a human skull preserved through contact with bronze artefacts in grave no. 2, loc. 3] suggests that the ancient Dong Son people were headhunters. This terrible custom had been widespread among Malayan and Melanesian tribes. It existed not long ago among the Dayaks in Sarawak (Borneo), a people whose ancient primitive culture has, not without reason, been compared with the ancient Dong Son people. 433

The primitive-civilized dichotomy comes through as an important organizing principle in his more scholarly reports as well. But the overall structure of Janse's scholarly reports must be understood as a consequence of his interest in artefacts primarily as museum pieces with potential for large-scale comparative analysis, in the spirit of his mentors Oscar Montelius and Henri Hubert. Such bold, large-scale comparisons are less common in archaeology today, and therefore the comparative analytical focus makes Janse's reports a challenging read for anyone with a more contextual interest (which is more common in archaeology today). Although each excavation campaign, and each tomb or trench (fouille or $l o c$.) are described in some detail, the following analysis does very little to connect the findings into units that together create a whole, such as the Dong Son settlement, or the Lach-truong necropolis. Hence it is almost impossible to see each grave and the artefacts in it as parts of the larger settlement or necropolis, and to get a sense of them in their own historical context. Rather than uniting the finds in a conceptualization of, for instance, the Dong Son settlement, Janse breaks them up, explodes them, to create abstract analytical links in analogical comparisons with "Stone Age" or "primitive" cultures more generally.

Of central importance for French human science at this time, was also the question of race, and particularly of race blending - métissage. Race was likewise an important issue in Sweden where Janse had his first language and his archaeological foundations, but the political meaning and importance invested in the concept of race was different to the French. In Sweden, which like Germany has a tradition linking the concept of

433. Janse 1959:110-111. In the Swedish original: "Det sistnämnda fyndet tyder på att de gamla Dong-son-borna varit huvudjägare. Detta förskräckliga bruk har varit mycket utbrett bland malajiska och melanesiska stammar. Det förekom för inte länge sedan bland dajakerna i Sarawak (Borneo), ett folk vars lika primitiva som urgamla kultur inte utan skäl har jämförts med de gamla Dong-son-bornas.” See also Janse 1958:56. 
the nation to racial purity (one race, one nation), race was often referred to in terms of blood, and tentative "full-bloods" were regarded as the ideal, most stable foundation for a nation. France had a less static view of the relation between race and nation, and there was an intense political debate on whether or not métissage contributed to healthier bodies and minds and hence to a stronger foundation for the French nation. ${ }^{434}$ In a newspaper article featuring a journey by train along the coast of Indochina, Janse describes the French views for a Swedish audience:

\begin{abstract}
We are fortunate, my wife and I, to travel in the company of some senior French railway engineers, who have spent most of their lives in Indochina. [...] The conversation eventually moves to another essential problem, namely the Métis and their status. My travel companions have a very wide view on the issue, and regard the problem in a way that ought to be characteristic for the lack of racial prejudice that we see in countries marked by French culture. Children in so-called mixed marriages, where one party is white and the other is of the yellow race, are generally healthy and much more robust than children of only white parents. ${ }^{435}$
\end{abstract}

The "lack of racial prejudice" that Janse talks about can also be described as an intense focus on issues of race in French Third Republic politics and society. ${ }^{436}$ It fell back on a long-lasting debate about the foundation of the French nation in prehistoric times, and the colonies were used as "racial laboratories" where the outcomes of different forms of métissage were scientifically observed. One side of the debate, often from the radical-liberal end of the political spectrum, advocated the benefits of métissage (as we see reflected here in the excerpt from Janse's article), while the other, mostly

434. Saada 2002.

435. Janse 1935 d. In the Swedish original: "Vi ha turen, min hustru och jag, att göra resan i sällskap med några äldre franska järnvägsingenjörer, vilka tillbragt större delen av livet i Indokina. [...] Samtalet glider så småningom in på ett annat problem av central betydelse, nämligen metiserna och deras ställning. Mina medpassagerare ha en mycket vid syn på saken, en uppfattning av problemet, som torde vara karakteristiskt för den fördomsfrihet beträffande rasfrågor, som råder i de länder där fransk kultur satt sin prägel. Barnen i s.k. blandäktenskap där en av kontrahenterna är vit och den andra av den gula rasen, bli i regel välskapade och mycket motståndskraftigare än barn födda av vita föräldrar."

436. The Third Republic refers to the French government between the fall of Napoleon III in the Franco-Prussan War (1870) and the German occupation of France (1940). 
at the conservative end maintained (although acknowledging the existence of several races in prehistoric France) that the different races within the nation ought to be kept separate and not blend into hybrid forms. ${ }^{437}$

Janse navigates between the Swedish purity-of-blood and the French métissage concepts when he formulates the results from his archaeological investigations in Indochina. Earlier in this chapter we have seen how he was occupied with the purity of blood, when writing for a Swedish audience about his meetings with native people such as the Cham. ${ }^{438}$ But in interviews intended for French or Indochinese audiences, and in his excavation report published in English, he adopts the French métissage concept and operates smoothly within the French discourse. This is particularly noteworthy when he talks about the Dong Son site as the birthplace of a Vietnamese nation:

The gradually growing invasion of Chinese and possibly Thai must be largely responsible for an ethnic mixture which resulted, at the beginning of our era, in the formation of the Annamite nation. ${ }^{439}$

437. Saada 2002; Conklin 2013.

438. Janse 1959:55.

439. Janse 1958:91.

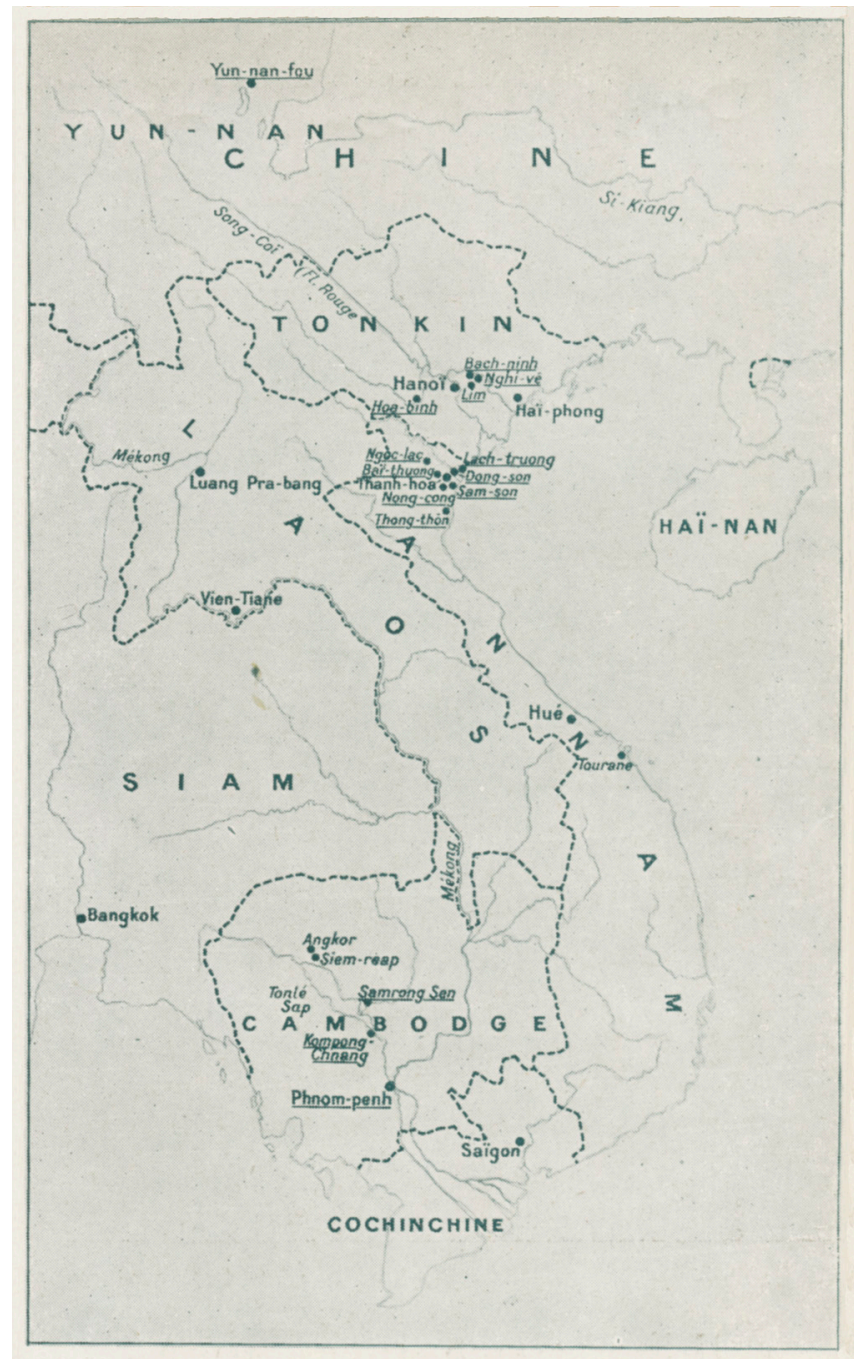

Mission archéologique et ethnographique de M. O. Jansé. Les sites des fouilles sont soulignés.

Fig. 42. Map of French Indochina, with sites visited or excavated in the first expedition underlined. 


\section{INTERLUDE}

MAY 1935-OCTOBER 1936

After the brief lecture tour in Japan, ${ }^{44^{\circ}}$ Olov and Ronny departed from Yokohama on the MS Tatsuta Maru on 25 April, bound for San Francisco. The journey took thirteen days, and a menu card kept in their personal archive gives some sense of the opulent standard on board. For the "farewell dinner" on 6 May there were, apart from a generous selection of hors d'œuvres and fruit, twenty-four dishes. Soup was followed by a Salmon Supreme Monte Carlo, Green Turtle Newburg Melba, Noisette de Pre Sale, a Raised Game Pie St Hubert, and Asparagus Mayonnaise Chantilly. For mains there was Beef à la Française, Roast Suckling Pig with sausage meat stuffing and baked apples, Roast Young Turkey, Boiled Swift Premium Ham, Beans, Cauliflower, and Potatoes - boiled, browned and snowflaked. Added to that was a cold buffet and salad, followed by sweets in the form of Plum Pudding Mt Fuji, Mince Pie with Apple Meringue, Iced Pineapple Queen Style, Bavaroise Ceylon, an Ornamented Farewell Cake, and a savoury Cheese Soufflé. ${ }^{441}$ Olov and Ronny travelled first class, and enjoyed the company of their fellow cosmopolitan travellers. They arrived in San Francisco on 8 May, departed again after ten days with the legendary SS Île de France, and arrived in Paris on 24 May.

Once back, there was no time for rest. At the Cernuschi Museum they immediately set out to unpack and organize their finds for the impending exhibition. Four weeks after their arrival in Paris, Ronny wrote a postcard

440. The lectures were noticed in Japanese press, and some of these clippings have been kept in NAA: Janse 2001-29.

441. Menu card for farewell dinner on MS Tatsuta Maru, 6 May 1935. NAA: Janse 2001-29. 
to Barbro and Birger Nerman in Stockholm, to mark the occasion of their daughter Elisabeth's first birthday. It is here quoted in original Swedish (translation in the note), because its unique style gives a rare glimpse of Ronny's own voice, and conveys a sense of intimacy, rush and exhilaration that will inevitably be lost in translation:

\begin{abstract}
Käraste Barbro och Birger,
De bästa och hjärtligaste hälsningar och lyckönskningar till vår lilla ettårig Elisabeth! Tysand kyssar, de ömaste! Tack so mycket för vänliga brevet. Snart skall vi svara men nu, förlåt, kan vi absolut inte göra det. Vi förberedda en utställning på museet av Olles fynd. Det är enastående fynd. Olle ha funnit saker som gör en revolution i arkeologin, påstår man. [...]
\end{abstract}

Er tillg vän Ronny ${ }^{442}$

They worked hard and were too busy to write letters, but they were also excited about the upcoming exhibition. Their finds - officially Olov's seemed to be about to revolutionize archaeology, and their display would be the showstopper at the grand reopening of the Cernuschi Museum. So they had every reason to be both content and excited.

Ten days after Ronny wrote her postcard, on Saturday afternoon, 29 June 1935, the Cernuschi Museum opened its doors after four months of renovation work. The Parisian press joined in praise of the new museum, ${ }^{443}$ and wrote that the architect Pierre Fournier had made a complete metamorphosis of the interior of the museum, from the earlier dark panelling and heavy warm-coloured velvet textiles, to a light, strict and

442. Postcard from Ronny Janse to Barbro and Birger Nerman, 19 June 1935. Riksarkivet. Kartong 3. Korrespondens Brev III 1935-1941. In English translation: Dearest Barbro and Birger, / All the best and heartfelt greetings and felicitations to our little one-year Elisabeth! Thousand kisses, the most tender! Thank you so much for the kind letter. We shall soon respond but now, sorry, we can absolutely not. We are preparing an exhibition at the museum of Olle's finds. They are outstanding finds. Olle have found things that make a revolution in archaeology, so they say. [...] Your devoted friend, Ronny.

443. Beaux-Arts: Le Journal des Arts, 5 July 1935: "Au Musée Cernuschi renové: Les découvertes archéologique de M. O. Jansé"; La Semaine de Paris, 5-11 July 1935: "La Réouverture du Musée Cernuschi."; Le Temps, 7 July 1935: "Art et Curiosité: On expose, dans les salles remises à neuf du musée Cernuschi, les premiers résultats de la mission Jansé"; Le Figaro, n.d.: (Raymond Lécuyer), "Au Musée Cernuschi Transformé: Une Exposition d'art chinois de haute époque."; La Liberté, n.d: (René Chavance), "La réouverture du Musée Cernuschi et les premiers résultats de la mission Jansé.” 
Fig. 43. Invitation card to the reopening of Cernuschi Museum in June 1935 .

\section{RÉPUBLIQUE FRANÇAISE}

Liberté - Égalité - Fraternité

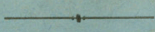

\section{LA MUNICIPALITE DE PARIS}

a I'honneur de vous prier de vouloir bien assister

à la RÉOUVERTURE du MUSÉE CERNUSCHI, avec présentation des nouveaux aménagements, et à I'EXPOSITION, organisée avec le concours de la Société des Amis de I'École Française d'ExtrêmeOrient, des PREMIERS RÉSULTATS de la MISSION JANSÉ en INDOCHINE, qui auront lieu le Samedi 29 Juin 1935, à quatorze heures.

elegant contemporary design, "in accordance with the latest museographic principles". ${ }^{444}$ The driving force behind the transformation was the museum's new director René Grousset, who wanted to emphasize the didactic and allow the museum to be a place for learning. In focus was the temporary display of finds from Olov Janse's Indochina expedition.

It was indeed a brave move by René Grousset, from the fine collectible Asian art that was the museum's trademark, to archaeological objects that were valued by their age and original authenticity, rather than masterful artistry. ${ }^{45}$ The new display was, however, well received and the press reports talk enthusiastically of Janse as a fortunate excavator who with great skill had brought a rich booty of ancient objects for the benefit of the French nation. The objects most frequently mentioned in the press are the kneeling figurine from Lach-truong, a tripod with a pheasant head, a bronze drum, and clay farm models skilfully reassembled by Monsieur Mercier at the Louis Finot Museum in Hanoi. ${ }^{446}$

444. Le Figaro, n.d.: (Raymond Lécuyer), “Au Musée Cernuschi Transformé: Une Exposition d'art chinois de haute époque".

445. In the chapter "Memorabilia" we discuss the situation for Janse's collections at the Cernuschi Museum today, and notice that the tension between "fine art" and archaeological collections has lingered in the museum to this day.

446.Le Temps, 7 July 1935: "Art et Curiosité: On expose, dans les salles remises à neuf du musée Cernuschi, les premiers résultats de la mission Jansé”; Le Figaro, n.d.: (Raymond Lécuyer), “Au Musée Cernuschi Transformé: Une Exposition d'art chinois de 
Soon after the successful opening of their exhibition, Ronny and Olov left Paris for a much-desired vacation in Sweden. They arrived in Stockholm on 11 July, and continued straight on to the Janse family's summer house at Skagshamn near Valdemarsvik, where they stayed for a month to relax before returning again to Stockholm. ${ }^{447}$

During the summer the Swedish press reported on their homecoming, with comments about the expedition, the Cernuschi exhibition in Paris, and the collection that had arrived at the Ethnographic Museum in Stockholm..$^{448}$ An article in his hometown paper Norrköpings Tidningar characterizes the Swedish interest with the subtitles "Professor Janse visits Sweden after 8 months research journey in the East"; "Hitherto unknown culture discovered"; and "Rich archaeological and ethnographic collections". An apparently content, if not complacent, Professor Janse is interviewed:

It has been a very rewarding research expedition, emphasizes Prof. Janse. It is of course not every day one discovers a previously unknown culture. ${ }^{449}$

But he was not only doing interviews about his results, he also spent the summer and autumn writing long popular articles about his expedition and findings. One article was published in two parts in the Illustrated London News, ${ }^{45}$ and another as a series of three articles in Norrköpings Tidningar. ${ }^{451}$ The latter article series is in some parts identical with the text in his memoirs (published twenty-four years later) ${ }^{452}$ revealing that parts of the memoir text were written as early as 1935 .

haute époque."; La Liberté, n.d: (René Chavance), "La réouverture du Musée Cernuschi et les premiers résultats de la mission Jansé".

447. Letter from O. Janse to T. Nerman, 15 July 1935. Arbetarrörelsens arkiv och bibliotek. Ture Nerman 3.1.7. Postcard from O. Janse to B. Nerman, 25 July 1935. Riksarkivet. Kartong 3. Korrespondens Brev III 1935-1941.

448.E.g. Dagens Nyheter, 6 August 1935: “'Mission O. Jansé' i museum Cernuschi.”; Östergötlands Dagblad, 7 August 1935: "Kinas gamla värld."; Norrköpings Tidningar, 14 August 1935: "Hem från Indokina."

449. Norrköpings Tidningar, 14 August 1935: In the Swedish original: "Det har varit en mycket givande forskningsresa, betonar prof. Janse. Det är ju inte var dag man upptäcker en förut okänd kultur."

450. Janse $1935 \mathrm{a}-\mathrm{b}$.

451. Janse $1935^{\mathrm{c}-\mathrm{e} \text {. }}$

452. Janse 1959 . 
Let us stop here for a moment and reflect on the press reports of their first expedition. Viewed from a national comparative perspective, they reveal interesting differences in how Janse's work was invested with meaning, in the Indochinese, Swedish, and French mass media.

In the French-speaking Indochinese press, Janse is referred to as an illustre or éminent savant, and described as a delegate from the French national museums. His gentle, smiling personality is a recurring theme. Much focus is on Dong Son and its indigenous or "Indonesian" origin, comparable to the native Muong people, and Janse suggests here for the first time officially the denomination "Dongsonian" for this archaeological culture. The excavations of Han tombs are repeatedly referred to as less important. The kneeling figurine is, however, mentioned as their most important find, with reference to the expert opinions of George Cœè̀s and Victor Goloubew at the EFEO. A second important issue in the Indochinese press is the future location of the excavated collections. Janse has to explain that the majority of objects, and certainly all the unique pieces, will be returned to Indochina after the exhibition at the Cernuschi Museum in Paris, and only a collection of duplicates will be kept in Paris. He also explains in this context that it is necessary to offer something to the museums of Paris in return for their generous support of his expedition. ${ }^{453}$

In the Swedish press, Janse is referred to as the Swedish professor or Norrköpingspojken - "the Norrköping lad", and is portrayed as a brave explorer of godforsaken lands and a discoverer of unknown cultures. Much focus is here on the ethnographic collections he sent to the Stockholm Museum of Ethnography. Another recurring theme is his meetings with exotic tribes, which are described in a paternalistic, often humorous tone. The archaeological focus is here on the excavations of Han graves, which are described as particularly rich and advanced, while Dong Son is mentioned only in passing. Both the Han tombs and Dong Son are here featured in

453.E.g. LAvenir du Tonkin, 19 March 1935: "Anciennes sépultures du Tonkin et du Nord-Annam: Conférence de M. O. Janse"; La Presse Indochinoise Saigon, 3 April 1935: "Une intéressante conference de H. O. Jause"; Le Populaire de l'Indochine, Huynh CongCan, 3 April 1935: "La conférence du Dr. Janse sur les récentes fouilles archéologiques dans le Tonkin et le Nord-Annam"; L'Opinion, 3 April 1935: "Conférence du Dr. O. Janse à la Philharmonique"; L'Impartial, 3 April 1935: "La belle conference du Dr O. Janse sur les fouilles archéologiques au Tonkin". 
terms of the discovery (Swe: upptäckt) of an unknown culture, described as a hybrid between Chinese and indigenous culture. ${ }^{454}$

And finally, in the French press he is referred to as a savant archéologique suédois, mais Français de cœur et d'adoption ${ }^{455}$ - a distinguished archaeologist of Swedish birth, but French by heart and adoption - and his contribution to the French nation is repeatedly acknowledged. Janse likewise repeatedly emphasizes the greatness of French values and French presence, which has made Indochina une oasis de paix et de travail - an oasis of peace and good work. ${ }^{456} \mathrm{He}$ is quoted several times describing Indochina as an ancient crossroads of several civilizatory currents, but when it comes to his archaeological work, most focus is on his excavations of Han tombs. When Dong Son is mentioned, it is in terms of an Indonesian culture under strong influence from the Chinese Han. The kneeling figurine from Lach-truong is also given some attention, as in the Indochinese press. The French press mentions regularly the "ample" or "rich" "booty" he brought to Paris, and shows a particular interest in particular artefacts, such as the house models. This interest could, however, be explained to some extent by the fact that most of these articles have the new exhibition at the Cernuschi Museum as their main object. On the same note, $\mathrm{Mr}$ Mercier at the Louis Finot Museum in Hanoi is often mentioned in the French press, for his skilful reassembling of the fragmented pieces on display in Paris. ${ }^{457}$

In summary, the Indochinese, Swedish, and French press reports concentrate on three different aspects of Janse's personal identity: In Indochina the gentle and distinguished scholar, in Sweden the hometown lad-cum-successful explorer, and in France his French nationality (by heart and adoption). They report differently on his scientific findings: In Indochina the focus is on Dong Son and its links to present native culture,

454.E.g. Stockholms-Tidningen, 8 May 1935: "Svensken vän med urfolket i Indokina: Professor Janse på hemväg efter enastående upplevelser i Fjärran Östern"; Dagens Nyheter 6 August 1935; Östergötlands Dagblad, 7 August 1935; Norrköpings Tidningar, 14 August 1935; Svenska Dagbladet, 20 November 1935: "300 etnografika hit från Franska Indokina. Prof. Janses första kollektion till Etnografiska museet”; Social-Demokraten, 1 October 1936: "Guldkalven är kinesisk predikstol: Asiatisk kuriosa skall utställas i oktober".

455. La nouvelle depêche, 29 June 1935: "Retour d'Indochine, M. Jansé nous parle de sa mission".

456. Janse 1936.

457. La nouvelle depêche, 29 June 1935: "Retour d'Indochine, M. Jansé nous parle de sa mission." 
in Sweden on ethnographic exploration and the discovery of hitherto unknown hybrid cultures, while in France the emphasis is on Han colonization and Indochina as a crossroad, hence a place for meeting and mingling of important cultural currents from elsewhere. And finally, the three national press contexts have different views on the most important results of the expedition: in Indochina there is a concern for the placement of the findings, in Sweden the focus is on the ethnographic collections shipped to Stockholm, and in France much positive attention is given to the "ample booty" of artefacts brought to France by the expedition. Altogether, these different foci offer insights as to how Indochina as a place of interest was valued and conceptualized by the newspaper-reading public in the three national contexts.

Of particular importance for us is also to see how Janse was aware of, and cunningly manoeuvred through and between these sometimes conflicting discourses. Hence he was not a passive, scientifically objective projection screen to stories produced by national media, but he actively adjusted to the three different contexts. We see it in interviews (which could have been manipulated by the journalists, but still reveal choices of themes and words that demonstrate considerable adjustment skills), but even more importantly in the texts he himself authored for newspapers and popular magazines.

As the summer came to an end, Olov and Ronny left Sweden and travelled back to Paris where they arrived on 2 September. They continued working with their collections at the Cernuschi Museum - "an interesting but time-consuming task". ${ }^{48} 8$ At the end of October, the Swedish Crown Prince (later King Gustaf VI Adolf) paid them a visit, and stayed five days in Paris. The day after his departure, Olov wrote to Birger Nerman:

I have now spent every day with the Crown Prince, who arrived here on the 22nd and left yesterday. On the 25 th we had a function at Musée Cernuschi, which the Crown Prince was kind enough to attend. He stayed at the museum for about 3 hours and studied every detail of the collections. Afterwards we had tea. The

458. Letter from O. Janse to B. Nerman, 12 October 1935. Riksarkivet. Kartong 3. Korrespondens Brev III 1935-1941. 
Crown Prince was very kind and seemed content with his visit. As a souvenir of the same, he was presented with a collection of Indochinese artefacts, which I excavated or obtained during my expedition. The Crown Prince will probably donate the collection to the Museum of Far Eastern Antiquities. ${ }^{459}$

Just as Janse guessed, the souvenir collection was later donated to the Museum of Far Eastern Antiquities. ${ }^{460}$ The visit was important for Janse, since it gave him a chance to spend time with the Crown Prince who nurtured a serious interest in archaeology and art history, for which he held a high reputation in Sweden and abroad. A keen collector and friend of Johan Gunnar Andersson's, he was also an influential board member of the Museum of Far Eastern Antiquities. Owing to the Crown Prince's high reputation among collectors and museum officials, the attention he paid to Janse's work gave it a stamp of special importance and quality, in both France and Sweden. In the spring the following year, the French museologist Georges-Henri Rivière (founder of the Musée d'Etnographie Trocadéro (MET) and later founder of ICOM) was interviewed during a visit to Stockholm:

I congratulate your country on having a Crown Prince with both an interest in and a knowledge of art. [...] Some time ago he visited Dr Olof Jantse's interesting exhibition at the Cernuschi Museum in Paris. Indeed, Dr Jantse is one of my best friends, says the Frenchman. ${ }^{61}$

459. Letter from O. Janse to B. Nerman, 28 October 1935. Riksarkivet. Kartong 3. Korrespondens Brev III 1935-1941. In the Swedish original: "Jag har dagligen varit med Kronprinsen, som kom hit den 22 och reste i går. Den 25 dennes hade vi en tillställning på Musée Cernuschi, som Kronprinsen hade vänligheten övervara. Han stannade på museet i c:a 3 timmar och studerade samlingarne i minsta detalj. Därefter intogs té. Kronprinsen var mycket välvillig och föreföll nöjd med sitt besök. Till minne av detsamma överlämnades till honom en samling indokinesiska fornsaker, som jag grävde upp eller förvärvat under min expedition. Förmodligen kommer Kronprinsen överlämna samlingen till Ö.S.”

460. See also the chapter "Memorabilia"; Solheim 2002; Prior 2003; Miyamoto 2003.

461. Svenska Dagbladet, 8 March 1936: "Nordiska museet deltar i Parisutställningen? Ros åt Nordiska museet och Skansen från fransk museiman". In the Swedish original: "Jag lyckönskar ert land till att ha en konstintresserad och konstförståndig kronprins [...] För någon tid sedan besökte han dr Olof Jantses [sic] intressanta utställning i Cernuschimuseet i Paris. Jo, dr Jantse är en av mina bästa vänner, fortsätter fransmannen.” 
The year 1935 ended on a high. Olov and Ronny enjoyed life in Paris and pursued their work at the Cernuschi Museum. The exhibition continued to attract positive attention and the Crown Prince's visit gave it an extra boost of importance and flair. Ronny, who had suffered from furunculosis with repeated skin infections since their time in Indochina, was now almost recovered. The political situation in the world also enhanced the feeling of relative calm and stability. On this note Olov wrote, in a letter to his socialist friend Ture Nerman:

It is looking good in the big world, right now. Mussolini seems, however, to have a difficult time civilizing the oil wells in Abyssinia. The Pope stays quiet in the name of Christian love. It is feeble. ${ }^{462}$

And 1936 began in much the same mood. On 10 January the City of Paris announced its decision to allocate 30,000 francs to a second expedition to Indochina. The first, which had been granted 25,000 francs by the City of Paris in 1934, was in the official announcement referred to as a tremendous success. Interestingly, success was in this context counted in monetary value alone. The renowned Sinologists Paul Pelliot and Henri Maspero were quoted estimating the market value of the collections brought to the Parisian museums at around 500,000 francs - twenty times the sum granted for the expedition expenses - and in the announcement it is concluded that "[a] refusal of this request for funding would put the City of Paris at risk of losing the benefits of an exceptional archaeological opportunity". ${ }^{463}$ Contrary to (some of) the media rhetoric speaking of scientific achievements and important discoveries of unknown cultures, and against the explicit native Indochinese interest in the future location of the excavated collections, the argument here is thus based entirely on the estimated monetary value of the collections kept in Paris.

462. Letter from O. Janse to T. Nerman, 27 December 1935. Arbetarrörelsens arkiv och bibliotek. Ture Nerman 3.1.7. In the Swedish original: "Det ser fint ut i stora världen, just nu. Mussolini tycks emellertid få det besvärligt att civilisera oljekällorna i Abyssinien. Påven tiger i den kristliga kärlekens namn. Det är ynkligt.”

463. Bulletin Municipal Officiale, 10 January 1936. In the French original: "Refuser le credit qui nous est demandé serait pour la Ville de Paris risques de perdre le bénéfice d'une occasion archéologique exceptionelle". The same argument is found in Svenska Dagbladet, 3 July 1936: (Adolf Schück), "Svensk succé i Paris." 
For Olov and Ronny Janse, this was fantastic news. Having already secured 30,000 francs from the French National Museums, and 20,000 francs from the French Ministry of Education (which meant a total of 80,000 francs), they could now safely proceed with their preparations for a second expedition. ${ }^{464}$

In early February they left Paris and travelled to London, to visit the International Exhibition of Chinese Art at Burlington House. The exhibition was organized by the Royal Academy of Arts and was "the largest exhibition of Chinese art ever mounted", with over four hundred thousand visitors between November 1935 and March 1936. The exhibition was organized chronologically, with each of the sixteen galleries devoted to objects from one or two ancient or historical dynasties. ${ }^{465}$ The exhibition also had considerable political effects. Although sceptical about the prevailing Western dominance and appropriation of Chinese art and archaeology through imperial treaties, ${ }^{466}$ the Chinese government contributed an official collection, hoping that the exhibition would "demonstrate the grandeur of the Chinese nation to a worldwide audience" and would help to raise sympathy for the Chinese in their resistance against the Japanese colonization of Manchukuo. ${ }^{467}$ In addition to the official Chinese collections, the exhibition displayed objects from 240 collectors across the world (including Janse's friends Johan Gunnar Andersson and C.T. Loo), most of whom were sponsored by their governments. ${ }^{468}$ The exhibition was something of a PR success for China, and has been regarded as a milestone in the discipline of Chinese Art History. But it was also subject to critique from high-profile cosmopolitan Chinese intellectuals like Lin Yutang, who argued that it had contributed to an unfortunate idea of Chinese culture as essentially primitive and historically stagnant, in contrast to the modern West. ${ }^{469}$ Ronny and Olov Janse stayed one week in London at the luxury Washington Mayfair Hotel while they visited the Chinese exhibition. Letters say that they were delighted with what they saw there, and that they took the opportunity to also

\footnotetext{
464. The "Ordre de Mission" was signed on 18 September 1936 by Henri Verne. NAA: Janse 2001-29.

465. Steuber $2006: 528$.

466. Steuber 2006:529-530.

467. Fan 2012.

468. Steuber 2006:528-531.

469. See a more elaborate discussion of Lin Yutang's critique against the exhibition as a display of a simplistic Western view of a "primitive" China, in Fan 2012.
} 
see some private collections in London before returning to France. ${ }^{470}$

Upon their return to Paris, Olov stepped in as Acting Director of the Cernuschi Museum, while René Grousset was in London. ${ }^{471}$ They planned to leave for Indochina in the autumn to arrive at the end of the monsoon rains, just in time for the dry season that was the most suitable for excavation. Awaiting the departure they continued their work at the Cernuschi Museum, and Olov lectured about the results of his expedition in France, Belgium, the Netherlands, and in Sweden. The luminous projections of film and still photographs appear to have been a particularly attractive feature of the lectures, and are regularly mentioned in advertisements and media reports. ${ }^{472}$

Already in early May they left Paris for a summer break in Sweden. They spent some of the time in the summer house in Skagshamn, but also took the opportunity to reconnect with the Museum of Far Eastern Antiquities in Stockholm. In a newspaper interview in August, Olov says that the main reason why they were in Stockholm was that Johan Gunnar Andersson had requested his assistance in putting together a monograph on Chinese Hsin Tien ceramics. In the interview, he also seized the opportunity to emphasize Andersson's great importance for his work in Indochina:

It may seem peculiar, concludes Professor Janse, that I have chosen to work in Indochina of all places. Therefore I wish to take the opportunity to say that I first and foremost have my teacher and friend, Professor J.G. Andersson, to thank for the fact that I began to take an interest in the archaeology of Indochina and East Asia. Several years ago, Professor Andersson observed during a visit to museums in France, some prehistoric bronze artefacts that appeared related to other bronze artefacts from Southwest-

470. Postcard from O. Janse to B. Nerman, 11 February 1936. Riksarkivet. Kartong 3. Korrespondens Brev III 1935-1941; Letter from O. Janse to T. Nerman, n.d., in Arbetarrörelsens arkiv och bibliotek. Ture Nerman 3.1.7. Letter from O. Janse to M. Mauss, 19 February 1936. Fonds Marcel Mauss au Collège de France: mauss-janse-0026.pdf

471. Letter from O. Janse to M. Mauss, 19 February 1936. Ibid.

472.E.g. Musée Guimet, 19 January 1936; The Swedish Chamber of Commerce in Paris, 19 February 1936; L'Institut belge des hautes études chinoises, 25 March 1936; Institut français/Maison Descartes in Amsterdam, 8 May 1936; Alliance française/Grand Hotel Stockholm, 13 May 1936. Invitation cards or press reports of all these lectures are found in NAA: Janse 2001-29. 
ern China, which the Professor had incorporated in the Museum of Far Eastern Antiquities' rich collections of Chinese bronzes. Upon request by Professor Andersson I came to study these artefacts on behalf of the Museum of Far Eastern Antiquities, and thereby my interest in East Asian art and culture was awakened. ${ }^{473}$

A new phase, with a new incentive, appears to be taking shape here during the summer of 1936 . The thought of becoming the Director of the Museum of Far Eastern Antiquities after Andersson's retirement might have crossed Olov's (and Ronny's) mind(s) much earlier, but here in the summer of 1936 we see for the first time indications that this had become a major motive for their work in Indochina. Perhaps it was sparked by the great success of the first expedition and the Cernuschi exhibition, or the time spent with the influential Crown Prince in Paris. But it could just as well have been driven by the insecure employment situation in Paris or a longing to return to a safe base in Sweden. Letters indicate that Olov's father Thure was getting weaker by age, and Ronny's family was struggling in Stalin's Soviet Union. Or it was a combination of these and other circumstances that made them set their sights on the Museum of Far Eastern Antiquities at this particular point in time. With this new incentive, whatever its reasons were, Olov was now keen to officially mark his strong relation to Andersson - his "teacher and friend". In the article quoted above, we see how he places both Andersson and the Museum of Far Eastern Antiquities firmly inside his Indochina project by making them the very reason for and origin of the expedition. Since there are no previous references to Andersson and the Museum of Far Eastern Antiquities as prime movers for the Indochina project, this must be understood as a piece of strategic storytelling.

473. Svenska Dagbladet, 6 August 1936: "Prof. Janse på expedition i 8 månader". In the Swedish original: "Det kan synas egendomligt, slutar professor Janse, att jag just slagit mig på Indokina. Jag vill därför passa på tillfället att tala om, att det i främsta rummet är min lärare och vän, professor J.G. Andersson, som jag har att tacka för, att jag överhuvud kom att ägna mig åt Indokinas och Östasiens arkeologi. För flera år sedan hade professor Andersson under en resa till Frankrike i några museer där observerat diverse förhistoriska bronsföremål från Indokina, vilka delvis visade släktskap med andra bronsföremål från sydvästra Kina, som av professorn införlivades med Östasiatiska samlingarnas oerhört rika bestånd av kinesiska bronser. På anmodan av professor Andersson kom jag att närmare studera dessa föremål för Östasiatiska samlingarnas räkning, och därigenom var det som mitt intresse väcktes för den östasiatiska konsten och kulturen.” 
At the end of August they left Sweden and returned to Paris. Before the departure they had a Swedish special passport (no. 256) issued by the Foreign Office in Stockholm, ${ }^{474}$ at the request of Gerhard Lindblom (1887-1969), Director of the Ethnographic Museum (Swe: Statens Etnografiska Museum). In an extensive letter to the Ministry of Foreign Affairs, Lindblom emphasizes the importance of Janse's first expedition to Indochina, and the rich collections of 250 objects that it had rendered to the Ethnographic Museum. To facilitate Janse's next expedition, when he was expected to continue the acquisitions and thus work for a state institution, Lindblom argued that it was reasonable that he was granted an official passport. 475

On the way to Paris they took the opportunity to make a stop and visit the Crown Prince at the royal summer retreat Sofiero. In a letter to Birger Nerman, Olov writes about the meeting:

At Sofiero I met the Crown Prince, who was as considerate as ever, and asked if I would not like to stay permanently in Sweden after this second expedition. I am honestly happy that I had the opportunity to speak undisturbed with the Crown Prince, who apparently is already well informed about what is going on. [...] The other day I sent an offprint re. the excavations in Indochina. Birger was kind enough to offer to review it in Svenska Dagbladet. It would be very helpful if Birger could arrange for the review to be published before H.R.H. and J.G.A. travel abroad, i.e. the first days of October. ${ }^{476}$

474. The passport, which included both Ronny and Olov, was issued on 24 August 1936. See also letter from O. Janse to S. Elisséeff, 23 September 1940. Harvard-Yenching Institute, Cambridge, Mass. Correspondence, 1938-1940.

475. Letter from G. Lindblom to the Ministry of Foreign Affairs (Swe: Kungl. Utrikesdepartementet), 25 August 1936. Riksarkivet. Box. Utrikesdepartementet 1920 års dossiersystem P 1188. Mapp: Kungl. Utrikesdepartementet. Avd: P, Grupp: 90, Mål: F XXXIX. Tillämpning av svensk passlagstiftning. Passutfärdande av K.U.D och dess underlyd. myndigheter.

476. Letter from O. Janse to B. Nerman, 9 September 1936. Riksarkivet. Kartong 3. Korrespondens Brev III 1935-1941. In the Swedish original: "På Sofiero träffade jag Kronprinsen, som var idel välvilja och som själv tog upp frågan om jag inte ville stanna definitivt i Sverige efter denna andra expedition. Jag är uppriktigt glad att jag fick tillfälle att i lugn och ro tala med Kronprinsen, som tydligen redan är mycket väl underrättad om vad som händer och sker. [...] Sände häromdagen ett särtryck ang. grävningarne i Indokina. Birger var nog vänlig lova recensera detsamma i Sv. Dagbl. Det vore mycket 
The letter confirms that Janse was now working actively through personal and official channels, directly aimed at the Crown Prince and Andersson - the two actors with the most influence on the matter - to promote himself as a candidate for the upcoming post at the Museum of Far Eastern Antiquities. The confident tone indicates that he was quite certain, at this point, of a positive outcome.

They arrived in Paris on the last day of August, and proceeded after a couple of days to Toulouse and the French Prehistory Congress, ${ }^{477}$ where Janse represented the EFEO and on 14 September presented a paper on his research in Indochina. The paper focused on his results from Dong Son and the spectacular finds from Lach-truong, and as usual he used projections of film and photographs in his presentation..$^{47^{8}}$ When the conference was over, they returned to Paris to make some final arrangements before their departure for Indochina.

Now, something (or rather, a series of things) occurred which marks the beginning of a mood change around the end of September - from euphoria to crisis. We are not entirely sure about what exactly happened to Ronny and Olov at this point in time, but it is clear that one factor was a sudden dramatic fall of the franc as a consequence of political instability around Léon Blum's socialist government in France. In a letter to Marcel Mauss, Olov writes:

For different reasons I will have to rush my departure for Indochina. The fall of the franc will force me to shorten my stay. I have serial misfortune at the moment, but hope that this mission will get me out of this bad phase. 479

vänligt om Birger kunde ombestyra att recensionen publiceras innan H.K.H. och J.G.A. reser utomlands, d.v.s. de första dagarne av oktober."

477. Congrès préhistorique de France, Toulouse, 13-20 September 1936. http://www. persee.fr/web/revues/home/prescript/article/bspf_0249-7638_1936_num_33_9_4485, accessed 18 April 2018.

478. "Congrès Préhistorique de France". NAA: Janse 2001-29.

479. Letter from O. Janse to M. Mauss, n.d., Fonds Marcel Mauss au Collège de France: mauss-janse-0027.pdf. In the French original: "Pour différentes raisons je vais être obligé de brusquer mon départ pour l'Indochine. La chute du franc me forcera d'y 
So with urgency and a sense of anxiety they rushed off to Marseille. On 16 October 1936 - the same day that a display of their collections opened at the Ethnographic Museum in Stockholm - they embarked on the SS Maréchal Joffre bound for Saigon. The film, shot onboard the ship and at the stops along the way, indicates that they were still in good mood and excited to be on the way to Indochina again. ${ }^{480}$

abréger mon séjour. J'ai en ce moment des malheurs en série. J'espère néanmoins que cette mission me fera sortir de cette mauvaise passe."

480. Swedish Television Archive. (C) SVT Arkiv. 


\section{CRISIS: INDOCHINA \\ OCTOBER 1936-DECEMBER 1937}

They arrived in Saigon on 9 November and immediately proceeded to the northern provinces. After a brief stop in Hanoi they reached Thanh Hoa where they were installed at Madame Renaud's hotel, which once again came to serve as their headquarters. Only two weeks after they had disembarked from the Maréchal Joffre in Saigon they were back at Lach-truong, ready to start their second excavation campaign. If the first excavation season had a character of discovery and enthusiastic curiosity, the second season was more about return and completion. Nguyen Xuan Dong joined them once again as the expedition secretary and draughtsman, and they were reconnected with their local team of workers from the first season. But there is a new sense of stress and rush in this second campaign, and it appears as if a primary concern is the accumulation of another "rich booty" to meet the inflated expectations of the press and museums in Paris.

\section{Back to Lach-truong}

At Lach-truong they took up the work where they had left it a year and a half earlier. In addition to the twelve Han period brick tombs excavated in the first season, they now opened and emptied another sixteen tomb vaults. ${ }^{481}$ None of them revealed amazing artefacts like the kneeling figurine found in Tomb 3. On the contrary, most of them had been to the

481. Tomb 13A-Tomb 26, reported in detail in Janse 1947: plates 33-48, 79, 161; Janse 1951:91-117. 
most part destroyed or emptied. Tombs 13A, 16, 17, and 18 were however partly untouched, although parts of the vaults were missing, ${ }^{482}$ and Tomb 24 contained silver objects that were rare for Han period tombs in this area. ${ }^{483}$ Tomb 19 was found untouched and contained some human skeletal remains, among which was a left parietal bone from a human skull preserved through contact with a bronze bowl. ${ }^{484}$ It makes an interesting parallel with the similar find of human skull bone preserved by bronze at Dong Son, which led to the conclusion that the inhabitants of Dong Son had been headhunters. But in the case of this second find, which was judged by its context of a "civilized" Han burial, Janse never suggests any relation with headhunting practices, but used the skull fragments only in a futile attempt to identify the age and sex of the buried individual..$^{45}$

\section{Quang-Xu'o'ng}

As soon as the excavations had been started at Lach-truong, Janse took the opportunity to continue his earlier surveys and start new excavations in the region of Quang-xu'o'ng (between the seaside resort of Sam Son and Thanh Hoa Town). ${ }^{486}$ The work pace was now fierce, with simultaneous excavations on several sites many kilometres apart. In the Quang-xu'o'ng region, they excavated five Han period brick tombs at the Yên-biên site, ${ }^{487}$ three at the Tho-Dai site, ${ }^{488}$ one at the Nho-Quan site, ${ }^{489}$ and three at Hoà-chung. ${ }^{490}$ At the Thung-Thôn site, which had been located in surveys during the first expedition, they now excavated six Han period brick tombs. Two of these graves - Tombs $1 \mathrm{~A}$ and $1 \mathrm{~B}-$ had particularly rich grave goods including gold bangles and traces of lacquer ware. ${ }^{491}$

On 22 February 1937 they had an official visit to the tomb site at Hoà-

482. Janse 1951:91-92, 96-100.

483. Janse 1951:116.

484.Janse 1951: plate 37.

485. Janse 1951:100-102.

486. See map in Janse 1951:179.

487. Janse 1947: plate $163 ; 1951: 156-163$.

488. Janse 1951:172-176.

489. Janse 1951:177.

490. Janse 1947: plate 165; Janse 1951:178-186, plates 88-91; Janse 1959:165-179.

491. Janse 1947: plate 164; 1951:164-171; Cahiers de l'École française d'Extrême-Orient, No. 9,1936, pp. 5-6. 
Chung by the Inspector General of the French Colonies Justin Godart, accompanied by the Governor of Annam Mr Guillemain and the French Resident of Thanh Hoa Mr Lagrèze, with wives and other dignitaries. The visit was noticed in the francophone Indochina press. In one article Olov is described as an already well-known scholar: un savant déjà connu, and Ronny as une collaboratrice trèséclairée et très entendue - a much cultivated and very competent female collaborator. ${ }^{492}$ Judging from the reports it was a successful public event, where the most eminent guest Justin Godart was offered an original artefact from the excavation to take home as a souvenir. ${ }^{493}$ Photographs taken at the event show that it attracted considerable local interest as well (fig. 44).494 The visitors were divided into three groups, materializing through official choreography the metaphorical distance that is a common theme in Janse's texts - between the allegedly primitive and the civilized. The first group, including high officials and EFEO staff from Hanoi, was allowed to enter the excavation trench where they were able to touch the exposed brick structures while having the ongoing excavation of the tomb demonstrated by Olov and Ronny Janse. A second group, with lower-ranking French people and Annamite officials, was allowed to watch the demonstration and take photographs from a more distant position on the side of the trench. The third and largest group, with locals or visitors from nearby villages, were kept at a clear distance from the first two groups, and had no contact with or clear vision of the happenings in the trench.

While the excavations of brick tombs were going on at Lach-truong and the sites in the Quang-Xu'o'ng region, Janse also resumed his excavations at the Dong Son settlement site. This means that by the end of 1936 , only a month after they had begun the second excavation campaign, they were already involved in simultaneous excavations in three separate geographical areas, with two distinct types of archaeological material: various sites with Han period brick tombs, and one prehistoric settlement site. How this was practically managed is not clarified in the reports, memoirs or any of the archive material we have at hand. But the arrangement must have meant that Janse himself was largely absent during the excavations, and hence probably required a regular delegation of formal

492. Notice in L'Avenir du Tonkin, 25 February 1937: "Fouilles intéressantes."

493. Janse 1947:viii; Janse 1951:186n.

494. The visit to Hoà-chung has also been filmed. Swedish Television Archive. (c) SVT Arkiv. 

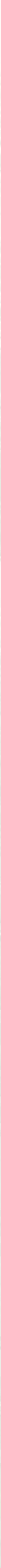
leadership to Ronny, Dong, and/or his local foremen. This is noteworthy because in all official accounts Janse is portrayed, and portrays himself, as an archaeologist of high scientific standards, essentially different from treasure hunters like Louis Pajot. His official position on this matter is eloquently expressed in a passage of his memoirs:

In archaeology it is of the utmost importance to have knowledge down to the tiniest detail - of the circumstances in which the finds have been encountered. Observations regarding the location of an object in a grave or a stratum could lead to the determination of the age and usage of the object, and offer valuable information about past social relations and religious beliefs. Even an apparently worthless little potsherd without the least aesthetic value can, for the scientist, be the key to the chamber where the solution to many of the mysteries of the past has been concealed. It can be of the same crucial importance as a fingerprint, a burnt-out match, or a tiny bloodstain, for the solution of a criminal drama. The field archaeologist is in some sense a Sherlock Holmes of prehistoric times. ${ }^{495}$

If Janse officially declared himself to be a fieldwork archaeologist comparable to Sherlock Holmes - known for a meticulous attention to every detail, and a surreal ability to find and join together miniscule fragments to meaningful renderings of past events - the reality of his fieldwork campaigns in Indochina was quite different. The first expedition had taken off at a high pace, and in the second they upped the speed even further, forcing Janse to leave his excavation sites on a regular basis (imagine Holmes leaving the primary investigation of a crime scene to Watson, or an untrained assistant) to increase the harvest of potential museum

495. Janse 1959:17-18. In the Swedish original: "När det gäller arkeologi är det av största vikt att äga kännedom - även i minsta detalj - om de förhållanden under vilka fynden anträffats. Iakttagelser rörande ett föremåls placering i en grav eller i ett visst kulturskikt kan [...] leda till bestämmandet av ett föremåls ålder och användning och ge värdefulla upplysningar om gångna tiders sociala förhållanden och religiösa föreställningar. Även en till synes obetydlig liten krukskärva utan minsta estetiska värde kan för vetenskapsmannen stundom vara nyckeln till den kammare, där lösningen till många av det förgångnas gåtor legat förborgad. Den kan vara av samma avgörande betydelse som ett fingeravtryck, en utbrunnen tändsticka eller en obetydlig blodfläck för lösningen av ett kriminaldrama. Fältarkeologen är på sätt och vis förhistoriens Sherlock Holmes.” 
pieces. Hence in reality - at this point certainly - his primary concern was the potential booty of collectible objects, and not the Holmesian detective work aimed at reconstructing past events, which was his officially stated ideal.

\section{Back to Dong Son}

Once back at Dong Son, Janse, Dong, and their team turned their attention to the pole structure that had been indicated to them by Louis Pajot and Victor Goloubew at the EFEO, and which they had registered in their survey in the first season. The pole structure was located at the northern end of the identified settlement area, where they now opened three extensive trenches - loc. 8, 9, and $9^{b i s}$ - on the bank of the Song Ma river. ${ }^{496}$ More than two metres below the ground they found wooden poles, preserved by the anaerobic conditions in the wet riverbank, along with locally made pottery. They seemed to indicate the presence of stilt houses, similar to contemporary lowland building techniques in the same area. This was before the discovery of more precise dating methods like radiocarbon and dendrochronological analyses, but typological dating of the pottery and other finds in the stratum that seemed to be contextually connected with the pole structures indicated that it dated back to the time of the early Han period settlement. ${ }^{497}$ There is, however, not much information about the excavations at Dong Son during this second campaign. In his report, Janse writes that parts of the findings were shipped to the Guimet Museum in Paris, but that the majority - along with drawings, notes and photographs from the excavations - had been left with Victor Goloubew at the EFEO in Hanoi. Goloubew, who seems to have nurtured a particular interest in Dong Son since before Janse started his excavations, had "expressed a desire to make a special study of the products of [their] excavations and to publish them". Janse had therefore "passed on to [his] colleague the notes, plans, prints and negatives [he] had prepared during the excavation", and left most of the finds from the second expedition's Dong Son excavations in Hanoi. ${ }^{498}$ To what extent this is a correct description is difficult to know, but Victor Goloubew did

496. Janse 1958:14-15, plate 6.

497. Janse 1958:28-32; Janse 1959:112; Cahiers de l'École française d'Extrême-Orient, No. 9, 1936, pp. 5-6.

498. Janse 1958:29. 
present one lecture in 1938 at the Musée Louis Finot in Hanoi under the title La maison Đông-so'nienne - "the Dongsonian house". ${ }^{499}$ Since the outbreak of the Second World War there is no trace of the finds or of the documentation material that was reportedly left in Hanoi.

They returned to work at Dong Son several times over the course of the second expedition. While they were in the area, they also took the opportunity to excavate two Han tombs in Dai-khoi, ${ }^{500}$ and six at Dongtac, where they found a figurine similar to the kneeling figurine at Lach Truong, and an object described as a golden monster mask, along with the more common finds of ceramics and metals. ${ }^{501}$

\section{Muong ethnography}

When 1936 gave way to 1937 , they were already well under way with the excavations at several sites in the Thanh Hoa province. One evening in January when Janse returned to Madame Renaud's hotel in Thanh Hoa Town, he found a letter waiting for him. It contained an invitation to join the French governor of Annam on an official visit to a remote Muong village on the next day. Janse was thrilled and later wrote that he viewed it as a unique opportunity to "see this shy and isolated people". The purpose of the visit was to inaugurate a new medical station, and they left before dawn in a delegation with three cars. The visit lasted only a few hours, and they were back in Thanh Hoa by the evening. But in a similar vein as he did his archaeological pursuits, Janse maximized the ethnographic output of the visit, and devoted one extensive Swedish newspaper article, and one whole chapter of his memoirs to this event. ${ }^{02}$ The preamble to the article immediately signals a familiar sense of adventure and distance, with temporal references similar to what we have seen in Janse's earlier travel writing:

With the Muong people, the semi-wild tribes in Northern Annam, where our famous archaeologist and ethnographer now completes his world-famous researches, time appears to be stand-

499. Cahiers de l'École française d'Extrême-Orient (Hanoi) № 14 . Premier trimestre de 1938, pp. 12-16.

500. Janse 1951:148-153, plates 62-65.

501. Janse 1947: plate 162; Janse 1951:138-147, plates 56-63, 66.

502. Svenska Dagbladet, 11 July 1937: “Gästabud i Annam: hos Muongfolket.”; Janse 1959:159-164. 
ing still, and the same ceremonies as 20 centuries ago are still performed today..$^{503}$

The article - and the almost identical text in the memoirs - is largely devoted to the French delegation's arduous journey through the countryside and mountains with wobbly ferries and leech attacks, and the eventual arrival at the village of Ngoc-lac, where the inauguration of the medical station was to take place. The clothing and jewellery of the villagers, who belonged to the Moung ethnic group, are accounted for in detail. The entertainment performed by the villagers to celebrate the occasion is described in a characteristically demeaning tone, with words that signal simplicity or childishness:

In front of the drum danced a wizard, whose hops and skips apparently were intended to imitate the movement of a bird, bobbing to and fro on the ground. Now and then he poked the drum with the sticks he held in each hand..$^{504}$

To emphasize the primitive character of the event, the shaman's dance is moreover compared with the stylized scenes depicted on the two-thousand-year-old kettledrums they had excavated at Dong Son: "We had here a typical example of how ancient ceremonies are still alive in these lands, where time seems to be standing still." ${ }^{05}$ The visit ended with a jar drinking ceremony (which is a common practice associated with festive events and hospitality in parts of mainland Southeast Asia), where the guests were invited to drink a fermented rice sherry from a large jar, sucking two by two on long bamboo straws. The ritual is described in an equally demeaning and humorous tone in Janse's article and memoirs.

Judging from Janse's account, the villagers of Ngoc-lac had made a great effort to set up an extraordinary festive event to welcome their visi-

503. Svenska Dagbladet, 11 July 1937. In the Swedish original: "Hos Muongfolket, de halvvilda stammarna i Norra Annam, där vår berömde arkeolog och etnograf nu slutför sina över hela världen uppmärksammade forskningar, tycks tiden stå stilla och samma ceremonier som för 20 sekler sedan förekomma alltjämt."

504. Janse 1959:161. In the Swedish original: "Framför trumman dansade en trollkarl, som tydligen avsåg att med sina krumsprång återge rörelserna hos en fågel, som guppar fram och åter på marken. Då och då petade han till trumman med de pinnar, som han höll i vardera handen."

505. Janse 1959:161. 


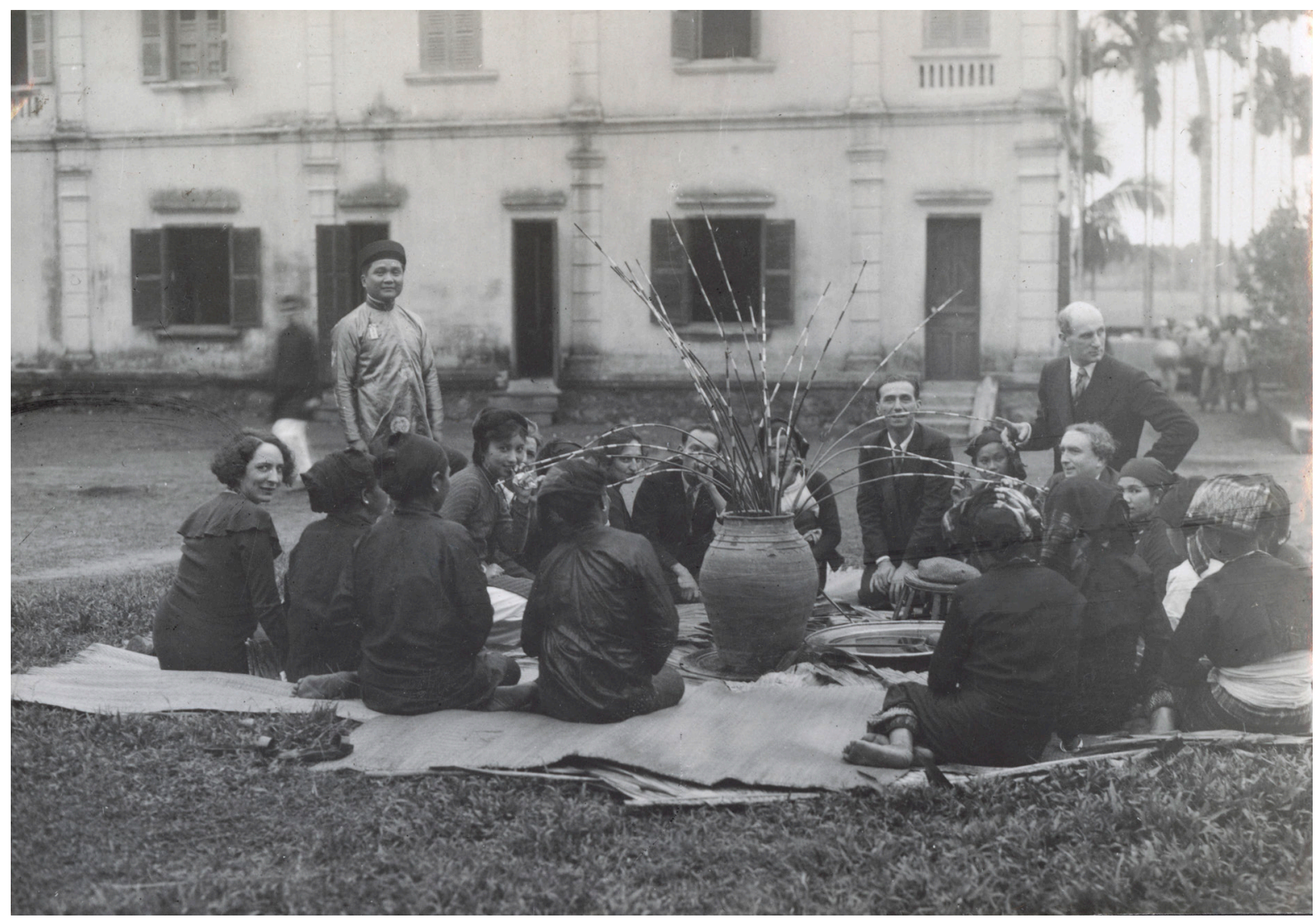

tors. Their rituals seem to have been far from simple or childish. And they lived in the 1930s, just as much as Janse himself. They did certainly not deserve to be described in demeaning words, and moreover be relegated to the past, by one of their invited guests. Olov Janse appears otherwise to have been a decent man with empathy and compassion, and is often described as a gentle and friendly person. So how can we understand this recurring theme of disrespect in his writing? Well, first of all it is worth noting that these texts are exclusively intended for Swedish audiences. The longer articles and reports written in French or English focus mostly on his archaeological work, and do not contain such travel writing and supposedly humorous anecdotes - only those written in Swedish do. Moreover, the format of the text in his Swedish articles and memoirs featuring native people in and around his Indochina expeditions, ${ }^{506}$ repeats

506. Another striking example is chapter 19 of his memoirs, featuring a visit to an elephant-hunting Moï community during the third expedition (Janse 1959:187-199). 
itself from his first published travel account from Iceland written in his early twenties. ${ }^{507}$ Hence you could say that these people - who showed Janse nothing but generosity and respect - are taken hostage within the confines of a certain marketable format for popular representation intended to amuse and impress a Swedish audience. Compared with the audiences in former colonies or major colonial powers such as France and the United Kingdom, most readers in Sweden in the mid twentieth century had little if any experience of places like Indochina, which could serve as an explanation why this format was particularly marketable there. And as we know from the reviews of his memoirs, Swedish readers were both amused and impressed. ${ }^{508}$ Although Janse's core activity was the archaeological investigations, the strong images of primitivity and civilization conveyed through his travel accounts are of great importance, not least from a Swedish perspective. They have been spread and consumed to a much larger degree, and have arguably had a much larger popular impact in Sweden, than any of his archaeological results.

Janse himself referred to this part of his work as "ethnography". It is, however, more aptly described as amateur ethnography, comparable to the hit-and-run amateur archaeology pursued by Louis Pajot and other untrained French and native people at and around Dong Son. Both were focused on obtainable objects, rather than context and academic analysis. Unlike serious ethnography that has a profound interest in human culture and human conditions and involves long-term involvement, language training, and habitation, Janse's hit-and-run ethnography was largely pursued on one-day visits to native villages where he shot films and photographs, and purchased objects to send back to Sweden and France. No serious knowledge of human culture, traditions, and rituals can come out of such brief encounters. It is rather the case that Janse's "ethnography" masquerades as professional pursuits by association with his professional knowledge in archaeology and the comparative studies (joining ethnography and archaeology) pursued by his mentors Henri Hubert and Marcel Mauss.

507. See the chapter "Travel Writing".

508. E.g. Wilhelm Holmqvist, 1959, "Exotisk forntid", Vi, no. 49. 


\section{Kilns at Tam-thô}

There is, however, one new focus in the second expedition that stands out among speedy artefact-oriented tomb excavations and hit-and-run ethnography. While the rest of the team was excavating Han period tombs in Quang-xu'o'ng (more specifically at the site of Yên-biên), ${ }^{509}$ Janse surveyed the vicinity for more sites to excavate. Close to the village of Tam-thô some eight kilometres from Thanh Hoa Town, he spotted some large, strange-looking mounds that he decided to investigate. He brought his team to the site and started excavations in early February 1937. It turned out that the big mounds - the largest almost 40 metres long - contained ancient pottery kilns. The mounds covering the oblong clay-lined cavities contained masses of ceramics: mostly potsherds and waste, but also pieces of miniature houses, spindle whorls, net-sinkers, bricks, roof-tiles, and pieces of small animal figurines. ${ }^{10}$ Some resembled the grave goods they had excavated from the Han period brick tombs, but there were also pieces that they had only seen equivalents of at the Dong Son settlement site. In the excavations of the Tam-thô kilns, we get a glimpse of the serious archaeologist Olov Janse. With no prospect of finding exclusive museum pieces for display, he devoted much work and effort to detailed investigation and a thorough report of these early industrial production sites. ${ }^{511}$

The investigation of the Tam-thô kiln sites is also one of the most important lasting results of Janse's Indochina expeditions. The kilns, which provided the local population from the Han period onwards with ceramics for everyday use and funeral deposits, were the first such sites to be found and excavated in Indochina. Before Janse's excavations at Tam-thô, it was believed that the "Han-style" ceramics had been imported from the Chinese empire. So this was quite a breakthrough and has been of great importance for later research.

However, in an arguably ill-founded conclusion to his report on the finds in Tam-thô, Janse writes assuredly that the kilns had been managed by immigrant Han Chinese, because "the Annamites always have been known to be poor ceramists". ${ }^{512}$ This is yet another example of how easily the translation of archaeological fragments into a meaningful story,

\footnotetext{
509. Janse 1951:156-163.

510. Janse 1947: plates 147-160; Janse 1951: plates 33-39.

511. Janse 1947:60-62, plates 138-160; Janse 1951:231-246.

512. Janse 1951:245.
} 


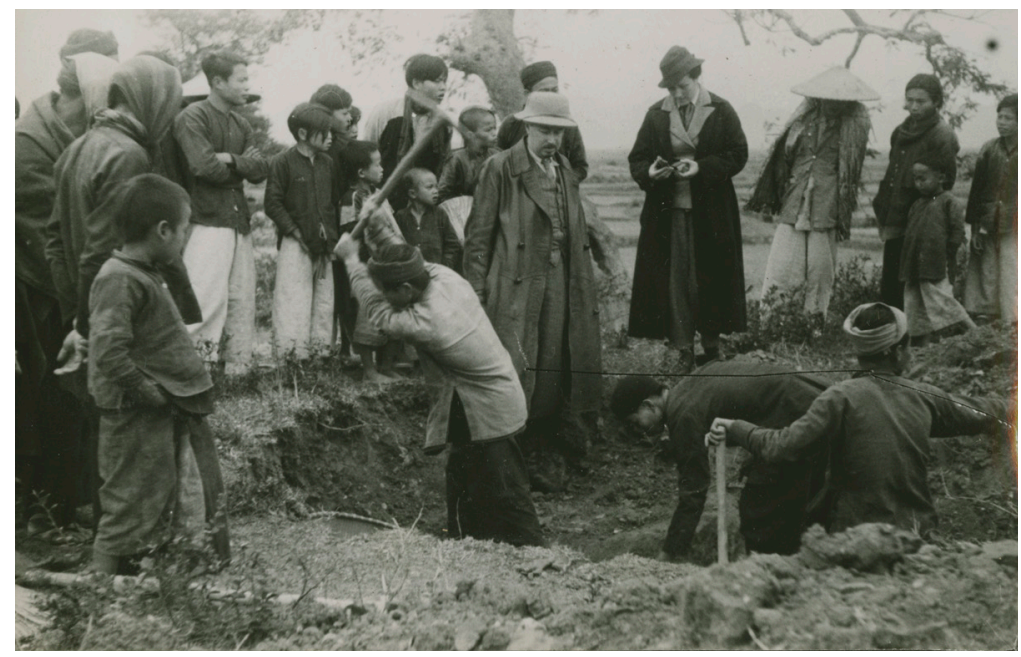

Fig. 46. Starting excavations at Tam-thô I:A, in February 1937. Olov and Ronny Janse in the centre, wearing trench coats.

Fig. 47. Tam-thô kiln sites II-IV, visited by the authors in October 2005 .

Fig. 48. Original drawing of the Tam-thô kilns.

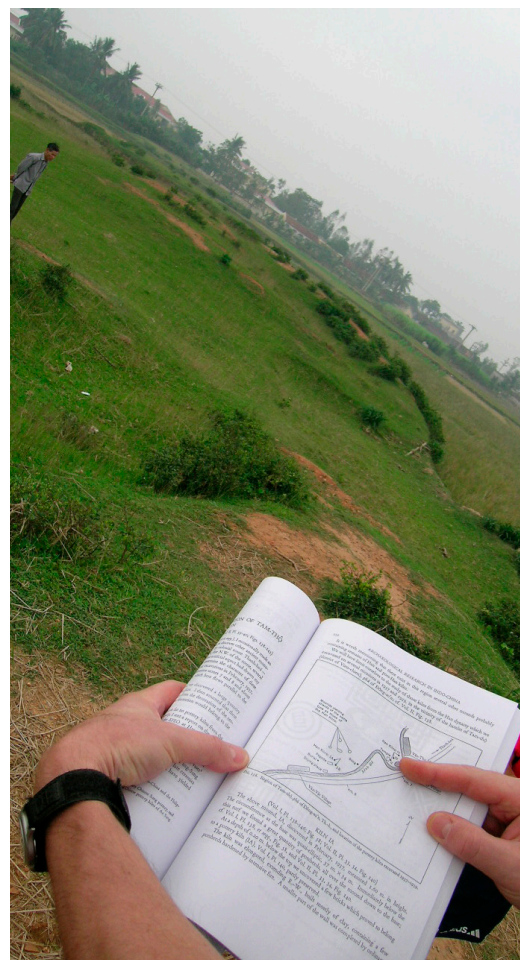

\section{LES FOURS A TAM-THO}
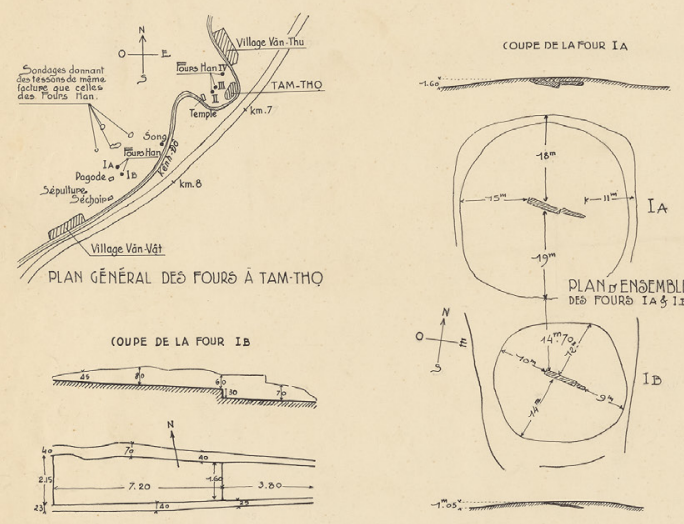

DLAN DE LA FOUR IB

COUPE DE LA FOUR 1 a
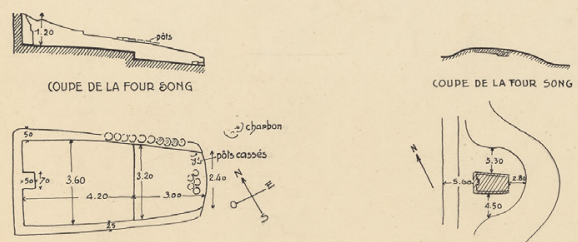

PLAN DE LAFOUR SONG
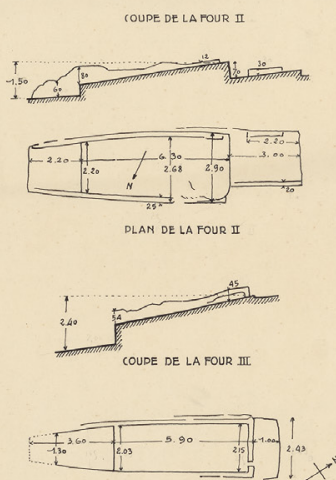

PLAN DE LA FOUR III
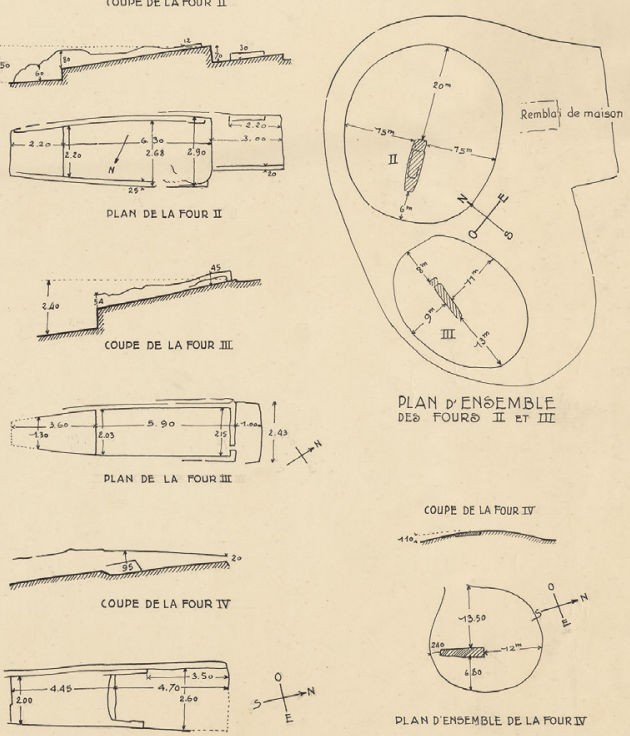

PLAN DE LA FOUR IV
COUPE DE LA FOUR IT

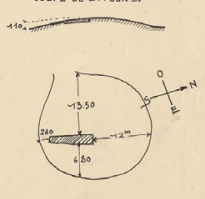


adopts a common-sense popular image - a "common truth" (such as the primitive character of the Dongsonian people and the civilized character of the Han Chinese, or the inadequate ceramic skills of the Annamites) - which immediately takes over as the principal image of the narrative and obscures every nuance and every possibility of a more interesting cultural analysis. With the fragmentary material that the archaeologist has at hand, the archaeological interpretation is more than most (if not all) other human sciences prone to rely on such "common truths", which the material is far too sparse to challenge. We see this very clearly in Janse's interpretations, simply because our "common truths" are now different. Hence what now appear to be ill-founded conclusions should not necessarily be seen as single mistakes or signs of poor quality. It should rather be regarded as a symptom of the vulnerable conditions for all archaeological interpretations of the past - in the 1930s, as well as in the twenty-first century. ${ }^{513}$

In February, when they had just begun to excavate at the Tam-thô kilns, Janse found some time to write letters for the first time since they left Paris in October. He wrote to Birger and Ture Nerman in Stockholm, and to Marcel Mauss in Paris, about his work and findings. The tone is cheerful when he describes some of the most valuable artefacts from the forty Han tombs opened thus far, and the discovery of the kiln sites, which he emphasizes with exclamation marks are the first of that kind ever found in Indochina. ${ }^{514} \mathrm{He}$ writes that they have plans to visit the French territory Kwang-Chéon-Wan near Hong Kong in the following weeks to do archaeological surveys. To Mauss, and Ture and Nora Nerman he also writes about a week-long visit to the northern military territory Tinh-tuc where he had encountered "semi-wild and shy" mountain tribes. The reason for the journey was the annual break for the Têt festivities celebrating the Annamite New Year (around 10 February), and he had travelled alone with a French friend, because Ronny was yet again suffering from furunculosis and had to stay in Hanoi to rest and recover. To Marcel Mauss he wrote that he also spent much time in Hanoi, because this time he would make sure to do all the cleaning of the objects before

513. E.g. Ion 2017.

514. Letters from O. Janse to B. Nerman, 2 February 1937. Riksarkivet. Kartong 3. Korrespondens Brev III 1935-1941; Janse to T. Nerman, 2 February 1937. Arbetarrörelsens arkiv och bibliotek. Ture Nerman 3.1.7; Janse to M. Mauss, n.d. Fonds Marcel Mauss au Collège de France: mauss-janse-०030.pdf. 
SOCIÉTÉ FONCIERE D ONKIN ET DE L'ANNAM - HOTEL MÉTROPOLE-HANOI SOCIÉTÉ ANONYME AU CAPITML DE 10.288.700 FRANCS - SIĖGE SOCIAL; 15, BQ HENRI-RIVIĖRE HOTEL MET METOPOLE DE LA CASCADEL D'ARGENT DE LA CASCADE D'ARGENT
TAM-DAO TEL.
GRAND HOTEL DE CHAPA
GRAND HOTEL DE DO-SON HOTEL DES TROIS MARECHAUX

WAGONS-RESTAURANTS

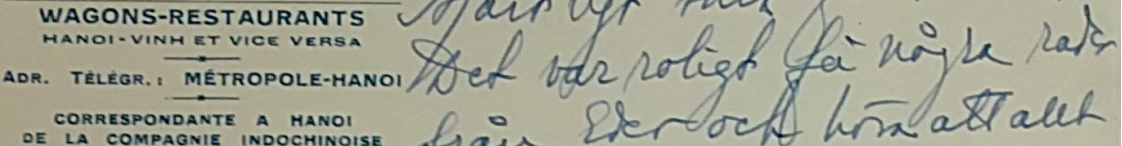

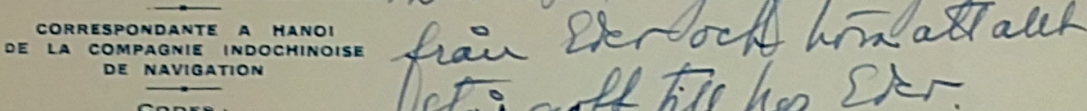
de navigation

Fig. 49. Letter from Olov Janse to Ture Nerman.

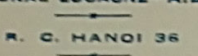

Yikar nu e: a 10 dagar haft mionfiranbe har. Nut arbete ligger di praletick toget nere. Jag passale po tillfillet ats vanner hair, gòna en ybtersot in trétsant och âventy r liq hesa tell till des. K halvirlda Stammanna i Norra Tonkins fialltraleter, en

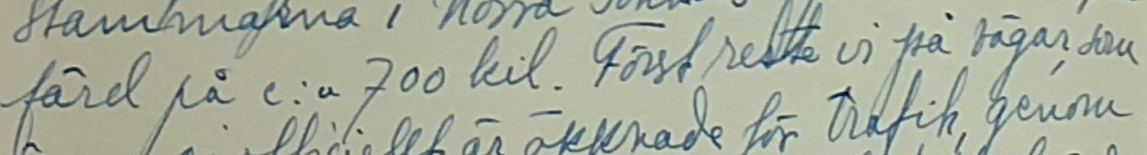
anne oj officielet àr oppenade for trafich, genom unierbaral lanier som i stort varifl hilt oberarda av vasterlaush hulter. Yi stamade c.'a en vecha pà en litéu oft inom f. D. Kiesesk ourraik Dàr juo lyckabes homma i kontalet med b. vanflifa fall mychet shygga bergsstammama. basefter reste ov lángs bu kineslika gráneen äter tel Hanoi. Srainingasma has gits ha. Shar fore det anpra nittika ny äre lyckads 
they were shipped to Paris to be displayed. He did not want to be occupied with any such work back in Paris, because he was determined to devote as much time as possible to the completion of Les Germains (the posthumous publication of Henri Hubert's work) under Mauss's direction: "I am for my part sorry for the delay and I look forward to finishing that work." ${ }^{15}$ In the letter to Ture and Nora Nerman, he also mentions that he has received some money from one of the donors to the Museum of Far Eastern Antiquities to purchase a collection of Indochinese artefacts on behalf of the museum, and adds: "I hope that the person concerned will think of me, when the position as director for Ö.S. becomes vacant after Andersson next year." ${ }^{16}$ Overall, he seems at this point to have been quite cheerful and pleased with the results they had obtained so far, and he was thinking ahead - planning their return to Paris and being attentive to news about the upcoming vacancy of Andersson's position in Stockholm.

The next two months followed in much the same manner. They were busy with excavations of the kiln sites, the Dong Son stilt houses, and Han tombs around the Thanh Hoa province. Over the Easter break they left Thanh Hoa and travelled south along the coast to central Annam and the Nghé An province, where they did surveys and some test-pit excavations at the kitchen-midden site of Càu-giât. ${ }^{17}$ In letters to Birger Nerman and Marcel Mauss he describes how they had also studied the customs and traditions of local fishermen, and collected ethnographic objects to send to the Ethnographic Museum in Stockholm..$^{518}$

515. Ibid.

516. Janse to T. Nerman, 2 February 1937.

517. Janse 1947:40n.

518. Letter from O. Janse to B. Nerman, 10 April 1937. Riksarkivet. Kartong 3. Korrespondens Brev III 1935-1941; O. Janse to M. Mauss, 12 April 1937. Fonds Marcel Mauss au Collège de France: mauss-janse--0031.pdf. 
In early April they returned to Hanoi, where the heat was increasing by the day, as they got closer to the monsoon rains. They stayed in Hanoi a couple of weeks to oversee the cleaning, photographic documentation, and packing of the latest finds before transportation to Paris. In a letter to Birger Nerman, Janse wrote that so far they had packed one hundred cases from the second expedition alone, and added that Andersson ought to regret that he missed out on a share of the extraordinary findings. ${ }^{519}$ Apparently Andersson had given Janse the impression - they had "practically agreed", according to Janse - that the finds from the latter part of the winter campaign would be allocated to the Museum of Far Eastern Antiquities, but Andersson had never provided the funding they had agreed on. Janse writes to Nerman, clearly disappointed:
During this particular period, we made the most interesting finds and their value exceeds many times the sum that Andersson had promised. It cannot hurt to let the matter be known here and there. When is A. resigning? Is it 1938 or $39^{\text {? } 520}$

The main reason why they stayed in Hanoi longer than necessary, despite the hot weather, was an upcoming visit of the Governor General Jules Brévié. Brévié nurtured a special interest in archaeology and had expressed a desire to witness ongoing excavations, so George Cœedès took the opportunity to showcase Janse's excavations as a part of EFEO's work. Janse had spared two large brick vaults that looked intact at the Bim Son site for this special event, and now they were awaiting the arrival of Monsieur Brévié. ${ }^{521}$

And finally, on 15 April 1937, Jules Brévié made an official visit to the excavations at Tam-thô and Bim Son. An unmarked newspaper clipping in Janse's personal archive describes the visit. On the afternoon of 15 April, the Governor General, along with a whole group of national and local dignitaries, visited the excavations at a kiln site at Tam-thô, where he "took a vivid interest in the work directed by Doctor Jansé". A little

519. Letter from O. Janse to B. Nerman, 10 April 1937. Riksarkivet. Kartong 3. Korrespondens Brev III 1935-1941.

520. Ibid. In the Swedish original: "Det var just under denna period, vi gjorde de intressantaste fynden och vilkas värde många gånger om överskrider den summa Andersson hade ställt i utsikt. Det kan ej skada om saken bleve känd här och var. När avgår A.? Är det 1938 eller 39 ?"

521. Ibid.; Janse to Mauss, 12 April 1937. 
later they attended the ongoing excavation of a brick tomb - Tomb $1 \mathrm{~B}$ at Bim Son - where several interesting ceramics, one of which was in perfect condition, were exhumed before their eyes. ${ }^{522}$ Representatives from the local community at Bim Son arranged a reception ceremony with flags and umbrellas, and in spite of the heat the visit was a great success. ${ }^{23}$ As a souvenir of the visit, Jules Brévié was presented with some original artefacts from the excavation, among which was a rather special lamp of glazed pottery. ${ }^{524}$ Pleased and content with the successful event, Olov and Ronny Janse were blissfully unaware that it would also mark the end of their happy days in Indochina.

A week after Jules Brévié's visit to Bim Son, Janse wrote a letter to Ture Nerman in Stockholm. Unlike the previous letters sent to Ture and his wife Nora, this was addressed to Ture in his function as Member of Parliament, and sent to his office in the Parliament building (from where it was forwarded to his home address) (fig. 51). In distress, Janse writes:

From a friend in Paris I now receive per airmail a newspaper clipping with a notice regarding the Academy's request for the government to appoint Karlgren as Andersson's successor. I am surprised that he already two years in advance makes this démarche, and while I am in East Asia where I am now, not without sacrifices, bringing together collections of antiquities for The Museum of Far Eastern Antiquities. [I have] turned to the Academy with a request to also be considered. Karlgren is exclusively a phonetician and to fill the position after Andersson there is need for an archaeologist and museologist. K. is neither, and has moreover never pursued excavations in East Asia. Should he get the post, his professorship at Gothenburg University would probably be withdrawn. For my own part I don't know what I'm going to do when this expedition ends. The position at MFEA is my last and only hope. With the new naturalization laws I am now

522. Newspaper clipping with the title "Voyage de M. le Gouverneur Général à Thanh Hoa." NAA: Janse 2001-29.

523. See photo in Janse 1947: plate 93.

524. Janse 1947: plate 92(3); Janse 1951:194n12. 


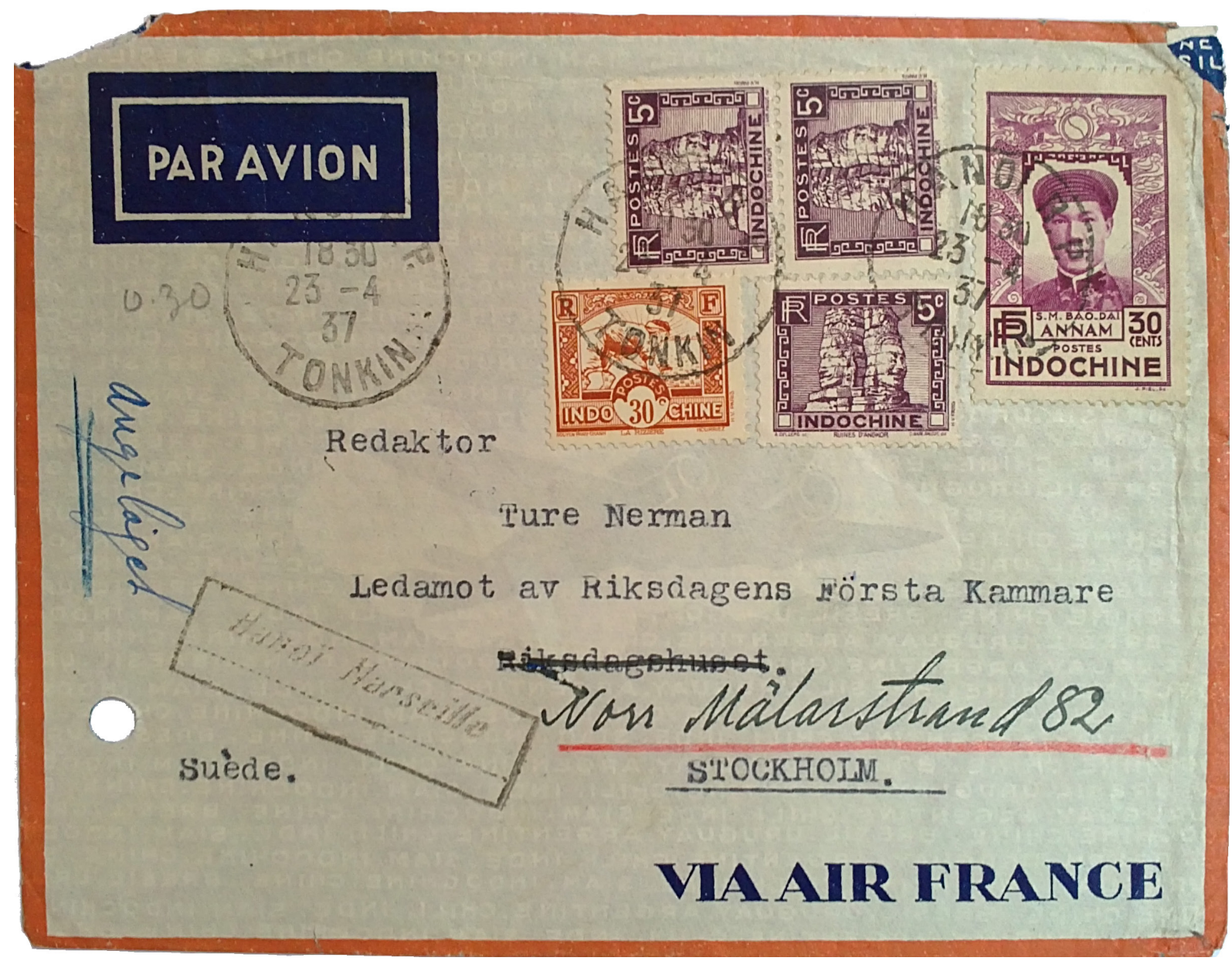

Fig. 51. Envelope for the letter to Ture Nerman, dated 22 April 1937 . also completely excluded from opportunities to get a paid state or municipal employment in France. My position is thus precarious. [... To try and exclude me from a position that I almost have the right to get, is to do me a cruel injustice. ${ }^{525}$

525. Letter from O. Janse to T. Nerman, 22 April 1937. Arbetarrörelsens arkiv och bibliotek. Ture Nerman 3.1.7. In the Swedish original: "Av en vän i Paris erhåller jag nu per flyg ett tidningsurklipp med en notis ang Vitterhets Akademiens hemställan till K M:t att utnämna Karlgren till Anderssons efterträdare. Jag är förvånad över att vederbörande redan två år i förväg gör denna demarche och medan jag ännu befinner mig i Östasien där jag nu icke utan uppoffringar sammanför samlingar av fornsaker åt Östasiatiska Museet. [Jag har] vänt mig till Vitterhetsakademien med anhållan om att även bli ihågkommen. Karlgren är ju uteslutande fonetiker och för posten till Anderssons efterträdare behövs en arkeolog och museolog. K. är varken det ena eller det andra och har dessutom aldrig 
He asks Ture for advice, and for help to raise the issue with the parliamentary ombudsman, with other Members of the Parliament, the press, and so on. We do not know what the response, if any, was. It is clear that the decision to appoint Karlgren after Andersson came as a complete shock for Janse, who had seen himself as the only rightful successor as Director of the Museum of Far Eastern Antiquities - "a position that I almost have the right to receive" - and moreover saw it as his "last and only hope" for a successful continuation of his career.

Looking at the official documentation surrounding the appointment of Karlgren, a rather different picture appears, in which Janse was never even considered for the post. The background was in fact rather complicated.

Johan Gunnar Andersson had become Docent in Geology at Uppsala University in 1905. In 1906 he was appointed Professor and head of The Geological Survey of Sweden, a position he held until 1914 when he asked for permission to leave the Survey to work with Chinese authorities on mining issues. During the ten years (until 1924) that he worked as a geologist in China and with Chinese authorities, Andersson excavated, bought or in other ways collected archaeological material from Chinese history and prehistory. Returning to Sweden in 1925, Andersson brought back a large collection of mostly prehistoric artefacts. The deal was that a majority of the material should be returned to China after scientific investigations in Sweden. The material was duly returned, but was lost and has not been found since the Second Sino-Japanese War (1937-1945).526

In 1925, Andersson was appointed Professor of Geology at Stockholm University. The same year "The China Committee" (Swe: Kinakommittén), which had been founded in 1919 by the wealthy industrialist Axel Lagrelius to support Andersson's collecting endeavours in China, offered to transfer Andersson's private collection to Swedish State ownership under the condition that the State could guarantee that the collections would be subject to scientific or scholarly (Swe: vetenskaplig) treatment

gjort utgrävningar i Östasien. Skulle han erhålla platsen kommer troligen hans professur vid Göteborgs Högskola att slopas. Själv vet jag ej vad jag ska ta mig till när denna expedition blir slut. Befattningen à Ö.S. är mitt enda och sista hopp. Jag är nu genom de nya naturaliseringslagarna även helt utstängd från möjligheter att i Frankrike erhålla en avlönad statlig eller kommunal befattning. Min ställning är alltså prekär. [...] Genom att söka utstänga mig från en befattning som jag nästan har rätt att erhålla, göres mig en grym orättvisa."

526. E.g. Fiskesjö 2014:77n26; Johansson 2012:110, see also 106, 108. 
and analysis. The offer was accepted in March 1926, and in July the same year Andersson was promoted to Professor of Far Eastern Archaeology and Director of the State's East Asian collection (Swe: Östasiatiska samlingarna), which continued to grow rapidly between 1928 and 1935. In the 1926 agreement between the Swedish State and Kinakommittén it was underlined that the collection, at the time of Andersson's retirement, would be integrated with the collections of the Swedish History Museum and there be supervised by a curator. Hence there would, according to the original agreement, be no prolongation of Andersson's professorship. ${ }^{527}$ But both Kinakommittén and Andersson thought that this would damage the development of the collection and potentially hinder further scientific and scholarly investigations. ${ }^{528}$ It was therefore important to them that a suitable successor could be found and prepared in good time before Andersson's retirement.

What Olov Janse did not know was that Andersson already in 1936 had decided that Bernhard Karlgren (1889-1978) would become his successor. Karlgren was a phonetician and sinologist who had studied for Paul Pelliot in Paris, had been professor of East Asian languages at Gothenburg University since 1918, and Vice Chancellor of Gothenburg University between 1931 and 1936. He would be put to the test as Acting Director when Andersson went on a last research trip to China and Indochina in 1936. But this pro tempore solution was also a strategic step to place Karlgren firmly within the museum's organization, and make sure that they could later argue that Karlgren had sufficient experience of working with museum matters..$^{52}$

But before he reached a decision, Andersson had entertained other possibilities. In 1932 he wrote to Karlgren explaining that his successor ought to be a highly skilled archaeologist in the field of comparative archaeology, familiar with the material and methods of comparative ethnography, and must read and speak English. A knowledge of Far Eastern languages would be a bonus. At this point Andersson focused his attention on the young ethnographer Karl Gustav Izikowitz (1903-1984), and also mentioned military historian F. Heribert Seitz (1904-1987) as a

527. Andersson 1929:11-27; see also Malmqvist 1995:286-288.

528. Malmqvist 1995:289.

529. Letter from B. Karlgren to J. G. Andersson, 5 April 1936. Östasiatiska samlingarnas arkiv. Korrespondens 1936 E1A: 13, 0328a,b-0329: Letter from J. G. Andersson to B. Karlgren, 9 April 1936. Östasiatiska samlingarnas arkiv. Korrespondens 1936 E1A: 13, 0334a,b-0335. 
potential man for the job..$^{530}$ Janse was never mentioned in this context, by Andersson or anyone else, even though he was clearly looking for an archaeologist with qualifications almost identical to Janse's. ${ }^{531}$

At about the same time as Andersson entertained the idea of having Izikowitz or Seitz as his successor, he corresponded with Sune Lindqvist, professor of archaeology at Uppsala University. In a letter to Lindqvist, Andersson describes Janse as klen. ${ }^{332}$ Klen is a Swedish word with different connotations. It can mean small, unhealthy, or physically and mentally weak as opposed to strong. But in the mid 1930 s it was also used to say that someone was not good enough, unfit or insufficient in relation to a task or activity. 533 Judging from the context, we believe that Andersson meant that Janse was not quite trustworthy or reliable with regard to his museum assignments.

In a letter to Sigurd Curman the same year, ${ }^{334}$ Sune Lindqvist confirms this sentiment, when he writes in a passive-aggressive tone that Janse's doctoral thesis lacks in quality, and that Janse is a paltry person because he has not mentioned Lindqvist's works in the publication to the occasion of the 1929 gold exhibition at the Swedish History Museum. ${ }^{535}$ Such designations passed between some of the most powerful actors in Swedish archaeology at the time, were of course not good for Janse's reputation. But he continued, nonetheless, to work for Andersson at the Museum of Far Eastern Antiquities for as long as $1936 . .^{36} \mathrm{It}$ is moreover noteworthy that Janse in a letter to Ture Nerman in 1937 says exactly what Andersson emphasized already in his 1932 letter to Karlgren, namely that Andersson wanted to see an archaeologist and not a phonetician as successor on his post. ${ }^{537}$ This indicates that Andersson might have discussed the issue with Janse at some point in the years 1931-1932, explaining what

530.F Heribert Seitz, Sv. biografiskt lexikon: https://sok.riksarkivet.se/sbl/Presentation.. spx $?$ id $=5853$, accessed 14 May 2018.

531. Letter from J. G. Andersson to B. Karlgren, 2 April 1932. Östasiatiska samlingarnas arkiv. Korrespondens 1932 E1A:7, $0106 \mathrm{a}, \mathrm{b}, 0107$

532. Letter from J. G. Anderson to Sune Lindqvist, 4 April 1932. Östasiatiska samlingarnas arkiv. Korrespondens 1932 E1A:7, 0321a,b.

533. S AOB: Svenska Akademiens Ordbok, 1936.

534. Letter from Sune Lindqvist to Sigurd Curman, 26 July 1932. Sune Lindqvist. Gustavianums arkiv. Husbyborg. Korrespondens med svenskar F8 D:10.

535. Janse 1928.

536. Svenska Dagbladet, 6 August 1936: "Prof. Janse på expedition i 8 månader."

537. Letter from O. Janse to T. Nerman, 11 September 1937. Arbetarrörelsens arkiv och bibliotek. Ture Nerman 3.1.7. 
he had in mind regarding his successor. Regarding himself as a competent comparative archaeologist, collecting objects for the Museum of Far Eastern Antiquities during his second expedition to Indochina, having worked close to Andersson during the early 1930 s and being an experienced museum man, it is reasonable to believe that Janse concluded that it was him that Andersson had in mind. Reading the letters from these years it is difficult for us too, even with the benefit of hindsight, to see any reason why Janse's name was never considered or even mentioned as a potential successor to Andersson. But he never was, in any documents we have seen.

When Andersson eventually changed his mind and decided that Bernhard Karlgren was be the successor he wanted and needed, they faced a fundamental formal and political problem. The Parliament would need to vote to end the agreement from 1926 for there to be a successor at all. And it was also up to the Parliament to decide who the successor would be. The material on which the decision was based was formulated by Vitterhetsakademien, which was led by Sigurd Curman (who was also Andersson's superior as Director of National Antiquities) and by Government clerks.

Sigurd Curman does not seem to have disliked Janse, but was not particularly interested in helping him either. Janse, on the other hand, as we know, helped Curman's daughter Brita on her visit to Paris ${ }^{53^{8}}$ and corresponded regularly with Curman until he understood that he must have been involved in the decision to make Karlgren Andersson's successor. From that point on there are no letters from Olov Janse in Sigurd Curman's archive. 539

Members of Vitterhetsakademien and Kinakommittén, including Curman, were now mobilizing to present the Parliament with correct information. On 25 January 1937, Kinakommittén delivered a memo to Vitterhetsakademien arguing that because of the rapid growth of the collection thanks to funding from private donations, there was need for a phonetician as the new Director. Museum curators lacked such special knowledge, and Sweden had only one expert in phonetics - Bernhard Karlgren. Kinakommittén referred to letters from the German art histo-

538. Letter from O. Janse to S. Curman, 18 September 1935. ATA: Sigurd Curmans arkiv. Vol. 115. F 2 b.

539. The last letter from Olov Janse to Sigurd Curman was sent on 24 September 1936. ATA: Sigurd Curmans arkiv. Volym 116. F 2 b. 
rian Otto Kümmel (1874-1952) and the French sinologist and orientalist Paul Pelliot (1878-1945, who knew Janse and had also been Karlgren's teacher in Paris), who both recommended Karlgren. The Crown Prince stood behind the memo. ${ }^{54^{\circ}}$ Olov Janse was never mentioned in any of these documents. Everyone appears to have accepted Andersson's suggestion already in 1936, and the focus now was on convincing the Parliament to rescind the crucial 1926 decision that Andersson would not be replaced when he retired.

When Kinakommittén delivered its memo to Vitterhetsakademien, Johan Gunnar Andersson was in China and Olov Janse in Indochina. Less than a year earlier, in the spring of 1936, Janse had met Andersson in Stockholm to discuss whether the Museum of Far Eastern Antiquities would be interested in contributing funding to his next expedition to Indochina. ${ }^{541}$ At this point there was some sort of dispute going on between Karlgren and Andersson relating to Karlgren's nomination as Director. ${ }^{542}$ Although no formal decision had been made, they discussed the matter as if it was a fact that Karlgren would replace Andersson. Janse of course had no knowledge of this when he visited Andersson.

Andersson left for his last journey to China in September 1936 and arrived in China two months later. In January 1937, one of the donors to the museum, Anders Hellström, wrote to Karlgren that he had donated 5,000 Swedish krona to the museum's bulletin and 5,000 to Musée Cernuschi for Janse's excavations, hoping that the museum in Stockholm would receive duplicates from Janse's collections. ${ }^{543}$ At about the same time Karlgren wrote to Janse thanking him for sending a publication on Han bricks. ${ }^{54}$ He moreover congratulated him on his success in Indochina saying that both he and the Crown Prince were pleased with the collaboration between him and the museum. ${ }^{545}$

540. Malmqvist 1995:289-290. We have not been able to find the actual memo that Malmqvist refers to in any archive.

541. Postcard from Olov Janse to J. G. Andersson, 5 May 1936. Östasiatiska samlingarnas arkiv. Korrespondens 1936 E1A:13, 0305a.

542. Letter from J. G. Andersson to B. Karlgren, 9 April 1936. Östasiatiska samlingarnas arkiv. Korrespondens 1936 E1A:13, O334a,b-0335.

543. Letter from A. Hellström to B. Karlgren, 4 January 1937. Östasiatiska samlingarnas arkiv. Korrespondens 1937-1938 E1A:17, 0315.

544. Janse 1936.

545. Letter from B. Karlgren to O. Janse, 16 January 1937. Östasiatiska samlingarnas arkiv. Korrespondens 1937-1938 E1A:17, 0337. 
In the meanwhile, Andersson had encountered severe problems in China and turned his focus to Indochina, where he intended to excavate Han period tombs - in other words, enter Janse's hunting grounds. A drama started to build up. Karlgren nervously followed the process at a distance, and wrote in a telegram to Andersson: "Thanks report I believe your idea Tonkin excellent never mind Janse Negotiations directly Coedes fine man writing fully our love Karlgren". ${ }^{56}$

On 8 March, Karlgren wrote a letter to comfort Andersson, who was disappointed over the situation in China, reminding him that "China in 1937 is not the same China as in 1923", encouraging him to turn his attention to Indochina instead. Investigations of Han tombs in Tonkin would be a very good alternative, he writes, because the museum has no such material in its collections. He continues: "it would be damnunculus acris [a witty paraphrase of the Latin name for buttercup, our remark] if the existence of a little Mr Janse in Tonkin were granted such importance that it would hinder the progress of J.G. Andersson." George Cœdès is a good man and an old friend, he concludes, and things will turn out for the best. ${ }^{547}$

On 6 April, Vitterhetsakademien sent a memo to the Parliament, stressing the importance of having Karlgren as the new Director of the Museum of Far Eastern Antiquities after Andersson..$^{548}$ There were two main threats to their plans. The first would be if the government clerks pointed to the 1926 agreement, and advised against a successor in Andersson's position. The second potential threat was Janse. If Janse made enough fuss in the media and could convince some of the politicians in Parliament that he was a better choice than Karlgren (which was not unlikely, considering his strong connections to Ture Nerman and other influential actors in Swedish media and politics), the Parliament might vote in his favour, or indeed return to the 1926 agreement.

And Olov Janse was indeed upset. He sent petitions to Curman and

546. Telegram from B. Karlgren to J. G. Andersson, 8 March 1937. Östasiatiska samlingarnas arkiv. Korrespondens 1936-1938 E1A:15, 0048.

547. Letter from B. Karlgren to J. G. Andersson, 8 March 1937. Östasiatiska samlingarnas arkiv. Korrespondens 1936-1938 E1A:15, 0049a,b. In the Swedish original: "att det vore väl fanunculus acris om existensen av en liten herr. Janse i Tonkin skulle tillmätas den betydelse att den skulle få lägga hinder i vägen för J.G. Anderssons framfart.”

548 . We have not been able to locate the memo, but it is quoted in Kungl. Maj:ts proposition $\mathrm{Nr} 104$ - Riksarkivet. 1938. 1 Saml. Band. K. Maj:ts propositioner Nr 89-135. C8 - and was probably signed by Curman. 
Vitterhetsakademien, and letters to Ture and Birger Nerman, pointing out that he had the perfect qualifications for the post, and moreover that he was currently in Indochina collecting materials to enrich the museum's collections. ${ }^{549}$ A nervous Bernhard Karlgren wrote to Andersson in Indochina that he had learned that the Academy had decided that Curman should write to Janse and spell out to him that the Academy had already recommended Karlgren. The idea was, according to Karlgren, that Janse would then accept the situation and withdraw his petition before it reached the press. But at the same time, he continued, it was possible that Janse's petition to the Academy was only the first step in what would be a series of complaints. Therefore it was important, Karlgren stressed, that Andersson send a letter to the Academy emphasizing "the man's weaknesses". 550

Andersson never wrote such a letter, as far as we know. But we know for certain that already in 1932 he described Janse as klen, and it was this sentiment (apparently shared by Karlgren) that he was now urged to emphasize for the Academy. This must have been complicated for Andersson, to whom Janse had become a useful person. Karlgren too agreed that Janse's text on Han bricks was important, ${ }^{51}$ and his work had apparently rendered him esteem in both France and Indochina. It was therefore impossible to claim without it being called into question that Janse was weak on his merits from museum work and as a scholar. Our interpretation of the word klen used by Andersson in this context, is that it was because Janse did not take his responsibilities at the Museum of Far Eastern Antiquities seriously enough, when he was working for Andersson in the early 1930s. He had recently got married, and focused on his achievements in Paris and later in Indochina. The Museum of Far Eastern Antiquities was in other words not his main priority at this crucial time when Andersson was looking around for a potential successor. So we believe that Andersson saw Janse as unreliable and not trustworthy,

549. We have not been able to locate the original petition to the Academy, but Karlgren quotes from it in a letter to Andersson (Letter from Karlgren to Andersson, 11 May 1937. Östasiatiska samlingarnas arkiv. Korrespondens 1936-1938 E1A:15, 0085a,b.) and there is a draft in Ture Nerman's archive (Ture Nerman 3.1.7.).

550. Letter from Karlgren to Andersson, 11 May 1937.

551. Letter from B. Karlgren to O. Janse, 16 January 1937. Östasiatiska samlingarnas arkiv. Korrespondens 1937-1938 E1A:17, 0337. We believe it is Janse's text from 1936, Briques et objets céramiques funéraires de l'époque des Han appartenant à la collection C.T. Loo et Cie. Paris: Les Editions d'art et d'historie, that Karlgren refers to. 
hence unfit to be in full charge of the museum in Stockholm. There is some archive information which points in this direction, for example that Janse asked Andersson for money, again and again, for a monograph on Hsin-Tien which he never completed. $5{ }^{52}$ Another possible interpretation, also relating to trust, is that Andersson may not have been sure that Janse would let him continue with his own work and research in the collections after his retirement, which appears to have been a key issue for him.

Olov Janse followed Curman's advice and withdrew his petition. At the same time he tried to convince Ture and Birger Nerman to pull strings in the Parliament. On 11 September he wrote to Ture Nerman:

Regarding the Academy's petition to Kungl. Maj:t recommending Karlgren to the position as Director of the museum, the fact is that J.G.A. has a strong thirst for power and wants to rule the museum even after he has retired. By formally recommending a person as the Director of the museum who is not a museum man nor an archaeologist and who has completely different interests, Andersson has made sure that he can rule over the collections as much as he wants. Curman has agreed, but has at the same time duped Karlgren to make a promise not to demand any extra funding for any other employees if Karlgren is appointed! But this is horse-trading. Regarding myself, it has been stated that I am out of the question because I am almost a French citizen!!! This is of course completely incorrect. I presume that Birger and Lunkan [Ernst J. Lundqvist (1893-1958), chief editor of the magazine FiB] have told you in what strange manner this issue has been managed by the Academy. The whole business is sick and it will be no problem at all to reprimand those responsible, even more so since the Parliament decided in 1927 [sic] that when Andersson retired no one should replace him. The easiest way out must be to make sure that Parliament dismisses the petition from the Academy. It would be great if you could do something in that direction. ${ }^{533}$

552. Letter from Olov Janse to J. G. Andersson, 27 April 1936. Östasiatiska samlingarnas arkiv. Korrespondens $1936 \mathrm{E} 1 \mathrm{~A}: 13$, 0304a,b.

553. Letter from O. Janse to T. Nerman, 11 September 1937. Arbetarrörelsens arkiv och bibliotek. Ture Nerman 3.1.7. In the Swedish original: "Beträffande akademiens hemställan till K.M:T att göra Karlgren till föreståndare för Ö.S. förhåller sig saken så att J.G.A. som är mycket härsklysten vill fortsätta att regera på Ö.S. även sedan han blivit pensionerad genom att formellt utnämna till chef en person som varken är museumman 
Janse was in many ways correct in his description of the situation. Andersson had not wanted to leave Sweden for China before it was clear that Karlgren would become his successor, and he also had a controversy with Karlgren regarding his own position at the museum after Karlgren had become Director. ${ }^{54}$ But Janse's idea that the Parliament would be on his side was completely wrong.

The petition from the Academy mentioned in Janse's letter was sent to the Parliament on the 6 April 1937.555 The proposition was debated in the Parliament a year later, on 30 March $1938,{ }^{556}$ after which it was decided that Bernhard Karlgren would succeed Johan Gunnar Andersson on the day after his retirement. ${ }^{557}$ The debate took a whole day, and a large number of politicians aired their opinions. The main question was the 1926 agreement, and they eventually voted against the clerks' advice and broke the agreement. But the idea of Karlgren being the most suitable, indeed the only possible, successor to the post raised no concerns. Janse's name was never mentioned.

While the issue of his successor was being debated in Stockholm, Johan Gunnar Andersson was in Indochina hoping to excavate Han tombs. He corresponded regularly with Karlgren and tried to work out a strategy to

eller arkeolog utan har helt andra intressen, beräknar Andersson väl kunna i lugn och ro få styra och ställa som han vill utan inblandning. Curman har gått med på affären men har dessförinnan avlockat Karlgren ett löfte att ej begära några anslag för medarbetare om K. blir utnämn! Detta är ju kohandel. Beträffande mig själv, ha vederbörande [sic] framställt saken så att jag inte kan komma i fråga då jag redan skulle vara i det närmaste fransk medborgare!!! Vilket ju [sic] fullkomligt oriktigt. Förmodar att Birger och Lunkan berättat för dig de egendomliga sätt på vilket detta ärende behandlats i akademien. Saken är sjuk och det bör inte vara svårt att få vederbörande prickad, allra helst som Riksdagen redan 1927 beslöt att efter Anderssons avgång ingen ny föreståndare skulle tillsättas. Det enklaste vore väl att i Riksdagen verka för att akademiens hemställan avslås. Vore bra om du ville göra något ditåt."

554. Letter from J. G. Andersson to B. Karlgren, 2 April 1932. Östasiatiska samlingarnas arkiv. Korrespondens 1932 E1A:7, 0106a,b, 0107.

555. The petition is summarized in Kungl. Maj:ts proposition Nr 104. Bihang till Riksdagens Protokoll vad Lagtima Riksdagen i Stockholm år 1938. Första samlingen Åttonde bandet. Kungl. Maj:ts propositioner nr 89-135. Riksarkivet.

556. Riksdagens protokoll vid lagtima riksmötet år 1938. Första kammaren. Andra bandet. $\mathrm{Nr} 24-34$. Nr 24; Riksdagens protokoll vid lagtima riksmötet år 1938. Andra kammaren. Andra bandet. $\mathrm{Nr} 20-28 . \mathrm{Nr} 24$. Riksarkivet.

557. Riksdagens skrivelse $\mathrm{Nr} 171$, p. 2. Bihang till Riksdagens protokoll vid Lagtima riksdagen i Stockholm år 1938. Fjortonde samlingen. Riksdagens skrivelser och förordnande, $\mathrm{nr}$ 1-477. Riksarkivet. 
bypass Janse, in Stockholm as well as in Hanoi. The tone of the letters, mostly those written by Karlgren, is rather harsh when commenting on Janse. $5^{58}$ One major problem had occurred, and it was that the Crown Prince had written to Janse and asked him to help Andersson in Indochina. He had done this on his own initiative, without informing Karlgren or Andersson. In November 1937 Karlgren wrote to Andersson:

Talking about Janse, the appeal to him from a certain direction [the Crown Prince, our remark] was slightly embarrassing. I thought, when I contacted Cœè̀s and he answered so amiably, that it had to do with what he knew about my work, and not due to some intervention by Janse. 559

Anyway, writes Karlgren in conclusion, "I will send a telegram to the Crown Prince and thank him." The reason why Karlgren and Andersson did not want the Crown Prince to get involved, was of course that it might play into the hands of Janse - and so it did. Karlgren was sitting alone in Sweden, and Andersson was in Indochina together with Janse and Cœdès. The ever-important Crown Prince had contacted Janse with a personal plea, indicating that Janse was a man of power and influence. Judging from the correspondence with Andersson, Karlgren was anxious about the whole situation. This is probably why he found every possibility to attack Janse, to make sure that Andersson would not change his mind. In a letter to Andersson in December 1937, Karlgren writes that Janse had appeared in a newspaper article in Dagens Nyheter, saying that he had facilitated Andersson's excavations in Indochina. The last paragraph of the article reads:

Lastly I would like to mention that the ample ethnographic collection I have managed to gather will mostly be donated to the

558. Letters between B. Karlgren and J. G. Andersson. Östasiatiska samlingarnas arkiv. Korrespondens 1936-1938 E1A: 15, 0041, 0049a,b; 0085a,b; 0159a,b-0160; 0165, 0166, 0167a,b, 0168a,b,; 1069; 0176a,b; 0178-0179; 0189-0191; 0194a,b-0195a,b; 0202; 0253 .

559. Letters from B. Karlgren and J. G. Andersson, 15 November 1937. Östasiatiska samlingarnas arkiv. Korrespondens 1936-1938 E1A:15, 0176a,b. In the Swedish original: “Apropå Janse var det ju litet förargligt med hänvändelsen till honom från ett visst håll. Jag tror att när jag såg tiden mogen för en sondering i Hanoi, och Cœè̀s svarade så utomordentligt älskvärt som han gjorde, detta berodde på vad han visste om mina arbeten och ej på Janses eventuella inlägg.” 
Ethnographic Museum in Stockholm, whose director, Professor Gerhard Lindblom, has shown a remarkable interest in these researches. Since I have for many years participated in the work at the Museum of Far Eastern Antiquities, it is of course my heartfelt wish to try to contribute to the development of those collections as well, to the extent that it is possible. And I hope there will be an opportunity for me to present as a gift some of the interesting archaeological finds from my excavations here. At the request of the China Committée in Stockholm I have also investigated with the French authorities the possibilities for Professor G. Andersson to excavate in Tonkin. As a result, a permit has been issued for him to excavate some prehistoric sites..$^{50}$

Janse played a devious game when - under the pretext of "helping" Andersson - he used his contacts in the French administration to steer attention away from the most prestigious sites with the most desirable collectible objects and effectuate a permit for excavations only at prehistoric sites where the find material consisted of stone tools and potsherds, that were of little interest for Andersson's museum collection of fine antiquities. In the Swedish press, as we see in the quotation above, he let the readers know of his own contributions to the Ethnographic Museum, his "heartfelt wish to contribute" to the Museum of Far Eastern Antiquities, and not least his selfless efforts to help Andersson get an excavation permit in Indochina. Karlgren was not happy about Janse's sly manoeuvres, and found the article "not at all pleasant". ${ }^{61}$ Johan Gunnar Andersson, who was no less of a cunning strategist, chose not to enter in

560.Dagens Nyheter, 1 December 1937: "Svensk i okända Indokina". In the Swedish original: "Slutligen vill jag nämna att det stora etnografiska material jag lyckats hopbringa till avsevärd del kommer att överlämnas till Etnografiska museet i Stockholm, vars chef, professor Gerhard Lindblom, visat synnerligen stort intresse för dessa forskningar. Då jag ju under flera år deltagit i arbetet vid Östasiatiska samlingarna, ligger det mig givetvis varmt om hjärtat att så långt det är möjligt söka bidra även till dessa samlingars utveckling. Och jag hoppas bli i tillfälle att dit som gåva överlämna något av de intressanta arkeologiska fynden från mina utgrävningar här. På anmodan av Kinakommittén i Stockholm har jag för övrigt här sonderat terrängen bland de franska myndigheterna beträffande möjligheter för professor G. Andersson att utföra grävningar i Tonkin. Och resultatet har blivit att tillstånd lämnats för honom att utgräva några prehistoriska fyndplatser."

561. Letter from B. Karlgren to J. G. Andersson, 1 December 1937. Östasiatiska samlingarnas arkiv. Korrespondens 1936-1938 E1A:15, 0178, 0179. 
a public dispute with Janse. But the correspondence with Karlgren shows a different side to him. It has a harsh and contemptuous tone when it comes to Janse. In response to Karlgren's letter about the article in Dagens Nyheter, Andersson writes:

It might interest you that the young archaeologists here are launching rather violent attacks on Janse. According to their information, i.e. those who have been in the field with him, they say that they have done all the technical work, mapping, surveying, and photographing, and that he in return has only been haughty and has not mentioned them in his publications..$^{562}$

The depiction of Janse as having a bad reputation among younger colleagues in Indochina is nothing we have come across in other sources. On the contrary, he is often described as a very likeable person, and as we have seen from previous examples he was always keen to acknowledge the contributions of both French and Annamite collaborators in his publications and when he was interviewed in the press. ${ }^{563}$ So we take these denigrations as situated items - as manifestations of Karlgren's and Andersson's mutual self-aggrandizing communication regarding the position in Stockholm and Janse's games concerning excavation permits in Indochina. For the latter, a letter from George Cœdès to Johan Gunnar Andersson eventually settled the issue and ended the discussion. Codès writes:

On the other hand, you probably know that Dr. Janse is now present in Indochina, working on the same sites [as you want to investigate] with the aid of French funds. Under these conditions, I do not think it would be wise to advise you to take up the Han period as the main object for your study, and after having discussed the matter with our prehistorian, Mlle Dr. Colani, I should rather

562. Letter from J. G. Andersson to B. Karlgren, 5 January 1938. Östasiatiska samlingarnas arkiv. Korrespondens 1936-1938 E1A: 15, 0202. In the Swedish original: "Det kanske intresserar Dig att höra att de unga arkeologerna här ganska våldsamt angripa Janse. Enligt deras uppgift, d.v.s. de som varit med honom i fält, uppge att de gjort allt tekniskt arbete, kartläggning, uppmätning och fotografering och att han till gengäld bara var hög och ej gett dem något omnämnade i sina publikationer".

563. E.g. L'Avenir du Tonkin, 22 March 1935: "Un entretien avec le Dr O. Janse." 
propose that you devote your time to prehistoric researches, a field which is far from being exhausted. ${ }^{54}$

Andersson accepted defeat, adapted calmly to the situation and soon set off to excavate prehistoric coastal sites in collaboration with EFEO's grande dame of prehistoric research, Madeleine Colani. ${ }^{565}$

Johan Gunnar Andersson and Bernhard Karlgren were the winners in Sweden, but Janse took the game in Indochina. This infected and nasty business ended with an awkward letter from Bernhard Karlgren to Olov Janse. Before the issue had been settled in the Parliament debate, Janse had written anxiously to ask Karlgren if there was any possibility for him to have a future position at the museum, arguing that there must be room in the museum's budget for this. ${ }^{56} \mathrm{In}$ his reply, Karlgren accounted for the museum budget in detail, and made it perfectly clear that there was no such room in the budget. He ended his letter with the rhetorical question if Janse might not have any contacts in America, since "American universities are in desperate need of competent archaeologists". ${ }^{567}$

All correspondence between Olov Janse and the Museum of Far Eastern Antiquities ends with this letter. There would be no more contacts between Janse and Karlgren, or Andersson.

In Hanoi in the spring of 1937 , Olov and Ronny Janse were at a standstill. The excavations were halted because of the hot and dry weather. In addition to the news about the affairs in Stockholm, Olov was troubled by a kidney condition, and they both suffered from the increasing heat. No letters were written, no interviews given. A month later they packed their belongings and travelled north, to the mining town of Tinh-tuc in the military territory (now Cang Bao province) near the Chinese border, where Janse had spent the Têt festivities a couple of months earlier. At the

564. Letter from G. Cœdès to J. Andersson, 19 October 1937. Östasiatiska samlingarnas arkiv. Korrespondens 1937-1938 E1A:16, 0040a,b.

565. For biographical research on Madeleine Colani, and her collaboration with Johan Gunnar Andersson, see Källén 2015: chapter 8.

566. Letter from O. Janse to B. Karlgren, 12 October 1937. Östasiatiska samlingarnas arkiv. Korrespondens 1937-1938 E1A:17, 0338a,b.

567 . Letter from B. Karlgren to O. Janse, 25 October 1937. Östasiatiska samlingarnas arkiv. Korrespondens 1937-1938 E1A:17, 0339a,b-0340. 
cosmopolitan meeting point Hôtel Métropole in Hanoi they had met the director of the Indochina mining industry, Charles Bastide, whom they were already acquainted with from Paris, and he had offered them to stay in his private villa overlooking the open tin and wolfram mines. With the prospect of escaping the heat of the lowlands for the cooler mountains and having some quiet time to rest, they accepted the offer. After a short stopover in the scenic Halong Bay, they arrived in Tinh-tuc in early June. ${ }^{568}$

They stayed the whole summer in Tinh-tuc. Janse later devoted an entire chapter of his memoirs to this sojourn, concentrating on his ethnographic encounters with the mountain tribes. ${ }^{569}$ But above all, this was a time for rest and refocus. A photograph in their personal archive shows a thin and tired-looking Ronny reclining in a rattan chair on the veranda of Bastide's villa. On another photo, with the villa seen from above, there is a note attached saying "Tin-Tuck, N. Tonkin, Vietnam, (our home)" in the characteristic hand of an ageing Renée (fig. 52). So Tinh-tuc must have made a lasting impression as a place they thought of as home.

During the four months they spent in Tinh-tuc they led a quiet and secluded life, and sent only a few letters to their friends in Sweden and France. The tone of these letters is radically different from the letters sent only a couple of months earlier, during the successful fieldwork campaigns in Thanh Hoa. The letters now give a sense of resignation and despair, and in some of them Janse is quite candid about the situation. In a letter to Marcel Mauss in early June, shortly after they had arrived in Tinh-tuc, Janse says that it breaks his heart to think about the delayed work on Hubert's Les Germains, but that he had no other choice owing to lack of support and funding. Not only had he needed to earn his own living over the last few years, he says, he also had to support his unfortunate parents-in-law in Russia, and had therefore, despite all his best intentions and good will, not been able to devote as much time as he had wished for the Germanics. Should the Musée des antiquités nationales have been willing to support him as he had suggested, Janse writes, the work would already have been done. In the same straightforward manner, which is quite different from his otherwise polite and slightly wary-toned correspondence with Mauss, he goes on to say that he has set aside some money to spend a couple of months with the Germanics and finish the

568. Janse 1959:208-212.

569. Janse 1959:208-221; see also the article by Olov Janse in Dagens Nyheter, 1 December 1937: "Svensk i okända Indokina." 

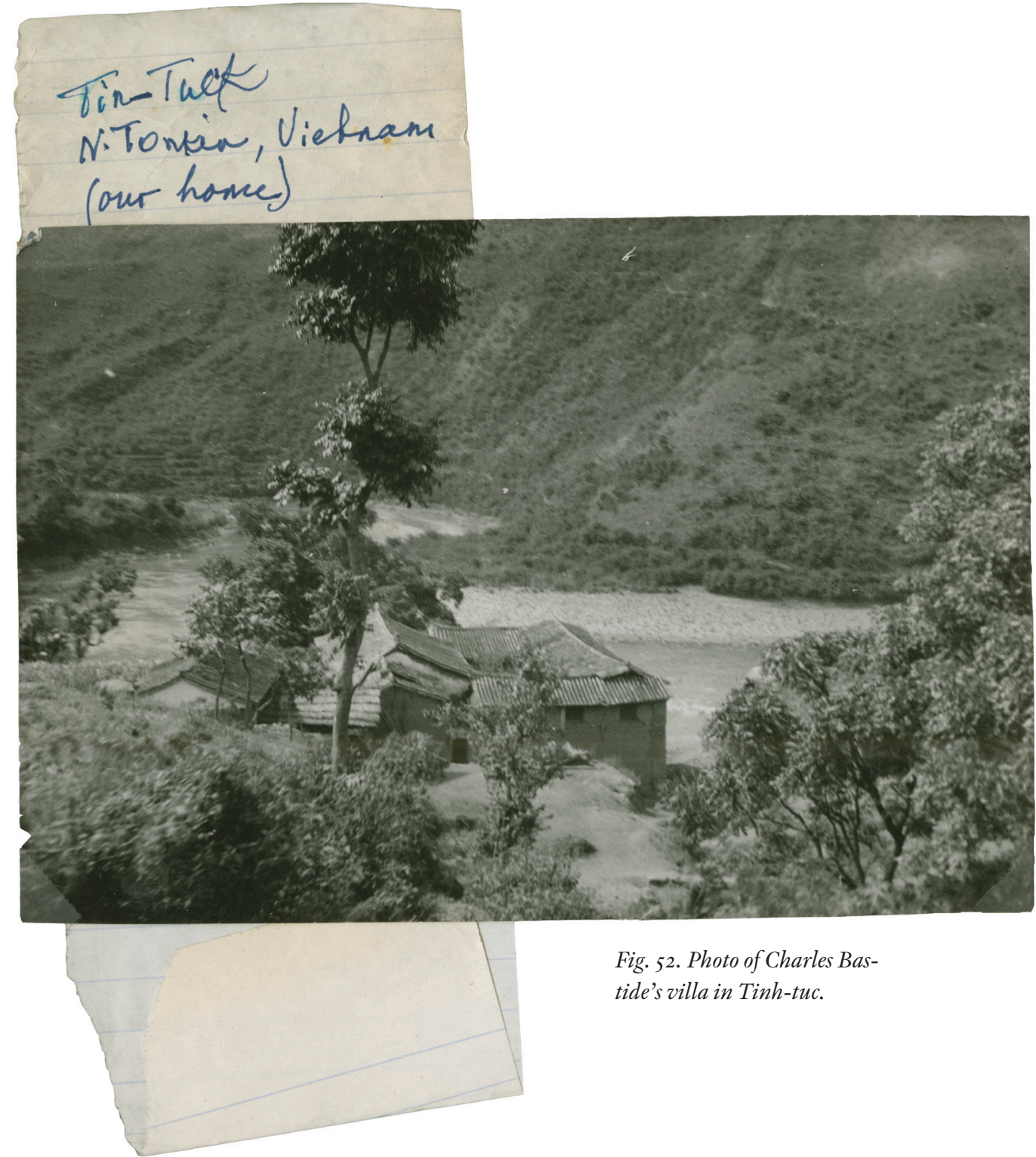

Fig. 52. Photo of Charles Bastide's villa in Tinh-tuc.

manuscript when he returns to Paris in January, but after that he has no idea where he will go. Even if he was naturalized, he would not get a position in France, he says: "I do not doubt that I will be able to earn my living, but I do not envisage a very bright future." 570

Only a couple of weeks later, Janse received notice from René Grousset in Paris that he had been granted further financial support from the Commission des Missions, thanks to interventions by Marcel Mauss and Lucien

570. Letter from O. Janse to M. Mauss, 3 June 1937. Fonds Marcel Mauss au Collège de France: mauss-janse-0032.pdf. 
Lévy-Bruhl..$^{51}$ Janse immediately wrote a letter to thank Mauss for his support, and the spirit of this letter is slightly more optimistic than the previous one..$^{572}$

When the summer came to an end, and they were about to return to Hanoi, Janse wrote a long letter to Ture and Nora Nerman. In a quite resentful tone he complains about the happenings in Stockholm. ${ }^{573}$ Johan Gunnar Andersson, who less than a year earlier was referred to as Janse's teacher and friend, and an instigator of his work in Indochina, is now "as we know very domineering" (Swe: ju mycket härsklysten). Sigurd Curman and his bureaucratic system of heritage management in Sweden, which he just recently aspired to become a part of, is compared in demeaning terms with the French administration in Indochina:

Our collaboration with the authorities here is the best imaginable, and it is a great relief to be free from all the Chinese walls of so-called expertise, guarantees, complications and writings which Curman loves to surround himself with. If the Curman system were applied here, not much would be done in terms of archaeology and excavation. ${ }^{574}$

Olov Janse was clearly upset and not quite in balance, at this point. And these are opinions that he would never have aired in the press. Even if

571. Lévy-Bruhl was a philosopher influenced by Durkheimian sociology who devoted his career to the study of "the primitive mind" as opposed to the modern Western mind, with book titles such as Les fonctions mentales dans les sociétés inférieures (1910), and La mythologie primitive (1935)).

572. Letter from O. Janse to M. Mauss, 22 June 1937. Fonds Marcel Mauss au Collège de France: mauss-janse-0033.pdf.

573. Letter from O. Janse to T. Nerman, 11 September 1937. Arbetarrörelsens arkiv och bibliotek. Ture Nerman 3.1.7. In the Swedish original: "Beträffande akademiens hemställan till K.M:t att göra Karlgren till föreståndare för Ö.S. förhåller sig nog saken så att J.G.A. som ju är mycket härsklysten, vill fortsätta att regera på Ö.S. även sedan han blivit pensionerad. Genom att formellt utnämna till chef en person som varken är museumman eller arkeolog utan har helt andra intressen, beräknar Andersson väl kunna i lugn och ro få styra och ställa som han vill utan inblandning."

574. Ibid. In the Swedish original: "Samarbetet med myndigheterna här är det bästa tänkbara och det är underbart skönt att vara fri från alla dessa kinesiska murar av s.k. sakkunskap, garantier, trassel och skriverier som en Curman älskar att omge sej med. Skulle man här tillämpa systemet Curman, bleve det nog inte mycket uträttat i fråga om arkeologi och grävningar." 
he played sly games he remained, on the surface, considerate and composed.

They left Tinh-tuc two weeks later and returned to Hanoi and Thanh Hoa, where they arrived at the end of September. They took up the excavations where they had left them in the spring, and worked for about a month before they took a break to travel by train to Yunnan. ${ }^{575}$ Once back in Hanoi, Janse wrote a letter to Birger Nerman, trying to persuade him and their other friends in Sweden to make noise in the press about the appointment of Karlgren. ${ }^{576}$ At about the same time, he also sent an article describing some of his ethnographic work in Tinh-tuc to the Swedish newspaper Dagens Nyheter - the article that Bernhard Karlgren found "not at all pleasant". 577

Two months after they had returned from Tinh-tuc they had wrapped up what was left of the excavations in Thanh Hoa, delivered a draft report to George Cœdès, and packed the last of the finds for transportation to the Guimet Museum, the French national museum of Asian art in Paris. "This time", Janse writes in a letter to Marcel Mauss, "the EFEO will reclaim almost nothing and even the statuette no. 2 will definitively stay in Paris." ${ }^{578}$ They left Hanoi on 27 November to travel south to Cochinchina, where after a short stopover in Saigon they set off to excavate on Tortoise Island. The excavations yielded some curious finds of Neolithic-type stone axes side by side with post-Song potsherds (i.e. dated to after AD 1280).579 A photograph in their personal archive (fig. 53) features a scene from the excavations. On the back is written: "This photo shows Dr. J and party in the jungle on Tortoise Island, temperature about $40^{\circ}$ cent." Compared with the photograph from Samrong Sen at the end of their first expedition (fig. 41) the sentiment communicated by the picture from

575. Letter from O. Janse to B. Nerman, 4 November 1937. Riksarkivet. Kartong 3. Korrespondens Brev III 1935-1941; Article by Olov Janse in Svenska Dagbladet, 24 November 1937: "Yunnan - kinaprovinsen nagel i ögat på japanerna. Prof. Olov Janse skriver till SvD från händelsernas brännpunkt."

576. Letter from O. Janse to B. Nerman, 25 November 1937. Riksarkivet. Kartong 3. Korrespondens Brev III 1935-1941.

577. Letter from B. Karlgren to J. G. Andersson, 1 December 1937. Östasiatiska samlingarnas arkiv. Korrespondens 1936-1938 E1A: 15, 0178, 0179.

578. Letter from O. Janse to M. Mauss, 5 February 1938. Fonds Marcel Mauss au Collège De France: mauss-janse-0034.pdf. In French: "Cette fois ci l'Ecole Française ne réclame presque rien et même la statuette n:o 2 restera définitivement à Paris." See also Janse 1947:viii.

579. Ibid. 
Tortoise Island is quite different. The jolly expedition leader with firm gaze and straight back is gone. Here we see instead a tired, broken man, whose focus is more on the hot climate than the site being excavated.

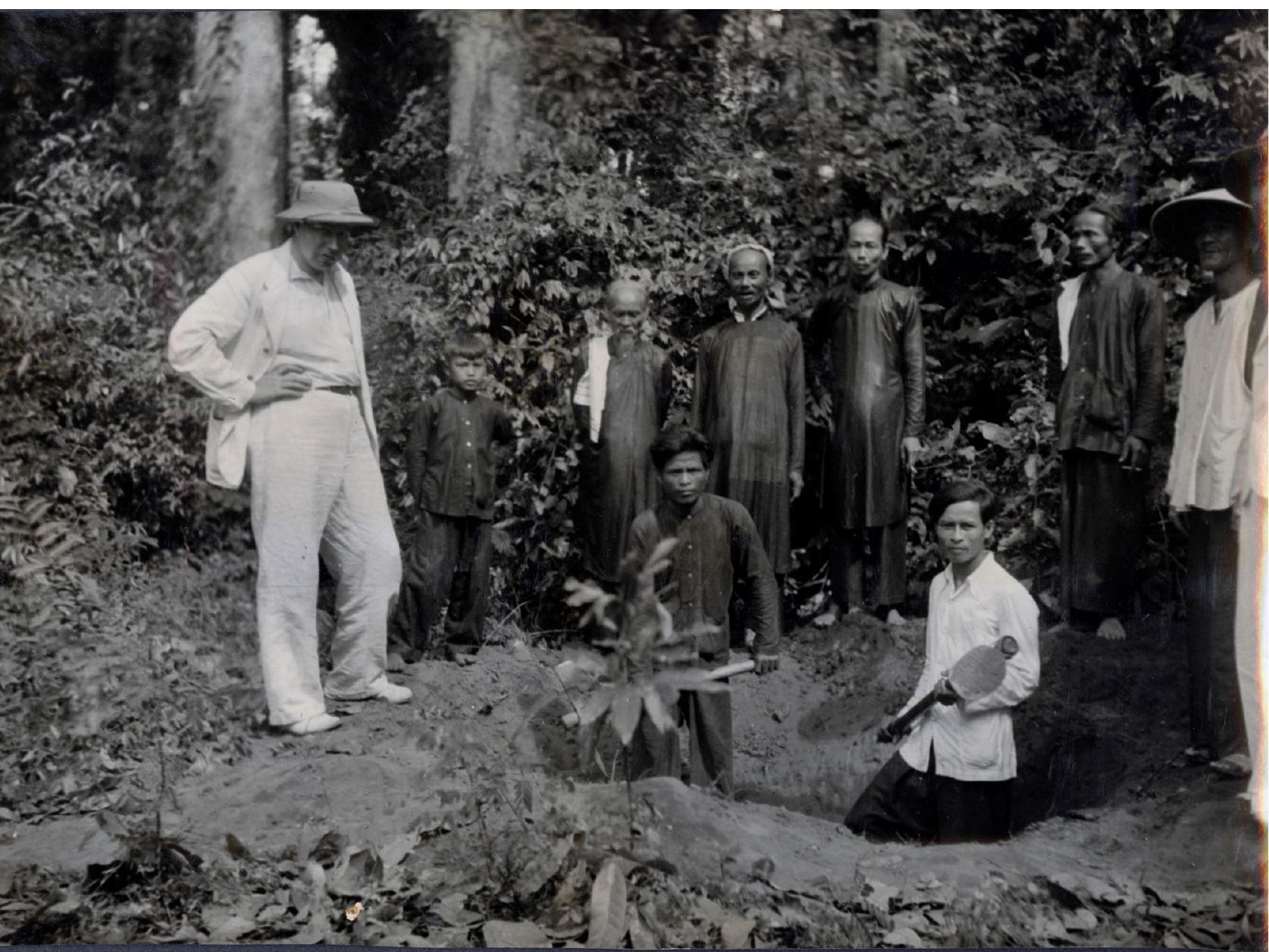

Fig. 53. Olov Janse with local staff and visitors at the excavation on Tortoise Island, in December 1937 . 


\section{INTERLUDE}

\section{DECEMBER 1937-NOVEMBER 1938}

Having ended the brief excavation sojourn on Tortoise Island, of which there is no record in the official reports, Olov and Ronny returned to Saigon and embarked on the luxury US ocean liner S S President Coolidge bound for Honolulu, on 23 December 1937. After a dramatic journey through storms and earthquakes, and stopovers in Hong Kong, Shanghai, Kobe, and Kyoto, they arrived on 21 January 1938 in Honolulu where they made a month-long stop to allow Olov to rest and recover from his liver condition, while taking the opportunity to study the collections of the Bernice Bishop Museum. Ronny later wrote in glowing terms to friends in Sweden about their month in Hawaii, how they were "surrounded by true-hearted and sympathetic friends", and "everything and everyone in this fairytale land was, quite simply, wonderful". 580 They departed from Hawaii on 23 February on the SS President Taft, and arrived in San Francisco a week later, on 1 March. There they took the opportunity to visit Los Angeles and see Hollywood, before they travelled north to Buffalo, NY, where they arrived on 20 March 1938.

The official reason for the turn towards the United States was an invitation from Chauncey J. Hamlin, the Director of the Buffalo Science Museum, to spend some time studying the museum's collections from

580. Letter from Ronny Janse to Birger and Barbro Nerman, 23 March 1938. Riksarkivet. Kartong 3. Korrespondens Brev III 1935-1941. In the Swedish original: "I Honolulu stannade vi över en månad och kännde oss omgivna av trogna och sympatiska vänner och alldeles glömde att vi äro utlänningar. Allt och alla i denna sagoland äro underbara helt enkelt." 
the Pacific on a special grant made by the Rockefeller Foundation. They ended up spending eight months in the United States. Most of the time they were in Buffalo, NY, where they rented an apartment in the city centre on 401 Delaware Avenue, and Olov worked in the Museum's new "Hall of Primitive Races", studying relations between Western, Far East, and Pacific arts. ${ }^{581}$ Over the eight months in Buffalo they also took the opportunity to travel and study other museum collections, at the Field Museum in Chicago, ${ }^{582}$ and at Harvard in Cambridge, Massachusetts.

If the official reason for the stay in the United States was the work for the Buffalo Museum, the unofficial reason was to establish a new professional platform away from Europe, and find means to continue their successful excavations in Indochina. The political situation in France and the debacle over the Museum of Far Eastern Antiquities in Stockholm had left them with little choice other than to look for a new base to work from. And the Unites States stood out as a good place to be when Europe was in turmoil. Soon after their arrival in Buffalo, Ronny wrote to Barbro Nerman who was pregnant with her second child in Stockholm:

We are very happy to stay here some time and work in peace and quiet. The Americans we have met are remarkably nice, sensible and humane, and you can sense it in their conduct. This is a country of great opportunities and built on people's capacity..$^{53}$

In fact, already during their month-long stopover in Hawaii, Olov began to work on his plans for the future. He wrote to Serge Elisséeff, a Russian-French Japanologist whom he knew from Paris, who had recently

581.E.g. Buffalo Evening News, 30 March 1938: "Museum adds aide"; Letter from O. Janse to M. Mauss, 5 February 1938. Fonds Marcel Mauss au Collège de France: maussjanse-0034.pdf.

582. Notice in Field Museum News, no. 4, April 1938: "Distinguished Visitors: Dr. Janse spent several days at Field Museum to study this institution's Chinese, Melanesian, and Filipino collections."

583. Letter from Ronny Janse to Birger and Barbro Nerman, 23 March 1938. Riksarkivet. Kartong 3. Korrespondens Brev III 1935-1941. In the Swedish original: "Vi äro mycket glada över att stanna här någon tid och arbeta i lugn och ro. De amerikanerna som vi har träffat äro utomordentligt trevliga, förståndliga och mänskliga och detta känns i deras uppträdande. Detta är en land av stora möjligheter och byggd på människornas kapacitet." 
been appointed Director of the Harvard-Yenching Institute in Cambridge, Massachusetts..$^{58}$

Janse, who was actively on the hunt for funding for a third expedition and even more importantly for him personally, for affiliation and support for his future career, also met and discussed the matter with Langdon Warner, legendary Harvard archaeologist and collector of Asian art. ${ }^{585}$ But it was with Elisséeff, his and Ronny's old acquaintance from Paris, that the ideas got rooted. Through Ronny, Janse also had a personal connection with Serge Elisséeff. Similar to Ronny's upbringing and experiences of the Russian Revolution, he was born and raised in a wealthy Russian family in St Petersburg. After returning home from university studies in Japan, he saw the devastating consequences the revolution had on his family and relatives, and fled with his wife Vera and their two young sons in the summer of 1920 . They escaped on a fishing boat to Finland and via Stockholm, Sweden, to Paris, where they settled and he continued his academic career and eventually became acquainted with Janse. ${ }^{586}$

In the letter to Elisséeff, Janse says that he is planning to spend some time in American museums, and that he has brought with him quite a few notes and drawings - "some rather unique" - of their investigations in Indochina, which he hopes to be able to continue to work with and publish. Considering the great interest in the United States in the archaeology and ethnography of the Far East, Janse writes, he is planning

584. All correspondence between Janse and Serge Elisséeff is kept at Harvard University - Harvard College Library Harvard-Yenching Library/Harvard-Yenching Institute Archives. Janse, Olov Robert T. Publication Projects and Expeditions. Correspondence, 1938-1940. Harvard-Yenching Institute, Cambridge, Mass; and Correspondence, 1941-1943. Harvard-Yenching Institute, Cambridge, Mass. In short: Harvard-Yenching Institute, Cambridge, Mass. Correspondence, 1938-1940; Harvard-Yenching Institute, Cambridge, Mass. Correspondence, 1941-1943.

585. Langdon Warner's (1881-1955) legacy is controversial, not least for his famous removal of original murals from the walls of the Dunhuang caves in the Gansu province of China. But Warner's contribution to the study of Asian art in the United States has also been celebrated, and in this vein he has been described as "the United States' first full-time teacher of Asian art" [whose] "true passion was in the field, where he worked as an explorer, archaeologist, and collector of Asian art. It has even been said that he is the inspiration for the character of Indiana Jones." http://www.monumentsmenfoundation. org/the-heroes/the-monuments-men/warner-langdon, accessed 15 May 2018; see also Hopkirk 1984: chapter 15; Fan 2009:257-258, Meyer \& Blair Bryzac 2015. Letter from Serge Elisséeff to O. Janse, 26 March 1938. Harvard-Yenching Institute, Cambridge, Mass. Correspondence, $1938-1940$.

586. Reischauer 1957. 
to put together a course on Indochina for an American university, and asks Elisséeff for advice:

\begin{abstract}
You have already so kindly promised to help me find a way in to the higher education of the United States, and I hope I am not being indiscreet by asking you for some good advice. May I ask which persons or universities you think would be willing to let me organize one or two courses with the title of "visiting professor" or "lecturer"? If you see a possibility for me to be admitted to Harvard, I ask you to think of me. ${ }^{587}$
\end{abstract}

The letter turned out to be the beginning of a whole new phase of Janse's career, and a restart for the investigations in Indochina. Serge Elisséeff not only gave Janse an opportunity to lecture at Harvard but also saw an opportunity to expand the interests of his institute. A bit further on in their correspondences, Elisséeff writes:

Will it be possible for you to come and lecture at Harvard during the last two weeks of April, which would be the last opportunity to have lectures here this year and have enough students and persons interested in archaeology present?

I was much interested in your proposition to subsidize archaeological excavations in Indo-China, and I immediately put it on the agenda for the next meeting of the Trustees of the Institute, which will be held the $11^{\text {th }}$ of April. I shall be very grateful if you can give me more information as to the conditions for such an expedition; what the tombs are; what things we could have here from the expedition; what our share in such an enterprise would be; when such a joint expedition would take place. I need more definite information to present to the Board of Trustees if the

587. Letter from O. Janse to S. Elisséeff, 2 February 1938. Harvard-Yenching Institute, Cambridge, Mass. Correspondence, 1938-1940. In the French original: "Vous m'avez déjà si aimablement promis de vouloir me faciliter l'entrée dans l'enseignement supérieur aux États-Unis que j'espère ne pas être indiscret en venant vous demender de me favoriser de quelques bons conseils. Puis-je vous demander quelles sont les personnes et les universities qui seraient disposes d'organiser pour moi un ou plusieurs cours à titre de 'visiting professor' ou 'lecturer'? Si vous voyez une possibilité de me faire admettre à Harvard, je vous demanderais de penser à moi." 
expedition is to be undertaken next year, so that an appropriation for it can be inserted in the budget for next year, which is made up at this meeting of the Trustees. ${ }^{58}$

On 1 April Janse wrote to Elisséeff with a list of proposed sites and monuments for investigation in a forthcoming expedition: 1) Han graves in Thanh Hoa (with transportation of a whole brick tomb set to the United States for reconstruction); 2) Pottery kilns from Han and post-Han periods, in Thanh Hoa and probably in Tonkin; 3) Traces of a Han village near Lach-truong in Thanh Hoa; 4) "Indonesian" settlements and cemeteries from the T'sin and Han periods in Laos, Tonkin, Annam, and Cambodge; 5) Neolithic sites such as Samrong Sen and Lung-prao in Cambodia; [no. 6 absent]; 7) Miscellaneous monuments outside Indochina (for instance in Kwang-Tcheon-Wan in China, and Siam, Malaysia and India for comparative studies of the material found in Indochina). In addition to these archaeological investigations he also proposes some ethnographic investigations of "the many primitive peoples isolated in the mountains" whose customs would be of great interest from a comparative point of view, and as explanations for the finds in the excavations. ${ }^{589} \mathrm{He}$ also offers to collect ethnographica for American museums that lack collections from Indochina. To realize these plans, he would need at least two years of continuous work, and estimates that he could do it for US $\$ 8,000$ per year. ${ }^{50}$ Three weeks later, Elisséeff wrote to Janse with good news:

I am happy to inform you that the proposition for an archaeological campaign in Indochina I presented to the Trustees at their recent meeting was accepted, and they voted that $\$ 8,000$ may be put in the budget for two years for this purpose. ${ }^{91}$

588. Letter from S. Elisséeff to O. Janse, dated 26 March 1938. Harvard-Yenching Institute, Cambridge, Mass. Correspondence, 1938-1940.

589. In a memorandum for internal communication at the Harvard-Yenching Institute, Elisséeff writes: "During the excavation a scholar interested in racial anthropology could collect data concerning the local people", which means a tentative expansion of Janse's object-collecting ethnographic pursuit, to more race-oriented anthropological research (See document, n.d. "Item 13. Archaeological Excavations in Indochina." Harvard-Yenching Institute, Cambridge, Mass. Correspondence, 1938-1940.)

590. Letter from Janse to Elisséeff, 1 April 1938. Harvard-Yenching Institute, Cambridge, Mass. Correspondence, 1938-1940.

591. Letter from Elisséeff to Janse, 21 April 1938. Harvard-Yenching Institute, Cambridge, Mass. Correspondence, 1938-1940. See also document "Memorandum in regard 
The Harvard-Yenching Institute had been founded in 1928 with funding from the estate of the aluminium industry magnate Charles Martin Hall, as a legally and fiscally independent public charitable trust located at Harvard University and with an office at Yenching University in China. The purpose of the Institute was to promote Western-style humanities education in Asia (particularly China) and humanist knowledge about Asian cultures in the United States. ${ }^{592}$ These official aims reflected an American self-image of superiority in terms of knowledge and education vis-à-vis Asia and China in particular. Hence modern scientific methods of the West would be the key to help the Chinese people to learn and appreciate their own cultural heritage, which would solve social problems caused by uncontrolled industrialization and national unrest. ${ }^{593}$ As such, the establishment of the Harvard-Yenching Institute rested on a foundation of Wilsonian internationalism, and was preceded by a project called the "Big Scheme", where pre-existing Asian or Oriental interests at Harvard were strategically refocused on China and the humanities, and hence reformatted to fit within the restrictions of Charles Martin Hall's testament. 594

The Fogg Museum (the oldest of the Harvard Art Museums) played an important role in defining the focus of the "Big Scheme". In 1925, the Fogg Museum had sent Langdon Warner, an archaeologist and collector of Asian art who was then a staff member at Fogg, on a mission to China. The official purpose of Warner's journey was to survey the possibilities for collaboration with Chinese university institutions along the lines of the "Big Scheme". Another purpose was to revisit the Dunghuang Caves in Gansu province of Western China, an important stop at an oasis on the Silk Road with a series of caves containing important Buddhist art dating back to the fourth century AD. Already in 1913, Langdon Warner had

to item 13 of agenda" in the same file. All correspondence between Janse and Elisséeff about the expedition and its funding has been saved and is kept in the Harvard-Yenching Institute archives. It is possible there to follow in detail how the expedition was set up over the course of eight months, from the first tentative proposal via all phases of negotiation, to realization.

592. Shuhua Fan moreover describes the foundation of the Harvard-Yenching Institute as "[reflecting] post-World War I American cultural internationalism, and [being] part of American private initiatives to export benevolence and to spread American dreams overseas" (2009:256).

593. Fan 2009:251.

594. Fan 2009:255-256. 
been sent on a mission to Asia by the Smithsonian Institution, but the First World War had interrupted his plans for further work on behalf of the Smithsonian. When he was later recruited to the Fogg Museum, they saw an opportunity to benefit from the unfinished work he had done for the Smithsonian, and sent him off on another mission along the Silk Road to China, in 1922-1924. On this mission Warner and his team removed, by means of strong glue and cheesecloth, more than twenty Tang period (AD 618-907) murals from the cave walls at Dunghuang. The removed murals were shipped back to Harvard and the Fogg Museum along with other artworks and heritage objects acquired along the way. When he was later criticized for the strong-glue removal (and subsequent damage) of parts of the cave sites, Warner defended his actions and referred to them as selfless, heroic acts by which he purchased the murals from the local community to secure and protect them from destruction by Russian soldiers. ${ }^{595}$ But it is difficult to ignore the fact that large art institutions in Europe were already pursuing a rather ruthless race to acquire original artefacts from Dunghuang, and the Fogg Museum was keen not to lag behind..$^{596}$ So Warner's 1925 mission had the double purpose of finding suitable collaboration partners for the new Institute for Asian Humanities at Harvard and enriching the Fogg Museum's collections of desirable pieces of art from China, particularly from Dunghuang. For this purpose, the Hall estate trustees allocated US \$30,000 for Warner's expedition.

When Olov Janse contacted Serge Elisséeff some thirteen years later, the Harvard-Yenching Institute had officially been running for ten years, and Elisséeff had been its Director (and Professor of Far Eastern Languages at Harvard University) for four years. ${ }^{597}$ At the Institute, Janse's proposal attracted special interest in the Board of Trustees. Later on in their correspondence, Elisséeff writes that "[s]ome of the Trustees are intensely interested in the problems of the relations between China and India", ${ }^{98}$ and this personal interest appears to have been instructive for their decision to sponsor Janse's work.

In terms of the official goals of the Harvard-Yenching Institute, Janse's proposed work in Indochina did not comply in any way with the aim of

595. Meyer \& Blair Brysac 2015: chapter 4.

596. Fan 2009: 264-265.

597. Reischauer 1957.

598. Letter from S. Elisséeff to O. Janse, 18 November 1939. Harvard-Yenching Institute, Cambridge, Mass. Correspondence, 1938-1940. 
promoting Western-style humanities education in Asia, and only contributed to some extent to the furthering of humanist knowledge about Asian cultures in the United States. Although the funding allocated for Janse's expeditions also included time for writing and publication of the research results under the auspices of the Harvard-Yenching Institute, it appears that there never were any concrete plans to offer Janse a permanent position at Harvard in order to secure the intellectual investment they had made in him as an expert in Asian humanities. Rather, the trustees of the Harvard-Yenching Institute and Serge Elisséeff expressed a remarkably strong interest in the future ownership of the excavated collections. Much like the French museums and official institutions backing the first two expeditions, the Harvard-Yenching Institute was in fact - and in contrast to their official aims - more interested in the material property than the intellectual property that would come out of Janse's expedition. This interest may in part be due to Elisséeff's links to and experiences from French museums from his time in Paris ${ }^{599}$ but it was also likely due to the Institute's historical connection with Langdon Warner's expeditions, and the kind of "art collecting" they represented.

Olov Janse was well aware of the "booty" being one of his main assets to acquire funding, and shrewdly presented his planned expedition as an opportunity for the Institute to gain possession of original artefacts. Hence the artefacts, through his ability to ascribe ownership over them, became means to pursue his own professional goals. His own goals were in this case to complete the excavations in Indochina, write up and publish the results, and most importantly, to find himself a secure professional platform for the future.

So to acquire funding, Janse entered negotiations with George Cœè̀s at the EFEO about the ownership and future location of their expected finds. Codès, whose resources were strictly limited by the crisis in France, was equally willing to allow the tentatively excavated artefacts to become part of an economy that also involved the United States, and welcomed the idea of a US-funded expedition. Janse wrote to Elisséeff on 1 April that Cœè̀s has told him that "he would be very pleased to see the establishment of a French-American collaboration", and that Janse himself "is sure that the division of the products of the excavations will

599. Serge Elisséeff worked as a research assistant at the Guimet Museum (the French national museum of Asian art in Paris) after he had arrived as a refugee from Russia in 1921 (Reischauer 1957:21). 
present no difficulty", because the EFEO "has no desire to store these things indefinitely". ${ }^{600}$

But Elisséeff, who was not content with Janse's reassurance, wrote to Cœedès to make sure that his institute would have formal ownership over the excavated collections. In his response, Cœedès writes that Janse is always welcome in Indochina and at the EFEO, of which Janse is a corresponding member, to continue a research collaboration with the EFEO with means provided by the Harvard-Yenching Institute. When it comes to sharing the finds (Fre: partage des fouilles) Codès writes:

[...] I am sort of the master of the situation, with a permanent delegation from the Governor General. Even though I must in certain sensitive cases ask for Government authorization to make a donation or transfer to a foreign museum, I have never met the least opposition. ${ }^{601}$

Coedès suggests a partage ${ }^{602}$ of the finds according to the model applied in Johan Gunnar Andersson's excavations in Tonkin (which he also funded by his own means, and carried out in direct collaboration with the EFEO, Cœdès adds), where Andersson's museum in Stockholm were given "the best duplicate collection", while the EFEO reserved for their own museum any unique pieces that they missed in their collections. Cœè̀s explains further that "our museum [Musée Louis Finot, now the National History Museum in Hanoi] is the only museum in the world with a considerable quantity of objects from Dongson and the Han in

600. Letter from O. Janse to S. Elisséeff, 1 April 1938. Harvard-Yenching Institute, Cambridge, Mass. Correspondence, 1938-1940.

601. Letter from G. Cœdès to S. Elisséeff, 20 July 1938. Harvard-Yenching Institute, Cambridge, Mass. Correspondence, 1938-1940. In the French original: "[...] je suis un peu le maître de la situation, ayant une delegation permanente du Gouverneur Général. Lorsque, dans certains cas partiqulièrement délicate, j'ai au à solliciter l'autorisation du Gouvernement pour un don ou pour une cession à un Musée étranger, je n'ai jamais rencontre la moindre opposition."

602. James Cuno has recently brought new light to the concept of partage, as a policy under which "foreign-led excavation teams provided the expertise and material means to lead excavations, and in return were allowed to share the finds with the local government's archaeological museum(s)." Cuno proceeds to argue for a restoration of the partage concept as an alternative to nationalist claims, and writes: "That is how the collections of archaeological museums at the University of Chicago, the University of Pennsylvania, and Harvard and Yale Universities were built [...]" (Cuno 2011:14). 
Indochina", and that he would be happy to provide the Harvard-Yenching Institute with a collection of excavated materials from Janse's expedition, as long as it did not cause any lacunae in their own artefact series. ${ }^{603}$ This solution was not quite to Elisséeff's satisfaction and was, as we will see a little further on, later revised to the benefit of the Harvard-Yenching Institute. But the first agreement was settled according to Cœè̀s's wishes to reserve the unique pieces for the Louis Finot Museum in Hanoi.

In the same letter to Elisséeff, Coedès also suggests that the Harvard-Yenching Institute should provide funding to pay for Paul Lévy (1909-1998), a young ethnologist and prehistorian at EFEO, to assist Janse with the stratigraphic and prehistoric work. Janse, Cœè̀s says, is by taste and to some extent by necessity, mostly interested in the objects he can retrieve from the excavations. Coedès believes that is why he has so far focused on the brick tombs, which, if they were not disturbed, have delivered a large quantity of objects in a restricted space, which has been rather easy to establish:

If, as I hope and believe, Janse's future campaigns will focus on the Dong Son cemetery, where he has so far only done quick sondage, he will face a more difficult situation. The burials are found directly in the ground, without trace of constructions, the objects are often much deteriorated, so when excavated they are more instructive by their disposition and their stratigraphy than their form or material. Therefore, I would be very pleased if it could be arranged so that Janse could be assisted by Paul Lévy. ${ }^{604}$

603. Letter from G. Cœdès to S. Elisséeff, 20 July 1938. Harvard-Yenching Institute, Cambridge, Mass. Correspondence, 1938-1940. In the French original: "Notre musée étant le seul au monde à posséder en quantité considerable du dongsonien et du Han d'Indochine."

604. Ibid. In the French original: "Le Dr. Jansé, par goût, et aussi un peu par nécessité, recherche surtout des objets: c'est pourquoi il s'est surtout attaqué jusqu'ici aux caveaux de briques qui, lorsqu'ils n'ont pas été violés, livrent une quantité d'objets dans un espace restreint dont le relevé coté est facile à établir. Si, comme je le suppose et l'espère, les futures campagnes de fouilles du Dr. Jansé l'amènent à s'occuper de la nécropole de Dôngso'n, où il n'a fait auparavant que de rapides sondages, il se trouvera en face de problèmes infiniment plus délicats. Les sépultures sont en plein sol, sans traces de constructions, et les objets, toujours plus instructifs par leur disposition, et leur stratigraphie que par leur forme ou leur matière. Sur ce point, j'aimerais qu'il fût convenu que le Dr. Jansé aura l'assistance de M. Paul Lévy." 
Codès's suggestion is both peculiar and interesting. This is the only time we have come across the idea that Janse was not using proper scientific methods in his excavations. On the contrary, he is, as we have mentioned, elsewhere referred to as the archaeologist who brought proper methods to the investigation of Dong Son. ${ }^{605}$ And with his training and many years of field practice in the methodologically oriented Scandinavian archaeology, it should be safe to say that he did not lack skills or competence to perform the kind of excavation procedure (with stratigraphic method, on sites lacking clear built structures) that Cœedès refers to. True, we have seen how his excavations became more and more rushed, in order to provide his funding agencies in Paris with the revenue they expected in terms of valuable objects for their museum collections, and we have seen how he was present at the excavation site mostly in time for the valuable objects to be excavated and removed. But this appears to have been owing more to pressure than lack of competence in excavation methodology. So in this respect George Cœdès's suggestion is peculiar.

The following correspondence between Janse and Elisséeff may offer some further clues. In a letter to Elisséeff on 6 October, Janse writes that he has known Paul Lévy for a long time, and likes him a lot. They have already worked together before, and he would be very happy to have him as a collaborator. However, he adds with emphasis, only if it does not affect the budget of the mission. ${ }^{606}$ Four days later, Elisséeff responds:

\section{[...] I think that we can arrange for the collaboration of Paul Lévi [sic]. Since he is an official attaché of the school, I do not see any reason even to think of paying him anything, because, as I wrote in my letter to you, he will taking advantage of the excavation only for his personal research work. He is not going there at our request. ${ }^{607}$}

After this, we see no more mention of Paul Lévy anywhere in the correspondence concerning Janse's third expedition, and he appears not to have been included on the excavation team. Hence we believe this can be read as an attempt on Cœè̀s's part to acquire funding for one of

605. Groslier 1966:160.

606. Letter from O. Janse to S. Elisséeff, 6 October 1938. Harvard-Yenching Institute, Cambridge, Mass. Correspondence, 1938-1940.

607. Letter from S. Elisséeff to O. Janse, 10 October 1938. Harvard-Yenching Institute, Cambridge, Mass. Correspondence, 1938-1940. 
his younger colleagues, ${ }^{608}$ in times of great financial difficulty. When the funding-fishing attempt failed, Coedès and the EFEO were no longer so keen to let Paul Lévy join the excavation team.

The correspondence surrounding the second and third of Janse's expeditions is indeed characterized by frequent reference to funding, and a very tight attitude to the same by all parties involved. Overall there is very little serious discussion of scientific quality or intellectual benefits, unless it had the potential to contribute to more funding and larger collections. It was the opportunity to fund one's own projects, and the value of the excavated collections that was at the centre of attention.

The irony was that despite their explicit desire to acquire and own the "booty" after Janse's expeditions, the Harvard-Yenching Institute had no previous experience of dealing with archaeological collections, nor had they any premises suitable for housing collections of excavated materials. The archaeological expeditions pursued by Langdon Warner and his team had been directed at objects of fine art, which fitted the profile of the Fogg Museum. Most of Janse's excavated materials were of a quite different character, with masses of unspectacular potsherds and artefacts that were valued by their age, authenticity and places in typological series, rather than masterful artistry. The Fogg Museum would neither have the capacity nor interest to house such collections. Janse therefore initiated a dialogue with the Peabody Museum, which housed anthropological collections on the premises next to the Institute, to see if they would support excavations of the prehistoric sites Samrong Sen, Lung-prao, and Cau-Giat. ${ }^{609}$ Lauriston Ward, Curator of Asiatic Archaeology, although interested and sympathetic towards the idea, explained that the museum was unable to back it:

The trouble is, of course, the money. I have talked this matter over with Mr. Scott and he informs me that at present the Museum has no money whatever for any new expedition - indeed it is having a hard time raising the funds to carry through the commitments already made. ${ }^{610}$

608. Paul Lévy was in 1938 Curator for Prehistory and Ethnology at the Musée Louis Finot, became a permanent member of EFEO in 1939, and later succeeded George Cœè̀s as Director of the EFEO 1947-1950. We will meet him again in the chapter "Darling, Dearest".

609. Letter from O. Janse to L. Ward, 20 June 1938. Peabody Museum.

610. Letter from L. Ward to O. Janse, 9 July 1938. Peabody Museum. 
So for the time being, it was the Harvard-Yenching Institute alone that contributed the funding for the expedition, and the storage of the collections would be a problem to solve in the future. ${ }^{611}$ Most of the plans for Janse's third expedition were made by mail sent between Elisséeff at Harvard, and Janse in Buffalo. Olov and Ronny visited Harvard in early May, when Olov gave two lectures at the Fogg Museum, hosted by the Harvard-Yenching Institute. On 2 May he talked about his "Latest Discoveries of Ancient Han and Sung Monuments", and on 3 May about "The Mysterious Culture of Dong-son". The lectures were followed by dinners at the Faculty club with members from Elisséeff's department. On the following day Olov had lunch with Elisséeff and the trustees of the Institute, to "talk about the possibilities of the archaeological excavations in Indo-China", while Ronny was invited to a separate lunch with Vera Elisséeff. ${ }^{612}$

Apart from the visit to Harvard, and later in May to Philadelphia to attend an American Museum Conference, ${ }^{613}$ where they also on the way back visited Washington, DC, for the first time and thought it was "a wonderful city", ${ }^{114}$ they spent most of the spring, summer, and autumn of 1938 in Buffalo, NY. Olov worked at the Buffalo Science Museum, ${ }^{615}$ while they also kept an eye on the happenings in Stockholm. In a series of letters to Birger and Barbro Nerman, ${ }^{616}$ and one to Ture and Nora Nerman, ${ }^{617}$ Olov and Ronny goes from being agitated and antagonistic,

611. After the completion of the third expedition, the excavated collections ended up in the stores of the Peabody Museum, where they remain today, as a loan from the Harvard-Yenching Institute, which still has formal ownership of it.

612. Letter from Serge Elisséeff to Olov Janse, 25 April 1938. Harvard-Yenching Institute, Cambridge, Mass. Correspondence, 1938-1940.

613. Mentioned in letter from Olov Janse to Birger Nerman, 16 May 1938. Riksarkivet. Kartong 3. Korrespondens Brev III 1935-1941.

614. Letter from O. Janse to B. Nerman, 3 June 1938. Riksarkivet. Kartong 3. Korrespondens Brev III 1935-1941.

615. Notice in Buffalo Evening News, 30 March 1938: "Museum adds aid"; Article in Buffalo Courier Express, 4 November 1938: "Fabled Lands of Cambodia Described by Museum Aide; Dr. Olav Janse gives thrilling talk on Indo-China at first travel lecture."

616. Letters from O. Janse to B. Nerman, 21 March, 31 March, 16 May, 3 June, 21 June, 18 October and 19 November 1938. Riksarkivet. Kartong 3. Korrespondens Brev III 1935-1941; Letter from Ronny Janse to Barbro Nerman, 23 March 1938. Riksarkivet. Kartong 3. Korrespondens Brev III 1935-1941.

617. From O. Janse to T. Nerman, n.d. Arbetarrörelsens arkiv och bibliotek. Ture Nerman 3.1.7. 
to despairing and resigned. In a letter from 21 March, Olov writes to Birger Nerman arguing that Vitterhetsakademien had acted in a way that is incompatible with the judiciary principles of a democratic society, for example in the external review process (which ranked Karlgren number one and did not even include Janse on the list), and the silencing of all critique and opposition by demonstratively invoking H.R.H. (i.e. the Crown Prince). In a letter to Barbro Nerman a couple of days later, Ronny writes that they must absolutely put up a fight against the beasts who sit in nice secure positions and make life impossible for others, and that it is a shame that the "most European civilized" are pushed back. Ronny continues with a sense of bitter wit, in a comment on Karlgren's claim that there was no room in the museum's budget to offer Janse a position:

They say that there are no funds to maintain the scientific work, but there is clearly enough for people like An[dersson], who spent an enormous sum of Swedish State money on journeys in China and found nothing, except a nice girl, who will probably be brought to Sweden since she travels with him everywhere, - but she is not yet an antiquity. ${ }^{618}$

The nice girl referred to is probably Miss Dorf, Johan Gunnar Andersson's young secretary and companion on his journey to Indochina. Regardless of what the relation between Dorf and Andersson was in reality, it is interesting to see how Olov and Ronny have so quickly turned so drastically in their views on Johan Gunnar Andersson (who less than two years earlier was officially referred to as Janse's teacher and friend) and the sly games for position and prestige involving the Crown Prince (which they recently appeared more than happy to be involved in) from the days in 1936 when they considered themselves to be part of the inner circle around Andersson, to now when they had been omitted from that privileged circle.

Only a week later, at the end of March, the tone has changed, from antagonistic to resigned. Here in a letter from Olov to Birger Nerman:

618. Letter from R. Janse to B. Nerman, 23 March 1938. Riksarkivet. Kartong 3. Korrespondens Brev III 1935-1941. In the Swedish original: "De säger, att de har inte pengar att uppehålla vetenskapsarbetet, men det finns tillräckligt nog för sådana som An., som utkastade en enorm summa av svenska statens pengar på resor i Kina och ingenting hittade, utom en trevlig flicka, som skall förmodligen tas över till Sverige, då hon reser med honom överallt, - men hon är inte än en antikvitet." 
It was a pity that the article on M.F.E.A. was distorted by Soc[ial] $\mathrm{D}$ [emokraten]. The main parts had been removed. It is perhaps best not to let me appear in the press for the time being. I think we have to regard the game as lost. There is no point bothering Lindhagen and best not to involve H.R.H. Would you please ask Ture and Lunkan to make sure that my letters and missives do not end up in other hands, since they could easily be abused.

In my last letter to Ture I forgot to answer the question regarding the possible purchase of land on Blidö. As long as I have no position in Sweden, it would be precarious to acquire land there. ${ }^{619}$

From here on, they appear to have accepted the situation, and were slowly letting go of the idea of returning to Sweden. ${ }^{620}$ Janse wrote in June to Birger Nerman about an upcoming visit to Stockholm by Chauncey Hamlin, the Director of the Buffalo Science Museum and his wife, asking Nerman to make a programme for them with visits to the most important historical museums and archives. ${ }^{621}$ Meanwhile he wrote in positive terms about his whereabouts in the United States. On 14 July they had been invited to a large function at the French counsellor's residence, and Janse was "compelled" to give the oration. ${ }^{622}$ When Birger Nerman (who was appointed Director of the History Museum in Stockholm in October 1938, after a feud over a professorship at Lund University) and his other Swedish friends tried to find possible positions for Janse as curator, or temporary lecturer in Stockholm, his responses were lukewarm with a

619. Letter from O. Janse to B. Nerman, 31 March 1938. Riksarkivet. Kartong 3. Korrespondens Brev III 1935-1941. In the Swedish original: "Det var synd att artikeln om Ö.S. blev förvanskad av Soc. D. Det viktigaste partierna hade strukits. Det är kanske bäst att tills vidare icke låta mig synas i pressen. Jag tror vi få anse spelet förlorat. Det är ingen idé att besvära Lindhagen och lämpligast att ej blanda in H.K.H. Vill Du vara vänlig bedja Ture och Lunkan blott se till att mina brev och skrivelser ej kommer i andra händer då de lätt skulle kunna missbrukas. // Glömde att i mitt senaste brev till Ture besvara frågan angående ev. jordköp på Blidö. Så länge jag ej har någon befattning i Sverige är det vanskligt att förvärva jord där."

620. But see a letter to Birger Nerman, 5 March 1939, which indicates some lingering hope. Riksarkivet. Kartong 3. Korrespondens Brev III 1935-1941.

621. Letter from O. Janse to B. Nerman, 3 June 1938. Riksarkivet. Kartong 3. Korrespondens Brev III 1935-1941.

622. Letter from O. Janse to B. Nerman, 21 July 1938. Riksarkivet. Kartong 3. Korrespondens Brev III 1935-1941. 
touch of bitterness. There was no point in returning to Sweden, he wrote in one letter, for someone who to such a degree was "persona ingratissi$m a$ " there. Instead he suggested that Nerman should come to the United States to see the "modern American museums" and lecture about Nordic archaeology: "Lecturers are well paid here, 75 to 100 dollars for a lecture is not too bad." ${ }^{23}$

While warming more and more to the idea of a new life in the United States, they continued their work in Buffalo and planned for the upcoming expedition. The departure was postponed from mid October to late November in order to secure enough funding, ${ }^{624}$ and Serge and Vera Elisséeff travelled to Buffalo to discuss the final details of the plans and their mutual agreement. On 24 October Janse sent Elisséeff a letter in English (he had previously written in French, while Elisséeff wrote in English) with the outlines of an official agreement. Added in pencil in the upper right-hand corner of the letter is "Contract with Dr Janse":

\section{Dear Professor Elisséeff,}

The archaeological expedition which will be conducted by me in Indo-China under the auspices of the Harvard-Yenching Institute and the Ecole Française d'Extrême-Orient shall be called the Harvard-Yenching Institute Indo-Chinese Archaeological Expedition.

A bank account to finance the expedition shall be opened in the Banque de l'Indo-Chine in Hanoi in the name of the Harvard-Yenching Institute Indo-Chinese Archaeological Expedition and all checks drawn against it will be signed by me.

The place or places where excavation shall be made will be fixed by me, as the Director of the Expedition, after consultation with the Director of the École Française d'Extrême-Orient. All the objects which are found will belong to the Harvard-Yenching Institute, with the exception of the rare pieces of which there is no specimen in the Ecole Française d'Extrême-Orient, according to the letter of July 20, 1938 of Professor George Codès.

It is understood that all the scientific data and materials and

623. Letter from O. Janse to B. Nerman, 18 October 1938. Riksarkivet. Kartong 3. Korrespondens Brev III 1935-1941.

624. Letter from O. Janse to S. Elisséeff, 10 October 1938. Harvard-Yenching Institute, Cambridge, Mass. Correspondence, 1938-1940. 
informations will be the property of the Harvard-Yenching Institute for publication purposes and will be prepared by me.

Sincerely yours,

Olov Janse

On 19 November, they wrote Elisséeff from Buffalo to say "god-by" [sic]. The next day they left Buffalo for San Francisco, and on 24 November 1938 they embarked on the MS Asama Maru bound for Kobe. 


\section{REFOCUS: INDOCHINA AND THE PHILIPPINES \\ NOVEMBER 1938-AUGUST 1940}

After a sixteen-day journey in first class on the exclusive Japanese ocean liner Asama Maru, Olov and Ronny arrived in Kobe. After a one-week stopover in Japan, where they travelled to Yokohama and Tokyo to meet the Swedish envoyé Widar Bagge and visit museums, they returned to Kobe, embarked on the SS Maréchal Joffre on 17 December and arrived in Saigon ten days later. Unlike their other journeys across the ocean, this passage has left no trace in their archives or publications.

They stayed in Saigon a couple of weeks before they continued to Hanoi, where they arrived on 13 January 1939. Immediately upon arrival, Olov wrote a letter to Elisséeff expressing some concerns. While he was very pleased to report that he had met with Cœè̀s, who had given "his entire approval of the plans", and was soon leaving for the Thanh Hoa province to resume work at the Tam-thô kilns, he was worried about the finances:

As I very soon will have to face difficult expenses for the excavations I should be very thankful, if you kindly would send me as soon as possible $[\ldots]$ the funds, which are to be devoted for the excavations of this season.

In a short time, I will send you a longer letter and give you more detailed informations concerning our work. ${ }^{625}$

625. Letter from O. Janse to S. Elisséeff, 13 January 1939. Harvard-Yenching Institute, Cambridge, Mass. Correspondence, 1938-1940. 
A couple of weeks later, Elisséeff responded:

I am looking forward to receiving the long letter you mentioned you were to send me; and I should also like a precise report on your plans for the coming archaeological season to present to the Trustees of the Institute at their meeting on April 10, 1939.626

This is the beginning of an intense correspondence between Janse and Elisséeff where, typically, Janse reports briefly on his doings and asks for transfers of the funding he had been promised, and Elisséeff questions Janse's spending and demands more detailed reports of the work done. On 9 February, Janse wrote:

Dear Professor Elisséeff,

Since more than two weeks, we are now working in the province of Thanh-hoa (Northern Annam), where we already have found interesting things.

The first time, I had to pay visits to the local authorities at the different places, where we have planned to carry out our excavations. As I know many of these authorities, since several years, and always have been in good terms with them, I obtained early their full consentement [sic] to excavate the monuments of which I have spoken to you.

To begin with I decided to continue the explorations of the "Han-kilns at Tam-thô" (ref the Ill. London News, issue of the $12^{\text {th }}$ Nov. 1938). As you know, they are the only kilns of the Han-period, which have ever been methodologically excavated. We have found great many rare specimens. If you desire, I can send you already by mail a collection of samples. There are numerous "doubles", which I think could be used for exchange with different museums.

Furthermore, we have started excavations of Han-tombs, situated in the circonscriptions (phu) of Dong-sôn and Tho-xuân. There are especially two interesting regions, indicated as no XII and XIII on the hereby enclosed map [not kept in the archive, our remark].

626. Letter from S. Elisséeff to O. Janse, 31 January 1939 Harvard-Yenching Institute, Cambridge, Mass. Correspondence, 1938-1940. 
All excavations in these regions have been reserved by the French School for us. I have started the work here near the village of Man-thôn (see map), where there is a large mound containing no less than three important funeral tile-constructions (Han). I have never before observed three such constructions beneath the same mound. We have just cleared (dégagé), designed [sic] and measured one of the constructions. Of course we have still to remove a quantity of earth before we can discover the funeral deposits.

We have a third "chantier" in the town of Tanh-hoa [sic], where there are too some very large Han-tombs.

Soon I am going to undertake some preliminary investigations of a locality situated about 10 miles from Thanh-hoa (ville) and where I expect to find kilns from the Song-time, containing specimens of the so-called Thanh-hoa ware.

As the season for excavations is very good now, I would like to enlarge our activities as much as possible and hope soon to receive the funds I need, as I exposed [sic] in my last letter.

I am very busy from early in the morning unto [ sic] the sunset, by the organization and the supervision of our works in the fields, but I hope rather soon to able [sic] to send you more detailed reports. ${ }^{627}$

Janse is clearly trying to please Elisséeff, and abide by his wishes to be informed in detail about their work. But he is not used to such a level of control, and before long he begins to feel mistrusted and diminished. Elisséeff, for his part, is clearly not content with Janse's behaviour, and seems burdened by his responsibility vis-à-vis the Institute's trustees. On 13 March he responds:

In your letter $[\ldots]$ you promised sending some samples of the objects which you have found. I should very much like to have some of them to show our Trustees at their November meeting. I shall also be very glad to have some photographs of the objects

627. Letter from O. Janse to S. Elisséeff, 9 February 1939. Harvard-Yenching Institute, Cambridge, Mass. Correspondence, 1938-1940. 
which you consider are the most important and which it will be possible to send here. ${ }^{628}$

For both Janse and Elisséeff, the expedition was a matter of resources and prestige. For Janse, the number one priority at this point was to have enough financial resources to pursue his work efficiently and in style, so he could make a triumphant homecoming bringing scientific results and collections that would give him prestige and contribute to a safe position in the United States. From what we can read from his letters, Janse seems to have had as a mental template his first successful expedition, when his French patrons and funding institutions trusted him with a big lump of money, he was left alone to make decisions on travelling and work methods, pursued his expedition more or less without metropolitan control, and upon his return rewarded his investors with extraordinary collections and exciting scientific results. For Elisséeff, this was the first major expedition he had backed as Director of the Harvard-Yenching Institute, and he was keen to make it a success. To that end he seems to have been anxious not to be accused of overspending, and was interested in concrete measures of success that could easily be presented to the trustees, such as the value of acquired collections.

In Thanh Hoa Janse and his team wasted no time. For unclear reasons Nguyen Xuan Dong had now left the team as EFEO representative, and a Mr Yen had taken his place as official secretary and draughtsman. ${ }^{62}$ Over the past two expeditions, Janse had worked closely with Nguyen Xuan Dong, and seems not to have established the same connection with Yen. But Janse maintained the connection with his work team, led by the foreman Soang from Dong Son, whom he had met through Louis Pajot already at the beginning of the first season. When he wrote in his report that Soang was still on the team in the third expedition, Janse referred to him as "my loyal and skillful cai", ${ }_{30}$ which is short Vietnamese for foreman. This, in combination with Soang's willingness to be employed as foreman for a third time, signals a strong and trustful relationship

628. Letter from S. Elisséeff to O. Janse, 13 March 1939 Harvard-Yenching Institute, Cambridge, Mass. Correspondence, 1938-1940.

629. We have not been able to find the full name of Mr Yen. We believe, however, that he is seen to the far left in the photograph of Janse 1941: plate 1; Janse 1947: plate 114. Nguyen Xuan Dong worked later (in 1958) as curator at the Cham Museum in Nhatrang. NAA: Janse 2001-29.

630. Janse 1951:217. 
between them. With Mr Yen as secretary and an experienced excavation team led by Soang, they resumed their work at the Tam-thô kilns in the end of January, and almost immediately extended the excavations to a number of Han tomb sites; some in the district of Dong Son, ${ }^{631}$ one at the Marché aux bestiaux in Thanh Hoa Town, ${ }^{632}$ and three more near the village of Man-thôn in the Tho-xuân district. They also did some supplementary investigations at the Dong Son settlement site. ${ }^{63}$ As in the previous expedition they worked on several sites simultaneously. And while his team shifted earth to uncover the brick tombs, Janse was constantly on the move searching for more sites to excavate.

\section{Man-thôn}

At Man-thôn, located 25 kilometres northwest of Thanh Hoa Town, farmers had encountered a brick construction when planting banana trees on a small mound in their rice field. They reported the find to the local authorities, and when the news reached George Codès at EFEO, he reserved the site for Janse to excavate. Janse and his team arrived at Man-thôn on 28 January 1939, and three days later they had done the necessary negotiations and ceremonies with the local community and could start the work. ${ }^{634}$

Already in his letter to Elisséeff from 9 February, Janse mentioned that they had located and started to excavate a mound covering three brick tombs. But the villagers were not quite at ease with the excavation, and despite negotiations, payments to the landowner, and food offerings to the local shrine, they continued to put pressure on Janse's team to stop the work. "Our work here", writes Janse in his report, "was constantly accompanied by the doleful sound of the temple drums." ${ }_{35}$ But he per-

631. It is unclear exactly where in the Dong Son district he excavated this time. Reference to this work is found only in a letter to Serge Elisséeff, 9 February 1939. Harvard-Yenching Institute, Cambridge, Mass. Correspondence, 1938-1940. On the map in fig. 128 (Janse 1951:216) there are 9 tombs marked in the Dong Son district, some 5-10 kilometres west of Thanh Hoa Town, which could represent the location of the excavations in January-February 1939.

632. The site at the Marché aux bestiaux is referred to as "Tomb of Phú-Co'c" in the report, Janse 1947: plate 67; Janse 1951:154.

633. Janse 1941:8-9; Janse 1958:14.

634. Janse 1951:215.

635. Janse 1951:217. 
sisted, employed nightwatchmen, and urged his team to continue with the excavations. It was not long before he had to stop working because he was "gravely stricken by an attack of malaria". ${ }^{636}$ One can only guess what the reluctant villagers thought of that coincidence (spiritual vengeance for the disturbance caused by the dig ought to have been what they feared the most), but Janse let Soang and Yen carry on with the work as usual while he remained in bed for a couple of days recovering. The patience and effort he invested in his relations with local communities during his first expedition (remember Long, the dragon at Hoà-chung), ${ }^{67}$ had now given way to a more restless hunt for untouched sites offering precious objects for retrieval.

The mound at Man-thôn (fig. 54) was unusual in that it contained three brick tombs (normally one mound covered one or two tombs). ${ }^{638} \mathrm{In}$ a letter to Elisséeff written on 17 February, Janse writes enthusiastically that the first tomb is "utmost interesting":

$[\mathrm{T}]$ he funerary deposit is quite untouched and all the objects we have discovered until now are obviously in the same position in which they were placed about two thousand years ago. As you know, the untouched Han-tombs are utmost rare and this find is in many respects quite unic [sic]. Every day we have hundreds of visitors, following our work with much interest. ${ }^{639}$

Janse's reports contain beautiful drawings and photographs of the three tombs (Man-thôn $1 \mathrm{~A}-\mathrm{C}$ ) in the process of excavation, ${ }^{640}$ along with detailed descriptions and photographs of the finds. ${ }^{641}$ The largest of the

636. Janse 1951:217.

637. Janse 1959: chapter 17 .

638. Janse 1947: plate 169.

639. Letter from O. Janse to S. Elisséeff, 17 February 1939. Harvard-Yenching Institute, Cambridge, Mass. Correspondence, 1938-1940.

640. Janse 1947: plate 114-116; plate 168-169.

641. Janse 1947: plate 117-123; Janse 1951:215-230. 
three vaults was six metres long and over two metres in height. Based on the rather exceptional objects they found inside, which consisted of ceramic and bronze bowls, weapons and tools of bronze and iron, a bronze mirror, a sledge-shaped sword scabbard with jade appliqué, beads, coins, and more, Janse described the grave as belonging to "a military mandarin". ${ }^{642}$ In the two smaller tombs, $1 \mathrm{~B}$ which was adjacent to $1 \mathrm{~A}$ and partly disturbed, and ${ }_{1} \mathrm{C}$ which was located some ten metres from the other two and had been opened before their arrival by Louis Pajot, the finds consisted apart from the usual ceramics and bronze vessels - mostly of coins, beads, and jewellery. A find of split jade rings in Tomb $1 \mathrm{C}$ was somewhat remarkable, since such rings were mostly found in the "Indonesian" tombs of Dong Son, and only very rarely in the brick tombs. ${ }^{643}$ In a later letter to Elisséeff Janse writes that he believes at least one of these tombs was "erected over the remnants of a woman". ${ }^{64}$ But apart from these remarks, Janse makes no further analysis or interpretation of the tombs at Man-thôn. In his letter to Elisséeff he concludes:

The objects we have found are almost all in good state and some of the bronzes have a smooth, green patina. When we have finished this tomb, I intend to excavate other-ones in the neighbourhood and hope that we there too may find interesting things. ${ }^{64}$

Elisséeff responded, in a letter of 13 March:

I was very much pleased to learn from your letter of February $17^{\text {th }}$ about the Mandarin tomb, and I am waiting with great interest for the photograph of the tomb sword about which you wrote. I hope that it is not an object which will not be permitted to leave Indo-China. ${ }^{646}$

642. Janse 1951:219. See also Letter from O. Janse to S. Elisséeff, 17 February 1939. Harvard-Yenching Institute, Cambridge, Mass. Correspondence, 1938-1940.

643. Janse 1951:228.

644. Letter from O. Janse to S. Elisséeff, 3 March 1939. Harvard-Yenching Institute, Cambridge, Mass. Correspondence, 1938-1940.

645. Letter from O. Janse to S. Elisséeff, 17 February 1939. Harvard-Yenching Institute, Cambridge, Mass. Correspondence, 1938-1940.

646. Letter from S. Elisséeff to O. Janse, 13 March 1939. Harvard-Yenching Institute, Cambridge, Mass. Correspondence, 1938-1940. 
Having finished the excavations of the three tombs in Man-thôn, Janse and his team located several more tombs nearby, and excavated one of them. In his report he mentions several more mounds, for instance two near the village of Dan-nê that were referred to as "the eyes of the dragon", and were so strongly protected by local taboo that he had to give up on excavating them. ${ }^{647}$

\section{Bim Son}

At the end of March, when they had finished the work in Man-thôn, in Thanh Hoa Town and at the Tam-thô kiln sites ${ }^{648}$ they moved the main excavation team north to the district of Hà-Trung near the border to Tonkin, and the site Bim Son. Janse had excavated two brick tombs ( $1 \mathrm{~A}$ and $1 \mathrm{~B}$ ) at Bim Son in the second expedition (in the presence of Governor General Jules Brévié, in April 1937), and had reported on the rich and unique finds in an article in Illustrated London Newss. ${ }^{649}$ Now he brought his team back to excavate fourteen more tombs, and apart from a drawing that was left unpublished (fig. 55) the findings were described in great detail in the reports. 650

But despite all the apparent success with his excavations, Olov Janse was a troubled man. Not only were he and the members of his team struck by malaria, which haunted the area around Bim Son. ${ }^{651}$ The Sino-Japanese War came closer to Indochina, with the Japanese invasion of Hainan on 9 February. And the heat was building up with the annual monsoon rains just around the corner. On 3 April he ended his usual report to Elisséeff: "As you see we are still working hard. I am now rather tired." ${ }^{652}$

647. There are at least four more sites marked within the area of Man-thôn on the map in Janse 1951:216, and they are likely the ones mentioned in the report as Vuc-Trung and Dan-nê (Janse 1951:229-230).

648. Janse 1947:60-62, plates 138-160; Janse 1951:231-246. It is not quite clear in which of the two expeditions (II and III) the different kiln sites were excavated, but in his preliminary report Janse indicates that they worked on all kiln sites over the course of the second and third expeditions (Janse 1941:254).

649. Janse 1937.

650. Janse 1947: plate 92-113; 1951:187-215.

651. Janse 1951:188; Letter from O. Janse to S. Elisséeff, 27 March 1939. Harvard-Yenching Institute, Cambridge, Mass. Correspondence, 1938-1940.

652. Letter from O. Janse to Elisséeff, 4 March 1939. Harvard-Yenching Institute, Cambridge, Mass. Correspondence, 1938-1940. 


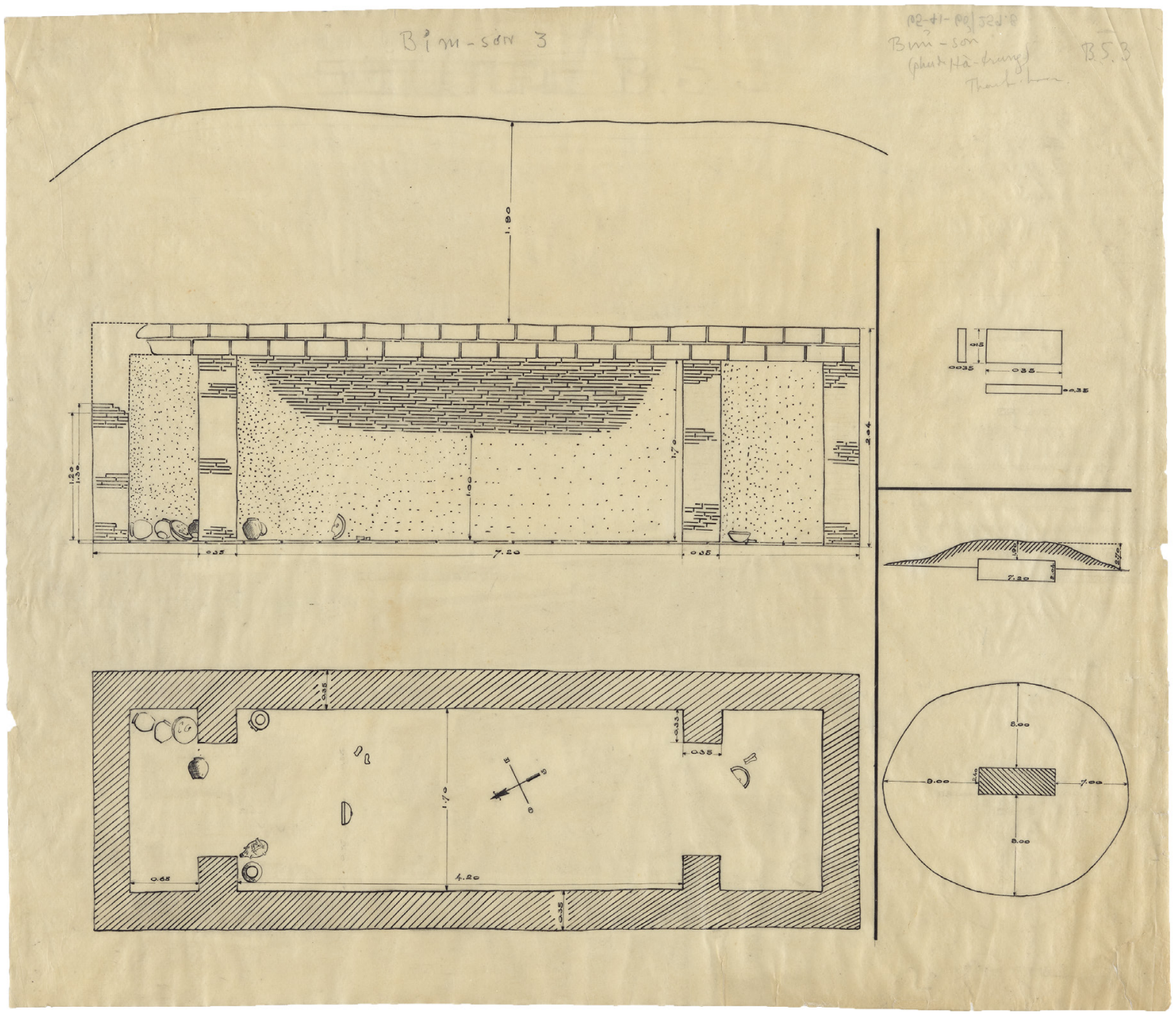

Fig. 55. Cross-section and plan drawing of Bim Son 3, excavated in March 1939.

Fig. 56. Ronny excavating Tomb 7 at Bim Son. In Olov Janse's hand with pencil on the back: "Mme Janse dégageant trois plateau (br.) superposés. Photo O Janse, Mars 1939". 
3.

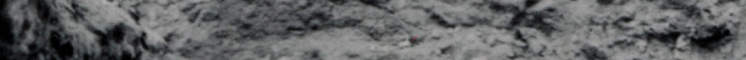

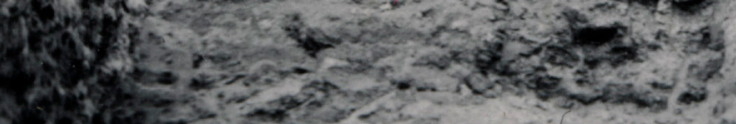

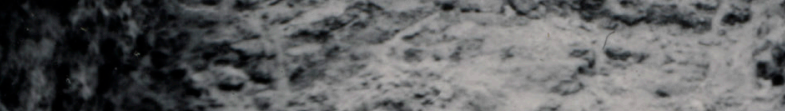

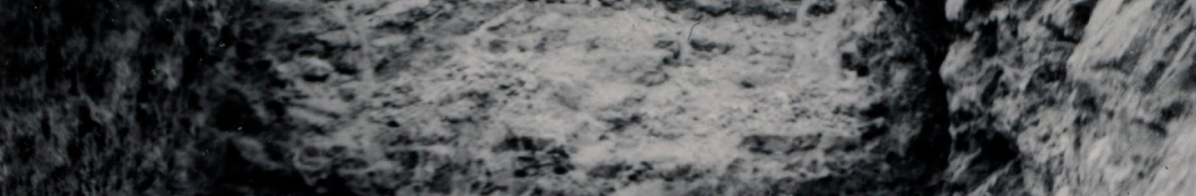

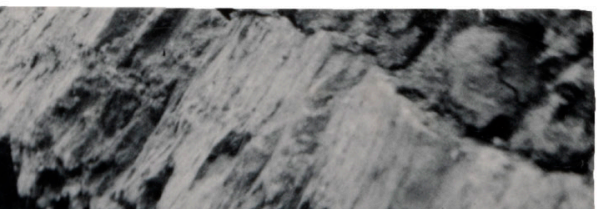
10
$(x)$

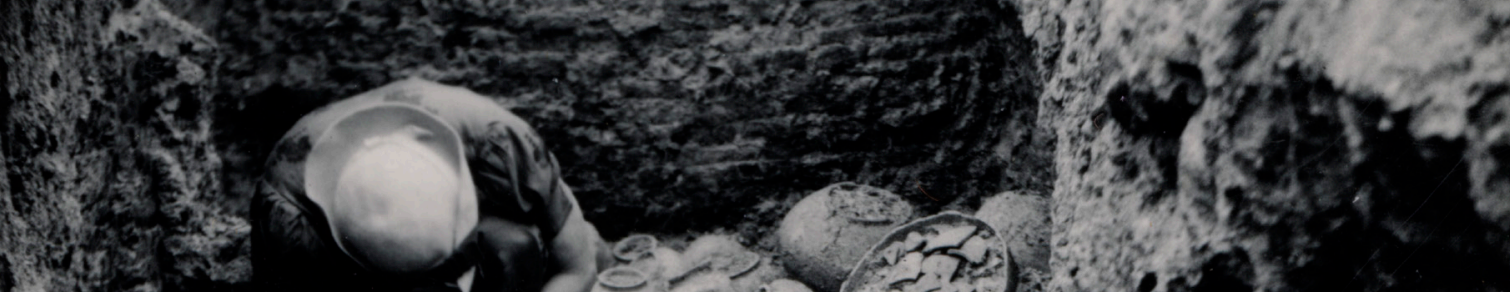

with

(4)

$x+3$

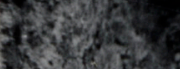

Sis

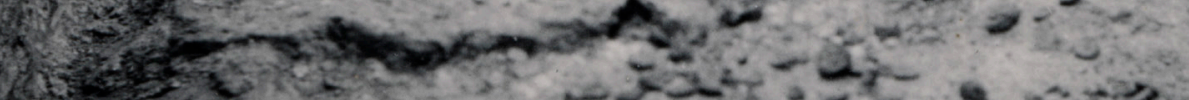

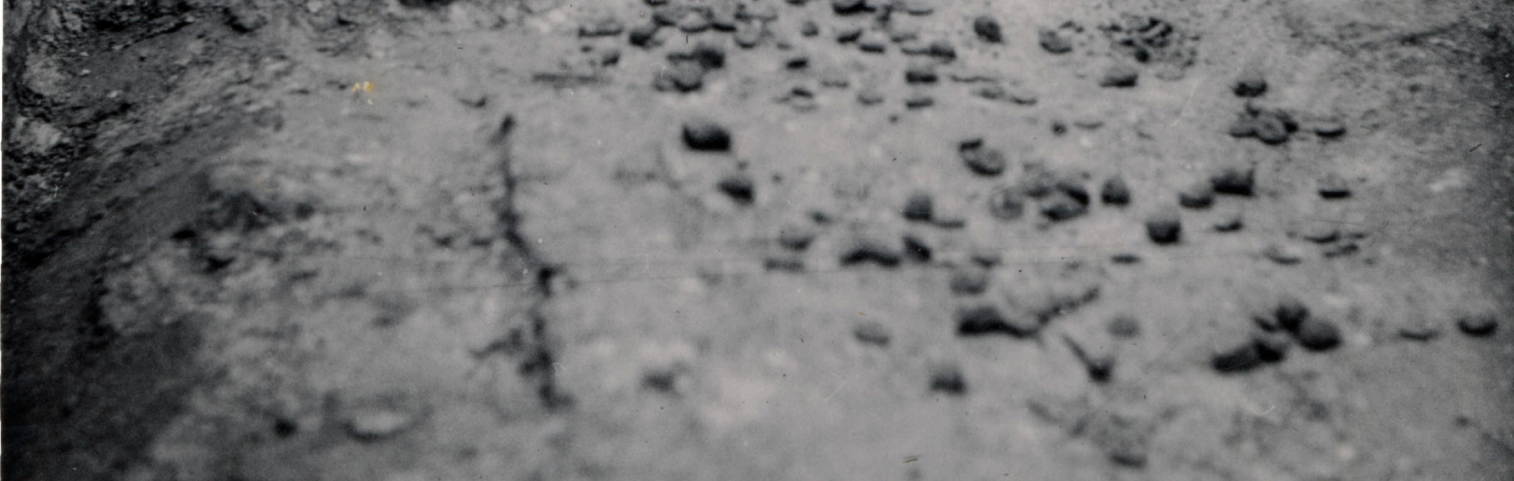


In parallel with the excavations, Janse was also writing lengthy reports on his doings and findings back to Elisséeff, and was asked to account for the funds he had spent. In a letter dated 22 February, he wrote:

It is now about four months since I left U.S. for Indo-China and you may understand that during this time I have had considerable expenses for traveling, fieldwork, salaries etc. As you ask me I give you here a short approximate account as to their expenditure:

Traveling Buffalo-Hanoi for me and my wife (who is acting as secretary and attaché as on earlier expeditions) 1200 \$

An automobile Peugeot $300 \$$

Cameras and films $200 \$$

Different expenses (gasoline, medicine for the coolies, implements etc) $50 \$$

Salaries for my collaborators $150 \$$

Salary for O Janse $(400 \$$ a month from 15 of Nov -15 of March $1600 \$$

Total: $3500 \$$

As you already have seen from my last letter, we have found many interesting things and I am sure that this expedition will be of the same success as the earlier ones. [...] P.S: Excuse me not to have type-written this letter but I send you these lines from a place where there is no type-writer. ${ }^{653}$

A conflict then builds up in their correspondence over the following months. Elisséeff questions, with reference to the Institute trustees, Janse's "excessive travel expenses", and wants to have listed the names of his "collaborators". ${ }^{654}$ The main reason for controversy, however, was the bank account. They had initially agreed that an account should be opened at Banque de l'Indochine in the name of the expedition, and all funding should be transferred to that account. But Janse went ahead and opened an account in his own name instead. For the Harvard-Yenching Institute it was a matter of principle that the account should be registered in the

653. Letter from O. Janse to S. Elisséeff, 17 February 1939. Harvard-Yenching Institute, Cambridge, Mass. Correspondence, 1938-1940.

654. Letter from S. Elisséeff to O. Janse, 13 March 1939. Harvard-Yenching Institute, Cambridge, Mass. Correspondence, 1938-1940. 
name of the expedition and not in Janse's own name. But for Janse, who was better acquainted with the administrative system in Indochina, and whose only interest was to have access to the necessary funds to proceed with his work, as swiftly as possible, this caused a lot of trouble. In a letter dated 3 April, he responds to a series of sour-toned letters from Elisséeff concerning the account:

As I mentioned already it is almost impossible to get the Expedition legally registered here. Such a decree i.g. have to be signed by the President of the Republic! When I asked the Bank to establish an account in the name of our Expedition I thought it was a mere formality. But even if the Expedition had been registered legally I could not have touched the money, as I have no legal certificate, stating that I am legally appointed Director of the Expedition and allowed to dispose the money of the account. ${ }^{655}$

The explanation appears to have had effect, and from this point on the funds were transferred directly in Janse's own name. And for the time being, the controversy over his spending had calmed down.

While the team was still at work at Bim Son, Janse himself was on the move, scouring the Thanh Hoa province for more sites to excavate. In a letter to Elisséeff on 26 April, he writes that he has visited "an important Indonesian dwelling-place from the Han time" at the Cau-công site in the Vinh-lôc district, ${ }^{656}$ and made some preliminary investigations of a site from the Song period (960-1279 AD) at Van-trai in the district of Tinh-gia, $4 \circ$ kilometres south of Thanh Hoa, where he located three tombs from the Song period and one from Tang (618-907 AD). ${ }^{67}$ In the letter he writes that he found and brought with him some ceramics of very good quality, among which was a jar with a floral design, of a kind he had not seen in any American museum. ${ }^{65}$ Like the excursions he undertook in the previous expeditions to kitchen-midden sites from earlier periods, the excavations at Van-trai are difficult to fit into the official

655.Letter from O. Janse to S. Elisséeff, 3 April 1939. Harvard-Yenching Institute, Cambridge, Mass. Correspondence, 1938-1940.

656. Janse 1958:88; Letter from O. Janse to S. Elisséeff, 26 April 1939. Harvard-Yenching Institute, Cambridge, Mass. Correspondence, 1938-1940.

657. Janse 1941:4; Janse 1951:231-233.

658.Letter from O. Janse to S. Elisséeff, 26 April 1939. Harvard-Yenching Institute, Cambridge, Mass. Correspondence, 1938-1940. 
overall aim of his research, which was focused on the Han period (206 $\mathrm{BC}-220 \mathrm{AD})$. They can rather be seen as attempts to please his patrons and mentors, by showing that he had listened to their advice, and as in this case, by bringing rare and beautiful ceramics home to the collections of the funding institute.

In early May the rains hit Thanh Hoa, and Olov and Ronny returned to Hanoi with Yen. They immediately set about cleaning and restoring their finds at the Musée Louis Finot under the supervision of the museum's technical advisor René Mercier (who can be seen to the upper left in the group photo of the EFEO in fig. 30). Yen was busy completing the excavation drawings, to accompany the objects when they were transported to the United States. Janse writes excitedly to Elisséeff: "work is humming!" ${ }_{59}$ A letter written a little later in the summer demonstrates that the future exhibitions were already on his mind. Somewhat surprisingly, he was keen to emphasize the scientific value of the findings:

I would appreciate very much if the exhibit organized by Harvard-Yenching could get a more scientific caracter [sic] and that the finds could be displayed together with graphic documents as plans photographs etc., showing the methods of our excavations, tomb constructions, objects in situ, etc. ${ }^{660}$

And he spared no effort to extend the collections. While rainstorms made it difficult to pursue the work in Thanh Hoa, and Mercier continued to work on the cleaning of the finds and Yen on the drawings at the museum, Olov and Ronny left Hanoi in late May for the southern coast of Annam. Janse wrote later in a letter to Elisséeff that they had an incident with the car some 500 miles from Thanh Hoa, which forced them to stay ten days in a seaside location (they presumably made the stop, whether because of car trouble or just a need for a short vacation by the sea, which seems just as likely). ${ }^{661}$ After the ten days by the sea they continued to Sa Huynh, which Janse describes in his memoirs as "a beautifully located village

659. Letter from O. Janse to S. Elisséeff, 11 May 1939. Harvard-Yenching Institute, Cambridge, Mass. Correspondence, 1938-1940.

660. Letter from O. Janse to S. Elisséeff, 23 July 1939. Harvard-Yenching Institute, Cambridge, Mass. Correspondence, 1938-1940.

661. Letter from O. Janse to S. Elisséeff, 30 June 1939. Harvard-Yenching Institute, Cambridge, Mass. Correspondence, 1938-1940. 
some $250 \mathrm{~km}$ north of Nha-trang". ${ }^{662}$ Among the sand dunes along the coast near the Sa Huynh, there were three sites (Sa Huynh, Phu-khuong, and Trang-long, which are often lumped together and known as "the Sa Huynh pottery complex") with interesting archaeological finds that were well known and previously excavated by French residents and members of the EFEO. ${ }^{663}$ Janse wanted to try his luck there as well, and met with the local French and native authorities in Sa Huynh to get their permission to excavate. On the way they had received a message from George Coedès about finds similar to those at Sa Huynh at the coastal site of Chau-rê near Phan-rang, 340 kilometres further south. ${ }^{664}$ And since the weather did not allow them to start the excavations at Sa Huynh straight away, they proceeded south to survey at Chau-rê. But before they reached Chau-rê they were compelled to stop and make a detour to Dalat, in the cooler mountains west of Phan-rang. In a letter some weeks later, Janse writes to Elisséeff:

Just before we came to Phan-rang I had several accesses of high fever and felt very tired, overworked as I was. (Since our arrival to Thanh Hoa I have been working all days even Sundays and holydays [sic], often under very rough conditions). On the advise [sic] of a doctor, we went from Phan-rang to the high mountains in the Langbian plateau near Phan-rang in order to change the climate, which is much more healthier here than on the plain. I am now rapidly recovering and hope to be able to send you soon - according to your wish - a short report for your review. ${ }^{665}$

Dalat was a town built by the colonial administration in the early 1900 s, to serve as a mountain sanatorium for the French settlers and functionaries. ${ }^{666}$ The climate on the mountainous Lang Bian plateau was more similar to Europe than the plains and coastal areas of Indochina, and the idea was to save the costs of repatriation for medical reasons by creating a healthy environment for rest and recreation. Hotels and European-style villas were constructed around a lake and a golf course, and there were

662. Janse 1959:180.

663. Solheim 1959.

664. Letter from O. Janse to S. Elisséeff, 30 June 1939.

665 . Ibid.

666. Jennings 2011:14. 
ample opportunities for riding and other sports activities. There were schools and a market where the local mountain tribes gathered, and a new railway station opened in 1938, only a year before Olov and Ronny Janse arrived. Interestingly, the creation of Dalat in the early twentieth century both concurred with and reinforced a French colonial discourse where Indochina was associated with various threats, illness and death, as opposed to the health and longevity represented by the European culture and climate. The historian Eric Jennings writes that the campaigns preceding Dalat's establishment "adroitly channeled a web of fears - of the climate, of mysterious fevers and emaciating digestive disorders, and even of indigenous peoples themselves - to justify a seemingly utopian project: the creation ex nihilo of a European health center, or even a French city, high atop the "uncharted' mountains of Annam". ${ }^{667}$ When Olov and Ronny Janse decided, following the doctor's recommendation, to spend the summer months in Dalat, they acted within this colonial discourse of fear, of the threats and negative impacts that Indochina had on their health. It is not difficult to see how the French image of Dalat as something essentially different from the rest of Indochina was part of the same colonial discourse as Janse's archaeological-cum-ethnographic narratives, maintaining a polarized absolute distance between the modern French and the archaic native cultures (particularly the moï - literally "savage"which was a common designation for the mountain tribes). To be in Indochina was, according to the logic of this discourse, to spend time in primitive prehistory, and this was considered detrimental to the modern European body. Hence Dalat was portrayed as a paradise in the midst of an inferno: a modern haven where everything from the air and temperature, to the schools, villas, and sports activities were "European". ${ }^{668}$

As expected, Olov felt the effect of the cool and healthy mountain air almost immediately on arrival in Dalat, and wrote to Elisséeff that he was rapidly recovering. When he eventually left to proceed with the excavations at Chau-rê, Ronny stayed in Dalat awaiting his return. In a newspaper interview a couple of years later, she said that along with Paris, Dalat was her favourite place on earth: "[it] is the coolest, freshest, and most beautiful spot she has ever seen". ${ }^{669}$

667. Jennings 2011:20.

668. Jennings 2011.

669. Article in Boston Traveler, 25 January 1941: (Natalie Gordon), "Our Gracious Ladies". 

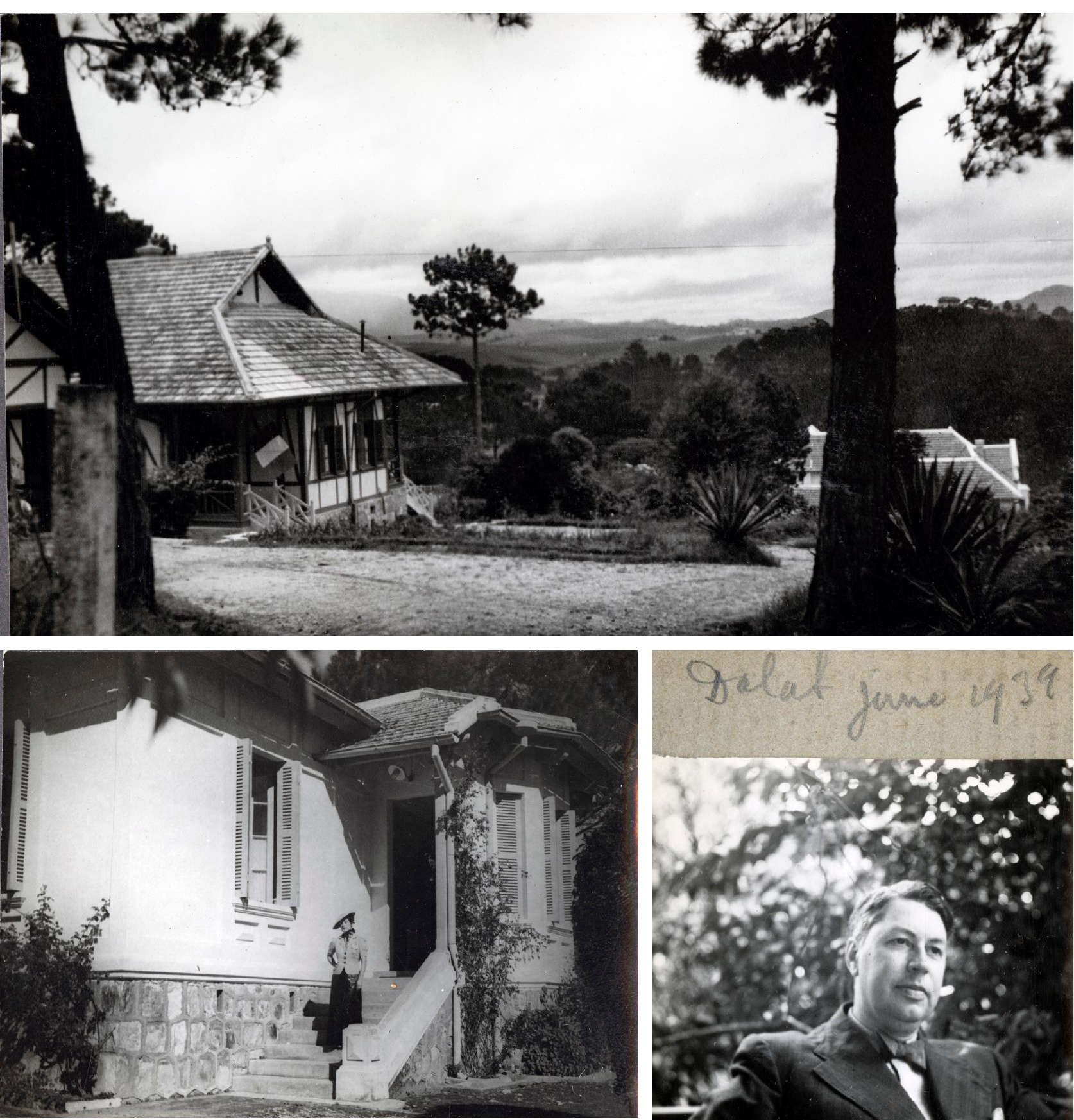

Fig. 57. Dalat villa, in a photo in Janse's archive.

Fig. 58. Ronny at "Villa Sabine" in Dalat.

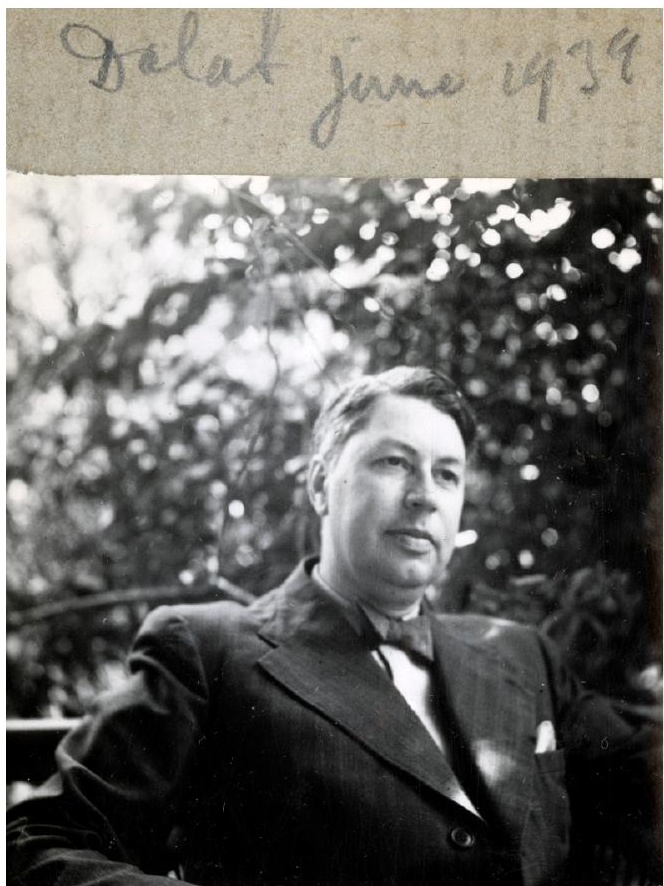

Fig. 59. Olov Janse in Dalat, June 1939. 


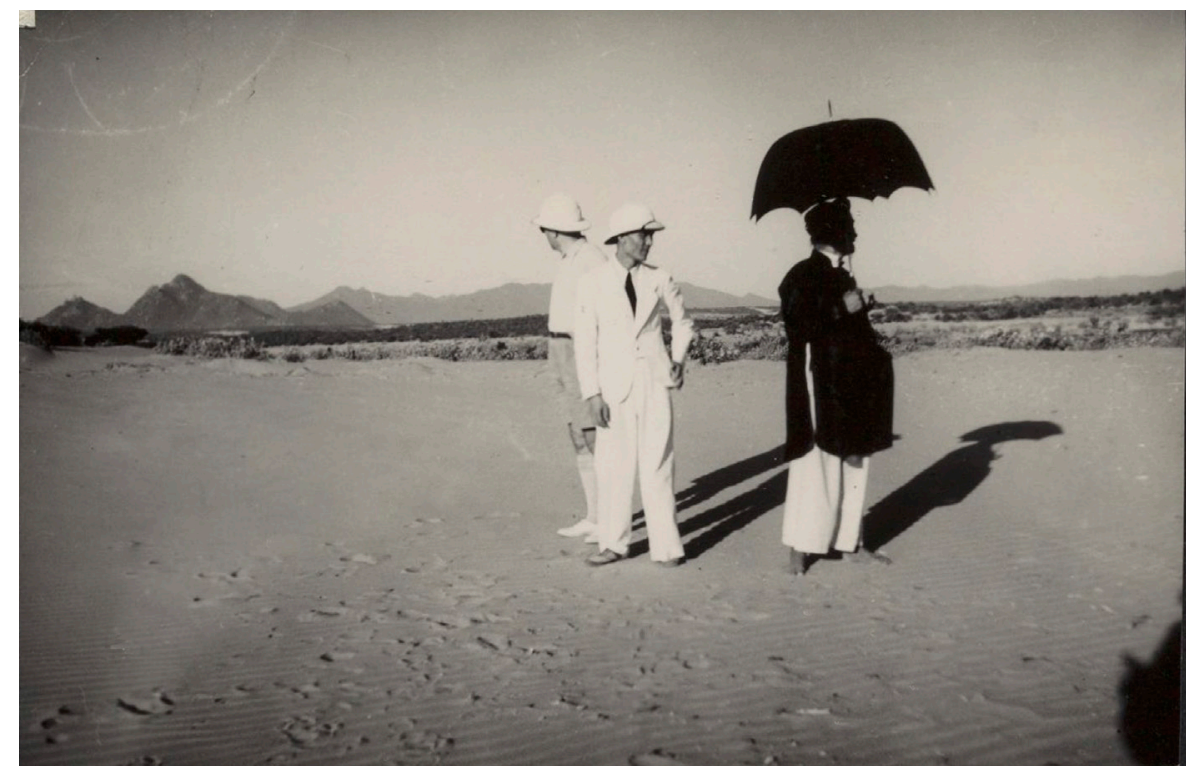

Fig. 60. Photo in the Harvard-Yenching Archives. Written in pencil on the back: "Our first visite [sic] to Châu R'ê near Phan-rang (Annam). From left to right: le Résident de France à Phan-rang, my interpreter, a native chief. Photo O. Janse august 1939."

After nearly two months on the cool mountain plateau, Olov left Dalat in early August. He travelled the short distance down to the coast and arrived at the site of Chau-rê near Phan-rang on 9 August. ${ }^{60}$ In his memoirs he writes about it under the heading "THE CHAU-RÉ INFERNO", and in a letter to Elisséeff he writes:

Never in my life, I have suffered so much from the heat as at Châu R'ê. It is one of the hottest places here in Indo-China. There is no shadow and the [sunlight] "réverbération" is terrible. It is possible to work on the plain only early in the morning and in the afternoon. At the middle of the day there is about $55^{\circ} \mathrm{C} ! !^{671}$

670. A chapter of Janse's memoirs has been devoted to Sa Huynh and Chau-rê (Janse 1959:180-186), but the descriptions there concerning the work procedure do not quite match the detailed information in letters to Elisséeff, and the history of Sa Huynh presented in Solheim 1959.

671. Letter from O. Janse to S. Elisséeff, 14 August 1939. Harvard-Yenching Institute, Cambridge, Mass. Correspondence, 1938-1940. 
The site where fragments of Chinese ceramics had been found was located on a sand plain six kilometres from the nearest town, Phan-rang. Janse was accompanied by the French Resident of Phan-rang, an official representing the local Annamite community, and an interpreter (see fig. 60). There is no extensive report on their work at Chau-rê, but it is mentioned briefly in a couple of publications, ${ }^{672}$ and in letters to Elisséeff. ${ }^{673}$ It appears to have been a very quick operation, just a few days, and they could work only in the earliest hours of the morning and in the evening because of the scorching sun. On the ground they encountered fragments of ceramics and human bone. They opened several trenches in different parts of the plain, where finds had been reported by the local community. In the trenches (two by one metres, and one and a half metres deep), they found ceramics and potsherds of Tang ( 7 th-10th century AD), Song (10th-13 th century AD), Ming (14th-17th century AD), and local Cham ware, along with an iron arrowhead and a shouldered stone axe with a zigzag-shaped edge. ${ }^{67}$ In some places they encountered hard blackish soil, which Janse thought were the floors of huts or simple houses. The local community told stories of an ancient temple at the site, but Janse thought that it had rather been a port for trading of Chinese ceramics, established in the Tang period and destroyed by war or natural disaster around AD 1500. ${ }^{675} \mathrm{He}$ himself could simply not bear the heat on the sand plain. In his memoirs he concludes:

It was as if the sand was on fire under my feet, and my face was almost burning. I had now had enough of heat and sunlight, and signalled for breakup. Lighthearted, I returned to Phan-rang and proceeded, as soon as I could, to the cool pine forests of Dalat, the wonderfully beautiful, modern summer resort in the mountains, where $\left[\right.$ Ronny] had retreated during my expeditions $[\ldots] .{ }^{676}$

672.EFEO 1939:332-333; Janse 1941:255-256, plates $19(2,3)$ and 21 (1); Janse 1959:183-186.

673. Letters from O. Janse to S. Elisséeff, 14 August and 17 October 1939. Harvard-Yenching Institute, Cambridge, Mass. Correspondence, 1938-1940.

674.Janse 1941: plate 19(3).

675.EFEO 1939:332-333; Janse 1941:255-256; Janse 1959:183-186.

676. Janse 1959:186. In the Swedish original: "Sanden började liksom glöda under skosulorna och det nästan sved i ansiktet. Jag hade nu fått nog av värme och solljus och gav tecken till uppbrott. Med lätt hjärta återvände jag till Phan-rang och begav mig sedan, så 
Having spent another couple of weeks in Dalat, they returned together to Hanoi in early September to monitor the cleaning, documentation, and packing of the finds. Already in July, while they were still in Dalat, Janse had discussed the partage of the finds with George Cœdès. Cœdès was now willing to let all the finds be transported to the United States "in order to show the American public the results of our work", and Janse suggested to Elisséeff that they should aim for an agreement to have the unique pieces returned to Hanoi and the EFEO after two years. He writes further:

It is my aim to procure for your institute a typical collection as complete as possible of antiquities (Han-Sung), illustrating the old southern Chinese culture, which as you know is not yet represented in the American Museums. ${ }^{67}$

On 6 September Janse wrote to Elisséeff from Hanoi: "If I can finish the packing this month, I expect to start the new excavations in Thanh Hoa already in october [sic]." ${ }_{678}$ Judging from this letter, Olov and Ronny Janse sat comfortably in Hanoi where they supervised the work at the museum and waited for better weather to proceed with their work in Thanh Hoa. The letters to Elisséeff also give the impression that they were planning even further ahead, with excavations of sites related to the Dong Son settlement site at Cau-công in Tonkin, and near Luang Prabang in Laos. ${ }^{679}$

Now, there is a letter in Birger Nerman's archive in Stockholm, which offers a radically different view of the situation. Dated 17 September 1939 (thus coinciding with the Soviet Red Army's invasion of East Poland) the letter, which is written in French (probably to avoid being caught by censor on the way), says that they plan to leave Indochina soon to go to the United States, and from there if possible travel to Sweden. The plan was to stop for some time in Hawaii, and Olov asks Birger to repay him

fort sig göra lät, till de svala tallskogarna i Dalat, den underbart vackra, moderna sommarstaden bland bergen, dit [Ronny] hade dragit sig tillbaka under mina expeditioner [...]".

677. Letter from O. Janse to S. Elisséeff, 23 July 1939. Harvard-Yenching Institute, Cambridge, Mass. Correspondence, 1938-1940.

678. Letter from O. Janse to S. Elisséeff, 6 September 1939. Harvard-Yenching Institute, Cambridge, Mass. Correspondence, 1938-1940.

679. E.g. letters 3 March, 23 July, 27 September 1939. Harvard-Yenching Institute, Cambridge, Mass. Correspondence, 1938-1940. 
a previous loan by making a transfer of 150 Swedish crowns to a bank in Honolulu. ${ }^{680}$ The letter ends "À la hâte !" - in haste - and reeks of stress and anxiety. It is likely that Germany's invasion of Poland on 1 September, which officially marks the beginning of the Second World War in Europe, was affecting them. And a letter sent several months later to Elisséeff explains the situation in Indochina more candidly:

As you remember, we had planned to excavate this winter principally some Han tombs in Tonkin (near the border of Kwangsi), a dwellingsite at Can Công in the Thanh Hoa. However it was not possible for me to excavate this places [sic] by following reasons.

The borderregion of Tonkin is a military zone for the time being and exposed to air-raids. Befor [sic] I left Indo-China not less than about 100 Indo-Chinese peoples had already been killed or injured by Japanese airraids due to "mistakes". Furthermore the railway region has been already several times attacked from the air and there are many civilians killed and injured. War state, and consequently force majeure. [...]

1. For every voyage from one place to another and for a stay of 24 hours there had to be granted a visa by the local authorities (The very coast is considered a military zone).

2. Restrictions of gasoline and order to civilians to avoid traveling as much as possible.

3. At a moment money could not be transferred from one place to another and finally when permission for transfer was given, the max amount which could be drawn from a bank by one person was only 500 p. monthly (about 120 US Dollars)

4. Telephonic and telegraphic communication were allowed only after special permission.

5. All foreigners who had stayed in Indo-China 6 months or more were to be considered as résidents and submitted to certain regulations.

6. A decree was suddenly issued restricting permits to take photographs and it was also prohibited to export graphic documents as prints, plans, etc, notes, manuscripts. Concerning this

680. Letter from O. Janse to B. Nerman, 17 September 1939. The accuracy of the date is confirmed by a later letter mentioning the first one, dated 2 December 1939. Riksarkivet. Kartong 3. Korrespondens Brev III 1935-1941. 
matter, may I mention that e.g. when I made a request to the Gov. Gen. to be granted permission to take with me our prints, plans, notes etc, I did not even receive an answer. It was only after personal "demarches" and thanks to my diplomatic passport that finally I was granted the permission requested.

There were also other circumstances due to the state of war (which I not can mention without indiscretion), which made it practically impossible for me to carry out successfully the investigations I had planned. [...]

The conditions during a state of war changes everything from one day to another and you can not forsee [sic] what is going to happen. $[\ldots]^{681}$

Although the Japanese forces did not officially invade Indochina until the end of September 1940, it is clear that the Second Sino-Japanese War (where the Republic of China supported by Germany, the United States, and the Soviet Union, fought with the Japanese Empire from 1937 to 1945, and which after the attack on Pearl Harbor in 1941 merged into the Second World War), had serious effects on the lands and people of Indochina already in the autumn of 1939 - so much so, that Olov and Ronny Janse made secret plans for an escape and return to the United States already in September 1939, while at the same time keeping a façade of tranquillity and control in the letters to Elisséeff and the Harvard-Yenching Institute. Nowhere in the published records of the third expedition (the reports, memoirs, or newspaper articles) are the effects of the war on their work and lives mentioned as a major factor in their decision to eventually leave Indochina. Instead there are frequent references to their health (malaria, liver conditions and fevers), and to natural disasters (tropical storms and typhoons which caused serious flooding of the sites they intended to excavate).

However, they did not leave Indochina yet for a while. When storms and flooding (and possibly obstacles owing to the war) prevented them from taking up work at the sites in Thanh Hoa and further north, Olov and Ronny left Hanoi in late September - never to return again - and travelled south along the coast to Sa Huynh, where he had arranged all the necessary permits on his last visit, but had not yet started to excavate.

681. Letter from O. Janse to S. Elisséeff, 12 February 1940. Harvard-Yenching Institute, Cambridge, Mass. Correspondence, 1938-1940. 
In his memoirs, Janse writes that the archaeological site at Sa Huynh had been discovered in the 1920s, and had previously been excavated by Henri Parmentier ${ }^{682}$ - Parmentier whom he had met at the visit to Angkor on his first expedition, and who had been quite sceptical to his excavation plans. But the history of Sa Huynh was in fact much more complex. The site, which is located among sand dunes by the coast in central Annam, was found and reported to the EFEO in 1909 by a French official posted in the area. Fourteen years later, the site, where the French official had found large jars containing beads and pottery, was discussed at a meeting at the EFEO, and Monsieur Labarre, a French customs officer at Sa Huynh, was asked to investigate what its current state was. His wife, Madame Labarre, took a vivid interest in the site and began to excavate there with the help of a French physician posted nearby, all under the auspices of the EFEO in Hanoi. Having finished her excavations, and having identified the site at Phu-khuong five kilometres from Sa Huynh through her own surveys, Mme Labarre sent her notes along with the finds to the EFEO in Hanoi, where Henri Parmentier compiled the information in an article that he published in his own name in the Bulletin of the EFEO $1924 .{ }^{683}$ After that, the sites at Sa Huynh were again left without further archaeological investigation for ten years. Meanwhile the local communities took an interest in them, not least because of the many stray finds of beads, which were reportedly sold to Chinese merchants. In 1934, EFEO once again renewed the interest in Sa Huynh and George Coedès sent Madeleine Colani, a skilled and respected prehistorian, to do further excavations. In her brief account of the excavations published in the Cahiers of the EFEO, Colani describes the location of the Sa Huynh site in a passage which qualifies as one of the most poetic and beautiful descriptions of an archaeological site ever written (readers literate in French are advised to read the footnote):

At Sa-huynh in the province of Quang Ngai, the sand dunes reach up to 19 meters in height. The site is situated between a bay and the sea. To the south, there is a small mountain. To the west, the tranquil water of the bay, backdropped by the dark Annamite mountain range. To the east the luminous sea, sometimes pretty, glittering; sometimes tragically dark, upset, menacing. Under our

682. Janse 1959:180.

683. Parmentier 1924; Solheim 1959. 
Fig. 61. The

Sa Huynh

site, with the

locations of finds

of potsherds

and a stone

axe marked by

arrows in pencil.

Photo by Olov

Janse 1939.

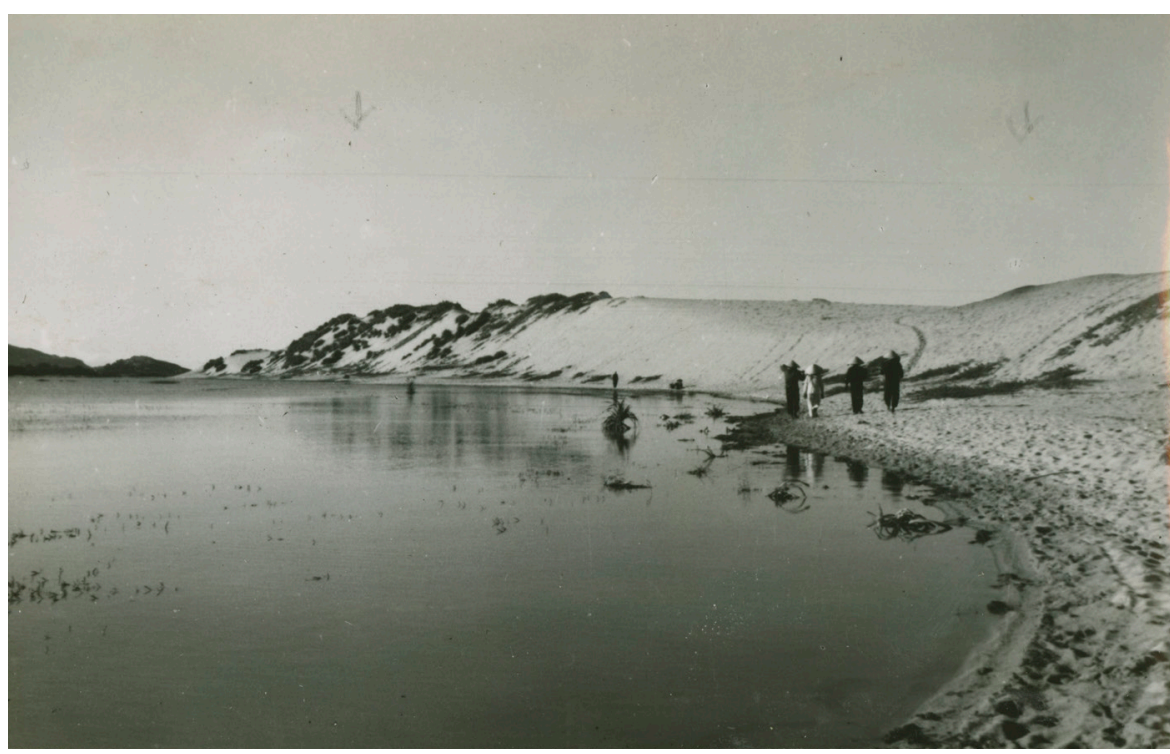

feet the sand, consisting largely of quartz grains, sparkles by the soft caress of the sun rays. ${ }^{68}$

Knowing the art of amplifying his own contributions, Janse leads the readers of his memoirs and articles to believe that he did the most important excavations of the Sa Huynh site. ${ }^{685}$ But that is far from the truth. Madame Labarre excavated 120 jars in the 1920 s and Madeleine Colani 55 jars in 1934, at the Sa Huynh site alone. In addition to that, Madeleine Colani excavated 187 jars at the Phu-khuong site, and some at Tranglong. These extensive excavations can be compared to the 30 or so jars that Janse excavated at Sa Huynh in $1939 .{ }^{686}$ A full report from Janse's excavations was supposed to be published in a fourth report volume of Archaeological Research in Indo-China, which was never completed. ${ }^{687}$ In

684. Madeleine Colani 1937, quoted in Solheim 1959:100. In the French original: "Dans la province de Quáng-ngãi, à Sa-huỳnh, la bordure de dunes atteint jusqu'à 19 metres de hauteur. Elle est située entre une baie et la mer. Au Sud, une petit massif rocheux, côte 93. A l'ouest, en bas l'eau tranquille du golfe; au fond, la sombre chaîne annamitique. A l'est la mer lumineuse, tantôt jolie, scintillante, tantôt foncée tragique, courroucée, menaçante. Sous nos pieds, le sable, composé en majeure partie de grains de quartz, brille sous la douce caresse des rayons du soleil."

685. Janse 1941:256-257; Janse 1959:180-183; Janse 1959b.

686. Solheim 1959:100-101.

687. Solheim 1959:100. 
a couple of shorter texts ${ }^{688}$ he describes the essence of his findings and presents photographs of the objects in situ during the excavation. ${ }^{68}$ Janse and his team, consisting of local fishermen, excavated six groups of jars, each containing between three and seven jars. The tall earthenware jars, measuring up to 130 centimetres in height, contained traces of bone along with smaller pots and bowls, bronze bells, iron tools, and various kinds of beads. The bases of the large jars had been perforated - like flower pots and some had flat-based red-slipped earthenware vases - resembling hats - placed on top as lids. Janse thought that the large jars, which were found together in linear groups, had been burial jars from the same period as the Han brick tombs, which had been deposited together in boats placed perpendicular to the shoreline. ${ }^{690}$

All Janse's finds from Sa Huynh were transported to Saigon and Musée Blanchard de la Brosse to be cleaned and repacked for shipment to the United States. In a letter to Elisséeff dated 7 October, he writes that they had already gathered ten cases of finds from Sa Huynh. He writes also that he is very tired because of the heat and humidity, and that he recently suffered another attack of malaria, which he had not quite recovered from. He complains that the funding he has received is not enough to cover an extended period of fieldwork, and says that he has no objection to return earlier to the United States with the fine collections they had gathered, and that, "as a matter of fact, I am very anxious to start the publishing of all the materials we have accumulated". ${ }^{691}$ Still there is no mention of the pressure of war, or the fact that they were planning to leave Indochina in the very near future.

A couple of days later they departed from Sa Huynh and travelled south along the coast, via Chau-rê where Janse took the opportunity to gather some more ceramics, to Saigon and Musée Blanchard de la Brosse (now Vietnam History Museum in Ho Chi Minh City), where they set about organizing and packing their finds from the southern provinces. In a letter to Elisséeff, Janse mentions that he has arranged for prints and documents to be sent from Hanoi directly to Harvard. He writes that he is trying to locate all documentation from his previous expeditions

688. Janse 1941:256-257; Janse 1959b

689. Janse 1941: plates 14(1), 15(2).

690. Janse 1941:256-257; Janse 1959b.

691. Letter from O. Janse to S. Elisséeff, 7 October 1939. Harvard-Yenching Institute, Cambridge, Mass. Correspondence, 1938-1940. 
in Paris and Stockholm and have them too sent to Harvard, and asks Elisséeff to receive them when they arrive. He ends the letter:

I am sorry, I can not now excavate the site of Câu-Cong, but the country is still flooded and will certainly be so for at least a month or two.

$$
\begin{array}{r}
\text { Hastly [sic] and Sincerely yours, } \\
\text { Olov Janse. }{ }^{692}
\end{array}
$$

A week later, on 24 October, Olov and Ronny Janse embarked on a French freight ship in Saigon and left Indochina. ${ }^{693}$ It would take nearly twenty years until Olov returned - then to South Vietnam - and Ronny would never come back again.

\section{The Philippines}

After a short stop in Singapore where they stayed in "an excellent hotel" and studied the collections of the Raffles Museum, and a visit to a find place for ceramics in Kota Tinggi (Johore) where they also acquired a reference collection of potsherds which was later given to the Peabody Museum, ${ }^{694}$ they embarked on the Italian liner S S Conte Verde ${ }^{695}$ bound for Manila. After a four-day journey across the South China Sea, they arrived in the Philippines on 10 November 1939.

The Philippines is an archipelago of seven thousand islands located some 1,500 kilometres west of Vietnam. Olov and Ronny arrived in the capital city Manila, located on Luzon - the largest island, which is also furthest to the north. With the exception of a month-long excursion to

692. Letter from O. Janse to S. Elisséeff, 17 October 1940. Harvard-Yenching Institute, Cambridge, Mass. Correspondence, 1938-1940.

693. Janse 1959:223.

694. Janse 1959:225. See also letter from O. Janse to S. Elisséeff, 39 November 1939. Harvard-Yenching Institute, Cambridge, Mass. Correspondence, 1938-1940.

695. The Italian ocean liner Conte Verde had a remarkable history. In September 1937 she collided with the Japanese ocean liner Asama Maru in a typhoon near Hong Kong. After months of repairs to both vessels, Olov and Ronny travelled to Kobe on the Asama Maru in November 1938. The Conte Verde was instead engaged in transportation of Jewish refugees from Germany and Austria to Shanghai. These transports continued through the time when Olov and Ronny travelled with her to Manila, but stopped soon thereafter, in June 1940, when Italy joined the war. 
the second largest island, Mindanao, and the small volcanic island of Jolo in the southern part of the archipelago, they spent the rest of the nine months and did all of their work on Luzon, not far from Manila.

The archipelago was colonized and largely catholicized by Spain from 1521 and was named Las Islas Filipinas as a tribute to the Spanish king Philip II. After that it had a complicated colonial history. There were numerous native rebellions and quests for independence, and the Spanish colonizers were also attacked by Dutch, Chinese, Japanese, and British forces during their 333 years of rule. ${ }^{666}$ After the Spanish-American War in 1898, and the Philippine-American War in 1899, the United States pursued a quasi-colonial policy in the Philippines until its formal independence in $1946 .{ }^{697}$ Hence it was almost at the end of the period of US intervention, that Olov and Ronny Janse arrived. Manuel L. Quezon had been President since 1935, and there was a transitional government known as the Commonwealth of the Philippines, with the mission to prepare the country for full independence. But the influence and military presence of the United States was considerable.

After their arrival, Olov and Ronny stayed six weeks in and around Manila. They immediately got in touch with the American collector, anthropologist, and autodidact archaeologist Henry Otley Beyer (18831966). Beyer had first arrived in the Philippines in 1905 as a twenty-twoyear-old chemistry and geology graduate on a mission to do an ethnological survey in the Ifugao province. After a brief sojourn back in the United States with one year of graduate education in anthropology, he returned to the Philippines where he married a fifteen-year-old native girl from Ifugao and settled in Manila for good. In a personal and beautifully written obituary of Beyer, his younger colleague Bill Solheim describes a rather eccentric man and devoted collector of Philippiniana. In 1926 Beyer began to collect tektites (molten debris from meteorites resembling black glass) and archaeological artefacts. ${ }^{698} \mathrm{He}$ built relations with communities all over the archipelago and paid them to collect artefacts for him. Over the decades he formed an outstanding private collection, along with an extensive library containing important literature on the Philippines. Reportedly, his collection of tektites was the largest in the world. Scholars and students came on pilgrimage to his Museum and Institute

696. E.g. Francia 2010.

697. Wolff 1961.

698. Byrne 2004:21, see also chapter 7 . 
of Archaeology and Ethnology in Manila to study books and artefacts, and "when distinguished or renowned guests of the Philippines had some leisure time, the governor general would turn them over to Beyer for some education on the Philippines". ${ }^{699}$ But Beyer was also a controlling character, and did not like competition. According to Solheim, he had more or less monopoly on Philippine archaeology up until $1950 .{ }^{700} \mathrm{He}$ would never let anyone study his collections in his absence, and he published very little. Anyone interested in his knowledge and collections had to come to him and listen, on his terms..$^{701}$

The first sign that Olov Janse had taken any interest in the Philippines is a letter that he sent to Otley Beyer from Hawaii in February 1938, on their way to the United States after the second expedition. That letter has been lost, but Beyer's response is kept in Janse's archive. ${ }^{702}$ From the response we can tell that Janse wrote to Beyer to ask about finds of Bronze Age type, similar to the artefacts he had found at Dong Son. Beyer had published an article in a weekly magazine about some bronze objects found in the Philippines, which Janse had seen. ${ }^{003}$ Beyer responded, thoroughly and amicably, that the bronze he had found in the Philippines was more similar to bronzes found in Hong Kong. But he had heard much about Janse's work from Madeleine Colani, Paul Lévy, and the other colleagues at the EFEO, and he was very interested in his finds of ceramic kilns in Thanh Hoa, with a ware resembling some of the ceramics he had collected in the Philippines. ${ }^{704}$ That ended the letter, and there is no sign of any continued correspondence until Janse decided to go to the Philippines in 1939. In a letter to Elisséeff while he was still excavating at Sa Huynh, Janse writes that he has "seen from the Philippine Magazine some similar objects have been found recently in the Ph. I.", and that he "would like very much when I return to U.S., to go by the way of the Ph. I. and study - from comparative point of view - the collections made there and even visite [sic] if possible, the places where the finds have been made". ${ }^{705}$ But apart from those few notes, there is nothing suggesting that

699. Solheim 1969:3.

700. Solheim 1969:1, see also Hutterer 1987:238-239.

701. Solheim 1969:3.

702. Letter from H. Otley Beyer to Olov Janse, 26 July 1938, NAA: Janse 2001-29.

703. Philippine Magazine 1935, vol. 33, pp. 482ff., mentioned in Janse 1941:257; Janse 1959:223.

704. Letter from Beyer to Janse, 26 July 1938; ibid.

705. Letter from O. Janse to S. Elisséeff, 10 October 1939. Harvard-Yenching Institute, Cambridge, Mass. Correspondence, 1938-1940. 
Janse's sudden interest in the Philippines was based primarily on scholarly interest. Rather, it seems like a decision largely based on political circumstances, with the war getting closer in Indochina, and the Philippines being under US army protection..$^{706}$

Twelve days after their arrival, the Manila Bulletin newspaper published an article with the title "Antiquity of Philippine Civilization Is Surprise to Visiting Archeologist". It says that Olov and Ronny planned to stay two weeks in the Philippines, for comparative studies to complement their investigations in Indochina. Olov is quoted:

Before I leave for the United States I will devote most of my time here to a study of the antiquities found in the Philippines which are of very great interest to me, especially from a comparative point of view. I am grateful to Prof. Otley Beyer for his kindness in showing me his important collections. May I add that this collection was for me a real revelation, as it shows obviously that the Philippines was once in the remotest times a cross road of different cultural currents [...]. When the scientific collecting activities started here some decades ago, our knowledge about the pre-history of the Philippines could be contained in a few pages. Today, thanks specially to the skillful work of Prof. Otley Beyer, there could be written passionate chapters and even whole volumes on the marvelous past of this country. ${ }^{707}$

With the courtesy and a sense of grandeur which can be recognized from his earlier encounters with the press, Janse gives praise to Otley Beyer, his "important" collections, and the "marvelous past" of the Philippines. But in reality, his relation to Beyer was far from frictionless. In his memoirs Janse describes how Beyer - whom he there refers to as a mere "collector of antiquities" - initially was very reluctant to let him see the bronze objects - particularly some axes - that he had come to study. ${ }^{708}$ After a couple of futile attempts in Beyer's Museum and Institute in Manila, Janse asked him to come on a weekend visit to the Batangas province on Luzon, south of Manila, and see the sites where the bronze axes were said

706. Which is also indicated by a reference to the war situation in Janse's memoirs (1959:222).

707. Article in Manila Bulletin, 22 November 1939: "Antiquity of Philippine Civilization Is Surprise to Visiting Archeologist".

708. Janse 1959:225. 
Fig. 62. Lunch at a

fish restaurant on the Taal lake, southern

Luzon. From left to right: "Pap", Otley Beyer (in black tie), Evett D. Hester, and Ronny Janse.

Fig. 63. Otley Beyer and Ronny Janse (both smoking cigars), with a man who may be Beyer's informant Esteban to the left, on the weekend study trip in Batangas, southern Luzon, November 1939.

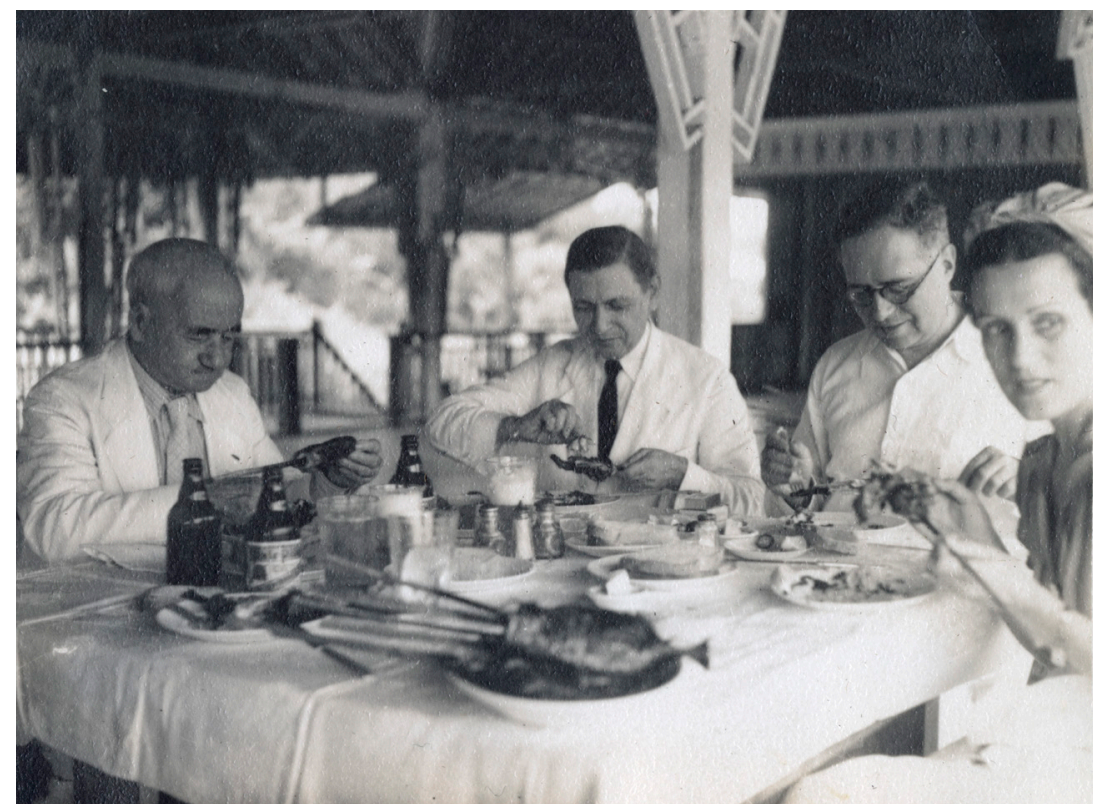


to have been found. Beyer agreed, and brought his friend E. D. Hester along with him on the trip..$^{709}$

Evett Dorell Hester was in the Philippines as an economic adviser to the US High Commissioner between 1930 and 1945. During this time, he collected ceramics on Luzon together with Otley Beyer, and built up a considerable collection in his own name. ${ }^{710}$ Janse refers to Hester as an "eager amateur archaeologist" and "Beyer's special friend". ${ }^{711}$

In Batangas, near the village of Mulasvin, Beyer and his local informant Esteban indicated some sites where the bronze axes were supposed to have been found. Janse, who could not see any cultural layers or other indications of archaeological sites, was not convinced. Upon their return to Manila, Beyer eventually made the bronze axes available for Janse to study. In his report and memoirs he writes that they looked just like the bronze artefacts they had found at Dong Son. ${ }^{712}$ But Beyer avoided Janse's questions about the circumstances in which they had been found. When Janse insisted (backed up by President Quezon himself, as we shall soon learn more about), Beyer gave him instructions to go look for the sites himself, with the help of local authorities and informants. But the instructions led Janse round in circles, and it soon dawned on him that Beyer was in conspiracy with the local informants to keep secret the places where they had made the finds. ${ }^{713}$ Janse was not happy about this, of course, and wrote in his preliminary report that the objects were "said to have been found in the province of Batangas" and were "purchased by Dr. Beyer". ${ }^{714}$ In another article written for the Smithsonian Institution, he wrote: "no records have been kept concerning the circumstances under which the objects were found, their documentary value is considerably weakened and they are partly to be regarded as curiosities" ${ }^{715}$ implying that he himself worked with proper scientific methods while Beyer lacked scientific rigour and only purchased objects - curiosities - for his own collections. This is not an entirely fair description; even if Beyer never published a detailed site report and appears to have been uninterested in stratigraphy, find contexts, and other rudimentary archaeological excavation

709. Janse 1959:229.

710. Evangelista 1969:101-102; Dutton 1999:233.

711. Janse 1959:229.

712. Janse 1941:257-258; Janse 1959:230-232.

713. Janse 1959:230-232.

714. Janse 1941:257-258.

715. Janse 1946:345. 
methods ${ }^{716}$ Janse could in all honesty not be described as representing the opposite end of the spectrum. Even though he was trained in archaeological excavation methodology and produced detailed drawings of some of the sites he excavated, Janse was, just like Beyer, primarily interested in typological, distributional, and comparative studies of artefacts. And for both of them, the ethnographic study and knowledge of living "primitive" tribes was part of the same conceptual package as the study of prehistoric movements and contacts between people. However, Janse's insinuation did not amuse Beyer, who wrote an equally sour remark in a publication some years later. ${ }^{77}$ Bill Solheim brings up their controversy as an example in his obituary of Beyer, where he writes:

Beyer had many a good chuckle in telling us about [his local foreman] Esteban and in surmising the "wild goose chases" that he must have taken Janse on in concealing from the archaeologist the true localities of the various finds that had been made. [...] Beyer had the information, in many cases, but didn't want anyone else bothering "his" sites..$^{718}$

Solheim, who knew Beyer well, and later became a good friend of Janse's, writes further on in his obituary that he considers "Beyer's secretive disposition an undesirable personality trait, the trait of a fanatic collector, who did not wish to share his collection". ${ }^{119}$ Indeed, it is not a very likeable character that stands out from these letters and publications. But from an altogether different angle, and with the benefit of hindsight, we can also see that Beyer's "fanatic" control saved many archaeological artefacts and ethnographic objects from being divided up between the United States and other museum superpowers of the early twentieth century, so that they now remain in the Philippines. ${ }^{720}$ And one should perhaps not be so sure that he acted purely out of personal greed or fanaticism. It may

716. Solheim 1969; Hutterer 1987:239.

717. Beyer 1949:13-14.

718. Solheim 1969:5.

719. Solheim 1969:8.

720. Although, says the processually oriented anthropologist and archaeologist Karl Hutterer in an overview of Philippine archaeology, most of the collection was reportedly destroyed in the war, or dispersed after Beyer's death, and most of the remaining parts lacked scientific value because there was no documentation of their provenance (Hutterer 1987:239). 
very well have been a way to protect the land he loved and had devoted his life to. ${ }^{721}$

Another interesting fact revealed in the Beyer-Janse controversy, is the lack of a national institution or system for the control of antiquities and heritage sites in the Philippines. It is noteworthy that one individual was allowed, as late as 1950 , with the government's consent, to control sites and artefacts in an entire country. ${ }^{722}$ And the control was not only for himself, but he also had the right - on a whim and according to personal taste - to decide on which other individuals were allowed or not allowed to collect artefacts (the eager amateur Hester - yes; the trained archaeologist Janse - no). In an article he wrote for the Smithsonian Institution on the work he did in the Philippines, Janse also refers to the lack of institutionalized control as a problem, and presented the EFEO as an excellent model worth taking after. As a final punch at Beyer (whose first name he, coincidently or not, consistently misspelled as Othley or Ottley in all his publications), Janse writes:

$[\mathrm{O}]$ ne of the most effective means of furthering archaeological research in the Philippines would certainly be the creation of a national board of archaeological survey [...] directing and sponsoring scientifically conducted excavations and research, and $[\ldots]$ recommending appropriate legislation prohibiting uncontrolled digging in ancient graves and dwelling sites, which generally are of little if any, benefit to archaeological science. May it also be suggested that adequate reports on excavations already carried out should be published, as well as descriptions of existing public and private collections of antiquities found in Philippine soil..$^{723}$

Knowing what we now know about Janse's own excavations in Indochina - rushed and museum-piece-focused, not rarely without proper documentation of stratigraphy or find contexts - one can ask if he was really in a position to deliver such blows, which everyone with the slightest

721. See Byrne 2014: chapter 7 for a beautiful account of the complicated entangled ethics of archaeology, looting and collecting, centering on Otley Beyer and the Philippines.

722. See a more detailed account of the history of archaeology in the Philippines in Evangelista 1969; Hutterer 1987; Byrne 2014: chapter 7.

723. Janse 1946:345, 355. 
knowledge of Philippine archaeology would know were aimed straight at Beyer. But that was the position he took vis-à-vis Beyer.

Back in Manila he had been cunning enough not to put all his eggs in Beyer's basket. As soon as he and Ronny arrived in early November, he telephoned the French Consul Gaston Willoquet. Willoquet did not only serve as French Ambassador to the Philippines between 1946 and 1949, he was also a keen amateur historian and later authored a book on Philippine history. ${ }^{724} \mathrm{He}$ offered to contact president Manuel Quezon and demand an audience on Janse's behalf. On Willoquet's recommendation they also moved from the "gloomy Spanish hotel" where they had stayed the first nights, to the "happy 'Restaurant de Paris", where they got "two excellent, comfortable rooms with a beautiful view over the Manila Bay". ${ }^{725}$ The Restaurant de Paris was located on the seafront avenue in the elegant Eremita district and owned by the American Gladys Savary and her French husband André. It was quite a party place, had its own French chef, and was advertised as "Manila's smartest restaurant". ${ }^{226}$ In a book featuring Gladys Savary and three other American women in the Philippines during the Second World War, Theresa Kaminski describes the interior of the restaurant:

The cocktail lounge was decorated in red, with the dining area made into a "tropical copy" of a Paris restaurant the Savarys particularly admired. Menus from different French restaurants, along with French prints, adorned the walls, banquettes provided comfortable seating, and a large Provençal-style sideboard displayed an eclectic collection of carvings and porcelains. The terrace, with its spectacular view of Manila Bay and Dewey Boulevard, offered open-air dining..$^{727}$

Janse writes that the Restaurant de Paris was a meeting place for the French community, and that they soon formed "a cosy coterie". ${ }^{228}$

724. Willoquet 1961.

725. Janse 1959:227. In the Swedish original: "det dystra, spanska hotellet till det glada 'Restaurant de Paris', där vi fick två utmärkta, bekväma rum med vacker utsikt över Manilabukten".

726. Kaminski 2016.

727. Kaminski 2016:28.

728. Janse 1959:227. In the Swedish original: "Ett gemytligt kotteri". 
Once settled at the Restaurant de Paris, Willoquet had arranged for them to meet the chairman of the chamber of commerce, Maxime Lévy Hermanos. In his memoirs Janse writes that it turned out they had already met him back in Paris, so it was a joyous reunion. Lévy Hermanos in turn introduced Janse to his friend Don Jacobo Zobel, owner of the large Hacienda Calatagan in Batangas, who had encountered several ancient burial sites on the grounds of his estate..$^{729}$

This demonstrates some of Janse's strength - unusual perhaps for an academic, but a key asset for an archaeologist moving so boldly between national contexts in the 1930s. Only days after their arrival in Manila, he had already established connections with important actors in the highest strata of society, connections which were reinforced by his previous networks of cosmopolitan highflyers, and were facilitated by his and Ronny's eagerness to socialize and take part in cosy coteries. Ronny played a key role in this part of their work. She maintained connections with the wives, the female parts of these networks which were of great importance, but often invisible in official reports. ${ }^{73^{\circ}}$ Ronny Janse was not only beautiful and impeccably dressed, as was expected of her as a wife. She was also bright and interesting, knew several languages, and had many stories of her own to tell. Together they made a perfect team in this socializing and networking part of their enterprise. By quickly forming networks when they arrived in a new place, their work was also less vulnerable to setbacks with single individuals, such as the frustrated relation with Otley Beyer.

When Lévy Hermanos introduced Janse to Jacobo Zobel, who happened to be in Manila at the time, he was very positive to the idea of an excavation, and invited Olov and Ronny to the Hacienda Calatagan for a quick survey over the weekend. Jacobo Zobel, whose full name was Jacobo Santiago Zóbel de Ayala y Róxas (1902-1971) was born in the sixth generation of the wealthy and influential Roxas-de Ayala-Zobel clan. Together with his brother and sister he had inherited the 10,000-hectare Hacienda Calatagan from their grandmother in 1930.731

729. Janse 1959:226-228.

730. An exception in Manila is Maxime Lévy Hermanos's mother Berthe Lévy Hermanos, who is mentioned in the acknowledgements in Janse 1944:38.

731. The Hacianda (now Hacienda Bigaa) has been kept in the Zobel family until this day. Historical information about Jacobo Zobel is taken from the blogs Remembrance of Things Awry: https://remembranceofthingsawry.wordpress.com/2010/12/05/mythic-creatures-mercedes-zobel-roxas-de-mcmicking/ and Architecture Manila http://arquitecturamanila.blogspot.se/p/am-shorts.html 
When the weekend came, they travelled together with Don Jacobo the 100 kilometres south to Calatagan in the Batangas province. Upon arrival, Ronny and Olov were installed in one of the comfortable guest rooms on the second floor of the estate's "clubhouse", and on the next day they were taken out to one of the sites by Don Jacobo and the estate manager Antonio Pertierra. The site, which Janse calls Penagpatayan ${ }^{732}$ or Pinagpatayan" 733 - literally "the massacre field" - was located a couple of kilometres west of the clubhouse, on a large and flat hill with gently sloping sides overlooking a distant mountain range. They had found pottery in the process of constructing an airfield there in 1934, and the finds had been given to the National Museum in Manila. ${ }^{734}$ In a quick test excavation Janse immediately found ceramics from the early Ming period (14th-15th century AD), which was exactly what he had hoped for.

Ceramics of the early Ming period were particularly interesting, simply because they were so rare. During the early Ming, the emperor Hung-wu had banned the use of ceramics in funerary deposits all over the Chinese Empire. And since archaeologists mostly encountered ceramics, particularly whole and fine pieces, in graves, this was a part of the Chinese ceramic tradition they knew little about and had very few collections from. Now, the Philippines had been involved in trade with the Chinese empire during the early Ming, but did not abide by its laws. Hence in the Philippines there were graves containing early Ming ceramics, and it was these that they had now found at Calatagan. In an article Janse writes:

Even though the wares exported were not always of the highest quality, they nevertheless are of great documentary value. With the aim of filling some gaps in our knowledge of early Ming ceramics and their use for funerary purposes in the Philippines, the writer during several months in 1940 made systematic excavations in various parts of the Philippines. ${ }^{335}$

Well, in fact, they did almost all of the excavations at the estate of Hacienda Calatagan. At the first weekend survey in December 1939 they

732. Janse 1946:348; Janse 1959:227.

733. Janse 1941:258; Janse 1944:37.

734. Letter from O. Janse to S. Elisséeff, 21 May 1940. Harvard-Yenching Institute, Cambridge, Mass. Correspondence, 1938-1940.

735. Janse 1946:348. 
identified two more possible burial sites of interest; Pulong Baca ${ }^{736}$ and Kay (or Panday) Tomas, and some caves which they never excavated. And before they left Hacienda Calatagan at the end of the successful weekend, they had made plans with Don Jacobo to return later for more extensive excavations. ${ }^{737}$

Back in Manila, two messages waited for Janse at the Restaurant de Paris. One was from Sweden with the news that Olov's father Thure Janse had died in his home in Norrköping. He was 75 years old and had been weak for many years. The outbreak of the Second World War with Germany's invasion of Poland in September meant the last straw. Olle wrote later in a letter to Ture and Nora Nerman: "Dad enjoyed life in his healthy days, but the world's destruction, hatred and lies weighed his spirit down, and his strength failed him." ${ }^{73^{8}}$ The news about his father's death obviously affected Olov, who took some days off from work. In a letter to Birger Nerman six months later, he writes that it "has been bitter days for us here, especially since we at a time like this were so far from the old home". ${ }^{739}$ But there was not much they could do. They were stuck in the Philippines with no tickets to get them to the United States, let alone to Europe where there was full-blown war.

The other message was all the more positive. Gaston Willoquet, the French Consul, had managed to arrange for an audience not only with President Quezon, but also with the US High Commissioner Francis Bowes Sayre. The High Commissioner, who was President Roosevelt's personal representative to the Commonwealth (and also happened to be professor at Harvard Law School, and his daughter Eleanor was an art historian involved in the Fogg Museum), ${ }^{740}$ received Janse accompanied

736. Janse 1944:38; Janse 1946:349; Also referred to as Pulo Bacao (Janse 1941:258) and Poulong Bacao (Janse 1959:237).

737. Janse 1959:228.

738. In the Swedish original: "I sina friska dagar gladde sig Pappa åt livet men världens förstörelse, hat och lögn nedstämde så hans sinne att krafterna ej längre stod bi.” Letter from O. Janse to T. and N. Nerman, 27 June 1940.

739. Letter from Olov Janse to Birger Nerman, 2 December 1939. Riksarkivet. Kartong 3. Korrespondens Brev III 1935-1941. In the Swedish original: "Som Ni väl förstå har det varit bittra dagar här för oss allra hälst vi vid ett dyl. tillfälle befann oss så långt borta från det gamla hemmet."

740. Letter from O. Janse to S. Elisséeff, 30 November 1939. Harvard-Yenching Institute, Cambridge, Mass. Correspondence, $1938-1940$. See also Oral history interview with Eleanor Sayre, 19 April 1993-10 January 1997, Archives of American Art, Smithsonian 
by Willoquet, listened to his plans, and promised to do what he could to facilitate the expedition..$^{71}$

The meeting with President Quezon is described in some detail in Janse's memoirs. The President received Janse and Willoquet in the "gloomy" Malacañang Palace, which was originally built as a Spanish country house in $175^{\circ}$, and had been the President's official residence since the beginning of the Commonwealth period in 1935. As the first president of the Commonwealth, Manuel L. Quezon was the first Filipino resident of the palace, where he welcomed Janse and Willoquet, with a smile, in December 1939. Describing his plans for the President, Janse also seized the opportunity to "make some hints at certain difficulties in organizing systematic archaeological excavations, when the Philippines lacked an office to authorize, survey, and promote heritage management". ${ }^{72}$ Quezon sat back in his armchair, and seemed to reflect for a moment on what he had just heard. After a short while he turned to Janse with a number of questions suggesting that this was something he had already considered, and asked Janse if he could not, while he was in the Philippines, write a proposal for the creation of a new national institute similar to the EFEO in Hanoi. ${ }^{743}$ Quezon promised to provide the necessary means to pursue this work, and moreover promised to support Janse's excavation plans in Batangas with the necessary permits and a travel grant. ${ }^{744}$

It was now clear that they would stay in the Philippines much longer than the two weeks they had first planned. They had initially had plans to return to Indochina, ${ }^{74}$ but the war situation was getting worse there. The prolonged stay was also partly owing to the opportunity to excavate

Institution, at https://www.aaa.si.edu/collections/interviews/oral-history-interview-eleanor-sayre-13089, accessed 16 May 2018.

741. Janse 1959:228.

742. Janse 1959:228. In the Swedish original: "gjort en del anspelningar på vissa svårigheter att organisera systematiska arkeologiska utgrävningar, då Filippinerna saknade ett ämbete med befogenhet att övervaka och befrämja fornminnesvården."

743. According to Janse's memoirs, he submitted a draft proposal to President Quezon along with a report of their excavations before his departure in August 1940 (Janse 1959:241), but there is no copy or record of this proposal in any of the archives we have researched.

744. Janse 1959:228-229; Letter from O. Janse to S. Elisséeff, 20 December 1939. Harvard-Yenching Institute, Cambridge, Mass. Correspondence, 1938-1940.

745.E.g. letter from O. Janse to S. Elisséeff, 1 May 1940. Harvard-Yenching Institute, Cambridge, Mass. Correspondence, 1938-1940. 
the early Ming graves at Hacienda Calatagan, and President Quezon's invitation to formulate plans for a new Philippine institute. But it was further owing to the fact that they could not get any boat tickets. The war with Japan was literally around the corner, and there were many people looking to escape the Philippines. Passenger ships bound for the United States were fully booked months in advance, and they had to wait around and hope for a gap to appear. ${ }^{746}$

As part of the task of formulating plans for a new institute, Olov did a month-long tour with the small passenger ship SS Elcano to the large Mindanao island and the smaller Basilan and Jolo islands in the Sulu archipelago in the southern part of the country. Ronny stayed in Manila, and along with him came instead the French businessman Cason-Bonardel, who had a personal interest in archaeology, and had accompanied Janse also on the futile excursion to find Beyer's sites in Batangas. They departed from Manila around 8 January and travelled south from Luzon. In the town of Zamboanga on the southernmost tip of Mindanao they met the resident American businessman Frederick Leas Worcester (1898-1954), son of the more well-known scientist, author, and businessman Dean Conant Worcester (1866-1924). Worcester was a keen collector of ceramics and was well acquainted with the Basilan island which was visible from Zamboanga. Worcester indicated places where ceramics had been found, and advised them to be careful with the superstitious natives and seek alliance and support from the chiefs, called datos, before they started any investigations. While they were in Zamboanga they also visited the Mayor to have his authorization to conduct investigations at Basilan. He was initially quite reluctant, but when Janse reminded him that they were there on a mission from President Quezon, he gave in and contacted his delegate at Basilan to announce Janse's arrival. ${ }^{747}$ Once on the island, they set off to investigate a site called Bohelebung near the small fishing village of Lamitan, after having visited and negotiated with the datos. When his team of local workmen started to dig test pits "here and there", they first encountered Ming ceramics, which encouraged Janse to dig further, and then remains of human bone. As soon as the bone saw the light, the men dropped their tools and stopped digging. The unfortunate man who had dug the pit with the bone in it left the site and sat down at a distance, shaking with fear. Janse, who was himself made rather uncomfortable by

746. Janse 1959:245.

747. Janse 1959:233. 
the hostile atmosphere that had suddenly appeared (probably enhanced by what he had heard about the natives' primitivity and unreliability), decided to immediately leave the site and the island of Basilan..$^{78}$

Janse's descriptions in memoirs of the visit to Basilan and later to some tribes near the US military base Fort Stotsenburg ${ }^{749}$ on Luzon north of Manila, repeat the narrative format that we have seen in many of his writings. In his memoirs (published in Swedish in 1959) he polarizes in temporal terms the primitive natives with his and his American companion's modern physique, psyche, and material culture. The tribes of "Negrito pygmies" near Fort Stotsenburg are described in more demeaning terms than any other people featured in his travel writings. They were, in his view, the most primitive of all:

[T] hese shy, extremely primitive creatures that have not yet left the Stone Age stage. [...] Only a few, miserable and ugly creatures of these tribes have defied modern culture. It will probably not be long before these remnants have disappeared too, [and they are nowadays considered] an ethnographic curiosity. Culturally they stand so low and are so cruel that they hardly even deserve to be counted as homo sapiens. $75^{\circ}$

In a photo taken at the same visit to the tribes near Fort Stotsenburg we see Janse, looking like a dim ghost with a blank face, posing with three fit and smart-looking men, a well-dressed woman and a child, in front of a large building and a fence.

The contrast between text and photograph is quite extraordinary, and would be laughable if the matter were not so serious. It is difficult to understand how Janse could defend and maintain such ruthless and obviously false descriptions. Moreover, the juxtaposition of Janse's text and photograph demonstrates the extraordinary resilience of nineteenth-

748. Janse 1959:234-237.

749. Later renamed to Clark Air Base, and wrongly referred to by Janse as Fort Statsenburg (Janse 1959:241-243).

750. Janse 1959:243. In the Swedish original: “[D] essa skygga, ytterst primitiva varelser, som ännu knappast kommit över stenåldersstadiet. [...] Endast få, ömkliga och fula varelser av dessa stammar har trotsat den moderna kulturen. Troligen kommer det inte att dröja länge förrän även dessa spillror helt har försvunnit, [och de betraktas] numera som en etnografisk kuriositet. De står kulturellt så lågt och är så grymma, att de knappast ens förtjänar att räknas till homo sapiens.” 


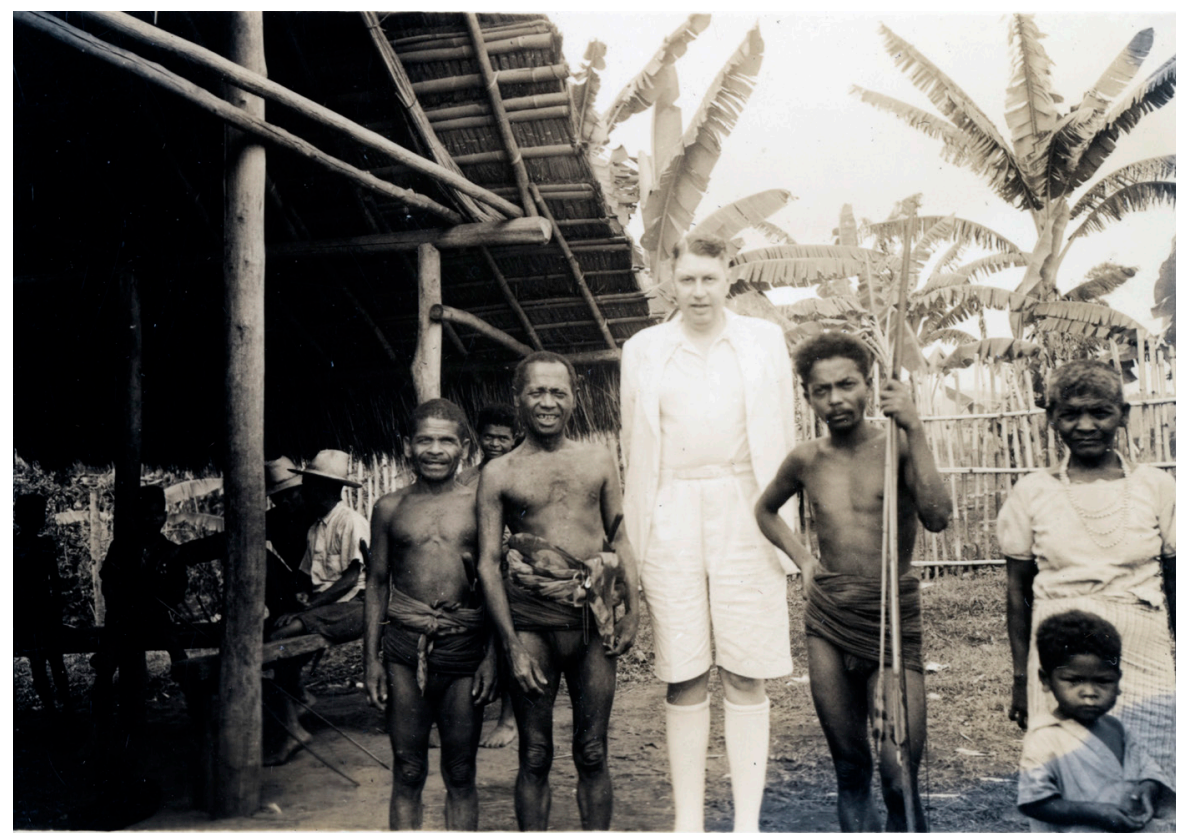

Fig. 64. Olov Janse with members of $a$ community which Janse refers to as "Negrito pygmies" near Fort Stotsenburg, June 1940. Photo by Lieut. R. Barker.

century scientific and popular teleological arrangements of humans on a scale from primitive to modern, and the continued marketability of this narrative format for travel writing in Sweden, as late as 1959.

When he returned to Manila on 11 February after his tour to the southern islands, a letter from a furious Elisséeff awaited him at the Restaurant de Paris.

I was much astonished to receive three letters from you from the Philippine Islands [...].

The first information I had that you were no longer in Indochina came from the Treasurer of the Institute, who informed me that you had cashed some money under your letter of credit in Manila. I was unpleasantly surprised that you did not inform me of your plans to leave Indochina and to make excavations in the Philippine Islands, because you put me in an unhappy situation before our Trustees. [...]

I never had any information from you about the influence of the war on your work in Indochina. It is still not clear to me why 
you left Indochina and went to the Philippine Islands. Also, what is the meaning of your sentence, "If, however, the war will soon be stopped - according to the latest news there may be hope for it - we certainly could continue our field work in Indochina." As far as I know, there is no war in Indochina. [...]

The money is not my own and I therefore have the responsibility of reporting to the Trustees in regard to its expenditure. I feel that it is doubly unpleasant for me because I recommended you for this expedition and backed your program, to which you have not held. ${ }^{751}$

Upset and disappointed, Elisséeff goes on to say that he has not received any reports from the work at Sa Huynh or Kota Tinggi, nor the notice for his journal which Janse had promised to send. Already in November, when he thought Janse was still in Indochina, Elisséeff had written another irritated letter complaining that he had not received any report on their work, nor any detailed financial report on their expenditure during the first year. ${ }^{752}$ And in a letter dated 8 February he continues to complain over Janse's spending, and that he was still lacking a detailed financial report. He complains that Janse after a spontaneous raise now has allocated US \$ 450 for his own salary: "a very high salary even for American standards which not even all professors receive at Harvard, where the salaries are regarded as the highest in American universities". And this, says Elisséeff, despite the fact that living costs in Asia must certainly be much lower than in the United States. Moreover, he complains about Ronny's salary of US \$ 150 per month: "How can you hope to continue to work with an American institution after [the Trustees] learn from me that you are taking $90 \%$ of the allocation for yourself and your wife?" 753

It is clear, and somewhat surprising, that Elisséeff as the director of an institute for Asian studies at one of the most prestigious universities in the United States, was poorly informed about the actual war situation in Indochina and the Philippines. But it is also clear that Olov and Ronny Janse's lifestyle in the highest exclusive strata of society (which, as we have seen, was a key to their success) took considerable resources to

751. Letter from O. Janse to S. Elisséeff, 1 October 1940. Harvard-Yenching Institute, Cambridge, Mass. Correspondence, 1938-1940.

752. Letter from S. Elisséeff to O. Janse, 18 November 1939. Ibid.

753. Letter from S. Elisséeff to O. Janse, 8 February 1940. Ibid. 
maintain, and this had never been clarified in the communication with Elisséeff. Their differences were clarified even further in Janse's responses to Elisséeff's complaints, which he sent in two long letters. In the first one, written immediately after he had received Elisséeff's letter upon his return from his tour around the southern islands, he explains at length the actual situation of war in Indochina (quoted earlier, see pp. 267-268) and continues:

In these circumstances, I understood that if I wanted to carry out meanwhile some investigations and fieldwork with some of success [sic], I had to turn my regards to the Ph. I., which offer so many similarities to Indo-China from archaeological point of view and where there are no restrictions and no feeling of war and where much useful work could be done. I explained all this in a letter to you before I proceeded to the Ph. I., but as I understand the letter has been stoped [sic] by the censorship. I had not the slightest idea that my trip to the $\mathrm{Ph}$. I. could rise [sic] any objection from your side and as I could not wait several months for an answer, I did not ask for a permission, but - as it is customary in similar situations - for an agreement. I have acted in the best of intentions and did not expect to be blamed for this. In similar circumstances, I am sure, you would have acted, too, as I did. The conditions during a state of war changes everything from one day to another and you can not forsee [sic] what is going to happen.

$[\ldots]$

Terminating this letter, may I point out once again that in abnormal times as ours, you will sometimes find yourself in a situation, where you have to take a rapid decision, as it was my case. I believe that nobody would blame me for this or that my explanations didn't reach you. Now, thanks our [sic] trip to the Ph. I. I have been able to gather interesting materials (of which I will speak in another letter) which will enable me to add several chapters to the volume we are preparing. Or, would you rather have preferred me to stay idle in Indo-China, waiting several months for an authorization? To judge from the other archaeological expeditions I know of, it is customary that the leader is entitled of, at least in certain serious conditions, to some kind of initiative of his own. I can not help that I am somewhat concerned that you feel so 
worried about a step taken only in order to favour the results of our expedition. ${ }^{754}$

When Elisséeff was not entirely content with this response and continued to complain about the reports and Janse's spending, Janse responded in another letter from Hacienda Calatagan on 15 April, now rather irritated:

[As] the success of the expedition is a "point d'honneur" for me, I will continue at the rate of $8000 \$$ a year even though this means that I have to spend - as I already have done - a large part of my own salary for the expenses of the expedition.

According to your proposal I agree to reduce my salary from 450 to $400 \$$, if necessary. In fact, I have never touched even $400 \$$ and wish I could retain at least this sum. May I add, meanwhile, that the living expenses here in the F.E. are on many places, at present, higher than in the U.S. and the prices go up constantly. $[\ldots]$ However, it is not only the level of the living expenses, which has to be taken into consideration for establishing a salary, but, above all, the health conditions and the trying climat [sic]. This is the principal reason why Gouvernement employés [sic] are entitled to an augmentation of $100 \%$, in private undertakings even more.

Concerning my wife may I mention that she always has assisted me on my expeditions. I need a technical assistant and she is quite accustomed to our fieldwork and the methods we use in handling our findings. I hardly believe that any American, having her experience, would accept to do the same work under such hard conditions as those of the F.E. for a salary of $150 \$$. May I also add that this sum includes all expenses needed for cleaning, repairing, classification etc.

As regards to her traveling expenses, I only want to mention that during my earlier expeditions they were always paid $1^{\text {st }}$ class. Now we travelled in tourist class.

I would have appreciated very much to have been advised before I started the expedition that I had to keep a detailed account besides my scientific work. As a matter of fact, it never

754. Letter from O. Janse to S. Elisséeff, 12 February 1940. Harvard-Yenching Institute, Cambridge, Mass. Correspondence, 1938-1940. 
before happened to me that I was requested to keep and present vouchers of the expenses. [...]

As I already have mentioned, I organized this expedition in the same way as those sponsored previously by French and Swedish institutions. I then received the necessary funds in advance and at the termination of the expedition, I brought the findings to the different institutions and presented a preliminary report on the scientific results of our work. There was never any question about "detailed reports concerning the accounts", vouches [sic] etc. As you certainly know yourself, the results of all my previous expeditions have been considered quite satisfactory to every body concerned. ${ }^{755}$

We see here a clash between two different eras and two different cultures of administration - French pre-war cosmopolitanism and post-war American institutionalism - literally on the verge of the Second World War. Both Elisséeff and Janse took the rules and procedures of their own side for granted, assumed that they spoke the same language, and did not realize the crucial differences between the two systems until it was too late and the conflict was a fact. The conflict was of course worsened by communication problems owing to the war, when letters disappeared or were held up for months by censorship. After Janse's explanations Elisséeff seems to have calmed down, although he continued to send remarks about reports and financial statements. ${ }^{756}$

After his month-long tour to the southern Mindanao and Jolo islands, Janse stopped only a couple of days in Manila before he and Ronny left for Hacienda Calatagan to resume the excavations. ${ }^{757}$ They spent three months at the Calatagan estate, from mid February to mid May 1940, as guests of Don Jacobo and his wife Doña Angela Olgado Calvo de Zobel,

755. Letter from O. Janse to S. Elisséeff, 15 April 1940. Harvard-Yenching Institute, Cambridge, Mass. Correspondence, 1938-1940.

756. Letter from S. Elisséeff to O. Janse, 27 April 1940. Harvard-Yenching Institute, Cambridge, Mass. Correspondence, 1938-1940. See also a response from Janse, 28 July 1940. Ibid.

757. In a brief report written in a letter to Elisséeff ( 21 May 1940. Harvard-Yenching Institute, Cambridge, Mass. Correspondence, 1938-1940), Janse mentions that they had applied for permission to excavate at Calatagan, and had it granted in early February. It does not, however, say who granted the permit. 
who was known first and foremost for her exceptional beauty. ${ }^{758}$ In the excavations they were assisted, as before, by the estate manager Antonio Pertierra, and he also helped to recruit a local workforce to do the digging. The estate also provided "an excellent drawer", and a physician - Dr Gerardo Manas - to examine the skeletal material. ${ }^{759}$ They walked to the excavation site in the mornings and worked long days, from sunrise to sunset, with twelve men in the workforce to finish before the agricultural season began..$^{70}$ Details of the excavations are described in Janse's memoirs, and have been reported in three different articles. ${ }^{761}$

As in Janse's reports from Indochina, there are no site maps that give away the precise location of the sites, or in which exact parts of the sites they excavated. But from letters ${ }^{762}$ and the reports it is possible to discern that the three sites - Penagpatayan, Pulong Bacao, and Kay Tomas - were located close to each other, near the coast, a couple of kilometres west of the estate's clubhouse. At Penagpatayan, the "massacre field", they excavated 29 graves. ${ }^{763}$ Almost all graves contained one skeleton buried in supine position with the head to the north, mostly well preserved by the calciferous soil. The skeleton was surrounded by grave goods, mostly ceramics (of the desirable early Ming ware, but also of Sawankhalok and other import and native wares). They also found spindle whorls, bracelets, beads, an iron dagger, and some other things. The finds suggested that the graves were from the early Ming period (14th-15th century AD).

Even closer to the sea was the second site, Pulong Bacao, which Janse describes as located on a small promontory where a native had found potsherds some years earlier. At Pulong Bacao, Janse's team excavated six

758.E.g. the blog Architecture Manila (http://arquitecturamanila.blogspot.se/p/amshorts.html, accessed 17 May 2018). Angela Olgado's beauty is also mentioned by Janse (1959:227), although he got her name wrong (Angelica Gelli).

759. Janse 1959:237-241.

760. Letters from O. Janse to S. Elisséeff, 16 February 1940. Harvard-Yenching Institute, Cambridge, Mass. Correspondence, 1938-1940.

761. Janse 1959:237-241; Janse 1941; Janse 1944; Janse 1946. Particularly Janse 1944 has a detailed description of the graves at Penagpatayan, and is richly illustrated.

762. E.g. letter from O. Janse to S. Elisséeff, 21 May 1940. Harvard-Yenching Institute, Cambridge, Mass. Correspondence, 1938-1940.

763. The number of excavated graves at Penagpatayan is a little confusing. A preliminary report (letter to Elisséef, 21 May 1940) says 31, while the text in one of the published articles says 27 graves (Janse 1944:39) and the schematic site drawing in the same article says 29 (Janse 1944: plate 17). 
graves with skeletons and Ming ceramics. Along the shore they also picked up stray finds of potsherds, spindle whorls, net sinkers, grindstones and some more, which Janse saw as an indication of a former village site..$^{74}$

The third site, Kay Tomas, was also close to the sea, on a promontory similar to Pulong Bacao. Passing by, Janse had noticed potsherds of Song and Ming type scattered on the ground, and started excavations on the site. Here they unearthed 32 skeletons buried in supine position, but oriented in various directions. In the graves they found ceramics, beads, arm rings, and spindle whorls, along with considerable amounts of stone artefacts, which Janse suggested had been found in a nearby Stone Age dwelling site and reused by the more "advanced" people that were buried in these graves (according to the same logic as his interpretations of the Dong Son material which also confused his ideal boundary between "primitive" and "civilized"). ${ }^{765}$ Around the graves they found some ceramics and other objects buried in pits without skeletons. The ceramics found in the graves at Pulong Bacao and Kay Tomas were from the middle and late Ming period, suggesting that they had been in use one or two centuries after Penagpatayan.

From an archaeological point of view, one of the most interesting aspects of these sites was the treatment and manipulation of the bodies and the placing of the ceramics in the graves. Several of the skeletons had been decapitated, some had their hands cut off, and one had the skull replaced by a ceramic bowl. Several skeletons had manipulated teeth, and one had two extra skulls placed between its feet. ${ }^{766}$

Olov and Ronny did in many ways thrive at Hacienda Calatagan. Compared with the unbearable heat in Indochina the climate was quite pleasant, and they enjoyed the company of their hosts and other guests who arrived from Manila at the weekends. But the war was there, like a black cloud on the horizon. On 9 April they heard on Antonio Pertierra's shortwave radio that Germany had invaded Denmark and Norway. ${ }^{767}$

Having closed the investigations they returned to Manila in mid May, and were keen to leave the Philippines as soon as possible. But when they checked with the travel agent whether there had been any cancellations

764. Letter from O. Janse to S. Elisséeff, 21 May 1940. Harvard-Yenching Institute, Cambridge, Mass. Correspondence, 1938-1940.

765. Janse 1959:107.

766. For details, see Janse 1944 .

767. Janse 1959:241. 
on the boats, they got the disappointing news that there were still no tickets available for at least a month. While waiting, Olov wrote and submitted the report on the establishment of a new institute, which he had promised President Quezon. ${ }^{768}$

He and Ronny also worked together to prepare their finds from Calatagan for shipment to the United States. But they only picked the things that they considered of interest for the Harvard-Yenching Institute, which were mostly the Chinese import ceramics. Hence the material from $\mathrm{Ca}$ latagan was divided up among several collections: the skeletal material and ceramics of native origin were deposited at St Thomas University (now University of Santo Tomas) in Manila, and some duplicates of the imported ceramics were incorporated in the Zobel collection (with the Zobel family's previous finds from Calatagan in 1934) at the National Museum of Manila. ${ }^{769}$ The finds that they had picked out for shipment to the United States, which (according to a tentative handwritten list kept in Janse's archive) consisted of 102 whole ceramic pieces, one iron dagger, and a number of glass bracelets, beads, spindle whorls, and potsherds, ${ }^{77^{\circ}}$ were handed over to a forwarding agent, to arrange with all the formalities of the shipment. ${ }^{771}$

Since they had left Indochina in a rush, their excavated collections had been cleaned, packed, and shipped from the Musée Louis Finot in Hanoi and the Musée Blanchard de la Brosse in Saigon. Four cases containing two and a half cubic metres of finds weighing 497 kilos had been shipped from Saigon on 28 February 1940 and arrived in Harvard around mid May. Another eight cases containing six cubic metres weighing 600 kilos had been shipped from Hanoi on 29 March, and arrived in New York in late May. From the latter collection, George Codès had kept eight pieces for the Hanoi museum, according to their previous agreement about unique finds. The rest of the collection was insured for US $\$ 3,000$, and the eight cases contained, according to the freight and insurance documents:

768. We have not found the actual report during our researches, but it ought to have been submitted in June 1940 and is mentioned in Janse 1946:346 and Janse 1959:241.

769. Janse 1944:38.

770. NAA: Janse 2001-29.

771. Janse 1959:242. 
1-3: 1169+823+1113 potsherds and ceramic fragments.

4: 106 potsherds, bowls, vases and house models.

5:359 potsherds, bricks, and vases.

6: 82 vases, lamps, cups, plates, lids, and stone discs.

7: Ceramics, vases and bronzes.

8: Plates, bowls, vases, documents and paper. ${ }^{77^{2}}$

In the Philippines, their collections were held up by the customs for a while with reference to a legal paragraph forbidding export of artefacts unless a permit had been given by the Ministry of Agriculture. Janse, who saw himself and the Harvard-Yenching Institute as the rightful owners of the collection, writes in his memoirs with an ill-concealed reference to Beyer: "maybe some amateur archaeologist had given the customs a hint, because he thought I had intruded on his hunting grounds." 773 But Janse pulled some strings in his high-level network, which included the US High Commissioner Sayres, and soon he had the necessary permit to proceed with the shipment. The collections, packed in four cases, were eventually shipped on 24 July $1940 .{ }^{774} \mathrm{He}$ writes, triumphantly: "My treasures were thus saved from the claws of the multi-headed dragon of bureaucracy." 775

They were now desperate to leave the Philippines, and the summer heat started to affect Olov's health. The letters reveal that he was suffering from sunstroke and repeated stomach problems. ${ }^{776}$ To escape the heat in Manila, and to keep them occupied while waiting for a boat ticket, Olov and Ronny left for the town of Baguio in the mountains of northern Luzon, where the American government had built a mountain resort similar to that at Dalat in Indochina. The climate was cooler than Manila, and Olov and Ronny spent some time visiting sites and doing trial excavations where finds of early Ming ceramics had been reported.

772. See documents and letters in Harvard-Yenching Institute, Cambridge, Mass. Correspondence, $1938-1940$.

773. Janse 1959:245.

774. Letter from O. Janse to S. Elisséeff, 28 July 1940. Harvard-Yenching Institute, Cambridge, Mass. Correspondence, 1938-1940.

775. Janse 1959:245. In the Swedish original: "Så var då mina skatter räddade ur den månghövdade byråkratiska drakens klor.”

776. Letter from O. Janse to T. Nerman, 27 June 1940. Arbetarrörelsens arkiv och bibliotek. Ture Nerman 3.1.24. 
On one occasion Olov was accompanied by the young Lieutenant Joseph Barker stationed at Fort Stotsenburg, ${ }^{777}$ who was interested in the history and culture of the Philippines, and had built relationships with some of the local communities. Together with Barker, Janse visited the village of "Negrito Pygmies" that he described in such demeaning terms. The trial excavations, of which the locations are unknown, were not particularly successful and have not been reported anywhere.

When they returned to Manila in July, they were told that there were no boat tickets available until October. And while they were in the mountains they had heard on the radio that German forces had occupied Paris on 14 June..$^{78}$ The war was not only getting closer to them where they were now, under the threat of attacks from Japan, but it was now taking over their beloved Paris where many of their friends lived. Moreover, the financial situation was desperate. Janse wrote to Elisséeff, begging him to persuade the Trustees to release the last portion of their funding:

At present we have thousands of refugees from Hong-Kong. The living expenses are becoming sky-rocking [sic] high. - In this situation what do you expect us to do without funds - and what would you suggest? [...] Under those circumstances, I hope sincerely, the Board of Trustees would agree to release the funds, I need so badly.

I am sure that you now will agree with me, that it was a good idea to devote a period of our work for excavations in the $\mathrm{Ph}$. I. As you certainly have seen from the news-papers, Indochina is now closed like an oyster in its shells. Even if we had continued our fieldwork there, I am afraid we would not have had the possibility any more to export the products of the excavations. Now you may see, your-self, that I acted entirely in the interest of our expedition, when I proceeded to the Ph. I. and not for any personal reasons. ${ }^{779}$

777. Barker (referred to as Baker, but a handwritten text on the back of the original photo in Janse's archive (NAA: Janse 2001-29) says Barker) can be seen on a photograph in Janse's memoirs (Janse 1959:240).

778. Janse 1959:245.

779. Letter from O. Janse to S. Elisséeff, 23 September 1940. Harvard-Yenching Institute, Cambridge, Mass. Correspondence, 1938-1940. 
Now, with the situation getting quite severe, Olov and Ronny Janse were once again saved by their cosmopolitan networks. The Austrian-American autodidact botanist, linguist, and ethnographer Joseph Rock, who has been described as "a larger than life character, embodying many of the myths and stereotypes about the arrogant but knowledgeable EuroAmerican explorer during the first half of the twentieth century", ${ }^{780}$ had been working in South China in the late 1930 s but was evacuated to Indochina from China because of the Sino-Japanese war in 1938. He spent the years 1939-1940 in Dalat, where we may expect that he met and socialized with Olov and Ronny. During that time he was also connected with both the EFEO, of which he was a corresponding member just like Janse, and the Harvard-Yenching Institute..$^{781}$ After he too had chosen to leave Dalat and go to Manila, Joseph Rock wrote to Serge Elisséeff on 7 July that he had to leave Indochina because of the threat of the war, and was planning to proceed as soon as possible to Hawaii. He wrote further: "Have seen Dr. Janse here who is trying to leave for the States but all boats are booked full up to September." ${ }^{82}$ But already at the end of July, thanks to an intervention by Rock's personal friend Mr MacCarthy, who was chief passenger agent for the President Lines, Olov and Ronny got tickets on a ship departing only a couple of days later, on 1 August $1940 .{ }^{.83}$ And on the same day, as a small stroke of luck, their last portion of funding - US \$ 2000 - was released from the Harvard-Yenching Institute, even before Elisséeff had received Janse's last letter of 23 July. Maybe it was the letter from Joseph Rock a couple of weeks earlier that convinced Elisséeff that Janse was not telling tales about the situation in Indochina and the Philippines. Tired and relieved, after a quickly assembled farewell dinner with old and new friends in Manila, Olov and Ronny Janse embarked on the SS Pres. Cleveland bound for Kobe.

780. Yoshinaga et al. 2012:116.

781. Yoshinaga et al. 2012:121, 146-147.

782. Letter from J. F. Rock to S. Elisséeff, 7 July 1940, published in Walravens 2002:193-194.

783. Letter from O. Janse to S. Elisséeff, 28 July 1940. Harvard-Yenching Institute, Cambridge, Mass. Correspondence, 1938-1940. 


\section{POSTLUDE}

After a month-long stop in Japan, where Olov had another malaria crisis, ${ }^{784}$ and they felt that the attitude to foreigners was hostile and supplies were scarce, ${ }^{785}$ they proceeded on the SS Kamakura Maru to Honolulu where they arrived on 15 September. A very dramatic crossing with two typhoons and a fire on board added to the already stressful situation, ${ }^{786}$ so they were exhausted once they arrived in Honolulu. The sweet memories of their month-long stop in Hawaii after the second expedition made them decide to stay six weeks to rest and recover.

Soon after their arrival in Honolulu, on 24-26 September, Japanese forces seized control over Tonkin, to prevent China from importing arms and other goods via the railways in Indochina. From that point on, the situation deteriorated quickly, and before the war was over many of their friends and collaborators would have been killed or imprisoned.

They were invited to stay as guests in Molly Craig's "beautiful and comfortable" home in the Puunui district of central Honolulu. ${ }^{787}$ Molly Craig was a friend of Ann Y. Satterthwaite, ${ }^{788}$ Secretary of the Pan Pacific Union, whom they had met and befriended during their previous visit.

784. Letter from O. Janse to S. Elisséeff, 23 September 1940. Harvard-Yenching Institute, Cambridge, Mass. Correspondence, 1938-1940.

785. Letter from O. Janse to B. Nerman, 25 October 1940. Riksarkivet. Kartong 3. Korrespondens Brev III 1935-1941.

786. Letter from O. Janse to B. Nerman. Ibid.

787. Janse 1959:12; Honolulu Star Bulletin (Margaret Kamm) 9 October 1940: "Mrs Janse Assists Husband in Archaeology".

788. Wrongly referred to as Miss Saterswaith in Janse 1959:12. 
Again, they were cushioned by their networks, and spent some pleasant and restful weeks in Molly Craig's home in Honolulu. It seems as if they were regarded as an interesting couple who, despite their professional association with dirt and hard work, were surrounded with flair and panache. In an article in the Honolulu Star Bulletin, the reporter describes her meeting with "[a]ttractive Mrs. Janse, in richly brocaded gold and blue housecoat with matching blue shoes", on "the cool, spacious lanai of the Puunui home at which they are guests". ${ }^{789}$

Elisséeff wrote urging them to hurry on so they could arrive in Harvard on 1 November, which was in accordance with their agreement, and in good time before the Trustees' meeting on 18 November. ${ }^{790}$ But Janse insisted, with reference to his poor health and the difficulty in finding tickets, that they stay longer but promised they would arrive just in time for the meeting with the Trustees. ${ }^{791}$ And he got his way. Olov and Ronny stayed in Honolulu until 1 November. A few days before their departure, Olov wrote to Birger Nerman in Sweden:

Here in Hawaii we have had a wonderful time, and have mostly been resting after all the hardships in East Asia. Here we have met several American friends, who have been very hospitable and friendly to us and have driven us around Hawaii and shown us many interesting places. It is with sincere sadness that we now leave this paradise..$^{792}$

789. Honolulu Star Bulletin (Margaret Kamm), 9 October 1940: "Mrs Janse Assists Husband in Archaeology". See also article in Honolulu Star Bulletin (Margaret Kamm) 14 October 1940: "Dr Olov Janse, Archaeologist: Indo-Chinese Culture Traced to Cantonese".

790. Letter from S. Elisséeff to O. Janse, 18 October 1940. Harvard-Yenching Institute, Cambridge, Mass. Correspondence, 1938-1940.

791. Letter from O. Janse to S. Elisséeff, 25 October 1940. Ibid.

792. Letter from O. Janse to B. Nerman, 25 October 1940. Riksarkivet. Kartong 3. Korrespondens Brev III 1935-1941. In the Swedish original: "Här i Hawaii ha vi haft det underbart skönt och ha mest vilat upp efter alla strapatserna i Östasien. Vi ha här träffat flera amerikanska vänner, som varit mycket gästfria och vänliga mot oss och som kört oss ikring på Hawaii och visat oss många intressanta platser. Det är med uppriktig saknad vi lämna detta paradis.” 
They sailed from Honolulu on 1 November, ${ }^{793}$ and arrived in San Francisco six days later. On Janse's recommendation Elisséeff had informed the customs about their arrival, and had made sure that with reference to Janse's "Swedish special passport no. 256 " he was allowed to bring with him his unusual luggage filled with documentation from his expedition. ${ }^{794}$ From San Francisco they proceeded immediately to Cambridge, Massachusetts, where they arrived on 14 November, four days before the meeting and following dinner with the Trustees.

The following years were marked by the ongoing war. While Olov and Ronny sat safe in Harvard, the Japanese forces continued the invasion and reached southern Indochina in July 1941. In December 1941, a little more than a year after they had left Hawaii, the Japanese attacked Pearl Harbor near Honolulu. Only hours later came the Japanese attack on the Philippines. At the end of the Japanese occupation (1942-1945) and the US-Filipino attack to regain control over the capital in 1945, much of the inner city of Manila had been destroyed along with other towns and villages around the country. Hundreds of thousands of Filipino, Japanese, and US soldiers had been killed or captured. Lieutenant Joseph R. Barker, who accompanied Janse on his visit to the "Negrito Pygmies" near Fort Stotsenburg, fought together with guerrilla groups in the mountains until January 1943, when he tried to enter Manila disguised as a Catholic priest, was captured by the Japanese on 14 January and imprisoned for over eight months before he was executed on 1 November 1943.795 Many of the people Ronny and Olov met and interacted with in Indochina and the Philippines were killed, captured, or had their lives in other ways destroyed by the war. Otley Beyer refused to leave the Philippines, and moved his collections to different storages before being put in Japanese internment. As soon as the war was over, he began to rebuild the collections from the fragments that were salvaged..$^{796}$

793. Several ships are mentioned in different sources, and it is unclear which one they travelled with.

794. Letter from O. Janse to S. Elisséeff, 23 September 1940. Harvard-Yenching Institute, Cambridge, Mass. Correspondence, 1938-1940.

795. http://www.findagrave.com/cgi-bin/fg.cgi?page $=$ gr $\&$ GRid $=56774659$, accessed 17 May 2018.

796. Byrne 2014:139. 
In the meanwhile, Olov and Ronny were installed at Harvard University near Boston in Cambridge, Massachusetts, where they worked with their collections. They worked in the premises of the Semitic Museum, just across the road from the Peabody Museum, because there was not enough room for all their stuff in Boylston Hall (one of the old buildings at the centre of Harvard University, where the Harvard-Yenching Institute was located until 1958). ${ }^{797}$ Altogether, they had brought to the Harvard-Yenching Institute a collection of over 300 ceramic vessels, more than 4,100 potsherds, almost 400 coins, 5,500 beads, and more than 700 other artefacts. From Indochina alone there were 190 ceramic vessels, 4,009 potsherds, 5,307 beads, 375 coins, and 640 other artefacts or fragments. ${ }^{798}$ From the Philippines 126 ceramic vessels, 155 potsherds, 9 pieces of bone or teeth, and 98 other artefacts or fragments. ${ }^{799}$ And in addition to these, there were 200 beads in the reference collection from Kota Tinggi, Johore.

The Harvard-Yenching Institute had allocated two years of funding to sort out the collections, put them on display and write reports. Olov and Ronny continued to work together as a team. Olov was officially managing the work and did occasional public lectures about their work, for instance at Salon Français de Boston and Boston Women's City Club (the latter with the title "Highways and Byways in French Indo-China"), while Ronny was employed as Technical Assistant to the Harvard-Yench-

797. Letter from S. Elisséeff to O. Janse, 17 May 1940. Harvard-Yenching Institute, Cambridge, Mass. Correspondence, 1938-1940.

798. From a detailed list in Harvard-Yenching Institute, Cambridge, Mass. Correspondence, 1938-1940, with a copy in the Peabody Museum: Sa Huynh: 22 ceramic vessels, 1123 potsherds, 255 beads, 117 other artefacts; Bim Son: 35 ceramic vessels, 1092 potsherds, 223 Chinese coins, 72 other artefacts; Chau-rê: 3 ceramic vessels, 202 potsherds, 5 other artefacts; Dong Son: 7 ceramic vessels, 63 bronze objects, 20 Chinese coins, 34 other artefacts and fragments; Ham-rong: 2 ceramic vessels, 3 other artefacts; Lien-hung: 1 artefact; Phu-coc: 4 ceramic vessels, 129 potsherds, 17 other artefacts; Vantrai: 29 ceramic vessels, 93 potsherds; Vuc-trung: 22 potsherds, 1 other artefact; Ngocam: 15 ceramic vessels, 38 potsherds, 5000 glass beads, 21 other artefacts, 1 tooth/bone fragment; Man-thon: 26 ceramic vessels, 124 potsherds, 52 beads, 123 bronze coins, 46 other artefacts or fragments; Unknown site, Thanh Hoa: 45 ceramic vessels, 8 bronze coins; Tam-thô: 2 ceramic vessels, 1186 potsherds, 73 artefacts, 1 coin, 166 tile fragments; Unknown site, Tonkin: 1 artefact; Somrong Sen: 19 bronze artefacts.

799. From a detailed list in the Peabody Museum: 120 ceramic vessels, 154 potsherds, 9 pieces of bone/teeth, 97 other artefacts or fragments; Luzon, sites unknown: 6 ceramic vessels, 1 potsherd, 1 other artefact. 
ing Expeditions of the Far East. In January 1941 Olov wrote to Ture Nerman that they had got excellent premises to work in, and that he was writing a catalogue of the finds in preparation for an exhibition, which he hoped would open in March. He concluded saying that although the United States for the moment was a good country to live in, they were longing to go to Sweden..$^{800}$

It took a little longer than they had hoped, so the first exhibition of their collections opened at the Fogg Museum on 7 May 1941. The invitation card read:

The Trustees of the Harvard-Yenching Institute invite you to be present at the opening at four o'clock on May 7, 1941, at the Fogg Museum of Art, Cambridge, Massachusetts, of the exhibition of the finds of the archaeological expedition which Professor Olov Janse conducted in Indochina under the auspices of the Institute in collaboration with the Ecole Française d'Extrême-Orient. Professor Janse will give a short talk in the gallery at 4:30 o'clock, to be followed by a tea in the Naumberg Room.

R.S.V.P.

17 Boylston Hall, Cambridge, Massachusetts ${ }^{801}$

The press announced before the opening, that "a Harvard-Yenching Institute expedition has brought back to the university the largest and most remarkable collection of antiquities ever imported from that region", and that the exhibition was "the only exhibition of its kind ever held in the United States" ${ }^{802}$ On the occasion of the exhibition, Janse had also produced a short preliminary report, published in Serge Elisséeff's Harvard Journal of Asiatic Studies. ${ }^{803}$ The exhibition was on display at the Fogg

800. Letter From Olov Janse to Ture Nerman, 3 January 1941. Arbetarrörelsens arkiv och bibliotek. Ture Nerman 3.1.24.

801. NAA: Janse 2001-29.

802. Boston Herald, 4 May 1941: "Fogg Art Museum to Exhibit Rare Indo-China Antiquities"; Boston Sunday Post, 4 May 1941: "Brings Harvard Rare Antiques from China”; Boston Sunday Globe, 4 May 1941: "Fogg Museum to Exhibit Rare Indo-China Relics found in Ancient Tombs"; New York Herald Tribune, 4 May 1941: "Harvard Group To Show Relics Of Indo-China: Big Collection of Antiques Found by Expedition To Be Placed on Exhibition".

803. Janse 1941. 
Museum for a month, and Janse wrote later in a letter to Birger Nerman that it had attracted unexpected numbers of visitors, and that the press reports had been very positive. ${ }^{804}$

In the same letter to Nerman, Janse also writes that he had got a new office in the Peabody Museum (the University's museum for ethnography and archaeology), where they were preparing for another display of their collections. He writes further that he had been appointed "Lecturer of Far Eastern Archaeology" at Harvard for the next academic year. This was a title, he explains, that was awarded to visiting professors from abroad, who lecture on subjects outside of the ordinary curriculum. And he adds, rather proudly, that Paul Pelliot and Albert Einstein had the same title when they lectured at Harvard some years ago: "It is thus quite an honourable position, pity though that it lasts only a year."

The second exhibition opened at the Peabody Museum on 7 April $1942 .{ }^{806}$ A note in one of Janse's publications suggests that it was shown much longer than the display at the Fogg Art Museum, and that it was paralleled by another display in the Library of the Harvard-Yenching Institute (both 1942-1943). ${ }^{807}$ In October 1948 the collection was formally deposited, as a loan from the Harvard-Yenching Institute, in the Peabody Museum where it remains today. ${ }^{808}$

Olov Janse continued to write on his three report volumes from Indochina, which were published in 1947, 1951, and 1958. A fourth volume was planned to contain reports from Sa Huynh, but was never realized. ${ }^{809}$ Apart from the report writing, the exhibitions at Harvard were in many ways the end of Olov Janse's career in academic archaeology. The form of archaeology that he pursued - comparative studies based on diffusion as model of explanation, with much focus on museums and artefact collec-

804. Letter from O. Janse to B. Nerman, 6 August 1941. Riksarkivet. Kartong 3. Korrespondens Brev III 1935-1941.

805. Ibid. In the Swedish original: "Det är alltså en rätt hedersam ställning, synd blott att den varar bara ett år."

806. E.g. The Christian Science Monitor, Boston 4 April 1942: "Rare Archaeological Finds at Peabody Next Week". We have found no information in the Peabody Museum or the Harvard-Yenching Institute Archives about this display.

807. Janse 1944:38.

808. With the exception of a donation of parts of the collection to the Vietnam History Museum (former Musée Blanchard de la Brosse) in Saigon (now Ho Chi Minh City) in 1963. This donation will be discussed in the chapter "Cocktails and Public Diplomacy".

809. Janse 1959 b. 
tions - would be terribly out of fashion after the war. And perhaps more importantly, the war situation also provoked a new and different interest in his knowledge and experiences of Southeast Asia. After the opening of their exhibition at the Peabody Museum, his work was featured with a somewhat different angle, with more emphasis on the contemporary situation in Asia. In August 1942 an article was published in The American Swedish Monthly, with the title "After having made Valuable Discoveries in Indo-China, Swedish Archaeologist Saves Rare Collection from Japanese Invaders" ${ }^{810}$ His public lectures now had titles such as "With Spade and Camera in Indochina", ${ }^{811}$ "A Travers le Cambodge Français", ${ }^{812}$ and "L'Action civilisatrice de la France dans son Empire: France et Indo-Chine". ${ }^{813}$

On 20 July 1943 he gave a lecture with the title "Indo-China and its People" at a two-day conference at the Institute on Asiatic Affairs in American Education at Harvard. In this lecture he claimed that "one of the most significant and essential steps ahead in international relations in our time is the effort to gain the point of view of the peoples of other lands", and said that Westerners" "failure to understand the mind of the Asiatic" was a crucial cause of conflict in the Far East. In particular he stressed how important it was to "understand and be generous with the religious feelings of the people where we have gone in and sought to introduce a modern economy". ${ }^{814}$ Janse's talk was very well received, and here he found a new field where he could make use of his knowledge and skills: that of international relations. Lecturing at the same Harvard conference in July 1943 was Howard E. Wilson, who would become Janse's main contact when he applied three years later for a position at UNESCO in Paris. But before then, Olov and Ronny Janse would be employed by the United States Intelligence Service, at the Office of Strategic Services.

810. The American Swedish Monthly (N.Y.): (F. N. Hollingsworth), August 1942: "After having made Valuable Discoveries in Indo-China, Swedish Archaeologist Saves Rare Collection from Japanese Invaders".

811. Public lecture at the Institute of Geographical Exploration, Harvard University, 14 December 1942.

812. Lecture at L'Alliance Française de Worcester, Massachusetts, 24 January 1943.

813. Lecture organized by France Forever, at the College Club, Boston, 10 March 1943.

814. Christian Science Monitor (Millicent Taylor) 21 July 1943; "Gaining Views Of Other Lands Held Essential"; See also Janse's lecture referred to in Hayter-Menzies 2013:114. 


\section{EXPERTISE}




\section{PRIVILEGED EXILE}

How can we understand Ronny and Olov Janse's situation in the United States during and after the war? In the past few decades, much research in humanities and social science has been devoted to experiences of mobility, such as that of the immigrant, the emigrant, the traveller, the refugee, and the exile. Much of this research has been done in the United States, often portrayed as a nation built on immigration, where concepts of race, language, and ethnicity, and questions of rights and belonging are continuously debated. In this context, what constituted Olov and Ronny Janse's identity in the years during and after the war? Can we talk about them as refugees, since they fled from a situation of war, when in fact they were invited for professional reasons?

In his book Guarding the Golden Door, Roger Daniels discusses refugee immigration, mostly Jews from Europe, to the United States during the 1930 s, framed in the complicated political situation of the United States at the time. ${ }^{815}$ During the war, the US immigration system was reformed several times. For example, Japanese, German, and Italian people were declared non-citizens in 1941. This category was later expanded to include Hungarians, Bulgarians, and Romanians. ${ }^{816}$ But Ronny and Olov Janse were not refugees, not in the sense of someone who had fled from a home where they could not survive if they stayed. They were willingly relocated, not violently displaced.

815. Daniels 2004:76-78.

816. Daniels 2004:87. 
Although it was a time and situation of war, Olov and Ronny Janse were invited to the United States and immediately employed at a high level of society. They were helped by being Swedish citizens, with professional skills and the valuable "booty" of artefacts they had brought, which enriched their new country and sparked the interest of many influential people who were also interested in the collection of art and artefacts from faraway lands. Of course they had to follow the rules and regulations of the new country, but they were, like many other professionals from Europe, viewed as resources and not primarily as refugees or immigrants. That does not, however, take away the feelings of loss or longing that tend to come with displacement.

Based on these factors, Olov and Ronny Janse's situation can best be understood, we believe, as a situation of privileged exile. This is something different from the experiences of refugees, immigrants, or victims of violent displacement. There is one category that they might fit into and that is the "eminent refugees", defined by Roger Daniels with a quotation from a US State Department report: "those with superior intellectual attainment, of indomitable spirit, experienced in vigorous support of liberal government and who are in danger of persecution or death at the hands of autocracy". ${ }^{17}$ Although they were not at any particular risk in their home country, they did support liberal governments and they did carry with them both experiences and skills that were sought after in the United States. Remember how Olov Janse proudly remarked in his letter to Birger Nerman that Einstein and Pelliot carried the same title as he now did, when they lectured at Harvard some years earlier. ${ }^{818}$ Being perhaps the model figure for an "eminent refugee", Albert Einstein emigrated from Germany to the United States in 1933.

The situation of privileged exile leads inevitably to questions of language, race, and ethnicity. It appears as if Ronny and Olov Janse stepped straight into academic life at Harvard University. At this time they had mostly French friends from their time in Paris and in Indochina, and the new American friends they had made in Buffalo, Manila, Honolulu, and at Harvard. Their white Caucasian race, ${ }^{819}$ Olov's Swedish ethnicity, Ron-

817. Daniels 2004:84.

818. Letter from O. Janse to B. Nerman, 6 August 1941. Riksarkivet. Kartong 3. Korrespondens brev III 1935-1941.

819. See Jacobson 2006 for a discussion of the importance of race, ethnicity, and language in US academic discourse. See also Fishman 1989. 
ny's bourgeois Russian background, their French sentiments, and broad language skills arguably helped them make American friends and create a new professional network in the United States - also because what they were not. Unlike the more loaded German, Italian, or Japanese ethnicities, the Swedish ethnicity had a more positive, "neutral" aura. And moreover, it seems as if Ronny's exotic "Caucasian temperament" and ex-Soviet bourgeois background gave them prestige and standing among American colleagues. ${ }^{820}$ Hence it can be argued that their Caucasian race, white skin colour, Scandinavian and Russian ethnicities, and their broad language skills demonstrating adaptability, were great assets in Olov and Ronny Janse's situation of privileged exile.

On the whole, we do not know much about Ronny and Olov Janse's first years in the United States. They kept no diaries and wrote few letters. The remaining fragments from the years after they arrived in Harvard in November 1940 have a glossy surface of success - after all they had made it to America, the promised land of the future. Yet, between the lines, we sense anxiety, insecurity and pain. To fill in the gaps and inform our interpretations, we shall juxtapose the few fragments we have with other experiences and analyses of exile in literature and theory from the mid-twentieth century onwards. In essence, this large and growing body of literature and theory explores exile as a situation of pain and loss, which can at the same time offer a new creative position for an artist, writer, or academic scholar. ${ }^{821}$ But most of this literature and scholarship refers to exile that is the result of a one-way movement: from a stable home or point of origin, to a precarious and vulnerable exile situation in an entirely foreign land. And this is not a fair description of Ronny and Olov Janse's situation in the United States. They did not depart from one stable and secure home, and their situation in the United States was in many ways a privileged exile. Long before the war they had both chosen a travelling cosmopolitan lifestyle built on constant displacement; she in response to a life-threatening situation in Stalin's Soviet Union, and

820. The different "waves" of Russian immigration to the United States is a complicated story discussed by Matthew Frye Jacobson in the book Roots Too (2006).

821. E.g. Robinson 1994; Robertson et al. 1994; Said 2000; Kim Thúy 2009: Trinh 2011. 
he in aspiration to be part of a larger Francophile world built on internationalist ideals beyond the German-oriented nationalism that was growing in Sweden. They had both, for different reasons, chosen to live and work outside their native countries' borders, and knew well how to move and survive in the social and administrative spaces in-between nation states and cultural contexts. For Ronny, moreover, exile in the face of violence had long been an established way of life.

The previous chapters have demonstrated how they used their language skills and worked their social networks to manoeuvre through hardship and turn difficulty into success. Their trajectories resonate with Marc Robinson's words on the importance of choice and purpose for the experience of exile: "the restlessness of the nomad has greater purpose than the stateless. [...] The traveller moves with a surer gait and follows a looser rhythm than the tourist." ${ }^{222}$ Moreover, in the context of $1940 \mathrm{~S}$ east coast United States, the colour of their skin, their Christian religion, their Swedish citizenship and his academic titles were all factors that signalled a privileged social standing and softened the impact when they found themselves in involuntary exile. It did not, however, make them immune to sentiments shared by many people in exile. The following excerpt, from a letter to Birger Nerman in March 1945, is typical of the few letters they wrote in the years during and immediately after the war. Even though they were comfortable and aware of their privileges in the United States - "We live here in great prosperity and have had a lovely summer" ${ }^{23}$ - they suffered from serial medical conditions and were consumed with longing to return "home".

We have now begun to make plans for a "home" trip (if I may say so) and expect to be able to embark on it in the autumn or in the coming winter. We are sincerely longing to see you again. We have met many sympathetic people here. Unfortunately, we do not fully tolerate the rather difficult climate here, and are often affected by diseases of some kind. Ronny has undergone another complicated operation (infection in the jaw) but is now almost fully recovered and on her feet again. We had an out-

822. Robinson 1994:xiv.

823. Letter from O. Janse to B. Nerman, 20 September 1942. Riksarkivet. Kartong 4. Korrespondens Brev IV 1942-1946. In the Swedish original: "Vi lever här i högönsklig välmåga och har haft en härlig sommar." 
standingly skilled doctor. Myself, I now and then suffer from my malaria. ${ }^{824}$

Homecoming is an issue of great concern for any cosmopolitan. Madan Sarup has defined homecoming as being "not the usual, everyday return, it is an arrival that is significant because it is after a long absence, or an arduous or heroic journey". ${ }^{825}$ In this sense, homecoming is linked to a discourse of travel in which the traveller departs from a place and returns to the same place, enriching that place and his own cosmopolitan identity with a booty of knowledge, experience, and souvenirs. ${ }^{826}$ Moreover, this kind of travelling is linked to the concept of narrative, which, "as a structure of development, growth and change - the acquisition of knowledge and solution of problems - is conceived as a physical process of movement, of disruption, negotiation and return". ${ }^{827}$ We have seen how Olov and Ronny Janse in the years before the Second World War built a reputation on such enriching travels and triumphant homecomings, where they brought with them not only a booty of knowledge and experience, but also travel stories, archaeological documentation and valuable artefacts for metropolitan museum collections. When a traveller like Olov Janse departed and returned from missions sanctioned by large institutions such as national museums, it was a matter of national concern and personal pride.

In the years during and after the Second World War, homecoming became, in an inverted way, equally important for Olov and Ronny Janse's identities. Homecoming then took the form of impossibility and longing - an inversion of the triumphant homecoming of the celebrated cosmopolitan. Speaking with Edward Said, "the pathos of exile is the loss of contact with the solidity and the satisfaction of earth: homecoming

824. Letter from O. Janse to B. Nerman, 3 March 1945. Riksarkivet. Kartong 4. Korrespondens Brev IV 1942-1946. In the Swedish original: "Vi börja nu att göra planer för 'hem'-resa (om jag må säja så) och beräknar kunna anträda densamma i höst eller under kommande vinter. Vi längta uppriktigt att träffa Eder igen. Vi ha här träffat många sympatiska människor. Tyvärr tåla vi ej riktigt det rätt så prövande klimatet här, och har ofta en eller annan åkomma. Ronny har igen genomgått en besvärlig operation (infektion i käken) men är nu nästan fullt återställd och på benen igen. Vi hade en utmärkt skicklig läkare. Själv har jag då och då känning av min malaria.”

825. Sarup 1994:91.

826. Stewart 1993.

827. Curtis \& Pajaczkowska 1994:197. 
is out of the question". ${ }^{828}$ Conceived from Said's own experiences of exile, arriving as an elite Palestinian in the United States in 1951, his famous essay Reflections on Exile begins with the oft-cited sentence: "Exile is strangely compelling to think about but terrible to experience." Notwithstanding the many apparent differences, there are also similarities between Edward Said's and Olov and Ronny Janse's experiences of exile. They once belonged to a privileged class, were exiled under privileged circumstances, and later became successful American academics. Said says: "while it is true that literature and history contain heroic, romantic, glorious, even triumphant episodes in an exile's life, these are no more than efforts meant to overcome the crippling sorrow of estrangement. The achievements of exile are permanently undermined by the loss of something left behind forever." ${ }^{229}$ Letters and later poetry in Olov and Ronny Janse's archive testify to recurring illness, depression, and feelings of loss in the decades after they arrived and settled in the United States. Here is a letter from Ronny to her friend Marie-Rose Loo in Paris, written in April 1942:

\section{Dearest Rose -}

You must wonder about this involuntary delay of my reply. You will understand without doubt if I tell you that all this last month, I have filled my time with making a thousand and one steps to obtain our permanent visa. It has taken so long! But you must know something. Now, finally, it's done! We had to make a trip to Canada to complete the long series of formalities.

Your letter has been a great comfort to me, especially in moments when I find myself caught in distress. How right you are when you say that time is the best remedy. I have already come to understand that. But I feel much better now and I even begin to have trust in the future.

What a shame that the spring is late to arrive and the sun, usually so generous in this country, does not show up, when we need it so much! [...]

I understand your grief being deprived of news of your loved

828. Said 2000:179.

829. Said 2000:173; see also Trinh 1994:11. 
ones. I hope that we will all soon come out of this cruel isolation that torments us all. ${ }^{830}$

Similar to the situation depicted by Edward Said, this private sense of sadness and loss appears to be balanced by, yet always remaining in tension with, an official image of success and achievement. Unlike many other exiled people in the United States, Ronny and Olov Janse received permanent visas, and later became US citizens. ${ }^{8{ }^{81}}$ Thanks to their previous international experience and strong networks they were offered stimulating job positions, ${ }^{832}$ and they continued to nurture and enrich their social networks with interesting acquaintances and influential friends. They were drawn to people who shared their passionate anti-Nazi, pro-French sentiments and met for instance with the critical French journalist Geneviève Tabouis, who was known for her strong voice and warnings against Hitler already before the Second World War, and who spent five years in the United States during the war. ${ }^{833}$ At a distance they supported Ture Nerman when he was convicted in 1939 and imprisoned one month for criticizing Hitler in his own journal Trots Allt!. Following Nerman's release from prison, Olov wrote him a letter: "It is pathetic to think that Berlin is now

830. Letter from Ronny Janse to Marie-Rose Loo, 12 April 1942. NAA: Janse 200129. In the French original: "Bien Chère Rose- // Vous devez vous étonner de ce retard involontaire de ma réponse. Vous comprendrez sans doutes si je vous dis que tout ce dernier mois, j'ai remplis mon temps à faire mille et une démarche pour obtenir notre visa permanente. Cela a été très long! Vous devez en savoir quelque chose. Maintenant, enfin, c'est fait! Nous avons du faire un voyage au Canada pur terminer la longue série de formalités. // Votre lettre a été pour moi d'un grand réconfort, surtout dans un moment ou je me trouve dans une mauvaise impasse. Combien vous avez raison quand vous dites que le temps est le meilleur remède. Je m'en suis déjà rendue compte. Or, je me sens beaucoup mieux et je commence d'avoir même de la confiance dans l'avenir. // Quel dommage que le printemps se fait attendre et que le soleil, habituellement si généreux dans ce pays, ne se montre plus, quand on en a tant besoin! // [...] Je comprend votre chagrin d'être privée de nouvelles des vôtres. J'espère que nous sortirons tous dans un avenir prochain de cet isolement cruel qui nous tourmente tous."

831. See the chapters "Darling, Dearest" and "Renée".

832. See the chapters "OSS and the State Department", "Darling, Dearest", and "Renée".

833. Letter from O. Janse to T. Nerman, 3 January 1941. Arbetarrörelsens arkiv och bibliotek. Ture Nerman 3.1.24. 
ruling in Sweden. Hope, however, that Ture has been well treated." ${ }^{34}$ They kept in touch with Sweden through occasional letters to uncle Otto, Ture, Birger and Barbro Nerman. And when Birger's twin brother Einar Nerman came to visit the United States with his wife Kajsa in the spring of 1944, they met Olov and Ronny (for the first time in ten years) at the residence of the Swedish Ambassador in Washington, DC. ${ }^{835}$ But most of their social efforts were spent on enriching and strengthening their new networks of friends in and around Harvard and Washington, DC. After the summer 1942, Olov wrote glowingly to Birger Nerman about their wonderful summer with friends in New Hampshire:

For one and a half months we have been in New Hampshire together with some lovely American friends from Boston. They own the major part of a small lake with islands in it. On one of these, they have a guest cottage with three rooms, a kitchen and a veranda, which was made available to us during the summer. We have rested, swum and sunbathed in landscape reminiscent of the Stockholm archipelago with pine, fir and granite rocks. Blueberries as big as grapes grow on two-metre-tall bushes. We often used to go round the corner of the house and pick a meal. ${ }^{836}$

Their socializing depended on both cultural sensitivity and language skills. Olov Janse was an homme de lettres, and had based much of his earlier work on his ability and talent for translation. In addition to his native Swedish he was fluent in French and English and also had a decent knowledge of German. For him and Ronny, the dependency on a second

834. Ibid. In the Swedish original: "Det är bedrövligt att tänka att Berlin nu regerar i Sverige. Hoppas emellertid att Ture blivit väl behandlad. [...]"

835. Letter from O. Janse to B. Nerman, 14 April 1944. Riksarkivet. Kartong 4. Korrespondens Brev IV 1942-1946.

836. Letter from O. Janse to B. Nerman, 20 September 1942. Riksarkivet. Kartong 4. Korrespondens Brev IV 1942-1946. In the Swedish original: "Har varit c:a 1 1/2 månad i New Hampshire tillsammans med några förtjusande amerikanska vänner från Boston. De äger där större delen av en liten insjö med tillhörande öar. På en av dessa har de en gäststuga med tre rum, kök och veranda, som ställdes till vårt förfogande under sommaren. Vi har vilat oss rott, badat och solat oss i en natur som påminner om Stockholms skärgård med tall, gran och gråstensklippor. Blåbär, stora som vindruvor, växer på c:a $2 \mathrm{~m}$ höga buskar. Vi brukade ofta gå ut kring husknutarna och plocka ett mål.” 
or third language was a familiar situation long before they ended up in exile in the United States. From the beginning of their married life in 1930, they spoke French or English rather than Swedish or Russian with each other. But their mastery of several languages did not necessarily take away the language side to the trauma of exile, and this may be one reason why Olov Janse chose to write his memoirs in Swedish long after he had lost hope of returning to live there. ${ }^{87}$ Trinh T. Minh-ha, who migrated to the United States as a refugee from Vietnam in 1970, has said that writers in diaspora can experience a double exile, "away from their native land and away from their mother tongue"..$_{38}^{8}$ When Janse found himself in exile and lost touch with his mother tongue in his everyday life, his dependency on second languages was probably to some degree connected with sorrow and loss. But his mastery of these languages had offered, and would continue to offer him considerable privileges as a cosmopolitan academic. In a similar mode, exile can be understood as being fundamentally defined by loss, and at the same time offering a privileged creative position. Speaking with Madan Sarup: "Exile can be deadening but it can also be very creative. Exile can be an affliction but it can also be a transfiguration - it can be a resource." ${ }^{89}$ From their work in Paris and Stockholm in the 1920 s and early 30s, they had both developed a capacity to translate social and cultural practices. Their capability to fit in, to understand and even master different social, cultural, and linguistic contexts, would continue to open new opportunities and allow for their seemingly smooth adaptation to changes in world politics.

In modern Western culture today, says Trinh T. Minh-ha, "[identity is a product of articulation. It lies at the intersection of dwelling and travelling and is a claim of continuity within discontinuity (and vice-versa). [It is a] politics rather than an inherited marking." ${ }^{80} \mathrm{With}$ the constructivist approaches to identity that came with social theory of the late twentieth century, it has become possible to regard exile as a privileged perspective, offering a plurality of vision and awareness of simultaneous dimensions. And such pluralities of visions, it has been argued, have constituted the building blocks of American academia and other intellectual and creative

\footnotetext{
837. Janse 1959 .

838. Trinh 2011:12.

839. Sarup 1994:94.

840. Trinh 1994:13.
} 
settings in the world after the Second World War. ${ }^{841}$ For the remaining chapters of this book about Olov and Ronny Janse, it makes sense to keep in mind this Janus-faced nature of exile - as a privileged creative position and the painful experience of an insatiable hunger for belonging and recognition. ${ }^{842}$

841. Said 2000:173, 186.

842. Letter from O. Janse to B. Nerman, 20 September 1942. Riksarkivet. Kartong 4. Korrespondens Brev IV 1942-1946. 


\section{OSS AND THE DEPARTMENT OF STATE}

The Swedish-American archaeologist Olov Janse lectures tonight about Indochina to the Royal Academy of Letters, History and Antiquities at the Nordic Museum. During the war, Professor Janse was working with psychological warfare in the United States, and his work primarily concerned Indochina. ${ }^{843}$

Following the capitulation of France in June 1940, a number of faculty members at Harvard University had organized a "defense group". Its purpose was to provide information about the situation in Europe and Asia, and give scholarly support to the war efforts in the United States and among its allies. Before the war ended, the group, officially named "American Defense, Harvard Group", had gathered more than 1,700 members and 240 active volunteers, among whom were Olov and Ronny Janse. They were encouraged to join the group after the attack on Pearl Harbor, about a year after they had returned to Harvard from their last expedition. In addition to practical arrangements to help refugees, and various initiatives to support military morale, the Defense Group pursued tasks that bordered on intelligence service, in the form of translations and analyses of foreign language radio and press reports. With her broad

843.Dagens Nyheter, 8 June 1955: "Indokinaforskare gästar Stockholm”. In the Swedish original: "Den svenskamerikanske arkeologen Olov Janse föreläser i kväll inför Vitterhetsakademien på Nordiska Museet om Indokina. Professor. Janse var under kriget sysselsatt med psykologisk krigföring i US A och främst var det Indokinafrågor som han fick ägna sig åt.” 
language skills, Ronny must have made a significant contribution to the group, which at its peak had thirty-five different languages represented among its members. ${ }^{84}$ Olov joined a sub-section with special focus on cultural heritage: The Committee on the Protection of Monuments. The members of this section had special knowledge of foreign countries and regions affected by the war, and they compiled lists of monuments in need of attention and protection in a situation of war. Greg Bradsher at the US National Archives has studied these lists and describes their overall purpose and format:

The longer lists were prefaced by an introduction outlining the significance of the material in the national and religious sentiment of the country in question, and a short historical outline. Each list was prepared by individuals or groups with special knowledge of the countries concerned, and included material not to be found in guidebooks. Throughout, special care was taken to include material which for any reason was treasured or revered by the local population, quite apart from any general historical or artistic interest. ${ }^{845}$

Olov Janse wrote one such long list: "List of Monuments in INDOCHINA by Olov R.T. Janse" ${ }^{846}$ Following very closely the format sketched by Bradsher, Janse's text gives a culture-historical background to the monuments of Indochina, with strong emphasis on the parts of Annam and Tonkin where he had worked during his three expeditions. He explains the importance of both Buddhism and animism, and he emphasizes that it is pivotal to consider the importance of spirits for the native populations in order to understand any cultural heritage of Indochina. The list of monuments (which includes museums, art collections, private collections, scientific institutions, libraries and archives) is clearly influenced by Janse's own work and travel experiences. It has a strong emphasis on Tonkin and Annam, particularly Hanoi and Thanh Hoa

844.http://oasis.lib.harvard.edu/oasis/deliver/ hua12007

845. "The American Defense, Harvard Group's Committee on the Protection of Monuments", blogpost by Dr Greg Bradsher 28 August 2014, The Text Message Blog. https:// text-message.blogs.archives.gov/2014/08/28/american-defense-harvard/

846. Now kept in Harvard University Archives. Pusey Library-Harvard Yard. Cambridge, Mass., US A. 
with surroundings, while Cochinchina, Cambodia and Laos are treated more superficially.

On Christmas Eve 1942, when Olov Janse had been Visiting Lecturer at Harvard University for two years and a year after they had joined the Defense Group, Kennard Rand, who was at the time Pope Professor of Latin at Harvard, wrote a letter to Professor Harold J. Coolidge at the Office of Strategic Services - a new secret intelligence organization in Washington, DC. Rand wrote that the University would not have any funding to support Janse's position as Visiting Lecturer after 1942, but suggested that he might be useful to the OSS. ${ }^{847}$ Coolidge responded a week later, on 1 January 1943 that he would contact Janse personally, adding: "Experts on Indo-China outside of the missionary field are surprisingly rare." ${ }^{48}$

After a short sojourn as consultant to the Board of Economic Warfare beginning in October 1943, Olov Janse was appointed to a position at the Morale Operations (MO) for OS S in Indochina, while Ronny worked as an OSS biographical analyst. They left Harvard in Cambridge Massachusetts, and moved to Washington, DC, where the OSS headquarters were located in the Old Naval Observatory on 23 rd and E Street. Two years later OSS was dissolved, and in September 1945 they were both transferred to the US Department of State where Olov became Deputy Chief of the South-East Asia section of the Research and Analysis Branch, ${ }^{849}$ and Ronny continued as biographical analyst. ${ }^{850}$

The Office of Strategic Services, which is often referred to as the OSS, is known as the predecessor of the CIA. It had been founded by President Franklin D. Roosevelt in June 1942. It sprung out of a need to have an organized body for international intelligence on US state level, which had not existed prior to the Second World War. The OS S was in many ways the child of one man: William Joseph "Wild Bill" Donovan (18831959) who became its first and only director. Donovan, who has been described as "a Hoover republican, an Irish Catholic, and a millionaire

847.Letter from K. Rand to H. Coolidge, 24 December 1942. National Archives at College Park, MD. Records of the Office of Strategic Services (Record Group 226), Entry 92, Box 197.

848. Letter from H. Coolidge to K. Rand, 1 January 1943. Ibid.

849. NAA: Janse 2001-29; Solheim 1984-85:10.

850. Renée Janse's Personal History Statement, July 1950, NAA: Janse 2001-29. 
Wall Street lawyer", ${ }^{851}$ was "charismatic, intellectually unconventional, a bit chubby, and certainly not elegant, intensely loyal to those loyal to him, and apparently without fear". ${ }^{852} \mathrm{He}$ was a personal friend to the President (although they represented opposite political parties) and had his full support in building the new intelligence organization. Widely travelled and with strong international networks since the First World War and the inter-war years, Donovan found international inspiration for the organization in the British MI6 (also known as the Secret Intelligence Service). ${ }^{85}$ With direct backing from President Roosevelt, Donovan had ample resources and encouraged the development of new creative ways to retrieve, process, analyse, and use intelligence data, at almost any cost. ${ }^{854}$ Hence the OSS is often associated with innovative James-Bond-style methods of espionage, especially among its field agents.

But Wild Bill Donovan was not only a daredevil recruiting fearless young spies and soldiers for extraordinary missions to foreign lands. Above all, it seems, he was a firm believer in the power of academic knowledge and analysis. The historian Robin Winks writes that "he had a high regard for professors, placing them above diplomats, scientists, and 'even lawyers and bankers'; he valued their 'card index' mentality". 855 The foundation for OSS therefore rested on academics from Harvard, Yale, and other Ivy League universities. Most were well-connected, wealthy men with a high level of cultural capital from the US academic, political, and social elite. ${ }^{856}$ An example is Harold Coolidge, who got the letter from Kennard Rand and took the first steps to have Janse involved with the OSS. Harold Jefferson Coolidge (1904-1985), a descendant of Thomas Jefferson, was a zoologist and expert on exotic mammals with degrees from the universities at Harvard and Cambridge, UK. Having participated as an assistant in a zoological expedition to central Africa in his early twenties, at the age of 24 he became leader of the Indochina part of the "Kelley-Roosevelt Asian Expedition for Chicago's Field Museum of Natural History", funded by Theodore Roosevelt's two sons Theo-

851. Smith 2005:1.

852. Winks 1996:64.

853. Smith 2005:24.

854. "Inevitably, activism also meant waste. Donovan procured for OSS an unlimited (and largely unvouchered) budget that ran into the hundreds of millions during the four years of war" (Smith 2005:3).

855. Winks 1996:67; see also Smith 2005:11.

856. Winks 1996. 
dore, Jr and Kermit, who desired to hunt and collect big game such as the giant panda. ${ }^{857}$ After the expedition's successful return to the United States, Coolidge became curator of mammals at Harvard University's Museum of Comparative Zoology, and later became the founding director of the World Wildlife Fund. ${ }^{858}$ Coolidge was in many ways typical of a high-ranking OSS officer. Like Coolidge, many of the men Donovan recruited to high positions in the OSS were young but already with established Ivy League university careers. They were wealthy and well travelled, with family, professional and social networks connecting them to the political elite of the United States.

In addition to the OSS branches that are perhaps most commonly associated with creative and adventurous espionage, such as Secret Intelligence and Special Operations, the OS S had a much broader base back in the United States, and involved as much as 13,000 personnel at its apogee in 1944. It was a hybrid military-civil organization and had branches for Counterespionage, Research \& Development, and units for Field Photography, Communications, Special Funds, and Medical Services. Last but not least were the two branches where Olov Janse worked: Morale Operations (MO) and Research \& Analysis (R\&A). ${ }^{859}$

The Morale Operations (MO) branch was established in January 1943 with the mission to perform psychological warfare, particularly in the form of false propaganda and the spread of rumours. By means of radio broadcasts, letters, postcards, leaflets, and other printed materials, the MO branch produced information and "black" propaganda that was communicated and advertised as if it came from the enemy or resistance movements. The intention was to create a sense of distrust, insecurity and ultimately chaos among enemy forces and civilians. ${ }^{860}$ It was a highly creative task performed mainly by psychologists, writers and other intellectuals. The MO branch was mostly focused on Europe and the Axis powers. As far as we can see, Olov Janse worked for the MO branch for two years, from August 1943 to September 1945. He worked with issues concerning Indochina and the Far East and wrote one MO report with the title Some Methods of Japanese Penetration in French Indochina Previous to

857. Coolidge \& Roosevelt 1933.

858. Sullivan 1985 .

859. Chalou 2002; Smith 2005; Liptak 2009.

860. Liptak 2009:9. 
the $\mathrm{War}^{861}$ almost immediately after he joined the OSS in August 1943. The Research \& Analysis (R\&A) branch, where he was working after the transfer to the State Department in September 1945, appears in many ways to have been a more suitable section for Olov Janse's profile and expertise. The R\&A staff were responsible for finding data (in libraries and archives rather than by adventurous field operations), and selecting, processing, and analysing it to create bodies of information about enemies and foreign cultures that would serve strategic warfare. This task required skilled academics, and real-life experiences of foreign lands such as those Janse had of Indochina were particularly valued. Historians and anthropologists in particular were recruited to the OSS and its R\&A branch. More than twenty university anthropologists, including Gregory Bateson and Cora Du Bois (whom Olov Janse corresponded with), ${ }^{862}$ were working for the organization. ${ }^{863}$ We believe that two reports and one film that Olov Janse produced during his time at OSS were for the R\&A branch. ${ }^{864}$

The work was secret, and it took until October 1945 before Olov mentioned his wartime assignment for the first time in a letter to Birger Nerman. ${ }^{865}$ In the letter, which is the only informal personal record we have from their time at the OSS, he describes how, shortly after the attack on Pearl Harbor, he was urged to join the Harvard Defense Group, ${ }^{866}$ where he dealt with issues concerning "protection and salvage of cultural monuments in the Far East". Janse published a long report on Indochina during his time in the group. ${ }^{867}$ In that capacity he was invited to Washington, DC, as a "temporary consultant of the Federal Government", and after the summer semester 1943 he was recruited to the OSS where

861. OS S R\&A Report No. 1279, by Olov R.T. Janse, 31 August 1943. Original document in National Archives at College Park, MD, USA.

862. Letter from Olov Janse to Cora Du Bois, 25 May 1944. National Archives College Park, MD. Records of the Office of Strategic Services (Record Group 226), Entry 92, Box 197.

863. Price 1998; Price 2008.

864. Janse $1944 ; 1945$.

865. Letter from O. Janse to B. Nerman, 3 October 1945. Riksarkivet. Kartong 4. Korrespondens Brev IV 1942-1946.

866. Formal name: American Defense, Harvard Group. https://hollisarchives.lib.harvard.edu/repositories/4/resources/4139

867. American Defense - Harvard Group. Committee on the protection of Monuments. List of Monuments in Indo-China, by Olov R. T. Janse, Records of American Defense, Harvard Group. Call number 3139, Box 76. 
he worked with issues concerning East Asia, and had "spent much time on cultural problems". At the time of writing he had, "by a letter from President Truman", been transferred to the Department of State, on a temporary mission lasting in the transit period between war and peace. Not being a US citizen, he writes, he would have no chance of turning it into a permanent position. And he concludes:

You must not mention anything about this to the press, but it is alright if you should happen to mention it to H.R.H., or to someone in our closest circle of friends. It has been stimulating to be in Washington during these intensive years. Ronny and I have also been out a lot, and have met many interesting people from every corner of the world. ${ }^{868}$

Olov Janse had evidently not lost the urge to have his activities and achievements known in Sweden, especially among highly influential people like the Crown Prince. We know also that he sent a copy of the anonymous publication Joint Army-Navy Intelligence Study of Indochina: People and Government from 1945 to a library in Stockholm with his name written, in his own hand, on the cover. ${ }^{869}$ Judging from the letter alone, he appears to have enjoyed the years with the intelligence services. Other letters, however, indicate that he hated it and thought of it as a particularly dull and boring period of his professional life. ${ }^{870}$

Because their missions were secret and the OS S archives are restricted, we know very little about what Olov Janse did for the OS S, and even less about Ronny's assignment. Other than his formal titles, which suggest that he was employed in the capacity of expert on East and Southeast Asia, Indochina in particular, we know for certain that he produced one film and three written reports for immediate intelligence purposes.

868. Letter from O. Janse to B. Nerman, 3 October 1945. Riksarkivet. Kartong 4. Korrespondens Brev IV 1942-1946. In the Swedish original: "Du får inte nämna något åt pressen om allt detta, men det är all right om Du händelsevis skulle vilja nämna det för H.K.H. eller till någon inom den allra närmaste vänkretsen. Det har varit spännande att vistas i Washington under dessa händelserika år. Ronny och jag har dessutom varit mycket i farten och träffat många intressanta personer från alla världens hörn.”

869. Janse 1945, attributed copy at the National Library of Sweden (Swe: Kungliga biblioteket), Stockholm (22 A d Fol.)

870.E.g. letter from Olov Janse to Ronny Janse, 9 January 1947. NAA: Janse 2001-29. 


\section{The film}

Setting off on their first expedition to Indochina in 1934, Olov and Ronny Janse brought a new film camera to record their journeys and their work. ${ }^{871}$ The camera was subsequently used throughout their three expeditions to document excavations, particularly when they had VIP delegations visiting the sites, and to make observations of mountain tribes in Tonkin and Annam, and indigenous groups along the coast of Annam. When contracted by the OSS as an expert on Indochina, Janse saw an opportunity to make use of the films. ${ }^{872}$ But the world was no longer the same as it was a decade earlier. The once lavish passenger ships were now used to transport troops and refugees across the seas, if they had not been bombed and sunk. Indochina was under Japanese occupation and the entire world was in turmoil. Hence it was necessary to transform the films in order to reactivate the contents. The OSS had ample resources for new and creative ways to form intelligence knowledge, ${ }^{873}$ which Janse activated to edit parts of films - which had been shot and partly edited as a documentation of a French colonial archaeological and ethnographic enterprise - into an instruction film for US Intelligence purposes. On 1 June 1944, he wrote to Lieut. Ray Kellogg at the OSS Field Photographic Division:

Members of several sections of the OSS and the Navy Department have expressed the desire to have projected here a $16 \mathrm{~m} / \mathrm{m}$ film which I took between 1937-40 in Indochina and the Phil-

871. It is unclear what sort of film camera Janse used and if he used the same camera during his different expeditions. In his autobiography he writes about his Kodak (Janse 1959:83) and one film is introduced with the label Ansco, which was a film-producing company in the US between the mid 1800 s and the 1980 s.

872. The films used at the OS S were shot during the second and third expeditions. The films shot during the first expedition were left in Paris before they set off on the second expedition. In letters to Ronny from Paris during the UNE SCO assignment 1946-47 (Letters from O. Janse to R. Janse, 31 December 1946 and 17 April 1947, NAA: Janse 2001-29) Olov mentions twice that he found a film among their other stored belongings, featuring their trips to Yunnan, excavations at Lach-truong, Bac Ninh, Sam Son, etc. This appears to be the same film that is mentioned in a letter to Johan Gunnar Andersson dated March 1936, where Janse writes that he has a film from his work in Indochina that is ready to be shown, if Andersson would like to see it (Letter from O. Janse to J. G. Andersson, 29 March 1936. Östasiatiska samlingarnas arkiv. Korrespondens 1936 E1A:13, 0300a,b-0301a,b).

873. Smith 2005:3. 
ippine Islands. We expect to have a show in the near future in the Administration Building of the OSS for personnel interested in these regions. Though the film is already provided with some titles, it has been suggested that some additional subtitles would make the film easier to understand, especially with references to various place-names and names of some little known native tribes. We would appreciate very much, indeed, if you would agree to have these additional subtitles made and inserted. ${ }^{874}$

Later the same month, Janse wrote once more to Kellogg:

I wish to express to you our appreciation for the work you have done to improve the SEA films [...] The films have now been shown and it has been suggested that parts of it be copied and sent overseas. For this reason it would be undoubtedly beneficial to our consumers if a few addition titles could be made (a list of which is here enclosed) $[\ldots] \cdot{ }^{875}$

The finished edited film is 23 minutes long and is divided into two parts; the first part with 19 subsections and the second part with 21 subsections. ${ }^{876}$

After the title slide (fig. 65) the first part of the film begins with 55 seconds with the title "Colombo and Mount Lavinia". The section, which was shot in 1936 at the stopover in Ceylon (now Sri Lanka) on their way to Saigon for the second expedition, features streets with traffic police and natives, walking by and standing still, posing for the camera. One segment is of the seaside, shot from the veranda of the Mount Lavinia Hotel. In the water are outrigger canoes, and a native man is fishing with a rod from the rocky shore. A group of people in colonial-style dress, shorts and helmets, socialize and watch the fisherman from the hotel's elevated veranda. The next section is 50 seconds long and titled "The harbour of Colombo". Most of it appears to be shot from the deck of the French passenger ship Maréchal Joffre and features the surrounding water and harbour with boats, cranes, and warehouses. Ronny embarks the ship

874. Letter from O. Janse to Ray Kellogg, 1 June 1944. National Archives at College Park, MD. Records of the Office of Strategic Services (Record Group 226) Entry 90, Box 19. Entry 90, Box 19.

875 . Ibid.

876. Swedish Television Archive. 


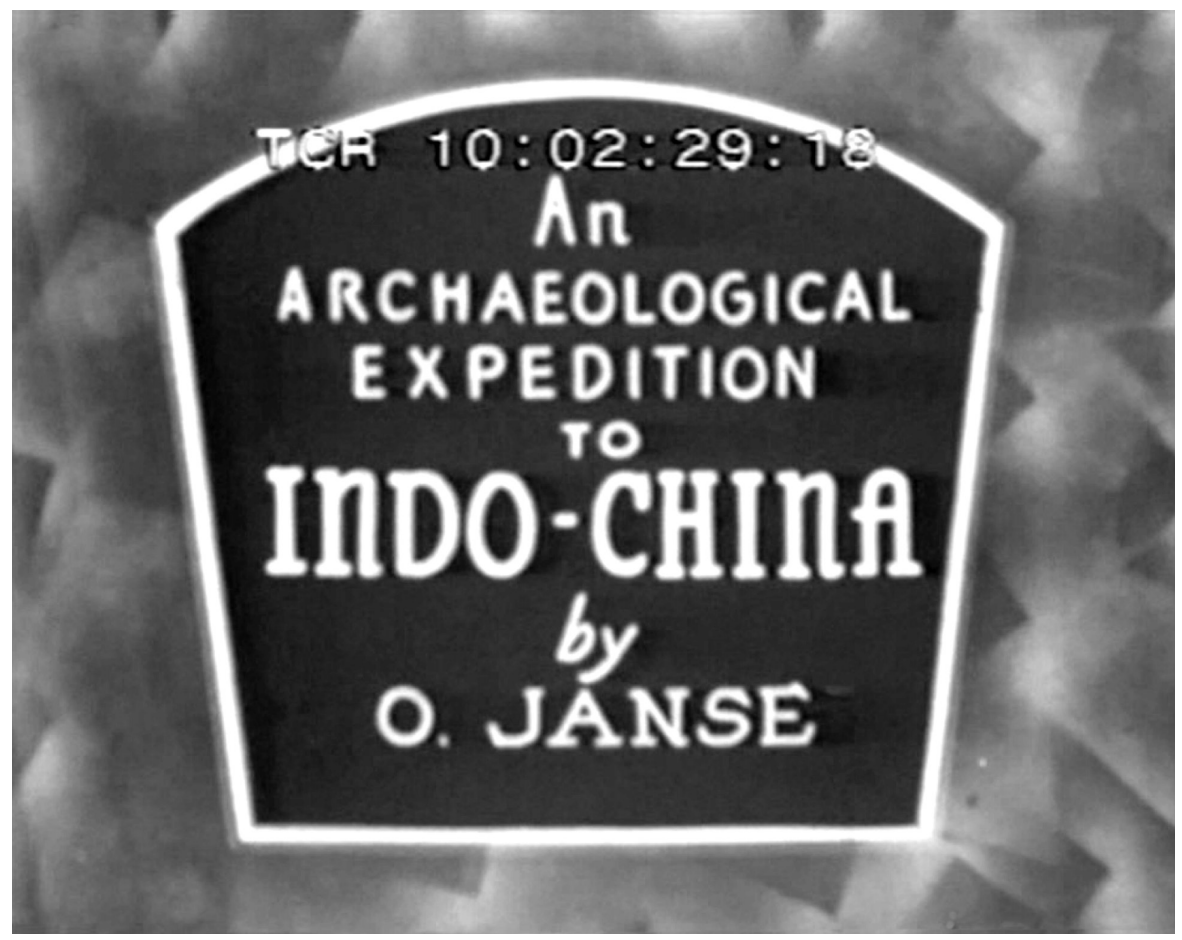

Fig. 65. Introductory title. Still from film, edited by Ray Kellogg at the OSS.

and stops to pose for the camera. A short segment shows the stern of the ship from afar, zooming in on the name Maréchal Joffre. This is followed by a 32 -second section titled "The Native Quarter of Colombo", where native people are seen standing, walking, or pulling rickshaws in narrow streets with small shops and lush gardens. A man in western-style outfit passes by on a bicycle. In contrast to this section is the next, titled "The modern section of Colombo", featuring 25 seconds of the British part of the city. A man in a white, colonial-style suit poses in front of the new town hall (which opened in 1928), Olov and Ronny pose with an umbrella in a park, and there is traffic on a broad, boulevard-style street.

The next six sections feature the journey from Colombo to Saigon, with a stop in Singapore. First 27 seconds "Along the coast to Sumatra and Singapore" with sea views of the Sumatra coastline, then 40 seconds "Approaching Singapore" with views of ships and smaller boats at a distance, followed by 14 seconds titled "The entrance to Singapore" with footage of mangrove. "The powerplant" features 7 seconds of a modern industry complex seen from the passing ship, and "The Archaeological Museum" contains 5 seconds of Ronny and an unknown man standing at the entrance of the Raffles Museum (now the National Museum of Sin- 
gapore). The longest section featuring Singapore is titled "The wharves". This 47-second section features Ronny and two unknown western women posing at a street market with a textile vendor approaching them. Native men transport boxes from a ship on pushcarts, and natives in five canoes, one with a monkey in it, skilfully manoeuvre the strong currents of the harbour. The section from Singapore ends with a frame of a small sailing vessel, seen from a distance.

After more than 5 minutes of film, they arrive in Indochina, with the 59-second section "Up the Saigon River to Saigon". From letters and other documents we know that it was shot on 9 November 1936, and it begins with Ronny posing at the gunwale. Flat green landscape passes behind her and children play on board the ship. A small aeroplane passes close by the ship. They meet a large passenger ship and another aeroplane passes. The landscape is flat but lush, and they pass several smaller ships before the camera is turned to the contours of the city with its characteristic two-tower cathedral appearing at a distance. The section ends when the ship approaches the quay.

The next section, "Tourane (Annam)", is 30 seconds long and features boats and native boat life along the sea, and native Annamite people in characteristic conical hats walking by in the street. "The Cham Museum at Tourane" is a 19-second view of a museum villa from the street, with a native man and a cycle-rickshaw passing by. It is followed by "Native fishing methods at Cua-tung (Annam)", which is one of the longer sections ( 2 minutes and 10 seconds). It features a fishing technique where fish are lured into a creel by means of fencing and beating the water with a certain kind of rope (see fisherman with rope in the chapter on the Indochina expeditions, fig. 50). Three shorter sections follow: "Miss Annam" with 13 seconds featuring a group of native children with particular focus on a small shy-looking girl; "Cua-tung Beach, A summer resort near Hue, Central Annam" with 15 seconds view over a beach with no people; and the 17 second long "Balang Beach in Thanh Hoa", where six natives in conical hats pull a rope from the water and Ronny walks towards the camera surrounded by a group of native children. The first part of the film ends with a 59-second long section titled "Sam-Son Beach, a summer resort in Thanh Hoa, Northern Annam", where naked native boys fish with long sticks and a group of natives in conical hats pull nets. The section ends with footage of natives paddling longboats at a distance, a view resembling the motifs on the Dong Son kettledrums.

The second part of the film begins with a 50 -second section titled 
"Dong-son (Thanh Hoa). Annamese comedians". After a very brief segment with what appears to be a trench for the excavation of pole constructions at Dong Son on the bank of the river Song Ma, and a glance of water buffaloes grazing a rice paddy, the rest is devoted to a village theatre performance with Annamite men in festive gear and groups of children looking into the camera, and an actor performing in elaborate costume with a crowd around him, and smoke produced as part of the setting for the performance. It is followed by "An Annamese procession at Thanh Hoa", which is a 39-second-long view from a balcony or rooftop, of a ritual procession in a broad street, with officials, flags, umbrellas, and two dignitaries in rickshaws. As in the previous section, smoke is produced as part of the setting for the procession.

The following five sections are of Hanoi. The first, "Hanoi (Tonkin) and its flower market" is a 40 -second view of Hanoi street life with traffic police, a native lady in the characteristic Áo dài tunic looking out over the Hoan Kiem Lake (which dominates the old city centre of Hanoi), the flower market with female vendors and buyers, and finally the iconic view of the Ngoc Son temple in the middle of the Hoan Kiem lake. Following that introduction to Hanoi are three short sections: "The Archeological Museum", with 9 seconds of exterior footage of the Musée Louis Finot (now the National History Museum); 7 seconds of "The Doumer Bridge crossing the Red River at Hanoi" with the bridge shot at a distance; and 15 seconds of "The picturesque native quarters of Hanoi" with a view of a street where native people walk and a man in colonial-style garment passes on a bicycle. The Hanoi part ends with a 30 second section titled "The Van Mieu Pagoda (Hanoi), temple of literature". It is set up like a visit to the temple, with a sequence of cuts from the gate through the garden to building facades. Ronny is seen entering one of the buildings in the company of two men (who we believe are the conservator René Mercier and EFEO's director George Cœè̀s), followed by a native woman and a boy in colonial outfit (who may be Cœdès's wife and son).

After the five sections from Hanoi follow thirteen sections featuring tribes in Tonkin (today Northern Vietnam), first with a 39-second-long piece that serves as an introduction to the new mountainous landscape. "Among the Muong and Man tribes at Hoa-binh (Tonkin)" features Ronny and Nguyen Xuan Dong travelling by longboat on a river. They pass a lake with mountains, other longboats and native boats with roofs. A native woman in a boat turns away when she sees the camera. The next section, "The market at Hoabinh is visited by the people of the Man 
Fig. 66. "The market at Hoabinh is visited by the people of the Man tribe". Still from film.

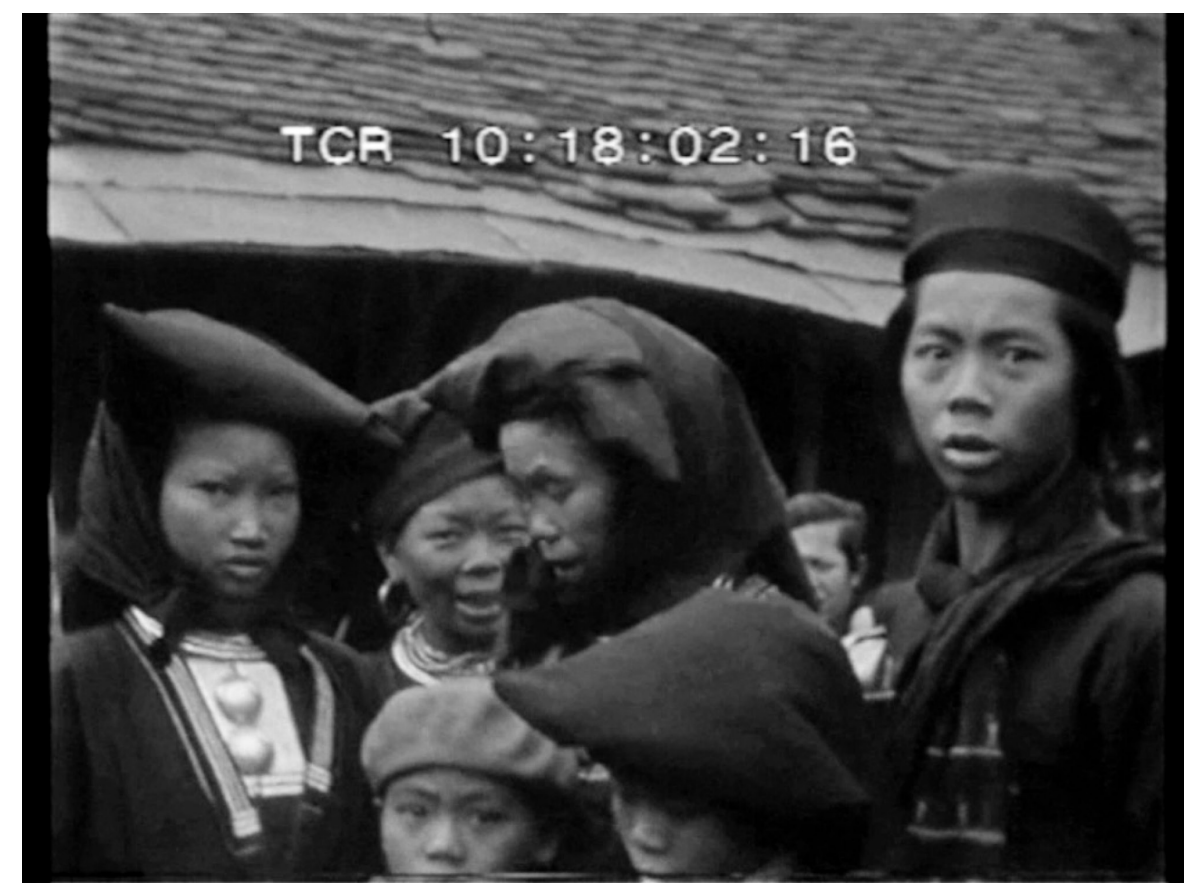

tribe" is 1 minute and 21 seconds long, and features natives of the Man tribe at the market. They are either unknowingly filmed from behind, or arranged by Ronny and Dong in exact poses for the camera. In one sequence they arrange a group with a man, an old woman, a middle-aged woman, a young woman, and children for a group photograph. The section also contains footage of baskets with chicken for sale and boats by the river near the market. "The home of a Muong Chief, at Hoa-Binh, Upper Tonkin" is 37 seconds long and begins with Dong coming out of a house smiling, followed by a group of native people in official clothing, arranged for a group photograph together with Ronny in front of the house. The section ends with a sequence of another native family walking on a dirt road with bags on sticks.

The remaining ten sections featuring tribes in Tonkin were shot in Tinh-tuc, the mining town in the mountainous northern region where Olov and Ronny spent the summer of 1937 in Charles Bastide's villa to escape the heat and stress of the lowlands. The first two sections from Tinh-tuc feature "The wolframite mines and the village of Tinh-tuc (Tonkin)" with a 23 second view over the open mines, and 28 seconds of village life under the title "The only street in the mining village". Another 28-second section with the title "Annamites and Thai mingle 
at the market of Cao-Bang, upper Tonkin" features groups of women at a market, some laughing, apparently embarrassed by the sight of the camera. Six more sections follow, all of which appear to have been shot in Tinh-tuc during the French national holiday on 14 July. The first is 25 seconds with groups of people in ethnic costume and colonial suits with tropical helmets, seen from behind. It is followed by "The greased pole", which is 30 seconds and features a native man attempting to climb a greasy pole, with a crowd around. Two native men in ceremonial gear pose in the front yard of a villa, turning to the side and back for the camera. They are followed by two native children and a woman, posing in a similar fashion in the same villa garden. A short, 12-second section follows: "Dancing Sorcerers of the Man tribe", where a group of musicians and sorcerers in ceremonial gear prepare a performance in the villa garden. In the cuts between frames a colonial-style assistant flashes by, helping to arrange their positions. After that is a 1-minute-long section, "Ritual dances performed by Man-Coc sorcerers at Tinh-tuc" where three sorcerers (as above) bow twice to the camera and start to perform a dance, one of them using cymbals. Three musicians play the traditional khène instrument and some sort of clarinets behind the dancing sorcerers. Two young native girls are watching from the side. Two shorter sections end the part from Tinh-tuc. First 20 seconds with the title "People of the Man-tien Tribe", where two girls in festive gear and one older man pose for the camera, smiling and laughing as they take instruction. They turn anti-clockwise from front to side to back, to front again, with the old man leading the way. And finally, 23 seconds titled "Ritual dances performed by Man-Tien sorcerers at Tinh-tue [sic]", where two men in ritual gear dance with cymbals in front of the same two girls as in the previous section.

The film ends with two sections featuring travels. First a journey by train titled "A trip from Tonkin to Yunnan (Southwestern China)", which is 1 minute and 15 seconds long and shot through the train window of mountainous landscapes, rice paddies and natives at a train station. The final section is 48 seconds from the scenic tourist destination Ha Long Bay: "The Gulf of Along (Tonkin)" with views over water and the iconic limestone karsts. The film ends with Ronny boarding a small covered boat, and some final shots from the boat of the water and limestone karsts. 
So, what did the OSS personnel see when they watched Janse's film in the Administration building in Washington, DC, in June 1944? With its forty sections with subsequent titles, the film assumes the logic of an ethnographic travelogue. It follows an actual geographical route from Marseille in France via Ceylon and Singapore to Saigon in southern Indochina. As it proceeds north through Annam and Tonkin to Yunnan and $\mathrm{Ha}$ Long Bay at the end of the film, it appears to present a range of visual facts about the lands on display. But the perspective it offers is, essentially, a view of Indochina and Ceylon through the eyes of the travelling colonizer.

Three main themes are accentuated in the film: native techniques (transport and subsistence), colonial infrastructure (industry, architecture and transport), and visual characteristics of ethnic groups (physical form and clothing). Most parts of the film were shot during the second overseas journey with the Maréchal Joffre, and the summer months they spent in Tinh-tuc, in Charles Bastide's villa by the tin and wolfram mines. Considering that the film is presented as "An Archaeological Expedition to Indo-China", it contains surprisingly little archaeological information. Archaeological museums are featured only as building exteriors, and a few seconds of an excavation trench, probably at Dong Son, swish by on one occasion. Archaeology seems here to be most valuable as a framework that gives a sense of purpose to the travelogue and authority to the eye of the camera.

The forty film sections feature people in colonial-style garments and tropical helmets travelling in modern vehicles and using advanced equipment, clearly divided from natives in primitive clothing or elaborate ethnic costume, using rudimentary techniques and simple means of transport. Natives are featured either in the process of doing practical everyday chores such as fishing, rowing, or digging, or they perform rituals. They are often seen posing for classic ethnographic documentation photos, from the front, side, and back. The colonizers smile and socialize, and assist the photographer to arrange the native objects in the most favourable positions and angles for the camera. Hence the colonizers are often found behind or beside the lens, creating a sense of belonging for the eye of the camera. The natives are always found in front of, never actively behind or beside the camera.

The two groups are not, however, entirely distinct in terms of race or ethnicity. Natives occur in a number of different groups, from Ceylon to Indochina. The outfits and social poses of the colonizer are sported not 
only by the French and the British, but also by Annamite and other native functionaries such as Janse's colleague Dong.

Pace is a key to the creation of distinct images that differentiate natives from colonizers. While the colonizers move, walk and travel fast with a sense of purpose to their movements, the natives use slow and primitive vehicles, walk slowly by, and are often featured sitting or standing still. Pace works here through the medium of the moving image, with the same effect as the contrasting words describing native and colonial societies in Janse's memoirs Ljusmannens gåta. ${ }^{877}$ It portrays and accentuates a developmental difference between natives and colonizers, which in turn demonstrates the necessity and righteousness of the French mission civilisatrice and other imperialist interventions by Western powers.

\section{The reports}

One of the few things we know for certain about Olov Janse's time at the OSS and US State Department is that he worked with issues concerning Indochina. The situation in Indochina after the Japanese occupation in September 1940 was complicated. ${ }^{878}$ The forty-two thousand French colons suffered from the brutal Japanese methods of occupation, as did the twenty-three million native inhabitants. But the French colonial policy remained intact, and France had no intention other than to restore Indochina as a French territory after the war.

In Indochina, however, several movements for independence were gaining ground. One of these movements was the communist Viet Minh, led by a man called Nguyen Ai Quoc (literally: He Who Loves His Country) who in 1942 changed his name to Ho Chi Minh (He Who Enlightens). ${ }^{879}$ Ho was the son of a Confucian scholar and teacher, and as a young man he travelled across the seas to France, the United States, and the $\mathrm{UK}$, working as a kitchen assistant on passenger ships. He was almost exactly the same age as Olov Janse, ${ }^{880}$ and they could very well have met in Paris in the early 1920s, "in the cafés of Montmartre, where everyone

877. See the chapter "Euphoria".

878. The section on Ho Chi Minh and the wartime situation in Indochina is based on the works of Logevall 2012; Tønnesson 2010; and Smith 2005 :chapter 10.

879 . He used around seventy different pseudonyms over his lifetime, often with potent political connotations indicating his current mission and ambition.

880 . His official year of birth was 1890 , but some sources claim that he was in fact born in 1892. See Logevall 2012:4n5. 
debated everything". ${ }^{81}$ They were also similar in some senses; the slight and slender Vietnamese with sharp eyes and piercing intellect, and the tall pale Swede with the grand gestures of an aspiring cosmopolitan. They were both strangers in Paris, but they were hommes de lettres and spoke several languages. Both have been described as charming and sensitive, with confidence-winning personalities. ${ }^{882}$ However, if the socialist sentiments of Janse's Ture-Nerman-inspired teenage years had started to fade by the early 1920s, Ho's socialist political interest was awakened during his years in Paris, 1919-1923. Already in the years following the First World War, when he had joined a group of Vietnamese nationalists in Paris, he had approached a United States delegate with a request for support to end French colonial rule in Indochina. On his journey round the world he had spent some time working in Boston and New York City, and was much attracted to the ideals of the US Constitution. In Paris, however, the US leaders did not respond to his call for support. Ho (then Nguyen Ai Quoc), who had already experienced the ambiguities of the French Empire, and seen with his own eyes how the fine liberal ideals of liberté, égalité, et fraternité had been used to gloss over oppressive or violent situations of colonial reality, realized that he could not count on steadfast support from the United States, despite their fine ideals and official anti-colonial policy. Instead he continued to search for support for his independence mission among socialist and communist groups in France, the Soviet Union and China, before he returned to Indochina in 1941 to lead the Viet Minh independence movement.

When the United States became involved in Indochina through the OS S during the Second World War, the Viet Minh movement was gathering momentum. The main objective for the OSS involvement in Indochina was to put an end to Japanese occupation. But the United States and President Roosevelt also maintained a strong policy against colonialism, and were therefore bound to support native movements for independence. It annoyed their French and British allies, who were obviously for the reinstitution of colonial rule, and it also complicated the intelligence relations with China. The US position was moreover complicated by the fact that Viet Minh was a communist organization, which was not compatible with US agendas. But the anti-imperialist policy eventually overruled all complications, and the OSS officers in Indochina came to

881. Logevall 2012:15.

882. Logevall 2012:15. 
offer direct support to Ho Chi Minh and the Viet Minh. The Viet Minh were given arms and military training by the OSS, and on one occasion in July 1945 it has been claimed that the OSS medic Paul Hoagland saved Ho's life in a small village northwest of Hanoi, by treating him for malaria, dysentery, and a variety of other diseases. ${ }^{883}$

Interestingly, Olov Janse's personal sentiments were quite different from OSS's official policy. He was a devoted Francophile, and saw no better future for Indochina than to be reunited with the French Empire after the war. With Ronny's family history in the Soviet Union he had also reason to question the benefits of state communism.

Janse wrote three reports for the OSS; Some methods of Japanese penetration in French Indo-China previous to the war in 1943; The Peoples of French Indochina (published by the Smithsonian Institution) in 1944; and a Joint Army-Navy Intelligence Study of Indochina: People and Government in $1945 .{ }^{884}$ The first appears to have been written for MO (Morale Operations) purposes, immediately after he joined the OSS in August 1943. It takes the form of an "Interoffice memo", and contains information about Cao Dai - a religious movement established in southern Indochina in 1926, whose leader had criticized the French colonial regime and been actively engaged in anti-French politics - as a means for Japanese infiltration in the area before the occupation in 1941. Compared with the other two reports, this one is written in first person and has a tone of personal reflection: "My attention was first called to ...", ${ }^{85}$ " a French customs employee stationed in central Annam, where I was carrying out archaeological fieldwork, told me that ...", ${ }^{86}$ and so on. Moreover, it offers a number of assumptions which are not properly grounded: "it can probably be assumed that he was acting as a Japanese agent" ${ }^{887}$ and "Communists in Indo-China are also said to have used sorcerers as secret agents". ${ }^{888}$ In response to these assumptions Janse finally presents a number of ideas and suggestions for Morale Operations to keep the native population of Indochina positive towards the Allies: "As almost all schools in Cambodia and Laos are in the hands of the bonzes, it is important to secure in them a friendly

883. Smith 2005:306.

884. Janse 1943; Janse 1944b; Janse 1945 (with an attributed copy at the National Library of Sweden (Swe: Kungliga biblioteket), Stockholm (22 A d Fol.)).

885. Janse 1943:1.

886. Janse 1943:2.

887. Janse 1943:4.

888. Janse 1943: Appendix III 
attitude toward the Allied Nations, and to arouse antagonism toward the Japanese", 889 and "the Man [ethnic group] used signal drums to send secret messages to their kinsmen, widely scattered in the inaccessible mountainous region. [...] It is possible that such a system of signaling could be improved and used in these regions by the Allies for sending secret messages and spreading rumours." 890

The latter two reports are of a different character. They are written in a more detached and scholarly language, and contain no creative suggestions or overt guesses, which is why we believe they can both be attributed to the R\&A rather than the $\mathrm{MO}$ branch. They are partly overlapping, and the first - The Peoples of French Indochina - was one in a series of booklets produced by the Smithsonian Institution, each with its own author, that together cover a large part of Southeast Asia and the Pacific. ${ }^{891}$ Initially Janse's part takes the form of a travel guide introduction, covering geography, climate, geology, economy, and so forth. Compared with the other booklets in the same series, and as indicated by the title, Janse has a particularly strong focus on the native population of Indochina. $\mathrm{He}$ describes the different tribes and ethnic groups with their history, language, customs, and physical appearance. These descriptions are almost identical to the descriptions of native people in the third report, which was published a year later.

Of the texts Janse wrote for the Harvard Defense Group and the OSS, the last one, the Joint Army-Navy Intelligence Study of Indochina from 1945, is the most elaborate and the most interesting. It is 36 pages long and divided into eight chapters:

100. General description and historic setting ( $\left.\mathrm{p}_{1-5}\right)$

101. Size and distribution of population (p $5-8)$

102. Physical and cultural characteristics ( $\mathrm{p} 8-19$ )

103. Educational and cultural institutions and agencies ( $\mathrm{p} 20-22)$

104. Labor (p 22-24)

105. Government ( $\mathrm{p} 26-34)$

106. Political attitudes (p $35-36)$

107. Principal sources ( $\left.\mathrm{p}_{3} 6\right)$

889. Janse 1943: Appendix II.

890. Janse 1943: Appendix V.

891. Price 2008:96. 
It was submitted when Janse was Deputy Chief of the South-East Asia section of the Research and Analysis Branch of the US State Department, and can in most parts be read as a companion piece to the film he produced for the OSS. If they were read and watched in tandem (which we can assume they were), the report offered details and profound analysis, while the film added context and a sense of reality to the account. And just like the film, the report could be described as a piece of pro-colonial propaganda masquerading as a rather dry account of facts and details:

\section{Relationships between local French and native peoples.}

Before World War I Indochina did not attract French administrative personnel of the highest calibre. The recruiting of high-grade officials was hampered, partly because of the bad reputation of Indochina's climate and the distance from France. Officials sent out to Indochina did not all have adequate training and high moral standards. As a result numerous serious conflicts arose between the French and the local population. The attitudes of French officials and private individuals were criticized by local and outside observers.

After World War I the situation improved considerably. A government-sponsored Colonial School under the guidance of highly qualified teachers was established in Paris to train personnel designated for overseas duty. In recent years the French have shown more respect for native customs and systems of justice, and have given the local peoples a greater share in administration.

In spite of criticism of the French in Indochina - from French, native, and outside sources - their Indochinese administration can be credited with creating an educational system adapted to local conditions, extending free medical care, improving public hygiene, abolishing slavery, constructing roads and railroads, repressing lawlessness, introducing labor laws, and preserving historical monuments. ${ }^{892}$

\section{Preservation of village organization.}

In most areas the village was the basic unit of administration. There the ancient forms of political and social control had been preserved and maintained. ${ }^{893}$

892. Janse $1945: 19$.

893. Janse 1945:27. 
Local Annamite administration. The village was the basic unit of local Annamite administration. The village was a kind of local state, jealous of its independence and stubbornly adhering to its own traditions and responsibilities. The French interfered very little with this traditional popular unit of government. ${ }^{894}$

\section{Japanese occupation of Indochina.}

Throughout this five-year period [1940-1945] the Japanese encouraged anti-foreignism and nationalism with the result that the Kings of Annam, Laos, and Cambodge recently have declared their "independence".

The fall of France in 1940 left Indochina in a precarious and virtually helpless position. ${ }^{895}$

France and the French colonial administration are described in positive words that signal progress, courtesy, and benevolence. If mistakes have been made, they have been corrected, thoughtfully and respectfully visà-vis native interests. In contrast to the French development and progress we have the village organization, which is described as an ancient and primitive form of administration - either stubbornly independent, or in need of French protection to be preserved and maintained. The Japanese presence and the subsequent declaration of "independence" by the Kings of Annam, Laos and Cambodia - with quotation marks to emphasize the impossibility or absurdity of the claim - is described in metaphoric terms as an assault on a helpless child who has lost the protection of her parents.

Religion is another theme described in starkly polarized terms. Descriptions of Christian interventions are characterized by positive words and judgements:

Catholic missions have been active in Indochina since 1815 and have met with considerable success. Converts now number between 1,500,000 and 2,000,000. [...] Educational, medical and social services as well as religious teaching have had considerable effect on the people, particularly in Annam. ${ }^{896}$

894. Janse 1945:30.

895. Janse 1945:5.

896. Janse $1945: 4$. 
... whereas the popular Caodaist movement is described as a threatening and deceitful sect:

Caodaism, sometimes called neo-Buddhism, is a politico-religious cult which professes to unify several religious systems. It was introduced into Indochina about 1924, probably with Japanese backing. [...] French authorities took measures to repress the movement and check its spread. In 1941, however, between 1 and 2 million people throughout southern Indochina reputedly were members of the sect. The Caodaist organization was used as a propaganda agent by the Japanese to combat French influence and to prepare the country for invasion. ${ }^{897}$

The people of Indochina are described in this report, and in the 1944 booklet, in racist and biologistic terms and with the sexualized discourse surrounding native women that is typical of French colonial texts: ${ }^{898}$

102. Physical and Cultural Characteristics. A. General factors.

The population of Indochina is composed of a great variety of peoples and tribes, each of which with its own language and customs. For many centuries Indochina has been a meeting place of peoples and cultural currents. The earliest settlers probably were negritos who were subsequently absorbed or driven out by Indonesians (also called Proto-Malays, Moi, etc., presumably of Caucasid affinities). Finally a Mongoloid element arrived, and mingled with the former settlers or pushed them into the remote mountains.

It is possible today to distinguish two chief physical types, though there is great individual variation. The Indonesian strain, in general, is short in stature, long-headed, with light or lightbrown skin, moderately broad nose, straight of wavy hair, and eyes set straight. The Chams are representatives of this group. The second and much more numerous type is the Southern Mongoloid $[\ldots]$ The Annamites and the Thai are considered as belonging to this stock. [...]

897. Janse 1945:4.

898.E.g. Norindr 1996. 
The impact of Chinese culture is clearly apparent in the northern and eastern parts of Indochina, while Hindu civilization spread in the west, especially in Cambodge. In recent years the population in urban centres, particularly the Annamites, has shown rapid adaptation to European culture. ${ }^{899}$

The region of Hue in central Annam is famed for the beauty and grace of its women, as well as for their aptitude for the fine arts.

In his behavior the average Annamite is reserved, cautious, and ceremonious. Generally he is capable of great self control, and does not display his feelings ostentatiously. He reacts strongly against those who antagonize him, especially by vulgar and brutal manners. He has a certain sense of humour, and tends to catch and capitalize the ridiculous. In general, he thoroughly dislikes irascible persons, and does not appreciate the back-slapping type of familiarity. .00

In the mountainous interior of Indochina there are a number of primitive tribes, partly nomadic, partly settled. [...] About $75 \%$ of all the mountain tribes in northern Indochina belong to the Thai group. [...] In many cases, they have been influenced strongly by their more highly developed neighbors. ${ }^{901}$

[About the Moï] In recent years the French administration made a great effort to civilize these backward and nomadic tribes and to have them settle as farmers and cattle-breeders. A few have been converted to Christianity by French and American missionaries..$^{902}$

A common figure in the accounts of the reports and the film is that of cultural development through influence. This common figure, which is a crucial justification for the entire French Empire, is illustrated historically by the name "Indo-China". Emphasized by the hyphen, as in the French Indo-Chine before 1900, and in American accounts throughout the twentieth century, is the identity of this landmass as the historical meeting of

\footnotetext{
899. Janse $1945: 8$.

900. Janse 1945:11.

901. Janse 1945:15.

902. Janse 1945:17.
} 
two great cultures: that of India and China. Janse continues the tradition of describing Indochina, or "Indo-China", as the historical meeting place of two great civilizations. By implication, the native peoples of Indochina are either stagnant in their primitivity, or have developed historically by influence of more advanced neighbours. The slightness of their own cultural importance is demonstrated by the minuscule hyphen between the two important civilizations. Hence they must wait for new influences from culturally advanced centres (such as France or the United States) to continue developing.

As a final piece of advice for Allied forces landing in Indochina, Janse writes:

\section{The attitude of the Indochinese toward an Allied landing.}

Because the Indochinese are a complex of peoples living on different cultural levels and possessing different degrees of political sophistication, their response to Axis and Allied appeals has varied greatly. [...] Some Annamites have been hostile to both the French and the Japanese; some have been passive before both; some have sought the favour of the one or the other. Allied airmen shot down in Indochina could never be sure whether the Annamites would turn them over to the French or to the Japanese. Most Indochinese villagers want only to avoid trouble and will therefore support the winning side. Probably most of the politically minded Indochinese prefer the French to the Japanese and, foreseeing that the restoration of French authority in Indochina is inevitable, will therefore assist, or at least not impede, Allied moves. ${ }^{903}$

We don't know what impact these texts and the film produced by Janse had, if any at all. From his Francophile position, Janse believed that the Japanese would eventually be thrown out and that the French would return and continue the work for development and civilization in the region. The peoples of Indochina would reach "a new post-war status, aiming toward their gradual emancipation within the framework of the French empire". ${ }^{904}$ This is a statement clearly contradicting President

903. Janse 1945:36.

904. Janse 1944:27. 
Roosevelt's anti-colonial policy,905 and must have been quite controversial in the OSS and the US Department of State.

Much smoother in relation to US policy was the image he presented of Indochina as a region with people in need of civilized help (to develop into modernity) and protection (of their monuments and traditions). If anything it was this image, presented with subtle choices of words and perspectives - connotations and metaphors, of pace, stillness, and movement - that would influence the OS S officers. If they watched Janse's film and read his reports, this image ought to have formed their expectations and calibrated their gaze prior to any real engagement with the land and the people of Indochina.

We see here clearly the development of a strong new theme in Janse's professional profile, which could be discussed in terms of public diplomacy. Public diplomacy has emerged as an important field of political historical research over the past few decades, and has focused largely on the soft politics of the United States. ${ }^{906}$ According to Nicholas J. Cull public diplomacy can be understood as "an international actor's attempt to conduct its foreign policy by engaging with foreign publics". 907 It can also be described in words such as "cultural diplomacy", "diplomacy of ideas", "soft diplomacy", "heritage diplomacy" and so on. But in most cases it falls under Cull's definition. An oft-cited example of public diplomacy is the US international broadcasting agency Voice of America, which was established in 1942..$^{908}$ This form of diplomacy has been in use for a very long time, and is not restricted to the US administration, although the term "public diplomacy" was coined in 1965 , and most of the research on public diplomacy has focused on the United States. ${ }^{909}$

Frank Ninkovich sees the origin and background to public diplomacy in an early twentieth-century philanthropical context. ${ }^{910}$ Its original purpose was, according to Ninkovich, to prevent future wars. It was based

905. E.g. Smith 2005 .

906.E.g. Dizard 2004; Cull 2008.

907. Cull 2008:xv, see also Osgood \& Etheridge 2010 for a definition of the concept. 908. Olov Janse spoke about Vietnam on Voice of America in July 1959.

909. Cull 2008:xv.

910. Ninkovich 1981, see also Dizard Jr. 2004 regarding the United States Information Agency (USIA). 
on the idea that wars were the consequence of lack of education, lack of civilization, and what could more generally be described as a lack of a gentleman's approach to the world. The philanthropical projects of education and civilization that were aimed at preventing war are in Ninkovich's view the origin of public diplomacy.

Although the research field of public diplomacy has been largely restricted to the public information politics of post-war United States, and Ninkovich traces the ideas further back to the early twentieth-century philanthropic era, it is possible to find much deeper roots to this phenomenon. The connection with the "soft politics" and civilizing missions of French and British colonial empires seems obvious, ${ }^{911}$ and the ideological foundation of this discourse can in turn can be traced back to the Enlightenment and the German philosopher Immanuel Kant (1724-1804). Here we would single out two of his essays - Answering the Question: What Is Enlightenment? from 1784, ${ }^{912}$ and Perpetual Peace: A Philosophical Sketch from $1795^{913}$ - which laid the foundation for future public diplomacy.

The first essay describes how man can become free, what freedom actually is and what responsibilities such freedom demands. The second essay underlines how states should act upon each other. Of particular interest here is Kant's argument that only states with similar systems can be included in this definition of the state and of "man", and it goes without saying that he refers mostly to European states. This implies that states and human beings outside these systems are not included in Kant's definition at all and can be treated in any way, because they lack the fundamental rights bestowed on humans and states inside the system. As a consequence of Kant's definition, the outsiders are not civilized, they lack education, and they do not behave according to the rules of the gentleman.

Part of the definition of the gentleman, moreover, is his willingness to educate and include others in his system. If everyone spoke the same language and shared the same ideas, there would be eternal peace, is Kant's fundamental idea. And this idea serves as the ideological foundation and justification for public diplomacy to this day. It is true that since the Second World War, such strategies of soft politics have been developed in the United States, but it has long and winding ideological roots leading

911. E.g. McClintock 1995; Norindr 1996.

912. German original: Beantwortung der Frage: Was ist Aufklärung?

913. German original: Zum ewigen Frieden: Ein philosophischer Entwurf. 
all the way back to Kant. But there is reason for concern, because if, as it was for Kant, everyone or everything that exists outside the parameters of one's own system is merely an Other with no rights, how shall that Other be understood and dealt with? Many solutions have been offered to this question since Kant's days: colonial racism, wars, exploitation, development programmes, missionary campaigns and public diplomacy. The overall aim of all these different actions has been to change and if needed force the Other into the system, to educate him, make him civilized, and turn him into a gentleman; often in the name of peace and benevolence. Let us bear this in mind when we follow Olov Janse through the following chapters.

For Olov and Ronny Janse, the years in exile working for the OSS and the US Department of State meant the beginning of a new phase in their lives and careers. For Olov it was a definitive turn away from archaeological research towards a life as civil servant in the highest levels of national and international bureaucracy. The world was about to change again, and Indochina would soon be at the centre of attention for US foreign policy. 


\section{DARLING, DEAREST LETTERS FROM UNESCO 1946-1947}

The war came to an end with the surrender of Japan following the atomic bombs on Hiroshima and Nagasaki on 6 and 9 August 1945. With the end of the war came also the end of Olov and Ronny Janse's wartime assignments, and they left the State Department in May 1946. With a sense of recovered freedom and hopes that the world they once knew would soon be brought back to normality, they began to look for opportunities to return to Europe.

In the meanwhile the United Nations was formed, in London, almost immediately upon the Japanese surrender. The UN, which was a reinvention of the League of Nations (a supranational organization that had been created in reaction to the First World War), ${ }^{914}$ rose like a phoenix from the ashes of the Second World War with the same peace-striving ideals and internationalist ambitions as its predecessor. The League of Nations had a special sub-organization for intellectual matters: the International Institute of Intellectual Co-operation (IIIC), ${ }^{915}$ and plans were now drawn up to create a similar organization attached to the United Nations. The IIIC had been concerned with international intellectual cooperation in fields like university education, scientific research, information, and artistic and literary relations, and its mission had been to

914. Valderrama 1995: chapter 1; Meskell 2018.

915. It was established as the League of Nations' Committee on Intellectual Cooperation in 1922 and in 1926 expanded with an International Institute of Intellectual Co-operation: IIIC. 
provide service to all forms of intellectual activities and scientific ideas. ${ }^{916}$ Although the IIIC was of an international character with members representing different countries, France assumed a central position in terms of funding, leadership, and the location of its headquarters in the Palais Royal in Paris. Olov Janse had occasionally acted as consultant to the IIIC while he was working in Paris during the inter-war years, so he was familiar with its aims and mission, as well as its organizational structure and practices. Thanks to their strong moral and financial credibility after the Second World War, the USA had assumed a leading position in the establishment of the UN and was now actively involved in the planning for the new organization, which was going to be called UNESCO - The United Nations Educational, Scientific and Cultural Organization. A strong voice in the planning and development of the new organization was Howard Wilson (1901-1969), Professor of Education, whom Janse knew from Harvard and the OS S. In September 1946, Janse wrote a letter to Wilson, who was then the deputy executive secretary of the Preparatory Commission for UNESCO: ${ }^{917}$

$$
\text { Washington, D.C., Sept } 121946
$$

Dear Howard,

The other day I happened to learn that you soon will leave for Paris to attend the UNESCO meeting. As I am anxious to get a position in this organization, when established, may I ask you kindly to let me know if, in your opinion, there will be any openings for me and if so, how to proceed and what people to get in touch with.

As you perhaps know my wartime assignment in ex-OSS and later in the Dept of State came to a close at the end of last May and I am now most desirous to join the UNESCO. I already am somewhat familiar with international cultural cooperation, because while connected with the French National Museums and Sorbonne, I was occasionally asked to act in capacity of consultant in the now defunct Institute of intellectual cooperation in Paris. At any event I enclose a short biographical sketch of myself. [...]

916. Valderrama 1995:2-3.

917. Sewell 2015:106; Academic Senate 1969:27. 
With kindest regards to both you and your wife.

Most sincerely yours.

Olov R.T. Janse $\mathrm{e}^{918}$

And before long, Wilson responded: ${ }^{919}$

Dear Olov,

Paris XV Ième, $25^{\text {th }}$ September 1946

I have just received your letter of the $12^{\text {th }}$ September, with its enclosed vita concerning yourself. Nothing would give me more personal pleasure than to have you join our staff, and I very much hope that can be arranged in time. As you perhaps know, we are at present a Preparatory Commission, and go out of legal existence before the end of 1946. The staff we have at present is a temporary staff and the full group of experts we need will be recruited only during 1947. I am calling your letter to the attention of the head of the Social Sciences section and the head of the Personnel Bureau, and we will communicate with you if any post in your field becomes available.

Best regards to you and your wife,

Sincerely yours,

HOWARD E. WILSON

True to his word, Wilson contacted the head of the Social Sciences department, the Egyptian geographer Mahomed Bey Awad, to promote Janse for a position in the new organization. A short handwritten note remains in the UNESCO archive:

Awad -

I know Janse well and he

is tops as an archaeologist.

He is a good man to

consider.

Wilson. ${ }^{920}$

918. Letter from O. Janse to H. Wilson, 12 September 1946. UNESCO archives: Olov R. T. Janse personal file.

919. Letter from H. Wilson to O. Janse, 25 September 1946. UNESCO archives: Olov R. T. Janse personal file.

920. UNESCO archives: Olov R. T. Janse personal file. 
So it happened that Olov Janse was contracted as Counsellor for the Humanities in the Social Sciences Section of the UNESCO Secretariat in Paris. Plans were made in great rush - the first General Conference was planned to take place in November - and two months after he wrote the letter to Howard Wilson he boarded an aeroplane for the first time in his life, and took off for Paris.

Back in Washington, DC was Ronny, who had taken up a position as Cataloguer at the Library of Congress and had her own professional career to tend to. It was the first time since they met, nearly twenty years earlier, that they were parted for such a long period of time. The letters he wrote to her testify to their spiritual closeness and longing for each other. Eighty-one of his letters, unfortunately none of her replies, have been kept in their archive. ${ }^{921}$ Thanks to her intimate involvement in his previous work in Paris and Indochina, the letters abound with details of his work in the UNE SCO Secretariat as well as his activities outside the office, where he connected the professional and personal sides of his life in Paris. Together they offer a rare and important glimpse of the realities at the UNE SCO headquarters during the first months of its operation. ${ }^{922}$

UNESCO was established officially only a year after the foundation of the United Nations, on 4 November 1946, when twenty states had signed and ratified its Constitution. ${ }^{923}$ This official moment was, however, preceded by a long period of meetings and preparations, which in turn departed from the legacies of the League of Nations' Institute of Intellectual Co-operation (IIIC). ${ }^{924}$ Its purpose was to serve as a supranational organization for the universal betterment and advancement of education, science, and culture, and its core values were formulated in the famous words of its constitution: "That since wars begin in the minds of men, it is in the minds of men that the defences of peace must be constructed." 925

UNESCO had its first headquarters in the Hôtel Majestic, on Avenue

921. NAA: Janse 2001-29.

922. Janse's time at UNE SCO has also been discussed, based on his letters to Ronny, in the article "The Invisible Archaeologist" (Källén 2014).

923. Valderrama 1995:26-28.

924. Valderrama 1995: chapter 1.

925. Pompei 1972:1.9. 
Kléber near the Arc de Triomphe in Paris. Its organizational structure mirrored that of the United Nations, with an Executive Board chaired by a Director General (at that time the British evolutionary biologist Julian Huxley) and a Secretariat. The Director General and the Secretariat both had their offices in the headquarters. The third important part of the organization, the General Conference with its broader international representation of high profile academics and cultural diplomats, gathered for a meeting once a year, the first time in November-December 1946.

The Secretariat worked according to the principles of invisible and neutral bureaucracy serving the wishes and decisions of the General Conference. In reality, however, it was the Executive Board and Secretariat that prepared the cases for decision-making and it was here that most of the work of UNESCO was done. ${ }^{926}$ The layout of the Secretariat's programme sections reflected the layout of the intellectual work of the new organization. There were sections devoted to Education, Libraries, Natural Sciences, Social Sciences, Arts and Letters, Museums, Mass Communication, and the one Olov Janse would become attached to (first as Counsellor and later as Head of): Philosophy and Humanistic Studies. All sections worked for the overarching aim to rehabilitate war-torn structures for intellectual and scientific cooperation, and create a peaceful world through intellectual efforts towards international solidarity. The number of employees increased steadily over the first few months of operation, and in April 1947 there were 162 executive members of staff in the Secretariat. Seventy per cent were citizens of France (48), the United Kingdom (44) or the United States (21), and Janse was the only Swede..$^{927}$ He was soon promoted to Head of Philosophy and Humanistic Studies, and had an office of his own, in room 254 on the second floor of the Hôtel Majestic. His salary was US $\$ 1,500$ per year, plus 30 francs per day in per diem allowance. He was (to our knowledge) the only archaeologist among the secretariat staff at the time, and archaeology had no specific space in UNESCO's programme. His section - Philosophy and Humanistic Studies - consisted of himself, the Assistant Jacques Havet from France, and the Secretary Mrs Perry-Warnes from the UK.

926. Hoggart 2011.

927. UNESCO Archives: UNESCO/Cons.Exec/2e Sess/14/1947. 
After he landed in Paris on 22 November 1946, he was immediately put to work at the first General Conference. He was 55 years old and excited to be back in France, the homeland of his younger soul. He brought over thirty years' experience of academic work in and between Sweden, France, Indochina, the Philippines, and the United States. To his ample academic record was added the experience of intelligence service from wartime assignments with the OSS and US Department of State. He was fluent in both French and English, and he had acted as consultant to the IIIC during the inter-war years. Altogether it made an almost perfect background for a UNESCO civil servant. For himself, on a professional level, a contract with UNESCO allowed him to make the most of his experiences and expertise, and to work for liberal internationalist ideals that had been a guiding light throughout his career. Moreover, on a personal level, an assignment with UNESCO gave him the opportunity to reconnect with a much happier time of his life, and could, if all went well, be the beginning of a permanent return to Europe for him and Ronny. So he landed in Paris with a light heart and great aspirations for the future.

It is mostly from his letters to Ronny that we know what he did in the eight months he spent in Paris. Although the Secretariat was (and still is) the creative hub of the organization, ${ }^{928}$ it is officially hidden behind a veil of neutral bureaucracy. ${ }^{929}$ From the onset, the Secretariat staff were subject to a series of strict regulations defining them as neutral international civil servants with no national or personal interests. ${ }^{930}$ In one of his letters to Ronny, Janse writes that any information about UNE SCO that he shares must stay between them, because a notice has been sent around informing them that their work is of a "caractère confidentiel", and they have been forbidden to agree to interviews or talk to the press. ${ }^{931}$ With hindsight we can now see that the Secretariat's promulgated invisibility and neutrality has been historically self-fulfilled, because the same bureaucratic ideal has dictated the structures of UNESCO's official archives. No working materials connected with the names of individual members of staff have been kept for the archive. Almost all documents in the archive can

928. Hoggart 2011:30; UNE SCO Archives: UNE SCO/C/Admin. \& Jur/S.C.Ad. \& Fin. /12.

929. Hoggart 2011; Weber 1978: Chapter XI; see also Källén 2014.

930. UNES CO Archives: UNESCO/C/Admin. \& Jur/S.C.Ad. \& Fin. /17. See also Källén 2014.

931. Letter from O. Janse to R. Janse, 5 January 1947. NAA: Janse 2001-29. 


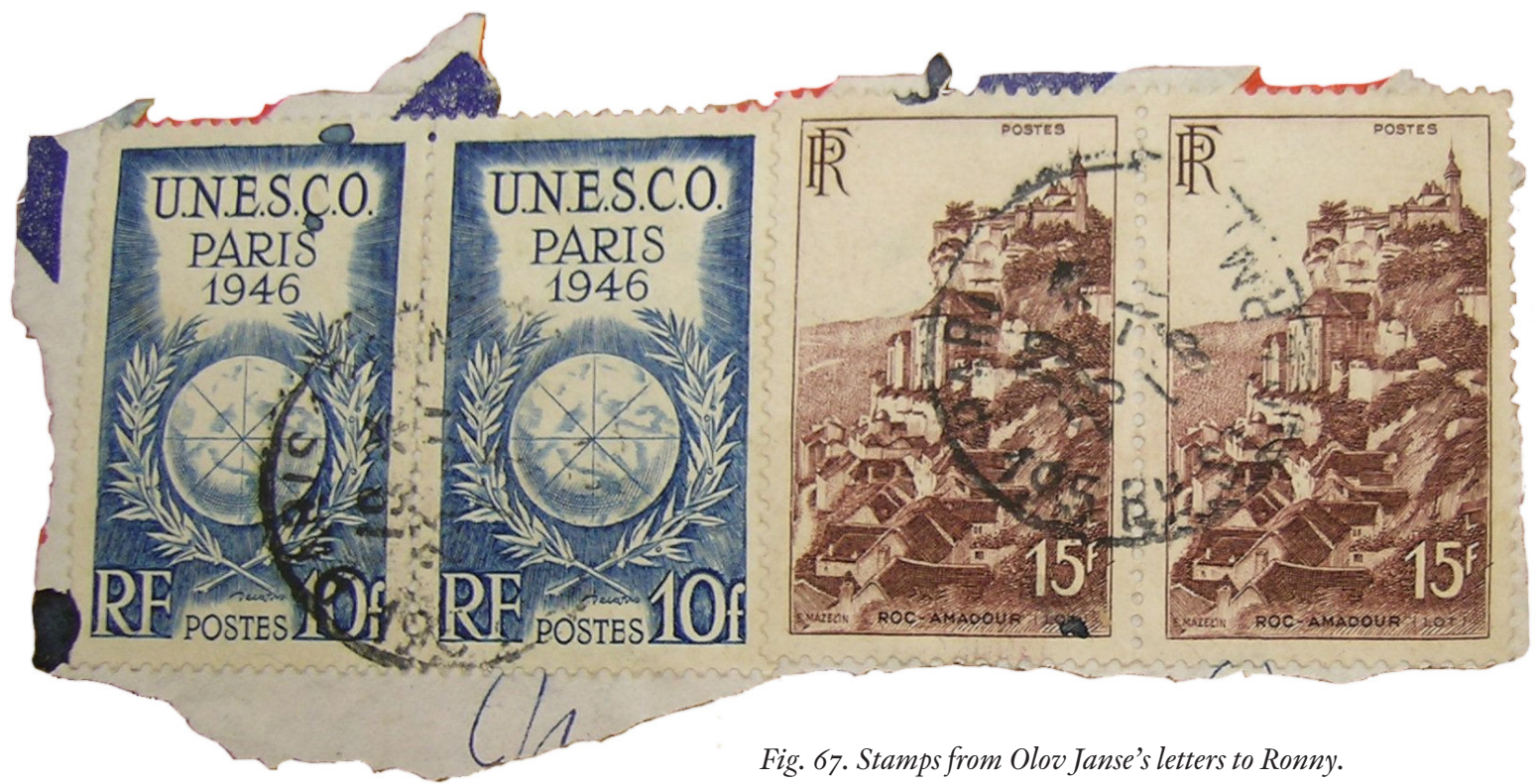

Fig. 67. Stamps from Olov Janse's letters to Ronny.

be connected with the more visible (but less important if you want to understand the situated background to the actual work that was done by UNESCO) Executive Committee and General Conference. ${ }^{932}$ For this reason it would be impossible to trace the work Olov Janse did for UNESCO if we relied on the official archive alone. Fortunately for us, Ronny kept his letters.

Eager to get started with his new assignment, he was thrown into the heart of the action as soon as he had landed in Paris. He arrived two days into the first General Conference and went straight to attend meetings as a representative of the Secretariat. Almost immediately he became engaged in discussions about a report concerning the future work in the section of Humanistic Studies. It had been presented by the Secretariat (represented by Mahomed Awad) and discussed in a meeting of the Sub-Commission of the Social Sciences, Philosophy and Humanistic Studies on 30 November, which Janse attended as a member of the Secretariat. A few days later he wrote to Ronny that he had found the report weak and insufficient, and had picked up the same sentiment in the comments from the American delegate George Shuster.933 Approaching Shuster after the meeting, he had his perception confirmed. He left

932. For two excellent recent studies pointing to the complex works of the UNE SCO diplomatic committees, see Hafstein 2018 and Meskell 2018.

933. Letter from O. Janse to R. Janse, 5 December 1946. NAA: Janse 2001-29. 
encouraged and spent the weekend writing an alternative report - which he presented to Shuster, who adopted it entirely and presented it at the next meeting as a proposal signed by the US delegation. ${ }^{934}$ Janse wrote to Ronny - with exclamation marks and underlining to mark his excitement - that his, or rather, the American proposal had been adopted almost unanimously (!!), and that he was very satisfied indeed to see his very first proposal being so well received - "Comme tu peux t'imaginer j'ai une très grande satisfaction de voir l'accueil qu'on a fait à ma première proposition ici." ${ }_{335}$ The report itself was not formally attributed to Janse after it was adopted by the US delegation, and its contents is of little concern here - but the measures and movements as described in the letters to Ronny are all the more interesting. They demonstrate how Janse acted in his new role as invisible civil servant, with active inputs of knowledge and strategy into the works of UNESCO, lending it to be used by the officially visible national delegations.

Although he did not get his name officially stamped on the report, nor on the new programme for Humanistic Studies that it resulted in, he was duly rewarded for his work. He was immediately given responsibility for the implementation of the idea of fact-finding boards (which was a main issue in the report), and was put in charge of the work in the section for Humanistic Studies. And on the evening after the meeting, he was invited to an exclusive cocktail reception at the legendary Hôtel de Crillon, with the top names of the American delegation. The Hôtel de Crillon at Place de la Concorde was (and still is) a legendary building in French and international politics, where the American delegation to UNE SCO had set up their headquarters. To Ronny he wrote, apparently proud and pleased, that there had not been more than thirty people invited, only Americans. "Very 'selective":

The same evening I was invited to Hôtel Crillon by Mr. Archibald MacLeish for a cocktail party where I was introduced to $\mathrm{Mr}$ and Mrs Benton, Assistant Secretary of State and Head of the American delegation, Mr Charles Thompson, Compton and others from the State Department, Chester Bowles, American Head of

934. See Källén 2014 for a more thorough description of the report and steps taken by the actors involved.

935. Letter from O. Janse to R. Janse, 5 December 1946. NAA: Janse 2001-29. 


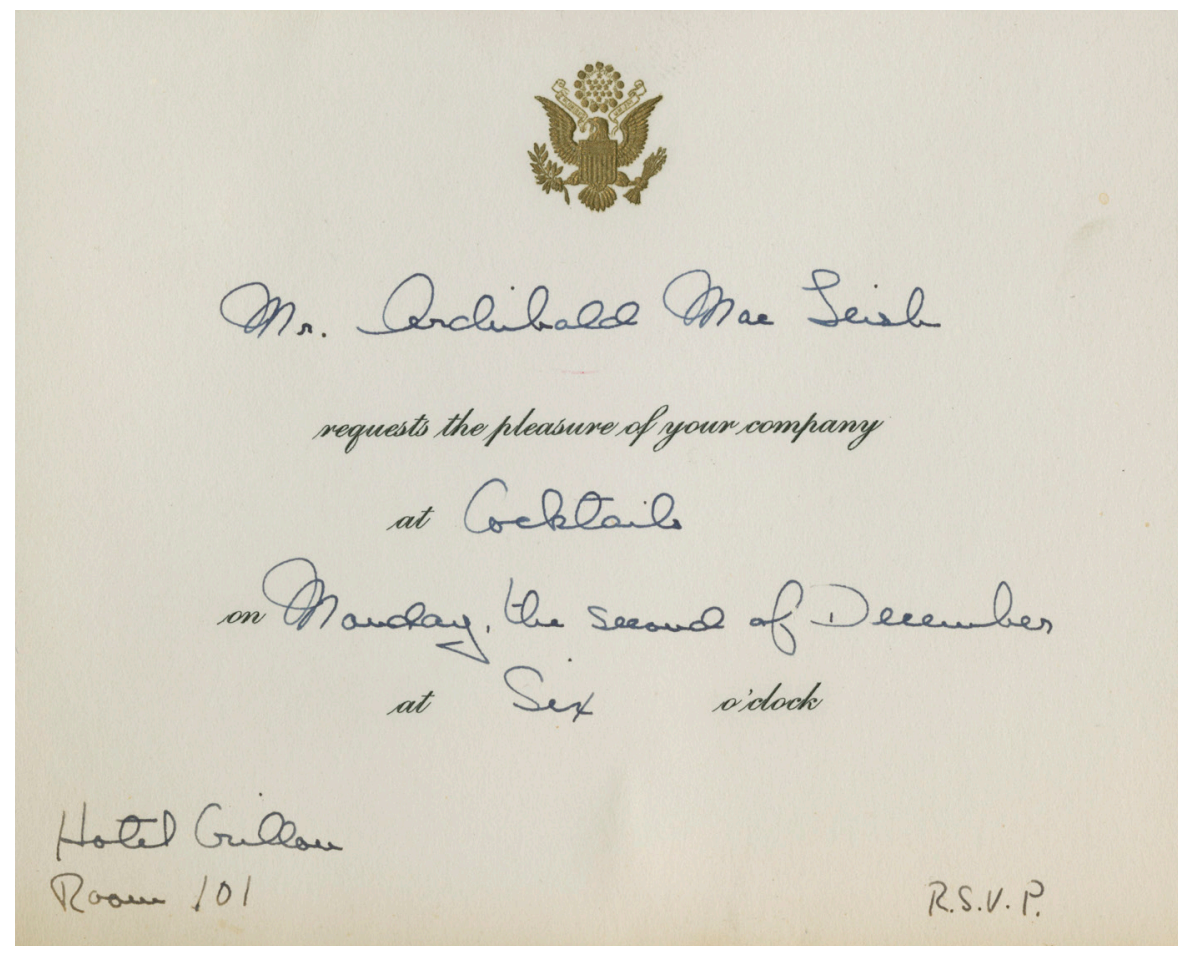

Fig. 68. Invitation for cocktails at Hôtel de Crillon, on 2 December 1946.

the Office of Price Administration. There were only Americans, and it was very "selective". Thirty or so people. ${ }^{936}$

It remains rather vague what projects and issues Janse worked with at UNESCO, apart from his involvement in that first report. He got on very well with the Director General Julian Huxley (1887-1975), an outspokenly anti-racist evolutionary biologist and proponent of eugenics [sic], with a firm belief in the progress-cum-evolution of mankind into one "world mind" by means of cultural, educational, and above all scientific guidance by leading Western nations. ${ }^{937}$ In his function as Head of Philosophy and Humanistic Studies, Janse attended and assisted Julian

936. Letter from O. Janse to R. Janse, 5 December 1946. NAA: Janse 2001-29. In the French original: "Le soir même j'étais invité à l'Hôtel Crillon par M. Archibald MacLeish à un cocktail party où j'étais présenté à $\mathrm{Mr}$ and Mrs Benton, assistant secretary of State et chef de la délégation américaine, Mr Charles Thompson, Compton etc du State Dept, Chester Bowles, ame. chief de l'O.P.A [Office of Price Administration]. Il n'y avait que des américains et c'était très 'selectif'. Une trentaine de personnes."

937. Waters \& Helden 1993. See also Meskell 2018:1-17, 24-27 for details on Huxley at UNE SCO. Julian Huxley's personal visions for UNESCO are detailed in a pamphlet 
Huxley in meetings (which he soon got very tired of, and started comparing with the OSS)..$^{938} \mathrm{He}$ wrote reports and monitored the work to reconstruct and support rebuilding of humanistic knowledge resources after the war, which was also one of UNESCO's main tasks. He was involved in a project for translation of classics - "a rather interesting, but a gigantic subject" 939 - and towards the end of his assignment he began to work with the issue of human rights, at the very onset of the project that led to the adoption of the Universal Declaration of Human Rights in December 1948.

Above all, it was the social, diplomatic, side of the UNESCO work that Olov Janse warmed the most to. He was a polyglot, mastering not only French and English to near perfection, but could also communicate with other Scandinavians in their native languages. And his skills went beyond language, to a broad cultural know-how that he had gained from living and working in Scandinavia, France, Indochina, and the United States. Not only could he act as a translator and bridge-builder between the different language spheres, but his experiences allowed him to navigate and negotiate sensibly between different cultures and administrative structures. This in-between competence allowed Janse to play a special role in negotiations of "soft", "cultural", or "public" diplomacy, which has been put center stage in many studies of UNESCO. $94^{\circ}$

In recent research on UNESCO, "diplomacy" has come with a number of different prefixes. Some examples from literature relating directly or indirectly to UNESCO are cultural diplomacy, deliberative diplomacy, preventive diplomacy, serial diplomacy, multilateral diplomacy, photographic diplomacy, boycott diplomacy, and heritage diplomacy.941 Out of these, only "cultural diplomacy" existed as a structural idea, albeit not as an explicit concept, at UNE SCO when Olov Janse worked there in 1946-47. The report from the first General Conference in November 1946 says:

It is evident then that diplomacy needs the collaboration of a United Nations Organisation in the intellectual, cultural and ed-

that he produced on his own initiative (Huxley 1947), but which was later criticized for not being representative of the visions of the organization at large (Sluga 2010:402-403).

938. Letter from O. Janse to R. Janse, 9 January 1947. NAA: Janse 2001-29.

939. Letter from O. Janse to R. Janse, 23 February 1947. NAA: Janse 2001-29.

940.E.g. Hafstein 2018; Meskell 2018.

941.E.g. Boutros-Ghali 1992; Götz 2011; Jordan 1984; Singh 2018; Winter 2015. 
ucational field, based on the free association, the creative activity and the common aspirations of the peoples of the United Nations, so that the efforts of diplomacy may be more fruitful. ${ }^{942}$

In total, the word "diplomacy" is only mentioned four times in this first report, which can be compared with the word "culture", which occurs 171 times. Diplomacy was clearly not a key issue in outspoken terms, and when it is discussed it is in the sense of diplomacy proper, i.e. diplomatic relations between nations. It was argued that the diplomatic relations needed to include intellectual, cultural, and educational fields to become more fruitful in the future. Even if it is not spelled out explicitly in the report, this idea and ambition could be called "cultural diplomacy", or even better, "public diplomacy" in the broader sense of the term (leading back to Kant's political philosophy in the eighteenth century) that we have discussed in the chapter "OSS and the US Department of State".

Judging from the online archives, the concept of "cultural diplomacy" does not occur literally at UNESCO until 1964, when it is stated in a book review in UNE S CO's journal International Social Science Journal that "[s]cientific co-operation can nowhere be divorced from cultural diplomacy - further evidence that the hope of keeping science apart from politics is a vain one". ${ }^{943}$ The concept of "public diplomacy" occurs for the first time eight years later, in a book published in 1972 that is listed in UNESCO's archive. ${ }^{944}$ Hence we can conclude that concepts such as cultural or public diplomacy were not in use at UNESCO in the 1940s, but are concepts of a much later date, which have become key in academic analysis only in recent decades. It could be argued that UNESCO in the first years of its existence did not need to define cultural diplomacy or public diplomacy explicitly, because the activities that such concepts embrace had been embedded for centuries in European political and philosophical thinking. ${ }^{945}$

Only six days after his arrival in Paris (still during the first General Conference), Olov wrote to Ronny that he was contemplating setting

942. Conference for the Establishment of the United Nations Educational, Scientific and Cultural Organisation, held at the Institute of Civil Engineers, London, from the 1st to the 16th November, 1945, p49. https://unesdoc.unesco.org/search/obo92c27-97d947b5-8935-78148a6795af, accessed 13 April 2019.

943. Anonymous, 1964 .

944. Fisher 1972.

945. See discussion in the chapter "OSS and the US Department of State". 
up an international organization for archaeology, and for this purpose he had reactivated his old network of academic friends in Paris, with high-profile scholars like René Grousset, Georges Salles, Georges-Henri Rivière, and Philippe Stern. ${ }^{946} \mathrm{He}$ was keen to reconnect with old friends and colleagues - perhaps also with a previous lifestyle - from the pre- and inter-war years. Three connected circles of old friends stand out in the letters. The first includes top academics and museum directors like René Grousset, Georges-Henri Rivière, Marcelle Minet, and André Varagnac. The second, in close connection with the first, consists of art collectors and patrons like David David-Weill, C.T. Loo, Gabriel Cognacq, Jacques Orcel, and Mary Churchill Humphries. These two categories belonged to, or shared social space with, the wealthy and influential Parisian bourgeoisie. Their relations with Olov and Ronny Janse were established before they set off to Indochina more than a decade earlier. The third category was less distinctive in terms of class and social situation, and included old friends and colleagues from Indochina, who had returned to France during or after the Japanese occupation. Among them were Paul Lévy, René Mercier, Jean-Yves Claeys, and George Coedès. Their relations could indeed have been complicated by Janse's war-time assignment with the OS S and US State Department (which were explicitly against a French reinstitution of power over Indochina after the Japanese occupation), but judging from the letters to Ronny, his personal loyalty to the French remained intact. In his spare time, he was a frequent guest in the homes of René Grousset and David David-Weill, and he asked them (particularly Grousset) for advice on his UNE SCO work. ${ }^{947}$ In fact, René Grousset welcomed Janse back to Paris almost like as a family member. He discussed and helped him with his UNESCO work, and Janse spent much of his spare time with the Grousset family. Following the tragic death of their daughter Ginette, Janse was invited to the family funeral, and he was present when René Grousset was installed on chair 36 as one of les immortels of the French Academy in January 1947, among a mere few of Grousset's closest personal friends. ${ }^{948}$ From his letters to Ronny, it is evident that his relationship with David David-Weill was likewise warm and cordial. Janse was a regular guest at the David-Weill home in Neuilly, both at larger functions and at private tea or luncheons. David-Weill

946. Letter from O. Janse to R. Janse, 27 November 1946. NAA: Janse 2001-29.

947. See "Conclusion".

948. Källén 2014. 
was seeking Janse's advice on matters of Asian art and museums, and purchased a collection of his excavated materials from Thanh Hoa in Indochina that had been stored in Paris during the war:

As I mentioned in my last letter, I went to Neuilly, where I sold some Th-h poteries [sic] and bronzes for $900 \$$ which will be sent to our savingsaccount [sic]. I may be able soon to send another smaller sum in addition. I had a very quiet and pleasant talk with Mr D.W. who asked me to come back some day and make a notice about the things he bought. I will probably go back there next saturday $[\mathrm{sic}] . .^{949}$

The affair was indeed a good deal for Janse. He wrote some days later to Ronny that he had "inquired on several places for the prices of the things and none would even pay half the price I received". 950 Such generosity vis-à-vis scholars and museum personnel was characteristic for David David-Weill, who was known as an important patron of the museums in Paris. He was at that time already coming to age, and died only five years later in his home in Neuilly. After his death he bequeathed over two thousand art objects to French and American museums. His collection of Chinese bronzes (which may have included the ones he bought from Janse) was donated to the Musée Guimet.

Janse was moreover keen to maintain good relations with the American delegation to UNESCO. Although France and the UK dominated the administration at the Hôtel Majestic, the United States delegation to the General Conference had a strong position thanks to its generous contributions to the budget of UNESCO, and the heroic status of the United States after the war. ${ }^{951}$ Janse writes to Ronny that he was in continuous contact with George Shuster, and met him and others in the American delegation regularly at the Hôtel de Crillon. It is, he adds in the letter, "very useful for me to meet all these people here". 952 He also met on several occasions with Chauncey Hamlin, Director of the Buffalo Science Museum where they worked in the interim between

949. Letter from O. Janse to R. Janse, 5 March 1947. NAA: Janse 2001-29.

950. Letter from O. Janse to R. Janse, 16 March 1947. NAA: Janse 2001-29.

951. Graham 2006.

952. Letters from O. Janse to R. Janse, 12 December 1946 (In the French original: "C'est très utile pour moi de rencontrer ici touts ces personnes"); 9 April 1947. NAA: Janse 2001-29. 
their second and third Indochina expedition. They talked about some textiles from Indochina that Janse had stored in the attic of the Guimet Museum, and Hamlin wanted to purchase from him. They also discussed Hamlin's ideas to create a new international museum organization. ${ }^{953}$ Shortly thereafter, the International Council of Museums (ICOM) was founded, with Chauncey Hamlin as its first president. From the letters it seems as if Janse was not particularly fond of Hamlin, but he continued to nurture their relation for strategic reasons:

I think that Hamlin soon will get the Legion of Honor and I hope also that he will not forget, that I made the first steps to get it for him. I wrote to him about this some days ago and I am convinced that it is essential to keep in contact with a man like him [...] All this is of course strictly between us. ${ }^{954}$

This demonstrates how Janse used his French connections to enhance his position vis-à-vis the Americans, and he also used his UNE SCO position to gain prestige in his French networks. This strategic positioning served mainly his personal interests but affected, in the form of cultural diplomacy, the work he did for UNESCO. ${ }^{955} \mathrm{He}$ acted as a translator and built bridges between the two groups, for example by arranging joint luncheons where he connected key actors. His letters reveal how he went about pulling threads from his different networks, and weaving them together in new formations:

There has been appointed a frenchman [sic] for the "Programme", he is the former head of the [IIIC], Mr [Jean-Jacques] Mayoux. I have a great deal to do with him. I have suggested to him to get [George] Codès and [René] Grousset connected in some way with Unesco especially as we are directed to lay special emphasis on India. He agreed with me and said that he would like to get in touch with them. Then I recalled that Mr D.W. [David-Weill] as president of the Nat Museums used to give occasionally luncheons to arrange for scholars to come together. So I went to the phone and called up Mlle [Marcelle] Minet and talked to her about the

953. Letter from O. Janse to R. Janse, 20 December 1946. NAA: Janse 2001-29. 954. Letter from O. Janse to R. Janse, 19 February 1947. NAA: Janse 2001-29. 955. Hoggart 2011:44. 


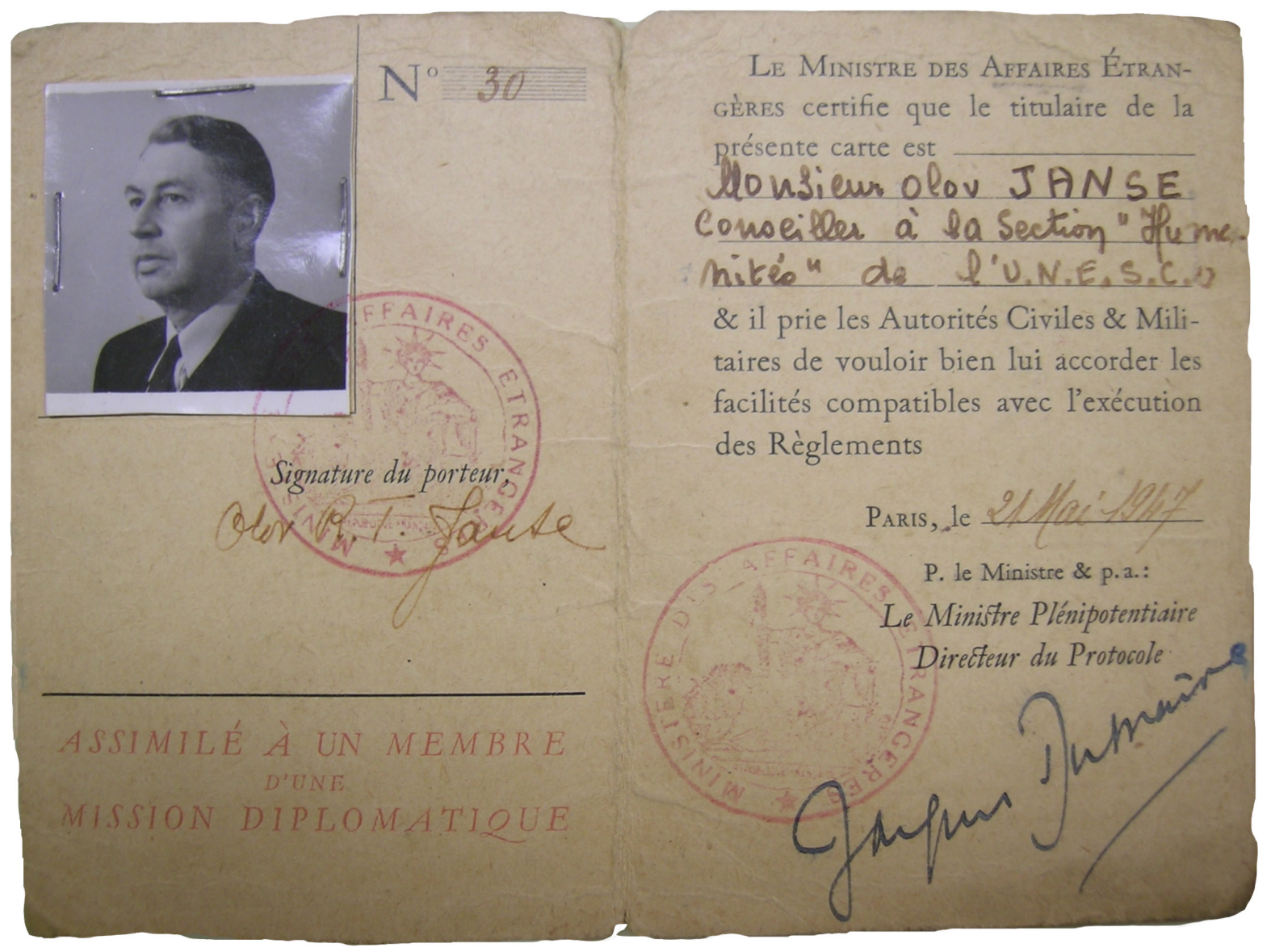

problem and then she said I am sure Mr and Mrs D.W. would be glad to organize a luncheon for the Unesco key officials to meet some French intellectuals as Grousset and Cœè̀s etc. Today she called me and said that the luncheon has been set for the $22^{\text {nd }}$ of May and Dr Huxley, the deputy directors, [Jacques] Jaujard, the Director of Beaux-Arts etc will be invited. ${ }^{956}$

In these interactions, his assignment with UNE SCO offered him a certain elevated "quasi-diplomatic" status, manifested with a special identity card issued by the French Foreign office. .57

956. Letter from O. Janse to R. Janse, 12 May 1947. NAA: Janse 2001-29.

957. Letter from O. Janse to R. Janse, 12 February 1947. NAA: Janse 2001-29. 
The social and diplomatic sides to the UNE SCO work seem to have sparked his enthusiasm initially, and the reactivation of his former networks gave strength and energy. During the first couple of months he wrote his letters to Ronny in French, and made plans for her to join him in Paris. Much of his spare time outside UNE SCO was spent scouring the stores of museums (Cernuschi and Guimet) and the attic of his friend C.T. Loo, renowned dealer in Chinese art and antiquities, for their collections and belongings that had been hidden during the war. The stores were a mess, having functioned as safe houses for private collections of artefacts or personal belongings. Olov's and Ronny's belongings had been packed and stored in a rush by their friends when they did not return from Indochina as planned. Going through the things in the attic - feeling the smooth touch of half a dozen silk shirts from Tokyo, the fragrance of jasmine tea, and a box of dried rose petals from their summer holidays as newly-weds with his family in Sweden - connected him physically and emotionally with bygone times. ${ }^{958}$ The letters tell that the reconnection with their old friends and their stored belongings also in some sense induced hopes for reconstruction - of the lives they lived and the social spaces of affluence and influence they used to occupy before the war.

But there were other sides to the reality at UNE SCO and in Paris that gradually wore him down. Post-war Paris was a sad shadow of the city he once loved. He wrote to Ronny:
When you say that it must be very interesting to listen to so many witty conversations I am afraid that you make some wish- ful thinking. Before the war it was much more interesting and we were perhaps less critical. Now the conversation deals mostly with matters like cold weather, problem of heating, food, etc. However, the little circle of friends we have here is quite interesting, but they are all trying to go to the U.S.A.959

Having expected a joyful return to the homeland of his soul, he was taken aback by the misery of the post-war situation. Although he and his colleagues - whom he refers to as Unescians - were privileged with a quasi-diplomatic status, income, housing, a restaurant and a cooperative for food and basic supplies, they were also affected by the general situation in Paris.

958. Letter from O. Janse to R. Janse, 5 December 1946. NAA: Janse 2001-29. 959. Letter from O. Janse to R. Janse, 31 January 1947. NAA: Janse 2001-29. 
I have just had a visite [sic] here in U. of Mme Maspero, widow of the famous sinologist who was killed in Büchenwald. She is asking for a job in Unesco to make translations or almost anything so she can at least get the benefit of the restaurant and the cooperative. Her eldest son was killed at the end of the war at Metz and she was during most of the war in a polish [sic] concentration camp. Grousset has asked me to do what I can for her here, but it is not easy for the French to get into Unesco, because their quota is already almost filled. There are many cases like this..$^{960}$

"People try to smile but life is not joyful", he writes to Ronny, only ten days after he arrived in Paris. There was fear for the future, and everywhere were mendicants, blind and mutilated people, as constant reminders of the war, in which the French had suffered terribly. ${ }^{961}$ Some of Janse's old colleagues and friends had lost their lives during the war, and many more had lost their minds or their fortunes. The shortage of food and basic supplies got worse and worse, and the Metro stank because there was no soap to keep clean..$^{962}$ The weather was miserable too. Endless rains were followed by the coldest and longest winter in living memory. The heating system failed, first in the Hôtel Pont Royal where he was staying, and later in the UNE SCO building. He was hungry, and the meals of the UNESCO restaurant were insufficient. There were strikes in the postal service, the Metro, taxis ... everywhere. ${ }^{963}$ Already in December he wrote: Tous ceux qui peuvent quitte le pays et tout le monde rêve d'aller en Amérique - all who can leave the country are leaving, and everyone is dreaming of going to America. ${ }^{964} \mathrm{He}$ lost weight and complained of nightmares. He too dreamt of America, and began to shift focus towards a future in Washington:

Once I have got U.S. citizenship I am sure I will get a job in Washington. I think, at present it is one of the best towns to live in. $[\ldots]$ It is also no pleasure to live here and the traveling in France, which we used to like so much, is not what it once was. ${ }^{965}$

960. Letter from O. Janse to R. Janse, 5 March 1947. NAA: Janse 2001-29. 961. Letter from O. Janse to R. Janse, 8 December 1946. NAA: Janse 2001-29. 962. Letter from O. Janse to R. Janse, 9 March 1947. NA A: Janse 2001-29. 963. Letter from O. Janse to R. Janse, 14 February 1947. NAA: Janse 2001-29. 964. Letter from O. Janse to R. Janse, 10 December 1946. NAA: Janse 2001-29. 965. Letter from O. Janse to R. Janse, 9 March 1947. NAA: Janse 2001-29. 
From Janse's letters we can tell that in the first year of UNE SCO's existence, surprisingly little attention was paid to the intellectual work and the actual contents of the programme. The descriptions of the situation in Janse's letters can be verified by UNESCO archive records of meetings, discussions and official documents from 1946-1947. Almost all concern the structure of the administrative system, contracts and salaries, problems with the office building, and not least a constant mulling over budget constraints. ${ }^{966}$ It is evident that this was frustrating for many members of the Secretariat and eventually led many of them, Janse included, to leave their assignments. He applied for a permanent position on 14 January, ${ }^{967}$ and his letters to Ronny show that he was still, at that time, enthusiastic about his work and the context of UNESCO. He wrote about arrangements for her to come visit him, made plans for the General Conference in Mexico in the autumn, and, perhaps most significantly, he wrote his letters in French. But by the end of January, he shifted to English. In his letters over the following months he made several insinuating comparisons with his time at the OSS. ${ }^{968} \mathrm{He}$ wrote about endless meetings, from 9.30 in the morning to 6.30 in the evening, even on Saturdays. ${ }^{969}$

\section{Darling, Dear,}

Since I wrote you my last letter nothing special has happened, no invitations, life continues dull and uninteresting here. The work is becoming rather monotonous, except for the meetings of the heads of section where there is a great deal of animation. [...] Next week we expect to start the execution of the programme for the Mexico conference and I presume it will be a very, very busy time. Rush, rush, rush. Never mind, I will do my best!970

In February they had a period with evening meetings as well, between 8.30 and 11 p.m., and Janse writes to Ronny: "It is very tiring and not so pleasant to sit in a smoke-filled room a whole evening." ${ }_{971} \mathrm{He}$ was longing to go home [sic] to Washington, and started looking for career opportunities at the Library of Congress. None of Ronny's letters have been

966. UNE SCO Archives: UNE SCO/C/Admin. \& Jur.

967. UNESCO Archives: O. Janse personal file.

968. E.g. letter from O. Janse to R. Janse, 9 January 1947. NAA: Janse 2001-29.

969. Letter from O. Janse to R. Janse, 39 November 1946. NAA: Janse 2001-29.

970. Letter from O. Janse to R. Janse, 14 March 1947. NAA: Janse 2001-29.

971. Letter from O. Janse to R. Janse, 2 February 1947. NAA: Janse 2001-29. 
saved, but from his responses we can tell that she suffered, was unwell and seems to have been depressed, while he was away. If they had originally nurtured plans to return and settle for good in Paris with his assignment at UNESCO, they both came out on the other end determined to settle for good in the United States. His contract was terminated on 31 May 1947. After that he used some saved vacation time to travel to Sweden to visit friends and relatives for the first time after the war, and got a chance to settle his father's estate. He returned thereafter to the United States with S S America from Cherbourg on 18 July 1947.

Olov Janse did not leave much of a lasting trace at UNESCO. There is a personal file with his name in the UNESCO archive, but it contains but a few documents relating to his employment. Apart from being an officially invisible cog in the machinery of the UNE SCO administration, and his occasional match-makings of influential French academics, art dealers, collectors, and colonial administrators with UNESCO's staff and members of the US delegation through meetings and joint luncheons, he pursued one particular question (out of own interest) that might have contributed to the future work of UNESCO. From his letters to Ronny we can see that he was nosing around something which could be described as an embryo to the World Heritage Convention, ${ }^{972}$ which was formed twenty-five years later and has since become the organization's flagship project. ${ }^{973}$

In December 1946, shortly after his arrival in Paris, he wrote to Ronny that he had discussed with Howard Wilson (who "endorsed it completely") an idea that "could spark the imagination of the entire world". The idea was to put major archaeological and historic monuments - for example Forum Romanum, Parthenon, the Pyramids, the Sphinx, and Angkor - under the trusteeship of UNESCO, and make replicas of the monuments for display in the sunny desert of Arizona. ${ }^{974}$ The idea to put an international trusteeship over important monuments was not entirely new, and it tallied well with UNESCO's overall aim to work against

972. Convention Concerning the Protection of the World Cultural and Natural Heritage, UNESCO 1972.

973.E.g. Meskell 2018.

974. Letter from O. Janse to R. Janse, 17 December 1946. NAA: Janse 2001-29. 
threats and destruction of cultural resources, particularly in a situation of war. ${ }^{975}$ Similar thoughts had been circulating already at the IIIC in the inter-war period, ${ }^{976}$ but Janse's idea of a UNE SCO-controlled trusteeship and replica-making of important monuments for placement in an American desert (however bizarre it may sound) captures in some sense the protection-consumption essence of the World Heritage concept today. Janse connected his idea with Roosevelt's idea of international governance, and thus presented it as a US-rooted concept. But the monuments he picked as examples - a classic choice of sites to visit on a nineteenth- and early twentieth-century round-the-world-trip - fell back on his European experiences, and reflect the classic Bildung ideals of the European cosmopolitan bourgeoisie and upper classes. All the monuments he suggested were also included on the World Heritage List from early on, and are still known as some of its most iconic sites.

Janse never presented his idea officially at UNESCO, but according to the letters he discussed it informally with several colleagues and acquaintances in and around UNESCO, and had positive responses from Howard Wilson and Chauncey Hamlin, who were both men of great influence in UNESCO and ICOM. Janse moreover discussed his idea with the French anthropologist Paul Lévy (the same Lévy that had been proposed by George Cœdès to participate in Janse's excavations during his third expedition to Indochina, and had now advanced to Director of the EFEO in Hanoi):

Paul Lévy tells me that my suggestion to place certain cultural monuments under Unesco trusteeship may be regarded as most welcome regarding Angkor. This strictly between us. He is very reluctant to return to Indochina. Will sail probably in about two months and stay there only for some time to arrange to get various collections and documents sent to France. He has promised to choose a nice head from Angkor and apply a very reasonable price. ${ }^{977}$

Janse mentions several times in his letters to Ronny this "head from Angkor" that Paul Lévy had promised to get them for "a very reasonable

975. Meskell 2018.

976. Turtinen 2006:46-49; Titchen 1995.

977. Letter from O. Janse to R. Janse, 12 February 1947. NAA: Janse 2001-29. 
price". What might seem like a paradox - to work for international trusteeship over Angkor, and at the same time arrange for a part of its monuments to be removed and shipped overseas to enrich one's own private collection (preferably at a bargain price) - was clearly no paradox for Olov Janse. This is a point worth dwelling on, for it says something important not only about Janse as a professional archaeologist, bureaucrat, and person, but also about the discourse concerning rights and ownership over cultural objects in the early UNE SCO Secretariat.

We may assume that Olov Janse was not the only member of the Secretariat who used the backstage of UNESCO to promote his own views - not only of what was best for UNESCO, which ought to have been his sole mission. He did it just as much, if not more, to enhance his own position; at UNESCO, in his French networks, and towards an envisioned future in America. He had learned the know-how of this practice from pre- and inter-war cosmopolitan archaeology, where networks of art collectors and intellectuals among the upper bourgeoisie and noble classes in France and Sweden supported his research in Europe and his archaeological expeditions to French Indochina. ${ }^{978}$ This practice was based on enlightenment ideals of the cosmopolitan individual, and was intimately linked to late nineteenth- and early twentieth-century European colonial societies with their well-known structural inequalities in terms of gender, class, and race. ${ }^{979}$ It would have been remarkable had Olov Janse not brought this practice with him, when only a few years later he came to work for a newborn UNESCO. Secretariat staff were recruited on the basis of extraordinary individual achievements and international experience in the academic fields of education, science and culture. Like Olov Janse, most of the executive members of staff had built their careers on visibility and a strong individual voice. Moreover, they were instructed to work for a Constitution enshrining the idea of free enquiry and with a programme built on humanist peace-striving ideals, which required informed experiences and personal points of view. ${ }^{980}$ They were, in other words, "by their oath required to be much more than faithful functionaries". ${ }^{981}$ So, what from early UNESCO policy documents may appear like a clean break with pre-war colonial structures, and the creation of

978. Hegardt \& Källén 2014.

979. E.g. Cooper 2001; McClintock 1995.

980. Hoggart 2011:11.

981. Hoggart 2011:41. 
a neutral supranational One-World organization, included in practical reality a continuation of a pre-war networking and positioning culture where actors like Olov Janse carried pre-war foundations for structural inequality into the new organization..$^{82}$

Notwithstanding its many connections with pre- and inter-war times, the establishment of UNESCO in 1946 represents the distinctive starting point of an international framework for cultural heritage management that remains to this day. Important policy documents which have defined twentieth- and twenty-first-century heritage conservation across the world, such as the Hague Convention, the Venice Charter and the World Heritage Convention, are all the works of UNE SCO. Established when the door had barely been closed on the Second World War, UNESCO carried passionate yet fragile hopes for a peaceful future built on intellectual cooperation and ideals of One-World internationalism. ${ }^{983}$ Many of its initial aims and ambitions in this vein remain with the organization today. ${ }^{984}$ It means also that political values that were at the heart of the initially dominant nations France, the UK, and the USA (universalist liberalism, and naturalization of European world-dominance through "neutral" structures of bureaucracy, for example) also remain at the core of UNESCO, where they are still flagged as universal values promoted for the peaceful future of all mankind..$^{95}$

Such curious inconsistencies between its aims and practical outcomes, and of course its centrality in late twentieth- and early twenty-first-century conceptions and management of heritage on a global scale, have recently made UNESCO a major research object and subject of debate in critical heritage studies. ${ }^{986}$ One of the most important questions for critical heritage studies has been to investigate the formation and workings of a professional corps for conservation and heritage management, which can be connected with UNESCO and its policy documents. The integrity and professional values of this corps are maintained and pro-

982. Sluga 2010 .

983. Sluga 2013.

984. Hafstein 2018; Meskell 2018.

985. See also the discussion of public diplomacy and its roots going back to Kant in the chapter "OSS and the US Department of State".

986. E.g. Harrison 2012; Meskell 2018. 
tected by what Laurajane Smith has called an Authorized Heritage Discourse (AHD), defining and justifying conservation and heritage management according to universal standards in terms of "best practice". ${ }^{987}$ Critical research over the past few decades has concluded that this "best practice" does not in fact include the views and visions of all of mankind, but has a strong bias in terms of class and Judaeo-Christian, rationalist, Western European values, which has long excluded alternative approaches to heritage that exist, for instance, in Buddhist contexts, and in vernacular situations all over the world. ${ }^{988}$ Olov Janse's trajectory through the earliest days of UNE SCO offers detailed insights into the foundations of the AHD, and offers explanations for some of its biases. The good will and passionate ambition to create a peaceful future was no doubt there (just as the French and British colonial projects were officially driven by good will for the colonial subjects in the name of universal development)..${ }^{989}$ But the dominance of the main pre-war European colonial powers and the world-leading nations of the post-war era in the new "neutral" Secretariat that was supposed to serve universal values, meant that the project was provided with blinkers for alternative views of education, science and culture (including heritage) right from the onset. Janse largely continued to work with the same ideals and intellectual strands as he had done in the service of Imperial France before the war. And no doubt the members of the Secretariat (like the Director General and General Conference) were, just like Janse, of privileged classes with a high level of classic European Bildung.

But there were also some changes that pointed to the future, for Olov Janse's career and for international archaeology and heritage management. One is the turn against communism as a common enemy and threat to world peace. ${ }^{990}$ Janse describes in one of his letters to Ronny how a Russian member of the Secretariat was considered indiscreet and discontented when she attended meetings - "luckily only on rare occasions". ${ }^{911}$ This in combination with other comments throughout his letter

987. Smith 2006.

988. E.g. Byrne 2014 .

989. See the discussion on public diplomacy and Kant in the chapter "OSS and the

US Department of State".

990. See also Graham 2006.

991. Letter from O. Janse to R. Janse, 16 January 1947. NAA: Janse 2001-29. In the French original: "Nous avons une femme qui est dans la section des Sciences. Quand elle assiste (rarement, heureusement) à des réunions, elle voit toujours des complications 
indicates a strong anti-communist, particularly anti-Soviet, sentiment in the UNESCO Secretariat at large. With the benefit of hindsight, it is not difficult to see embryos of some of the major world conflicts of the twentieth century - Korea, Vietnam, Cuba - in this universalist peace-seeking mission dominated by two former colonial powers and the USA, where more and more attention was focused on combating communism in the Soviet Union and East Asia. Although they did not see it at the time, blinded as they were in their ambitions for peace by the facts of the Second World War, the Cold War was gaining momentum. And anti-communist policy, later also known as McCarthyism, would dominate the rest of Janse's career after his return to the United States.

If Janse's inter-war endeavours were driven by research questions and ambitions for museum collecting, and his wartime assignments with the OSS and the US State Department were driven by state policy alone, the eight months at UNESCO allowed him to combine his research knowledge and networks with work concerning supranational policy, administration, and soft diplomacy. These were experiences that he would build on and continue to develop in his future work in the United States.

inutiles, pose mille questions indiscrètes paraît toujours mécontente de tout et de tout le monde." 


\section{RENÉE}

Do blondes have more fun?

Yes, looking in the mirror! ${ }^{992}$

A year after Olov's return from Paris, Olov and Ronny were naturalized and became US citizens. On the same date, 7 September 1948, Ronny changed her name to Renée - Renée S. Janse. All thoughts and aspirations of returning to Europe were gone, and their efforts were now focused on their new life in the United States. In 1949 they bought a piece of land and built a summer cottage at Cove Point, close to the sea in Maryland, a couple of hours by car from their home in Washington, D C. 993

Ever since she became Mrs Janse in 1930, Ronny had been celebrated in her role as wife of a successful cosmopolitan archaeologist. In their archive are a series of clippings with articles featuring their adventures, where she is described in glowing terms as an extraordinary woman whose exciting life "sounds like a Cook's Grand Tour":

Mrs. Olov T. Janse, wife of the distinguished Swedish archaeologist now at Harvard, is one of the most fascinating and cosmopolitan women whom it has been our privilege to interview [...] Mobile and sensitive features, a charming laugh, and eyes that crinkle at the corners when she smiles make her a most responsive person with whom to converse. .94

992. Typed note in Janse's archive. NAA: Janse 2001-29.

993. Letter from O. Janse to T. Nerman, 21 December 1949. Arbetarrörelsens arkiv och bibliotek. Ture Nerman 3.1.46. The letter includes photographs from the cottage.

994. Gordon 1941. 


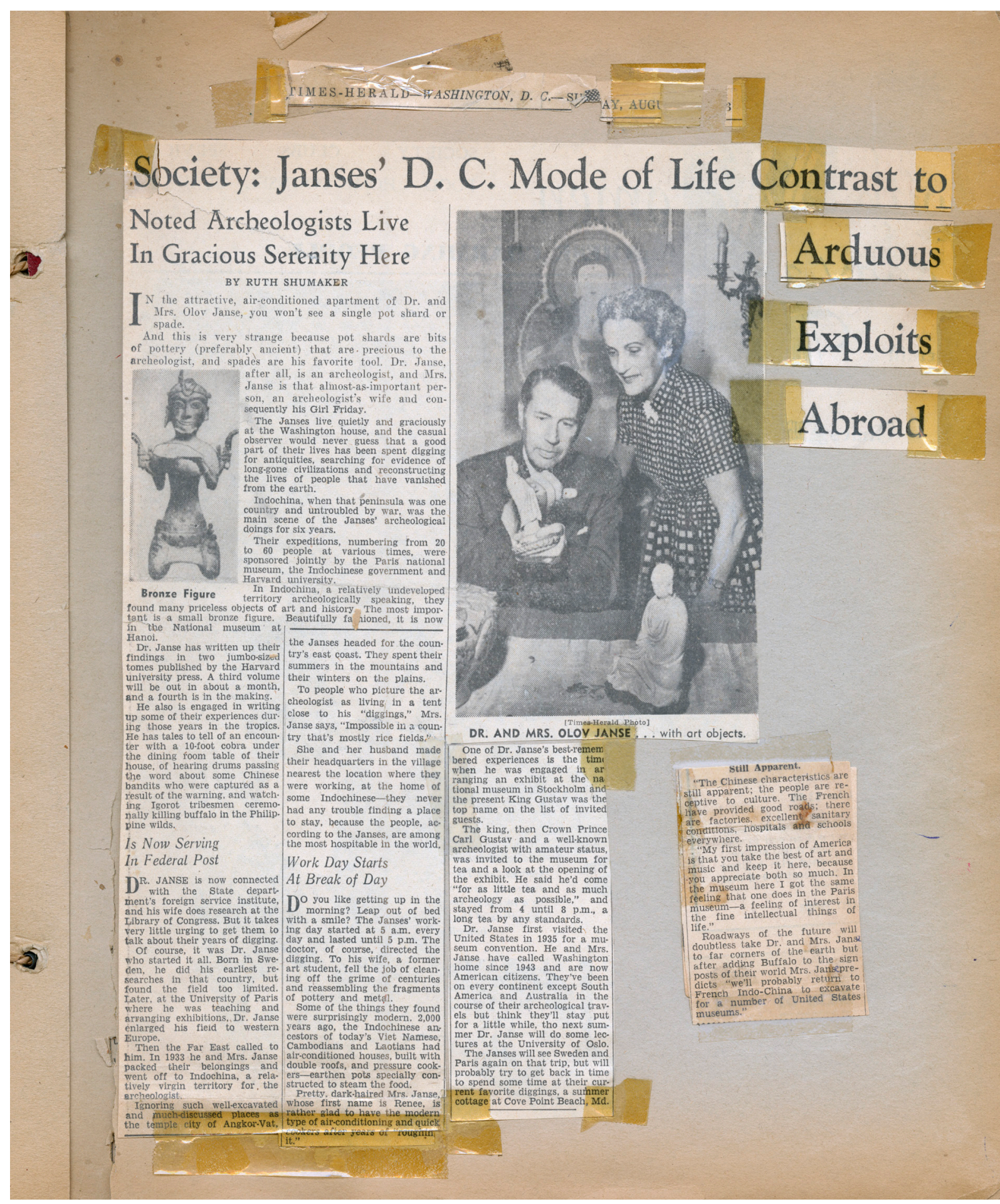

Fig. 70. Newspaper article in The Washington Times-Herald, 23 August 1953. 
In all articles, ${ }^{995}$ focus is on her attractive looks, her clothing, and her charming appearance. She is moreover often described as intelligent and educated in art history. Another recurring theme is her complete readiness to assist her husband in his work, however arduous the circumstances, while at the same time keeping her integrity as a lady (for example by riding side-saddle and longing for a proper stove). One article seems to have been particularly important for them, and several copies are kept in their archive (fig. 70).

The article, published in The Washington Times-Herald in August 1953, features their new life in the United States, five years after they became US citizens. It is described as calm and serene, and a great contrast to their adventurous exploits abroad. They are presented as Dr Janse, the distinguished archaeologist, and Mrs Janse: "that almost-as-important person, an archaeologist's wife and consequently his Girl Friday". ${ }^{996}$ In the photograph she is seen standing, smiling, behind her seated husband who is pointing seriously at a detail of a figurine. In contrast to newspaper articles featuring him and his scientific work, the ones where she also takes place are all written by women, and are more focused on the practical aspects of their work. Their roles are very clear, in text and imagery: he was the person of official importance, and she was his perfect, beautiful, and ready supporter. As we have seen in the chapter on the Indochina expeditions, her contribution was of crucial importance to his archaeological research, and these articles (written by female reporters, for magazines or newspapers' society sections) are testimony to that. The importance of the female segments of their cosmopolitan communities was clearly much greater than the limited historical visibility they have been granted.

In the years they spent at Harvard after the return from Indochina, Olov and Ronny became close friends with Arthur and Augusta Hartt (fig. 71), and they acted like family for Ronny during the time Olov was at UNESCO in Paris.

Augusta Batchelder Hartt (1872-1961) was a joining force of the female community at Harvard University. She was already a noted leader of the Massachusetts Girl Scouts, ${ }^{997}$ when she founded the Women's Travel Club

995.E.g. Kamm 1940; Gordon 1941; Shumaker 1953.

996. Shumaker 1953 .

997. Massachusetts Girl Scouts Records, 1915-1967. MC 263, Schlesinger Library, Radcliffe Institute, Harvard University, Cambridge, Mass. 
Fig. 71. Olov

Janse, Mrs

Keller, $A u$ -

gusta Hartt,

Arthur Hartt,

and Ronny

Janse, at the

New Hamp-

shire home of

Carl T. Keller,

book collector

and trustee

of the Har-

vard-Yench-

ing Institute.

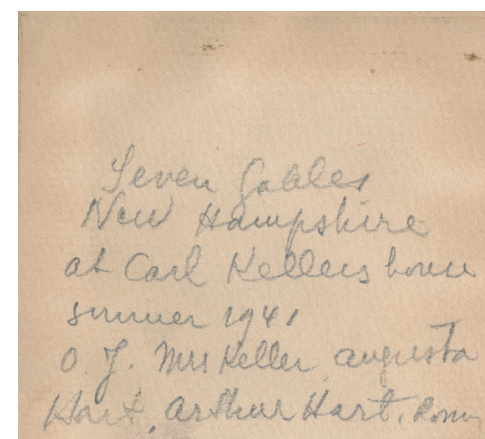

at Harvard in January $1935 .{ }^{998}$ The club was set up as a women's alternative to the men-only Harvard Travellers Club, and was a venue for well-travelled women to meet, share experiences and give advice to other travellers. The club met once a month in a building on Fairfield Street in Boston, where they listened to talks given by the members or invited guests. Among the invited guests in the early years were Margaret Mead and Karen Blixen, and the talks had titles such as: Travels in Southern Arabia, or Over the Old Jade Road from Yunnanfu to Mandalay. ${ }^{999}$ Ronny Janse became a member of the Women's Travel Club shortly after she and Olov had arrived in Harvard after the completion of their last Indochina expedition. In her archive is a blue ring file where her and the other $106 \mathrm{mem}$ bers' travels are listed. ${ }^{1000}$ Interestingly, all married women have been listed with their husband's name only: Mrs Alfred Kidder, Mrs Bradford Washburn ... and Mrs Olov R.T. Janse. Included in the file are five typed manuscripts of short talks that appear to have been prepared by Ronny, and may have been presented to the club: Imagination; The Ancient Temple; Human Struggle; About Reading; and The South Sea Fishing. ${ }^{1001}$ They all draw on her experiences of the world, and some more clearly of her travels. But they also have a distinct political edge, as in these excerpts:

998. Women's Travel Club Records, 1933-2014. MC 795, Schlesinger Library, Radcliffe Institute, Harvard University, Cambridge, Mass.

999. https://hollisarchives.lib.harvard.edu/repositories/8/resources/6661/collection_ organization, accessed 19 August 2018.

1000. NAA: Janse 2001-29.

1001. NAA: Janse 2001-29. 
Certainly we cannot indulge in sheer fancy-dreaming, but we ought to be constantly aware of an ideal born from our imagination. Our democratic ideals are the results of an active imagination and level-headed inspiration of the great men who made our history. [...] The recent war was fought primarily for ideals we all cherish. The hard struggle under way devoted to the realization of one of such principles - the Equality of Nations as well as men. (-Imagination)

For the sake of those millions of innocent lives sacrificed throughout the world in the bitter fight for the high ideal of peace and justice that we have to take up this battle-cry and fight with means of industrial genius and on the fields of scientific achievement, as to insure the continuity of their efforts. We cannot let them die in vain! We cannot and should not relax our vigilance just now when one phase of this obstinate struggle - on the battle-field - is won. Let us unanimously stand by our President in his surhuman [sic] effort to insure the hard won peace to the tormented world of today. (-Human Struggle)

Although the female segments of the academic and cosmopolitan society Ronny was part of are not documented and historically researched to the same extent as the male, it does not mean that these women were uninformed or uninterested in world politics, or that their opinions were not heard. Women like Augusta Hartt were highly respected, and together with their husbands they created mixed-gender informal gatherings like the one we see in figure 71. In the case of Olov and Ronny, or Renée Janse, it is clear that she was deeply involved in his work and that they influenced each other's positions. We see it for instance in his aversion to communism, his work for UNESCO's principles (as clearly mirrored in the talk on Imagination above), and later in his tendency towards Cold War McCarthyism.

Olov and Ronny did not have children. There are no clear indications whether it was a deliberate choice, or if they wanted but were unable to. The circumstances that prevented them from returning to Sweden as planned after their Indochina expeditions, and the war that led them in exile might also have been decisive factors. Relatives of their family and friends that we have interviewed have also offered differing explanations. One said that they were so fond of children that it caused them much 
sorrow not to have children of their own. Another said that Ronny did not want to have children, because she was afraid to lose her figure. Apart from those family stories, we know for a fact that Renée towards the end of her life was an active supporter of family planning, with several clippings in her archive, and a donation to the organization Planned Parenthood is listed in her testament. ${ }^{1002}$ We also know that Ronny, and later Renée, enjoyed working and wanted a career of her own.

Only a couple of years into her married life, Ronny wrote to Barbro Nerman from Paris that she had not lost her desire to serve and earn. ${ }^{1003}$ In fact, she retained the desire to work for most of her life. While Olov worked with the Indochina expeditions, she had an important role to fill as his assistant. And when that work came to an end with their Harvard assignments, they were both recruited by the OSS and later transferred to the US Department of State. But when they started to see the end of that assignment and Olov left to work for UNE SCO in Paris, Ronny at last got a position on her own, at the Library of Congress.

The Library of Congress is located on the National Mall in Washington, DC. It serves as the research branch of the US Congress and is as such the oldest federal cultural institution of the United States. Ronny Janse's first position at the Library of Congress, beginning in 1946, was at the Descriptive Cataloging Division where she functioned as Cataloguer. In $195^{\circ}$ she was promoted to the position of Research Librarian and Research Bibliographer, focusing on the Soviet Union and civil engineering. A bibliography of Soviet Transportation and Communications that she compiled and edited was published by the Library of Congress in $1952 .{ }^{1004} \mathrm{In}$ 1953 she was again promoted, to Technical Research Analyst in the field of structural engineering, and in 1965 to Research Analyst and Foreign Language Specialist. In the latter position, which she held until her retirement, she could make use of her broad language skills translating and writing reports in French, Russian, and the Scandinavian languages. ${ }^{1005}$

1002. NAA: Janse 2001-29. A copy of the testament is in Per Janse's archive.

1003. Letter from R. Janse to B. Nerman, 18 February 1933. Riksarkivet. Kartong 2. Korrespondens, Brev II 1923-1934. In the Swedish original: "Utom mina conjugala förpliktelser, hör jag på kurs i Louvre och Sorbonne om fransk konst- och litteraturhistoria. Det intresserade mig alltid väldigt och nu är jag mycket belåten. [...] Fortfarande har jag inte förlorat min lust att arbeta och förtjäna [...]."

1004. Janse, R.S. 1952.

1005. Information retrieved from an Application for Posted Vacancy Form. NAA: Janse 2001-29. 
One supervisor's report on her work says that she "performs in a professional and competent manner. [...] She is cooperative and willingly accepts assignments over and above her immediate tasks [...]." Another says: "she has performed her duties as a foreign language analyst with interest and devotion [...] although she has a tendency to get too deeply involved in marginal details which tend to effect [sic] the quantity of her production". ${ }^{1006}$ She was clearly a devoted employee, and when she neared the expected age of retirement she made several attempts to keep her job. In her archive is an "Appeal for Retention of Present Grade", that she wrote on 2 March 1970. In the same plastic folder there are several newspaper clippings with headlines about bias against over- 40 employees marked in red pencil, and a clipping of a typed note:

SENIORITY is Competence plus Experience.

YOUTH is a state of mind! ${ }^{1007}$

When she eventually retired in December 1971, after serving twenty-five years at the Library of Congress, the Chief of the Federal Research Division wrote in a letter that they would miss her "succinct observations, refreshing candor and [her] congeniality". ${ }^{1008}$ She was a woman devoted to her task - sharp, frank, and likeable, and who did not like to be retired.

But let us go back ten years in time, to the early 1960 s when Renée was 60 years old and was working as Technical Research Analyst at the Library of Congress. In her archive are a series of poems dated to the autumn 1963 and spring 1964 that give voice to sorrow and despair:

Time stop!

Why hurry so

Can't you give back one day

Of joy I lost on the way? ${ }^{1009}$

1006. NAA: Janse 2001-29.

1007. NAA: Janse 2001-29.

1008. Letter from William R. Dodge to R. Janse, 14 December 1971. NAA: Janse 2001-29.

1009. NAA: Janse 2001-29. 
Two themes stand out in the poems. One is the sorrow of war and misery in the world:

\section{THAT DOWNTRODDEN HUMANITY \\ IN DESPAIR}

With no shelter, nor hope or care

Crowding the streets in deep

sorrow

With that sightless stare

Of a lost TOMORROW!...1010

... and the other is a more personal sadness, which seems connected with ageing and the passing of the years:

A thick blanket of misty clouds

Shrouds my heart with heavy doubts.

The impact of unexplainable sadness

Still hovers in the wake of eery madness.

I try hard to expell from my mind

As I now leave the last chapter behind... ${ }^{1011}$

There are indications of sadness already in the letters from Olov from Paris 1946-47, when Arthur and Augusta Hartt acted as her supporting family. So it must have been a hard blow when Arthur Hartt died in 1960 , and Augusta only a year later - along with her close friend Barbro Nerman in Stockholm - in 1961. But Renée's sorrow seems to have had a much broader base. It seems to have been connected to the loss of her native family and the world that used to be hers in Europe. In her archive is a letter sent from a cousin to her father, Jean Friedmann, in $1947 .^{1012}$ The letter, which is a response to a letter sent by Ronny in an attempt to locate and contact her distant relatives, has been cherished, and she scribbled notes on it as late as 1996. Jean Friedmann, who was an engineer living in Rio de Janeiro, writes that his family were spread over five continents: from Uganda to South Africa and England, and that he

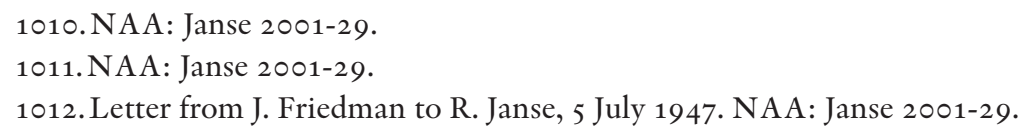


had no knowledge of where the Sokolsky family had disappeared. One paragraph of his letter seems to capture some of her predicament:

It is natural that sentiments of kinship are, if not gone, then at least alleviated. Yet when a letter like yours - which can be compared to a ray of sunshine in the darkness that surrounds me arrives, one is stirred, upset, and one would like to know where the other debris of the same trunk are, and one feels a little less lonely in this big and at the same time small world. ${ }^{1013}$

Although Jean Friedmann and Ronny Janse were of different generations, had survived wars and revolutions, and had landed on both feet with secure homes and careers in America, they shared a sense of incompletion and loss - as scattered debris of something that was once whole. Five years earlier, in the middle of the war, Ronny wrote a letter to her friend Marie-Rose Loo in Paris. ${ }^{1014}$ Marie-Rose had complained that she suffered from insomnia, and Ronny responded: "I know myself how it is to have an eye open during the nights. It's horrible!" ${ }^{1015}$ and recommended Marie-Rose to try Seconal Sodium, which she wrote she had good experience of. ${ }^{1016}$ She writes:

I understand your grief of being deprived of news of your loved ones. I hope that we will all soon escape from this cruel isolation that torments us all. Luckily, the young can endure all sorts of difficulties better than we can. Although I experienced the horrors of revolution and starvation, I came out of it without bitterness and

1013. Ibid. In the French original: "Il est naturel que les sentiments de parenté sont si non pas disparus, bien attenues. Pourtant, quand une lettre comme la vôtre, - laquelle le peux comparer à un rayon de soleil dans les ténèbres qui m'entourent, - arrive, on est remue, bouleversé et on voudrait savoir ou se trouvent les autres débris du même tronc, et on se sent un peu moins solitaire dans ce grand et en même temps petit monde."

1014. Letter from R. Janse to M.-R. Loo, 12 April 1942. NAA: Janse 2001-29. See also the chapters "Between France and Sweden" and "Ronny" for details of Marie-Rose and her husband C.T. Loo.

1015. Letter from R. Janse to M.-R. Loo, 12 April 1942. NAA: Janse 2001-29. In the French original: "Je sais moi-même ce que c'est de ne pas fermer l'oeil pendant des nuits. C'est atroce!"

1016. Seconal Sodium, or Secobarbital Sodium, is a drug used in treatment for epilepsy, insomnia, and for anaesthesia. It has been linked to the deaths of Judy Garland and Dinah Washington, among others. 
without resentment, thanks to an essence of optimism inherent in the soul of the young. ${ }^{1017}$

Hence her darkness appears to have been a complex combination of sorrow over the situation in the world, grief over her scattered and destroyed family, and anxiety about the youth that was gone and the optimism that had disappeared with it. The dates attached to her poems suggest that she reached a low point sometime in the autumn of 1963 , and the pieces written in the spring of 1964 are of quite a different character. Sometime around New Year 1964, it seems as if she made a decision to give her life a new, positive turn. In her new life happiness and joy was all about attitude, about discipline, smartness, and - above all - stamina:

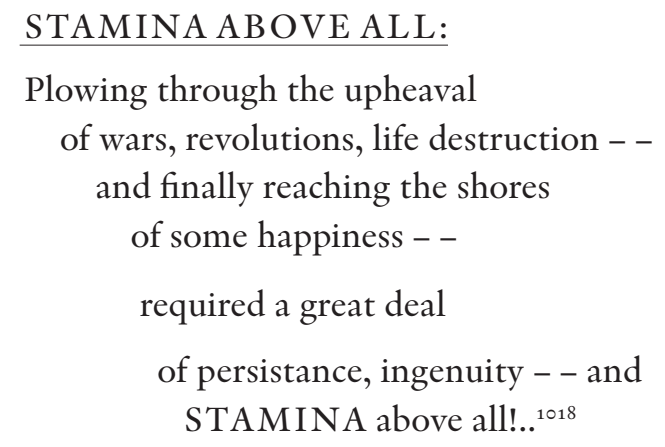

At about the same time Renée went through a radical physical transformation - from warm, sharp-eyed brunette, to a doll-like blonde with perfectly curled hair, exact makeup, tight posture, and eyes at the horizon.

The archive abounds with photographs of Renée after her transformation. Often in spectacular hairstyles and outfits, or posing in swimsuits. There are hundreds of swimsuit photographs. With this abundance, the archive gives the impression of being a monument over the transformation from Ronny, the adventurous and cosmopolitan yet troubled Girl

1017. Letter from R. Janse to M.-R. Loo, 12 April 1942. NAA: Janse 2001-29. In the French original: "Je comprend votre chagrin d'être privée de nouvelles des votres. J'espère que nous sortirons tous dans un avenir prochain de cet isolement cruel qui nous tourmente tous. Heureusement que la jeunesse peut supporter mieux que nous toutes les difficultés. Bien que j'avais traversé des horreurs de la révolution et de la famine, j'en suis sortie sans amertumes sans racune, grâce à un fond d'optimisme inhérant à l'âme de la jeunesse."

1018. See this and other poems in NAA: Janse 2001-29. 
Friday, to Renée, the exemplary civil servant at the Library of Congress, with perfect hair and a new, happy, identity. ${ }^{1019}$

But the archive also reveals cracks in the apparent perfection. There are letters to doctors asking about a brain scan to investigate inexplicable depression, ${ }^{1020}$ and requesting a medicine called Vincamine that claims to reduce the ageing of the brain cells. ${ }^{1021}$ Most striking, perhaps, are the manipulated photographs of Renée, never Ronny, where the eyes have been cut out, or the face contour or hair colour has been changed with ballpoint pens and sharp objects (fig. 73). Manifested in such brute nakedness, Renée's perfection project is uncomfortable and intrusive. It insists on our attention and reflection.

In an article from 1998, the feminist philosopher Sandra Lee Bartky writes about the control of women's bodies in the United

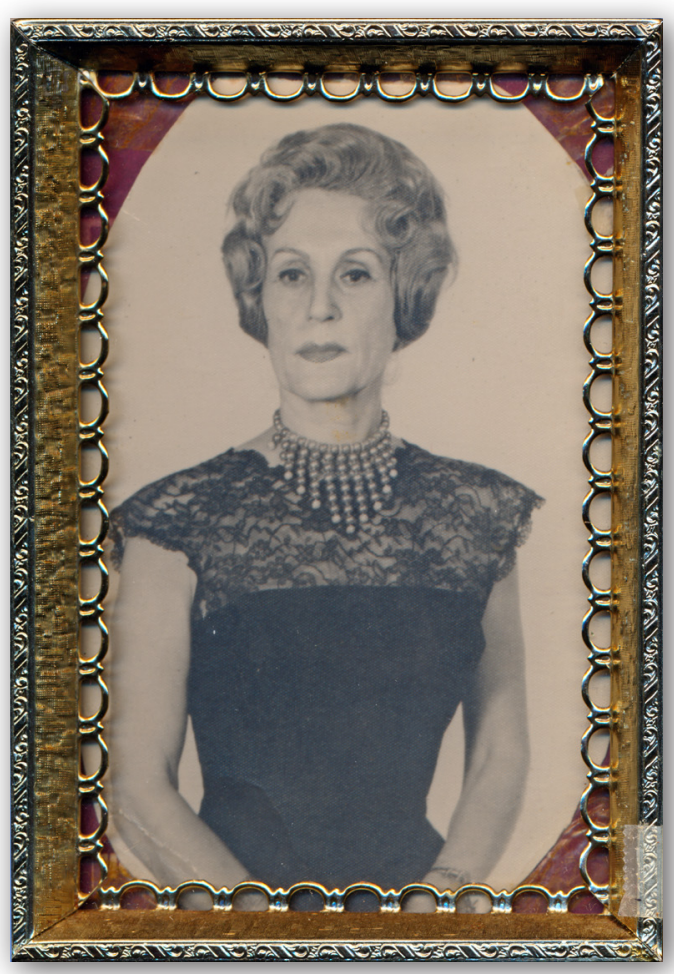
States in the 1980s. She describes diets and hair removal as a way of disciplining the female body towards an unachievable prepubescent ideal form. Women learn, says Bartky, not to Fig. 72. Renée express emotions with the face in order to avoid wrinkles. A woman's body should first and foremost be regarded as a decorated surface, the stomach pulled in and the shoulders pushed back to allow her bust to be presented as attractively as possible. The gaze should be directed down or away, because only a loose woman looks directly at what and who she wants. The disciplinary project of femininity, says Bartky, demands such radical and extensive bodily transformations that practically every woman who tries is doomed to fail. ${ }^{1022}$

But Renée Janse manages in an almost caricatural way to achieve

1019. A more thorough discussion [in Swedish] of Renée's voice through the archive is found in Källén \& Hegardt 2015.

1020. Letter from R. Janse to Dr. Walsh, 29 May 1963. "[...] recommend a good neurologist who could in some way help my husband to overcome the trying days when he suddenly feels hopelessly sick and under a nervous depression". NAA: Janse 2001-29.

1021. NAA: Janse 2001-29.

1022. Bartky 1998:28-32. 


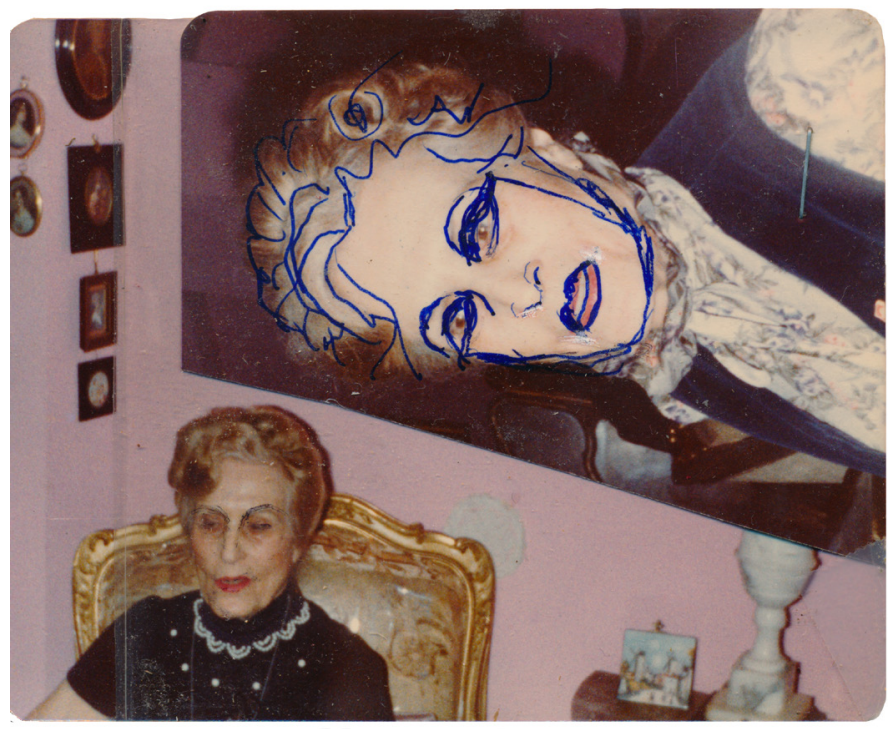

the disciplined body ideal that Bartky describes. The transformation from Ronny, the brunette who laughed and looked straight into the camera, is remarkable. In her poems written 1963-64 we can follow quite literally the process from which she comes out determined to create a new, happy life through self-discipline. It seems as if she reinvented her youthful, happier self in the shape of a perfect American woman. Bartky further discusses the disciplined woman's body as

Fig. 73. Manipulated photo of Renée, in her archive.

an alternative heterosexual identity for middle-aged women who do not ascribe to the normative mother identity - and maybe that could also be a discussion relevant to understand the transformation of Renée Janse. ${ }^{1023}$

Bartky argues that disciplining of the female body by default leads to women's powerlessness and subordination. But at the same time she sees a paradox in the discipline project. Regardless of its effect, she says, the discipline can give the individual a sense of control and security. ${ }^{1024}$ Renée Janse seems to be caught within this paradox. She creates her new, blonde, tight persona to encapsulate emotions she cannot otherwise control. It gives her a sense of control and security that is illustrated by countless swimsuit pictures in her archive. But something is itching, and we see her scratches manifested in manipulated portrait photographs.

An image kept among her personal documents epitomizes some of Renée's struggle. We find her in the right-hand corner of the photograph, perfectly dressed and made up, alone, glass in hand, watching with a tight smile the easy entrance of a young woman. The young woman is Princess Christina of Sweden, who spent a year as a student at Harvard University 1963-64. Renée is here sixty years old, and is at the end of a period of dark thoughts and existential reflection. Her poetry speaks of loss, decay,

1023. Bartky 1998:39, 42.

1024. Bartky 1998:39. 
and how she struggles to find meaning and joy in life. But it indicates a turning point around the time this picture was taken. She then decided to leave her former troubled self behind, and create a new identity with a new body. Ronny, the young brunette who looked calmly and confidently into the lens of Olov's camera on their travels and fieldworks, is now replaced by Renée, a doll-like platinum blonde posing in exact angles at high society events. The photograph can to some extent speak for itself, but Renée's tight smile and perfectly made blonde hair are given an extra human dimension by the small newspaper clipping attached to it with medical surgery tape:

The art of life is to know how to enjoy a little and to endure much.

Fig. 74. Soci-

ety event with

Princess Christina of Sweden, in Washington, DC, 1963 or 1964. Photographer unknown.

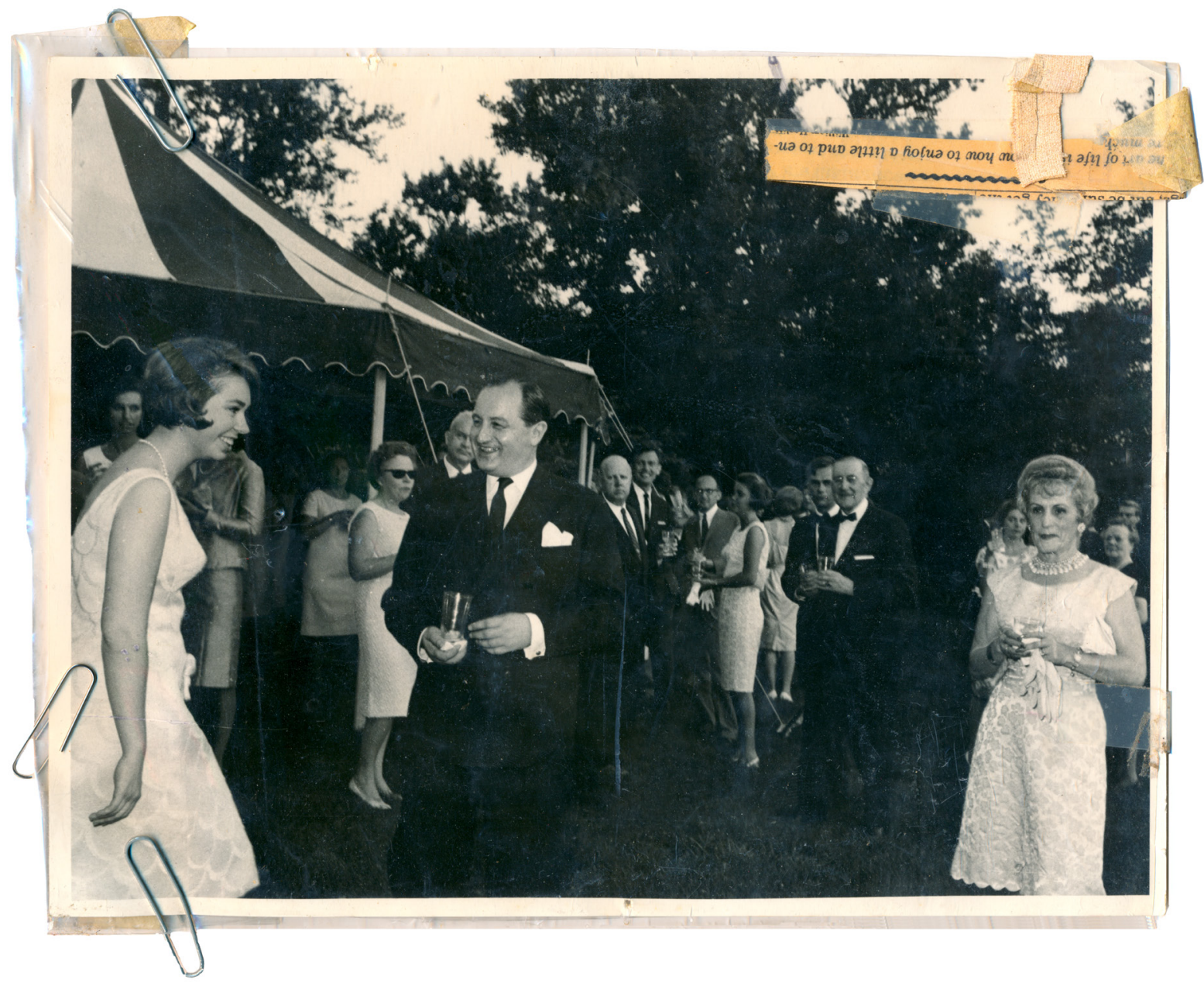




\section{COCKTAILS AND PUBLIC DIPLOMACY}

I doubt if there is anyone in the United States who is so well acquainted with the people of Viet-Nam. These are very strong statements, but Dr. Janse is an unusual person, and I imagine that you know how few people there are who know anything in terms of scientific detail about Viet-Nam. [...] In terms of knowledge and experience, Dr. Janse is, I believe, beyond doubt the top man in the United States for a [visiting] lectureship in art and archaeology in Viet-Nam. But over and above these qualifications, I think there are other reasons why he should be selected. His appreciation of the people and their culture is of a high order. ${ }^{1025}$

The end of Olov Janse's professional life coincided with a period of great political turmoil in the United States, and in the world at large. In the decades following the Second World War, characterized by the political tensions of the Cold War, the self-image of the United States as the essentially good guy who could never fight a bad war or represent the wrong cause, ${ }^{1026}$ would be tested and contested, not least in the events following

1025. Letter from J. O. Brew, Director of the Peabody Museum at Harvard, to Miss Sylvia Miller, Conference Board of Associated Research Councils, Washington, DC, 16 November 1957. NAA: Janse 2001-29.

1026. Phrasing borrowed from interview with the journalist Neil Sheehan in part 2 of The Vietnam War, a television documentary series written by Geoffrey C. Ward, directed by Ken Burns and Lynn Novick, 2017. The overall description of the situation in the Unites States and its foreign policy relating to Southeast Asia during the Cold War refers to Logevall 2012 and Tønnesson 2010. 
the breakup of Indochina that eventually led to the Vietnam War. ${ }^{1027}$ Olov Janse's name has barely been mentioned in the history of US politics and diplomacy leading to the Vietnam War. In the 1950 s and the first couple of years of the 1960s, when Janse was the most active in the relations between the United States and Vietnam, nothing seemed to indicate that Vietnam less than a decade later would become the place where the contained fears and stubborn polarized positioning of Cold War politics would be released and played out in brutal reality. Everyone in Washington was focusing on the Soviet Union, and Janse was no exception.

In hindsight, however, we can see that he was right at the centre of some of the most important institutions and events of that time. At a time when, incredible as it may sound, many people in the United States did not even know the location of Vietnam, let alone anything about its culture and political history, Olov Janse was known as one of the United States' main experts on Indochina's history and culture. ${ }^{1028}$ From a position that has been nearly invisible to historians focusing on the archives of politicians, diplomats, and high-profile units of official administration, he mediated between key actors, shared knowledge, and communicated narratives that were used for purposes of public diplomacy. During the 1950 s and early 1960 s he worked at the US Department of State and the Smithsonian Institution, made two long journeys to Europe on research grants from the State Department, and together with Renée he mingled at cocktail parties with the political and cultural elite of Washington, DC. In 1958-59 he spent six months as a visiting professor and heritage adviser in South Vietnam and Korea, on a public diplomacy mission supported by the Smith-Mundt Act. A year later, he had a key role in setting up The Art and Archaeology of Viet Nam, a travelling exhibition shown in both Vietnam and the United States. It has been described as "one of the most important episodes in [President Ngo Dinh] Diem's plan to win American public support for his regime". ${ }^{1029}$ Yet at this time, everyone, Janse included, was blinded by the threat from the Soviet Union and the fear of communism spreading across Asia. Few if any took Ho Chi Minh

1027. What is most known in the Western world as the Vietnam War was also fought in the neighbouring countries, most notably in Laos, and in Southeast Asia it is widely known as The American War.

1028. NAA: Janse 2001-29; Solheim 1984-85:10.

1029. Masur 2004:170. 
and the Viet Minh seriously as an intelligent force with the strategic capacity to defeat the United States and its allies.

\section{$1947-1953$}

Olov Janse returned from UNE S CO in Paris in July 1947 determined to settle for good in the United States. He and Ronny became US citizens on 7 September 1948, and at the same time Ronny changed her first name to Renée. ${ }^{1030}$ She worked at the Library of Congress, in the Descriptive Cataloging Division. She was later promoted to other departments within the library, where she stayed employed until her retirement in 1971. Olov's employment was less steady. During the first years back in the United States, he had assignments with the Department of State and the Smithsonian Institution in Washington, DC. ${ }^{1031}$ At the Department of State he worked in the Foreign Service Institute, where experts offered instruction and training for diplomats and other members of the Foreign Service. At the Smithsonian Institution he investigated the possibilities to establish "an international body of archaeologists and a permanent bureau for archaeology". ${ }^{1032}$

Otherwise this was a period of low professional activity for Olov Janse. Correspondence with his old friends Ture and Birger Nerman in Stockholm shows that he spent much time and effort working on his philatelic collections, exchanging stamps with Ture and his son Anders. He and Ronny built a summer cottage at Cove Point near Chesapeake Bay in Maryland, and spent almost every long weekend there. In letters he compares their house with Ture's summer house on Blidö in the Stockholm archipelago, and describes how the mild climate in Maryland -"on the same parallel as Venice"- allowed them to grow figs and peaches, and swim in the sea from early spring to late autumn. Their primary focus was on putting down roots in their new country.

1030. Luther H. Evans, Library of Congress, Information Bulletin 21-27 September 1948,4 .

1031. We have not found any formal documentation of his employment in this period, so this is concluded from comments in letters and press records (e.g. Shumaker 1953).

1032. The initiative came officially from the successor in Janse's position at UNE SCO, J.J. Mayoux, but appears also to have been in Janse's own interest. The plans were never realized, and the project is only mentioned in a letter to Birger Nerman (with typed memorandum in English attached). Letter from Janse to Nerman, 29 September 1947. Riksarkivet. Kartong 5. Korrespondens Brev 1947-1950. 
Olov's main professional focus during these years, in the late 1940s and early 1950s, was on completing the archaeological reports from their Indochina expeditions, the first volume of which was published in 1947. ${ }^{1033}$ A couple of years later he received a travel grant from the State Department to spend eight months in Europe to complete the second and third report volumes. Renée came along with him. In April 1946 she had been appointed to a position at the Library of Congress as a cataloguer of Slavic material, particularly Russian publications. In the Library of Congress's Information Bulletin she was praised in these terms: "Persons possessing her special talent are hard to find, and we were delighted that Mrs. Janse was available for this urgent program." ${ }^{1034}$ The Library of Congress had sent her to study Slavic literature in European libraries. She visited libraries in Paris, Rome, Naples, Stockholm, Uppsala, and Helsin$\mathrm{ki}$, and on her return she wrote a report for the Library of Congress. ${ }^{1035}$ Olov Janse filmed parts of their journey and bought films produced for the tourist market. ${ }^{1036}$

On 29 March 1950 they boarded the luxury art deco ocean liner S S Ille de France in New York, bound for Le Havre in France. On what was Renée's first visit to Europe after the war, they spent a month together in Paris before they travelled by bus to Italy and by train to Sweden, where they stayed a couple of weeks seeing family and old friends. When Renée had to return to tend to her work at the Library of Congress, Olov spent several busy months in Paris working on his third report volume. ${ }^{1037}$

Soon after he had returned to the United States and joined Renée in Washington, his friend and mentor René Grousset came to visit. It was now late autumn 1950. Olov and Renée arranged for Grousset to give a lecture at the prestigious art institution Dumbarton Oaks, and hosted a reception for him in their home, where French cultural and diplomatic dignitaries such as Jean Marx and Alexis Léger (aka Saint-John Perse,

1033. Janse 1947 .

1034. Library of Congress, Information Bulletin 18-24 February 1947, 4.

1035. Office of the Secretary, The Librarian Director, Reference Department. Mrs. Renée S. Janse, Bibliographer Air Information Section, Air Studies Division. Travel Report and Survey of Slavic Collections abroad April 10-June 17, 1950; Authority No. $50-277$. Library of Congress.

1036. Swedish Television Archive. (C) SVT Arkiv.

1037. Letter from O. Janse to T. Nerman, 21 June 1950. Arbetarrörelsens arkiv och bibliotek. Ture Nerman 3.1.46. 
Nobel Laureate in literature 1960) mingled with representatives from several of Washington's embassies. ${ }^{1038}$

The second volume of Janse's report from Indochina was published shortly after Grousset's visit. ${ }^{1039}$ It received a glowing review by Paul Mus, his former colleague at the EFEO in Hanoi, in the Journal of the American Oriental Society. ${ }^{1040}$ Mus was not in agreement with Janse's conclusions on the Mediterranean connections of some of the most prolific artefacts, including the kneeling figurine from Lach-truong. ${ }^{1041}$ Apart from that, the review is outstandingly positive. With words such as "monumental" and "brilliant", Mus praises Janse's results and his stylish and comprehensive presentation. He is particularly impressed by the elaborate index, which, Mus wrote, by the use of adjectives not only helped the description but also the interpretation of objects and style elements. Once again Janse's French connections were reinforced and reinvigorated.

This was, however, a period of growing tension in US foreign politics. After the immediate shock of the Second World War and the dramatic effects of the Marshall Plan in the years following, came the fear-based passive aggression of the Cold War. Harry S. Truman was President and his Secretary of State was Dean Acheson. ${ }^{1042}$ Acheson has been described as "a central player, arguably the central player, in the drama of the late 1940 s and early 1950 s that saw the United States become a global hegemon, the self-appointed defender of Western civilization". ${ }^{1043}$ The Soviet Union's nuclear bomb test in Kazakhstan in August 1949 and Mao Zedong's proclamation of the People's Republic of China in October the same year saw Truman and Acheson instigate a new Top Secret National Security Council Report. This report - N S C 68 (signed in April 1950) ${ }^{1044}$ - revised the foreign policy of the United States in response to what was perceived as a threat of unfathomable proportions:

1038. Letter from O. Janse to T. Nerman, 3 January 1951. Arbetarrörelsens arkiv och bibliotek. Ture Nerman 3.1.46.

1039. Janse 1951.

1040. Mus 1952.

1041. See the chapter "Euphoria".

1042. Logevall 2012:217-220; Acheson 1969.

1043. Logevall 2012:217, emphasis in the original.

1044. "A Report to the National Security Council - NSC 68", 12 April 1950. President's Secretary's File, Truman Papers. 
The issues that face us are momentous, involving the fulfilment or destruction not only of this Republic but of civilization itself. They are issues which will not await our deliberations. With conscience and resolution this Government and the people it represents must now take new and fateful decisions. ${ }^{1045}$

As indicated here by the NSC 68 report, the threat from the Soviet Union and the spread of communism in Asia manifested by Mao's revolution in China overshadowed, or tinted, all judgements and decisions made at the US State Department at this time. NATO was formed in direct response to the situation described in the NSC 68 report. And when the Korean War broke out in June 1950 with the invasion of the Republic of Korea by the communist Korean People's Army, (supported by the Soviet Union and China), the United States chose to get involved in the hostilities and support the Republic of Korea via the United Nations, which in turn was strongly influenced by the United States and President Truman.

In Indochina, as in Korea, there was an ongoing struggle for political control after the Second World War. The Viet Minh led by Ho Chi Minh was the largest and most successful of several movements for independence. The Viet Minh was a communist organization, but when he declared the establishment of the Democratic Republic of Vietnam in Hanoi in September 1945, Ho begun with a Vietnamese translation of the words of Thomas Jefferson in the United States Declaration of Independence:

[We believe that ] all men are created equal, [that] they are endowed by their Creator with certain unalienable Rights, and among these are Life, Liberty and the pursuit of Happiness.

Having been supported by the OSS during the Second World War, Ho Chi Minh wrote a telegram to President Truman in February 1946 requesting further support from the United States in their struggle for independence. ${ }^{1046}$ The United States, however, did not intend to support a communist independence movement - communism should be contained, not supported. Moreover, the French did not intend to let go of what had been the most esteemed of all their colonies - la perle of the French em-

1045. "A Report to the National Security Council - NSC 68", 12 April 1950. President's Secretary's File, Truman Papers, p. 4 (Corrected).

1046. Logevall 2012:78. 
pire. ${ }^{1047}$ French forces had already taken back Saigon in the south (while the Viet Minh controlled the northern parts of the country) already in the autumn 1945, and several years of guerrilla warfare followed around Saigon. The French scholar Paul Mus, who had grown up in Indochina, who wrote the review of Janse's second report, and who would later be known as one of the world's most prominent scholars in Vietnamese studies, ${ }^{1048}$ met Ho Chi Minh in the jungles of northern Vietnam to present a French proposal to settle the war through diplomatic agreement. The meeting was in vain, and the fighting continued between the French forces and the Viet Minh. When Ho Chi Minh gained recognition for his government from China and the Soviet Union in 1950, the conflict escalated into a conventional war between a new French-supported alternative government, the State of Vietnam, in the south, and Ho's Democratic Republic of Vietnam in the north. When France sought support from the United States to suppress the communist upsurge, President Truman and Secretary of State Acheson hesitated. They were caught between two key principles: their policy of containment of communism in Asia, and the strong principle to defend the liberty of postcolonial nations that Truman had inherited from his predecessor Franklin D. Roosevelt. In the end, the fear of communism won (also in keeping with the NSC 68 report), and the US government eventually decided to support the French with weaponry and military observers.

At this critical time in the political relationship between the United States and Vietnam, Olov Janse - described as one of few people in the United States with profound knowledge and long-term experience of Indochina ${ }^{1049}$ - worked at the State Department on issues concerning Scandinavia. At the Foreign Service Institute, where experts offered instruction and training for new members of the Foreign Service, he was an expert in the Swedish language. He wrote a dictionary of Swedish for everyday use, ${ }^{1050}$ and circulated his friend Ture Nerman's anti-Soviet journal Trots Allt! among his Swedish-speaking colleagues at the State

1047. A detailed account of the complicated political turns in and around Indochina after the Second World War is found in Logevall 2012: chapters 3-15.

1048. Chandler 2009, Logevall 2012:189-195.

1049. Letter from J. O. Brew, Director of the Peabody Museum at Harvard, to Miss Sylvia Miller, Conference Board of Associated Research Councils, Washington, D.C., 16 November 1957. NAA: Janse 2001-29.

1050. Janse 1955; see also Letter from Olov Janse to Ture Nerman, 10 September 1952. Arbetarrörelsens arkiv och bibliotek. Ture Nerman 3.1.46. 
Department. ${ }^{1051}$ Like most of his colleagues, he was much occupied with the developments in and around the Soviet Union. ${ }^{1052}$ In the evenings, he relaxed by playing solitaire and attending to his stamp collections "to forget about Hitler and his ghosts, Gulag and ugly Josef with the pipe". ${ }^{1053}$ Stamp collection was one of his key interests at this time, and he appears to have had broader ambitions with it than just leisure. He wrote to Ture Nerman:

What do you think of the latest NATO stamps? Why does the Swedish postal service always look backwards never forward when it comes to what I would like to call enlightenment stamps. Here, the stamps are considered quite important as they can serve the enlightenment in the world and the Congress has quite a lot to say about new stamps. Why not bring the matter up for debate in Stockholm? ${ }^{1054}$

He was clearly seduced by the aims of US public diplomacy, and thought it could be a good idea for the Swedish government too, to use stamps to "serve the enlightenment in the world". ${ }^{1055}$ In 1952 he formed a philatelic club at the US State Department. ${ }^{1056}$

He celebrated his sixtieth birthday in August 1952, hoping that the eloquent and progressive Democratic candidate Adlai Stevenson would win the presidential election. A couple of months later, however, the Republican candidate Dwight Eisenhower was elected new President of the United States.

1051. Letter from O. Janse to T. Nerman, 9 October 1951. Arbetarrörelsens arkiv och bibliotek. Ture Nerman 3.1.46.

1052. Letters between O. Janse and T. Nerman, 1947-1952. Arbetarrörelsens arkiv och bibliotek. Ture Nerman 3.1.46.

1053. Letter from O. Janse to T. Nerman, 29 July 1950. Arbetarrörelsens arkiv och bibliotek. Ture Nerman 3.1.46.

1054. Letter from O. Janse to T. Nerman, 30 April 1952. Arbetarrörelsens arkiv och bibliotek. Ture Nerman 3.1.46. In the Swedish original: "Vad tycker du om de senaste Nato-frimärkena? Varför blickar svenska postverket bara bakåt aldrig framåt när det gäller vad jag skulle vilja kalla upplysningsfrimärken. Här anses frimärkena ganska viktiga då de kan tjäna upplysningen i världen och Congressen har rätt mycket att säga till om när det gäller nya frimärken. Varför inte ta upp saken till debatt i Stockholm?”

1055. Letter from O. Janse to T. Nerman, 30 April 1952. Arbetarrörelsens arkiv och bibliotek. Ture Nerman 3.1.46.

1056. Letter from O. Janse to T. Nerman, 17 November 1952. Arbetarrörelsens arkiv och bibliotek. Ture Nerman 3.1.46. 
The death of Josef Stalin in March 1953 brought a sense of relief to the US Department of State. In his election campaign a year earlier, President Eisenhower had promised to end the Korean War, and after hints that the United States might make use of its nuclear arsenal, the parties declared an armistice in July 1953. The truce in Korea in combination with Stalin's death seemed to indicate a release of Cold War tensions and sparked hopes of the possibility to contain communism in Asia. Yet Eisenhower had named John Foster Dulles his Secretary of State. Both Eisenhower and Dulles were staunch anti-communists, and Dulles in particular was known for his stern personality and straightforward decision-making: "He had it all in his head. He did not need the ambassadorial analyses and the studies of the policy planning staff and the host of departmental experts. He had a big yellow pad at his bedside and he jotted down thoughts as they occurred to him." ${ }^{1057}$ Dulles wanted a stronger US foreign policy with more "heart", and maintained that the policy of "containment" (of communism) ought to be replaced by a policy of "liberation". ${ }^{1058}$ True to his intentions, in 1954 John Foster Dulles was the prime mover in the creation of SEATO (the Southeast Asian equivalent of NATO) to strike down any attempts at further expansion of communism in Asia.

Meanwhile, in Indochina the war escalated over the first years of the 1950 s. It reached a crescendo in the battle of Dien Bien Phu in the spring 1954, where the Viet Minh (supported by China and the Soviet Union) had a devastating victory over the French forces (supported by US funding and allied armies from the neighbouring countries) at the cost of thousands of lives on both sides. The battle of Dien Bien Phu began during the Geneva Conference (April-July 1954), a meeting that was intended to settle the conflicts in Korea and Indochina and reach a diplomatic agreement on the post-colonial partition of Indochina. As a result of France's defeat at Dien Bien Phu and the diplomatic efforts at the Geneva Conference, the former French Indochina was divided in 1954 into the independent Kingdom of Laos, the Kingdom of Cambodia, the Democratic Republic of Vietnam (often referred to as North Vietnam), and the State of Vietnam (South Vietnam). The division of Vietnam

1057. The New York Times, 25 May 1959: "Dulles Formulated and Conducted U.S. Foreign Policy for More Than Six Years".

1058. Ibid. 
at the 17 th parallel was meant to be a temporary solution, the ultimate intention being to unite North and South Vietnam in one nation state. The north, with the capital in Hanoi, was ruled by Ho Chi Minh and the Viet Minh. The south, centred around its capital in Saigon, was ruled by Bao Dai, the Francophile former emperor of the Nguyen dynasty, and his Prime Minister Ngo Dinh Diem.

Ngo Dinh Diem was, however, not pleased with the deal. Only a year after the settlement of the Geneva Accords, he pursued a public campaign against the emperor, organized and won an election, after which he deposed Bao Dai and declared the Republic of Vietnam with himself as President. ${ }^{1059}$ Ngo Dinh Diem was of a Vietnamese Catholic family, which had been persecuted and almost extinguished in his father's generation during an anti-Catholic riot led by Buddhist monks. He received both Confucian and French education in his hometown Hué, before he followed his brother (who later became the highest ranking Catholic bishop in Vietnam) to stay in a monastery, where he swore celibacy. From there he built a career as a mandarin (a learned bureaucrat) in the native administration of Indochina. Hence Ngo Dinh Diem, often referred to by his given name Diem, was a Catholic single man who lived for his work and resented both Buddhists and the French colonizers whom he regarded as wrongful occupants of his native land. After the end of the Second World War, Diem had represented a Third Force movement for independence that united non-communist and anti-French nationalists. ${ }^{1060}$ Like Ho Chi Minh, Diem sought support from the United States already in the early 1950 s, and eventually gained the confidence of many high-ranking US officials, including Justice William O. Douglas, the former OSS director Bill Donovan, and then-senator John F. Kennedy.

On "Independence Day", 4 July 1954, Olov Janse wrote one of very few direct observations on the political situation in Indochina, to his friend Ture Nerman. In what we can assume is a heartfelt comment, unlike press interviews or articles that are of a more careful and strategic character, he writes:

It is looking troublesome in the world at the moment. Will be interesting to see the outcomes in Geneva. France is losing its

1059. Chapman 2013: chapter 6.

1060. Chapman 2013. 
colonies in Africa too. Shame though that they will not be free, but end up under the Russians. ${ }^{1061}$

The short comment reflects what appears to have been a broader conceptualization of the Viet Minh among the US administration, not as a force of its own, but as a Russian marionette. On a more personal level, we also see in Janse's words a sense of sadness or disillusionment about the political chess game that was using the people of Indochina as pawns.

A couple of months earlier, in March 1954, just before the battle of Dien Bien Phu, Olov Janse was called to the Swedish Embassy in Washington, DC, where he was awarded the Order of the Polar Star (Swe: Nordstjärneorden) for "civic merits, for devotion to duty, for science, literary, learned and useful works and for new and beneficial institutions". He wrote later to Birger Nerman that he was "of course happy to have received it, but would probably never wear it". He wrote also that he was getting tired of office work and longed to go back to his archaeological research. ${ }^{1062}$ He was saddened by the deaths of several of his old friends and family in Europe: René Grousset and David David-Weill died in 1952, the Norwegian archaeologist Haakon Shetelig in 1955 , his uncle Gustaf Janse in 1956, and C.T. Loo and his uncle Otto Janse, with whom he was very close, in 1957. Both he and Renée suffered from persistent flus and pneumonia. Renée needed treatment for arthritis, and their friends in Sweden were often unwell. In his letters to Ture and Birger Nerman, Olov offers to include American "wonderdrugs" for all their problems and diseases in the packages with coffee and nylon tights that they regularly dispatched. The long weekends in the summer cottage with Scandinavian-style cultivation and cold baths in Chesapeake Bay were now replaced by frequent recreational trips to Fort Lauderdale in "paradisal Florida", "where fresh trade winds now make the climate ideal and we for a moment can steer our minds away from world politics". ${ }^{1063}$

1061. Letter from O. Janse to T. Nerman, 4 July 1954. Arbetarrörelsens arkiv och bibliotek. Ture Nerman 3.1.46. In the Swedish original: "Det ser otrevligt ut i världen just nu. Skall bli intressant få se hur det går i Genève. Frankrike håller nu på att mista också sina kolonier i Afrika. Synd bara att de inte blir fria utan kommer under Ryssarna." 1062. Letter from O. Janse to B. Nerman, 9 March 1954. Riksarkivet. Kartong 6. Korrespondens Brev 1950-1956.

1063. In the years 1952-1960 they visited Florida to rest and for recreation almost every year. (E.g. letters from O. Janse to T. Nerman, 15 September 1953 and 4 July 1953. Arbetarrörelsens arkiv och bibliotek. Ture Nerman 3.1.46.) 
The years between 1952 and 1957 were also an increasingly busy time for Olov Janse. His letters abound with references to stress and much partying (Swe: mycket fästande [sic]), and he no longer had time to tend to his stamp collection. The growing political interest in Vietnam had led to an increasing visibility of Southeast Asia in popular media in the United States, and Janse saw an opportunity to capitalize on the attention by writing a popular account of his experiences in Indochina. It would have an emphasis on "the human interest" and make the most out of his own experiences: "I would think that few Europeans have been so much in touch with the so-called broader strata out there, and since Indochina is now in focus for the daily news it might be time to have the manuscript printed [...]." ${ }^{1064} \mathrm{He}$ wrote more than ten chapters in English, but never found a publisher in the United States. Instead he wrote a Swedish version, which was published as his memoirs, Ljusmannens gåta, in 1959. ${ }^{1065}$

The focus on Southeast Asia also led to more activity in Washington's diplomatic community. In April 1954, at the time of the Geneva Conference, Olov and Renée attended a reception at the Embassy of Laos to celebrate the golden jubilee of King Sisavang Vong. At the reception they met Vice President Richard Nixon and his wife Pat. Shortly thereafter Janse sent Nixon copies of the first two volumes of his archaeological reports from Indochina and "The Peoples of Indochina" booklet that he had produced earlier for the State Department. Nixon wrote back on 28 April to thank him for the books: "This is just a note to thank you for your letter of April 15 and to tell you how very much Mrs. Nixon and I enjoyed meeting you and Mrs. Janse the other day [...]." ${ }^{1066}$

In early 1955, Olov was contracted to give a new course in Advanced International Studies at Baltimore University (but located in Washington, DC), and in the spring he and Ronny travelled to Europe where Olov lectured in Paris and Oslo. He made preparations for a fourth volume of Archaeological Research in Indochina ${ }^{1067}$ and they spent several weeks on study trips-cum-vacation in Italy and Sweden. On the study trips he vis-

1064. Letter from O. Janse to T. Nerman, 28 July 1953. Arbetarrörelsens arkiv och bibliotek. Ture Nerman 3.1.46. ; Letter from O. Janse to B. Nerman, 9 March 1954. Riksarkivet. Kartong 6. Korrespondens Brev 1950-1956.

1065. Janse 1959.

1066. Letter from R. Nixon to O. Janse, 28 April 1954. NAA: Janse 2001-29.

1067. The volume, on which he worked, according to letters, between 1955 and 1969, was never published. Nor have any manuscripts been found in the archives we have consulted. 


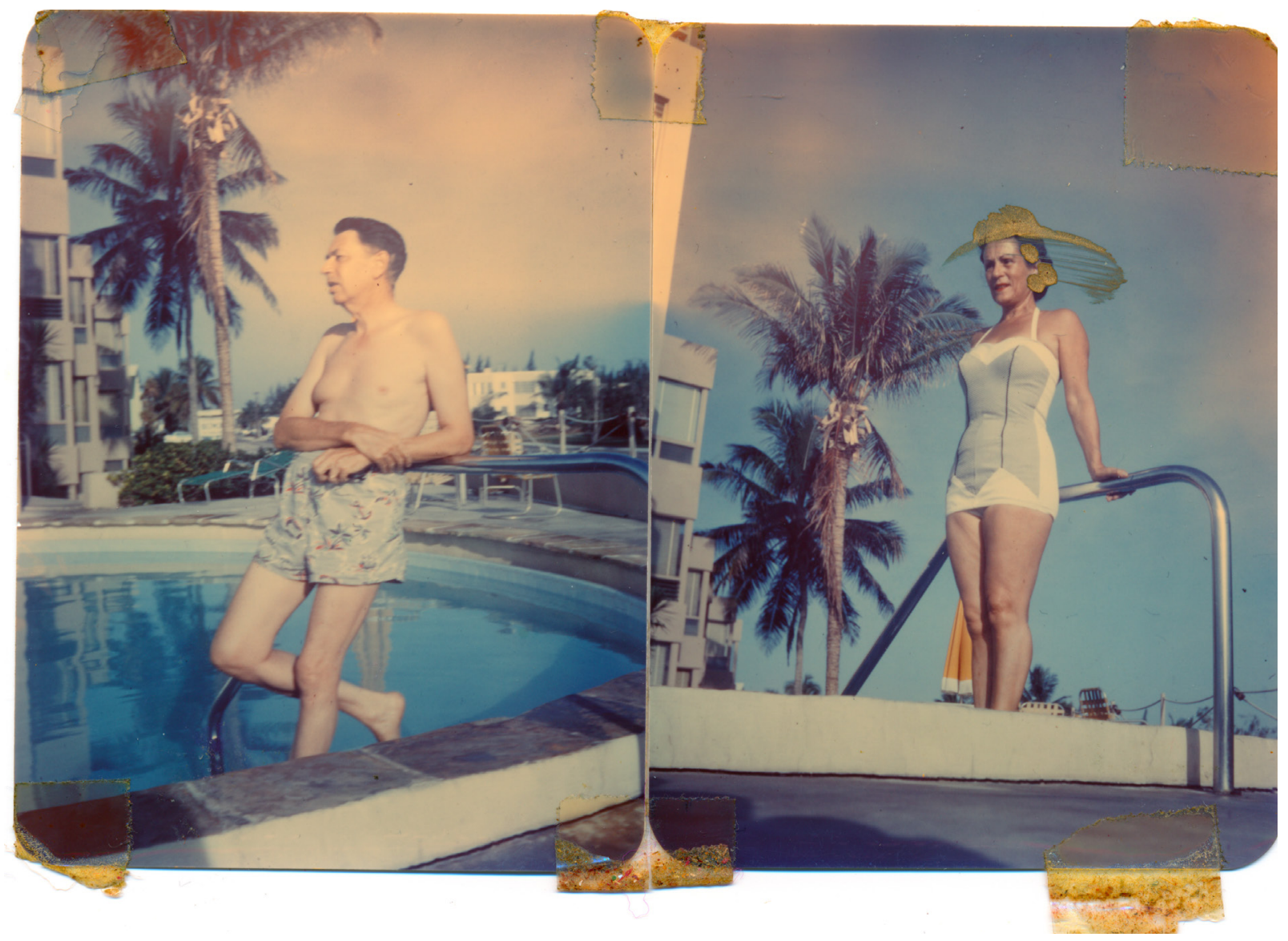

Fig. 75. Holi- ited museums in Rome and Naples, where he found "many new evidences day in Florida, of Hellenistic influence on Southeast Asian art". ${ }^{1068}$ As he picked up his in the 1950 s. archaeological research again, after more than a decade working mainly on bureaucratic tasks, it was the long-distance East-West connections within a template of cultural diffusion from the Mediterranean to the Far East that once again sparked his enthusiasm. In an article written around this time for a Norwegian journal, he writes: "The research of the past decades has, as we know, demonstrated that the peoples of East Asia were affected by cultural impulses from the Western world, already during the Stone Age." Many gaps remain to be filled, he continues, particularly in the southern Chinese cultures which are distinctive, and which he had investigated during his three expeditions. He also mentions some recent

1068. Postcard from O. Janse to B. Nerman, 15 July 1955. Riksarkivet. Kartong 6. Korrespondens Brev 1950-1956. 
finds at Oc Eo, an ancient trading site in the Mekong Delta, where there is proof of trade contacts with the Roman Empire, and he emphasizes that "it is necessary to recall the influence of the Hellenistic culture in India after the victory of Alexander the Great in the fourth century BC". ${ }^{1069}$ Seduced by his own master narrative of cultural diffusion from West to East, he let it serve as the template for all material he had encountered at his excavations two decades earlier. Examples of rich and complex cultures where Mediterranean influences could not so easily be argued for (such as the Dong Son kettledrums and the ceramic kilns at Tam-thô) were completely disregarded or downplayed in his presentations at this time. With the narrative he maintained, he once again reinforced and gave scientific legitimacy to the French colonial image of Indochina as a grateful receiver of cultural impulses from the Mediterranean world, from the Stone Age to historic times.

In 1957, things started to move faster. The Soviet Union, then led by Nikita Khrushchev, demonstrated the success of its space programme by launching two Sputnik satellites into orbit. In Vietnam, President Ngo Dinh Diem received increasing support from the United States, which took on the responsibility to "help" Diem turn South Vietnam into a liberal Western-style democracy, and defeat Ho Chi Minh to unite the country once again. Secretary of State John Foster Dulles had shocked the readers of Life Magazine in January 1956, when in an interview he commented on the situation in Vietnam with alarming arrogance, and claimed that the United States was "on a brink of a War". It became clear that there was a very real risk that the US policy of containment of communism would be replaced by a policy of aggression. ${ }^{1070}$

At this time, Olov Janse was helping to organize a travelling exhibition of Vietnamese art and archaeology, in a collaboration between Diem's

1069. Janse 1958a; in the Swedish original: "De senaste decenniernas forskning har, som bekant, visat att Östasiens folk redan under stenåldern påverkats av kulturimpulser, vilka utgått från Västerlandet. [...] Många luckor återstår emellertid att fylla. Det gäller främst det sydkinesiska området, som i flera avseenden visar en speciell kulturprägel. [...] [Det] är utanför det egentliga Kina, hos dess södra granne (nuvarande Viêt Nam), som vi i senare år, genom systematiska utgrävningar erhållit en bättre kännedom om själva den sydkinesiska särkulturen [...] Härvid är det emellertid nödvändigt att erinra om det inflytande, den hellenistiska kulturen kom att utöva i Indien efter Alexander den Stores segertåg på trehundratalet f. Kr.”

1070. Radio programme with analyses of Dulles's interview in: http://pastdaily. com/2013/01/18/looking-at-the-rose-through-world-colored-glasses-january-18-1956/, accessed 28 August 2018. 
government in Saigon and the Smithsonian Institution in Washington. Janse was in fact the prime mover of the exhibition. He first presented the idea in 1954, and throughout the planning phase served as a "special adviser" behind the front organizer Thomas Beggs, Director of the Smithsonian Institution's National Collection of Fine Arts. ${ }^{1071}$ He contributed archaeological knowledge to the physical planning of the exhibition, but he also served as a diplomatic liaison between the Smithsonian Institution and the Vietnamese Embassy, with Ambassador Tran Van Chuong and Second Secretary Du Phuoc Long. ${ }^{1072}$ In the planning phase, the exhibition was presented as a project of public diplomacy that would benefit both the United States and the Republic of Vietnam. In the United States, it would contribute to a much-needed increase in the public knowledge about the culture of Vietnam. From the Vietnamese side, the exhibition was intended to show "the evolution of the Vietnamese people; their race, politics, customs, and art". It was regarded as "a good opportunity" to engage in "political and cultural propaganda for the government and people of Vietnam". ${ }^{1073}$ The historian Matthew Masur has pointed to the intense activity on the part of the Vietnamese in planning this exhibition, and has called it "one of the most important episodes in [President] Diem's plan to win American public support for his regime". ${ }^{1074}$ Masur argues that it has too often been assumed that public diplomacy during the Cold War was essentially driven by the United States to serve US purposes, for the reason that most historians active in this field have only consulted material in English in US archives. ${ }^{1075}$ Masur's own studies of Vietnamese archives have demonstrated the important role played by Vietnamese officials, up to presidential level, in the planning of this particular exhibition.

On 9 May 1957, in the midst of planning for the Smithsonian exhibition, Olov and Renée Janse were invited to a state dinner hosted by Secretary of State John Foster Dulles and his wife Janet. ${ }^{1076}$ There they met President Ngo Dinh Diem, who was on a state visit to the United

1071. Masur 2004; Masur 2009; Letter from O. Janse to B. Nerman, 10 September 1959. Riksarkivet. Kartong 7. Korrespondens Brev 1957-1961.

1072. Masur 2004:171.

1073. Masur 2004:172, and original documents cited there.

1074. Masur 2004:170.

1075. Masur 2009:311.

1076. Invitation card in fig. 76. They probably met Diem also at a reception at the Vietnamese Embassy on 11 May 1957. 
States. The visit took the form of a promotional tour and was largely organized by the lobby group "American Friends of Vietnam", which also supported the plans for the Smithsonian exhibition. Meeting Janse at the dinner party, Diem showed "a serious and scholarly interest in the project". ${ }^{1077}$ Diem's visit to the United States certainly stimulated government interest in the exhibition, and gave an extra boost to the plans. ${ }^{1078}$

In the spring of 1957 , other plans were also taking shape for Janse. The Vietnamese Ambassador to the United States Tran Van Chuong, with whom he collaborated in the exhibition planning, had approached the US Department of State with a proposal to send Janse on a mission to Saigon, to help the National Institute for Historical Research with archaeological excavations, and to give a series of lectures at the University of Saigon about the results from his previous investigations in Indochina - all under the auspices of the Smith-Mundt Act. ${ }^{1079}$ The Smith-Mundt Act was instituted and signed into US law in 1948 "to promote the better understanding of the United States among the peoples of the world and to strengthen cooperative international relations". This goal was going to be achieved by two principal means:

(1) an information service to disseminate abroad information about the United States, its people, and policies promulgated by [official institutions] having to do with matters affecting foreign affairs; (2) an educational exchange service to cooperate with other nations in (a) the interchange of persons, knowledge, and skills; (b) the rendering of technical and other services; (c) the interchange of developments in the field of education, the arts, and sciences. ${ }^{1080}$

In short, the Smith-Mundt Act specified and regulated the US government's involvement in public diplomacy, as a peacetime instrument of foreign policy. It carries some of the legacy of the Office of War Information (OWI) and its secret sister OSS, which were both created for

1077. Mentioned in an article in The Times of Viet Nam, 28 February 1959. NAA: Janse 2001-29.

1078. Masur 2009296.

1079. Official name: The United States Information and Education Exchange Act of 1948.

1080. Public Laws-Ch 36-Jan. 27, 1948, available at US Department of State website: https://www.state.gov/pdcommission/library/177362.htm, accessed 14 January 2018. 
Fig. 76. Invitation card for State Dinner, 9 May 1957.

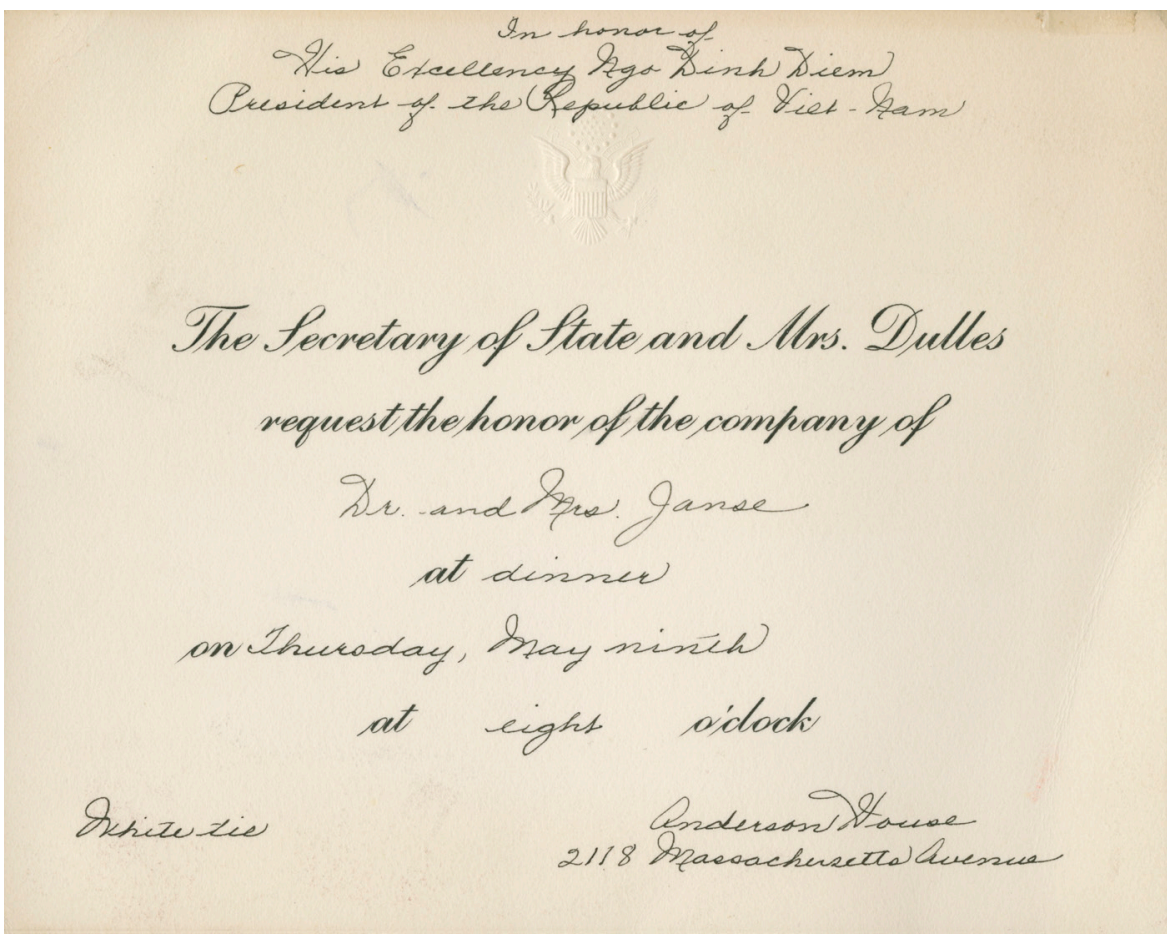

information, intelligence, and propaganda purposes during the Second World War and were dissolved in $1945 .{ }^{1081}$

To support the Smith-Mundt Act, ample funding was allocated by the State Department to enable exchanges and public diplomacy activities. In late April 1957, a couple of weeks before Janse met President Diem at Dulles's dinner party, Nghiem Tham, Director of the Vietnamese Historic Monuments Service in Saigon, wrote a formal letter in French to Manuel Espinosa, Head of the International Exchange Service at the US Department of State, in which he very warmly (Fre: très chaleureusement) recommends Janse for a mission according to the Smith-Mundt Act. Nghiem Tham, who gained his archaeological training in Paris and had been married to a Danish pianist, writes that he has known Janse for a long time, and: "at the moment, Dr Janse is the only scholar [Fre: savant] who could guide us in our archaeological research. Therefore I would be very grateful if you would treat his case with benevolence, and give him

1081. The OW I and the OSS were both dissolved in 1945, but many of their missions and responsibilities were taken over by the US State Department and later the CIA. 
the opportunity to come to Vietnam for a period of 9 months." ${ }^{1082}$ Later in the autumn of 1957 , the Director of the Peabody Museum at Harvard wrote on the same matter to Sylvia Miller, Assistant to the Executive Secretary of the Conference Board of Associated Research Councils:

In the course of this work he has come to know the people well, including not only people of importance in the capital and larger cities, but also the people scattered through the villages and countryside. I doubt if there is anyone in the United States who is so well acquainted with the people of Viet-Nam. These are very strong statements, but Dr. Janse is an unusual person. [...] He will be an extremely sympathetic consultant and advisor to those people in Viet-Nam who are interested in the development of the study of their own prehistory and the presentation of it in museums and schools and colleges. His interest and abilities along these lines seem to me to make his appointment ideal, as I understand the purposes of the Smith-Mundt Act. ${ }^{1083}$

\section{$1958-1963$}

The following March, Olov Janse received a government grant "to participate in an International Educational Exchange program" and "serve as a visiting professor in Viet Nam and other points in surrounding areas as directed by the Department of State". ${ }^{1084}$ It was a generous and prestigious grant, US \$ 915 per month plus travel expenses, and government duty status for six months. Most of the spring and summer was spent on preparations for his journey, and together with Renée he continued to attend dinners and cocktail parties. In August they moved to a more spacious apartment at 4000 Massachusetts Avenue near Georgetown.

On 8 September 1958 he left Renée in Washington, as she could not be absent from her work at the Library of Congress, and travelled via

1082. Letter from Nghiem Tham to Manuel Espinosa, 29 April 1957. NAA: Janse 2001-29.

1083. Letter from J. O. Brew, Director of the Peabody Museum at Harvard, to Miss Sylvia Miller, Conference Board of Associated Research Councils, Washington, DC, 16 November 1957. NAA: Janse 2001-29.

1084. United States Government Grant Authorization (Authorization number 993-8, Obligation Number 2392), 28 March 1958. NAA: Janse 2001-29. 
Brussels, Paris, Athens, New Delhi, Lahore, Taxila and Bangkok, to Saigon, where he arrived on 3 October 1958. In Brussels he visited the modernistic world fair Expo 58, which he found "interesting" which he captured on colour film. Further along the way he studied collections of "Hellenistic" artefacts from the time of Alexander the Great in Taxila. In India, where he stayed more than a week, he was hosted by the National Board of Antiquities and was taken on a guided tour to see the Taj Mahal. Having arrived in Saigon he wrote to Ture Nerman and complained that the journey, although interesting, had also been exhausting. It was the first time that he travelled to Asia by plane, and he explained that he now "had to go to bed when [he] would usually wake up, and vice versa". ${ }^{1086}$

He checked in at the Hotel Majestic in Saigon, and gave his first lecture on Saturday evening, 12 December, to a packed auditorium at the Faculty of Letters at Saigon University. It was the first of three lectures in French, ${ }^{1087}$ all titled "Les origines de la civilization du Viet-Nam" - The origins of Vietnamese civilization. The lecture was chaired by the Minister of Education Tran Huu The, and in the audience were members of the diplomatic community, a delegation from Michigan University, members of Vietnamese and foreign communities, members of the educational corps, and a great number of students. ${ }^{1088}$ The Vietnamese linguist and author Nguyen Dinh Hoa was also there. In his memoirs he recalls:

There was no lack of intellectual excitement in Saigon in those days. Olov Jansé spoke on the origins of the Vietnamese civilization; Father Nguyen Van Thich on Dai-hoc, one of the Four Books of Confucianism; Bui Quang Tung on the uprising of the Trung Sisters; Thai Van Kiem on place names and folklore of South Vietnam; Georges Condominas on Mnong Gar ethnography; Truong Buu Lam on Vietnamese history; Father A. Gélinas on the Chinese classics; Vuong Hong Sen on the classical theatre,

1085. Letters from O. Janse to T. Nerman, 5 August 1958; 16 September 1958. Riksarkivet. Kartong 7. Korrespondens Brev 1957-1961.

1086. Letter from O. Janse to T. Nerman, 3 October 1958. Ibid.

1087. The lectures in French were given on 12, 17, and 19 December 1958.

1088. Vietnam Press Report 13 December 1958: "Conférence du professeur. Janse de l'Université de Harvard sur 'Les origines de la civilisation du Viet-Nam'". NAA: Janse 2001-29. 

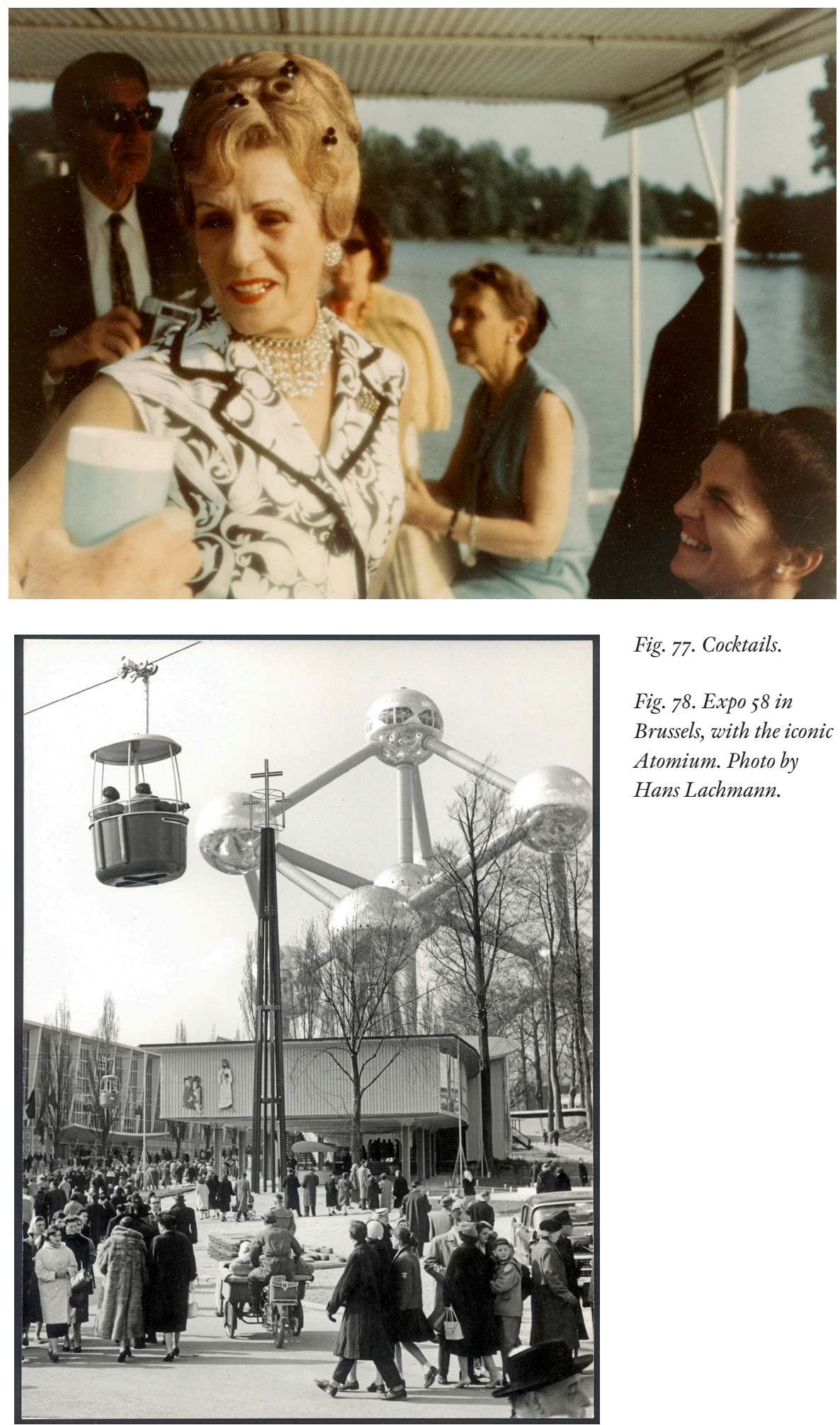

Fig. 77. Cocktails.

Fig. 78. Expo 58 in

Brussels, with the iconic

Atomium. Photo by

Hans Lachmann. 
just to name some of the enlightening presentations that I had the pleasure to attend in 1958 alone. ${ }^{1089}$

In January 1959 Janse continued with a series of three lectures in English in the Auditorium of the Vietnam-America Association. ${ }^{1090}$ The lectures were enthusiastically advertised in the Foreign Service Newsletter, issued by the United States Information Service:
A series of colorful slides will illustrate the lecture. Dr. Janse has many absorbing details to disclose. Plan to be present at one of the finest intellectual treats which Saigon can offer. [...] This is your chance to break away from that television set! ${ }^{1091}$

In his English lectures Janse spoke about his excavations at Dong Son, and of the Dong Son civilization as a mix of Protomalayans, Muong, Chinese, and a cultural element from the Near East or Central Europe - a people with Indo-European language which had invaded China in the eighth century BC, and the frontline troops of which had conquered northern Vietnam. This was a river-valley civilization, he continued, and there are probably many settlements similar to Dong Son yet to be discovered. It is very likely, he said, that the development work on the Mekong that has already begun will uncover other settlements of the same type as Dong Son. The Dong Son finds are remarkable for their outstanding forms and decorative motifs, of which some may explain certain traditions that have remained in Southeast Asia to our days, he concluded. ${ }^{1092}$ The newspaper The Times of Vietnam, which was closely associated with President Diem's regime, reported on the lectures:

Western civilization was brought to this country by an Indo-European type of people who, according to available sources, invaded Western China during the 7 th century before Christ. It is very probable that the vanguard of the invading army actually reached North Viet Nam.

1089. Nguyen Dinh Hoa 1999:138.

1090. The lectures in English were given on Wednesday evenings on 14, 21, and 28 January 1959.

1091. NAA: Janse 2001-29.

1092. Vietnam Press Report, 29 January 1959: "Conférence du Professeur Olov Janse au siège de l'Association Vietnam-Amérique”. NAA: Janse 2001-29. 
This opinion was expressed by Professor Olov Janse Wednesday night at the headquarters of the Vietnamese-American Association. [....] His companion [at the excavations] was Mr Nguyen Xuan Dong, who is presently curator of the Cham Museum at Nha Trang. Together these two men conducted research around several monuments dating back to the beginning of the Christian era and brought to light the famous Dong Son ruins [...]. ${ }^{1093}$

Just like the press reports by the native Indochinese press at the time of his expeditions two decades earlier, and unlike the press in France or the United States that always focused on the kneeling figurine from Lach-truong, the reports in the Vietnamese press had a strong focus on Dong Son. Now, however, much emphasis was on the Western origin of the Vietnamese civilization, even in descriptions of Dong Son, where the original native character had previously been emphasized. All references to French collaboration, which were key during the colonial years, were now replaced by an emphasis on his collaboration with Nguyen Xuan Dong.

Beyond Saigon he lectured in Hué (the town of President Diem's birth), and he also gave a radio interview on 3 March $1959 .{ }^{1094} \mathrm{He}$ ended his stay with a final lecture in French at the Alliance Française in Saigon on 4 March, with the title LeViet-Nam: Carrefour de peuples et de civilisationsVietnam: Crossroads of peoples and civilizations.

Apart from the lectures, most of Janse's activities during his stay in Saigon remain obscure. The excavations mentioned in the planning phase were never realized, and it is unclear how much assistance he offered to the Vietnamese heritage authorities, apart from helping to select artefacts for display in the Smithsonian exhibition. On 25 January he set out on an excursion to find the location of a historic site (the Thuân-Kiêu stronghold) in greater Saigon, together with a group of Vietnamese and international colleagues and diplomats. ${ }^{1095}$ We know also that he visited Angkor Wat during the Christmas break in the company of the French art historian Bernard Philippe Groslier (1926-1986), who had just published two popular history books on Angkor, and was stationed in Siem Reap to

1093. Ibid.

1094. Mentioned in letter from Camille Bergeaud to O. Janse, 4 March 1959. NAA: Janse 2001-29.

1095. The Times of Vietnam, 28 January 1959: "Stronghold built a century ago located by archaeology party". 


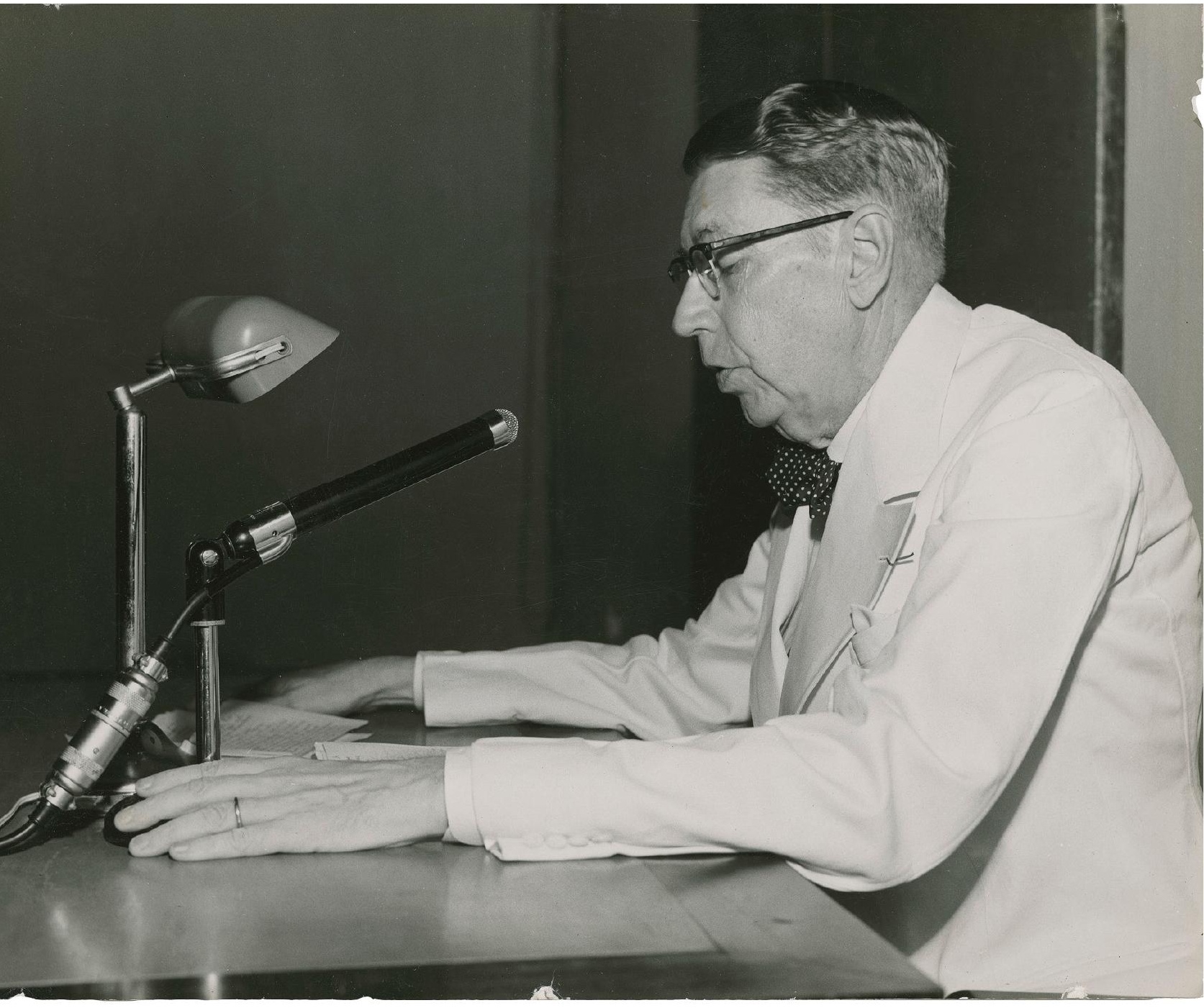

Fig. 79. Olov Janse lectures in Saigon 1959. conduct surveys for the EFEO. As we have mentioned earlier, Groslier would later, in a popular history book on Indochina, describe Olov Janse as the person who introduced order into research on Dong Son. ${ }^{1096}$

During his stay in Saigon Janse also met the young American archaeologist William G. Solheim II (1924-2014), known to most as "Bill", who had contacted Janse already during the Second World War with the intention to join the OSS in Indochina. Now they met in Saigon for the

1096. Groslier 1966:160. 
first time, by chance, and founded a friendship that would last for the rest of Janse's life. Janse introduced Bill Solheim to the idea of starting an archaeological salvage programme around the Mekong river in connection with the Mekong River Project, which under UN auspices surveyed the possibilities to contribute to the development of the countries in mainland Southeast Asia by building dams and other technological developments on the Mekong and its tributaries. ${ }^{1097}$ We shall return to that project and to Bill Solheim in a little while.

In a long feature article in The Times of Vietnam, we get a glimpse of how Janse was perceived during his stay in Saigon:

"I have now retired", says Dr. Janse. But the tall, scholarly man's eyes give out with something that has no hint of retirement when he begins to speak of his work. [...] It is quite evident that his continuing extra-curricular activities actually mean that he is continuing his profession fulltime. [...] The undercurrent of the excitement of discovery comes into his voice - and it is contagious, stirring up images of men in pith-helmets frantically working under the hot sun of the tropical jungles or the deserts to dig up more and yet more of a new find. ${ }^{1098}$

Discussing the finds from his excavations in the 1930s, Janse now suggests "that many of these objects were made in what is now South Viet Nam - possibly in workshops in localities of cosmopolitan character such as Oc Eo, just 25 kilometres from Saigon". ${ }^{1099}$ Oc Eo was a high-profile archaeological site that had been found and excavated in 1940 by Louis Malleret, who later became director of the EFEO. It has been described as the port to the ancient mandala of Funan in the first to sixth centuries $\mathrm{AD}$ and was undoubtedly an ancient trading site of considerable importance, although the existence of Funan as a discernible political entity, as well as its connection with Oc Eo, has since been a matter of contestation. Malleret's investigations at Oc Eo were in fact the first major archaeological research programme focused on southern Vietnam, and investigations

1097. Solheim 2002 ; Jacobs 2000.

1098. The Times of Vietnam, 28 February 1959: "Dr. Olov Janse Completes Archaeological Goodwill Mission - Forthcoming Exhibits, Author's Writings Give World New Insight Into Ancient Viet Nam's Civilization".

1099. Ibid. 
were resumed there at the end of the 1940 s when France was working to restore its colonial institutions in Indochina. ${ }^{100}$ In his interview, however, Olov Janse referred to Oc Eo for confirmation of his own thesis of Western, particularly Hellenistic, influence on the origins of Vietnamese civilization. He ended the interview talking about the new generation of archaeologists, and how impressed he was

by the eagerness of the Vietnamese students to enlarge their knowledge and serve their country. As you know [...] there is a growing consciousness in Viet Nam, among your people and in your Government, of the value of your cultural and national heritage - a heritage of which any country would have a right to be very proud. Those who in the future will be entrusted with the custody of this heritage must be adequately trained. ${ }^{1101}$

He talked about the necessity of high-quality training for Vietnamese archaeologists, and the international importance of a well-functioning heritage administration:

Southeast Asia, and Viet Nam in particular, has been since time immemorial a cross-roads of peoples and civilizations. The importance of archaeology of Viet Nam goes far beyond its national boundaries, and orientalists all over the world are genuinely interested in the matter. If one of the international organizations working on the Mekong Valley Project, for example, should incidentally discover an important site - a strong possibility, by the way - who would be responsible for carrying out systematically conducted excavations? Who would make the final decisions concerning the disposal of the findings? Who would grant the needed funds for publishing the scientific reports? All these questions have scientific implications on an international and political level. ${ }^{1102}$

1100. EFEO 2002:188-189. See also Clémentin-Ojha \& Manguin 2001, pp. 36-40 on the history of EFEO in Hanoi and Saigon 1940-1961.

1101. The Times of Vietnam, 28 February 1959: "Dr. Olov Janse Completes Archaeological Goodwill Mission-Forthcoming Exhibits, Author's Writings Give World New Insight Into Ancient Viet Nam's Civilization.”

1102. Ibid. 
"Oh, yes?" asked the Vietnamese reporter. "Oh, yes", Janse concluded. "When we are planning for the exploration of the past, it is always advisable to look toward the future." ${ }^{1103}$

We see here how the meaning of Janse's archaeological knowledge was transformed for a new context and new purposes. Always attentive to his current social setting, he now gave his results value and meaning in relation to the new Republic of Vietnam, and to his own mission as a representative of the United States. Native archaeologists were important, but not fully accomplished, and therefore needed guidance. However, the patronage was no longer in the form of a French colony, but an international concern. The Vietnamese civilization was no longer based on a prehistory of colonization (as in his 1930s "investigations of the southern expansion of the Chinese Han empire"), but on a cosmopolitan melting pot with foundational influences from Classical Greece. ${ }^{1104}$ The Chinese connection, which used to be key, was downplayed or not mentioned at all. Journalists and editors were also to some extent responsible for the way his knowledge and opinions were featured and presented in newspapers and magazines. Yet we see very similar sentiments expressed in his letters, and his own articles.

There was, however, one complication. Despite his backing from the United States, and his apparently honest and sincere feelings for Vietnam and its people, Olov Janse was a Francophile. In a letter sent just before Janse's departure from Saigon, the French Cultural Consul Camille Bergeaud wrote euphorically how delighted he was to have made Janse's acquaintance, and how much he had enjoyed and benefitted from attending his lectures. Notwithstanding Janse's admirable knowledge, says the Consul, he had just as much appreciated the lectures' spirit of friendly, loyal, and generous cooperation. ${ }^{105}$ In a second letter, Bergeaud specifies that it was particularly the "courtesy and fairness" of Janse's emphasis on the French contribution through the EFEO that he had appreciated the most. ${ }^{1106}$ In an interview given around the same time for the French-Vietnamese newspaper Journal d'Extrême-Orient, Janse "underlines the French

1103. Ibid.

1104. This makes an interesting comparison with the United States, which is often described as a salad bowl, or, indeed, a melting pot of cultures, and draws on plenty of classicistic elements in its manifestations of national heritage (for example in the Capitol and the Lincoln Monument on the Mall in Washington, DC).

1105. Letter from C. Bergeaud to O. Janse, 4 March 1959. NAA: Janse 2001-29.

1106. Letter from C. Bergeaud to O. Janse, 6 March 1959. NAA: Janse 2001-29. 
contribution to archaeological research in Vietnam", and praises the work done in Paris in terms of research and conservation of the finds from his expeditions. "Too much nationalism", he says here, can sometimes hinder collections from being seen and researched in other contexts than their own country can offer. Rather, he advocates acting "in a spirit of mutual interest and above all put scientific interest above human passions". In the long run, he says, "it is obviously in the interest of Vietnam itself to have its cultural heritage better known and more appreciated in the world". For after all, "there are more visitors to the Guimet Museum than to the Saigon Museum". ${ }^{1107}$ Janse's steadfast loyalty to France, and his belief in the French colonial contribution in Indochina as something ultimately beneficial, no doubt complicated his relations with the political leadership of the United States, as well as the Vietnamese independence parties, both north and south.

Janse's activities during his stay in Saigon were regularly reported by the local press, particularly the English-language daily newspaper The Times of Viet Nam. Owned and run by the American couple Gene and Anne Gregory, ${ }^{1108}$ who were close friends with President Diem's sisterin-law, the legendary Madame Nhu, ${ }^{1109}$ The Times of Viet Nam was closely associated with Diem's presidency. Gene and Anne Gregory were well informed of Janse's stay in Saigon and hosted a farewell cocktail party for him at their home in Saigon, at 6 p.m. on 6 March 1959. At his departure two weeks later, Janse said in a statement to Viêtnam-Presse that he was positive about future collaborations between the United States and Viet Nam in issues concerning archaeology and cultural heritage. Especially because "the rich heritage of Viet Nam is of such a character that it concerns a much larger part of the world, and because the interests

1107. Journal d'Extrême-Orient, 5 March 1959: "Le professeur Janze [sic] souligne la contribution de la France aux recherches archéologique au Vietnam." In the French original: "Parfois un excès de nationalisme objecte à l'idée de voir même des collections d'études établies à l'étranger, mais dans ce domaine il faut essayer à mon avis d'agir dans un esprit d'intérêt mutuel et avant tout mettre l'intérêt scientifique au-dessus des passions humaines et donc momentanées le plan du premier ressortissant au pérenne c'est évidemment dans l'intérêt même du Viêt-Nam de faire mieux connaître et mieux apprécier dans le monde son héritage culturel. Bien entendu il y a plus de visiteurs au musée Guimet qu'en Musée de Saigon."

1108. Hoffman 2008: 32. See also Newsweek, 24 September 1962: "The Gregorys of Saigon".

1109. Brinson Demery 2013:141. 
of science transgress national boundaries". He suggested broad collaborations between Vietnamese institutions and orientalists all over the world, according to the principles already established by UNE SCO. ${ }^{1110}$

From Saigon, Janse travelled to Seoul in South Korea, where he arrived on 25 March 1959, and stayed for two weeks. He lectured at the Korean National Museum on the topic "Vietnam: Crossroads of People and Civilization", and to a full house at Yonsei University. He also made a tour of the country, visited the famous temple site at Kyongju near Taegu, ${ }^{1111}$ and "had the opportunity to see some magnificent monuments and collections that are little known". ${ }^{1112}$ On the night before his departure, he wrote to Renée that he had just had a long chat with the Director of the Asia Foundation about setting up a school for Asian studies, which was followed by

a wonderful lunch at Vietnamese Embassy here. There were the German Ambassador [Richard Hertz], the French Chargé d'Affaires, the rector of the University and his wife, the director of the Nat. Museum and his wife and the Hendersons. It was very pleasant and $\mathrm{Mr}$ and $\mathrm{Mrs}$ Anh send you their very best regards. This was one of the rare occasions you would have liked and we all regretted you were not there. [...] The Hendersons send you their best regards and love. ${ }^{113}$

Gregory Henderson (1922-1988) was a leading Korea scholar and collector of Korean Art at Harvard, and had served with the United States Foreign Service and worked as Vice Consul and Cultural Attaché in Seoul. ${ }^{1114}$ His wife Maia (or Maria-Christine Elisabeth von Magnus Henderson) was born in an aristocratic German family in Berlin. She was as well-respected an art collector as her husband, and later became a well-known

1110.Viêtnam-Presse, 21 March 1959: "Déclaration du Pr Olov R.T. Janse, archéologue americain à son départ de Saigon".

111. Advertisement for Janse's visit to Seoul, not dated. NAA: Janse 2001-29.

1112. Letter from O. Janse to T. Nerman, 12 May 1959. Arbetarrörelsens arkiv och bibliotek. Ture Nerman 3.1.46.

1113. Letter from O. Janse to R. Janse, 2 April 1959. NAA: Janse 2001-29.

1114. Gregory Henderson has written an interesting personal account of Korea in 1950, in Cotton \& Neary 1989:175-182. See also Henderson 1968. 
philanthropist in Harvard. ${ }^{115}$ The Hendersons were in many ways the typical friends of Olov and Renée Janse: well-educated cosmopolitans who mixed art and artefact collection with academic careers and foreign service. Janse's note at the end of his letter indicates that he was not overly enthusiastic about the current social context in Saigon, and moreover it testifies to Renée's importance to the social side of his profession: "This was one of the rare occasions you would have liked and we all regretted you were not there $[\ldots] . "$

Olov returned to the United States via Tokyo, and arrived in Washington, DC, in early May 1959. In July he spoke about Vietnam on the Voice of America radio station, and in the autumn he lectured at Yale University about his experiences from Southeast Asia. His mission in Vietnam was also noted in the US press, and in an interview in The Washington Post, Janse emphasizes the important new finds at the Oc Eo site. Oc Eo is here described as "a city" and "cosmopolitan centre of traders and artisans". It was only now, Janse says, when he was back as a visiting professor in 1958-59 that he saw and understood the importance of the new finds and immediately saw them as confirming his own theories on cultural diffusion through prehistoric connections between Vietnam and the Mediterranean. Having studied Malleret's finds from Oc Eo at the museum in Saigon, he was now convinced that "the [kneeling figurine] sculpture was executed from a Mediterranean-style design by one of the artisans of Oc Eo or another of the many hidden cities which have since been discovered from the air in that vicinity". The end of the article takes a turn towards the present:

The strife-torn post-war years have not only halted work on Oc-Eo, but have stymied attempts to uncover several other city sites also visible from the air. But it is Janse's hope that an international commission - British, American, French, Italian and Japanese - which is planning hydraulic projects in the area can be persuaded to aid in further work under scientific supervision. ${ }^{1116}$

\footnotetext{
1115. Obituary in The Boston Globe, 23 December 2007: "Maria-Christine von Magnus Henderson."

1116. The Washington Post, City Life section (Tony Gieske) 20 July 1959: "Hidden City in Viet-Nam Yields Pre-Christian East-West Ties".
} 
At this time, his mind was occupied with the plans for archaeological and anthropological investigations connected with the massive development programme around the Mekong River: The Mekong Project. Initiated by the United Nations Economic Commission for Asia and the Far East (ECAFE) in 1952, and formalized with the appointment of an international "Mekong Committee" and a "Statute of the Committee for Coordination of Investigations of the Lower Mekong Basin" in 1957, the project sought to establish a basis for economic development by creating irrigation systems, building hydroelectric dams, and in other ways using the water resources provided by "the mother of waters", the mighty Mekong. ${ }^{1117}$ It seemed an excellent opportunity for all parties involved. The governments of the nations along the river, Thailand, Laos, Cambodia, and South Vietnam, saw opportunities for economic uplift, the United Nations saw an occasion to unite international knowledge and science in a project for the betterment of humanity, and the United States (as well as the UN) saw it as a chance to strengthen the more or less fragile non-communist West-friendly governments in all four countries to prevent the further spread of communism over Southeast Asia.

It is possible to draw parallels here between the Mekong Project and the construction of the Aswan High Dam in Egypt in 1960. The Aswan Dam became an arena for international Cold War politics, and the operations known as the Rescue of Nubian Monuments and Sites became a well-known flagship project for UNE SCO. ${ }^{1118}$

Olov Janse and his new friend Bill Solheim also saw the potential of the Mekong Project. If an international effort, similar to those that had already been initiated in the fields of sediment analyses, aerial surveys, river measurements, fish inventories, and cement and construction technology, could be made in the fields of anthropology and archaeology, it could mean a dramatic increase in the cultural and historical knowledge of a major part of mainland Southeast Asia. ${ }^{1119}$ Moreover, they rightly pointed to the importance of understanding the cultural and historical setting for the outcome of the entire project. Here in the words of Bill Solheim and Robert Hackenberg:

In the majority of [similar engineering programs] it has been assumed that everyone is for progress and all that presumably goes

1117. Cosslett \& Cosslett 2013: chapter 4.2.

1118.E.g. Meskell 2018: chapter 2.

1119. Solheim \& Hackenberg 1961:2459-2460; Solheim 2002:8. 
with it. High level planners never stop to think that people in specific areas to be affected by such a program have been living their present way of life for some time and feel emotionally and practically committed to this way of life. [...] The people, their culture and the historic and prehistoric background of their culture, are a major subject for research and understanding if the total program is to be successful. [The] best way to go about this study is through an anthropological-archaeological approach. ${ }^{1120}$

In the article they further emphasize such aspects as the Buddhist tradition of merit-making and the principle of material impermanence, which could easily end up in conflict with the capitalist principle of accumulation of surplus upon which the Mekong Project was built. ${ }^{1121}$ Janse and Solheim spent much time and effort over several years to gain funds and support for their project. On his visits to Washington, DC, Solheim stayed with Olov and Renée "in their very interesting Washington apartment; interesting in the large number of photos from Vietnam and of receptions etc. by or for the King of Sweden, to which [they] were always invited" ${ }^{1122}$ According to Bill Solheim they "received much moral support, but no funds" for their proposed project. ${ }^{1123}$ Janse, on the contrary, writes in a letter to Ture Nerman in August 1961, that they "have succeeded fairly well in raising interest among all interested parties, and the [US] Congress has voted the necessary funds". ${ }^{1124}$ Their efforts would, however, prove to be in vain. Owing to increasing political tensions in Southeast Asia, the Mekong Project would effectively be put on hold in the early 1960 s.

Another major concern for Olov Janse after his return from Asia, was the Art and Archaeology of Vietnam exhibition at the Smithsonian Institution. As a "consultant" to the official organizer Thomas Beggs, Janse played a key role in organizing the exhibition space, selecting the artefacts to be displayed, and writing the exhibition catalogue. ${ }^{1125}$ The personal connections and friendships that had allowed him to act as liaison be-

1120. Solheim \& Hackenberg 1961:2460.

1121. Ibid:2467.

1122. Solheim 2002:8.

1123. Ibid.

1124. Letter from Olov Janse to Ture Nerman, 20 August 1961. Arbetarrörelsens arkiv och bibliotek. Ture Nerman 3.1.46.

1125. Smithsonian Institution 1960. 
tween the US organizers and Vietnamese scholars and diplomats had been reinforced by his recent visit to Saigon. On 1 August 1960 Nghiem Tham, Director of the Vietnamese Monument's Department in Saigon, arrived in Washington along with the collections to be put on display. The exhibition had been previewed at the Dien Hong Palace in Saigon before it was packed and shipped, in 27 packing cases that left Saigon together with Nghiem-Tham at the end of June. When Nghiem Tham arrived with the 27 cases in Washington, DC, he was greeted by Olov Janse. In an interview in The Times of Viet Nam to mark the occasion, Janse says:

The exhibit is important in that it shows that Viet Nam was linked with the Western world some 2,000 years ago, and that Vietnamese culture, far from being a branch of the Chinese, has ties with the Greco-Roman empire and the Christian culture of Asia Minor as well as that of China and Southeast Asia. ${ }^{1126}$

The disconnection from China was a major theme of the exhibition. ${ }^{1127}$ Janse's updated narrative, which emphasized connections with the classical traditions of the Western world, fitted perfectly with the ambitions of the Diem regime. In the words of Matthew Masur, "it constructed a historical narrative of a people fiercely protective of their independence, as evidenced by their millennia of resistance to China. But it also suggested a degree of cultural flexibility - a Vietnamese willingness to adopt the best characteristics of other cultures", ${ }^{1128}$ notably of cultures rooted in the classical Mediterranean. The exhibition pressed all the right buttons in the relationship between Diem's Republic of Vietnam and the United States of America, and as such it served as an important piece of public diplomacy.

The exhibition opened at the Smithsonian's Museum of Natural History on 26 October 1960 , the national day of the Republic of Vietnam. In the entrance hall stood an altar devoted to the cult of ancestors, with incense-burners, candlesticks, votive tablets, parasols, and traditional weapons. Visitors were enveloped by "the soft sounds of Vietnamese music

1126. The Times of Viet Nam, 26 August 1960: "Vietnamese art exhibition slated for Smithsonian in October".

1127. See also a review in The Washington Post, 11 September 1960: "At Smithsonian: Viet Nam Relics Shown" where there is much focus on Oc Eo and the Mediterranean connection.

1128. Masur 2009:302-303. 
and the scent of burning incense". ${ }^{1129}$ One visitor said that he felt as if he was "transported half way around the world in a fraction of seconds". ${ }^{1130}$

In the other ten rooms of the exhibition there was also information of a drier character: a large map of Vietnam, a collection of Vietnamese stamps, two glass cases containing books and pamphlets about Vietnam and photographs representing the country's famous historical and artistic sites. Five rooms were reserved for ancient art objects, such as bronze kettledrums, ceramics, Cham art, and artefacts excavated from Oc Eo. The artefacts in the ancient art section had been borrowed from other collections, most of them excavated by Janse, at museums in Brussels, Harvard, Saigon, and Hué. ${ }^{1131}$ One room contained "common articles" connected to ethnic minority groups, and one displayed objects from Vietnamese traditional music and theatre, including instruments and costumes. Another room showed paintings of contemporary artists, and the last one showed handicraft articles, furniture, jewellery, and clothing. ${ }^{1132}$

Matthew Masur has emphasized the direct influence of the Diem regime on the layout and contents of the exhibition. Some overt political propaganda for Diem was also included, such a poster with Diem's portrait, but that did not go down well with the visitors in Washington, DC. Yet no one complained of the propaganda for a certain West-oriented state formation in Vietnam, that was embedded in the historical narratives and themes of the exhibition. On the contrary, "visitors tended to respond positively to materials $[\ldots]$ described as 'of a cultural nature"'. ${ }_{1133}$

After Washington, the exhibition toured New York, Philadelphia, Cleveland, and Baltimore, and the states of Massachusetts, Missouri, California, and Oregon, before it was packed up and returned to Saigon. It was a great success with more than a hundred thousand visitors, many of them influential, culturally aware, and politically engaged Americans. ${ }^{1134}$

While the exhibition was a success in terms of raising the awareness of Vietnam's history and culture in the United States, and creating a sense of purpose in the relations between them, it was not so much a success

1129. Masur 2009:293.

1130. Masur 2009:293, and sources cited there.

1131. Smithsonian Institution 1960:16; see also letter from J. O. Brew to O. Janse, 13 September 1960. The Peabody Museum archive, XF_41-63_01.

1132. The information about the exhibition layout is taken from an album in Janse's personal archive (NAA: Janse 2001-29).

1133. Masur 2009:308.

1134. Ibid. 


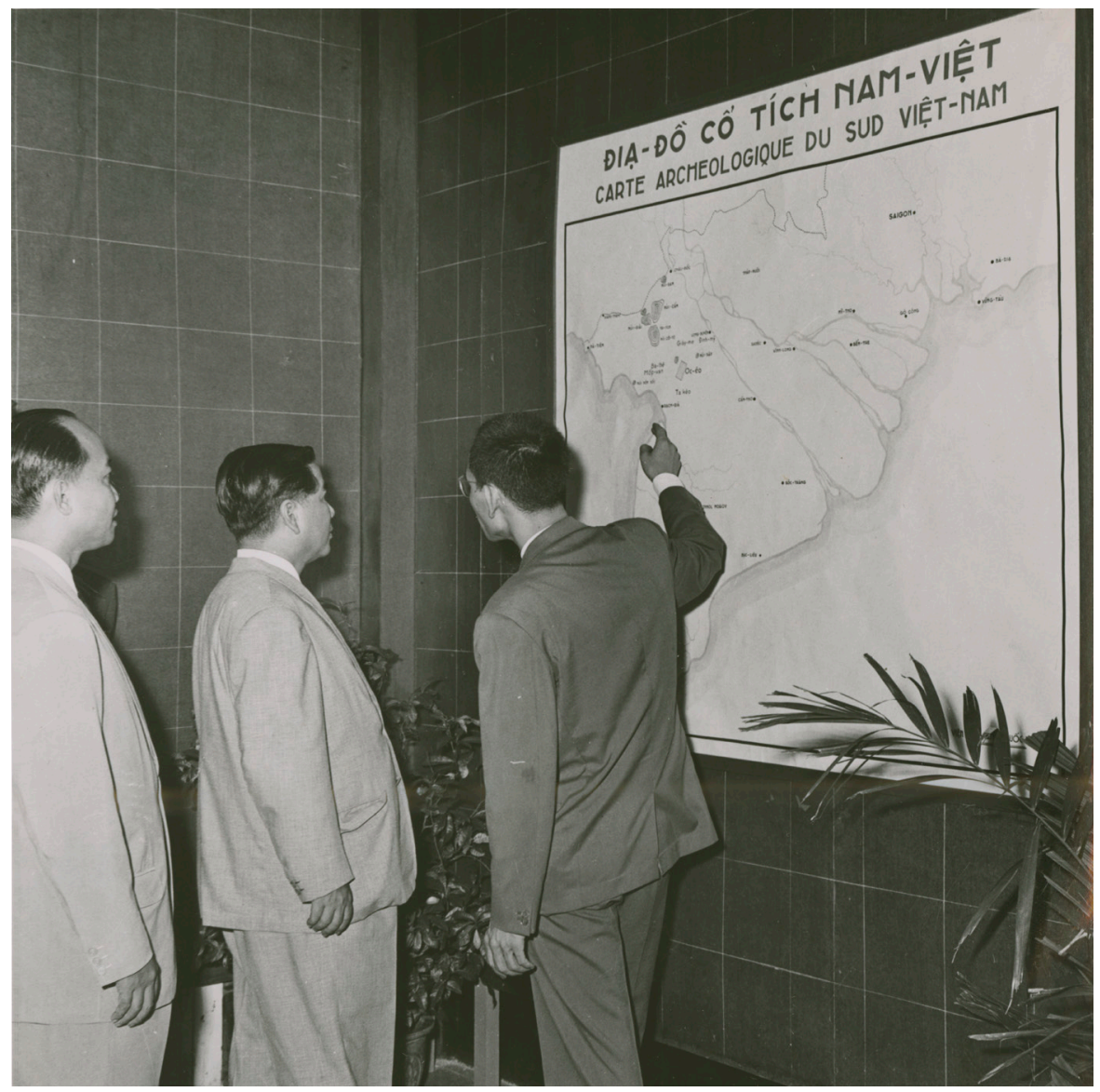

Fig. 80. Dr.

Nghiem Tham shows President Diem the location of Oc Eo, on a map in the room of antiquities at the preview of Art and Archaeology of Vietnam in Saigon 1960.

for Diem personally. The personal propaganda elements had a more negative than positive effect among the American visitors, and moreover, the exhibition coincided with a coup in Vietnam. On 11 November, a mere fortnight after the opening of the exhibition in Washington, a group of military officers launched a coup against Diem in Saigon. It failed, but it indicated some serious problems with Diem's rule in South Vietnam. The situation was indeed fragile. Diem's brother Ngo Dinh Nhu had acquired a very strong position in government affairs, and his wife, Madame Nhu, had gained so much influence that she was sometimes referred to as the First Lady of South Vietnam. All three - the President, his brother and his sister-in-law - lived together in the presidential palace. They led an extravagant lifestyle, and Madame Nhu in particular made lofty, arrogant comments about the Vietnamese people. In combination with Diem's 
repressive style of rule, his religious preferences and open resentment of Buddhism, along with accusations of corruption, the regime was weakened by the day.

In the United States, John F. Kennedy won the presidential election in November 1960 (to Janse's delight) and was inaugurated in January 1961. His Vice President was Lyndon B. Johnson. At about the same time in North Vietnam, Ho Chi Minh and his associates formed the National Liberation Front - NLF - as a new organization to replace the Viet Minh. Among its enemies, the NFL would go under the scornful name Viet Cong - "Communist Traitors to the Vietnamese Nation".

The new leaders of the United States were concerned about the seeming fragility of Diem's regime, but they had no intention of abandoning the campaign against communism. In his inauguration address, John F. Kennedy said: "To those new states whom we welcome to the ranks of the free, we pledge our word that one form of colonial control shall not have passed away merely to be replaced by a far more iron tyranny." ${ }^{1135}$ Despite doubts in President Diem's ability to rule in South Vietnam, the United States got more and more deeply involved in the conflicts that bubbled beneath the surface in Saigon.

In May 1961, Lyndon Johnson made a state visit to India and Southeast Asia during which he met President Diem and Madame Nhu, and famously called President Diem "The Churchill of Asia". Upon his return to Washington, Johnson invited Olov Janse to dinner, with representatives of the states he had visited on his journey, as well as some advisers to President Kennedy. "Very interesting and instructive", says Janse in a letter to Ture Nerman. ${ }^{1136}$

Although Janse was invited to this and other functions at embassies or hosted by US government officials, ${ }^{1137}$ he was never used in any direct advisory role to decision-making politicians or policy-makers, despite the apparent lack of broader experience and more profound cultural knowledge that continued to characterize US involvement in Vietnam.

In the summer of 1961 , Janse received another generous research grant

1135. John F. Kennedy Presidential inauguration address, 20 January 1961.

1136. Letter from O. Janse to T. Nerman, 30 August 1961. Arbetarrörelsens arkiv och bibliotek. Ture Nerman 3.1.46.

1137. Around this time he was also in contact with Senator J. William Fulbright (Letter from Fulbright to Janse, 27 July 1959. NAA: Janse 2001-29) and Supreme Court Justice William O. Douglas (Letter from W. O. Douglas to O. Janse, 25 April 1960. NAA: Janse 2001-29), both with high profiles in the US debates about the Vietnam War. 
of US $\$ 20,800$ from the US Department of State. In September he travelled with Renée by plane to Europe, where they visited London, Paris, Vienna, Athens, Rome, the French Riviera, and Paris again. They stayed in luxury hotels, and he worked on a new book about "the Eurasian cultural complex". ${ }^{113^{8}}$ They returned to Washington, DC, in early November.

Back in the United States, after the Smithsonian exhibition had been shipped back and Janse had returned from his research trip to Europe, he took the initiative to transfer artefacts from his excavated collection at the Peabody Museum, to the National History Museum (formerly Musée Blanchard de la Brosse) in Saigon. The Peabody Museum and Harvard-Yenching Institute approved of the plans, Janse selected the artefacts, and in February 1963 a collection of 150 objects, or "samples", from Janse's original collection from Indochina were dispatched to Saigon. ${ }^{1139}$ An article in The Times of Viet Nam reports on the reception of the collection in Saigon:

Education Secretary Nguyen Quang Trinh and U.S. Ambassador Frederick Nolting jointly presided at a ceremony held yesterday afternoon at the Viet Nam National Museum [in Saigon] to commemorate the transfer to the Museum of samples of archeological findings offered by the Harvard Yenching Institute and the Peabody Museum of Cambridge, Massachusetts. [...] Ambassador Nolting said that the restoration of these samples of archaeological findings contributed to a better understanding between the American and Vietnamese people in both the cultural and economic fields. In his reply, Mr Trinh said that these samples of findings made 30 years ago by Prof. Olov Janse testify to the fact that Viet Nam has its own basic civilization traced back to times immemorial and helps to explode the deep-rooted belief that this civilisation came solely from the Chinese one. ${ }^{1140}$

1138. The book was never completed, and just like the fourth report volume, we have not found any manuscripts for these works.

1139. Detailed list of artefacts in the Peabody Museum Archive, XF_41-63_01. See also Källén \& Hegardt 2014.

1140. The Times of Viet Nam, 22 May 1963: "VN Antiques Returned to National Museum". 
The American Embassy in Saigon was very pleased with the result of the transfer in terms of its public diplomacy value, and the Chargé d'Affaires wrote to the Director of the Peabody Museum John Otis Brew:

There can be no doubt that this demonstration of unselfishness and sincere interest in Viet-Nam will contribute to a better understanding between the United States and Viet-Nam. ${ }^{141}$

Having read the press reports, an amused and apparently embarrassed Glen Baxter at the Harvard-Yenching Institute wrote to John Otis Brew:

You will be interested to know that the objects were returned to Vietnam grâce à la généreuse initiative de MM Brew, Reischauer, and Baxter. On the matter of initiative, I do think dear old Janse might have been mentioned, since he was the one who urged it in the first place. ${ }^{1142}$

In fact, it was not a very costly endeavour for the Peabody Museum and the Harvard-Yenching Institute to let go of Janse's collection. The collection sat rather uneasily in Harvard, where neither the Harvard-Yenching Institute (which lacked physical premises to house artefact collections) nor the Peabody Museum (which had no particular interest in archaeological artefact collections from Asia) had any use for them. Hence everyone involved seemed to agree that the artefact transfer back to Vietnam was a good initiative with positive effects.

Overall, the end of the 1950 s and first years of the 1960 s were a period of great success for Olov Janse. He could harvest the results of personal and professional efforts and endeavours after a long and at times difficult career. In Sweden, his memoirs received glowing reviews, ${ }^{1143}$ and in November 1961 he became a (foreign) member of Vitterhetsakademien, The Royal Swedish Academy of Letters, History and Antiquities. In the

1141. Letter from William C. Trueheart at the American Embassy in Saigon, to John Otis Brew, Director of the Peabody Museum, 24 May 1963. Peabody Museum Archive: XF_41-63_01.

1142. Letter from Glen W. Baxter to John Otis Brew, 23 July 1963. Peabody Museum Archive: XF_41-63_01.

1143.E.g. Review in Svenska Dagbladet, 10 February 1960: by Hanna Rydh, "Ljusmannens gåta"; "Exotisk forntid", review of Ljusmannens gåta, by Wilhelm Holmqvist, Vi no. 49,1959 . 
United States, he was a sought-after lecturer and conversation partner at some of the most important academic and policy-making institutions of the time.

Yet Janse was not quite content. In the years around 1960, his letters have a sense of bitterness that seems to stem from a feeling of exclusion. At the centennial celebrations of the student union at his former high school in Norrköping, he wrote to Ture Nerman and complained that he had not been invited: "I should have been invited to the jubilee, shouldn't I, but they don't give a shi fig about me, as usual." ${ }^{1144}$ Around the same time he got very upset and engaged in the situation of the Swedish archaeologist Hanna Rydh, whom he knew from the years in Paris and Stockholm. She had been a student of Oscar Montelius and the first Swedish woman to earn a doctoral degree in archaeology, and was one of few Swedish archaeologists of Janse's generation who promoted a broad, international comparative perspective like his. In addition to her archaeological work, she was politically engaged with women's issues in Sweden and in international organizations. Among her many important professional endeavours, Rydh had led an archaeological expedition to India in the early 1950 s, and published the report Rang Mahal in 1959. ${ }^{1145}$ In several letters to Birger Nerman, Janse writes about Hanna Rydh, that he wants to contribute to a higher and much-deserved recognition of her work, and has therefore written two reviews of Rang Mahal for international journals. ${ }^{1146}$ Hanna Rydh, in turn, had just written a very sympathetic review of Janse's memoirs for a Swedish newspaper, where the preamble reads: "A Swedish humanities scholar with a career almost entirely outside of his home country, is rare. Olov Janse $[\ldots]$ has earned an international reputation for his archaeological work." ${ }^{1147}$ In one of the letters to Birger Nerman, Janse reveals how his sentiments for Hanna Rydh were entangled with a bitterness over his own marginalized position in Swedish academia: "Based on previous experience, I suppose

1144. Letter from O. Janse to T. Nerman, 10 January 1960. Arbetarrörelsens arkiv och bibliotek. Ture Nerman 3.1.46. In the Swedish original: "Så jag borde väl ha blivit inbjuden till jubileet, men mej ski-struntar de i, som vanligt".

1145. Rydh 1959.

1146.E.g. Janse 1960-1961. Also one similar review in France-Asie in August 1960.

1147. Review in Svenska Dagbladet, 10 February 1960: by Hanna Rydh, "Ljusmannens gåta". In Swedish: "Att en svensk humanist gör en vetenskaplig karriär nästan helt utanför sitt hemland hör till ovanligheten. Olov Janse [...] har vunnit internationell ryktbarhet som arkeolog." 
that [they] don't care much about me, and that my judgement makes no difference. I guess that Hanna Rydh is pretty much a victim of Swedish jealousy." ${ }_{1148}$

Even if the pace was less hectic, Olov continued his work in the first years of the 1960s. Renée worked at the Library of Congress, and Olov, who was now formally retired, spent most of his days there as well, working on his fourth report volume. He made occasional trips to the other university cities on the east coast - Boston (Harvard), New York, and Philadelphia - and he and Renée continued to attend functions at embassies and other political and diplomatic institutions. As late as 1963 , he considered an invitation to return to South Vietnam as adviser to the heritage authorities there, but "the plans [were] still a bit vague". ${ }^{1149}$

In their private life, however, Olov and Renée were slowing down and downsizing. Renée wrote dark poetry, and eventually developed a new blond persona. They were heartbroken by the deaths of their Swedish friend Ernst J. Lundqvist (always called Lunkan) in 1958, their American friends Arthur and Augusta Hartt in 1960 and 1961, and their close, almost-like-family friend Barbro Nerman in 1961. In the end of 1962, shortly after Olov had celebrated his seventieth birthday, they sold the summer cottage at Cove Point and moved to a bigger apartment in the same condominium as before, at 4000 Massachusetts Avenue, overlooking a green city park. Olov writes in a letter to Birger Nerman: "At first country life was pleasant for a change, but it is too much to deal with. We are quite busy here, and with the location of our new apartment we have the pleasures of the countryside combined with the comforts of the city." ${ }_{1150}$

Meanwhile, in Indochina, the situation was spiralling out of con-

1148. Letter from O. Janse to B. Nerman, 10 June 1960. Riksarkivet. Kartong 7. Korrespondens Brev 1957-1961. In the Swedish original: "Att döma av tidigare erfarenheter, har jag på känn att vederbörande inte bryr sig så mycket om mig och att mitt omdöme inte spelar någon roll. Förmodar att Hanna Rydh till stor del är ett offer för den svenska avundsjukan."

1149. Letter from O. Janse to T. Nerman, 5 January 1963. Arbetarrörelsens arkiv och bibliotek. Ture Nerman 3.1.46.

1150. Letter from O. Janse to B. Nerman, 12 July 1962. Riksarkivet. Kartong 8. Korrespondens Brev 1962-1971. In the Swedish original: "I början var det roligt med lantlivet som en omväxling med det blir för mycket att styra med. Dels är vi rätt så upptagna här, dels har vi med läget av vår nuvarande bostad både landets behag med stadens bekvämligheter i förening." 
trol. ${ }^{1151}$ The NLF was fighting against President Diem's Army of the Republic of Viet-Nam (ARVN) to gain full control over Vietnam. John F. Kennedy was at first reluctant to offer support to ARVN with ground troops, but just like his predecessors he was caught in a Cold War logic, which saw Ho Chi Minh and the NLF first and foremost as marionettes in the hands of an international communist conspiracy. The US involvement could thereby be justified as a battle against evil forces, for a better world. Hence Kennedy doubled US funding and material support for ARVN, authorized the use of napalm and Agent Orange, and increased the number of military advisors, who soon (in violation of the Geneva Accords) got involved in direct combat situations. In an interview about the sentiment in the United States at this time, journalist and foreign policy expert Leslie Gelb says:

None of us knew anything about Vietnam. Vietnam in those days was a piece on a chessboard, a strategic chessboard, not a place with a culture and a history, that we would have an impossible time changing, even with the mighty force of the United States. ${ }^{1152}$

In South Vietnam, the people's resentment of President Diem grew as he launched a programme for forced relocation of villages, and his brother Nhu organized ruthless security forces that pursued all who were not loyal to the regime. It has been argued that many people then offered their support to the NLF, not so much because they wanted to live under communist rule, but as a reaction against the unjust treatment by Diem, his family, and his American allies. Ho Chi Minh, who worked conscientiously to gain the trust of people in rural areas, promised to reunite the war-torn country, throw out the foreigners and liberate the people. Towards the end of 1962 , President Kennedy began to realize that the Vietnamese people hated the American involvement in their country, but with a weak Diem by his side he probably saw no other choice but to continue the fight against communism, to keep the trust of his own people and win the next presidential election.

1151. The summarized descriptions of the situation and political events leading up to the war in South Vietnam and the United States refer to Chapman 2013, Logevall 2012, and Tønnesson 2010.

1152. Interview with Leslie Gelb, in The Vietnam War, a television documentary series written by Geoffrey C. Ward, directed by Ken Burns and Lynn Novick. 2017. 
In June 1963, a protest against the repression and persecution of Buddhists by the Catholic Diem regime led to public uproar where the monk Thich Quang Duc set fire to himself at a crossroads in Saigon as an ultimate manifestation of the Buddhist protest. The previous resentment or fear of the Diem regime was for most people turned into disgust or hatred when Madame Nhu made shockingly arrogant comments on television about the violent protest, calling it a "barbecue" and offering to provide matches if they wanted to do it again. On 1 November 1963, a group of ARVN generals launched a coup (neither supported nor combatted by the United States) against President Diem, which ended in the brutal assassination of both Diem and Nhu. Madame Nhu, who was on a PR trip to the United States, was the only one who escaped.

The coup and the assassination of President Diem sent shock waves through the United States administration, but the situation was almost immediately overshadowed by the assassination of President Kennedy in Dallas three weeks later, on 22 November 1963.

\section{The end}

Something happened at this point in Olov's and Renée's lives. It might have been the cumulative effect of a series of events - we can only speculate. The situation in Vietnam, where their fundamental understanding of the Vietnamese people as gratefully Western-friendly was completely shattered, and on top of that the assassinations of both Diem and Kennedy, must have been incredibly difficult to process and accept, especially for Olov who had been so closely involved with the governments of both countries. We know from Renée's poetry and notes in her archive that she suffered some kind of depression in autumn 1963 and early 1964. We notice at the same time a break in Olov's otherwise regular correspondence with Ture and Birger Nerman between January 1963 and June 1964. In the first letter after the break, he has a slightly different, less distinct hand, when he writes that he is sorry that he hasn't been able to write for a long time, because he has been quite unwell during the winter. Having worked too much, he says, he has been out of gear and has suffered from some kind of heart condition. ${ }^{153}$ Yet his language is changed too - not anglicized, but rather with uncharacteristic disruptions, spelling mistakes

1153. Letter from O. Janse to B. Nerman, 12 June 1964. Riksarkivet. Kartong 8. Korrespondens Brev 1962-1971. 
and inconsistencies suggesting that he might have suffered from a stroke or some neurological ailment.

The break around 1963-64 also put a definite end to Olov Janse's academic career. The fourth report volume was never completed, the book on "the Eurasian cultural complex" was never mentioned again, and the few texts and notes that remain from the last two decades of his life seem to confirm that something happened around 1964 that affected his brain and his capacity for academic analysis. In the following years he returned to his research from the early twentieth century, examining bracteates and similar issues, but without any real focus. His last writings are theories about prehistoric drugs and mushrooms, secret societies, gnosticism, astrology and mysterious numerical series scribbled on loose pieces of paper. ${ }^{1154}$

Despite this apparent decline, Olov and Renée continued to be regular guests at functions at the embassies of Sweden, France, Morocco, Tunisia, Vietnam, Iceland, Laos, Senegal, Latvia, and Lithuania. They also travelled a lot. They visited Sweden twice, in 1964 and 1968, and they went on frequent holidays to Florida - "The Venice of the United States", and to more exotic destinations such as Mexico and the Virgin Islands. Birger Nerman came to visit them in Washington, DC, in 1965, and Olov kept corresponding with Ture Nerman on political developments around the world. More than anything they were upset about student demonstrations, and anti-American protests against the war in Vietnam. Ture Nerman, who had devoted his intellectual life and professional career to political protests, was particularly upset and called the demonstrating students "små snorungar" "som inte begriper något av historien" - "little brats" "who are ignorant about history". ${ }^{1155}$

The correspondence with Ture and Birger Nerman ended in the late 1960s. Ture died in October 1969, and Birger two years later, in August 1971. Olov then disappears from our radar, but he continued his retired life with Renée in their apartment at 4000 Massachusetts Avenue until he died, 92 years old, on 6 March $1985 .{ }^{1156}$ In their archive remains a note, in Renée's shaky hand:

1154. These documents are stored at Antikvarisk-Topografiska Arkivet in Stockholm. Enskilda Arkiv. 59 Olov Janse.

1155. Letter from T. Nerman to O. Janse, 12 December 1966. Arbetarrörelsens arkiv och bibliotek. Ture Nerman 3.1.46. See also Nerman 1967.

1156. Svenska Dagbladet, 28 March 1985: "Obituary" by Margit Althin. 
Fig. 81. The note.

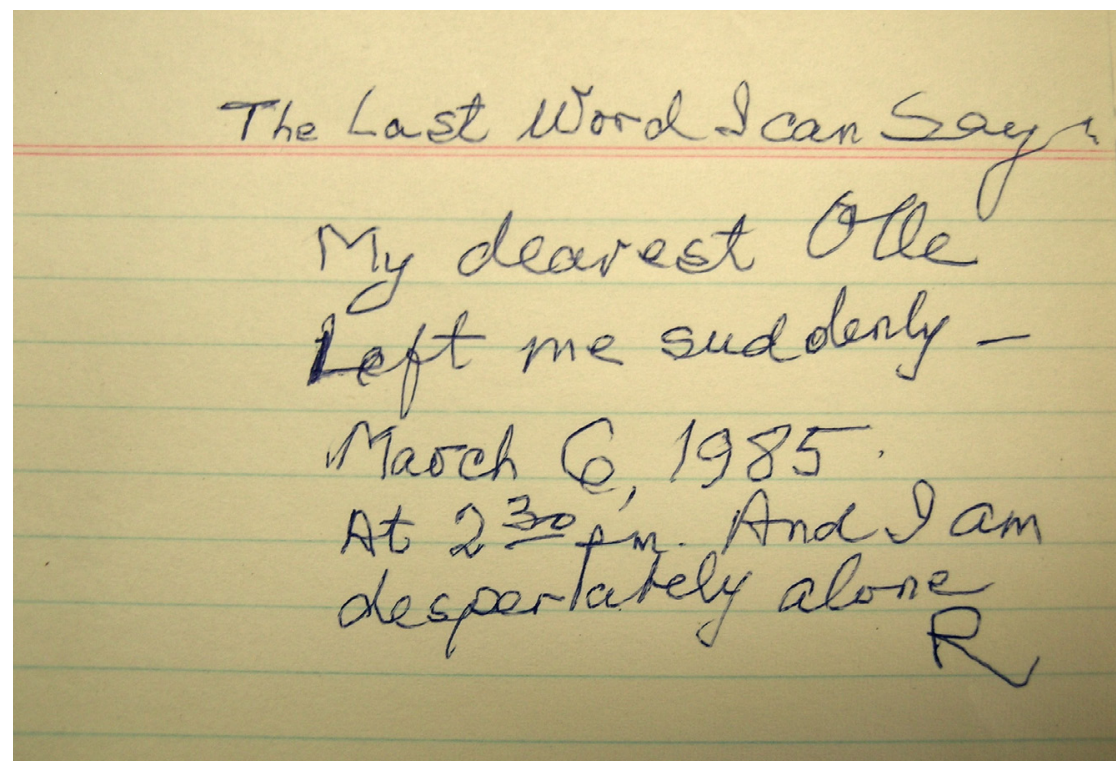

What can be learnt from Olov Janse's years in US government service? In a formal, official sense, he was not particularly important. With very few exceptions, he has not even been noticed by historians of the OSS and Cold War years. Moreover, it does not seem as if he ever thought of himself as an actor of importance in the political processes that led to the Vietnam War. In some sense, he was a lost opportunity. Regarded as one of very few Americans with profound knowledge and insights into the cultures of Indochina, urban and rural, he was not considered for any central advisory role, in a situation that has been criticized in hindsight, particularly for the lack of knowledge about Vietnamese culture among the US administration. This absurd situation can probably best be explained by the blind focus on the Soviet Union among the entire administration, Janse included.

His informal influence can only be speculated about, though he wrote several information texts for administrative purposes, particularly during his time with the OSS and Department of State, ${ }^{1157}$ and he did indeed

1157. These texts were read by key actors in the US administration, for instance Justice William O. Douglas at the US Supreme Court, who wrote a letter to Janse on 25 April 1960, with questions concerning Janse's "War Background Studies" text on Indochina. We know also that Janse sent some of these texts and his archaeological reports to Vice 
meet and mingle with some of the most influential actors in the political administration at the time, both Vietnamese and American. Moreover, he was respected for his knowledge and experience of Indochina. So we can assume that some of his views on Vietnamese culture and history were absorbed and adopted by members of the political administration in Washington, DC.

In connection with his Smith-Mundt-Act-supported visit to Saigon and Korea, and the important exhibition at the Smithsonian Institution which coincided with a crucial moment in the relations between the United States and Diem's regime in South Vietnam, Janse contributed a foundational historical narrative focused on independent resistance against China and fundamental influences from Ancient Greece, which fitted perfectly with the political ambitions of both governments. It took a little tweak, but no major revision of his previous interpretations of the finds from his expeditions to Indochina, to create this new narrative. Yet while he was open to some tweaking in order to rule China out of the picture, Janse stayed true to his comparative archaeological perspective with diffusionism as the main explanatory model. He also kept his devoted love for France and the French colonial system, despite all the inconveniences it must have brought.

In conclusion, Olov Janse lent himself to US government service, and thereby altered some of his perspectives and results. At the same time, though, he kept most of his passions intact. Some were convenient in the US setting, such as his aversion and fear of the Soviet Union, and the notion of necessary mental development from primitive natives (in Indochina) to culturally-accomplished Western citizens (in the new Republic of Vietnam). Others were not so convenient, for instance his love for France and his steadfast belief in French colonialism. In other words, he was neither entirely adaptable nor entirely rigid. Rather, he was both flexible and resilient - flexible enough to adapt to the new situation, but largely resilient and loyal to his former principles and passions, even when they did not offer him any immediate benefits.

The sad irony is that the part of Janse's knowledge and experience of Indochina that could potentially have contributed the most to US policy making was never considered important. We see a glimpse of it in the article about the Mekong Valley Project, where a deeper understanding

President Richard Nixon in 1954 and Senator J.William Fulbright in 1959. NAA: Janse 2001-29. 
of the discourses of rural Indochina (Buddhist, animist, native administration...) is brought up as a major factor to consider for a successful outcome of the river development project. ${ }^{1158}$ Indeed in his colonialperiod expeditions, Janse had already taken an interest in the cultural logic behind the actions of rural communities in Indochina. He wrote about such issues at length in his memoirs ${ }^{1159}$ and in parts of the texts he produced for the OSS and the US Department of State. ${ }^{160}$ It was exactly this kind of interest in the cultures of Vietnam that was missing from the "strategic chess play" in the US administration leading to the Vietnam War. For Olov Janse too, such interests were overshadowed by his own fear of the Soviet Union, and his staunch belief in the French mission civilisatrice.

1158. Solheim \& Hackenberg 1961.

1159. Janse 1959.

1160. See the chapter "OSS and the US Department of State". 


\section{CONCLUSION: THE ARCHAEOLOGIST IN-BETWEEN}

He was a brown-eyed man, 178 centimetres tall with brown hair and fair skin, born into a world filled with candy in the same year as Hailie Selassie, Walter Benjamin, Edith Södergran, J.R.R. Tolkien, and - possibly - Ho Chi Minh. From his first home in Norrköping, Sweden he set off on a remarkable, almost unbelievable journey lasting over five decades, before he settled for good at 4000 Massachusetts Avenue in Washington, DC. He travelled around the world several times, often to find the places and people he used to know changed or destroyed by violent conflicts. He was present at a number of crucial moments in twentieth-century world politics, worked at some of the world's most important institutions, and had a network of influential friends that covered large parts of the northern hemisphere. An obituary in a Swedish newspaper says:

Olov Janse was a particularly noble, and at the same time modest person, who made considerable international achievements on the highest level through extensive knowledge combined with unusually broad language skills. A man who was once Swedish and then became a citizen of the world - a man to remember with pride and joy. ${ }^{1161}$

1161. Obituary "Olov Janse" by Margit Althin, Svenska Dagbladet, 28 March 1985. In the Swedish original: "Olov Janse var en sällsynt nobel och samtidigt personligen blygsam person som gjort stora internationella insatser på högsta nivå genom sina kunskaper inom vidsträckta områden kombinerade med ovanligt stora språkkunskaper. En man som en gång var svensk och sedan blev världsmedborgare - en man att minnas med stolthet och glädje." 
Yet he is not widely remembered today. He is nearly invisible in the international history of archaeology, in the history of the French Musée d'archéologie nationale (formerly the Musée des antiquités nationales) and the Swedish History Museum, in the history of French Indochina, in the history of UNESCO, and in the history of US foreign policy in the years before the Vietnam War, despite his real contributions in all these contexts. His name has been spelled in more or less creative variants: Alov Janse, Olor Janse, Olax Janse, Olof Janse, Otto Janse, Dr Jansse, Olof Jantse, Professor Janze, O. Jause, Osvald Jansé, and Alois Joure.

How can this lack of visibility be explained? In the history of archaeology, a major reason ought to lie in the historical focus on nation states in archaeological narration as well as archaeological practice. James Cuno explains:

[Archaeologists] are dependent on nation-states to do their work. Nation-states hold the goods - antiquities and archaeological sites as national cultural property and cultural patrimony - and they control access to them. The history of archaeology as a discipline is deeply embedded in the history of the politics of the regions within which archaeology has been practiced. There is no denying this. And some would say there is no way out of it, either. ${ }^{1162}$

Olov Janse's work was nearly always located in-between nations. Yet that is a location that defies exact definition, or rather, that fits under several different definitions. His professional position and personal space can be described as travelling, transnational, cosmopolitan, colonial, international, migrant, exilic, and diplomatic - often in overlapping forms. ${ }^{16_{3}}$ All of these in-between experiences have been investigated by their own fields of theoretical inquiry: tourism studies; transnational studies; cosmopolitanism; postcolonial theory; internationalism; migration studies; exile studies; and public diplomacy studies. In our writing we have benefitted from insights from most of these fields, but none of them can alone account for the diverse practices, perspectives, and experiences

1162. Cuno 2011:154.

1163. E.g. Seyhan 2001:10. 
that were contained in Olov Janse's private and professional personae. Moreover, although his work was located in-between nations he had to abide by and work within the parameters of the national structures for archaeological heritage management to which Cuno refers in the quotation above. These structures were reinforced by political ambitions that brought a strong focus on nation states and reinforcement of national borders after the First World War. Janse's invisibility is at least partly due to his slippery, unreliable presence in such ideal national units, particularly in his native Swedish context, where he was considered klen, or unreliable, because he was "almost French". In France and French Indochina he was appreciated for speaking near-perfect French and for his willingness to become French "by adoption", but was nonetheless seen as a stranger, with whom it was difficult to make lasting attachments. Later, in the United States, he was never quite American. Even long after he became a US citizen, he was referred to as Swedish.

Moreover, the history of important institutions such as the Swedish History Museum, the Musée d'archéologie nationale, the OSS, the US Department of State, and even the supranational organization U NE SCO, has been written mainly from stable national perspectives. A mobile actor such as Janse, who was not easily categorized in national terms or in relation to steady institutional belonging even during his lifetime, has been granted little or no room in such history writing. If his name occurs at all, it is often mentioned in passing, as a temporary visitor - even in contexts where we know that he made significant contibutions. ${ }^{1164}$

Another important factor is his internationalist attitude to archaeological interpretation and narration. Janse maintained throughout his entire career a firm belief in the benefits of broad and bold comparative studies of human culture, and an internationalist attitude to museum collections. Remember his warning of "too much nationalism" in the interview in Saigon 1959, and how he advocated that everyone "try to act in a spirit of mutual interest and above all put scientific interest above human passions", because after all, "there are more visitors to the Guimet Museum [in Paris] than to the Saigon Museum". ${ }^{1165}$ In hindsight it is

1164. One example is in relation to the works of Henri Hubert and Hubert's last years in life, where we know Janse played an important role, but is not even mentioned in most of the literature (e.g. Olivier 2018).

1165. "Le professeur Janze souligne la contribution de la France aux recherches archéologique au Vietnam.", Article in Journal d'Extrême-Orient, 5 March 1959. NAA: Janse 2001-29. 
clear that the spirit of mutual interest he refers to, and the scientific interest that ought to be free and above political ambitions, was formulated within the premises of an already-unequal playing field. It was a playing field defined not only by national parameters but also by colonial and imperialist politics, where some actors and areas were considered more important and accomplished than others.

Janse did not acknowledge the political dimensions of his own archaeological work. His interpretations and narratives were presented as if formulated according to scientific interests, above and beyond human passions. ${ }^{1166}$ In reality, of course, they were contingent upon their political contexts and did not escape national storytelling paradigms. Archaeology is expected to provide origin stories for modern nation states, and most sovereign states, then and now, want to have their origins located within their present national borders. The Swedish state has little interest in locating its origin in present France, just as the present state of Vietnam is not likely to look for its origin in Greece. In such a context, Janse's broad internationalist, and even pro-colonial narratives became uncomfortable and threatening to the dominant narratives of the nation states. This should, however, be regarded not as a natural given, but as a consequence of political decisions in a nationalist trend that started in the late nineteenth century and had its ups and downs since, but is experiencing a renaissance in many parts of the world today.

Which support systems and technologies enabled Janse's movements? First of all he was born and raised with a male gender, Swedish nationality, white Scandinavian ethnicity, and bourgeois class, which created a more or less ideal identity package for an archaeologist in-between in

1166. Not many archaeologists have acknowledged the political aspects of their own work. On the contrary, it is common to distinguish conceptually between archaeological methodology (which is supposedly free from passions and of a scientific character) and narration, particularly popular narration (which is more prone to be "politicized" or "used" for political purposes), especially after the Nazi uses of archaeological narratives in the Second World War. However, we firmly maintain that methodology and narration (academic, official, or popular) are two intimately intertwined parts of archaeological knowledge production which are both politically and historically contingent, and that any individual or group of archaeologists should be regarded as historically contingent with both aspects in mind. 
the early twentieth century. It gave him opportunities and resources to be mobile and move in-between spaces and units that would not have been forthcoming had he been born with another gender, nationality, ethnicity, or class.

In terms of technology, most obvious perhaps are the travel technologies that enabled physical movement, and which are often used as narrative vehicles in his travel writing - from the horse-cart owned by his father and borrowed by his uncle Otto that gave him his very first archaeological inspiration, to the various mechanical vehicles that took him around the world and facilitated his surveys and excavations. He travelled by train across the European continent to study museum collections before, between and after the two World Wars, by car to excavation sites in Sweden, France, and Indochina, and to holidays in Florida. A particularly important means of travel were passenger liners. The first-class voyages in luxurious ships during their first two expeditions were, during the war years, replaced by more modest second-class passages in crowded vessels. But as soon they could, when they returned to Europe after the war and exile years, they travelled with the legendary luxury ocean cruiser Ile de France. Later in life, Olov travelled alone by aeroplane a couple of times, but never warmed to that means of transport. In letters he complained that the pace was too fast, and that he preferred to travel by boat. Aeroplanes offered a fast and efficient means of transport, but passenger liners offered a much more attractive package for travelling and traversing distance. The weeks spent on board offered time to relax and reboot. Socializing with fellow passengers provided opportunities to expand their networks and prepare for the work that awaited them at the destination. Travelling in style on the right ships was in that sense a way to gain social prestige and position. Boat journeys moreover offered opportunities for triumphant homecoming - particularly on the visits Olov and Renée made to Sweden in the 1950 s and ' 60 s - when journalists waited by the gangway to get an interview with the famous people on board.

In addition to the technologies that enabled transportation and travelling in a physical sense, Janse was also keen to use media technologies that enabled a mental and phantasmic transportation of his audiences to bygone times and far-away lands. In the advertisements before and press reports after his public lectures, Janse's use of slides was often mentioned for its extraordinary effects. He worked with film, both to record memories of their journeys and their archaeological work, and for the purpose of ethnographic documentation. The films were later recycled into a new 
context in the Office of Strategic Services, where they served a different purpose, but communicated much the same message as the original colonial films. In addition to the visual techniques of photography and film, Olov also worked with multisensory museum technology such as incense and traditional music in the Art and Archeology of Viet-Nam exhibition in 1961, which allowed a museum visitor to find himself "transported half way around the world in a fraction of seconds". ${ }^{1167}$

An archaeologist moving in the spaces between nations and institutions could not rely on the same support system as an archaeologist who worked within one nation and one institution. Most administrative structures for archaeological practice (such as museums, databases, archives, contract archaeology programmes, and university education) were and remain defined and restricted by national and institutional borders. Such institutional and administrative structures have also contributed to a stabilization of discourses around nation states as historical units. These structures have changed little since the early twentieth century, when Janse deplored having to choose between a life in Stockholm and a career in Swedish archaeology, or a life in Paris and a career in French archaeology.

Janse, however, found ways to move and keep moving in-between nations and institutions. He found structural stability in the mobility by creating a customized support system for himself. Unlike the common national structures of archaeology, which are ideally based on impersonal bureaucratic institutions and legal frameworks, the core structure of Janse's support system was based on personal relations with a number of influential mentors and patrons. These mentors and patrons gave him the necessary support, in terms of both position and funding, to move in his own ways in the spaces between national administrations. In return, the mentors and patrons gained prestige, information, and desirable things from far-away lands. In particular, Janse relied on the support from his mentors Henri Hubert, René Grousset, and Johan Gunnar Andersson, and from the wealthy influential patrons David David-Well, Gabriel Cognacq, and C.T. Loo. Let us stop here for a moment and take a closer look at the gift economy that was created by their relations and interactions,

1167. Masur 2009:293, and sources cited there. 
with the use of a classic essay written by another one of Janse's mentors, Marcel Mauss.

Marcel Mauss, Émile Durkheim's nephew and Henri Hubert's best friend, first published his famous Essai sur le don - Essay on the Gift, in L'Année Sociologique in 1925. Since then the essay, often referred to as The Gift, has become a legendary text in the fields of anthropology, sociology, and archaeology. It represents the exchange of objects, or gifts, as something much more complex than simple material transactions. It emphasizes the relations created around an exchange, through resilient obligations to accept the gift and reciprocate. The immediate focus for Mauss's study is what he describes as "archaic" institutions, in historic contexts such as ancient Rome, and in contemporary ethnographic cases. It is, however, the almost unlimited comparative possibility that it contains, that "there is always implicit a comparison, or contrast, between the archaic institutions he is writing about and our own", ${ }_{1168}$ that has contributed to its longevity and broad usefulness. For, as E.E. Evans Pritchard says in his foreword to the English translation, Mauss "is asking himself not only how we can understand these archaic institutions but also how an understanding of them helps us the better to understand our own, and perhaps to improve them". ${ }^{1169}$ If that is true, then Mauss's theories on gift exchanges and reciprocity may help us to understand the gift economies of which he was himself a part, which enabled Olov Janse's archaeological pursuits in-between nations and institutions.

The core argument of The Gift is that a non-capitalist exchange of objects builds relationships between the people involved, directly or indirectly, in the process of exchange. Like most Durkheim-inspired sociology, this essay also had a political edge, and should be read as a critique of the Anglo-Saxon liberal focus on the individual as something universal. Mauss saw the "archaic" society as something to take inspiration from as an alternative to capitalist society, ${ }^{1170}$ and set out to demonstrate that the fundamental form of object exchange between humans is that of total prestations (that involve exchanges of not only goods, but courtesies, entertainments, ritual, feasts, etc.) which come with contracts of obligation and thus create and maintain relationships.

Janse's academic mentors Hubert, Grousset, and Andersson inspired

1168. Evans-Pritchard 1966:ix.

1169. Ibid. See also Conklin 2013:4.

1170. See also Conklin 2013:4. 
him to develop a certain (bold, comparative, continent-spanning) structure of cultural analysis and archaeological thought. These intellectual "gifts" were crucial building blocks in the in-between archaeology Janse wanted to pursue. In return, his mentors received information and research results to strengthen this particular structure of comparative archaeological (and ethnographic) thought that they (Hubert and Grousset) had mainly developed and maintained from their armchairs or museum storerooms in Paris. They could also count on Janse's loyal input when it came to writing positive anniversary notices in the newspapers, giving their lectures when they fell ill, or finding private collectors with desirable objects in cities far away. His patrons, on the other hand, gave him funding and means to build a structure for practical activities (travels, excavations, purchases, films, exhibitions, etc.), which he reciprocated by bringing precious gifts to enrich their collections, and, not least, by allowing them to pose in public events as his benefactors and hence enhance their own prestige. His funding patrons could further rely on his loyal scholarly support with archaeological knowledge and new research results to illuminate their collections. As a long-term consequence, these necessary structures of bold comparative thought and practical collecting activities, together infused a gift economy which was fundamental for establishing the museum collections and popular imaginations of Asia that still reside in European cultural institutions today.

According to Mauss's essay, the exchanges between Janse and his mentors (of support, funding, desirable objects, knowledge, research results, and the possibility to pose as a generous philanthropist at a public event) should be regarded not as mechanical but moral transactions, which created and maintained relationships between individuals and groups. ${ }^{171} \mathrm{Al}-$ though the exchange of objects between individuals is always in some way related to groups or institutions (as is also confirmed by Janse's case), ${ }^{1172}$ gift exchange is also an articulation of social order. By accepting the involvement in a mentor-disciple or patron-client relationship by means of gift exchanges, Janse would remain in a subordinate, dependent position vis-à-vis his mentors and patrons, for as long as the relationship was maintained. His broken relation with Johan Gunnar Andersson is of particular interest in this respect. After the conflict over the position of Director at the Museum of Far Eastern Antiquities in 1938, Janse stopped

1171. Evans-Pritchard 1966:ix.

1172. Mauss $1966[1925]: 3$. 
all forms of reciprocation vis-à-vis Andersson. He never mentioned him in official writing, never invited him to anything, nor did he send any objects from his last Indochina expedition to the Museum of Far Eastern Antiquities. In that way, he had effectively broken their relationship and withdrawn from the gift economy in which they had previously engaged.

In the sense of political critique, which is a main theme in The Gift, Janse's mentor and patron relationships do not conform to Mauss's model of exchange as a non-individualistic enterprise. The lasting impression is that Janse himself engaged in these relationships with the prospect of personal gain (whether it was for his livelihood, an opportunity to develop his career, or pursue a scientific project he was passionate about). The result was not necessarily noble or solidary. On the contrary, it is possible to see how the gift economies created or activated around Janse contributed to the whitewashing of artefact-collecting activities in the slippery borderlands between legal and criminal, in the name of academia and public institutions.

Joined by their gift economies, Janse's mentors and patrons can be seen as more or less visible, more or less structurally important, threads in the fabric of Janse's career. When the threads met through their involvement with Janse (and indeed other projects that had already joined many of them), they also became entwined with each other. This is particularly clear in the relations between official museums and private collectors of Asian art and archaeology in Europe and the United States. Grousset and Andersson, who represented official national institutions, were intimately entwined with David-Weill and Cognacq who represented a semi-institutional collecting enterprise, and with Loo who was building a private business on Asian art and artefacts, and was accused of breaking Chinese law. An interesting and somewhat outstanding thread in the textile of Janse's career is the Swedish Crown Prince, later King Gustaf V I Adolf, who embodied the official and private in one person, ${ }^{1173}$ and was regularly used as a lubricant in the meeting between private and official artefact collection, by Johan Gunnar Andersson, David David-Weill, C.T. Loo, and Olov Janse.

It was not only in relation to his mentors and patrons that Janse had a certain skill in mastering the gift as a way to create helpful relations. Remember how he worked cunningly with gifts - a coin, a piece of candy, or a promise of employment - to create relations and a sense of mutual

1173. See also Isaksson 1972 ; Whitling 2014. 
obligation with the farmers near his excavation sites in Indochina. For this ability to "make friends" with people around him he was widely recognized as particularly talented to work in faraway lands such as Indochina.

If we see Janse's relationships with mentors and patrons as a form of gift economy in Mauss's sense, it also offers a more complex understanding of the value of artefacts for an archaeologist in-between. Even if Janse kept and occasionally sold some artefacts from his excavated collections, their value was not primarily monetary. They had a much greater value as potential exchange objects. With artefacts, or even more importantly, with promises of future artefact collections, he secured support and funding for his work, and thereby gained professional prestige. Moreover, the exchange, shipments, or donations of artefacts or moulages indeed, nearly all forms of artefact traffic between nations - gave positive echoes in the press. By organizing shipments of artefact collections (from Stockholm to Paris; from Paris to Stockholm; from Hanoi to Paris; from Saigon and Manila to Harvard; and back from Paris to Hanoi and from Harvard to Saigon), Janse could pose in the press as a national benefactor who enriched the recipient nation with valuable treasures. It gave him, just as it gave all his patrons and all institutions involved, much goodwill value and positive prestige. A lasting legacy of the gift economies created around Janse's archaeological career can be seen in official museum collections in Europe, Asia, and the United States still today. ${ }^{1174}$

If narration is equally as important as methodology for the formation of archaeological knowledge, are there motifs and narrative structures in Janse's work that can be connected with his mobile in-between situation? Well, first of all, the in-between demands a notion of elsewhere. Hence the distant elsewhere became a motif of great value for Olov Janse. Distance was a privileged figure in all of his work, and already in the first texts he wrote as a young student in Sweden he found a rhetoric regarding distance that he would repeat for the rest of his career.

Talking, writing, and showing photographs and films of the elsewhere - from Iceland to Indochina - he put emphasis on geographical distance and maintained notions of developmental distance between primitive

1174. See the chapter "Memorabilia". 
and civilized. In many examples through the different chapters of this book we have seen how he worked with the figure of distance by means of extrapolation. With ample use of contrasting adjectives signifying high and low, beauty and ugliness, health and sickness, prosperity and misery, his texts extrapolate civilized life at one end, from primitive life at the other.

Another narrative strategy is his use of temporal metaphors to denote distance and extrapolate between primitive and civilized culture. These metaphors are connected with a common-sense metonymical use of archaeological terminology, where "Stone Age" means the most distant and utterly primitive, and "medieval" means something slightly less primitive, in a linear teleological development movement towards the modern present. The association with ancient times is typically denoted by reference to technical details signifying primitivity that deserve to be regarded as "museum pieces", to simple clothing, or rituals which (so it was claimed) had been the same for hundreds of years. We have seen examples of this narrative strategy in his descriptions of Iceland in his very first travel report, of Port Said and Djibouti on his first expedition with Ronny to Indochina, of mountain tribes in Indochina on their second expedition, and of natives in the Philippines on their third expedition. As a rhetorical device, it creates an illusion of a distant past that is retrievable from deep down in the archaeological trenches and played out in real life before the eyes of the traveller to distant lands.

The letter from Yunnan-fu quoted in our introduction, which describes a town "almost completely untouched by Western culture" where people "still live fully in the Middle Ages" and where they had found a firesteel quite similar to "those that were used in Sweden in the Viking Age", ${ }^{1175}$ demonstrates eloquently how Janse operates as an archaeological-cum-ethnographic travel writer by moving through time and space, claiming a double control over distance. He gains prestige and position by moving between distant locations (between modern and prehistoric times, between West and East), and by offering explanatory translations between them.

1175. Letter from O. Janse to T. Nerman, 28 February 1935. Arbetarrörelsens arkiv och bibliotek. Ture Nerman. 3.1.7. In the Swedish original: "Staden är nästan fullständigt oberörd av västerländsk kultur. Människorna där lever ännu i full medeltid. På loppmarknaden i Yunnan-fu köpte jag ett eldstål av järn, alldeles av samma typ som de vilka var i bruk i Sverige på vikigatiden. I Yunnan-fu används de fortfarande.” 
His use of temporal metaphors to describe living people in Iceland, Port Said, Djibouti, Indochina, the Philippines, and Yunnan-fu contributes to a metaphorical back-projection of these people to the distant past. This is a well-known rhetorical strategy, often in colonial contexts, that Johannes Fabian has called the denial of coevalness. ${ }^{1176}$ It is a tactic with much political potential. The projection of native people back into the past gives an illusion of their inevitable development towards modernity (since time has a natural movement "forward") if they are not to stagnate in prehistoric misery. Hence the denial of coevalness offers an attractive self-image to colonizers and imperialists who can present various forms of colonial exploitation as benevolent contributions to the cultural development of otherwise backward and helpless people. In the context of French Indochina, this tallied well with colonial policy, and fitted what Alice Conklin has described as an "ambiguous positioning" of the new French school of ethnology fronted by Marcel Mauss: "trained in a humanist and anti-racist tradition, yet dependent in many ways on a racist practice of imperial governance". ${ }^{1177}$

The fact that Janse was a qualified archaeologist - an expert on the past - added credibility and extra spice to his travel writing. Indeed, a Swedish review of Janse's memoirs opines that the "opportunity to experience prehistory in a sort of double exposure" was considered one of the most important qualities of the book. ${ }^{1178}$ The same authority and credibility allowed him to contribute to the US administration's fatal underestimation of native Vietnamese people in the 1950 s and the first years of the 1960 s.

Travelling and translating between distant places, Olov Janse built a successful career on his capacity to bridge and master distance. In a newspaper article from 1926 he is described as a "Swedish-French museum man". ${ }^{1179}$ His identity was in the hyphen, literally in the space between

1176. This is a common characteristic of early ethnographic writing, which has been discussed and critiqued at length by Johannes Fabian (1983) and James Clifford (1988) among others.

1177. Conklin 2013:191.

1178. "Exotisk forntid", review of Ljusmannens gåta, by Wilhelm Holmqvist, Vi no. 49, 1959.

1179. "Norrköpingsbo vik. fransk professor: D:r Olof Janse som svensk-fransk museiman”, Norrköpings Tidningar, 23 January 1926. 
national or institutional units. The function of the hyphen is to separate distinct units in the text, at the same time as it connects them into a new combined form. The same can be said about Olov Janse's identity as an archaeologist in-between. Hence distance was not important per se. Distance was necessary for his in-between identity to be articulated, but it became meaningful and bore fruit only when it was bridged and the distant units were connected.

Longing is another central theme in Janse's work and personal life, from his earliest longing for cosmopolitan adventures in his teenage years in Norrköping, to the longing for his Swedish homeland in his senior years in the United States. A longing for the elsewhere kept him in movement throughout his life. From early on, and enhanced by his engagement in Indochina, his desire for adventure was connected with a more general longing for a colonial experience, here in the words of Stevan Harrell:

To be a European outside Europe in the early twentieth century meant privileges almost unconceivable in the twenty-first century. [...] The privilege these explorers and scientists enjoyed was less about direct political power than about the general assumption that a white person anywhere had a certain high rank in a worldwide hierarchy. In actual colonies, a white person outranked everyone, and the hierarchy was explicitly marked by a huge panoply of colonial ceremony and discipline, backed, of course, by the threat of violence. ${ }^{1180}$

To long for a colonial experience is also to desire a privileged identity, and that identity becomes connected with the distant colonial elsewhere. In Janse's narratives, as in most colonial travel tales and adventure stories, the distant elsewhere is made interesting and attractive by means of longing. Longing (for a simpler, warmer, more privileged, or less complicated life) connects one's own space with a distant, essentially phantasmatic, elsewhere. ${ }^{1181}$

The temporal dimension is important here too. In her book On Longing, Susan Stewart writes that the main task of the antiquarian is to create an imagined past, wholly detached from the messy present, a time that

1180. Harrell 2012:16.

1181. Norindr 1996. 
can be longed for, and that can be made available for consumption. ${ }^{1182}$ Ancient artefacts are similar to exotic souvenirs, says Stewart, because they both represent appropriated distance. The souvenir and the artefact are both specimen and trophy. They are connected with nostalgia, a longing for a place of origin that is in some sense lost. They are valuable because they carry the signs of the foreign and exterior, but their value is also derived from their association with the immediate experience of their possessor, or collector. Souvenirs and artefacts are thereby involved in a transformation of distant time and space to interiority and personal or communal space. Hence the artefact and souvenir is placed "within an intimate distance". ${ }^{1183}$ Olov Janse used both artefacts and souvenirs (often in hybrid forms when he gave excavated artefacts from Indochina as souvenirs to his Swedish friends or dignitaries visiting the excavation sites) as a way to create goodwill, confirm friendship, and enhance his own position and professional prestige.

Yet on its own, the artefact or souvenir is never complete. It must be complemented by narratives, in a narrative discourse that gives meaning, and creates a sense of longing for its distant origin. ${ }^{1184}$ In Janse's handling of artefacts and souvenirs - in and between museum collections, as gifts to patrons and friends, and as souvenirs to influential people in key positions - distant time and space was controlled, tamed, and brought into the domain of modern Western culture, materialized in the bourgeois European home or the metropolitan museum collection. Distant time and space was thereby transformed to interiority by means of Janse's immediate experience, knowledge, and academic credibility.

In this context, the archaeologist poses as a magician who tames and controls the prehistoric Other by traversing temporal distance. He is the translator of prehistoric fragments into animated narratives. His stories make prehistoric times come alive again, in a format that is contained and packaged for consumption here and now. Olov Janse, however, offers to perform a double trick, with the "double exposure" of prehistory here in distant times, and now in distant lands, moving through time and space and thus claiming a double control over distance. Mobility is therefore key to the archaeological travel writer, as is translation. By moving between distant units (in time and space), traversing the gap and

1182. Stewart 1993:143

1183. Stewart 1993:147.

1184. Stewart 1993:136 
translating between them, the archaeological travel writer gains prestige and position. We have seen Janse's movements and translations resulting in concrete activities and narratives in a number of important institutions of twentieth-century culture and politics: from major museums in Sweden, France, Vietnam, and the United States, to the OSS, UNESCO, and the US Department of State.

Although mostly invisible in studies of political institutions, the political impact of academics in the humanities and social sciences is increasingly recognized:

The social sciences stand at the nexus of power and knowledge in the modern world. Universities and other research institutions have generated, incubated and helped to disseminate forms of knowledge, and programmes for social and political action, that have played a fundamental role in shaping the world in which we live. Global politics during the twentieth century and into our own times cannot be understood adequately without taking into account this dimension of human activity. ${ }^{1185}$

Olov Janse's scholarly archaeological perspective can be summarized as comparative and diffusionist. Hubert's comparative perspective and the Salle de Mars "laboratory" at the Musée des antiquités nationales worked to collapse distance in time and space. Similarity, not distance, was of key interest for the comparative sociological perspective. Social institutions, materialized in the form of artefacts, could be compared through time and space - like Marcel Mauss's essay on the gift, where Roman society was juxtaposed with ethnographic studies of the Pacific Northwest, in an analysis that was intended as a critique against contemporary liberal Western society.

Like the comparative sociological perspective, the diffusionist explanatory model in archaeological analysis connects distant parts of the world. But it relies (implicitly, but importantly) on a hierarchical notion of cultures as being more or less complex, following a law-bound trajectory from simple to complex. A "complex" culture, according to the diffusionist model, is bound to spread and replace "simpler" cultural forms. Thus the diffusionist model extrapolates cultural difference (from the most simple to the most complex) at the same time as it connects geographi-

1185. Bell 2009:3. 
cally distant places. Combined with the colonial explanatory model with its teleological, evolutionary view of cultural development, diffusionism has the effect of emphasizing and hierarchizing cultural inequality. ${ }^{1186}$ When the comparative perspective meets diffusionist explanations in Olov Janse's work, the diffusionist explanation overrules the emphasis on similarity in the comparative perspective.

In a more practical sense, Janse built the first phase of his career on traversing distance, being a translator and mediator between geographically distant units. It was a position that gave him both benefits and problems. From a Swedish perspective, his presence in France was at first mostly regarded as an asset. He was a knowledgeable translator of events in Parisian academic life and the happenings in the Glozel affair; a facilitator of contacts between Swedish and French academics and institutions; a motor for artefact exchanges; and a door-opening guide for Swedes visiting Paris. He kept this bridging function for the rest of his life and career, and continued to gain professional value and prestige by sharing knowledge and building bridges to various distant elsewheres. Assuming this position, however, he eventually became a slippery figure. He was described as untrustworthy, as the man who is never present (by Sigurd Curman, Sune Lindqvist, Johan Gunnar Andersson, and Serge Elisséeff). Hence his chameleon talents were Janus-faced. His great ability to adjust to different cultural and linguistic contexts (for instance when he navigates between the French republican view of a nation resting historically on a foundation of several races, and a Swedish conception of the nation as built on one race with the ideal of purity of blood), made him unreliable from bounded national perspectives.

The biography of Olov Janse shows that the work of an archaeologist in-between is not necessarily less constrained by administrative and political structures than the works of an archaeologist operating within the

1186. In descriptions of diffusionism in the history of archaeological theory, it is sometimes described as a fundamentally different perspective from Darwinist evolutionary theory. In practical reality, however, we find that they are often combined as complementary models of explanation for change in archaeological narration (i.e. cultural change can be explained both by the occurrence of internal innovations ("mutations") and by external influences), as exemplified in the works of Oscar Montelius and Olov Janse (cf. Trigger 1989:158-160; Conklin 2013:42n 58). 
parameters of only one nation and one institution. The constraints are, however, defined in different terms, and the results and contributions of actors whose identities were defined by a hyphen have for long been more or less unnoticed in historical research.

In recent years, however, with the understanding of culture that we find in the works of Homi Bhabha and Trinh T. Minh-ha among others, the hyphen represents an interesting, creative space of cultural production. If an earlier understanding of culture (as essentially stable, homogenous and naturally contained within national borders) reduced the hyphen in "Swedish-French" to a mute non-space, Trinh's and Bhabha's works have demonstrated that the most fundamental form of human culture is hybrid, that the idea of bounded national culture is essentially a political project, and that it is in fact at boundaries and in border zones, where differences are articulated and made meaningful, that culture is created and recreated in new forms. ${ }^{1187}$

Olov and Ronny Janse both used mobility as a strategy to escape pressure, and ultimately, to survive. In Olov's family history, his mother and uncle escaped the Ljung estate in the 1880 s, and just like Olov half a century later, his uncle Axel Herman Svensson emigrated to a new life and new opportunities in the United States. Olov escaped from Norrköping after his mother's death and his father's depression, and Ronny survived literally by escaping from the Soviet Union. And their mobility later allowed them both to escape from direct involvement in the Second World War. Importantly, their escapes offered them new experiences that led to new positions, which together created the fabric of their lives and careers. Ronny's employment in Stockholm led to their first meeting in 1929, and a life-changing marriage a year later. Olov's studies under Henri Hubert in Paris meant a life-long intellectual inspiration. His fortuitous location in Paris led to a working relationship with Johan Gunnar Andersson, which in turn rendered him an extensive network of influential mentors and patrons. It resulted in three archaeological expeditions to Indochina and the Philippines, which filled museum stores in Vietnam, Paris, Brussels, Stockholm, and at Harvard with ancient artefacts and ethnographic collections, and resulted in a three-volume archaeological report, a memoir and numerous academic articles. When the crisis of potential unemployment and the Second World War led them to settle in the United States, their broad knowledge of languages and cultures gave

1187. Bhabha 1990; 2004, Trinh 2011. See also Anderson 1996. 
them both positions in some of the most influential institutions of the post-war and Cold War period - at UNESCO, OSS, the US Department of State, and the Library of Congress.

A particularly important field of activity in the space between nations is that of public diplomacy. Olov Janse's activities in the years that he spent on the move between France and Sweden in the 1920s could be framed in terms of public diplomacy (although the concept has been used in academic studies mostly for post-war US politics). He organized and attended cultural events and lectures that worked as stages for diplomatic exclamations, and means to connect members of the political sphere and diplomatic community with the academic, intellectual, and museum worlds. At his first public lecture at the Sorbonne in 1924 (on the topic of Scandinavian Bronze Age rock carvings) there were over 200 people in the audience, among whom were the Swedish minister Albert Ehrensvärd, a number of notable French academics, and representatives from the Scandinavian embassies in Paris. The host of the lecture, Paul Verrier, emphasized in his introduction the importance of political and cultural contacts between France and Scandinavia through history. ${ }^{1188}$ In Paris, Olov also made himself a name as facilitator and guide for visiting Swedes from a much wider circle than his closest associates. He continued to act as a translator between national contexts and a promoter of political and cultural contacts (a practice which could be described in terms of public diplomacy) during his Indochina years, and in his work for UNESCO and the US Department of State. During the Cold War, when public diplomacy was developed as an important section of US foreign poli$\mathrm{cy}^{1189}$ he was right at the centre of the important relations between the United States and Vietnam. In that function, he organized events such as the Art and Archeology of Viet-Nam exhibition in 1961. In this manner, he also contributed a particular organization of knowledge (of Vietnam's past and present), and an organization of relations (by invitations and meetings with key actors in the political, cultural, and diplomatic corps).

Olov Janse made a particularly canny use of press media to have his activities registered and acclaimed in the spaces between nations and lan-

1188. "Dr O. Janse föreläser i Paris: Intressanta föredrag om hällristningar i Skandinavien", by Harald Wägner, Aftonbladet, 15 December 1924; Letters from Olov Janse to Birger Nerman dated 9 December 1924; 14 December 1924. Riksarkivet. Kartong 1. Korrespondens brev II 1923-1934.

1189. Osgood \& Etheridge 2010. 
guage contexts. Reporting on his work in Indochina, he adjusted smoothly to the different languages and interests of the press in France, Sweden, and Indochina. In all three contexts, his work was described as a great success - based, however, on quite different criteria. We have seen how he pressured his Swedish friends to have his successful activities abroad noticed in the Swedish newspapers, and moreover urged his friends to use the press to get public opinion on his side in the inflamed struggle for the Director's post at the Museum of Far Eastern Antiquities. He was always keen to be noticed in relation to international media events, such as the Glozel affair, where he could act as the perfect translator between French academic archaeology and Swedish readers. Press media were also crucial for him to have his activities known across borders - from his earliest academic endeavours in Paris, to the goodwill journey to South Vietnam that ended his academic career.

Shifting focus - from bounded national and institutional units, to movements in-between - has allowed us to emphasize the importance of connection, cultural ambiguity and translation in historical research. Following in the footsteps of Olov Janse has opened our eyes to the importance of soft "public" or "cultural" diplomacy in relation to archaeology and heritage; of narrative strategies that extrapolate human culture at the same time as they bridge distance; of technologies of physical travel and media communication; of the value of networks and personal relations built on gifts and the promises of total prestations; and of museum collections as professional currency in the slippery borderlands between official and private artefact collection. Despite their invisibility in official history-writing, such in-between movements and techniques have in fact influenced the formation of archaeological knowledge, and have left lasting legacies on bookshelves and in museum collections around the world. 


\section{POSTLUDE:}

MEMORABILIA

What remains after the life and career of an archaeologist in-between? Most obviously perhaps, his writings. The three reports from his Indochina expeditions stand out as Olov Janse's most important academic oeuvre, but he also wrote more than sixty articles in Swedish, French, and English for academic journals, magazines, and newspapers. The most personal account of his life and work is found in his memoirs Ljusmannens gåta, which can be read in the Swedish original from $1959,{ }^{1190}$ or in a Vietnamese translation from 2001. ${ }^{1191}$ There are also the generous funds that Renée bequeathed in her final will to members of both their families, the Royal Swedish Academy of Letters, History and Antiquities, and to "Stiftelsen Thure Johan och Hilma Janses minnesfond", which every year award stipends to students graduating from Olov's old high school (now De Geergymnasiet) in Norrköping. But there are also more tangible traces of Olov's and Renée's lives and the archaeological work they pursued. And just as their lives were lived in movement and dispersion, the things they left behind are now dispersed over three continents. We have found them in unexpected places, often in fragile situations with little guarantees of future maintenance or preservation. These things work as memorabilia, mnemonic devices that carry stories, evoke personal memories, and produce echoes of the personal and professional endeavours of Olov and Renée Janse.

1190. Janse 1959 .

1191. Janse 2001. 


\section{The marble table}

Christina Janse Petersson lives with her husband Jan-Erik in a villa south of Söderköping. She is related to Olov Janse through the marriage between her grandmother Signe Andersson and Olov's father Thure Janse in July 1918. Thure adopted Signe's son Bengt - Christina's father - from a previous marriage, but Olov never warmed to his father's new family and was never close to his stepmother and stepbrother. When Thure Janse died, Olov was stuck on the Philippines on his way to the United States and could not return to Sweden until seven years later, when he was working for UNESCO in Paris. When he eventually returned in June 1947, he ended up in conflict with Signe over Thure's estate. ${ }^{1192}$ Unable to bring much in terms of furniture and large objects from his childhood home back to the United States, he urged Signe to pay him the equivalent of his share of the estate in cash and threatened to have it all sold at auction to release the cash value. Of all the furniture from his father's home he brought only a chest of drawers, which we believe is seen in the background of the cover photograph of this book. Yet despite all the resentment between them, Signe kept one special thing for him - a small table with a chess-patterned marble top, which can be seen next to his mother Hilma in the photo from his childhood home in Norrköping. ${ }^{1193}$ It was precious to his mother and, judging from its distinctive red colour, we believe that it was made of limestone from Marmorbrottet, the marble quarry where she was born.

Olov Janse never returned to col-

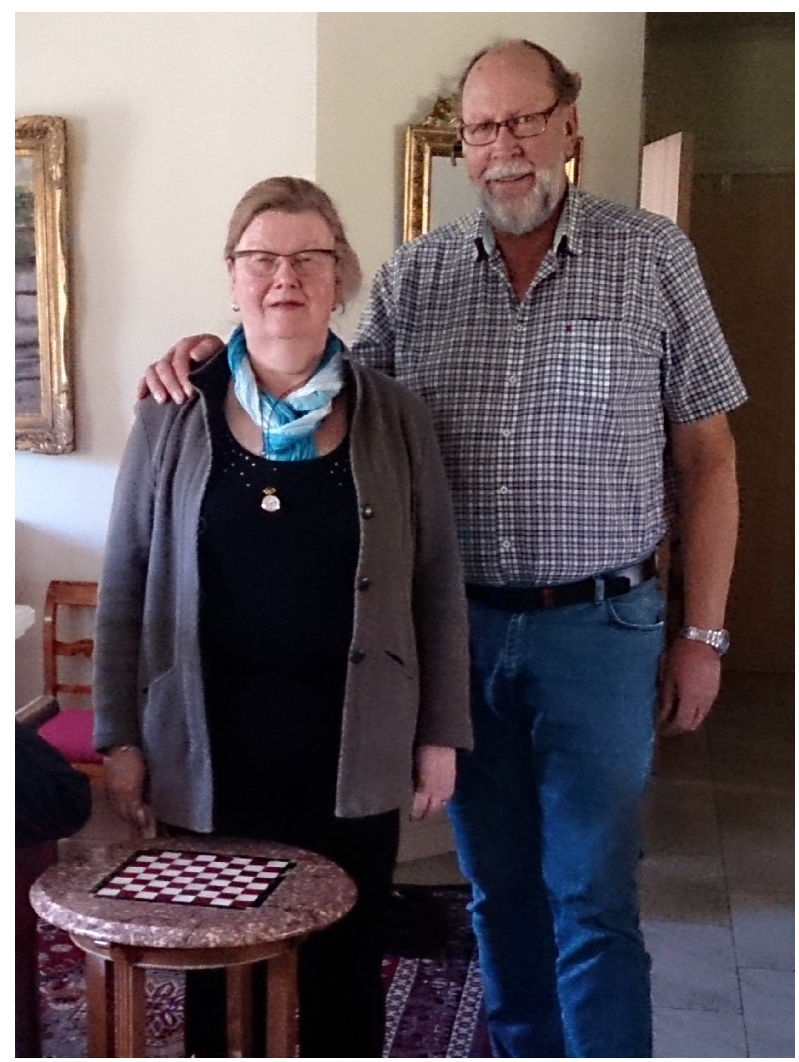

1192. Letters from O. Janse to R. Janse, 25 June 1947; 28 June 1947; 4 July 1947, in NAA: Janse 2001-29.

1193. See fig. 9 in the chapter "Otto and the Candy Factory". 
lect his table. ${ }^{1194}$ It now stands in Christina's and Jan-Erik's house near Söderköping, between Valdemarsvik where Thure Janse was born, and Norrköping where Olov Janse was born, fifty kilometres east of Marmorbrottet.

With its characteristic red limestone, which was also used to build the never-successful sugar factory that was part of the final fall of the Ljung Estate and now stands as a ghostly ruin by the main road, the table can be seen as a symbol of the great promises and broken dreams of the sugar and candy industry of the late nineteenth and early twentieth century - promises and failures that so severely affected Hilma's native family, built a life of hope and social standing for herself, and broke her husband after she died. For Christina and Jan-Erik, the table carries the story of an absent adventurous man, who never came to collect his belongings. ${ }^{1195}$

\section{Per Janse's archive}

When Renée Janse died on 21 December 2000, her estate was divided according to her testament. In the absence of children or other close relatives in the United States, most of their belongings were sold at auction and the total worth of the estate - more than US \$4,000,000 - was distributed to relatives in Russia and Sweden. ${ }^{1196}$ In Sweden, one of the beneficiaries was Per Janse, grandson of Olov's uncle Otto Janse. The testament came as a surprise to Per. As far as he can remember he had only met Olov and Ronny Janse once, when they came to visit his parents' home in Djursholm near Stockholm in August 1968 (fig. 83). He was 21 years old and has vivid memories of the visit. He found Olov sympathetic but did not warm to Renée, who he remembers spoke in racist terms of "blackies". ${ }^{1197}$ To him they gave the impression of being människor av värld - people of the world. ${ }^{1198}$

From the moment when he was first informed about the testament in

1194. Christina Janse Petersson also had in her possession a collection of photographs of Olov Janse and his family, which has been donated to Norrköping's City Archive.

1195. Interview with Christina Janse Petersson and Jan-Erik Petersson 30 September 2014 .

1196. Seventy per cent of the total estate was given to Renée's relatives in Russia. We have tried to locate the beneficiaries in Russia in order to learn more about her family and her early years in Krasnodar and Moscow, but all attempts have failed.

1197. Swe: Svartingar. Derogatory term for black persons.

1198. Interview with Per Janse, 11 April 2012. 


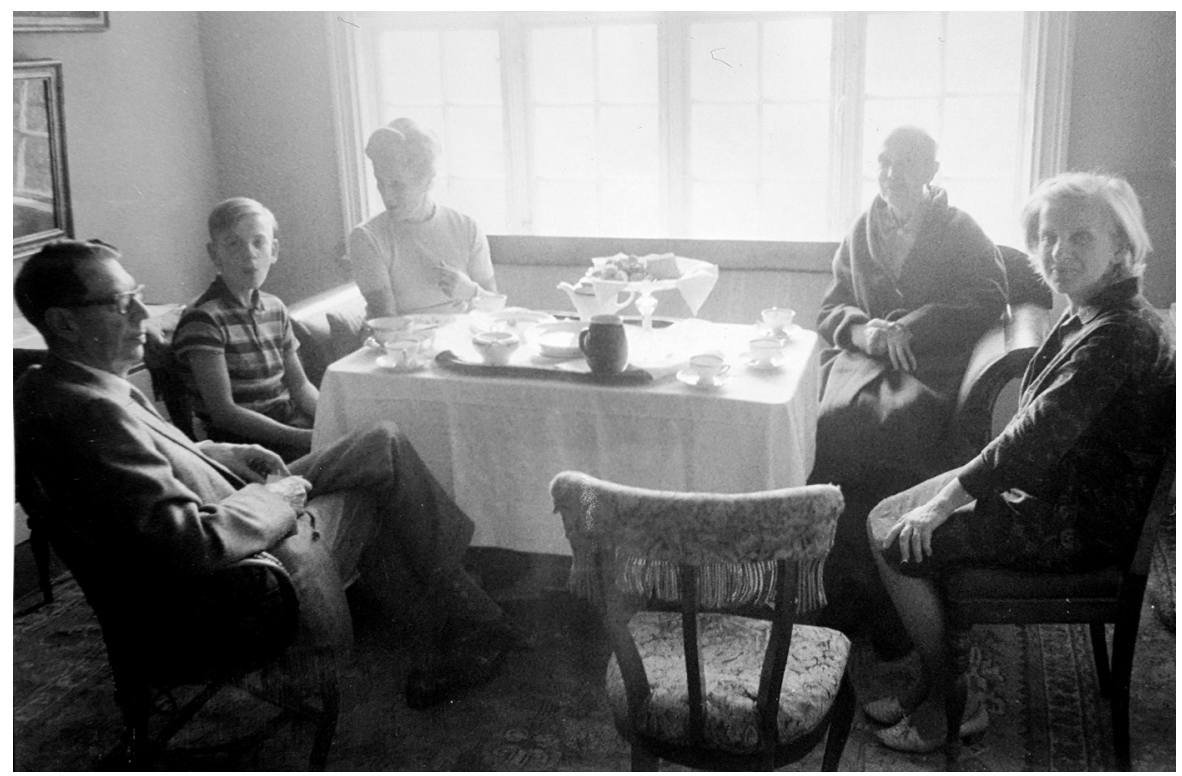

Fig. 83. Olov

and Renée

visiting Olov's

cousin Per Janse

in Djursholm

1968.

2001, Per Janse became something of a spokesperson for the legatees in Sweden. They were either descendants of Thure Janse's brother Otto and sister Theresia, or children or grandchildren of Ture and Birger Nerman. The testament aroused an interest among the family to know more about Olov's and Renée's lives, and Per asked the testament executor if he could have some of their personal documents to keep in the family, before they were donated to a public archive.

And so it happened that a collection of photographs and personal documents, mostly of an ageing Renée, often in a swimsuit, ended up in a green cardboard box in Solna north of Stockholm. Per Janse has kindly allowed us to use the photos and documents for our research, and they will be returned to the family on the completion of our project.

\section{Anders Nerman's bowl}

Ture Nerman had two sons, Bengt and Anders, and Birger Nerman had two daughters, Elisabeth and Agneta. Olov and Renée seem to have been fond of the children, and always mentioned them in their correspondence. They were godparents to Elisabeth, and the two sisters went to visit Olov and Renée in the United States in the early 1980s. Agneta, who had followed in her father's footsteps and become an archaeologist 
Fig. 84 .

Anders

Nerman

with Song

bowl.

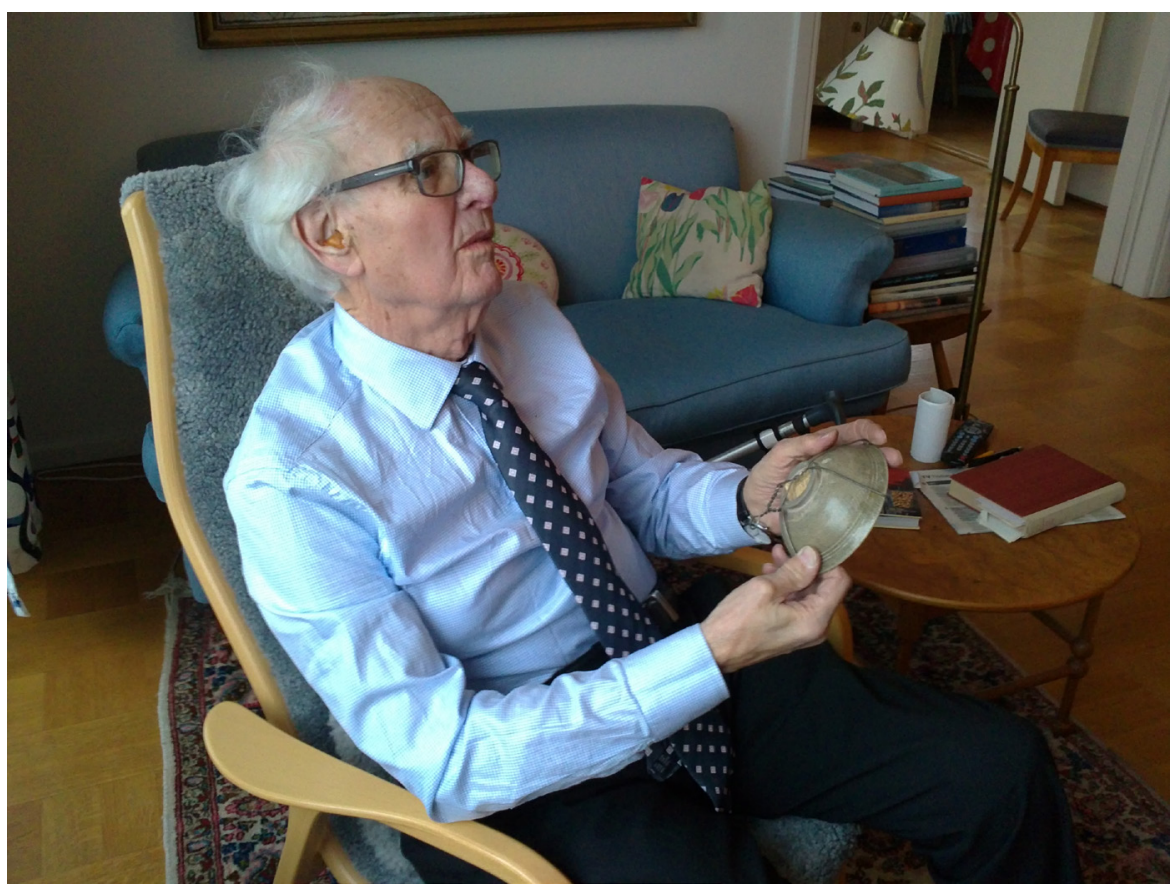

and museum director in Stockholm, visited them on the occasion of a Viking exhibition at the Metropolitan museum in New York. ${ }^{1199}$ She was 42 years old at the time, and recalls how Renée ordered her to take off her Indian-style tunic, dressed her in 1950 s clothing, and painted her eyebrows. Her older sister Elisabeth visited them in Washington, DC, a couple of years later. With a mixture of horror and delight she remembers Renée, who was then 80 years old, as a lovely but strong and dominant person "who drove her car like a madwoman". ${ }^{1200}$

Olov and Renée's relations with Ture Nerman's sons appear to have been less personal. When they were young boys, when Bengt was 13 and Anders 12 years old, he sent them each an ancient bowl as a souvenir from his excavations in Thanh Hoa. In several letters written in 1936 on their way to Indochina for the second expedition, Olov mentions the two bowls that would be delivered to Bengt and Anders Nerman by a friend returning to Stockholm from a visit to Paris. ${ }^{1201}$

1199. On display October 1980-January 1981.

1200. Interview with Elisabeth Nerman and Agneta Lundström, 11 February 2013.

1201. E.g. letter from Olov Janse to Ture and Nora Nerman, 13 October 1936. Arbetarrörelsens arkiv och bibliotek. Ture Nerman 3.1.7. Their mutual friend "Lunkan" (the editor of Folket $i$ Bild Ernst J. Lundqvist (1893-1958)) was given a third bowl. 
When we visited him in his stylish modern apartment in Stockholm late in the autumn 2012, Anders Nerman showed us the small green bowl that dates back to the Chinese Song Dynasty (AD 960-1279). ${ }^{1202}$ In the bottom was written (in Swedish): Gift 1936 from Janse. Grave find N. Annam/ Thanh Hoa. Song Dynasty. Despite their modest appearance, ceramics of the Song Dynasty are considered among the finest that have ever been produced. Anders Nerman had kept the bowl and knew that it was valuable, but he had no particular relation to it. Nor did he have any particular memories or recollections of Olov and Renée Janse, other than that she had "an exotic aura". Anders Nerman told us that his father's famous summer house at Grönvik (sometimes referred to as Bolshervik, where the red flag waved during the 1920s) on Blidö in the Stockholm archipelago, was in fact built of wood from boxes used to transport American cars imported to Sweden in the early twentieth century. The summer house, itself a rather interesting material parallel to the eclectic political life of its owner (Ture Nerman was first a devoted communist, turned into a social democrat, and ended his life promoting conservative American values and pro-NATO policies), was for long an object of desire at the centre of Olov and Ronny Janse's dreams of coming home to a life in Sweden. They had spent some of the happiest summers of their lives at Grönvik and in the Janse family's summer house at Skagshamn near Valdemarsvik. In the exile years, Olov and Ronny nutured plans to buy a piece of land and build a summer house near to Ture and Nora on Blidö. ${ }^{1203}$ But shortly after they became US citizens, they gave up all such plans and built an American summer cottage instead, at Cove Point in Maryland.

Bengt Nerman, who lived in the house in Grönvik, died in 2016. Anders Nerman died a year later, in June 2017. Both were 93 years old.

\section{Film reels}

Twelve years ago, when we first began to plan for the research project that eventually resulted in this book, we visited Per Janse's brother Carl Otto and his daughter Helga Janse in Östhammar north of Stockholm. Over coffee they described the internal relations of the Janse family, which we then knew very little about, when Carl Otto suddenly said: "and then of course we have the films". They pointed us to the study in the next

1202. See also Janse 1958: p. 101, pl. 66, pl. 80-82.

1203. Letter from O. Janse to Birger Nerman, 30 March 1938. Riksarkivet. Kartong 3. Korrespondens brev III 1935-1941. 


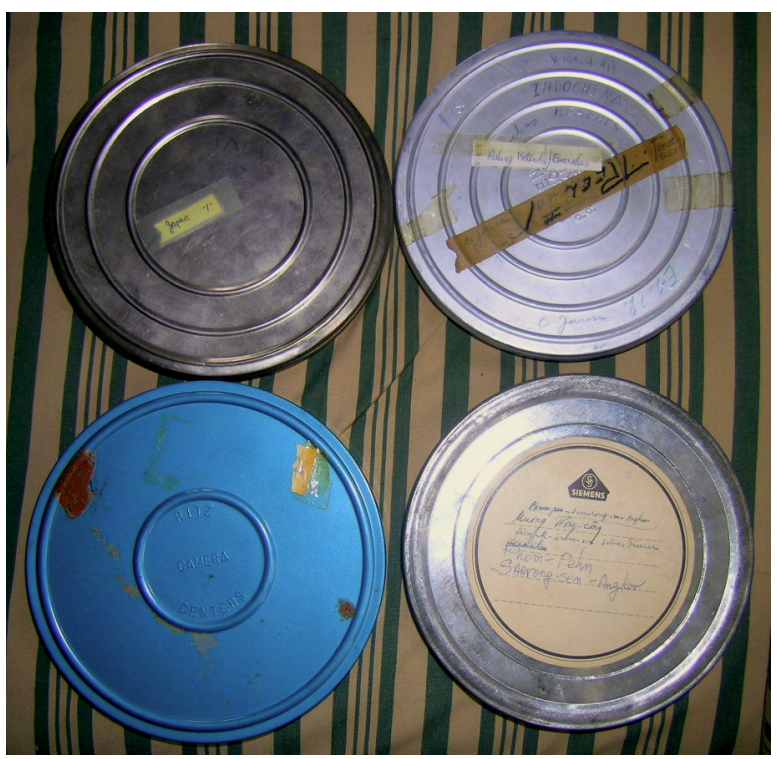

room, where there was a paper bag full of original film reels standing in a corner. Like Olov Janse at the discovery of the Lach-truong site in February 1935, we "nearly swooned" at the sight of them.

The reels, 16 in total, had been given to Carl-Otto when he visited Renée in Washington together with one of Helga's sisters, some years after Olov's death. The reels contained mostly original films, but also some purchased ones, dating from the 1930 s to the 1970 s. Some had scribbled notes attached to them that indicated their contents. After consulting the Swedish Television Ar-

Fig. 85. The film reels.

chives, the family was advised to submit the original films to the archive for safety reasons (since they contained chemicals which could lead to spontaneous combustion). Hence the films were donated to the television archive in Stockholm, ${ }^{1204}$ and DVD copies were made for the family and for our research purposes.

\section{Memories at Lach-truong}

In October 2005 we travelled to Thanh Hoa in northern Vietnam, to visit some of the sites Olov Janse excavated. First we spent a week in Hanoi, trying in vain to find traces of his presence there seventy years earlier. But despite considerable efforts supported by colleagues at the Institute of Archaeology, ${ }^{1205}$ we found nothing but vague fragments - a dedication on a frontispiece of an offprint in a library, a mention in a list of colonial-era archaeologists, and the like, but no proper documents, drawings, or other materials we hoped to be able to trace. We were told that all colonial-era documents and archives had been removed, reformed, or destroyed. The exception was the National History Museum (previously Musée Louis

1204. Swedish Television Archive. (C) SVT Arkiv.

1205. In Hanoi we received generous help from Dr Nguyen Kim Dzung and Dr Nguyen Tien Dong from the Institute of Archaeology. 
Finot), where we found a translated version of Janse's memoirs, ${ }^{1206}$ and many of his most important finds on display. Among them were ljusmannen, the candle-bearing kneeling figurine that gave name to his memoirs. But we were told by the museum staff that the museum buildings had undergone major interior reconstructions since colonial times, and that all artefacts from EFEO's excavations had been split and reorganized into new groups according to the material rather than the excavating archaeologist. Hence there was not much to find in terms of direct connections with Olov Janse and his Indochina expeditions. The search made us realize the extensive impact that a revolution and decades of socialist rule had on historical documentation. According to communist orthodoxy and in response to popular resentment towards colonial rule, the revolutionary government did not allow research or official storytelling about individuals in pre-revolution historic times, particularly individuals connected with French colonial rule. If the interest existed among Vietnamese researchers today, they were faced with the massive task of reconstructing historic data, and the hustle of breaking with decades of administrative tradition and social convenience.

Knowing that there was not much for us to find in Hanoi, we set off on a two-day excursion to the nearby province of Thanh Hoa. In the company of two Vietnamese colleagues, Dr Nguyen Tien Dong from the Institute of Archaeology in Hanoi, and Dr Luan an Trong from the Thanh Hoa Culture Office, we visited Janse's old excavation sites at Dong Son ${ }^{1207}$ and the Tam-thô kilns, and the Sam Son resort where Olov and Ronny stayed in Madame Renaud's seaside establishment while they excavated at Quang-xu'o'ng. From Sam Son we travelled, as Olov and Ronny once did, in a car with a chauffeur who drove through the flat landscape with lush green rice paddies on both sides to the village Lach-truong, ${ }^{1208}$ where they made the extraordinary discovery of the kneeling figurine in the spring of 1935 . We had brought the DVD copy of one of the films found in Carl Otto Janse's study, and showed a sequence from Janse's excavations to the people at the village office. A young man said that he knew someone who was old enough to remember the excavations, and rushed off on a motorbike with us following in the car closely behind. In a small farmstead not far away we were invited to the house of Nguyen Van Tan,

1206. Janse 2001.

1207. In Vietnamese: Đông-so'n.

1208. In Vietnamese: Lach-Tru'òng. 


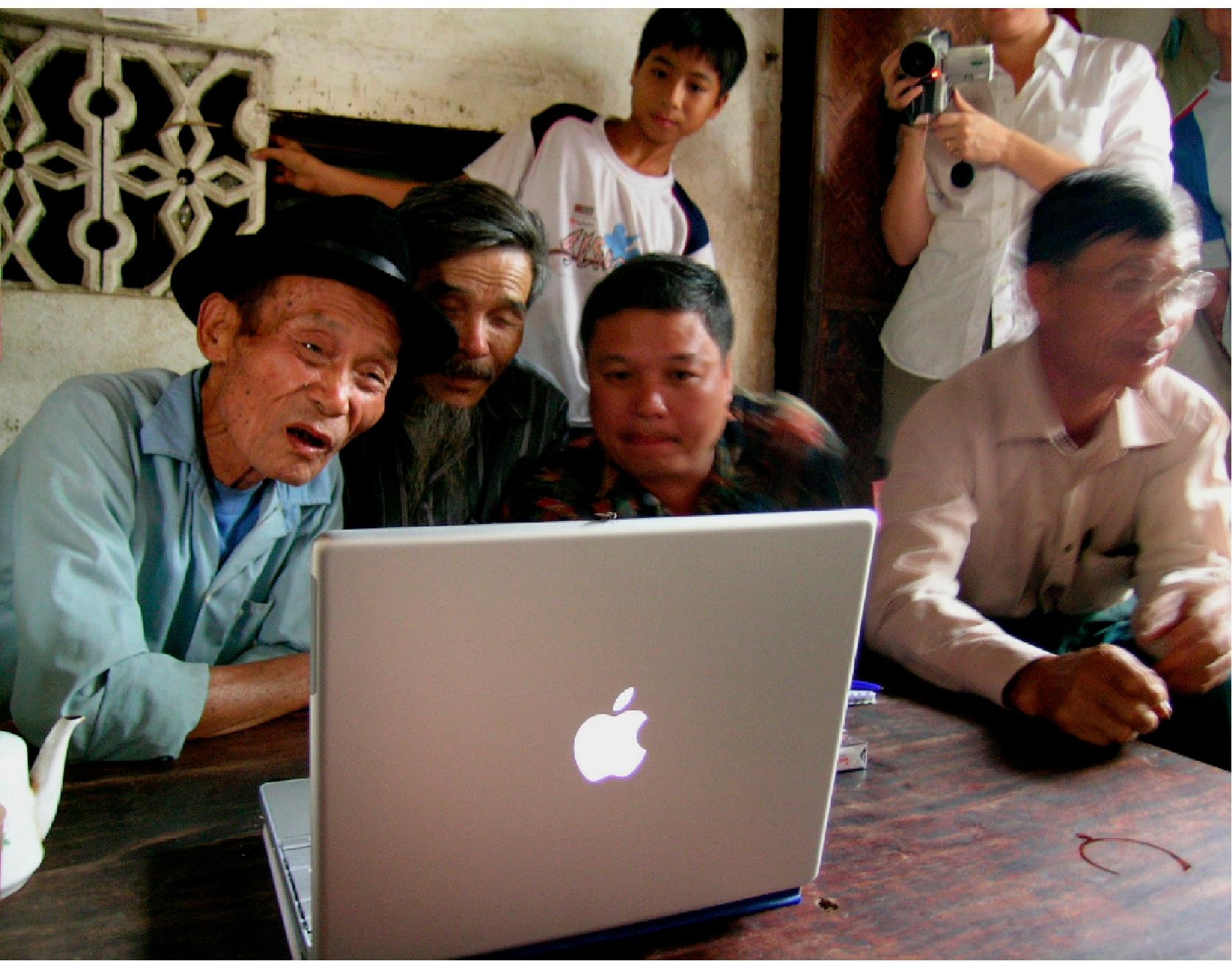

Fig. 86. Janse's film watched by Nguyen Van An in Bai Troung, October 2005 . who had witnessed the excavations as a young boy. He was 85 years old when we met, and when he watched the film on our laptop he recalled seeing foreign men and women arriving in the village and excavating two graves. Yet he did not remember any names or details, other than that they had a film camera.

After the visit to Nguyen Van Tan's house, we were invited to another house in the nearby village Bai Truong where we met Nguyen Van An, who was twelve years old when Olov and Ronny Janse arrived in his village, and remembered that they came by car along with a mandarin. Watching the film (fig. 86) he pointed at Olov Janse wearing a white trop- 
ical helmet, and said that he was a nice man who took time to tease and play with the village kids, and that he sometimes withdrew to his car to have cookies. Van An also recalled seeing vaulted brick tombs being excavated, and objects of bronze and ceramics being removed. As he watched the film he said that all his friends from that time were now dead, and that he recognized some of them on the film. He also recognized some men with weapons and the mandarin in his official outfit. The viewing attracted a crowd of people, squeezing into the room and leaning over to see the film. A scene with people dressed in bulgy coats and hats made of bamboo leaves caused outbursts of laughter, especially among the children. Mr Van An then explained that such outfits were used as protection against the sun.

The world around Lach-truong has undergone many changes since Nguyen Van An saw Olov Janse eating cookies in the car. Van An and Van Tan have lived through two wars and have had to adjust their lives to several governments with differing agendas. Their memories have offered new details and dimensions to our knowledge about Janse. And equally importantly, Janse's film and the discussions that arose when it was viewed, could add otherwise forgotten layers to the history of the villages around Lach-truong.

\section{Collections on the periphery}

Most of the artefacts that Olov Janse excavated and removed from Lachtruong and other sites around Indochina, are now found in museum collections around the world. Most of the objects brought back to France at the end of their first expedition (1934-1935) were incorporated into the collections of the Cernuschi Museum (Fig. 87). The museum was for fine Asian art rather than archaeological artefacts, so it was owing to Janse's close relationship with the museum's new director René Grousset and his steady support of Janse's expedition that the artefacts were placed there. They were used as currency and tokens of reciprocal relations, to reimburse patrons and institutions for their financial and moral support. And Janse's archaeological collection was a tremendous success when it was first put on display, at the reopening of the modernized museum in June 1935 .

The Cernuschi Museum now holds a collection of around 1,300 objects from Olov Janse's first expedition. There are mainly artefacts of bronze and pottery, but also some of stone, iron, glass, and bone. One - a ceramic 


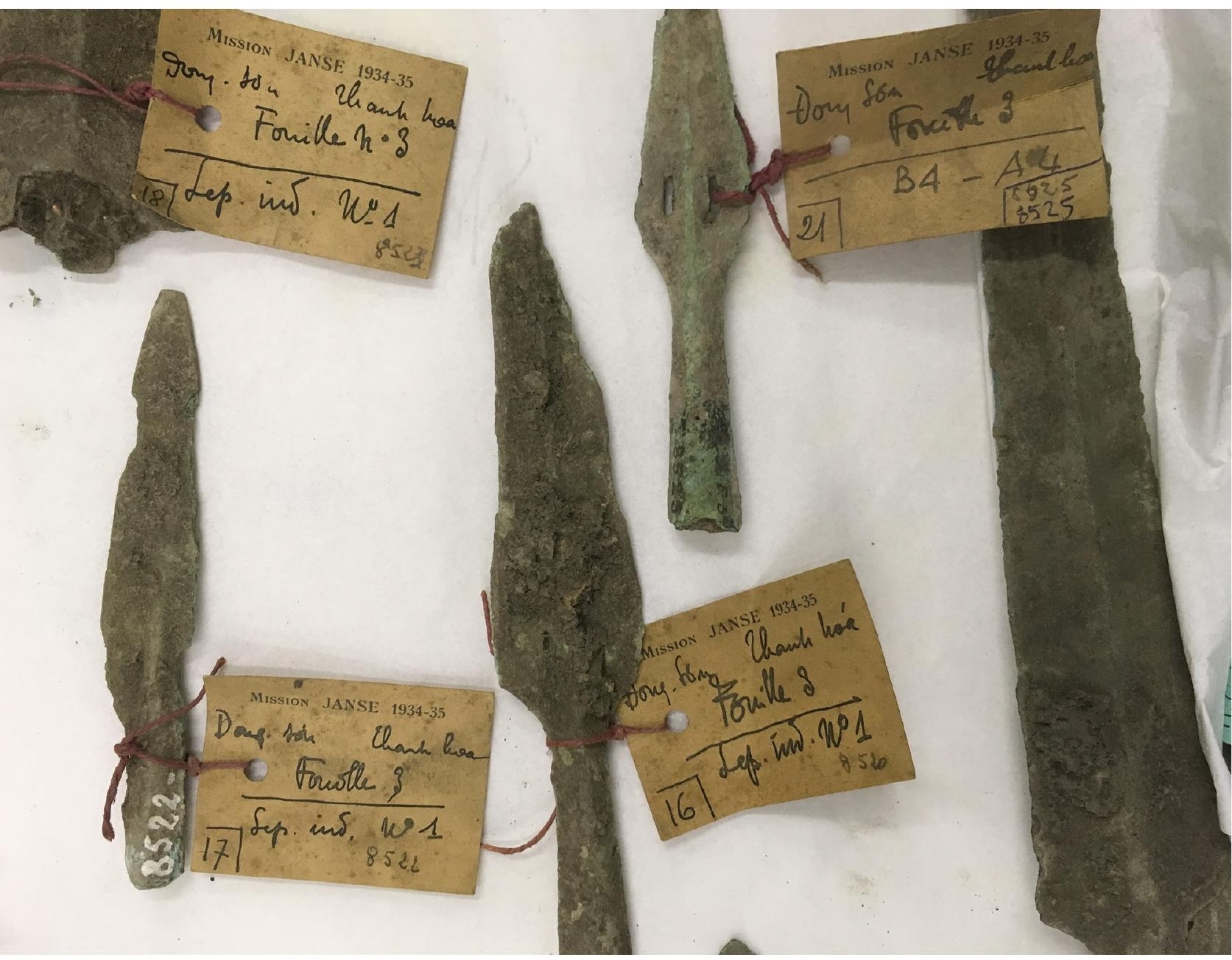

Fig. 87. Objects at Cernuschi. Photo by Anne Fort. farm model, originally used as a grave offering in one of the Han tombs Janse excavated in Indochina - is incorporated in the permanent display. We met the curator Anne Fort at the Cernuschi Museum in March 2014. She had taken an interest in Janse's collection and showed us the objects in storage and those on display. She told us that the former and present directors of the museum have expressed doubt about the value of the collection and the interest shown in it, and they have been reluctant to spend resources on it, or to use it for any major exhibitions. After the successful first display in 1935, which pointed to a new, more inclusive definition of Asian art in the Cernuschi collections, the museum has reverted to its original definition as a museum of "fine" Asian art. A misspelling 
of both Janse's names - Osvald Jansé - on signs in the display cabinet and in the store confirm the peripheral role he and his collection plays at the Cernuschi Museum today. Almost all of the objects he brought from Indochina are out of reach to the public eye in the store, and some are still in their original packing from the excavation and shipping. The latter remain uncleaned and some are in a bad state of corrosion. Thanks to Anne Fort's efforts, however, there was a small temporary display of objects from Janse's collection at the time of our visit, and the history of the collection is now described on the museum's website. ${ }^{1209}$

The artefact collection that originally arrived and was displayed at the Cernuschi Museum in 1935, was later divided into four parts. One consists of the 1,300 objects that now remain at Cernuschi. One part was transferred to the Guimet Museum, which is the national museum of Asian art in Paris. A third part of the collection was shipped back to Hanoi already in the 1930 s where it was incorporated into the collections of the Musée Louis Finot (now the National History Museum). And a fourth part of the collection was offered as a gift to the Swedish Crown Prince Gustaf Adolf in October 1935. The gift encompassed one complete ceramic vessel, 72 potsherds, 25 stone artefacts, 23 bronze objects, 34 beads, and 30 other artefacts from several of Janse's excavation sites, mostly Dong Son and Samrong Sen, and it was donated by the Crown Prince to the Museum of Far Eastern Antiquities in 1936. In $195^{\circ}$ the Guimet Museum offered the Crown Prince, who had just become King Gustaf VI Adolf, a complementary collection from Janse's excavations, which was donated to the Museum of Far Eastern Antiquities the same year. That gift encompassed 34 complete ceramic vessels, 22 potsherds, 6 stone artefacts and 221 beads. The new gift was added to the former items at the Museum of Far Eastern Antiquities, and they remain in its collections. ${ }^{1210}$ Until the late 1990 s the Museum of Far Eastern Antiquities pursued a similar official emphasis on "fine" Asian art as we saw in the Cernuschi case (somewhat paradoxically, given the geological and archaeological background of its founder, Johan Gunnar Andersson). Olov Janse's collections in Stockholm thereby met much the same destiny as the ones at the Cernuschi Museum, hidden away in the stores. When the museum was reorganized in the late 1990 s the new director, the anthro-

1209. http://www.cernuschi.paris.fr/en/collections/vietnamese-collection (accessed 3 January 2018)

1210. http://collections.smvk.se/carlotta-om/web. 
pologist Magnus Fiskesjö, was keen to increase the public knowledge about the archaeological history of the collections, and to include the hitherto ignored Southeast Asian parts of the museum's collections. ${ }^{1211}$ So, during a couple of years in the early 2000 s, Olov Janse's collections were digitized, researched and used in a small temporary display. ${ }^{1212}$ Apart from that effort, Janse's collection at the Museum of Far Eastern Antiquities remains little known.

Another collection on the periphery is that housed by the Peabody Museum of Archaeology and Ethnology at Harvard University. The collection, which ended up there as a permanent deposition following an agreement with the Harvard-Yenching Institute in 1941, included more than eleven thousand objects from Indochina, ${ }^{1213}$ two hundred beads from Johore, and almost four hundred objects from the Philippines. ${ }^{1214}$ Over six thousand objects from the original collection from Indochina were later returned to the History Museum in Saigon (then South Vietnam) in $1962,{ }^{1215}$ so the remaining collection consist of around five thousand objects - mostly potsherds - from Olov Janse's work in Indochina and the Philippines. In connection with the return of parts of the collection to Vietnam in the early 1960 s, Janse donated a set of original slides with on-site photos of artefacts and excavations at Sa Huynh and the Philippines to the Peabody Museum, where they are now accessible for online search. ${ }^{1216}$ Similar to Janse's artefact collection at the Cernuschi Museum, the Peabody collection has barely been used since it was

1211. Anna Källén worked on a temporary assignment at the Museum of Far Eastern Antiquities at this time, and was in charge of the inventory and digitization of the Southeast Asia collections, including the Janse collection.

1212. Prior 2003, Karlström \& Fiskesjö 2002.

1213.126 pottery vessels*, 4009 potsherds, 177 ceramic tiles*, 7 spindle whorls, 5 ear decorations, 47 iron artefacts*, 74 stone artefacts, 134 bronze or other metal objects* ${ }^{*} 83$ coins, approx. 6150 beads (of shell, glass, bone, amber, carnelian and gold), 1 large wood fragment, 1 pottery toilet box, and 146 misc. objects and artefacts. [ ${ }^{*}$ or fragments of]. Detailed list of sites and artefact types in the Peabody Museum Archive, XF_41-63_02.

1214. 126 pottery vessels, 5 parts of pottery vessels, 155 potsherds, 4 gold-plugged teeth, 49 glass bracelets, 27 spindle whorls, 1 metal fragment, 5 bone fragments, 4 stone objects, 1 iron ring and 1 shell. Detailed list of sites and artefact types in the Peabody Museum Archive, XF_41-63_02.

1215. Detailed list of artefacts in the Peabody Museum Archive, XF_41-63_01.

1216. Copy of letter to Helen Whiting from J. O. Brew, 25 September 1962, in the Peabody Museum Archive. See also https://pmem.unix.fas.harvard.edu (accessed 5 January 2018) 
first displayed in April 1942. Just like the Cernuschi display in 1935, the purpose of the Peabody display was to celebrate the triumphant homecoming of the archaeologist by showing his rich booty. The artefacts he brought back boosted the museums' prestige by enriching their collections. But the logic that led to later negligence was different at Peabody than at the European museums of "fine" Asian art. The arrangement with the Trustees of the Harvard-Yenching Institute, who wanted the prestige of a collection but had no room for it, was awkward right from the beginning. Senior Archivist Pat Kervick and Curatorial Associate Susan Haskell, who guided us through archives and storerooms on our visit to Harvard in April 2013, confirmed that Janse's collection is an odd bird in the museum, where most efforts today are spent on cases of repatriation to Native American tribes and interest groups. Hence the Peabody Museum, with its focus on American archaeology and ethnology, was destined to become a passive container for Janse's collection. There it now sits silently in the stores, with its giant jars, potsherds, and bronze fragments. The museum has welcomed researchers, but only a few have taken an interest in the collection. ${ }^{1217}$

If Janse's archaeological collections are largely unknown, his ethnographic collections are even more invisible. He used etnographica in much the same way as he used archaeological artefacts - as a form of currency to repay patrons and institutions for their investments in his expeditions, and as a means to attract media attention to his endeavours. Considering the support Janse received from Marcel Mauss, who was a leading actor at the Musée d'Ethnographie de Trocadéro (MET) at the time, it was only logical that some of his ethnographic collections from the first Indochina expedition ended up in Paris. Today there is a small collection of ethnographic objects originating from the expedition 1934-35 at the Musée du Quai Branly. It was transferred to Quai Branly at the opening of the new museum in 2006 , along with the other national collections of ethnography that had previously been housed by the MET (18781937) and Musée de l'Homme (1937-2006). There are 108 objects in total from Janse's expedition, and none of them have been on display. Most are objects made of perishable materials; bamboo, wood, silk and paper,

1217. In addition to these larger collections, there is according to information on Wikipedia (https://en.wikipedia.org/wiki/Olov_Janse) also a small collection from Janse at the National Museum of Singapore (previously the Raffles Museum). We have not been able to verify this information. 
and all but seven have an accession number from $1935 .{ }^{1218}$ Six objects were added in 1947 (when Janse was back in Paris for the first time after the war, and was spending his spare time searching the attics of friends and museums for hidden belongings). ${ }^{1219}$ One final object, a keepnet, was added in 1961.

But the largest collection of ethnographica after Janse's Indochina expeditions is kept at Etnografiska museet - the Ethnographic Museum in Stockholm. ${ }^{1220}$ Even though almost all the funding for the first expedition came from museums and patrons in France, Janse's intention was to use collections (first the prospect of, later as real gifts) to enhance his professional position and reputation in Sweden as well. When the archaeological collections from the first expedition were already bound to go to the Cernuschi Museum in Paris, it was mainly the ethnographic collections that he was able to offer to the Swedish museums. Through contacts with Gerhard Lindblom, Director of the Ethnographic Department of the Museum of Natural History, he arranged for a collection to be sent directly to Stockholm after the first expedition. The collection arrived in Stockholm in 1935, just after the museum had been divided from the Museum of Natural History and become Statens etnografiska museum - the National Museum of Ethnography. Janse's collection was put on temporary display in October 1936, along with two other new collections of objects from China, Japan, and East Turkestan. The collection has never been displayed again, but it is still kept at the museum (now Etnografiska museet) under the name Professor Olof [sic] Janses samlingar frän franska Indokina insamlade arren 1934-1935. ${ }^{1221}$ The collection contains 301 objects from Janse's first expedition, and is divided into four parts: (i) Archaeological artefacts from Samrong Sen (Cambodia); (ii) Sung period ceramics; (iii) Collection from Cambodia; and (iv) Collection from various parts of Indochina. The archaeological artefacts from Samrong Sen and Sung period ceramics (AD 960-1279) are both curious choices for an ethnographic collection, and suggest that the temporal aspect was

1218. http://www.quaibranly.fr/fr/explorer-les-collections.

1219. The six objects added in 1947 were two fire steels from Kunming (China), one basket with lid ascribed to the Cham culture, one long-shafted machete from Vietnam, one shield made of lacquered wood from Laos, and one basketry shield from Vietnam (http://www.quaibranly.fr/fr/explorer-les-collections).

1220. http://www.varldskulturmuseerna.se/etnografiskamuseet/forskning-samlingar/ sok-i-samlingarna1/.

1221. Collection number 1935.32. 
not as important as the geographical origin of the objects. The collection from Cambodia consists of Buddhist objects collected with the help of their friend Suzanne Karpelès at the Royal Library in Phnom Penh. The fourth and largest category contains a variety of mundane objects, such as tools, jewellery, and costume details of ethnic groups around Indochina. In the museum's catalogue is a note that most of the ethnic clothing in Janse's collection had been purchased at markets, rather than on site in the villages. The provenance of the clothing is therefore uncertain and the ethnographic value is questionable. ${ }^{1222}$ The first collection was supplemented in 1947 with 59 objects from Indochina, China and Hawaii that had been stored away in Paris during the war. These objects are similar, and in some cases almost identical to those in the collection at the Quai Branly Museum. ${ }^{1223}$ Two more minor additions were later made to the collection; one earring and three finger rings from Vietnam in 1950; ${ }^{1224}$ and in 1955 a two-piece women's dress from northern Laos, purchased during Janse's third expedition. ${ }^{1225}$ At the Etnografiska museet in Stockholm there is also a collection of 147 photographs from his first two expeditions, along with a few sketches and prints. ${ }^{1226}$

\section{Collections in use}

The most important archaeological collection from Janse's work in Indochina is housed at the National History Museum in Hanoi (formerly Musée Louis Finot). We do not know how many objects there are in the collection as a whole, but we know that many of the objects that were on display at the Cernuschi Museum in 1935 were returned to the museum in Hanoi. When we visited the museum in October 2005, members of the staff said that the collection had been split up and was now registered according to other parameters than Olov Janse's name. They said that it would be possible to restore the connections through the registries, but it would require considerable efforts that we were unable to invest at the time. But the permanent display indicated that many of the most important objects from Janse's investigations are in the possession of the Hanoi

1222.http://collections.smvk.se/carlotta-em/web/object/1021410.

1223. Collections number 1947.28 and 1947.40.

1224. Collection number 1950.19 .

1225. Collection number 1955.15.

1226. ID numbers $0312 ; 0525$. 
museum (fig. 40). There was the famous kneeling figurine Janse called ljusmannen and his Pan-like associate, along with a number of iconic objects found in the Han tombs. There were also a considerable number of kettledrums and impressive bronze objects associated with the Dong Son culture. The connection with Olov Janse's name is here of little importance. ${ }^{1227}$ Emphasis is instead on the sites he and his team excavated and the cultural associations of the objects he found, particularly connections to the Dong Son culture which has been used as a glorious point of origin for the Viet people in postcolonial nation-building narratives. ${ }^{1228}$

We encountered a similar situation for Janse's collections housed by the History Museum (formerly Musée Blanchard de la Brosse) in Ho Chi Minh City (formerly Saigon). We know that over 6000 objects from the third expedition were returned to Indochina and received by the History Museum in Saigon in 1962. ${ }^{1229}$ But at our visit to the museum in 2005 no one was able, or willing, to give information about the present whereabouts of these objects. Our communication with these two museums has been hindered by us not speaking or reading Vietnamese. But the impression remains that there is a definite difference between the European and US approach which is more person-oriented, and a Vietnamese approach to the same collections, which is depersonalized in terms of the archaeologist in charge, and much more focused on the sites or cultural associations of the objects. This does not necessarily mean that Olov Janse and his expeditions are unknown or of no interest in contemporary Vietnam. All archaeologists we have met in Vietnam were well aware of his work, and the translation of his memoirs to Vietnamese by the National History Museum in Hanoi in $2001,{ }^{1230}$ indicates a broader interest in him and his work. It is just not emphasized or showcased in official

1227. The absence of direct links to Janse's name in Vietnam today can also be seen as a reaction to the lopsided French and international accounts of the history of archaeology in Indochina, where only (with very few exceptions) French or European scholars are mentioned by name. In reality, as has been demonstrated for instance by Haydon Cherry (2004), the contributions by the many native scholars at an institution like EFEO were of equal importance but remain invisible in international accounts.

1228. Hà Văn Tàn 1991; Han Xiaorong 1998.

1229.37 pottery vessels, 67 potsherds, 3 tiles, 5 spindle whorls, 5 ear decorations, 5 stone artefacts, 28 bronze artefacts, about 200 coins, some 5,900 beads, 1 pottery toilet box, and 21 miscellaneous objects, including ceramic house- and stove-models for funerary use. Detailed list of artefacts in the Peabody Museum Archive, XF_41-63_o1.

1230. Janse 2001. 


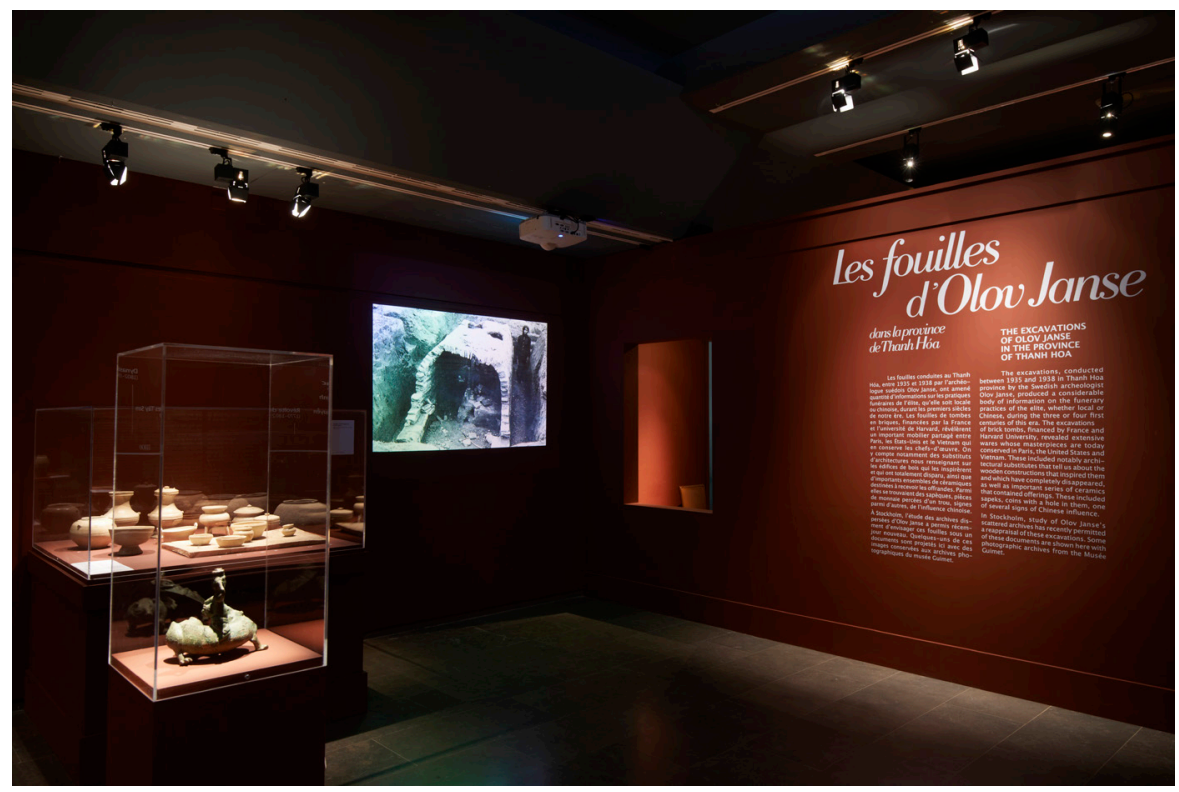

Fig. 88. Part of

the display in

the exhibition

L'Envol du

dragon at

the Guimet

Museum in

2014.

museum displays, where the objects we associate with him are used as memorabilia for other people or other contexts.

The most extensive, and most visible, collection from Janse's Indochina expeditions outside Vietnam is housed by the Guimet Museum at Place d'Iéna in Paris. Guimet is the French national museum for Asian art, and has one of the largest collections of Asian art outside of Asia. We have not been able to obtain information on the exact number of objects relating to Janse in the collections of the Guimet Museum, but we know that substantial collections from his first two expeditions to Indochina are located there. Parts of the collection were transferred from the Cernuschi Museum after the successful display following the first expedition in 1935, and it was completed after Janse's second expedition, when all excavated objects that left Indochina went to the Guimet Museum. A part of the collection was put on display in the temporary exhibition $L^{\prime} E n$ vol du dragon - Art royal du Vietnam, which showed 9 July-15 September $2014 .{ }^{1231}$ The exhibition, which was organized as part of the France-Vietnam year 2013-2014, was a collaborative effort between curators from the National History Museum in Hanoi and the Guimet Museum. Objects

1231. See exhibition catalogue "L'Envol du dragon: Art royal du Vietnam", Musée Guimet, 2014. See also http://www.guimet.fr/event/lenvol-du-dragon-art-royal-duvietnam/ (accessed 25 August 2018). 
from Janse's excavations at Dong Son and several Han brick tombs were displayed along with descriptions of his work in Indochina. The focus on Janse as a scholar, with descriptions of his contributions to the archaeological knowledge of Vietnam, was much more pronounced here than in the examples from Vietnam or the United States.

\section{The storage system}

At the Swedish History Museum in Stockholm, there are artefacts and archaeological materials connected with Janse's excavations of Swedish sites, during the earliest years of his career. ${ }^{1232}$ There is also a small collection of Stone Age artefacts from Wales that he for unknown reasons donated to the museum in $1957 .{ }^{1233}$ Until recently, there were also the artefacts belonging to the Piette collection that Janse brought to Stockholm through an obscure exchange agreement with Henri Hubert in the 1920s. They were, however, restored to the Musée d'archéologie nationale in Saint-Germain-en-Laye in 2012.

At the Swedish History Museum in Stockholm there is also a more subtle trace of Olov Janse's earliest years as a professional archaeologist. In the storerooms, archaeologists and curators still work with the system of shallow wooden trays where the artefacts are organized in carton boxes that was invented by Olov Janse and Axel Bagge in 1925. The original card index has been replaced by computer databases, but the standard procedure for the entries is very much the same. The structure, once invented in response to an unmanageable chaos in the storerooms, is now taken for granted by generations of Swedish archaeologists, us included. Few if any now connect it with Olov Janse.

\section{The archive}

The most complex and important collection of memorabilia of Olov and Renée Janse is their personal archive contained in five cardboard boxes in the Smithsonian Institution's National Anthropological Archives in Maryland, USA (fig. 2). It has been the main source of information for our research, and it has given us access to personal and professional dimensions of Olov and Renée Janse's lives without which this book could

1232. Janse 1924a; Janse 1925.

1233. Inv. nr. 25775, Swedish History Museum. 


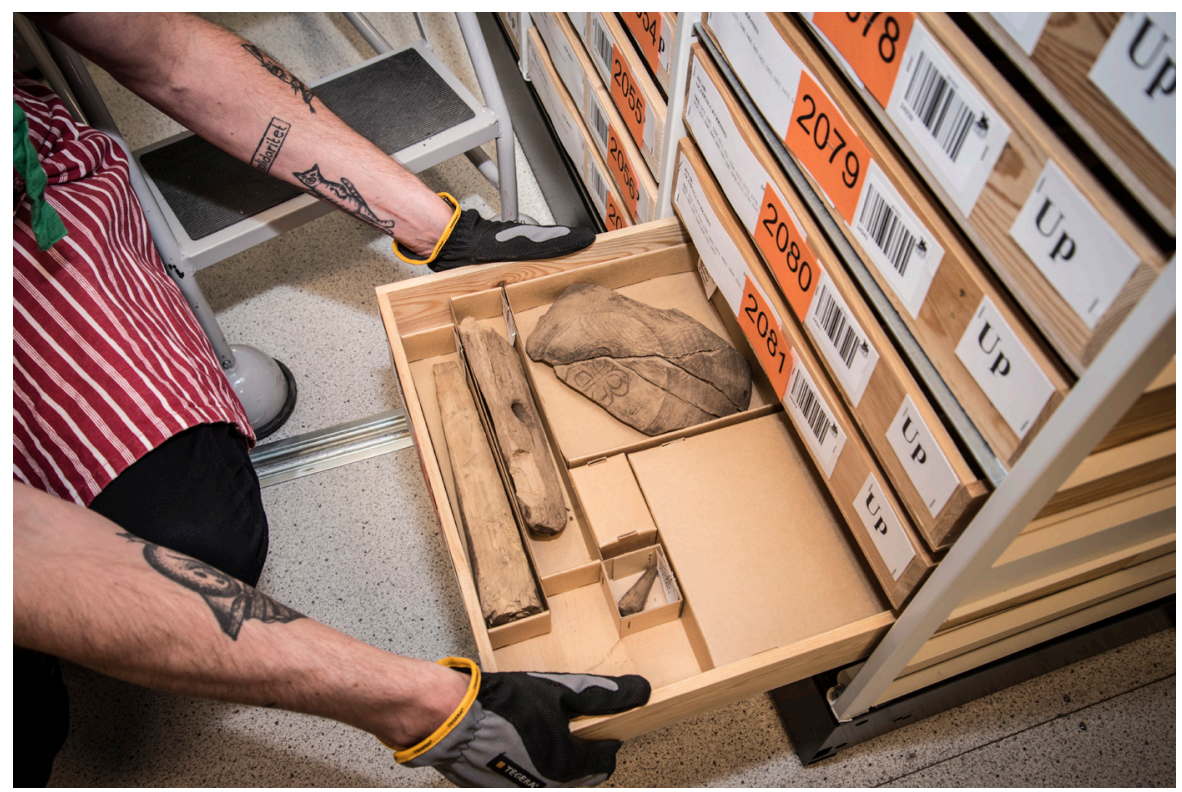

Fig. 89. The

archive at the

Swedish History

Museum is

today still based

on the system

introduced by

Janse and Bagge

in 1925

not have been written. Fragmentary pieces of information and vague indications found in this archive have pointed us in new search directions, and have helped us locate their presence in other official archives, personal memories, museum collections, and media resources on three continents. It has been invaluable for a research project that has investigated complicated and unpredictable relations across borders, between nations and institutions.

Yet it was a close call that it was not destroyed. In June 1985, Paul M. Taylor, Curator of Asian Ethnology at the Smithsonian Institution, wrote a letter to Renée Janse. Taylor had been informed about Olov's death three months earlier by their colleague and mutual friend Bill Solheim. Taylor asked Renée to consider the National Anthropological Archives as a future repository for Olov's scholarly papers. She took his advice and wrote an entry according to his letter in her testament. Fifteen years later, when Renée had died and the estate was to be settled, the Smithsonian Institution archivists were faced with the question of accepting or declining the donation. Email correspondence kept in the acquisition files tell that it was not an easy decision. ${ }^{1234}$ Who was this Olov Janse? No one had heard of him. Hence they declined parts of the material at first, but changed their minds after realizing his connection to the Smithsonian

1234. NAA: Janse 2001-29, acquisition files. 
and that Paul Taylor had approached Renée on the matter. So in the end they accepted most of the donation, apart from some old family photographs (which may very well be the photos and documents that were given to Per Janse by the family solicitor). Two archivists went with a car to Renée's old apartment in suite 530 at 4000 Massachusetts Avenue, where they met her solicitor and picked up the five boxes just before the apartment was emptied.

There are a couple of collections from Janse's work that we have been unable to locate during the course of our research. One is the collection of finds, drawings, notes, and photographs from the excavations at Dong Son that was left with Victor Goloubew in Hanoi at the end of Janse's second expedition and has not been seen since the outbreak of the Second World War and Goloubew's death in 1945. A second is a "considerable packet of notes, photographs, and reprints of articles on his archaeological research in Vietnam" that Janse reportedly gave to Bill Solheim shortly before he died, and which Solheim claims to have handed over to the Institute of Archaeology in Hanoi. ${ }^{1235}$ It is our hope that these and other materials and memories connected with Olov, Ronny and Renée Janse will turn up in the future to further enrich our understanding of their work and the contributions they made to the history of archaeology.

1235. Solheim 2002. 


\section{REFERENCES}

Åberg, Nils. 1929. "Typologie (Typologische Methode)." Reallexikon der Vorgeschichte, herausg. v. Max Ebert, Bd 13. Berlin, pp. 508-516.

Academic Senate. 1969. University of California: In Memoriam. Berkeley, CA: University of California.

Acheson, Dean. 1969. Present at the Creation: My Years in the State Department. New York: W.W. Norton \& Company.

Åkerlund, Andreas. 2010. Mellan akademi och kulturpolitik. Lektorat i svenska språket vid tyska universitet 1906-1945. Avh. Studia Historica Upsaliensia 240. Uppsala: Uppsala universitet.

Almgren, Oscar. 1905. "Kung Björns hög” och andra fornlämningar vid Håga/på föranstaltande af H.K.H. Prins Gustaf Adolf undersökta 1902-03 af Oscar Almgren. Stockholm: Kungl. Vitterhets-, historie- och antikvitetsakad.

Anderson, Benedict. 1996 [1983]. Imagined Communities: Reflections on the Origin and Spread of Nationalism. London \& New York: Verso.

Andersson, Johan Gunnar. 1929. "The Origin and Aims of the Museum of Far Eastern Antiquities." Bulletin of the Museum of Far Eastern Antiquities, no. 1, pp. 11-27.

Anonymous [attributed to Olov Janse]. 1945. "Joint Army-Navy Intelligence Study of Indochina. People and Government. October 1945." Janis 70. Chapter X. Published by The Joint Intelligence Study Publishing Board. Military Intelligence Division, G-2; Division of Naval Intelligence; Office of Assistant Chief of Air Staff, Intelligence; Office of Strategic Services; Office Chief of Engineers. Washington, DC.

Anonymous. 1964. Review of Jean Meynaud and Brigitte Schröder, "Les savants dans la vie internationale." International Social Science Journal, UNESCO, vol. 16, no. 1, p. 153 .

Arnold, Bettina. 2006. "'Arierdämmerung': Race and Archaeology in Nazi Germany." World Archaeology, vol. 38, no. 1, pp. 8-31.

Auboyer, Jeannine. 1955. "René Grousset (1885-1952)." Bulletin de l'École française d'Extrême-Orient, vol. 47, no. 1, pp. 1-6.

Barraclough, Geoffrey. 2004. "The Revolt Against the West." In Prasenjit Du- 
ara (ed.). Decolonization: Perspectives from Now and Then. London \& New York: Routledge, pp. 118-131.

Bartky, Sandra Lee. 1998 [1988]. "Foucault, Femininity, and the Modernization of Patriarchal Power." In Rose Weitz (ed.). The Politics of Women's Bodies: Sexuality, Appearance, and Behavior. Oxford: Oxford University Press, pp. 25-45.

Baudou, Evert. 2002. “Åberg, Montelius och Kossinna.” Fornvännen, vol. 97, no. 3, pp. 177-190.

Baudou, Evert. 2012. Oscar Montelius: Om tidens återkomst och kulturens vandringar. Stockholm: Atlantis.

Bell, Duncan. 2009. "Writing the World: Disciplinary History and Beyond." International Affairs, vol. 85, no. 1, pp. 3-22.

Berggren, Lena. 1999. Nationell upplysning: Drag $i$ den svenska antisemitismens idéhistoria. Stockholm: Carlsson.

Bergström, Anders \& Edman, Victor. 2005. Folkhemmets museum: Byggnader och rum för kulturhistoriska samlingar. Stockholm: Byggförlaget.

Bert, Jean-François (ed.). 2015. Henri Hubert et la sociologie des religions. Liège: Presses Universitaires Liège.

Beyer, H. Otley. 1949. Supplementary illustrations to the "Outline Review of Philippine Archaeology by Islands and Provinces." Manila: private print.

Bhabha, Homi K. 1990. "DissemiNation: Time, Narrative, and the Margins of the Modern Nation." In Homi K. Bhabha (ed.). Nation and Narration. London: Routledge, pp. 291-322.

Bhabha, Homi K. 2004 [1994]. The Location of Culture. London: Routledge.

Biaggi, Cristina (ed.). 1994. Glozel: Les graveurs du silence. Orcines: B GC Toscane.

Boutros-Ghali, Boutros. 1992. An Agenda for Peace: Preventive Diplomacy, Peacemaking and Peace-keeping. Report of the Secretary-General pursuant to the statement adopted by the Summit Meeting of the Security Council on 31 January 1992. New York: United Nations.

Brinson Demery, Monique. 2013. Finding the Dragon Lady: The Mystery of Vietnam's Madame Nhu. Philadelphia: PublicAffairs.

Burke, Peter. 1992. The Fabrication of Louis XIV. New Haven: Yale University Press.

Byrne, Denis. 2014. Counterheritage. London: Routledge. 
Carlsson, Hannes \& Ryding, Krister. 2006. En svunnen tid: Vykort från Valdemarsvik 1898-1930. Valdemarsvik: Hannes Carlsson.

Chalou, George C. (ed.). 2002 [1992]. The Secrets War: The Office of Strategic Services in World War II. Washington, DC: National Archives and Records Administration.

Chapman, Jessica M. 2013. Cauldron of Resistance: Ngo Dinh Diem, the United States, and 1950s Southern Vietnam. Ithaca: Cornell University Press.

Chandler, David. 2009. "Paul Mus (1902-1969): A Biographical Sketch." Journal of Vietnamese Studies, vol. 4, no. 1, pp. 149-191.

Chen Xingcan \& Magnus Fiskesjö. 2014. "Oscar Montelius and Chinese Archaeology." Bulletin of the History of Archaeology, vol. 24, no. 10. E-journal (https://www.archaeologybulletin.org/articles/10.5334/bha.2410/).

Cherry, Haydon Leslie. 2004. "Social Communication and Colonial Archaeology in Vietnam.” ARI Working Paper No. 21, March 2004. Source: www. nus.ari.edu.sg/pub/wps.htm. Asia Research Institute, National University of Singapore.

Clémentin-Ojha, Catherine \& Pierre-Yves Manguin. 2001. Un siècle pour l'Asie: L'École française d'Extrême-Orient, 1898-2000. Paris: Les éditions du Pacifique, École française d'Extrême-Orient.

Clifford, James. 1988. The Predicament of Culture: Twentieth Century Ethnography, Literature, and Art. Cambridge, Mass.: Harvard University Press.

Clifford, James. 1997. Routes: Travel and Translation in the Late Twentieth Century. Cambridge, Mass.: Harvard University Press.

Conklin, Alice L. 2013. In the Museum of Man: Race, Anthropology, and Empire in France, 1850-1950. Ithaca: Cornell University Press.

Coolidge, Harold Jefferson \& Roosevelt, Theodore. 1933. Three Kingdoms of Indo-China. New York: Thomas Y. Cromwell Company.

Cooper, Nicola. 2001. France in Indochina: Colonial Encounters. Oxford: Berg.

Cosslett, Tuyet L. \& Cosslett, Patrick. 2013. Water Resources and Food Security in the Vietnam Mekong Delta. Natural Resource Management and Policy 44. London: Springer.

Cotton, James \& Neary, Ian (eds.). 1989. The Korean War in History. Studies on East Asia. Manchester: Manchester University Press.

Craddock, Paul. 2009. Scientific Investigation of Copies, Fakes and Forgeries. Oxford: Elsevier.

Cull, Nicholas J. 2008. The Cold War and the United States Information Agency: 
American Propaganda and Public Diplomacy, 1945-1989. Cambridge: Cambridge University Press.

Cuno, James. 2011. Who Owns Antiquity? Museums and the Battle over Our Ancient Heritage. Princeton, NJ: Princeton University Press.

Curtis, Barry \& Pajaczkowska, Claire. 1994. “'Getting There’: Travel, Time and Narrative.' In Robertson, George et al. (eds.). Travellers' Tales: Narratives of Home and Displacement. London: Routledge, pp. 197-214.

Daniel, Glyn (ed.). 1981. Towards a History of Archaeology: Being the Papers Read at the First Conference on the History of Archaeology in Aarhus, 29 August-2 September 1978. London: Thames and Hudson.

Daniels, Roger. 2004. Guarding the Golden Door: American Immigration Policy and Immigrants Since 1882. New York: Hill \& Wang.

Demiéville, Paul. 1954. "René Grousset (1885-1952)." T’oung Pao, Second Series, vol. 42 , livr. 5 , pp. 411-415.

Dias Nélia. 1991. Le Musée d'ethnographie du Trocadéro (1878-1908). Anthropologie et Muséologie en France. Paris: Editions du Centre national de la recherche scientifique.

Dizard Jr., Wilson P. 2004. The Story of the United States Information Agency. Boulder, CO: Lynne Reinner Publishers.

Dussaud, René. 1927. "Henri Hubert.” Syria, T. 8, Fasc. 3, pp. 275-276.

Dutton, Lee S. (ed.). 1999. Anthropological Resources: A Guide to Archival, Library, and Museum Collections. New York: Garland Publishing.

Eckhoff, Emil \& Janse, Otto. 1936. Visby stadsmur. D 1. Stockholm: Wahlström $\&$ Widstrand.

Edwards, Penny. 2007. Cambodge: The Cultivation of a Nation, 1860-1945. Honolulu, HI: University of Hawai'i Press.

EFEO. 1903. Compte rendu analytique des séances / Premier Congrès international des études d'Extrême-Orient, Hanoi (1902). Hanoi: École française d'Extrême-Orient.

EFEO. 1939. Bulletin de l'École française d'Extrême-Orient. Hanoi.

EFEO. 2002. Chercheurs d'Asie: Répertoire biographique des membres scientifiques de l'École française d'Extrême-Orient. Paris: EFEO.

Engström, Elin. 2015. Eketorps veckningar: Hur arkeologi formar tid, rum och kön.

Diss. Stockholm: Stockholm University. 
Evangelista, Alfredo E. 1969. "The Philippines: Archaeology in the Philippines to 1950." Asian Perspectives, vol. 12, pp. 97-104.

Evans-Pritchard, Edward Evan. 1966. "Introduction.” In Mauss, Marcel, The Gift: Forms and Functions of Exchange in Archaic Societies. London: Cohen \& West Ltd., pp. v-x.

Fabian, Johannes. 1983. Time and the Other: How Anthropology Makes Its Object. New York: Columbia University Press.

Fan Liya. 2012. "The 1935 London International Exhibition of Chinese Art: The China Critic Reacts." China Heritage Quarterly, nos. 30-31, June/September. E-journal (http://www.chinaheritagequarterly.org/features.php?searchterm=030_fan.inc $\&$ issue $=030$ ).

Fan Shuhua. 2009. "To Educate China in the Humanities and Produce China Knowledge in the United States: The Founding of the Harvard-Yenching Institute, 1924-1928." The Journal of American-East Asian Relations, vol. 16, no. 4 (Winter), pp. 251-283.

Fan Shuhua. 2014. The Harvard-Yenching Institute and Cultural Engineering: Remaking the Humanities in China, 1924-1951. Lanham, Mass.: Lexington Books.

Feliciano, Hector. 1997. The Lost Museum: The Nazi Conspiracy to Steal the World's Greatest Works of Art. New York: Basic Books.

Fisher, Glen H. 1972. Public Diplomacy and the Behavioral Sciences. Bloomington: Indiana University Press.

Fishman, Joshua A. 1989. Language and Ethnicity in Minority Sociolinguistic Perspective. Clevedon, PA: Multilingual Matters.

Fiskesjö, Magnus. 2014. "Art and Science as Competing Values in the Formation of the Museum of Far Eastern Antiquities, Stockholm." In Steuber, Jason \& Lai, Guolong (eds.). Collectors, Collections \& Collecting the Arts of China: Histories \& Challenges. Gainesville: University Press of Florida, pp. 67-99.

Fiskesjö, Magnus \& Chen Xingcan. 2004. China Before China: Johan Gunnar Andersson, Ding Wenjiang and the Discovery of China's Prehistory. Stockholm: The Museum of Far Eastern Antiquities.

Foucault, Michel. 1970. The Order of Things: An Archaeology of the Human Sciences. (Original: Les mots et les choses 1966). London: Routledge.

Fournier, Marcel. 1994. Marcel Mauss: A Biography. Paris: Fayard.

Francia, Luis H. 2010. A History of the Philippines: From Indios Bravos to Filipinos.

New York: The Overlook Press. 
Gerard, Alice. 2005. Glozel: Bones of Contention. Lincoln, NE: iUniverse.

Goloubew, Victor. 1929. "L'âge du bronze au Tonkin et dans le Nord Annam." Bulletin de l'École française d'Extrême-Orient, vol. XXIX, pp. 1-46.

Gordon, Natalie. 1941. "Our Gracious Ladies.” Boston Traveler, 25 January 1941.

Götz, Norbert. 2011. Deliberative Diplomacy: The Nordic Aapproach to Global Governance and Societal Representation at the United Nations. Dordrecht: Republic of Letters.

Graham, S.E. 2006. "The (Real)politiks of Culture: U.S. Cultural Diplomacy in Unesco, 1946-1954." Diplomatic History, vol. 30, no. 2, pp. 231-251.

Gräslund, Bo. 1974. "Relativ datering. Om kronologisk metod i nordisk arkeologi." Tor. Tidskrift för nordisk fornkunskap [Uppsala], vol. XVI.

Groslier, Bernard Philippe. 1966. Indochina. London: Frederick Muller Ltd.

Grousset, René. 1951. "Échanges spirituels entre Orient et Occident." FranceAsie [Saigon], tome VII, no 61-62, juin-juillet.

Hà Văn Tàn. 1991. “From Pre-Đông So’n to Đông So'n: Sociocultural Changes." Paper presented at the conference The High Bronze Age of Southeast Asia and South China. Hua Hin, Thailand, 14-19 January 1991.

Hafstein, Valdimar. 2018. Making Intangible Heritage: El Condor Pasa and Other Stories from UNESCO. Bloomingon: Indiana University Press.

Han Xiaorong. 1998. "The Present Echoes of the Ancient Bronze Drum: Nationalism and Archaeology in Modern Vietnam and China", Explorations of Southeast Asian Studies, vol. 2, no. 2, pp. 27-46.

Haraway, Donna. 1988. "Situated Knowledges: The Science Question in Feminism and the Privilege of Partial Perspective." Feminist Studies, vol. 14, no. 3, pp. 575-99.

Harrell, Stevan. 2012. "Introduction: Explorers, Scientists, and Imperial Knowledge Production in Early Twentieth-Century China." In Glover, Denise M. et al. (eds.). Explorers and Scientists in China's Borderlands 1880-1950. Seattle: University of Washington Press, pp. 3-25.

Harrison, Rodney. 2012. Heritage: Critical Approaches. London: Routledge.

Hayter-Menzies, Grant. 2013. Shadow Woman: The Extraordinary Career of Pauline Benton. Montreal: McGill-Queen's Press.

Hedin, Naboth. 1929. "Pre-Viking Age of Gold in Sweden." International Studio, vol. XCIII, no. 385, June, pp. 27-29. 
Hegardt, Johan. 1997. Relativ betydelse: Individualitet och totalitet $i$ arkeologisk kulturteori. Diss. OPIA 12. Uppsala: Uppsala University, Department of Archaeology \& Ancient History.

Hegardt, Johan. 2015. "Historiska museet och dess narrativ". In Grundberg, Malin et al. (eds.). Ett museum måste irritera: Fyra röster om historiska museet. The Swedish History Museum, Studies 24. Stockholm: Historiska museet, pp. 211-345.

Hegardt, Johan \& Källén, Anna. 2014. "Translated Objects: The Olov Janse Case." Museum Worlds, vol. 2, pp. 42-62.

Henderson, Gregory. 1968. The Politics of the Vortex. Harvard: Harvard University Press.

Hildebrand, Bror Emil. 1844-45. "Pro Memoria: Utdrag ur Academiens Protocoller." Stockholm: Kungl. Vitterhets-, historie- och antikvitetsakad.

Hildebrand, Hans. 1873. Den vetenskapliga fornforskningen, hennes uppgift, behof och rätt. Stockholm: A.L. Norman.

Hillström, Magdalena. 2010. "Contested Boundaries: Nation, People and Cultural History Museums in Sweden and Norway 1862-1909." Culture Unbound, vol. 2, pp. 583-607.

Hoffman, Joyce. 2008. On Their Own: Women Journalists and the American Experience in Vietnam. Boston: Da Capo Press.

Hoggart, Richard. 2011 [1978]. An Idea and its Servants: UNESCO from Within. London: Transaction Publishers.

Hopkirk, Peter. 1984. Foreign Devils on the Silk Road: The Search for the Lost Cities and Treasures in Chinese Central Asia. Oxford: Oxford University Press.

Hubert, Henri. 1932. Les Celtes. Bibliothèque de l'Evolution de l'Humanité. Paris: Albin Michel.

Hubert, Henri. 1952. Les Germains. Posthumous publication, edited by M.P. Chalus. Paris: Albin Michel.

Hubert, Henri \& Besnard, Philippe. 1979 [1915]. "Texte autobiographique de Henri Hubert." Revue française de sociologie, vol. 20, no. 1, pp. 205-207.

Hutterer, Karl L. 1987. "Philippine Archaeology: Status and Prospects." Journal of Southeast Asian Studies, vol. 18, no. 2, pp. 235-249.

Huxley, Julian. 1947. UNESCO: Its Purpose and its Philosophy. Washington, D C: Public Affairs Press.

Isaksson, Olov (ed.). 1972. Kungen gräver: En bok om arkeologer och arkeologi. Stockholm: Askild \& Kärnekull. 
Jacobs, Jeffrey W. 2000. "The United States and the Mekong Project." Water Policy, vol. 1, iss. 6, pp. 587-603.

Jacobson, Matthew Frey. 2006. Roots Too: White Ethnic Revival in Post-Civil

Rights America. Cambridge, Mass.: Harvard University Press.

James, Wendy \& Allen, N.J. (eds.). 1998. Marcel Mauss: A Centenary Tribute.

London: Berghahn.

Janse, Olov. 1911. "Den tredje passageraren (Fritt efter Heine).” Östergötlands

Dagblad, 17 January.

Janse, Olov. 1913a. "Stenåldersplatserna vid Bråviken: Nya grävningar."

Östergötlands Dagblad, 28 June.

Janse, Olov. 1913b. "Island: Intryck från en resa. Över Norge till Bergen, Über den Wellen. Färöarna.” Östergötlands Dagblad, 17 July.

Janse, Olov. 1913c. "Island: Intryck från en resa. II. Thorshavn. Förbi Färöar-

na. En sägen. Åter på havet. Om Islands första bebyggelse. Faskrudsfjord.”

Östergötlands Dagblad, 25 July.

Janse, Olov. 1913d. "Island: Intryck från en resa. III. Runt Islands kust från

Farerudsfjord till Reykjavik. Ridrutter inåt land.” Östergötlands Dagblad, 31 July.

Janse, Olov. 1913e. "Island: Intryck från en resa. IV. Reykjavik. Tillbaka till

Siglufjord." Östergötlands Dagblad, 5 August.

Janse, Olov. 1913f. "Island: Intryck från en resa. Det modärna trawlfisket. En

besvärlig ridtur. Hur den isländske bonden bor. Farväl till Island.” Östergötlands Dagblad, 12 August.

Janse, Olov R.T. 1918. “Oscar Montelius 75 år.” Dagens Nyheter, 8 September.

Janse, Olov. 1919a. "Den geografiska fördelningen av folkvandringstidens

skandinaviska guldbrakteater. I." In Ambrosiani, Sune; Lindqvist, Sune \&

Nerman, Birger (eds.). Studier tillägnade Oscar Almgren 9.11.1919. Stockholm:

Norstedt \& söner, pp. 81-89.

Janse, Olov R.T. 1921. "Notes sur quelques représentations des bractéates en or scandinaves.” Revue archéologique, Cinquième Série, vol. 14 (Janvier-Juin), pp. 373-395.

Janse, Olov R.T. 1922. Le travail de l'or en Suède à l'époque mérovingienne: Études précédées d'un mémoire sur les solidi romains et byzantins trouvés en Suède.

Orléans: Paul Pigelot \& fils.

Janse, Olov R.T. 1924a. "Undersökningar av ett gotländskt järnåldersgravfält."

Fornvännen, vol. 19, pp. 89-101. 
Janse, Olov. 1924b. "Notes sur les premiers rois païens de la Suède." Revue des Études anciennes, vol. XXVI, no. 3, juillet-septembre 1924.

Janse, Olov R.T. 1925. "En nyupptäckt östgötisk stenåldersboplats.” Fornvännen, vol. 20, p. 83.

Janse, Olov R.T. 1928. Svenska guldfynd från tiden 100-600 e. Kr. Stockholm: Historiska museet.

Janse, Olov R.T. 1930. "Quelques antiquités chinoises d'un caractère Hallstattien." Bulletin of the Museum of Far Eastern Antiquities, vol. 2, pp. 187-220.

Janse, Olov R.T. 1931. "Un groupe de bronzes anciens propres à L'ExtrêmeAsie méridionale." Bulletin of the Museum of Far Eastern Antiquities, vol. 3, pp. 99-174. Stockholm.

Janse, Olov R.T. 1935a. "Breaking New Archaeological Ground in Indo-China." Illustrated London News, 13 July, pp. 50-54.

Janse, Olov R.T. 1935b. “The Mysterious Culture of Dong-Son.” Illustrated London News, 28 December, pp. 1172-75.

Janse, Olov R.T. 1935c. "Längs mandarinernas väg: Intryck från en färd genom Saïgon, staden som växt upp till en storstad på en mansålder.” Norrköpings Tidningar, 5 October.

Janse, Olov R.T. 1935d. "Vid Indokinas fornminnen och riviera." Norrköpings Tidningar, 12 October.

Janse, Olov R.T. 1935e. "Hanoi stöpsleven där österns och västerns kulturformer mötas och omformas." Norrköpings Tidningar, 30 November.

Janse, Olov R.T. 1935-36. "Rapport préliminaire d'une mission archéologique en Indochine auprès de l'École Française d'Extrême-Orient." Revue des arts asiatiques, vol. IX, pp. 144-153 \& 209-217, vol. X, pp. 42-52.

Janse, Olov R.T. 1936. "A la recherche des origines de la civilisation indochinoise." Le Monde Colonial Illustré, no. 451, Février, p. 40.

Janse, Olov R.T. 1937. "Han Dynasty Art as Developed in Indochina." Illustrated London News, 25 December, pp. 1142-1146.

Janse, Olov R.T. 1941. "An Archaeological Expedition to Indochina and the Philippines: Preliminary Report." Harvard Journal of Asiatic Studies, vol. 6 , pp. $247-267$.

Janse, Olov R.T. 1943. Some Methods of Japanese Penetration in French Indo-China Previous to the War. R \& A report, no.1279; O.S.S./State Department intelligence and research reports. Part I, Japan and its occupied territories during World War II. Washington, DC: National Government Publication. 
Janse, Olov R.T. 1944a. "Notes on Chinese Influences in the Philippines in Pre-Spanish times." Harvard Journal of Asiatic Studies, vol. 8, no. 1, pp. 34-62. Janse, Olov R.T. 1944b. The Peoples of French Indochina: War Background Studies, 19. Washington, DC: Smithsonian Institution.

Janse, Olov R.T. [Attributed; Anonymous] 1945. Joint Army-Navy Intelligence Study of Indochina: People and Government. October 1945. Janis 70. Chapter X. Published by The Joint Intelligence Study Publishing Board. Military Intelligence Division, G-2; Division of Naval Intelligence; Office of Assistant Chief of Air Staff, Intelligence; Office of Strategic Services; Office Chief of Engineers. Washington, DC.

Janse, Olov R.T. 1946. "Archaeology of the Philippine Islands." Annual Report, Washington, DC: Smithsonian Institution, pp. 345-360.

Janse, Olov R.T. 1947. Archaeological Research in Indo-China. Volume I: The District of Chiu-Chen During the Han Dynasty: General Considerations and Plates. Cambridge, Mass.: Harvard University Press.

Janse, Olov R.T. 1951. Archaeological Research in Indo-China. Volume II: The District of Chiu-Chen During the Han Dynasty: Description and Comparative Study of the Finds. Cambridge, Mass.: Harvard University Press.

Janse, Olov R.T. 1955. Spoken Swedish. No publisher. In the holdings of Kungliga biblioteket, Stockholm.

Janse, Olov R.T. 1958. "Dionysos i Indokina (including French version: "Dionysos au Viêt Nam")." Viking: Tidsskrift for norron arkeologi, vols. XXI/XXII, pp. $1-50$.

Janse, Olov R.T. 1958. Archaeological Research in Indo-China. Volume III: The Ancient Dwelling-site of Dông-so'n (Thanh Hoa, Annam): General Description and Plates. Bruges: St. Catherine Press.

Janse, Olov R.T. 1959. Ljusmannens Gåta: Arkeologiska upplevelser i Sydöstasien. Stockholm: Rabén \& Sjögren.

Janse, Olov R.T. 1959b. "Some Notes on the Sa-huỳnh Complex". Asian Perspectives, vol. 3, no. 2, Special Issue, "Sa-huỳnh Pottery Relationships in Southeast Asia" (1959), pp. 109-111.

Janse, Olov R.T. 1960-1961. "Rang Mahal, The Swedish Archaeological Expedition to India, 1952-1954 by Hanna Rydh, Holger Arbman, K. Gösta Eriksson." Review by Olov R.T. Janse. Harvard Journal of Asiatic Studies, vol. 23 , pp. $167-171$. 
Janse, Olov R.T. 1961. "Vietnam - Crossroad of Peoples and Civilisations." Asian Culture. A Quarterly Review [Saigon], vol. III, nos. 3-4, pp. 103-132.

Janse, Olov R.T. 2001 [1959]. Bi Mai Cua Cay Den Hinh Nguoi. Translation of original: Ljusmannens gåta. Hanoi: National History Museum.

Janse, Renée S. (ed.). 1952. Soviet Transportation and Communications: A Bibliography. Washington, DC: Library of Congress.

Jennings, Eric T. 2011. Imperial Heights: Dalat and the Making and Undoing of French Indochina. Berkeley: University of California Press.

Johansson, Perry. 2012. Saluting the Yellow Emperor: A Case of Swedish Sinography. Leiden: Brill.

Jordan, Robert S. 1984. "Boycott Diplomacy: The U. S., the U. N., and UNES CO.” Public Administration Review, vol. 44, no. 4 (July-August), pp. 283-291.

Kaeser, Marc-Antoine. 2002. "On the International Roots of Prehistory." $A n$ tiquity, vol. 76, no. 291, pp. 170-177.

Källén, Anna. 2014. "The Invisible Archaeologist: Letters from the UNESCO Secretariat 1946-1947." Journal of Social Archaeology, vol. 14, no. 3, pp. 384405 .

Källén, Anna. 2015. Stones Standing: Archaeology, Colonialism and Ecotourism in Northern Laos. Walnut Creek, CA: Left Coast Press.

Källén, Anna \& Hegardt, Johan. 2014. "A Cosmopolitan History of Archaeology: The Olov Janse Case." Bulletin of the History of Archaeology, vol. 24, no. 7, pp. 1-13.

Källén, Anna \& Hegardt, Johan. 2015. "Renées rop från arkivet.” In Larsson, Marianne et al. (eds.). Utkanter och marginaler: 31 texter om kulturhistoria. Stockholm: Nordiska Museets förlag, pp. 91-101.

Källén, Anna (ed.). 2019. Heritage and Borders. KVHAA Konferensserie 100. Stockholm: Vitterhetsakademien.

Kaminski, Theresa. 2016. Angels of the Underground: The American Women who Resisted the Japanese in the Philippines in World War II. New York: Oxford University Press.

Kamm, Margaret. 1940. "Mrs Olov Janse Assists Husband in Archaeology." Honolulu Star-Bulletin, 9 October.

Kanji Tawara. 2005. "The Olov Janse Collection." Bulletin of the Indo-Pacific Prehistory Association, vol. 25, pp. 139-140.

Kant, Immanuel. 1992 [1784]. "Svar på frågan: Vad är upplysning?”. In 
Östling, Brutus (ed.). Vad är upplysning? Kant, Foucault, Habermas, Mendelssohn, Heidegger (transl. Hallberg, Ulf Peter). Stockholm: Stehag: Symposion, pp. 27-36.

Kant, Immanuel. 2003 [1795]. Perpetual Peace: A Philosophical Sketch (transl. Humphrey, Ted). Indianapolis: Hackett Publishing Co.

Karlström, Anna \& Fiskesjö, Magnus (eds.). 2002. Glimpses of Southeast Asia: Exhibition Catalogue and Introduction to Southeast Asian Collections at the Museum of Far Eastern Antiquities, Stockholm. Stockholm: Östasiatiska Museet.

Kim Thúy. 2009. Ru. Montreal: Libre Expression.

Klindt-Jensen, Ole. A History of Scandinavian Archaeology. London: Thames \& Hudson.

Kohl, Philip L. \& Fawcett, Claire (eds.). 1996. Nationalism, Politics and the Practice of Archaeology. Cambridge: Cambridge University Press.

Länsstyrelsen Östergötland. 2002. Riksintresse: KE 38. Ljung, Ljungs socken, Linköpings kommun. Länsstyrelsen Östergötland: Kulturmiljöenheten.

Lenain, Géraldine. 2013. Monsieur Loo: Le roman d'un marchand d'art asiatique. Paris: Éditions Philippe Picquier.

Lewuillon, Serge. 2018. "L'homme sans quantités: Hubert et la sociologie historique." In Olivier, Laurent (ed.). La Mémoire et le Temps: L'œuvre transdisciplinaire d'Henri Hubert. Paris: Demopolis, pp. 151-184.

Liptak, Eugene. 2009. Office of Strategic Services 1942-45: The World War II Origins of the CIA. Oxford: Osprey Publishing.

Logevall, Fredrik 2012. Embers of War: The Fall of an Empire and the Making of America's Vietnam. New York: Random House.

Long Le 2011. “'Colonial' and 'Postcolonial' Views of Vietnam's Pre-history." SOJOURN, Journal of Social Issues in Southeast Asia, vol. 26, no. 1, pp. 128-148.

Lorre, Christine. 2015a. "Henri Hubert et l'archéologie de l'Asie du Sud-Est: Un moment de formation personnelle et d'échanges intellectuels." Bulletin de l'École française d'Extrême-Orient, vol. 101, pp. 31-54.

Lorre, Christine. 2015b. "Montrer, démontrer la Préhistoire: perspectives comparatistes et Préhistoire au musée d'Archéologie nationale de SaintGermain-en-Laye (1862-1927).” Antiquités nationales, vol. 46, pp. 141-154.

Lundbeck-Culot, Karin. 1997. "Frédéric VII, roi du Danemark, Napoléon III et l'archéologie. Les deux premiers donateurs du Musée des antiquités 
nationales de Saint-Germain-en-Laye.” Antiquités nationales, vol. 29, pp. 99-118.

Malleret, Louis. 1959. "La civilisation de Dong-son d'apres les recherches archeologiques de M. Olov Janse." France-Asie, vol 160-161, pp. 1197-1208.

Malmberg, Ernst \& Malmberg, Gustaf. 1943. En bok om Valdemarsvik. Norrköping: Östergötlands Dagblad.

Malmqvist, Göran. 1995. Bernhard Karlgren: Ett forskarporträtt. Stockholm: Norstedts Akademiska Förlag.

Masur, Matthew B. 2004. Hearts and Minds: Cultural Nation-Building in South Vietnam, 1954-1963. Diss. Ohio: Ohio State University.

Masur, Matthew. 2009. "Exhibiting Signs of Resistance: South Vietnam's Struggle for Legitimacy, 1954-1960." Diplomatic History, vol. 33, no. 2, pp. 293-313.

Mauss, Marcel. 1966 [1925]. The Gift: Forms and Functions of Exchange in Archaic Societies (orig. "Essai sur le don" in L'Année Sociologique). London: Cohen \& West Ltd.

McClintock, Anne. 1995. Imperial Leather: Race, Gender and Sexuality in the Colonial Contest. New York: Routledge.

Meskell, Lynn (ed.). 2009. Cosmopolitan Archaeologies. Durham: Duke University Press.

Meskell, Lynn. 2018. A Future in Ruins: UNESCO, World Heritage, and the Dream of Peace. Oxford: Oxford University Press.

Meyer, Karl E. \& Blair Brysac, Shareen. 2015. The China Collectors: America's Century-Long Hunt for Asian Art and Treasures. New York: Palgrave Macmillan.

Miyamoto, Kazuo. 2003. "The Chronology of Eastern Han Style Tombs in Thanh Hoa District Through the Olov Janse Collection (1938-1940).” In Karlström, Anna \& Källén, Anna (eds.). Fishbones and Glittering Emblems: Southeast Asian Archaeology 2002. Stockholm: Museum of Far Eastern Antiquities, pp. 181-191.

Montelius, Oscar. 1899. "Typologin eller utvecklingsläran tillämpad på det mänskliga arbetet." Svenska fornminnesföreningens tidskrift, vol. 10, pp. 237268.

Morton, Patricia A. 2000. Hybrid Modernities: Architecture and Representation at the 1931 Colonial Exposition, Paris. Cambridge, Mass.: Massachusetts Institute of Technology Press. 
Murray, Tim \& Evans, Chris (eds.). 2008. Histories of Archaeology: A Reader in the History of Archaeology. Oxford: Oxford University Press.

Mus, Paul. 1952. Review of Archaeological Research in Indo-China, by Olov Janse. Journal of the American Oriental Society, vol. 72, no. 2, pp. 88-94.

Musée d'Ethnographie. 1931. Instructions sommaires pour les collecteurs d'objets ethnographiques. Paris: Musée d'Ethnographie et Mission scientifique Dakar-Djibouti, Palais du Trocadéro.

Nerman, Birger. 1913. Studier över Svärges hedna litteratur. Uppsala: Uppsala University.

Nerman, Birger. 1927. "Ett bidrag till frågan om gånggrifttidens havsnivå vid Östergötland.” Fornvännen, vol. 22, pp. 247-250.

Nerman, Birger. 1945. "In memoriam: Oscar Almgren.” Fornvännen, vol. 40, pp. 359-361.

Nerman, Ture. 1948. Allt var ungt: Minne och redovisning. Stockholm: Kooperativa förbundets förlag.

Nerman, Ture. 1967. Sverige på glid. Stockholm: Andromeda.

Nguyen, Dinh Hoa. 1999. From the City Inside the Red River: A Cultural Memoir of Mid-century Vietnam. Jefferson, NC.: McFarland Publishing.

Ninkovich, Frank A. 1981. The Diplomacy of Ideas: U.S. Foreign Policy and Cultural Relations, 1938-1950. Cambridge: Cambridge University Press.

Nordström, Patrik. 2015. "Ordning-kaos-konflikt: Aktörer på Historiska museet.” In Grundberg, Malin et al. (eds.). Ett museum måste irritera: Fyra röster om Historiska museet. The Swedish History Museum, Studies 24. Stockholm: Historiska museet, pp. 21-123.

Norindr, Panivong. 1996. Phantasmatic Indochina. Durham: Duke University Press.

Olivier, Laurent (ed.). 2018. La Mémoire et le Temps: L'œuvre transdisciplinaire d'Henri Hubert. Paris: Demopolis.

Osgood, Kenneth A. \& Etheridge, Brian C. (eds.). 2010. The United States and Public Diplomacy: New Directions in Cultural and International History. Leiden: Brill.

Parmentier, Henri. 1918. "Le tombeau de Nghi-vê." Bulletin de l'École française d'Extrême-Orient, vol. XVIII, no. 10, pp. 1-7.

Parmentier, Henri. 1924. "Notes d'archéologie indochinoise: VII. Dépôts de jarres à Sa-huynh (Quáng-ngāi, Annam)." Bulletin de l'École française d'Extrême-Orient, vol. 24 , no. 1, pp. 325-343. 
Pompei, Gian Franco. 1972. "History of the Organization." In the Minds of Men: UNESCO 1946-1971. Paris: UNESCO.

Pratt, Mary-Louise. 2008. Imperial Eyes: Travel Writing and Transculturation (2nd ed.). New York: Routledge.

Price, David H. 1998. "Gregory Bateson and the OSS: World War II and Bateson's Assessment of Applied Anthropology." Human Organization, vol. 57, no. 4 , Winter, pp. 379-384.

Price, David H. 2008. Anthropological Intelligence: The Deployment and Neglect of American Anthropology in the Second World War. Durham: Duke University Press.

Prior, Ruth. 2003. "Pots from Tombs: A Study of Ceramics Excavated by Olov Janse Held in the Museum of Far Eastern Antiquities, Stockholm, and in the Peabody Museum, Boston.” In Karlström, Anna \& Källén, Anna (eds.). Fishbones and Glittering Emblems: South East Asian Archaeology 2002. Stockholm: Museum of Far Eastern Antiquities, pp. 191-203.

Proust, Clotilde. 2017a. "Les ateliers du Musée des Antiquités nationales: Aux origines de la restauration en archéologie." Unpublished Diss. Nanterre: École doctorale Archéologie (Paris) et Archéologies et sciences de l'Antiquité, 15 May.

Proust, Clotilde. 2017b. "Les ateliers du Musée des Antiquités nationales: Aux origines de la restauration en archéologie." Antiquités nationales, vol. 47, pp. 211-222.

Reinach, Salomon. 1922. “O.R. Janse: Le travail de l'or en Suède à l'époque mérovingienne: Études précédées d'un mémoire sur les solidi romains et byzantins trouvés en Suède." Revue archéologique, Cinquième série, vol. 15 (janvier-juin), p. 377.

Reinach, Salomon. 1928. Glozel: La découverte, la controverse, les enseignements. Paris: KRA éditeur.

Reischauer, Edwin O. 1957. “Serge Elisséeff - 英利世夫先生小傳." Harvard Journal of Asiatic Studies, vol. 20, nos. 1-2, pp. 1-35.

Ringborg, Edward. 1923. Bidrag till Norrköpingsindustriens historia, D. 2. Norrköping.

Rival, Laura. 2010. "What Sort of Anthropologist was Paul Rivet?" In Parkin, Robert \& de Sales, Anne (eds.). Out of the Study and Into the Field: Ethnographic Theory and Practice in French Anthropology. Oxford: Berghahn Books.

Robertson, George et al. (eds.). 1994. Travellers' Tales: Narratives of Home and Displacement. London: Routledge. 
Robinson, Marc (ed.). 1994. Altogether Elsewhere: Writers on Exile. London: Faber \& Faber.

Rydh, Hanna. 1959. Rang Mahal: The Swedish Archaeological Expedition to India. Acta Archaeologica Lundensia. Lund: Gleerups förlag.

Saada, Emmanuelle. 2002. "Race and Sociological Reason in the Republic: Inquiries on the Métis in the French Empire (1908-37)." International Sociology, vol. 17, no. 3, pp. 361-391.

Said, Edward. 2000. Reflections on Exile and Other Essays. Cambridge, Mass.: Harvard University Press.

Sarup, Madan. 1994. "Home and Identity." In Robertson, George et al. (eds.). Travellers' Tales: Narratives of Home and Displacement. London: Routledge, pp. 89-101.

Schwab, Catherine. 2008. La Collection Piette - Musée d'archéologie nationale, château de Saint-Germain-en-Laye. Paris: Réunion des Musées Nationaux.

Seligman, Charles Gabriel. 1927. "Henri Hubert." Man, vol. 27, p. 162.

Sewell, James Patrick. 2015 [1975]. UNESCO and World Politics: Engaging in International Relations. Princeton, NJ: Princeton University Press.

Seyhan, Azade. 2001. Writing Outside the Nation. Princeton, NJ: Princeton University Press.

Shumaker, Ruth. 1953. "Society: Janses' D.C. Mode of Life Contrast to Arduous Exploits Abroad." The Washington Times-Herald, 23 August.

Singh, J.P. 2018. "UNESCO: Scientific Humanism and its Impact on Multilateral Diplomacy." Global Policy, November, vol. 9, pp. 53-59.

Slomann, Wencke. 1955. "Haakon Shetelig (1877-1955)." Viking: Tidsskrift for norron arkeologi, vol. XIX, pp. v-ix.

Sluga, Glenda. 2010. "UNES CO and the (One) World of Julian Huxley." Journal of World History, vol. 21, no. 3, pp. 393-418.

Sluga, Glenda. 2013. Internationalism in the Age of Nationalism. Philadelphia: University of Pennsylvania Press.

Smith, Laurajane. 2006. The Uses of Heritage. London: Routledge.

Smith, Richard Harris. 2005 [1972]. OSS: The Secret History of America's First Central Intelligence Agency. Guilford, CT: The Lyons Press.

Smithsonian Institution. 1961. Art and Archeology of Vietnam: Asian Crossroad of Cultures. Smithsonian Publication 4430. Washington, DC: Smithsonian Institution. 
Solheim, Wilhelm G. II. 1959. "Introduction to Sa-huỳnh." Asian Perspectives, vol. 3 , no. 2 , pp. 97-108.

Solheim, Wilhelm G. II. 1960. "Vietnam." Asian Perspectives, vol. 4, nos. 1-2, pp. 63-65.

Solheim, Wilhelm G. II. 1969. "H. Otley Beyer.” Asian Perspectives, vol. XII, pp. $1-18$.

Solheim, Wilhelm G. II. 1984-85. “Olov R. T. Janse 1895-1985.” Asian Perspectives, vol. XXVI, no. 1, pp. 9-13.

Solheim, Wilhelm G. II. 1989. "A Brief History of the Dongson Concept." Asian Perspectives, vol. XXVIII, no. 1, pp. 23-30.

Solheim, Wilhelm G. II. 2002. "Reminiscences on Olov R.T. Janse.” In Karlström, Anna \& Fiskesjö, Magnus (eds.). Glimpses of Southeast Asia: Exhibition Catalogue and Introduction to Southeast Asian Collections at the Museum of Far Eastern Antiquities, Stockholm. Stockholm: Östasiatiska Museet, p. 8.

Solheim, Wilhelm G. II \& Hackenberg, Robert A. 1961. "The Importance of Anthropological Research to the Mekong Valley Project." France-Asie /Asia, vol. XVII, no. 169, pp. 2459-2474.

Steuber, Jason. 2006. "The Exhibition of Chinese Art at Burlington House, London, 1935-36." The Burlington Magazine, no. 148, August, pp. 528-536.

Stewart, Susan. 1993. On Longing: Narratives of the Miniature, The Gigantic, the Souvenir, the Collection. Durham: Duke University Press.

Stiegler, Bernard. 1998. Technics and Time, 1: The Fault of Epimetheus. Stanford: Stanford University Press.

Strenski, Ivan. 1987. "Henri Hubert, Racial Science and Political Myth." Journal of the History of Behavioural Sciences, vol. 21, pp. 353-367.

Stuart-Fox, Martin. 1997. A History of Laos. Cambridge: Cambridge University Press.

Sullivan, Walter. 1985. "Harold Coolidge, Expert on Exotic Mammals." The New York Times, 16 February.

Thomas, Julian. 2004. Archaeology and Modernity. London: Routledge.

Thordeman, Bengt. 1958. "Otto Janse 10/9 1867-3/3 1957: in memoriam." Fornvännen, vol. 53, pp. 72-74.

Thordeman, Bengt. 1973-1975. “Otto T. Janse." Svenskt biografiskt lexikon, vol. 20, p. 108.

Titchen, Sarah M. 1995. "On the Construction of Outstanding Universal Val- 
ue: UNESCO's World Heritage Convention and the Identification and Assessment of Cultural Places for Inclusion in the World Heritage List." Unpublished Diss. Canberra: Australian National University.

Tønnesson, Stein. 2010. Vietnam 1946: How the War Began. Berkeley: University of California Press.

Torpey, John. 2000. The Invention of the Passport: Surveillance, Citizenship and the State. Cambridge: Cambridge University Press.

Trigger, Bruce G. 1984. "Alternative Archaeologies: Nationalist, Colonialist, Imperialist." Man, New Series, Vol. 19:3, pp. 355-370.

Trigger, Bruce G. 1989. A History of Archaeological Thought. Cambridge: Cambridge University Press.

Trolle, Alice. 1944. De voro ett lysande följe. Stockholm: Medéns förlag.

Trinh T. Minh-ha. 1994. "Other than myself/My other self.” In Robertson, George et al. (eds.). Travellers' Tales: Narratives of Home and Displacement. London: Routledge, pp. 8-26.

Trinh T. Minh-ha. 2011. Elsewhere, Within Here: Immigration, Refugeeism and the Boundary Event. New York: Routledge.

Turtinen, Jan. 2006. Världsarvets villkor: Intressen, förhandlingar och bruk i internationell politik. Diss. Stockholm: Stockholm University.

Vahlquist, Staffan. n.d. “Ture Nerman (1886-1969).” Svenskt översättarlexikon. http://www.oversattarlexikon.se/artiklar/Ture_Nerman.

Valderrama, Fernando. 1995. A History of UNESCO. Paris: UNE SCO Publishing.

Walravens, Hartmut. 2002. Joseph Franz Rock (1884-1962): Berichte, Briefe und Dokumente des Botanikers, Sinologen und Nakhi-Forschers. Stuttgart: Franz Steiner Verlag.

Waters, C. Kenneth \& Van Helden, Albert (eds.). 1993. Julian Huxley: Biologist and Statesman of Science. College Station: Texas A\&M University Press.

Weber, Max. 1978. Economy and Society: An Outline of Interpretive Sociology. Berkeley: University of California Press.

Webart, Bozena. 2000. "Svar till Evert Baudou angående nationalismen i den svenska arkeologin under 1900-talet." Fornvännen, vol. 95, pp. 251-255.

Whitling, Frederick (ed.). 2014. Svensk antikforskning vid Medelhavet: Gustaf VI Adolf och fältarkeologi i historiskt perspektiv. Stockholm: Vitterhetsakademien. 
Willoquet, Gaston. 1961. Histoire des Philippines. Paris: Presses Universitaires de France.

Winks, Robin W. 1996 [1987]. Cloak and Gown: Scholars in the Secret War, 19391961. New Haven: Yale University Press.

Winter, Tim. 2015. "Heritage Diplomacy." International Journal of Heritage Studies, vol. 21, no. 10, pp. 997-1015.

Wolff, Leon. 1961. Little Brown Brother: How the United States Purchased and Pacified the Philippine Islands at the Century's Turn. Garden City, NY: Doubleday.

Wulf, Andrew James. 2015. U.S. International Exhibitions During the Cold War: Winning Hearts and Minds through Cultural Diplomacy. London: Rowman \& Littlefield.

Yoshinaga, Alvin et al. 2012. "Classifying Joseph Rock: Metamorphic, Conglomerate, and Sedimentary". In Glover, Denise M. et al. (eds.). Explorers and Scientists in China's Borderlands 1880-1950. Seattle: University of Washington Press, pp. 116-148. 


\section{ARCHIVES}

\section{France}

Collège de France, Paris

Fonds Marcel Mauss au Collège De France:

mauss-janse-0001a.pdf.

mauss-janse-0002.pdf.

mauss-janse--0005.pdf.

mauss-janse- 0006 .pdf

mauss-janse-॰o०8.pdf.

mauss-janse- 0016 .pdf.

mauss-janse-0023.pdf.

mauss-janse-0026.pdf.

mauss-janse-0027.pdf.

mauss-janse-0030.pdf.

mauss-janse-०031.pdf.

mauss-janse-0032.pdf.

mauss-janse-0033.pdf.

mauss-janse-०034.pdf.

École française d'Extrême-Orient (EFEO), Paris

We have visited this archive, but have not found any substantial material on Olov Janse.

Musée Cernuschi, Paris

Holds a large collection of artefacts and ceramics from Olov Janse's Indochina expeditions, but no official archive material.

Musée d'Archéologie nationale et Domaine national de Saint-Germain-en-Laye $(M A N)$

General Correspondence/Janse. 
Fonds Hubert/Correspondance dossiers/Dossier Janse.

Fonds Hubert/Correspondance non classé.

Correspondance/Hubert à Reinach.

Document from Le Directeur des Musées Nationaux et de l'École du Louvre, Salmon Reinach.

Fonds Hubert/Dossier personnel.

Musée Guimet, Paris

Holds a large collection of artefacts and ceramics from Olov Janse's Indochina exhibitions, but no official archive material.

Musée du Quai Branly, Paris

Collections number 1947.28 and 1947.40.

Collection number 1950.19 .

Collection number 1955.15.

UNESCO, Paris

Olov R. T. Janse personal file.

UNESCO/Cons.Exec/2e Sess/14/1947.

UNESCO/C/Admin. \& Jur/S.C.Ad. \& Fin. /12.

UNESCO/C/Admin. \& Jur/S.C.Ad. \& Fin. /17.

UNESCO/C/Admin. \& Jur.

\section{Sweden}

Antikvarisk-topografiska arkivet (ATA), Stockholm

Enskilda arkiv 59, Olov Janse. Arbetspapper vol. 2.

Nils Åbergs arkiv.

Sigurd Curmans arkiv, vol. 108.

Sigurd Curmans arkiv, vol. 115. F 2 b.

Sigurd Curmans arkiv, vol. 116. F 2 b.

Arbetarrörelsens arkiv och bibliotek (Swedish Labour Movement's Archive and Library), Stockholm

Ture Nerman 3.1.7. 
Ture Nerman 3.1.24.

Ture Nerman 3.1.46.

Gustavianums arkiv (Gustavianum Archive), Uppsala

Sune Lindqvist. Korrespondens med svenskar (F8 D:10).

Statens etnografiska museum (The Etnographic Museum), Stockholm

ID numbers $0312 ; 0525$.

Statens Etnografiska Museum. Inkl skrivelser:

Huvudserie 1934. E 1:7.

Huvudserie 1935. E 1:8.

Huvudserie 1936. E 1:9.

Huvudserie 1937. E 1:10.

Huvudserie 1938. E 1:11.

Huvudserie 1945. E 1:19.

Huvudserie 1946. E 1:20.

Huvudserie 1947. E 1:21.

Huvudserie 1948. E 1:22.

Huvudserie 1952. E 1:27.

Kungliga biblioteket (The National Library of Sweden), Stockholm

Joint Army-Navy Intelligence Study of Indochina: People and Government (22 A d Fol.).

Janse, Olov R.T. 1955. Spoken Swedish. No publisher.

Landsarkivet (Regional State Archives), Vadstena

Parish records, including infomation on births, deaths, and residence, for Norrköping and Ljung: Kv. Kannan 4 och 5 a: Hedvig församlingsbok 1916-21.

School records: Norrköpings Högre Allmänna Läroverk.

Norrköpings stadsarkiv (Norrköping City Archive), Norrköping

Architectural drawings of Thure Janse's factory and home.

Application for extension to Thure Janse's factory and home.

Christina Janse Petersson's donation of Thure Janse's family photographs and documents. 
Riksarkivet (Swedish National Archives), Stockholm

Birger Nerman:

Kartong 1. Korrespondens Brev I 1897-1922.

Kartong 1. Korrespondens Brev II 1923-1934.

Kartong 2. Korrespondens Brev II 1923-1934.

Kartong 3. Korrespondens Brev III 1935-1941.

Kartong 4. Korrespondens Brev IV 1942-1946.

Kartong 5. Korrespondens Brev 1947-1950.

Kartong 6. Korrespondens Brev 1950-1956.

Kartong 7. Korrespondens Brev 1957-1961.

Kartong 8. Korrespondens Brev 1962-1971.

Kartong 9. Korrespondens Brev Osorterade.

Kartong 10. Korrespondens X.

Parliamentary records and bills

- Kungl. Maj:ts proposition Nr 104. 1938. 1. Saml. Band. K. Maj:ts propositioner $\mathrm{Nr} 89-135$. C 8.

- Kungl. Maj:ts proposition Nr 104. Bihang till Riksdagens Protokoll vad Lagtima Riksdagen i Stockholm år 1938. Första samlingen Åttonde bandet. Kungl. Maj:ts propositioner nr 89-135.

- Riksdagens protokoll vid lagtima riksmötet år 1938. Första kammaren. Andra bandet. Nr 24-34. Nr 24.

- Riksdagens protokoll vid lagtima riksmötet år 1938. Andra kammaren. Andra bandet. $\mathrm{Nr}$ 20-28. $\mathrm{Nr} 24$.

- Riksdagens skrivelse Nr 171, p. 2. Bihang till Riksdagens protokoll vid Lagtima riksdagen i Stockholm år 1938. Fjortonde samlingen. Riksdagens skrivelser och förordnanden, nr 1-477.

Stockholms stadsarkiv (Stockholm City Archive), Stockholm

Olov \& Ronny Janse Banns- and Marriage Book: Lysnings- och vigselbok Hedvig Eleonora 6/11 1930.

Olov \& Ronny Janse Banns Certificate: Lysningsbevis 238.

Olov \& Ronny Janse Marriage Record: Vigselprotokoll 1199. 
Swedish Television Archive, Stockholm

Two DVD copies: Olov Janses filmer 40-05/2112-004-016. Olov Janses filmer, 40-05/2112-017-020. The second copy contains the OS S film.

Östasiatiska samlingarnas arkiv (The Museum of Far Eastern Antiquities Archive), Stockholm

Korrespondens 1928-1934.

Korrespondens 1929 E1A:3.

Korrespondens 1932 E1A:7.

Korrespondens 1936 E1A:13.

Korrespondens 1936-1938 E1A:15.

Korrespondens 1937-1938 E1A:16.

Korrespondens 1937-1938 E1A:17.

Uppsala universitets katalog, Carolina Rediviva (Uppsala University Library), Uppsala Uppsala universitets katalog, 40-41, H.T. 1913.

Uppsala universitets katalog, 92, V.T. 1915.

Uppsala universitets katalog, 92-93, V.T. 1916.

Uppsala universitets katalog, 85-86, H.T. 1916.

Uppsala universitets katalog. 88, V.T. 1917.

\section{$U S A$}

Library of Congress, Washington, DC

Library of Congress, Information Bulletin, 18-24 February 1947.

Library of Congress, Information Bulletin, 21-27 September 1948.

Office of the Secretary, The Librarian Director, Reference Department. Mrs.

Renée S. Janse, Bibliographer Air Information Section, Air Studies Division. Travel Report and Survey of Slavic Collections abroad 10 April-17

June 1950; Authority nos. 50-277.

National Anthropological Archives (NAA), Smithsonian Institution, Suitland, MD

Olov and Renée Janse's personal archive: Janse 2001-29. 
National Archives at College Park, MD

Records of the Office of Strategic Services (Record Group 226), Entry 92, Box 197.

Records of the Office of Strategic Services (Record Group 226) Entry 90, Box 19.

Records of the Office of Strategic Services (Record Group 226), Entry 92, Box 197.

OSS R\&A Report No. 1279, by Olov R.T. Janse, 31 August 1943.

Freer Gallery of Art \& Arthur M. Sackler Gallery, Washington, DC

Holds information about photos bought from Olov Janse in 1947: $171 \mathrm{small}+$

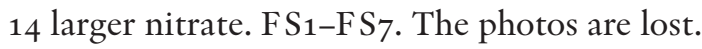

$35+16$ in glass plates, new paper wrapping. From Cambodia and China.

Brown boxes. 1950. F S10-F S19.

Small box with Eastman film holds glass plates (might not be by Janse). On the box a note reads: "developed before 1936". FS8-F S9.

The Galleries also have some of Olov Janse's library books.

Harvard University Archives, Cambridge, Mass.

Records of American Defense, Harvard Group. Call number 3139, Box 76.

Harvard-Yenching Institute, Cambridge, Mass.

Harvard University - Harvard College Library Harvard-Yenching Library/ Harvard-Yenching Institute Archives: Janse, Olov Robert T. Publication Projects and Expeditions. Correspondence, 1938-1940. Harvard-Yenching Institute, Cambridge, Mass.

Harvard University - Harvard College Library - Harvard-Yenching Library/ Harvard-Yenching Institute Archives. Janse, Olov Robert T. Publication Projects and Expeditions. Correspondence, 1941-1943. Harvard-Yenching Institute, Cambridge, Mass.

Peabody Museum, Cambridge, Mass.

Peabody Museum Archive, XF_41--63_01.

Peabody Museum Archive, XF_41-63_02.

Peabody Museum Archive, XF_41-63_03.

Peabody Museum Archive, XF_41-63_04.

1. Drawings. D 17. Folder: Archaeological Research 1. 


\section{Vietnam}

École française d'Extrême-Orient (EFEO), Hanoi

Cahiers de l'École française d'Extrême-Orient (Hanoi), no. 14. Premier trimestre de 1938.

Museum of History, Ho Chi Minh City

Objects from Olov Janse's expeditions to Indochina are stored at the museum, but no official archive material.

National Library of Vietnam, Hanoi

Holds Olov Janse's "Le Style du Houai" - a booklet published in 1934, with Janse's dedication on the frontispiece: "A Monsieur le Gouverneur Général en témoignage de profonde gratitude. O Janse". The booklet bears the stamp of "la bibliothèque de Pierre Pasquier".

Vietnam National Museum of History, Hanoi

Objects from Olov Janse's expeditions to Indochina are stored at the museum. Database in Vietnamese, but no official archive material. 


\section{PICTURE SOURCES}

Fig. $\circ$ (cover photograph). Olov Janse, probably in the 1960 s. He holds a copy of his Archaeological Research in Indo-China. Courtesy of Olov and Renée Janse papers, National Anthropological Archives, Smithsonian Institution.

Fig. 1. Courtesy of Olov and Renée Janse papers, National Anthropological Archives, Smithsonian Institution.

Fig. 2. Photo by Anna Källén. Courtesy of Olov and Renée Janse papers,

National Anthropological Archives, Smithsonian Institution.

Fig. 3. Reproduced from Carlsson \& Ryding 2006.

Fig. 4. Courtesy of Per Janse.

Fig. 5. Courtesy of Christina Janse Petersson.

Fig. 6. Courtesy of Patrik Nordström.

Fig. 7. Courtesy of Norrköping City Archive.

Fig. 8. Architectural drawings from Norrköpings Stadsarkiv.

Fig. 9-10. Courtesy of Per Janse.

Fig. 11. https://gratiscvmallar.com/uppsala-karta/, accessed 6 December 2020.

Fig. 12. Courtesy of Postnord. (C) PostNord Frimärken.

Fig. 13. ATA: Olov Janse. Enskilda arkiv 59. Arbetspapper vol. 2.

Fig. 14. Photo by Olof Palme. Uppsala University Library.

Fig. 15-16. Courtesy of Olov and Renée Janse papers, National Anthropological Archives, Smithsonian Institution.

Fig. 17. Photo (C) MAN / Loïc Hamon.

Fig. 18. Courtesy of Olov and Renée Janse papers, National Anthropological Archives, Smithsonian Institution.

Fig. 19. Photo by Johannes Bøe. Courtesy of Olov and Renée Janse papers, National Anthropological Archives, Smithsonian Institution.

Figs. 20-23. Courtesy of Olov and Renée Janse papers, National Anthropological Archives, Smithsonian Institution.

Fig. 24. Photo by Anna Källén.

Fig. 25. Courtesy of Christina Janse Petersson. 
Fig. 26. Postcard published by Granbergs Konstindustri Aktiebolags Förlag, Stockholm, Sweden.

Figs. 27-28. Courtesy of Per Janse.

Fig. 29. Courtesy of Olov and Renée Janse papers, National Anthropological Archives, Smithsonian Institution.

Figs. 30-31. Photos by Olov Janse. Courtesy of Olov and Renée Janse papers, National Anthropological Archives, Smithsonian Institution.

Fig. 32. Courtesy of Olov and Renée Janse papers, National Anthropological Archives, Smithsonian Institution.

Figs. 33, 34a and 34b. Photo by Olov Janse. Courtesy of Olov and Renée Janse papers, National Anthropological Archives, Smithsonian Institution.

Figs. 35-39. Courtesy of Olov and Renée Janse papers, National Anthropological Archives, Smithsonian Institution.

Fig. 40. Photo by Johan Hegardt.

Figs. 41-46. Courtesy of Olov and Renée Janse papers, National Anthropological Archives, Smithsonian Institution.

Fig. 47. Map in Janse 1951:323. Photo by Anna Källén.

Fig. 48. Courtesy of the Peabody Museum of Archaeology and Ethnology, Harvard University, PM65-41-60/259.17

Fig. 49. Arbetarrörelsens arkiv och bibliotek. Ture Nerman 3.1.7. Photo by Johan Hegardt.

Fig. 50. Photo by Olov Janse. Courtesy of Olov and Renée Janse papers, National Anthropological Archives, Smithsonian Institution.

Fig. 51. Arbetarrörelsens arkiv och bibliotek. Ture Nerman 3.1.7. Photo by Johan Hegardt.

Figs. 52-53. Courtesy of Olov and Renée Janse papers, National Anthropological Archives, Smithsonian Institution.

Fig. 54. Courtesy of Harvard-Yenching Institute.

Fig. 55. Courtesy of the Peabody Museum of Archaeology and Ethnology, Harvard University, PM65-41-60/259.8.

Figs. 56-59. Courtesy of Olov and Renée Janse papers, National Anthropological Archives, Smithsonian Institution.

Fig. 60. Courtesy of Harvard-Yenching Institute.

Fig. 61. Photo by Olov Janse 1939. Courtesy of Olov and Renée Janse papers, National Anthropological Archives, Smithsonian Institution. 
Figs. 62-64. Courtesy of Olov and Renée Janse papers, National Anthropological Archives, Smithsonian Institution.

Fig. 65. Still from film, edited by Ray Kellogg at the OS S. Courtesy of the Swedish Television Archive. (C) SVT Arkiv.

Fig. 66. Still from film. Courtesy of the Swedish Television Archive. (C) SVT Arkiv.

Fig. 67. Photo by Anna Källén. Courtesy of Olov and Renée Janse papers, National Anthropological Archives, Smithsonian Institution.

Figs. 68-71. Courtesy of Olov and Renée Janse papers, National Anthropological Archives, Smithsonian Institution.

Figs. 72-73. Courtesy of Per Janse.

Fig. 74. Photographer unknown. Courtesy of Per Janse.

Fig. 75. Courtesy of Per Janse.

Figs. 76-77. Courtesy of Olov and Renée Janse papers, National Anthropological Archives, Smithsonian Institution.

Fig. 78. Courtesy of Archiv der Evangelischen Kirche im Rheinland.

Figs. 79-81. Courtesy of Olov and Renée Janse papers, National Anthropological Archives, Smithsonian Institution.

Fig. 82. Photo by Johan Hegardt.

Fig. 83. Courtesy of Per Janse.

Figs. 84-86. Photos by Johan Hegardt.

Fig. 87. Photo by Anne Fort. Courtesy of Musée Cernuschi.

Fig. 88. Courtesy of Musée Guimet.

Fig. 89. Photo by Katarina Nimmervoll, The Swedish History Museum/SHM (CC BY). 


\section{INDEX OF INSTITUTIONS}

Board of Economic Warfare 318

Buffalo Science Museum 18, 134, 231, 232, $243,245,355$

Cernuschi Museum 7, 14, 18, 118, 121, $122,136,137,138,156,163,174$, 180-188, 190, 217, 453-456, 458, 459, 461

Cham Museum at Tourane 326

Collège de France 8,76

École du Louvre 17, 85, 98, 99, 100, 101, $102,104,128$

École française d'Extrême-Orient (EFEO) $8,17,18,74,138,139,147,150-154$, $157,171,174,184,193,196,197$, $200,201,210,225,229,238,239$, $240,242,246,251,252,260,261$, $265,266,269,274,279,284,297$, $327,362,384,402-405,451,460$

École pratique des hautes études (EPHE) 72, 76, 97, 98, 99, 109

EFEO see École française d'Extrême-Orient (EFEO)

EPHE see École pratique des hautes études (EPHE)

Ethnographic Museum in Stockholm 139, $143,147,156,183,194,209,223$, $45^{8}$

Fogg Museum 18, 236, 237, 242, 243, 283, 302,303

Guimet Museum 8, 18, 121, 122, 190, $200,229,238,355,356,406,427$, 455,461

Harvard University 18, 20, 135, 232-239, 243, 271, 272, 283, 288, 294, 299, 300-304, 307, 308, 316-321, 334, $344,367,369,370,372,378,380$, $386,397,398,407,434,456$

Harvard-Yenching Institute $8,14,18$, $133,134,192,233-243,246-255$, $258,259,260,264,265,266,268$, $271,272,274,282,283,284,288$, 290-303, 370, 415, 416, 456, 457

Historiska museet see Swedish History Museum

History Museum, Saigon, Vietnam 8, 20, $271,303,415,456,460$

ICOM $118,187,356,362$
II IC see International Institute of Intellectual Co-operation (IIIC)

International Institute of Intellectual Co-operation (IIIC) 343, 344, $346,348,356,362$

League of Nations 343,346

Library of Congress 19, 25, 346, 360, 372, $373,377,382,383,397,418,442$

Louvre $82,103,117,372$

Lund University $30,54,57,58,245$

Michigan University 398

Morale Operations (MO), part of Office of Strategic Services (OSS) 318, $320,333,334$

Musée Blanchard de la Brosse 145, 271, $294,303,415,460$

Musée Cernuschi see Cernuschi Museum

Musée de l'Homme 102, 149, 457

Musée des antiquités nationales 17,25 , $73,75,78-81,83-87,89,90,92,94$, 96, 97, 99, 101, 104, 107, 108, 109, $115,116,136,137,226,426,439$

Musée d'ethnographie de Trocadéro (MET) 122, 139, 187, 457

Musée du Cinquantenaire 139

Musée Louis Finot 157, 163, 169, 174, $201,239,242,260,294,327,450$, 455,459

Museum of Comparative Zoology 320

Museum of Far Eastern Antiquities (MFEA) 7, 18, 114, 115, 116, 118, $133,157,163,187,190,191,193$, 209, 210, 211-219, 223, 225, 232, $432,433,443,455,456$

NAA see National Anthropological Archives (NAA)

National Anthropological Archives (NAA) $8,22,64,86,99,123,133,137,138$, $139,170,180,189,190,193,211$, $251,274,294,296,302,312,318$, $322,323,346,348-352,354-362$, $365,367,370,372-377,380,381$, $386,391,395,397,398,400,401$, $405,407,412,414,423,427,445$, 462,463

National Board of Antiquities, India 398 
National Board of Antiquities, Sweden $89,90,108$

National History Museum, Hanoi, Vietnam $8,21,162,163,167,170,239$, $327,450,455,459,460,461$

National Library of Sweden 322, 333, 486

Nationalmuseum see National Museum in Stockholm

National Museum in Stockholm 59, 60, $75,91,111,113$

National Museum of Singapore 8, 325, 457

National Museums of World Culture 139

NATO 385, 387, 388, 449

Nordic Museum 71, 316

Nordiska museet see Nordic Museum

Office of Strategic Services (OSS) 18, 19, $23,25,312,316,318-325,330-335$, $340,342,344,348,352,353,354$, $360,364,365,366,372,385,389$, $395,396,402,422,424,427,439$, 442

Peabody Museum 8, 133, 242, 243, 272, $301,303,304,380,386,397,412$, $415,416,456,457,460$

Raffles Museum 272, 325, 457

Research \& Analysis (R\&A), part of Office of Strategic Services (OSS) 320, 321, 334

Royal Swedish Academy of Letters, History and Antiquities 45, 58, 59, 69, $80,81,89,90,91,95,212,216,217$ $218,219,244,316,416,444$

Saigon University 398

Salle de Mars 75, 82, 86, 113, 439

SEATO 388
Smithsonian Institution 8, 20, 22, 133 , $237,277,279,283,333,334,381$, $382,394,395,401,410,411,412$, $415,423,462,463$

Sorbonne $17,72,73,76,96,97,98,102$, $128,344,372,442$

Statens museer för världskultur see National Museums of World Culture

State's East Asian collection see Museum of Far Eastern Antiquities (MFEA)

State's Museum of History, Stockholm, Sweden 7, 17, 20, 25, 30, 31, 41, 44, $59,62,63,75,80,86,87,89,90$, $91,92,107-113,214,215,245,426$, $427,450,461,462,463$

St Thomas University 294

Swedish History Museum 7, 17, 20, 25, $30,31,41,44,87,89,90,91,92$, $107,108,110,111,112,214,215$, $426,427,462,463$

UNESCO 8, 13, 14, 15, 19, 25, 304, 323, 343-366, 369, 371, 372, 382, 407, $409,426,427,439,442,445$

United Nations (UN) 19, 343, 344, 346, $347,352,353,385,403,409$

Uppsala University 17, 29, 54, 57, 92, 213, 215

US Department of State 12, 19, 25, 318, $340,342,348,353,364,365,372$, $381,388,395,396,415,424,427$, 439,442

Vitterhetsakademien see Royal Swedish Academy of Letters, History and Antiquities

Östasiatiska museet see Museum of Far Eastern Antiquities (MFEA)

Östasiatiska samlingarna see Museum of Far Eastern Antiquities (MFEA)

Baguio 295

Baltimore 391, 412

Bangkok 398

Basilan Island 285, 286

Batangas 275, 276, 277, 281, 282, 284, 285

Bac Ninh 150, 151, 152, 323 
Bergen 48, 49, 72, 81

Berlin 107, 114, 115, 312, 313, 407

Bim Son 210, 211, 255, 256, 259, 301

Blidö 128, 245, 382, 449

Bohelebung 285

Boston, MA 262, 301-304, 313, 332, 370, 408, 418

Boulogne-sur-Mer 68

Brussels 107, 139, 398, 399, 412, 441

Buffalo, NY 18, 134, 231, 232, 243, 245, $246,247,258,307,355$

Büchenwald 359

Calatagan 18, 281, 282, 283, 285, 290, 291, 293, 294

Cambridge, MA 8, 18, 134, 135, 232, 233, $300,301,302,415$

Carnac 63

Charente 88

Chau-rê (Châu R'ê) 261, 262, 264, 265, 271,301

Cherbourg 361

Chesapeake Bay, MD 382, 390

Chiu-chen 175

Christiania see Oslo

Clermont-Ferrand 104

Có-dinh 163

Cologne $68,107,109$

Colombo 144, 324, 325

Cove Point 367, 382, 418, 449

Cua-tung 326

Dai-khoi 201

Dalat 261-266, 295, 297

Dien Bien Phu 388, 390

Djibouti 140-143, 145, 435, 436

Dong-son see Dong Son

Dong Son 18, 63, 133, 136, 156, 157, 159, $160-163,167,173,175,176,177$, $179,184,185,193,196,197,200$, 201, 202, 204, 205, 209, 240, 241, $243,249,251,252,254,266,274$, $277,293,301,326,327,330,393$, $400,401,402,451,455,460,462$, 464,477

Dorpat 87,90

Dumbarton Oaks 383

Dunghuang Caves 236, 237

Ekaterinodar see Krasnodar

Eskilstuna 92

Fort Lauderdale 390
Fort Stotsenburg 286, 287, 296, 300

Fridensberg 33

Georgetown 397

Glozel 103-108, 136, 440, 443

Gothenburg 54, 211, 214

Grodno 123

Gryt 107

Grönvik 449

Hannover 107

Hannäs 107

Hanoi $8,11,17,18,21,74,113,134,138$, $147,148,150-154,157,162,163$, $167,169,170,174,182,185,195$, $197,200,201,207,210,222,225$, $226,228,229,239,240,246,248$, $258,260,266,268,269,271,284$, $294,317,327,333,362,384,385$, $389,404,434,450,451,455,459$, $460,461,464$

Harvard, MA 294, 299, 300, 308, 313, $408,412,418,434,441$

Helsinki 383

Hiroshima 343

Hoa-binh $173,327,328$

Hoà-chung 158, 196, 197, 198, 253

Ho Chi Minh City see Saigon

Honolulu 134, 231, 267, 298, 299, 300, 307

Hué 389, 401, 412

Häradshammar 107

Kandy 140, 144

Kay Tomas 283, 292, 293

Kiel 109

Klockrike 107

Kobe 231, 247, 248, 272, 297

Kongsvinger 48

Kota Tinggi 272, 288, 301

Krasnodar 17, 124, 125, 127, 446

Kummelby 69

Kvicksund 92

Lach-truong $163,164,165,167,168,169$, $173,177,182,185,193,195,196$, $197,235,323,384,401,450,451$, 453

Lahore 398

Lamitan 285

La Quina 88,90

Liesle 68

$\operatorname{Lim} 152,153,154,156$ 
Limoges 117

Ljung 32, 33, 35, 441, 446

London 112, 114, 115, 119, 183, 189, 190, $249,255,343,353,415$

Los Angeles 231

Lung-prao 235, 242

Manila 134, 272-275, 277, 280-283, 285, $286,287,291-297,300,307,434$

Man-thôn 250, 252-255

Marseille 17, 122, 140, 171, 194, 330

Metz 359

Moscow 125, 446

Nagasaki 343

Naples 383, 392

Neuilly $117,354,355$

New Delhi 398

New York 18, 119, 294, 302, 332, 383, 388, $412,418,448$

Nghi-vê 154, 155, 156

Ngoc-lac 202

Nha-trang 148, 261

Nho-Quan 196

Nord-Annam 170-173, 184

Norrköping 7, 15, 17, 24, 31-35, 39-42, $44-48,53,54,61,64,67,69,70,77$, $80,81,184,283,417,425,437,441$, $444,445,446$

Oc Eo 168, 393, 403, 404, 408, 411, 412, 413

Oslo 58, 81, 391

Paris $8,17,18,19,25,32,45,58,65,67$, $68,70,72,73,76,77,78,80,81$, 85-89, 93-103, 106-109, 114-119, $121,122,123,128,134,136,138$, $139,140,153,163,170,171,174$, $180,181,183-193,195,200,207$, 209-212, 214, 216, 217, 219, 226, $227,229,232,233,238,241,262$, $272,280,281,287,296,304$, $307,311,314,323,331,332,335$, 344-349, 353, 354, 355, 358, 359, $361,367,369,372,374,375,382$, $383,391,396,398,406,415,417$, $427,430,432,434,440-443,445$, $449,455,457,458,459,461$

Penagpatayan 282, 292, 293

Phan-rang 261, 264, 265

Philadelphia, PA 243, 412, 418

Phnom Penh 147, 170, 459
Phu-khuong 261, 269, 270

Port Said 141, 142, 143, 145, 435, 436

Pulong Bacao 283, 292, 293

Quang-xu'o'ng 196, 197, 205

Rekane 92

Reykjavik 50

Rio de Janeiro 374

Rome 383, 392, 415, 431

Sa Huynh 133, 260, 261, 264, 268, 269, $270,271,274,288,301,303,456$

Saigon $8,17,19,20,28,41,43,45,52,64$, $122,134,140,144,147,148,150$, $151,171,172,173,184,194,195$, 229, 231, 248, 271, 272, 294, 303, $324,325,326,330,386,389,394$, $395,396,398,400-408,411-416$, $420,423,427,434,456,460$

Saint Germain 81, 87, 136

Samrong Sen 169, 170, 229, 235, 242, 455, $45^{8}$

Sam Son 163, 164, 196, 323, 451

San Francisco 18, 116, 180, 231, 247, 300

Shanghai 119, 231, 272

Sigtuna 66

Singapore $8,140,272,325,326,330,457$

Skagshamn 107, 128, 183, 190, 449

Skanör 107

Skärkind 107

Solna 447

Stockholm 7, 9, 17, 18, 21, 30, 54, 59, 60, $62,65,66,67,71,75,77,80,81$, $82,84-90,92,95,96,99,104,107$, $108,109,113,114,116,120,123$, $125,127,128,130,133,134,136$, $137,139,143,147,156,157,163$, $168,181,183,184,186,187,190$, 192, 194, 207, 209, 210, 211, 213, $217,220-224,225,228,232,233$, 239, 243, 245, 266, 272, 313, 314, $316,322,333,374,382,383,387$, $417,421,430,434,441,446-450$, $455,458,459,462,486$

St Petersburg 233

Sundsvall 45

Säter $44,45,52,62$

Söderköping $31,445,446$

Tam-thô 205, 206, 207, 210, 248, 249, $25^{2}, 255,301,393,45^{1}$

Taxila 398 
Thanh Hoa 8, 151, 156, 157, 158, 163, 168, 173, 175, 195, 196, 197, 201, $203,205,209,211,226,229,235$, $248-252,255,259,260,261,266$, $267,268,274,301,317,326,327$, $355,448,449,450,451$

Tho-Dai 196

Tho-xuân 249

Thung-Thôn 196

Tinh-tuc 207, 225-229, 328, 329, 330

Tonkin $145,151,156,170-173,184,197$, $218,223,224,226,235,239$, $255,266,267,298,301,317,323$, 327-330

Tonle Sap 170

Toronto 167

Tortoise Island 229, 230, 231

Trang-long 261, 270

Trier 109

Trullhalsar 69

Uppsala $17,25,29,31,39,40,44,45,47$, $48,51,53-57,59,61-69,77-80,92$, $213,215,383$

\section{INDEX OF PERSONS}

Acheson, Dean 384,386

Alexander the Great 393,398

Alexandrov, Grigorij 127

Almgren, Oscar 25, 44, 45, 57, 59, 62, 63, $64,66,67,71,92,98$

Althin, Margit 425

Andersson, Bengt Ludvig 40, 445

Andersson, Johan Gunnar 91, 113, 114, $115,116,118,120,136,137,157$, $187,189,190,191,193,209,210$, 211, 213, 214-225, 228, 229, 239, $244,323,430,432,433,440,441$, 455

Andersson, Signe Karolina (married Janse) $40,124,445$

Andersson, Thure Ludvig $4 \circ$

Arne, Ture 71, 93

Audollent, Auguste 104

Bagge, Axel 91, 92, 248, 462, 463

Barker, Joseph R. 287, 296, 300
Valdemarsvik 29, 31, 107, 128, 183, 446, 449

Van-trai 259, 301

Versailles 72

Vichy 103,105

Vienna 415

Villambis 129

Vincennes 129, 133, 137

Washington, DC 8, 19, 20, 22, 26, 189, $243,313,318,321,322,330,344$, $346,359,360,367,368,369,372$, $375,379-384,386,390,391,394$, $397,405,408,410-415,421,423$, $425,448,45^{\circ}$

Yên-bien 196, 205

Yunnan 11, 12, 115, 149, 150, 229, 323, $329,330,435,436$

Yunnan-fu 11, 12, 115, 149, 150, 435, 436

Zamboanga 285

Örebro 33

Östhammar 449

Bartky, Sandra Lee 377,378

Bastide, Charles 226, 227, 328, 330

Bateson, Gregory 321

Baxter, Glen 416

Begg, Thomas 394

Bell, Duncan 13

Benjamin, Walter 425

Benton, William $35^{\circ}$

Bergeaud, Camille 401, 405

Beyer, Henry Otley 18, 273-281, 285, 295, 300

Bezacier, Louis 151

Bhabha, Homi 441

Bloch, Fernand 120

Blum, Léon 193

Bonnard, Pierre 117

Bourdelle, Antoine 118

Bowles, Chester 350, $35^{1}$

Bradsher, Greg 317

Breuil, Henri (Abbé) 103, 104, 105 
Brévié, Jules 210, 211, 255

Brew, John Otis 380, 386, 397, 412, 416, 456

Broca, Paul 149

Brøgger, Anton Wilhelm 72

Bøe, Johannes 93

Caffieri, Hector 117

Carpeaux, Jean-Baptiste 117

Celsius, Anders 54

Cernuschi, Henri 121, 138

Christina, Princess 378

Chung, Mr 152

Churchill Humphries, Mary 354

Claeys, Jean-Yves 151, 171, 354

Cognacq, Ernest 118

Cognacq, Gabriel 118, 122, 139, 354, 430, 433

Cognacq-Jaÿ, Louise 118

Colani, Madeleine 151, 224, 225, 269, 270,274

Compton, Arthur H. 350,351

Condominas, Georges 398

Conklin, Alice 61, 93, 102, 122, 149, 179, $431,436,440$

Coolidge, Harold J. 231, 318, 319, 320

Coolidge, Harold Jefferson 319

Craig, Molly 298, 299

Crown Prince see Gustaf Adolf, Crown Prince of Sweden

Cull, Nicholas J. 340

Cuno, James 426

Curman, Brita 96

Curman, Sigurd 90, 91, 92, 93, 96, 106, $108,109,215,216,218-221,228$, 440

Coedès, George 138, 151, 152, 157, 173, $184,210,218,222,224,225,229$, $238-242,246,248,252,261,266$, $269,294,327,354,356,357,362$

Daniels, Roger 306, 307

Darwin, Charles 61, 62

David-Weill, David 114, 116, 117, 118, 120, $122,138,354,355,356,390,433$

Degas, Edgar 117

Diem, Ngo Dinh 381, 389, 393, 394, 395, $396,400,401,406,411-414,419$, 420,423

Dobray, Liubov 124
Dong, Nguyen Xuan see Nguyen Xuan

Dong

Donovan, William Joseph "Wild Bill" $318,319,320,389$

Dorf, Vivian 244

Douglas, William O. 389

Doumer, Paul 146, 147

Du Bois, Cora 321

Dulles, John Foster 388, 393, 394, 396

Du Phuoc Long 394

Dupon, Pierre 151

Durkheim, Émile $72-75,431$

Dussaud, René 72, 76, 103-106

Eckhoff, Emil 31

Eckhoff Leijonhufvud, Märta Sofia 31

Ehrensvärd, Albert 97, 442

Einstein, Albert 303, 307

Eisenhower, Dwight 387,388

Elisséeff, Serge 18, 134, 192, 232-241, 243, $246-255,258-262,264-268,271$, $272,274,282,283,284,287-293$, 295-302, 440

Elisséeff, Vera 243, 246

Engström, Albert 51

Ésperandieu, Émile 104

Esteban, $\operatorname{Mr}$ 276, 277, 278

von Fersen, Axel 32

Fabian, Johannes 150

Foucault, Michel 58

Fournier, Pierre 181

Fradin, Émile 103

Frederik VII, King of Denmark 86

Friedmann, Jean 374, 375

Fries, Ellen 54

Gauguin, Paul 117

Gelb, Leslie 419

Gélinas, André 398

Godart, Justin 197, 198

Goloubew, Victor 151, 157, 173, 184, 200, 464

Gregory, Anne 406

Gregory, Gene 406

Grousset, Ginette 354

Grousset, René 114, 118, 120, 121, 122, $136,137,138,182,190,227,354$, $356,357,359,383,384,390,430$, $431,432,433,453$

Guiffrey, Jean 82

Gustaf Adolf, Crown Prince of Sweden 
$62,95,114,116,163,186,187,188$, 191, 192, 193, 217, 222, 244, 322, 433,455

Gustaf V I Adolf, King of Sweden 455

Gyldenstolpe, Carl August 32

Gyldenstolpe, Louise 32, 33

Hackin, Joseph 139

Hall, Charles Martin 123, 232, 236, 237, 301,302

Hamlin, Chauncey 231, 245, 355, 356, 362

Harrell, Stevan 437

Hartt, Arthur 369, 370, 371, 374, 418

Hartt, Augusta 369, 370, 371, 374, 418

Havet, Jacques 347

Hedblom, Nora (married Nerman) 80, 127

Hellström, Anders 217

Henri-Martin, Léon 88

Hermanos, Maxime Lévy 281

Hester, Evett D. 276, 277, 279

Hildebrand, Bror Emil 58, 59, 60, 62

Hildebrand, Hans 59-62, 65

Hitler, Adolf 128, 312, 387

Ho Chi Minh 303, 331, 332, 333, 381, 385, $386,389,393,414,419,425$

Houdon, Jean-Antoine 117

Hubert, Henri 17, 25, 72-78, 80-104, 107, $108,109,113-116,122,136,137$, $157,177,204,205,209,226,427$, $430,431,432,439,441,462$

Huxley, Julian 347, 351, 352, 357

Izikowitz, Karl Gustav 214

Janse, Ann-Mari 30, 124

Janse, Carl 28

Janse, Carl Otto 449

Janse, Emma 29

Janse, Erik 28

Janse, Erik Johan 28, 31

Janse, Gustaf 28, 390

Janse, Johan 28

Janse, Johanna (born Johansdotter) 28, 31 Janse, Nils Harald Thure 33

Janse, Otto 17, 28, 30, 31, 40, 41, 42, 62, $64,89,90,109,124,390,426,446$, 451

Janse, Per 22, 30, 124, 447

Janse, Renée/Ronny 9, 11, 17, 19-26, 113, $118,120,122-130,133,134,137$, $140,147,151,156,163,164,171$,
$180,181,183,186,188,189,191$, 192, 193, 197, 198, 199, 206, 207, $211,225,226,231,232,233,243$, $244,248,256,260,262,263,265$, $266,268,272,273,275,276,280$, 281, 282, 285, 288, 291, 293, 294, $295,297,299,300,301,304,306-$ $313,315-318,322-329,333,342$, $343,346,348,349,350,353,354$, $355,358-362,365,367,369-379$, $381,382,383,390,391,394,397$, $407,408,410,415,418,420,421$, $429,435,441,444,446-45^{2}, 462$, 463,464

Janse, Signe see Andersson, Signe Karolina (married Janse)

Janse, Theresia (married Karlholm) 29

Janse, Thure $15,24,28,31,33-36,39,40$, $124,283,445,446,447$

Jaujard, Jacques 357

Jefferson, Thomas 319, 385

Jennings, Eric 262

Johnson, Lyndon B. 414

Kaminski, Theresa 280

Kant, Immanuel 341, 342, 353, 364, 365

Karlbeck, Orvar 114, 115

Karlgren, Bernhard 211-225, 228, 229, 244

Karpelès, Suzanne 147, 170, 459

Kellogg, Ray 323, 324, 325

Kennedy, John F. 389, 414, 419, 420

Khrushchev, Nikita 393

Kidder, Mrs 370

Klercker, John af 88, 104, 105, 107

Koechlin, Henry 87

Kossinna, Gustaf 93, 94, 95

Kümmel, Otto 217

Labarre, Madame 269, 270

Labarre, Monsieur 269

Lagrelius, Axel 213

Lagrèze, Antoine 197

Lantier, Raymond 101, 102, 108, 109

Léger, Alexis (Saint-John Perse) 383

Lenin, Vladimir 127

Leroi-Gourhan, André 75

Lévy-Bruhl, Lucien 227, 228

Lévy, Paul 151, 240, 241, 242, 274, 354, 362

Lévy, Sylvain 122 
Lindblom, Andreas 30, 96

Lindblom, Gerhard 139, 192, 223, 458

Lindqvist, Sune 92-95, 109, 215, 440

Linnaeus, Carl 54

Lin Yutang 189

Loo, Chang-Tsin see Loo, C.T.

Loo, C.T. 114, 115, 116, 118, 119, 120, 129, $189,219,311,312,354,358,375$, $376,390,430,433$

Loo, Marie-Rose 119, 120, 129, 311, 312, 375

Lu Huan Wen see Loo, C.T.

Lundborg, Karin Maria 30

Lu Qin Zhai see Loo, C.T.

MacCarthy, Mr 297

MacLeish, Archibald 350, 351

Maillol, Aristide 117

Malortigue, Édouard 115

Manas, Gerardo 292

Manet, Édouard 117

Mannikus, Jean 151, 171

Mao Zedong 384, 385

Marie Antoinette 32

Marx, Jean 383

Maspero, Henri 188, 359

Masur, Matthew 381, 394, 395, 411, 412, 430

Matisse, Henri 68

Mauss, Marcel 8, 25, 73, 74, 75, 77, 102, $107,108,109,113,116,122,133$, $149,170,171,190,193,204,205$, 207, 209, 210, 226-229, 232, $431-434,436,439,457$

Mayoux, Jean-Jacques 356,382

Ma Yüan 175

von Mecklenburg, family 32, 33

Mercier, René 151, 182, 185, 260, 327, 354

Miller, Sylvia 397

Minet, Marcelle 118, 354, 356

Montelius, Agda 63

Montelius, Oscar 25, 59-65, 67, 71, 74, 75, $78,79,80,89,92,93,177,417,440$

Morlet, Antonin 103

Mortillet, Gabriel de 74

Mouhot, Henri 47

Mus, Paul 384, 386

Napoleon III 81, 86, 178

Naudin, Georgette 145

Nerman, Agneta 447
Nerman, Anders 9, 382, 449

Nerman, Barbro 127, 128, 129, 181, 231, $232,243,244,313,372,374,418$

Nerman, Bengt 448

Nerman, Birger 15, 17, 24, 34, 41-44, 45, $47,48,53,54,55,57,59,62,65$, $68,69,71,72,76,79,80,87,90$, 91, 93-97, 100, 101, 104-109, 124, $127,128,129,162,181,183,186$, $187,190,192,207,209,210,219$, $220,229,243-246,266,267,283$, 298, 299, 303, 307, 309, 310, 313, $315,321,322,372,382,390,391$, $392,394,417,418,420,421,442$, 447,449

Nerman, Einar $17,24,34,41-45,57,59$, $62,68,71,124$

Nerman, Elisabeth 9, 181, 447

Nerman, Ida 34, 43, 107, 124

Nerman, Janne 34, 43

Nerman, Kajsa 124, 313

Nerman, Nora 80, 124, 127, 128, 168, 207, 209, 211, 228, 243, 283, 448, 449

Nerman, Ture 11, 12, 17, 24, 34, 36, 39, $40-45,47,53,55,56,57,59,62,65$, $68,70,71,77,80,97,124,127,143$, $168,169,183,188,190,207,208$, $211,212,215,218,219,220,228$, $243,295,302,312,367,383,384$, $386,387,389,390,391,398,407$, $410,414,417,418,421,435,447$, 448,449

Nghiem Tham 396, 397, 411, 413

Ngo Dinh Diem see Diem, Ngo Dinh

Ngo Dinh Nhu 413

Nguyen Ai Quoc see Ho Chi Minh

Nguyen Dinh Hoa 398, 400

Nguyen Quang Trinh 415

Nguyen Van Thich 398

Nguyen Xuan Dong 17, 152, 154, 156, 159, $161,164,171,195,199,200,240$, $251,327,328,331,401$

Nhu, Madame 406, 413, 414, 419, 420

Nilsson, Sven 74

Ninkovich, Frank 340, 341

Nixon, Pat 391

Nixon, Richard 391, 423

Nordén, Arthur 67, 79

Norindr, Panivong 146 
Nourry, Émile 104

Nourry-Saintyves, Camille 104

Orcel, Jacques 130, 139, 354

Pajot, Louis 157, 158, 199, 200, 204, 251, 254

Parmentier, Henri 147, 148, 153, 154, 269

Pelliot, Paul 122, 139, 188, 214, 217, 303, 307

Perry-Warnes, Mrs 347

Persdotter, Brita Katarina 32

Perse, Saint-John see Léger, Alexis (SaintJohn Perse)

Pertierra, Antonio 282, 292, 293

Petersson, Christina Janse 445

Petersson, Jan-Erik 445

Pettersson, Betty 54

Piette, Édouard 89

Pradenne, Vayson de 103

Pratt, Mary-Louise 46, 47, 48, 50, 51, 141, 142

Pritchard, E. E. Evans 431

Quezon, Manuel L. 273, 277, 280, 283, $284,285,294$

Rand, Kennard 318, 319

Reinach, Salomon 78, 79, 82, 84, 85, 88, $92,95,100,101,103-106,108,136$, 137

Reischauer, Edwin O. $233,237,238,416$

Renaud, Madame 163, 164

Renoir, Auguste 117

Rivet, Paul 75, 102, 122, 149

Rivière, Georges-Henri 118, 122, 139, 187, 354

Robin, René 147

Rock, Joseph 297

Rodin, Auguste 117

Roosevelt, Franklin D. 283, 318, 319, 332, $340,362,386$

Roosevelt, Theodore 319

Rudbeck, Olof 54

Rydh, Hanna 91, 94, 150, 416, 417, 418, 474

Saada, Emmanuelle 149

Said, Edward 310, 311, 312

Salles, Georges 139, 354

Sarrazin, Jacques 117

Sarup, Madan 310, 314

Satterthwaite, Ann Y. 298

Savary, André 280
Savary, Gladys 280

Sayre, Eleanor Bowes 283

Sayre, Francis Bowes 283

Schnittger, Bror 94

Scott, Donald 242

Seitz, F. Heribert 214

Selassie, Hailie 425

Shetelig, Haakon 63, 72, 75, 93, 390

Shuster, George 349, 350, 355

Sisavang Vong, king of Laos 391

Soang, Mr 157, 159, 161, 251, 252, 253

Sokolovskaya, Mathilde 123

Sokolsky, Alexandre 123, 124

Sokolsky, Ronny 17, 25, 113, 123, 124, 125, 126 see also Janse, Renée/Ronny

Sokolsky, Semen Jr 123, 124

Sokolsky, Semen Seymour 123

Solheim II, William G. (Bill) 8, 20, 157, $161,187,261,264,269,270,273$, $274,278,318,381,402,403,409$, $410,424,463,464$

Stalin, Josef 127, 191, 308, 387, 388

Stern, Philippe 354

Stevenson, Adlai 387

Stewart, Susan 437

Stiernstedt, Marika 96

Stjärna, Knut 63

Sueji Umehara see Umehara, Sueji

Svensson, Anders Peter 32

Svensson, Axel Herman 33, 441

Svensson, Hilma Wilhelmina (married Janse) 31-34, 36, 38, 39, 40, 43, 70, $444,445,446$

Södergran, Edith 425

Söderlundh, Lille Bror 70

Tabouis, Geneviève 312

Thai Van Kiem 398

Thich Quang Duc 420

Thompson, Charles 350, 351

Thomsen, Christian Jürgensen $58,59,60$

Thô, $\mathrm{Mr} 151$

Tolkien, J.R.R. 425

Tolstoy, Lev 55

Toulouse-Lautrec, Henri de 117

Tran Huu The 398

Tran Van Chuong 394, 395

Trinh, Mr 415, 441

Trinh T. Minh-ha 314, 441

Truman, Harry S. 322, 384, 385, 386 
Trung-Trac 175

Truong Buu Lam 398

Umehara, Sueji 96, 113

Valot, Jules 68

Varagnac, André 354

Verrier, Paul 98, 442

Vuillard, Édouard 117

Vuong Hong Sen 398

Walsh, Dr. 377

Wang Mang, emperor 175

Ward, Lauriston 242

Warner, Langdon 233, 236, 237, 238, 242

Washburn, Mrs Bradford 370
Weill, Alexandre 117

Willoquet, Gaston 280, 281, 283, 284

Wilson, Howard 304, 344, 345, 346, 361, 362

Winks, Robin 319

Worcester, Dean Conant 285, 304

Worcester, Frederick Leas 285

Yen, Mr 251, 252, 253, 260

Yutang, Lin 189

Zhang Jinjiang 119

Zobel, Don Jacobo 281, 282, 283, 291, 294

Åberg, Nils 61, 67, 71, 76, 78, 79, 91, 93 
